


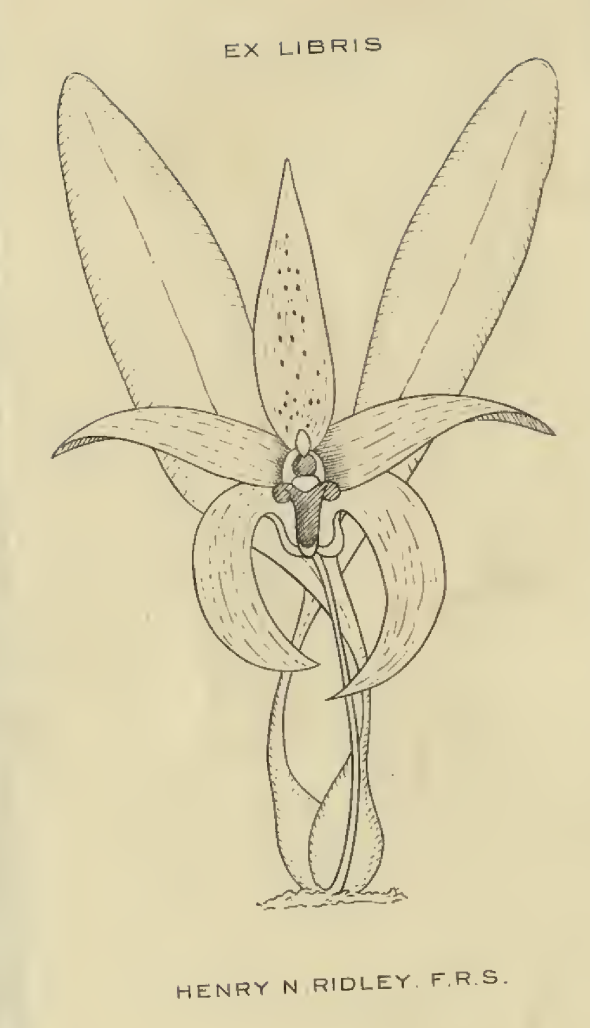




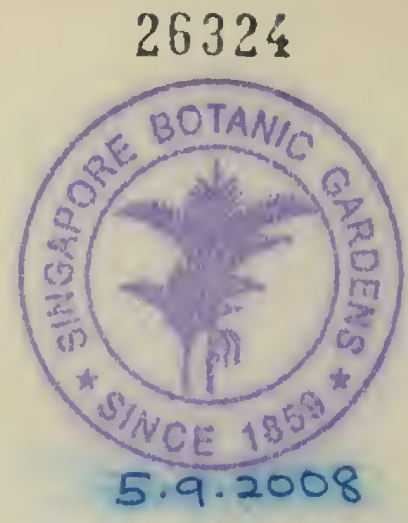


$740=11 \quad$ is 
THE FLORA OF

THE MALAY PENINSULA 


\section{BOTANIC GARDENS LIBRARY SINGAPORE \\ - 5 SEP 2008 \\ 26324 \\ $581.9(595.01)$ \\ RID.}




\section{THE FLORA}

OF THE

\section{MALAY PENINSULA}

BY

HENRY N. RIDLEY, G.M.G., F.R.S., F.L.S. LATE DIRECTOR OF GARDENS AND FORESTS, STRAITS SETTLEMENTS

WITH ILLUSTRATIONS BY

J. HUTGHINSON, F.L.S.

VoL. III.-APETALÆ

PUBLISHED UNDER THE AUTHORTTY OF THE GOVERNMENT OF THE STRAITS SETTLEMENTS AND FEDERATED MALAY STATES

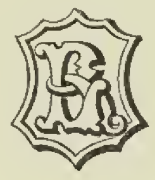

LONDON

L. REEVE \& CO., LTD.

6 HENRIETTA STREET, COVENT GARDEN, W.C. 2 I924 
Made and Printed in Great Britain. Richard Clay \& Sons, Limited, Printers, Bungay, Suffolk. 


\section{CONTENTS}

\begin{tabular}{|c|c|c|c|c|c|c|c|c|c|}
\hline ORDER & & & & & & & & & PAGE \\
\hline CIX. & NYCTAGINEÆ & - & . & - & . & . & . & - & $\mathbf{I}$ \\
\hline $\mathrm{cx}$ & AMARANTACE $A E$ & · & . & . & . & · & • & • & 3 \\
\hline CXI. & POLYGONACEÆ & . & - & . & . & • & • & • & 10 \\
\hline CXII. & ARISTOLOCHIACEA & & - & - & . & • & • & . & 14 \\
\hline CXIII. & CYTINACEA & - & - & . & . & . & • & • & 19 \\
\hline cxiv. & NEPENTHACE $\mathbb{E}$ & . & . & - & • & $\cdot$ & • & · & 20 \\
\hline $\mathrm{CXV}$ & PIPERACEÆ . & - & - & - & · & • & . & - & 25 \\
\hline CXVI. & CHLORANTHACE $\approx$ & - & . & - & . & • & • & • & $5^{2}$ \\
\hline cxvil. & MYRISTICACEÆ & - & - & . & • & • & . & • & 53 \\
\hline xxvili. & MONIMIACEÆ & - & - & . & • & $\cdot$ & . & • & 73 \\
\hline CXIX. & LAURINEE • & . & - & - & • & . & . & · & 75 \\
\hline $\operatorname{cxx}$. & HERNANDIACEÆ & . & . & . & . & . & . & . & I 38 \\
\hline CXXI. & PROTEACEÆ & - & . & . & . & • & . & • & 140 \\
\hline CXXII. & 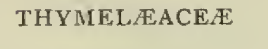 & . & . & . & • & · & . & • & I 43 \\
\hline Xxili. & ELÆAGNACEÆ & - & - & . & . & . & . & - & 148 \\
\hline cxxiv. & LORANTHACEÆ & . & . & - & • & • & • & - & I 49 \\
\hline cxxv. & SANTALACEÆ & • & . & . & . & . & . & • & 166 \\
\hline XXXVI. & OPILIACEE . & • & . & - & . & • & • & · & I 7 I \\
\hline XXVII. & BALANOPHORACE $A$ & & . & - & • & . & . & • & 173 \\
\hline XVIII. & EUPHORBIACE $Æ$ & . & - & - & · & • & . & • & 176 \\
\hline & URTICACEÆ & • & . & - & . & • & . & - & 3 I 7 \\
\hline
\end{tabular}




$$
\text { vi }
$$

CONTENTS

ORDER

CXXX.

JUGLANDACE.压

368

CXXXI, MYRICACE $A$

CXXXII. CASUARINEE

370

CXXXIII. CUPULIFERE

CXXXIV. SALICINEAE .

INDEX

ERRATA

395

406 


\title{
FLORA OF THE MALAY PENINSULA
}

\author{
VOLUME III
}

\section{ORDER CIX. NYCTAGINEÆ.}

Herbs, shrubs or trees. Leaves usually opposite. Flowers hermaphrodite (or unisexual) regular. Perianth monopetalous, petaloid, tube persistent enclosing fruit (usually), lobes plicate in bud. Stamens I to 30 ; filaments unequal. Ovary free, I-celled; ovule I, erect basal. Fruit indehiscent, enclosed in tube. About 220 species, all warm regions. (Gamble, Journ. As. Soc. Beng. lxxv. 2.) Cultivated plants in our gardens belonging to this Order are the Bougainvilleas of S. America, and Mirabilis jalapa, the Marvel of Peru, a tuberous herb with flowers of all colours.

Herbs with pink flowers; flowers bisexual d
Trees or shrubs, one spiny; flowers unisexual, green or white

I. Boerhaavia

2. Pisonia

\section{BOERHAAVIA, Linn.}

Herbs, sub-erect or prostrate, diffuse. Leaves opposite. Flowers small, panicled sub-umbellate, or sub-capitate, pink (rarely white). Perianth-tube usually short, ovoid below; limb funnel-shaped, 5-lobed. Stamens I to 5, exsert connate below ovary; filaments capillary. Ovary stipitate. Fruit small, enclosed in the viscid calyx-tube. Species about 30, tropics and sub-tropics, usually in sea sand.

Flowers capitate .

Flowers umbelled
(I) B. diffusa

(I) B. diffusa Linn. Sp. Pl. 3. B. repens Limn. Sp. Pl. 3; Gamble, Journ. As. Soc. Beng., l.c. 2. (Fig. I32, p. 2.)

Prostrate herb; branches often ascending I2 to $I 8$ in. tall, slender, internodes long. Leaves ovate or orbicular, rather fleshy, blunt or acute, truncate or cordate at base, I in. long or less, .5 in. wide; petioles $\cdot 3$ in. long. Flowers bright rose-pink in very small heads in slender panicles I to 2 in. long. Perianth 05 in. long. Stamens 2. Fruit 05 in. Iong, obovate. Hab. Seashores in sand. Singapore, Galang. Province Wellesley, Telok Ayer Tawar.

Fl.M.P., 3 
Penang, Tanjong; Batu Feringhi (Curtis). Lankawi, Kwala Malacca. Patalung (Annandale). Distrib. All the tropics.

(2) B. repanda Willd. Sp. Pl. i. 22.

Rhizome stout, woody; a straggling even scandent herb, 2 to $6 \mathrm{ft}$. long. Leaves triangular acute, ovate or repand-sinuate, $\mathrm{I}$ to 3 in. long, I to I.5 in. wide; petioles slender, $\cdot 25$ to .5 in. long. Perianth .25 in. long, rose pink. Stamens long-exsert. Fruit sub-clavate glandular. Hab. Perlis, Chupeng at the mouth of a cave. Distrib. India to Burma.

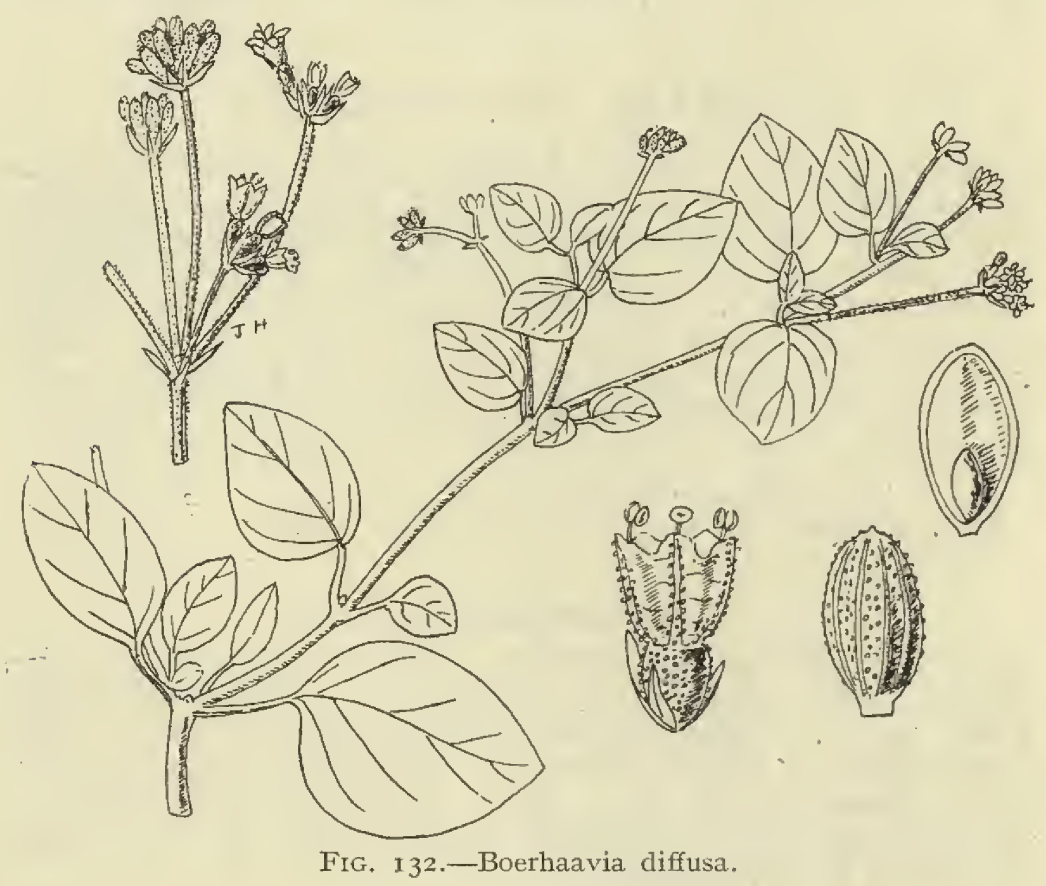

2. PISONIA, Linn.

Trees or shrubs, armed or not. Leaves opposite, alternate or whorled. Flowers green or white in corymbose cymes, usually unisexual. Perianth, male funnel-shaped, female tubular, 5- to Io-toothed. Stamens exsert, 6 to Io. Ovary sessile. Fruit enclosed in the perianth-tube, cylindric or clubbed, sticky. Species 6o, tropics generally, chiefly maritime.

$P$. alba Span. the lettuce tree is often cultivated near the sea for its bright yellowish-green foliage. Native of the Andamans.

Armed climber; cymes dense

Tree, unarmed; flowers panicled .

(I) P. aculeata

(2) P. excelsa 
(I) P. aculeata Limn. Sp. Pl. I026; Hook. fil. F.B.I. iv. 7II.

A long woody climber with axillary recurved spines. Leaves elliptic acuminate, base cuneate, 2 to 3 in. long, I.5 in. wide; petioles $\cdot 25$ in. long. Cymes dense, corymbose, I.5 in. long. Flowers greenish white, $\cdot I$ in. long. Males campanulate, females ovoid. Fruit panicle spreading; fruits narrow clubbed, 5-ribbed muricate, $\cdot 5$ in. long, sticky, on pedicels 75 in. long. Hab. Generally near the sea, in dry spots, Perlis, rocks of Bukit Lagi near Kanga. Distrib. Tropics generally.

(2) P. excelsa Bl. Bijdr. 735; Hook. fil. F.B.I. iv. 7rr.

Tree about $40 \mathrm{ft}$. tall, unarmed. Leaves opposite alternate or whorled, large dark shining green, elliptic, narrowed to base and tip; nerves about 6 pairs; 6 to $\mathrm{I} 2$ in. long, $2 \cdot 25$ to 4 in. wide; petioles $\mathrm{I}$ in. long. Flowers numerous in a panicle 3 in. long and wide, small, greenish white. Males cylindric, $\mathrm{r} \cdot 25$ in. long. Fruit cylindric, I.25 in. long, grooved, very sticky, Hab. Woods at base of limestone rocks, Perak, Kwala Dipang (Ridley). Distrib. Andaman and Malay isles.

\section{ORDER CX. AMARANTACEE.}

Herbs, rarely shrubby. Leaves opposite or alternate. Flowers very small in terminal, simple or panicled spikes, or cymes. Bracts and 2 bracteoles scarious. Sepals 5 , stiff, imbricate in bud. Stamens I to 5, opposite sepals, filaments free or connate. Ovary I-celled; styles I to 3 ; ovules I or more. Fruit an utricle rarely a berry or capsule within or on the persistent sepals. Seed orbicular or ovate. Species nearly 500, chiefly tropical.

Leaves alternate; anthers 2-celled; ovary 2- to many-ovuled.

Shrubby; fruit a berry; flowers in long spikes.

Herb; fruit membranous; flowers in a short spike; bracts large

Leaves alternate; anthers 2 -celled; ovary I-ovuled.

Flowers capitate bisexual .

Flowers $\cdot 3$. Allmania

Flowers capitate bisexual id clusters
Flowers unisexual in panicled clus

Flowers I to 3 perfect surrounded by deformed ones.

Stamens with interposed staminodes . . 5. CyathulA

Flowers all perfect, no staminodes . . . 6. Psilotrichum

Flowers all perfect, with staminodes.

Sepals hyaline woolly . . . 7. Aerua

Sepals spiny

Leaves opposite; anthers I-celled; ovary $\mathrm{I}$-ovuled.
Prostrate decumbent plant with axillary heads

Erect plant hairy with globose white or red terminal heads.

I. DEERINGIA

2. Celosia

8. Achyranthes

9. Alternanthera

Io. GOMPHRENA 


\section{DEERINGIA, Brown.}

Herbs or scandent shrubs. Leaves alternate. Flowers unior bi-sexual in Iong simple or panicled spikes. Perianth-lobes 5, oblong, imbricate. Stamens 4 or 5 ; filaments broad and connate in a cup at base; anthers 2 -celled reniform-oblong. Ovary ovoid; ovules many; stigmas 2 to 4 . Fruit a globose berry. Species 5 to 6 , Africa, Asia and Australia.

Flowers in long slender panicled spikes; fruit red . (I) D. celosioides

Flowers in short simple spikes; fruit white . . (2) D. indica

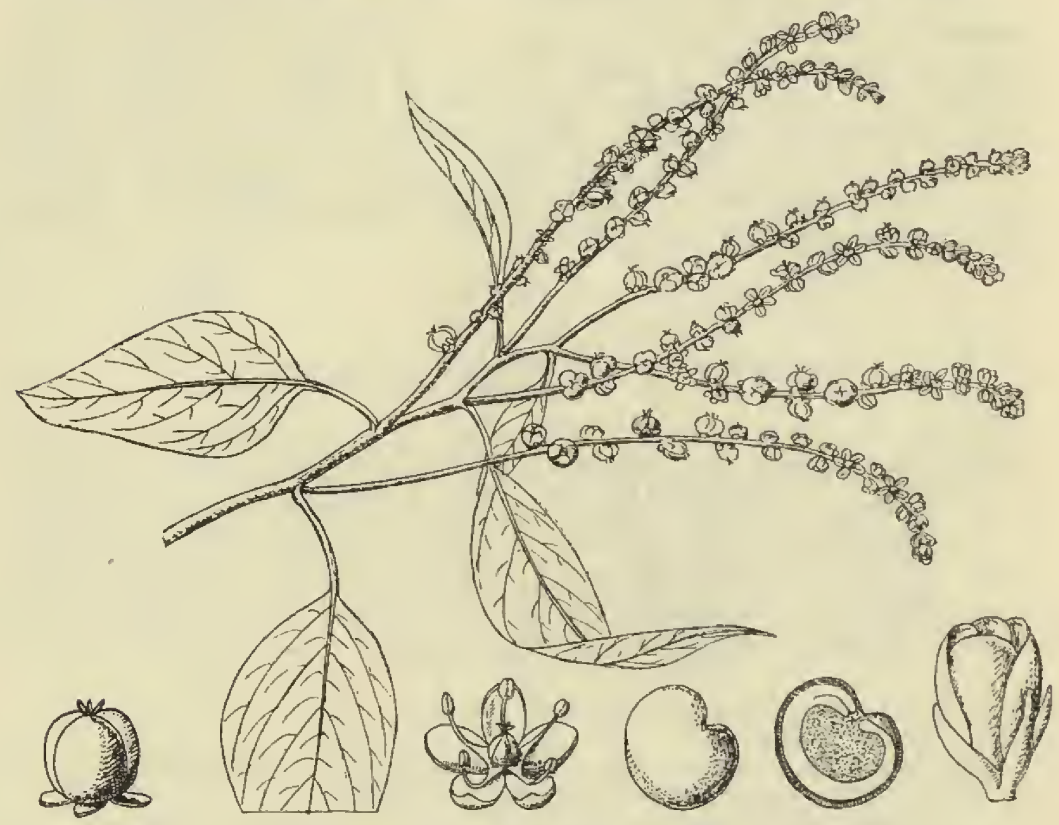

FIG. 133.-Deeringia celosioides.

(I) D. celosioides Brown, Prodr. Nov.-Holl. i. 4I3; Gamble, l.c. 5 .

Long scrambling shrubby plant. Leaves fleshy, membranous ovate acute, rounded or cordate, $3 \mathrm{in}$. long, I.5 in. wide; petioles .5 in. long. Panicles I ft. long or more, axillary and terminal, the slender many-flowered spikes I ft. long or less. Flowers white, very small. Stamens exsert. Drupe scarlet, ${ }^{\prime} \mathrm{I}$ in. through. $H a b$. On limestone rocks, generally near the sea, Selangor, Kamuning in forests (Ridley). Perak, Batu Kurau (Scortechini). Distrib. Indo-Malaya, China. 
(2) D. indica Zoll. Syst. Verz. Pl. Jav. I Io; Gamble, l.c. 6.

A sub-erect shrub about $3 \mathrm{ft}$. tall or more, rather fleshy. Leaves fleshy, membranous lanceolate-acuminate, base cuneate, 5 in. long, 2.75 in. wide; petioles 5 in. long. Spikes simple, I.5 to 2 in. long. Flowers $I$ in. long, scarious. Stamens hardly exsert. Fruit $\cdot 2$ in. through, white. Hab. Limestone rocks, Pahang, Gunong Senyum (Evans). Selangor, Kamuning. Perak, Kwala Dipang; Goping (Kunstler); Waterloo (Curtis). Perlis, Chupeng. Distrib. Malay isles.

\section{CELOSIA, Linn.}

Herbs erect. Leaves alternate. Flowers bisexual in dense terminal and axillary spikes, white or pink. Bracts and perianth scarious. Perianth-lobes 5, slightly connate below. Stamens 5, filaments connate in a cup. Fruit an utricle dehiscing transversely. Seeds 2 or more lenticular, black. Species 30, tropics generally.

The cock's comb, C. cristata Lindl., is often cultivated in various forms, its origin is unknown.

(I) C. argentea Linn. Sp. Pl. 205; Gamble, l.c. 7.

Glabrous, erect branched or simple herb about $3 \mathrm{ft}$. tall. Leaves linear to linear-lanceolate, 2 to 4 in. long, 5 in. wide. Spikes 3 to 6 in. long, rose pink withering white. Sepals 25 in. long, lanceolate. Hab. Dry open spots, waste ground. Singapore, Mt. Pleasant (Hullett). Pahang, Kwala Semantan. Perak, Kwala Temengoh covering the rocks with a pink mass by the river; Plus River (Wray). Kelantan, Kamposa. Distrib. Tropics generally.

\section{ALLiMANIA, Brown.}

Erect or diffuse herbs. Leaves alternate, linear, spathulate or obovate. Flowers bisexual in globose or ovoid heads. Bracts I, bracteoles 2. Perianth-segments 5, scarious, oblong-lanceolate. Stamens 5, connate in a cup at base; anthers 2-celled. Ovary ovoid, I-celled; ovule I; style long, straight; stigma bifid. Utricle ovoid circumsciss. Seed I, orbicular. Species about 3, tropical Asia.

(I) A. nodiflora Brown in Wall. Cat. 6890; Gamble, l.c. 8.

Branched diffuse herb about 6 to I2 in. tall. Leaves linearlanceolate to oblong, sessile, I.5 to I.75 in. long, .08 to $\cdot 3$ in. wide. Flowers in a globose head, $\cdot 5$ in. through. Perianth-lobes $\cdot 25$ in. long, lanceolate, acuminate. Seed large, flat with a 2-lobed aril. $H a b$. Seashores and sandy spots.

var. esculenta with narrow linear leaves.

var. b. procumbens. Leaves spathulate or oblanceolate, $3 \mathrm{in}$. across. Hab. Singapore, Changi, both varieties. Malacca, Pulau Besar (Griffith). Pahang, Sungei Meang (both var. esculenta). Tringganu (Yapp). Distrib. Indo-Malaya, China. 
4. AMARANTHUS, Linn.

Annual weedy herbs. Leaves alternate, thin. Flowers small, green or in cultivated forms red, in cymules or dense axillary clusters or terminal and axillary spikes or panicles. Sepals 3 or 5 , in males ovate-lanceolate, in females oblong or spathulate. Stamens 3 or 5 ; anthers 2 -celled. Ovary ovoid, I-celled, I-seeded; stigmas 2 to 3. Fruit a round or ovoid utricle, indehiscent or circumsciss. Seed round and flat. Species Io or more over the whole world. Several are cultivated as spinach (Bayam) and some for their red leaves or panicles; such are $A$. tricolor with red and green and yellow leaves, "Turk's Cap;" A. hypochondriacus with erect crimson spikes; A. salicifolius with linear drooping leaves, orange, carmine and yellow.

Sepals and stamens 5. Utricle circumsciss.

Whole plant spiny; spikes rather short

Plant unarmed; spikes long pendent

(1) A. spinosus

Sepals and stamens 3 .

Utricle circumsciss; sepals long-awned.

Robust plant; flowers in dense long spikes

Weak plant; flowers in small axillary heads

Utricle indehiscent; sepals short-awned
(3) A. gangeticus
(4) A. mangostana
(5) A. viridis

(I) A. spinosus Linn. Sp. Pl. 991; Gamble, l.c. 9.

About I $\mathrm{ft}$. tall with axillary yellowish spines $\cdot 3$ in. long. Leaves thin ovate or oblong blunt, mucronulate, base cuneate, I in. long, .5 in. wide; petioles slender, 5 in. long. Flowers in dense axillary clusters and terminal slender spikes 2 to 3 in. long, upper flowers usually male, lower females or mixed. Sepals 5, usually about .05 in. long. Utricle circumsciss. Hab. A common weed, Singapore, Galang, Malacca, Selangor, Province Wellesley, Krian. Penang. Distrib. Whole tropics. Native name: Bayam duri. Use: A pot herb.

(2) A. caudatus Limn. Sp. Pl. 990 ; Gamble, l.c. Io.

Rather robust. Leaves membranous, elliptic or ovate-lanceolate, tip blunt, base cuneate, 3 in. long, 2 in. wide; petioles $2.5 \mathrm{in}$. long. Spikes terminal, drooping 2 to 6 in. long and axillary clusters. Sepals 5, oblanceolate mucronate keeled. Stamens 5. Utricle circumsciss. Hab. Cultivated, and a weed in waste ground. Singapore and other localities. Pahang, Kwala Tahan (Seimund). Distrib. Whole world in warm countries. Native name: Bayam Selasih. Use: As spinach.

Cultivated forms with long red spikes are known as "Love lies bleeding" and "Prince of Wales' Feathers." The common form has a big terminal panicle of slender spikes, and the cultivated form has often fewer, but longer, very thick spikes. l.c. Io

(3) A. gangeticus Limn. Syst. Nat. ed. Io, I268; Gamble,

Rather robust, I 8 in. or more tall. Leaves lanceolate, ovate, 
rhomboid or deltoid mucronulate, base broad then decurrent narrowed to petiole, I to 4 in. long, 5 to 3.5 in. wide; petioles up to 2.5 in. long. Flowers very numerous in large clusters of cymules axillary and stout erect terminal spike. Sepals 3, lanceolate, long-awned. Stamens 3. Ovary ovoid; stigmas 3. Utricle circumsciss. Hab. A weed of cultivation, Singapore, Macpherson Road. Pahang, Kwala Tahan. Penang Town (Deschamps). Distrib. Whole world. Native name: Bayam Merah. Use: Pot herb.

(4) A. mangostana Linn. Amoen, Acad. iv. 294; Hook. fil. F.B.I. iv. 720 .

Diffuse and somewhat procumbent. Leaves deltoid, blunt, base cuneate decurrent I in. long, 5 in. across; petioles $\cdot 5$ in. long. Cymules axillary small, pale, 25 in. across, no terminal spikes. Bracts and sepals awned lanceolate. Hab. Malacca (Griffith).

This is possibly a poor decumbent form of gangeticus.

(5) A. viridis Limn. Sp. Pl. ed. 2, I405; Gamble, l.c. II.

Herb, about 6 to 12 in. tall. Leaves thin, ovate or deltoid blunt and often notched at tip, base decurrent cuneate, $I \cdot 5$ to 3 in. long, 75 to $I \cdot 75$ in. wide. Flowers mostly in terminal and axillary slender racemes or spikes. Sepals 3, ovate acuminate in male, obovate in female, very small, green. Stamens 3. Utricle orbicular indehiscent. $H a b$. A very common weed in waste ground, rubbish heaps, and dung-hills, Singapore, Malacca, Selangor, Lankawi at Kwah. Distrib. Whole world. Native names: Bayam Munyit; Bayam putih.

\section{CYATHULA, Lour.}

Herb. Leaves opposite. Flowers small, bisexual in clusters in a long terminal spike, perfect flowers $I$ to 3 , surrounded by several imperfect ones. Sepals 5, scarious acuminate, in imperfect flowers reduced to hooked awns. Stamens 5, filaments connate below with intervening (laciniate) or bifid staminodes into a cup; anthers 2-celled. Ovary obovoid, I-celled; ovule I; style simple; stigma capitate. Fruit a utricle, ovoid. Species ro, tropics and temperate regions of both worlds.

(I) C. prostrata Bl. Bijdr. 549; Gamble, l.c. I2.

Straggling prostrate herb; stems ascending $2 \mathrm{ft}$. tall, upper parts tomentose. Leaves elliptic-rhomboid acute, base cuneate, strigose, hairy on both sides, I to 2 in. long, $\cdot 75$ in. wide; petioles $\cdot 2$ in. long. Spikes 4 to Io in. long, slender, lower part nude, lower cymules scattered, ' I in. across, white. Flowers violet, hairy. $H a b$. Common in orchards, campongs, etc. Whole peninsula, Singapore, Johor, Kota Tinggi. Malacca, Negri Sembilan, Perak, Penang. Distrib. Whole world tropics.

var. major. Leaves thin ovate-lanceolate, 6 in. long, $2 \cdot 25$ in. wide bristles purple. Hab. Forests, Selangor, Sungei Buluh (Ridley). 


\section{€. PSILOTRICHUM, Bl.}

Herbs branched. Leaves opposite. Flowers white, bisexual in (axillary or) terminal solitary (or panicled) spikes (or clusters). Bracts small, scarious. Sepals 5, slightly connate below, ovate or lanceolate acuminate, ribbed. Stamens 5, connate below in a small cup. Anthers 2-celled. Staminodes o. Ovary oblong or sub-globose; ovule I; style slender; stigma capitate (or bifid). Utricle included in hardened perianth. Seed lenticular. Species Io to I2, Old World tropics.

(I) P. trichotomum Bl. Bijdr. 545; Gamble, l.c. I4.

Flaccid decumbent herb about 6 to Io in. tall. Leaves thin elliptic or lanceolate, acute, base long narrowed, 5 to I in. long, .2 to $\cdot 3$ in. wide; petioles short or none. Spikes $\cdot 2$ in. long, white or greenish. Flowers claret colour. Bract persistent. Sepals lanceolate acuminate, $\mathrm{I}$ in. long. $H a b$. Rare in dry open spots, Perak, Ulu Kal, 800 to Iooo ft. altitude (Kunstler). Setul, heath (Ridley). Distrib. India to Philippines.

\section{AERUA, Forsk.}

Herbs (or undershrubs). Leaves (alternate or) opposite. Flowers bisexual in simple or panicled spikes. Bracts small. Sepals 5 (or 4), lobes equal or outer broader. Stamens 5, with staminodes between in a cup; anthers 2-celled. Ovary ovoid or sub-globose, I-celled, I-ovuled; style simple; stigma capitate. Utricle membranous. Seed reniform. Species I5, Africa and Asia.

(I) A. Curtisii Oliv, Ic. Pl. t, 2201. (Fig. I34, p. 9.)

Straggling plant slightly woody below, I ft. tall or more. Leaves opposite, membranous, lanceolate, acuminate, long, decurrent on petiole, pubescent beneath, $\cdot 5$ in. long, I.5 in. wide; petioles $\cdot 3$ in. long. Spikes elongating to 3 in. long, slender terminal several together and axillary pubescent. Bracts small, persistent. Sepals 8 in. long, ovate, ribbed. Stamen-cup rather deep; filaments and staminodes triangular-lanceolate. Hab. Local on rocks in forests, Perak, Waterloo Estate (Curtis); Temengoh; Lenggong (Ridley).

\section{ACHYRANTHES, Linn.}

Herbs, slightly woody below. Leaves opposite. Flowers bisexual in slender elongating; simple or compound spikes, deflexed after flowering. Bracts spiny. Sepals 5, lanceolate aristate stiff. Stamens (2 or) 5; filaments connate alternating with square fimbriate staminodes; anthers 2-celled. Ovary oblong, I-celled, I-ovuled; style filiform; stigma capitate. Utricle oblong-cylindric. Seed oblong. Species I5, tropics and temperate regions.

(I) A. aspera Limn. Sp. Pl. 204; Gamble, l.c. I6.

Erect, slightly shrubby below about $3 \mathrm{ft}$. long, pubescent. 
Leaves rather thick membranous elliptic acuminate both ends pubescent 2 to 4.5 in. long, $\cdot 5$ to 2 in. wide; petioles $\cdot 5$ in. or less. Spikes elongating to $\mathrm{I} 2$ or I4 in., stiff, stout, hairy. Bracts ovate, awned. Sepals lanceolate, ${ }^{\prime} 5$ in. long, acute. Whole flower abruptly deflexed. Hab. Common in woods and villages, Singapore, Garden Jungle; Telok Kurau. Pahang, Sungei Meiang; Telom.

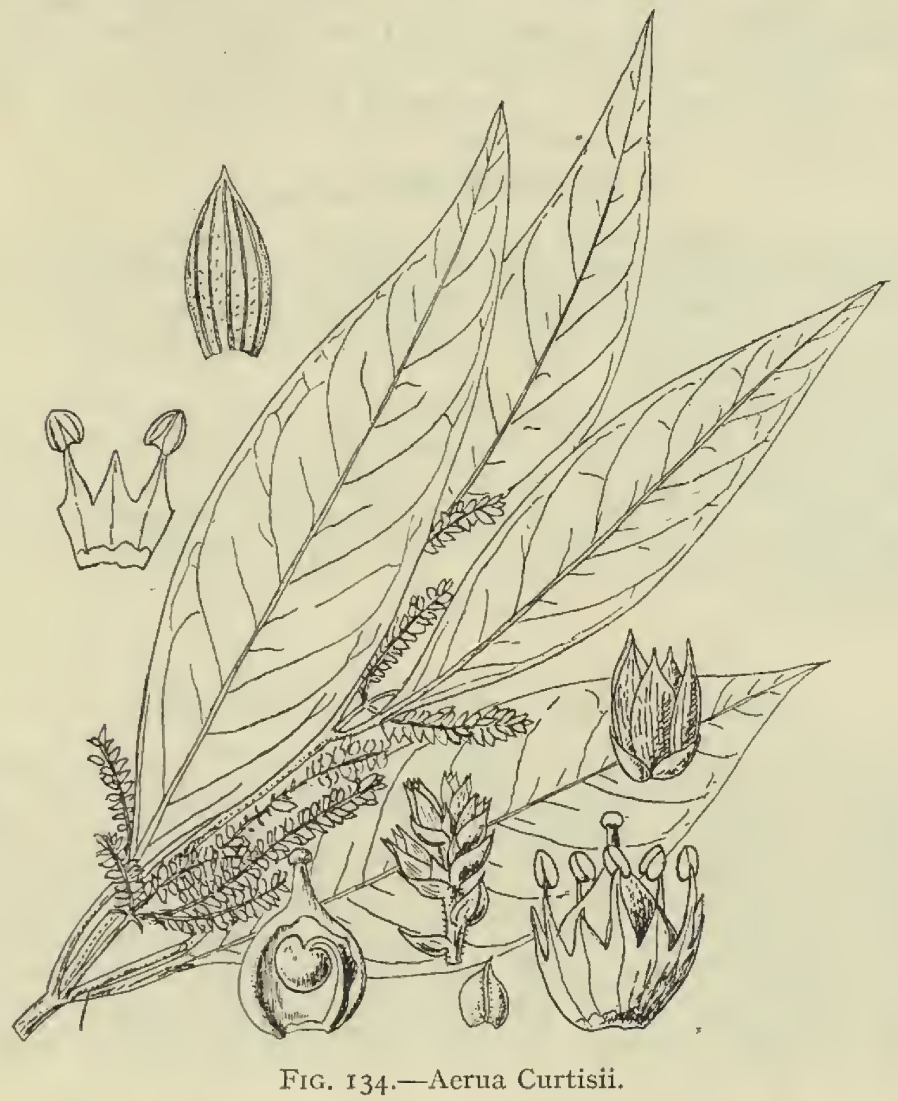

Malacca, Pulau Besar. Penang, Sepoy lines (Curtis). Distrib. All warm countries.

9. ALTERNANTHERA, Forsk.

Prostrate herbs. Leaves opposite. Flowers small, white, bisexual in axillary heads. Sepals 5 , unequal. Stamens 2 to 5 ; filaments connate in a short cup (with) or without staminodes. Anthers I-celled. Ovary orbicular or ovoid; ovule I; style 
short; stigma capitate. Utricle obcordate, edges thickened. Species about I6, cosmopolitan.

(I) A. sessilis Brown Prod. Fl. Nov.-Holl, 4I7; Gamble, l.c. 7.

Rather fleshy prostrate herb. Leaves linear-oblong lanceolate, blunt or sub-acute, glabrous, rather fleshy, I.5 to $I \cdot 25$ in. long, - I to .5 in. wide; petioles short or none; heads sessile, 24 in. through, white. Hab. Very common weed in waste grounds all over the peninsula, as it is in all warm parts of the world. Native names: Akar rumput; Bayam pasir; Bayam tana; Kelama hijau; Kerak Kerak paya; Kerumak bukit paya. Use: As a pot herb and valued as a febrifuge.

\section{GOMPHRENA, Linn.}

Hairy erect herbs with opposite leaves. Flowers capitate (or spicate) white, pink, or crimson. Sepals 5, lanceolate-acuminate. Stamens 5; anthers I-celled. Ovary sub-globose; style bifid. Utricle indehiscent with one round, flat seed. Species 7o, S. America and Australia.

(I) G. globosa Lim. Sp. Pl. 224.

About I ft. or more tall. Leaves 2 to 4 in. long. Heads I to I.5 in. through, terminal. Bracts magenta, rose pink or white. Sepals woolly. Hab. Occasionally escapes from gardens, where it is a very popular plant, especially with Tamils. Probably a native of S. America.

\section{ORDER CXI. POLYGONACEÆ.}

Herbs or shrubs. Leaves usually alternate. Stipules usually membranous and forming a tube (sheath) encircling stem. Inflorescence axillary racemose capitate or panicled. Flowers usually bisexual pedicelled. Sepals 3 to 6 , usually 5, free or connate imbricate, persistent. Stamens 5 to 8 . Disc annular glandular or 0 . Ovary free, biconvex or 3- to 4-angled; ovule I, orthotropous; styles I to 3. Nutlet hard, enclosed in perianth. Species over 6oo. Whole world (A. T. Gage, Journ. As. Soc. Beng. lxxv. I8).

The Honolulu creeper, Antigonon leptopus, of tropical America belongs to this Order.

\section{POLYGONUM, Linn.}

Herbs (rarely shrubby). Leaves alternate; stipules forming a sheath round the stem. Inflorescence a spiciform raceme or panicle. Flowers small, pink or white in axils of small bracts. Sepals 5 . Stamens 5 to 8 , usually with yellow glands between each. Ovary lenticular or trigonous; styles I to 3 . Nut biconvex or trigonous. Distrib. Whole world, most abundant in temperate regions. 
Inflorescence of spiciform racemes.

Ovary and nutlets biconvex.

Stem stout, tall; leaves large tomentose . . ( I) P. tomentosum Stem slender; leaves small . . . . (2) P. minus

Ovary and nutlet trigonous; stout plants; perianth eglandular, Sparsely hairy Densely silky on underside of leaves
lender plants; perianth glandular.

Racemes long pendulous; flowers remote Racemes rather short, erect; flowers crowded Inflorescence of panicles of heads.

Scandent long shrubby; leaves broad ovate

Slender erect; leaves smaller; heads few. Nutlet trigonous; leaves narrow Nutlet biconvex; leaves oblong-ovate

(3) P. barbatum

(4) P. stagninum

(5) P. flaccidum

(6) P. hydropiper

(7) P. chinense

(8) P. strigosum

(9) P. pedunculare

(I) P. tomentosum Willd. Sp. Pl. ii. 447; Gage, l.c. I9.

Stems $2 \mathrm{ft}$. tall or more, stout, unbranched slightly pubescent. Leaves lanceolate long-acuminate, base narrowed, softly hairy on both sides, 6 to 7 in. long, I.5 to I.75 in. wide; petioles $\cdot 25$ in. long; sheath membranous grooved, hairy, mouth truncate, ciliate. Racemes spike-like, slender branched, 2 to 3 in. long. Bracts tubular, ciliate. Flowers 4 to 6 in a bract, shortly pedicelled. Sepals white. Stamens 5 to 8 , nearly as long as sepals. Ovary lenticular; style bifid. Nut orbicular, biconvex. Hab. Wet spots, open country, Malacca (Griffith). Perak, Teluk Anson (Kunstler); Ipoh (Curtis). Penang, Batu Feringhi (Curtis). Perlis, Kanga. Distrib. Africa, tropical Asia.

(2) P. minus Huds. Fl. Angl. i. I48; Gage, l.c. I9.

Slender herb, glabrous, about 6 to I2 in. long, creeping, ascending, branched. Leaves sessile, linear or lanceolate, acute, 2.5 to 3 in. long, I to $\cdot 25$ in. across, sessile; sheath shorter than internodes, strigose truncate, ciliate on mouth. Spiciform racemes branched slender, $I \cdot 75$ in. long. Flowers minute, 5 or more in axil of bract; pedicel as long as flower. Nut minute lenticular. Hab. Wet spots. Not rare. Pahang, Pulau Tawar; Pekan, etc., along Pahang River. Selangor, River bank, Petaling Road, Kwala Lumpur. Perak, Kinta River (Kunstler), Dindings, Bruas (Curtis). Setul Heath. Distrib. Europe, Asia, Australia. Native name: Saruas Samalam.

This is one of the very few natives of England among our flowering plants.

(3) P. barbatum Linn. Sp. Pl. 362; Gage, l.c. 20.

Plant about $3 \mathrm{ft}$. tall. Leaves lanceolate or linear-lanceolate, acuminate both ends, glabrous or more or less strigose, 3 to $5 \mathrm{in}$. long, $\cdot 5$ in. across; petioles $\cdot I$ in. long; sheath much shorter than the long ( 3 in.) internodes, mouth truncate, stiff, ciliate. Spiciform racemes rather thick, $I \cdot 5$ to 2 in. long; peduncles I in. long or more. Bracts ciliate. Flowers 4 or more in axil of bract. 
Perianth white, small. Ovary trigonous; style trifid. Nutlet trigonous. Hab. Common in ditches, Singapore, Galang; Chan Chu Kang, Johor, Batu Pahat; Bukit Muar (Feilding). Pahang, Gunong Senyum (Evans). Selangor, Langat; Kwala Lumpur, Perak, Ipoh (Curtis). Penang, Balik Pulau; Pulau Betong (Curtis). Kedah, Gunong Geriang. Perlis, Chupeng. Kelantan, Chaning; Kota Bharu. Distrib. Tropics of Old World. var. typicum. Hairy. var. glabratum. Leaves glabrous.

(4) P. stagninum, Ham. Wall. Pl. As. Rar. iii. 56; Hook. fil. F.B.I. v. 37 .

Stout plant about 2 or $3 \mathrm{ft}$. tall, lower part glabrous, upper parts and back of leaves strigose silky. Leaves 3 to 5 in. long, .5 in. wide, lanceolate long-acuminate narrowed to base; sheaths almost or quite covering internodes, strigose. Racemes 2 in. long, erect; peduncles strigose. Flowers white. Styles long, slender, connate below. Hab. Rare in ditches. Perlis at Kanga (Ridley). Distrib. India and Burma.

Very near $P$. barbatum, but silky grey, with strigose peduncles and short racemes.

(5) P. flaccidum Meissn, DC. Prod. xiv. I, 107.

Stem 4 to $8 \mathrm{ft}$. tall, or less, simple or branched, glabrous or strigose. Leaves lanceolate or elliptic-lanceolate acuminate, very many-nerved, glabrous or more or less hairy, 5 in. long, I in. wide; petioles $\cdot 3$ in. long; sheath much shorter than long internodes strigose, mouth with long cilia. Racemes very slender, filiform, 6 in. long, pendent. Bracts distant with 3 or more very small flowers. Perianth pink. Stamens 7 to 8 . Ovary. trigonous; style trifid nearly to base. Nut trigonous. $H a b$. Wet open spots, Pahang River near Pekan. Selangor, Kwala Lumpur (Goodenough); Semangkok Pass. Perak, Kota Tampan; Tanjong Malim; Kwala Kangsa; Kinta River (Kunstler). Kelantan, River banks. Distrib. Indo-Malaya. Native names: Kalina Paya; Kasum. Use: As an Emmenagogue.

(6) P. hydropiper Linn. Sp. Pl. 360 ; Gage, l.c. 2 I.

Herb, about I8 in. tall or less. Leaves sub-sessile, lanceolate or oblong-lanceolate, glabrous, 3 to 4 in. long, $\cdot 4$ in. wide; sheath much shorter than internode, shortly ciliate. Spiciform racemes 2 to 4 in. long, slender. Bracts distant, tubular, glabrous. Flowers 2 or more in a bract; pedicels as long. Sepals pink, 2 outer narrower than the 3 inner. Ovary trigonous; style trifid. Nut trigonous. Hab. Damp, sandy spots near river, Pahang, River bank. Negri Sembilan, Seremban. Distrib. Cosmopolitan.

This species is also common in England.

(7) P. chinense Linn. Sp. Pl. 363; Gage, l.c. 22.

Climber over bushes, several feet long, Leaves stiff, ovate 
acute, base truncate or round, sometimes cordate, glabrous, nerves conspicuous, 5 in. long, 3 in. wide; petioles $\cdot 4$ in. long with round auricles at base; sheath .5 in. long. Inflorescence of panicled cymes I to $3 \mathrm{in}$. long with leafy bracts. Flowers few in small clusters, I in. through, white or pink. Stamens 7 to 8 , in 2 whorls. Ovary trigonous; style trifid above. Nutlet trigonous, pulpy, black. Hab. Mountains at $4000 \mathrm{ft}$. altitude, very showy. Pahang, Bukit Fraser (Foxworthy). Perak, Gunong Berimbun near Telom;

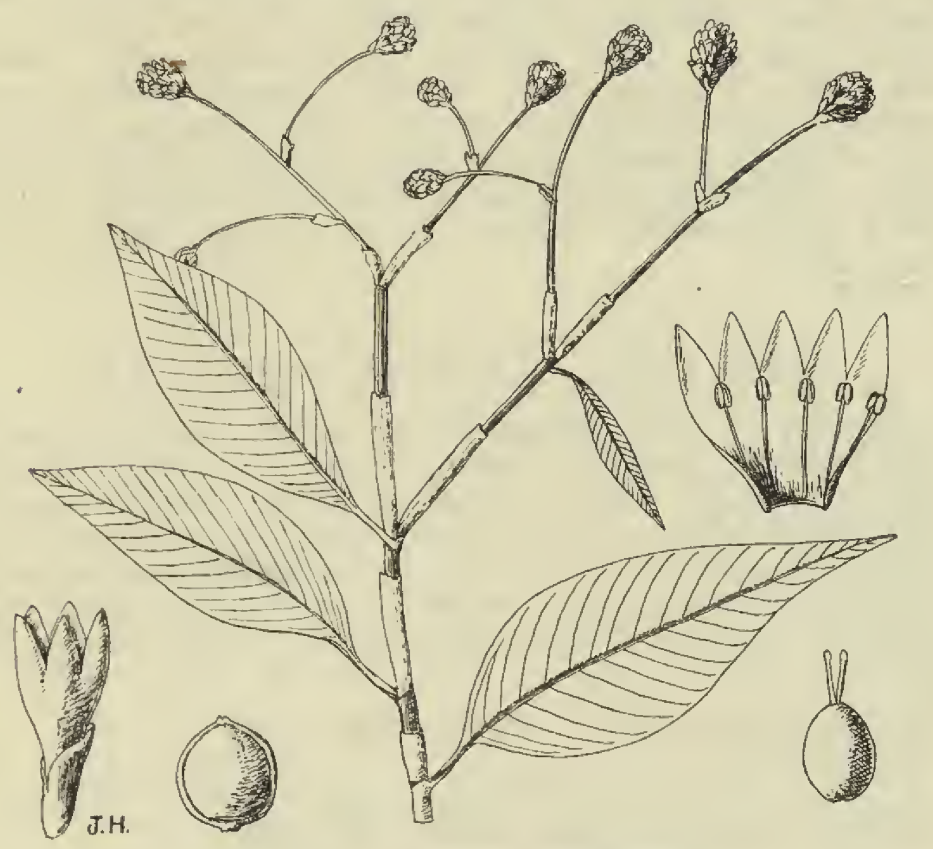

FIG. I35.-Polygonum pedunculare.

Jor; Tapah; Gunong Kerbau (Haniff). Distrib. India, Malay isles, China and Japan.

(8) P. strigosum R. Brown Prod. Fl. Nov.-Holl. 420; Gage, l.c. 22 .

Straggling plant 2 to $4 \mathrm{ft}$. long, angles, petioles and nerves of leaves prickly with recurved thorns. Leaves linear or linear-oblong acuminate, base truncate, I to 5 in. long, I5 to .5 in. wide; petioles 0 to $\cdot 5$ in. long. Racemes oblong, panicled, - I3 to $\cdot 3$ in. long, with slender peduncles. Flowers pink. Stamens 6 to 8 . Nut trigonous. Hab. Penang (Wallich No. I697D), not seen again. Distrib. Indo-Malaya, China. 
(9) P. pedunculare Wall. Cat. I7I8; Gage, l.c. 23. (Fig. I35, p. I3.)

Stems slender, branching about I ft. tall. Leaves lanceolate acute, base narrowed shortly, often oblique; internodes $I$ to 3 in. long; 2 to $2 \cdot 75$ in. long, $\cdot 5$ to $\cdot 75$ in. wide; petioles $\cdot 4$ in. long, slender; sheath small, much shorter than internode. Inflorescence 3 in. long, of slender branches with small $\cdot 25$ in. heads at the ends. Flowers crowded, pink. Stamens 5. Ovary lenticular; style bifid. Nutlet biconvex. Hab. Aquatic in ditches and ponds, very pretty. Singapore, Kalang (Wallich). Johor, Serom; Kota Tinggi. Pahang, Pekan. Malacca, Jus (Goodenough). Selangor, Batu Caves; Dusun Tua; Kwala Lumpur (Curtis). Negri Sembilan, Tampin (Burkill). Perak, Kwala Kangsa; Changkat Jerin (Wray). Penang, Balik Pulau; Pulau Betong (Curtis). Kedah, Bukit Jenum (Haniff). Kelantan, Kota Bharu. Distrib. Indo-Malaya, Australia, China. Native names: Bunga Kowah; Jangut Rimau.

\section{ORDER CXII. ARISTOLOCHIACEÆ.}

Climbing or erect shrubs (rarely herbs). Leaves alternate, entire or lobed. Flowers bisexual, terminal or axillary. Perianth more or less adnate to the top of the ovary, 3-lobed, regular or irregular and tubular; lobes valvate. Stamens 6 or more, adnate to style-column, extrorse. Ovary 4- to 6-celled; ovules numerous; style columnar with 3 or more stigmas. Fruit capsular (or baccate). About 200 species, chiefly tropical (Gamble, Joum. As. Soc. Beng. lxxv. 23).

Erect or creeping shrubs; perianth regular; capsule slender, long.

Stamens in I row; flowers small . . . . I. Apama

Stamens in 2 rows; flowers medium or large : 2. ThorteA

Climbers; perianth irregular, tubular, base inflated; oblong. Capsule oblong

3. Aristolochis

1. APAMA, Lam.

Shrubs or undershrubs usually stellate hairy. Leaves subcoriaceous; nerves and reticulations prominent beneath. Flowers in axillary panicles or racemes. Perianth campanulate, trilobed, valvate. Stamens 6 to $\mathrm{I} 2$ in I row. Ovary inferior, 4-celled; ovules numerous; style short; stigmas 3 or more expanded in a disc or free. Capsule elongate pendulous, 4-angled. Seeds very many, 3-angled. Species 4 or 5, Indo-Malaya, China.

The genus is better known as Bragantia Lour.

Big shrub with small, yellowish flowers

Creeping undershrub; flowers moderate, lilac

(I) A. corymbosa

(2) A. tomentosa 
(I) A. corymbosa Soler. Pfanzenreich, iii. 272; Ganble, l.c. . 25. Bragantia corymbosa Griff. Trans. Linn. Soc. xix. 335.

Shrub about $5 \mathrm{ft}$. tall. Leaves glabrous, $3^{-}$to 5 -nerved from base, sub-coriaceous, ovate or ovate-lanceolate acuminate, base round, very finely reticulate, glabrous above, pubescent beneath, 6 in. long, 2.5 in. wide; petioles $\cdot 2$ in. long. Panicles terminal, lax of few branches about $2 \cdot 25$ in. long, gradually lengthening, pubescent. Flowers yellow or greenish, 'I5 in. across. Stamens 8 to ro. Stigmas in a disc. Capsule ro to I4 in. long, - I5 in. through, 4-keeled. Hab. Common in forests, Malacca, Ayer Panas (Griffith); Bukit Panchur (Derry). Pahang, Raub (Machado). Selangor, Batu Caves; Klang Gates; Kwala Lumpur. Negri Sembilan, Gunong Berimbun (Cantley). Perak, Thaiping; Relau Tujor (Wray); Goping (Kunstler). Province Wellesley, Ulu Kubang (Curtis); Nibong Tebal. Distrib. Sumatra. Native names: Akar Julong Bukit; Akar Surai. Use: Drug used in confinement as diuretic.

(2) A. tomentosa Soler l.c.c.; Gamble, l.c. 25. Bragantia tomentosa Bl. Enum. Pl. Jav. 82; Benn. Horsf. Pl. Jav. Rar. 43, t. II.

A creeping and rooting undershrub forming masses on the ground in forests. Stems ascending up to 6 in. long, hairy. Leaves coriaceous ovate blunt, base round, strongly nerved beneath and reticulate, 4 to 7 in. long, 4 to 5.5 in. wide, tomentose beneath. Racemes I or 2, panicled from near base of stem, close to the ground, lengthening to 2 in., hairy. Flowers 25 in. across, lilac. Stamens 6. Style arms 3 , erect. Capsule $2.5 \mathrm{in}$. long, $\cdot 2$ in. thick, cylindric, beaked. Hab. Common in forests, Pahang, Tahan River; Kwala Tembeling. Perak, Ipoh (Curtis); Temengoh; Penang, Waterfall; Tanjong Sirih; Paya Terobong (Curtis). Lankawi, Telok Woh (Curtis). Kelantan, Kwala Aring (Yapp). Distrib. India, Java, Sumatra, Andamans.

Our form is more tomentose than the Indian and Javan form, hence Hooker's variety lanuginosa.

\section{THOTTEA, Rottb.}

Erect shrubs. Leaves alternate, $3^{-}$to 7 -ribbed; nerves and reticulations prominent. Flowers small, large or very large, purple, in short axillary racemes. Perianth broad, campanulate, 3 -lobed, valvate. Stamens in 2 rows, numerous insert round style column. Ovary inferior, 4-celled elongate; style short, thick, arms 5 to 20 radiating. Capsule elongate 4 -angled, 4 -valved. Seed oblong, 3-angled. Species 5, Malayan.

Perianth tumbler-shaped, very large, pale hairy out-

side, deep purple within ${ }_{\text {Perianth-tube globose; limb broad funnel-shaped, }}$ 75 in. across

(I) T. grandiflora

(2) T. dependens 
Perianth urceolate, $\cdot 25$ in. across, slightly expanded . (3) T. tricornis Perianth small, '25 in. across, campanulate

(4) T. parviflora

(I) T. grandiflora Rottb. Nye. Dansk. Vidensk. Selsk. Skrift. ii. 530, t. 2; Griff. Notule, iv. 346; Ic. Pl. As. t. 530.

An erect shrub about $2 \mathrm{ft}$. tall, villous. Leaves coriaceous ovate-oblong blunt, acute or shortly cuspidate, base cordate, glabrous above, pale hairy pubescent beneath, I4 in. long, 6 in. wide; petioles thick, $\cdot 25$ in. long. Racemes dense, villous, stout, 2 in. long below or in axils of lower leaves. Bracts leafy, persistent, villous. Perianth tumbler-shaped, pendent, 4 in. long, 2 in. across, outside pale hairy, inside deep purple, glabrous. Stamens in 2 series of 15 each. Column of style thick, of 8 to I5 rays. Capsule 6 in. long, pubescent. $\mathrm{Hab}$. Common in woods in the south, Singapore, Reservoir; Kranji; Bukit Timah. Johor, Bukit Murdom (Kelsall); Batu Pahat; Gunong Pantai. Malacca, Batu Tiga; Ayer Panas; Bukit Bruang (Curtis). Negri Sembilan, Tampin. Perak, Ulu Kerling (Kunstler). Native names : Seburut; Kurubut. Use: As a tonic in fever.

(2) T. dependens Klotzsch. Monatsb. Berl. Akad. 589. Lobbia dependens Planch. Hook. Lond. Journ. Bot. vi. I44, $t$. 3 .

Shrub about $3 \mathrm{ft}$. tall, fistular, glabrous. Leaves lanceolate, long-acuminate or oblanceolate, base cuneate, glabrous above, puberulous beneåth; nerves about 6 pairs with reticulations strongly elevate beneath; 9 to I2 in. long, 3 to 6 in. wide; petioles .4 in. long. Racemes simple or branched, drooping from near base, glabrous. Bracts small. Perianth urceolate-globose at base with broad funnel-shaped limb .75 in. long and as wide, dark purple outside, pink inside glabrous. Stamens in 2 rows, outer I6, inner Io. Column of styles thick, rays 6 . Capsule slender, glabrous, about 5 in. long. Hab. In forests, not common, Singapore (Wallich); Sungei Morai. Malacca, Mt. Ophir on Bukit Besar. Dindings, Bruas; Lumut. Perak, Tapah (Wray). Penang, Waterfall; and Pulau Betong (Curtis).

The leaves are very variable in form in this curious plant.

(3) T. tricornis Maing. in Hook. fil. F.B.I. v. 74; Gamble, l.c. 29 .

Shrub 5 or $6 \mathrm{ft}$. tall, pubescent. Leaves coriaceous, oblong acuminate, blunt or acute, glabrous above, pubescent beneath; nerves 5 pairs, reticulations numerous, prominent; 8 in. long, 4 in. wide; petioles thick, $\cdot 25$ in. long. Compound cymes axillary, I in. long, I*5 in. wide, densely hairy; bracts small, lanceolate. Perianth urceolate only slightly open at mouth, lobes short, densely hairy, grey and red, $\cdot 25$ in. long. Stamens in 2 rows, outer I2 to I4, inner 6 to 8 . Style-column with 4 to 6 arms. Capsule pubescent, 5 in. long, 4-angled, $I 7$ in. through. Hab. Rare, forests, Malacca (Maingay). Perak, Goping (Scortechini, Kunstler). 


(4) T. parviflora Ridl. Journ. Roy. As. Soc. S. Br. 57, p. 89.

Shrub $3 \mathrm{ft}$. tall; branches nearly $25 \mathrm{in}$. through, pubescent, hairs stellate. Leaves ovate or obovate acute, base short narrowed, glabrous above, beneath sparsely hairy, 8 in. long, 4 in. wide or less. Racemes .25 in. long, hairy. Flowers crowded opening singly, .25 in. across, violet; pedicels $\cdot 25$ in. long. Perianth $\cdot 25$ in. across, hairy outside, lobes blunt. Stamens I6. Stigma 5-lobed. Fruit slender, 2 in. long, beaked. Hab. Dense forests, local. Perak, Temengoh woods (Ridley).

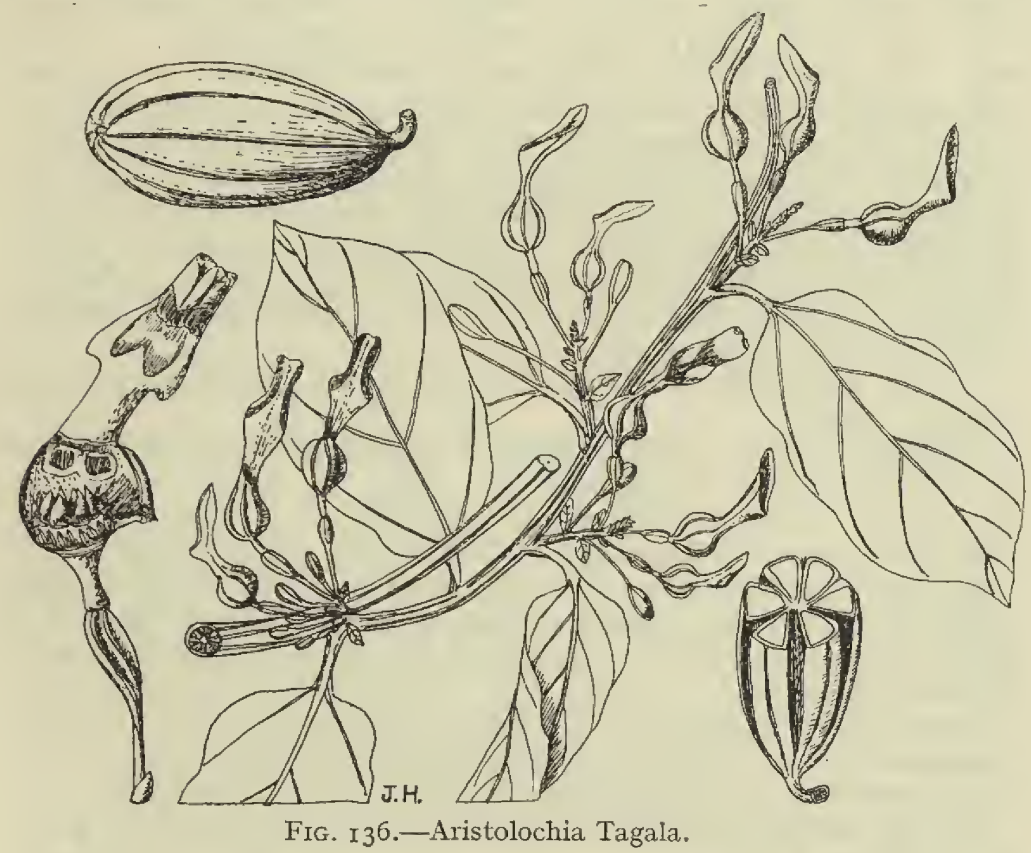

3. ARISTOLOCHIA, Linn.

Climbers (or erect shrubs or herbs). Leaves alternate. Flowers solitary or fascicled, axillary or racemose. Perianth tubular, dilate at base, thin, narrow to an oblique 2-lipped limb. Stamens 6 , adnate to styles, forming a column, cells extrorse. Ovary inferior, 6-celled; ovules many; style with a 3- to 6-lobed stigmatic disc. Capsule 6-valved. Seeds flattened. Species I80, chiefly tropical.

Leaves ovate entire, deep cordate.

Perianth 2 in, long; seeds winged, flat . . . . (I) A. Tagala

Perianth I in. long; seeds not winged, concave - (2) A. minutiflora

Fl.M.P., 3 . 
Leaves trilobed.

Racemes short, bracts small . . $\quad$. * (3) A. ungulifolia Racemes long, bracts large ․ . . . (4) A. Curtisii

(I) A. Tagala Cham. Linnaa, vii. 207; Gamble, l.c. 30. A. Roxburghiana Klotsch, Monatsh. Berl. Akad. 597. (Fig. I36, p. I7).

Slender climber. Leaves entire, glabrous, ovate or ovateoblong acute, cordate, 6 in. long, 4 in. wide; petioles I in. long. Racemes axillary, about $\mathrm{I} \cdot 5$ in. long in flower, lax puberulous. Bracts small leafy, oblong. Perianth 2 in. long, base globose then curved cylindric pale green ending in a 2-lobed funnel, upper lobe very short, lower tongue-shaped, brownish black, $I \cdot 25$ in. long. Capsule pyriform, chartaceous pendulous (like a hanging reversed parachute or basket) I in. long on pedicels as long, splitting pedicel and all half-way into 6 . Seeds flat, triangular, blunt, many 25 in. long. Hab. Not rare, climbing on bushes, Pahang, sandbanks in the river. Malacca, Selandor (Cantley). Negri Sembilan, Bukit Sulu (Cantley). Selangor, Dusun Tua. Perak, Ipoh (Curtis); Ulu Bubong (Kunstler); Tapah (Wray). Penang (Wallich); Waterfall (Curtis). Kelantan, Kota Bharu. Distrib. Indo-Malaya to Philippines.

(2) A. minutiflora Ridl. in Gamble Kew. Bulletin, I9I0, p. 79; Gamble, l.c. $3 \mathrm{I}$.

Slender climber, base woody. Leaves entire, ovate cordate or ovate-lanceolate acuminate, 6 in. long, 2.5 in. wide; petioles $\mathrm{I} \cdot 5$ in. long. Racemes axillary, few-flowered, $\cdot 2$ in. long. Perianth $I$ in. long, very narrow, base globose then a curved tube; limb narrow acuminate, linear. Capsule obovate, I in. long, marked outside by the seeds. Seeds ovate acute, 2 in. long. Hab. Not common on edges of woods, Dindings, Simpit near Lumut. Perak, Thaiping (Kunstler).

var. dolabrata Gamble, l.c. Leaves narrower, 3.75 by $I \cdot 5$ in. Perianth-tube the shape of an oblique pickaxe, French grey, throat dark claret brown. Perak, Thaiping Hills (Wray, Kunstler).

(3) A. ungulifolia Mast. Joum. Limn. Soc. xiv. 494; Hook. fil. Bot. Mag. t. 7424 .

Long slender climber. Leaves 6 to 7 in. long, trilobed, base shortly narrowed, central lobe longest oblong, 5 in. long, 2 in. wide, laterals curved, oblong rounded at tip, 2 in. long, I.5 in. wide; petioles $I .5$ in. long. Racemes short, I in. long, fewflowered. Perianth-base broad, oblong, 75 in. long, violet, tube slender as long, funnel-shaped at mouth, limb spathulate-oblong, .75 in. long, nearly .5 in. wide, violet. Hab. Rare in long grass; the largest flowered species here. Singapore, Jurong in a grassy swamp (Ridley). Distrib. Borneo, Sumatra.

(4) A. Curtisii Gamble, Kew Bulletin, I9ro, p. 78 ; Journ. As. Soc. Beng. l.c. 32 .

Slender climber. Leaves chartaceous, digitate, 3-lobed, middle 
lobe oblong-lanceolate, side lobes broad spathulate narrowed at base, whole leaf 5 to $8 \mathrm{in}$. long, lobes 2 to 3 in. wide or less, base of leaf cuneate; petioles 2 in. long. Racemes several, 3 in. long, with amplexicaul bracts 25 in. long. Perianth puberulous, base oblong inflate, .75 in. long, tube narrow, .5 in. long, limb linear acuminate, "75 in. long, "velvety dark blue (claret-colour) and pink" (Kunstler). Capsule oblong blunt with 6 low keels. Hab. Penang, Waterfall (Curtis, Kunstler); Telok Bahang. A very local plant.

\section{ORDER CXIII. CY'TINACEÆ.}

Parasitic fleshy herbs, leafless or with a number of scales on the stem. Flowers solitary (or a number in a spike) unisexual or bisexual, fleshy campanulate; tube adnate to ovary, above of 3 to I2 lobes. Stamens usually innumerable; anthers sessile on a central column. Ovary inferior or half superior, unilocular or with many placentas. Stigma I, cup-shaped or discoid or many on numerous styles. Fruit fleshy, unilocular. Seeds minute. (Ridley, Journ. As. Soc. Beng. lxxv. 393.) About 25 species in temperate and tropical regions.

Flowers large, solitary, lobes 5 ; stigmas many . . I. RAFFLESIA

Flowers medium, solitary, lobes numerous; stigma I . 2. Brugmansia

1. RAfFlesia, R. Br.

Large fleshy plants, parasitic on woody climbers, stemless with ovate bracts on the base of the flower. Perianth very large fleshy, dull red fotid, tube hemispheric, limb 5-lobed, lobes blunt, glabrous, with a raised corona in mouth. Genital column short, thick with a single or double ring round it; top flat with stylelike processes. Male with a single row of anthers surrounding the neck; anthers opening by one pore. Female with abortive stamens and styliform processes hairy at top. Species about 6, Malayan.

(I) R. Hasseltii Suringar Act. Soc. Reg. I879; Veth, MiddenSumatra, iv., Flora, ii. t. I, 2.

Perianth I8 in. across, tube broad, campanulate, covered inside with short-branched processes, lobes Indian red with dull white irregular raised blotches; anthers in male 20. Styliform processes I5 to I7, white. Hab. In forests on big lianes on the ground, it has a faint scent of carrion. Perak, Thaiping Hill (Cantley, Wray); Temengoh (Ridley). Distrib. Sumatra. Native name: Kerubut. Use: As an astringent drug.

\section{BRUGMANSIA, Bl.}

Uni- or bi-sexual parasites on woody creepers, stemless; bracts ovate. Perianth fleshy coriaceous, tube campanulate; lobes 5 or 6 , splitting again when expanded, inside hairy. Genital column 
cylindric; anthers numerous, opening by 2 pores. Stigma large, hairy, cup-shaped. Ovary unilocular. Species 2, I Japanese, I Malayan.

(I) B. Lowii Becc. Atti. Soc. Ital. Sc. Nat. xi. 198; Farecett, Trans. Lim. Soc. ii. 244, Pl. 36.

Unisexual, dark brownish red, about 3 in. tall and 6 in. across, dark brownish red with long reddish hair inside, lobes I4 to I6, acuminate acute. $H a b$. In lowland woods growing on prostrate stems of vines. Rare. Pahang, Kwala Tembeling (Ridley). Distrib. Sumatra, Borneo.

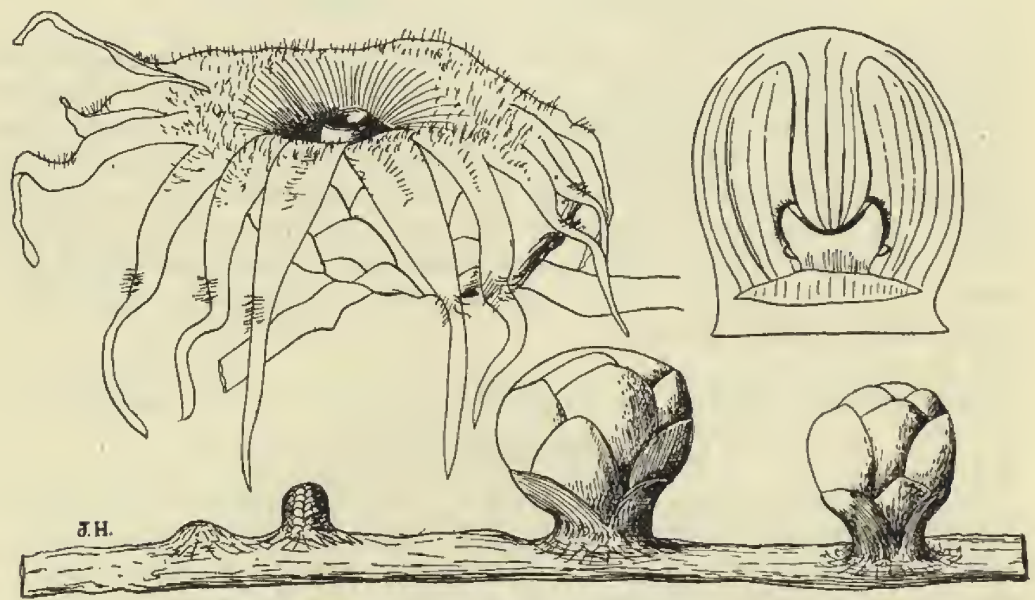

FIG. I37.-Brugmansia Lowii.

\section{ORDER CXIV. NEPENTHACEÆ.}

Climbing shrubs. Leaves alternate, sub-coriaceous, base oblong then a tendril-like midrib, ending in a pitcher usually with 2 ciliate wings, and the mouth corrugated (peristome) and a terminal oval or round lid at first closing the mouth, pitcher glandular inside and often on lid, usually containing water, and forming an insect trap. Flowers small, green, brown or red, in cymes panicled or on a simple raceme, unisexual, regular. Sepals 4 , in pairs. Stamens usually 8 to $\mathrm{x} z$, rarely 4 to 6 , or indefinite in a staminal column. Pistil of 4 syncarpous carpels. Ovary $3^{-}$to 4 -celled; ovules many; style short or 0 . Capsule sub-woody. Seeds small with a bicaudate filiform wing. (Macfarlane, Joum. As. Soc. Beng. 1xxv. 279). One genus Nepenthes. Species about 70, Madagascar, Ceylon, India, Australia, Polynesia I species each, the rest Malay Peninsula and islands. The pitcher plants are called Priok Kra 
(Ape's cups) by Malays. Use: The stems are used for binding hedges.

Leaves not distinctly petioled, not decurrent on stem.

Inflorescences of panicled cymes, pitcher-lid very narrow

(I) N. ampullaria

Inflorescence racemose; pedicel $I^{-}$to $3^{-}$ flowered, lid wide, dorsal spine simple.

Pitchers elongate, a white ring below peristome.

Pitchers elongate, slender, fuscous, black .

Pitchers elongate, slender, white often rose spotted

Pitchers elongate dorsal spine trifid, hairy .

Pitchers large red with spiny neck, lid glabrous

Pitchers large, green or spotted red, lid hairy

Leaves decurrent.

Pitchers green, narrow cylindric, peristome rigid

Leaves distinctly petiolate.

Pitchers large, goblet and globular in shape.

Pitchers cylindric

(2) N. albo-marginata

(3) N. gracillima

(4) N. alba

(5) N. ramispina

(6) N. sanguinea

(7) N. Macfarlanei

(8) N. gracilis

(9) N. Rafflesiana

(Io) N. phyllamphora

(I) N. ampullaria Jack. Comp. Bot. Mag. i. 27x; Hook. f. Bot. Mag. t. 5 Iog; Macfarlane, l.c. 280.

Tall climber, tomentose in young parts, base creeping and bearing large whorls of small pitchers buried in the ground, above pitchers whorled on stem and these pitchers without laminas; above this are pitchers borne on a petiolate amplexicaule lamina oblong, narrowed to base, 5 to 7 in. long, I.75 in. wide, uppermost with no pitcher but a tendril 2 to 3 in. long. Pitchers globose, 4 in. long, 3 in. through or less, green spotted dark red; peristome .5 in. wide, finely and closely ribbed, wings .25 in. wide, ciliate; petioles of the lowest pitchers hairy; lid small, narrow, 2 in. long, .25 in. wide, green. Flowers in a dense tomentose panicle of cymes 8 in. long, 2 in. through, green. Stamens red. Capsule $I$ in. long. $H a b$. In wet places, low country. Singapore (Jack), Jurong; Garden Jungle, etc. Johor Town. Pahang, Kwantan (Durnford). Malacca, Brisu (Derry); Ayer Panas (Griffith). Selangor, Gunong Mengkuang Lebah (Robinson). Rantau Panjang (Kloss). Perak, Thaiping (Kunstler); Ipoh (Curtis). Distrib. Sumatra, N. Guinea.

(2) N. albo-marginata Lobb. Gard. Chron. 1849, p. 580 ; Macfarlane, l.c. $28 \mathrm{I}$.

Slender species about $6 \mathrm{ft}$. tall or less. Lamina of leaf narrowed to both ends, $8 \mathrm{in}$. long, I in. wide; pitcher cylindric narrowed to base and upcurved there, 5 in. long, I.5 in. through, green spotted red; peristome very narrow, finely ribbed, below it a white band; lid, oblong, rounded, I.5 in. long, I in. wide or less, green, spotted red. Raceme 8 in. long, glabrous; flowers rather scattered; 
pedicels slender, lower ones 2 -flowered, $\cdot 5$ in. long; flowers $I_{5}$ in. across, tomentose outside. Capsule narrowed to a truncate top, I.25 in. long. Hab. Mountainous places. Malacca, Mt. Ophir (Derry, Hullett). Perak, Bujong Malacca. Penang Hill at $2500 \mathrm{ft}$. altitude, common. Kedah Peak. Distrib. Sumatra, Borneo.

(3) N. gracillima Ridl. Journ. Linn. Soc. xxxviii. 320; Macfarlane, l.c. 282.

Slender climber. Leaves linear, sessile, coriaceous, 2 in. long, .2 in. wide; tendrils slender, 4 in. long; pitchers cylindric, 3 in. long, dark blackish purple; peristome narrow, corrugate; lid orbicular, $\cdot 5$ in. long; wings very low, no cilia. Raceme 4 in. long, base 3 in. long, nude, pubescent at top; pedicels at base 2-flowered above I-flowered, $I$ in. Iong. Perianth $I$ in. across, glabrous. Capsule $\cdot 5$ in. long, rather thick in the middle, narrowed to both ends. Hab. Mountains, Pahang, Gunong Tahan (Ridley).

var. major. Leaves oblong, 4 in. long, I in. wide; pitchers 4.5 in. long, I in. through; mouth I. 5 in. across. Racemes longer and laxer. Some pitchers with fine cilia on the ridges. Selangor, Gunong Semangkok; Menuang Gasing (Kloss). Pahang, Telom (Ridley).

(4) N. alba Ridl. N. Singalana Macfarlane, l.c. 282 (not of Beccari). N. Bongso Ridl. Journ. Limn. Soc. xxxviii. 320 (not of Korthals).

Fairly stout, scrambling, with a stout root. Leaves coriaceous, sessile, amplexicaul narrowed at top to tendril, 6 in. long, I in. wide; tendril about 3 in. long; pitcher cylindric narrowed to base, 3.5 in. through, ivory white sometimes spotted with rose pink in the mouth and.lid, rarely canary yellow; wings and cilia o; peristome rather narrow corrugate; lid orbicular, I in. long and wide. Raceme 7 or 8 in. long, rather slender, red pubescent, especially above. Flowers mostly in pairs; pedicels $\cdot 25$ in. long. Perianth I5 $_{5}$ in. across, pubescent. Staminal column longer than sepals. Capsule $\cdot 5$ in. long. $H a b$. On bare rocks and among bushes, Pahang, Gunong Tahan, at 5000 to $7000 \mathrm{ft}$. altitude (Ridley).

(5) N. ramispina Ridl. Journ. F.M.S. Mus, iv. 58

Stem woody above rather stout. Leaves elliptic-lanceolate amplexicaul, coriaceous glabrous except midrib pubescent, 3.5 to 5 in. long, $I$ in. wide; tendril 2 to 8 in. long, pubescent; pitcher cylindric, narrowed at base, 6 to 8 in. long, I in. through, pubescent; wings low with or without cilia; peristome narrowed, ridges close, very small, running up to a distinct neck; lid orbicular cordate, I. 5 in. across, spur at the back forked with 3 or 4 forked processes pubescent. Racemes slender, 6 in. long, pubescent. Flowers solitary on pedicels $\cdot 3$ in. long. Sepals $\cdot I$ in. long, back pubescent edged hairy. Staminal column as long, pubescent. Capsule 5 in. long, fusiform pubescent. Hab. Mountains 4000 to 
$5000 \mathrm{ft}$. altitude. Pahang, Telom. Selangor, Semangkok Hills; Menuang Gasing (Kloss); Mengkuang Lebah (Robinson).

(6) N. sanguinea Lindl. Gard. Chron. I849, p. 580 , Fig. 2 ; Macfarlane, l.c. 283 .

Scandent, stout. Leaves lanceolate-oblong, sessile, amplexicaul, 4 to 5 nerves; lower pitchers 7 to 8 in. long, 3 in. through, cylindric, ventricose; wings large ciliate, green and red or all deep red; upper pitchers cylindric or funnel-shaped without cilia

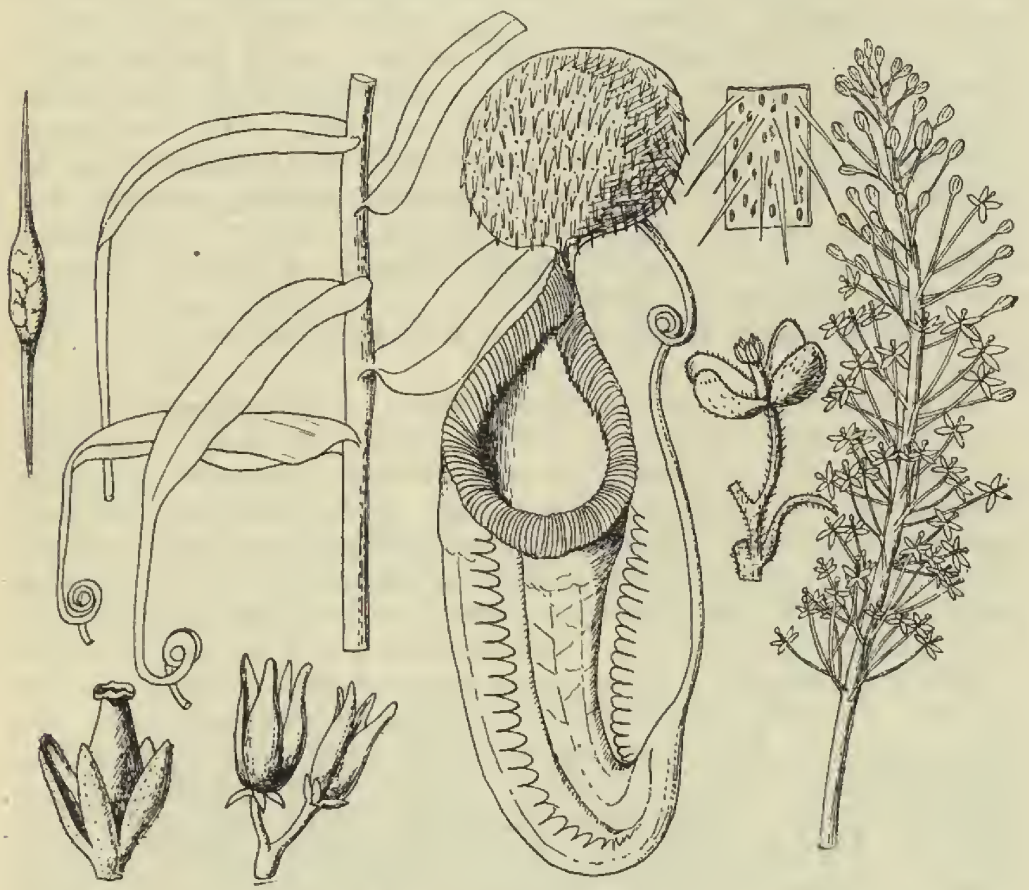

Fig. 138.-Nepenthes Macfarlanei.

on the edges, peristome narrowed upwards behind to a point, very broad and closely ridged; lid oblong-ovate, blunt, 2 in. long, $\mathrm{I} \cdot 5$ in. wide, glaucous, purplish. Racemes I 8 in. long. Flowers scattered, very numerous; pedicels slender, .5 in. long. Perianth - I5 in. across, staminal column as long as sepals. Capsule I in. long. Hab. Mountains at 4000 to $5000 \mathrm{ft}$. altitude. Malacca, Mt. Ophir. Pahang, Kwala Terbang (Barnes); Telom. Selangor, Bukit Hitam (Kelsall). Perak, Gunong Bubu (Murton); Thaiping Hills; Gunong Batu Putih (Kunstler); Bujong Malacca (Curtis). Distrib. Borneo. The largest-pitchered species we have. 
(7) N. Macfarlanei Hemsl. Proc. Limn. Soc. I905, I2; Ic. Pl. 28I4, 28I5; Macfarlane, l.c. 284. (Fig. I38, p. 23).

A stout climber but often dwarf and epiphytic, red hairy when young. Leaves oblong, 5 in. long, $I \cdot 25$ in. wide, sessile, half amplexicaul; lower pitchers ventricose, 8 in. long, 3 in. or more through, wings low ciliate, apple green, or spotted red to deep red, peristome broad running up to a point behind strongly spiny, ridges numerous; lid ọblong-ovate, rounded, 2.5 to 3 in. long, 2 to 3 in. wide, hairy; upper pitchers cylindric not ventricose, smaller. Racemes 5 to Io in. long, dense, very many-flowered, red hairy. Flowers orange or red, I to 3 on a pedicel, hairy. Sepals $\cdot 2$ in. across, broad hairy. Stamen-column very short. Capsule dilate in centre, narrowed to both ends, I in. long. $H a b$. Mountain at $4000 \mathrm{ft}$. altitude, often terrestrial, the pitchers embedded in moss, Pahang, Gunong Tahan. Selangor, Semangkok at $4000 \mathrm{ft}$. altitude. Perak, Gunong Bubu (Murton, Wray); Gunong Batu Putih (Wray); Gunong Kerbau (Robinson). A beautiful species, easily recognised by its hairy lid.

(8) N. gracilis Korth, Verh. Nat. Gesch. Bot. 22, t. I; Macfarlane, l.c. 285 .

Slender climber; stem green and purple. Leaves linear to elliptic, herbaceous, sessile decurrent shortly acute, 5 in. long, I in. wide; tendrils slender, 3 in. long; pitchers usually pale green sometimes reddish, cylindric, rather narrow, lower ones somewhat ventricose, upper narrow; wings occasionally shortly ciliate, usually not winged, 3.5 in. long, I in. through; peristome very narrow and finely inconspicuously ridged shortly narrowed to lid; lid orbicular with large glands near the base. Inflorescence 6 to 8 in. long; pedicels I- (rarely 2-)flowered. Sepals tomentose outside. Staminal column shorter. Capsule thick, I.25 in. long, long-narrowed to base, shortly to top. Hab. Common in thickets, low country, Singapore, Bukit Timah; Holland Road; Changi. Johor, Tebing Tinggi. Malacca (Jack); Ayer Panas (Griffith); Bukit Bruang (Curtis). Pahang, Pekan. Dindings, Pulau Sembilan (Curtis). Perak, Lahat; Thaiping (Wray). Penang, Batu Feringhi (Curtis). Kedah Peak (Robinson). Distrib. Malay isles.

var. arenaria Ridl., is a non-climbing tufted plant in sandhills at Pekan.

(9) N. Rafflesiana Jack, Comp. Bot. Mag. i. 270; Macfarlane, l.c. 286 ; Bot. Mag. t. 4285 .

Stout climber, upper parts tomentose. Leaves sub-coriaceous, petioled; petioles stout, 4 in. long, blade oblong narrowed at both ends, 6 to ro in. long, 2 to 4 in. wide; tendril stout, I2 in. long; pitchers of two forms, lower ones broad ventricose, 5 in. long, 3 in. through, base round, green, more or less thickly blotched red, wings I in. wide, ciliate; peristome thick, strongly ribbed, narrowed up to lid spiny; lid oblong orbicular, 3 in. long and wide, green 
spotted purple red; upper pitchers funnel-shaped, narrowed at base, 8 to 9 in. long, 2 to 3 in. wide at top, peristome and lid as in lower ones. Raceme 8 to I2 in. tall, stout, red-tomentose; flowers very numerous, dense, 5 in. across, green or purplish red, very tomentose on back; pedicels stout, red-tomentose. Staminal column as long. Capsules I in. long, tomentose at first. Hab. Wet spots on edges of woods; common in south, up to $3000 \mathrm{ft}$. altitude. Singapore (Jack) ; Bukit Timah ; Kranji. Johor, Gunong Pulai and Gunong Pantai. Pahang, Pekan. Malacca, Mt. Ophir (all collectors, very large here); Merlimau (Cantley). Perak, Maxwell's Hill (Fox). Distrib. Bangka, Borneo.

(ro) N. phyllamphora Willd. Sp. Pl. iv. 2, 874; Macfarlane, l.c. 287 .

Stout climber. Leaves coriaceous, petioled; petioles 2 to 3 in. long, winged to base; leaf 6 to 8 in. long, $2 \cdot 5$ to 3 in. wide, oblong, shortly narrowed at both ends; tendril rather slender 3 in. long or more; pitchers cylindric, slightly dilate at base green, 5 in. long, I.5 in. through, wings hardly elevate not ciliate or distinctly so; peristome rather narrow only slightly narrowed upwards to lid, red, ridges very fine; lid orbicular oblong, $I \cdot 25$ in. long, $\cdot I$ in. wide. Racemes thick, 4 in. long on a long stout peduncle ro in: long, pubescent. Pedicels $\cdot 25$ in. long. Perianth $\cdot 4$ in. across, tomentose outside, red. Capsule 75 in. long, broad and thick. $H a b$. Not very common in open places, Singapore, Changi (Wallich); Jurong. Perak, Ulu Bubong (Kunstler). Province Wellesley, Tasek Gelugur (Curtis). Penang, Telok Bahang; Mt. Elvira (Curtis). Lankawi (Haniff). Distrib. Cochinchina,

\section{ORDER CXV. PIPERACEÆ.}

Herbs or shrublets, often aromatic. Leaves simple herbaceous or fleshy. Flowers minute in spikes. Perianth o. Stamens I to Io. Ovary I-celled; I orthotropous ovule. Fruit indehiscent bristly or a drupe. Species 2000, tropics (Cas. DeCandolle, Journ. As. Soc. Beng. Ixxv. 288.)

Fruit dry with hooked bristles . . . . . I. ZIPPELIA

Fruit minute; stamens 2 ; stipules o, erect herbs . . 2. PEPEROMia

Fruit pulpy; stamens 2 to 6 ; stipulate, often climbing - 3. PIPER

\section{ZIPPELIA, Bl.}

Erect herb rhizomatous. Leaves oblique cordate; petioles dilated into amplexicaul stipules. Flowers racemose, distant, small. Stamens 6. Ovary muricate. Fruit dry, globose with numerous hooked bristles. Species $I$.

(I) Z. lappacea Bl. R. \& S. Syst. viii. I6I4; Bennett, Pl. Jav. Rar. 76, t. I6. Piper lappaceum C. DC. Fl. Indo-Ch. v. 68; Journ. As. Soc. Beng. l.c. 339. 
Herb about I ft. tall ; stems from rhizome unbranched. Leaves alternate, ovate sub-acute, base unequally cordate; nerves 7 , radiating from base; 4 in. long, 2.5 in. wide; petioles $I$ in. long. Racemes terminal, slender, 5 in. tall, base nude, above I 2 or more distant flowers on pedicels nearly $\cdot I$ in. long. Fruit white, $I$ in. through, Hab. Local in forests, Perak, Ulu Batang Padang; Kwala Dipang (Ridley). Distrib: Tonkin, Java.

\section{PEPEROMIA, Ruiz and Pavon.}

Succulent small herbs often epiphytic or on rocks. Leaves exstipulate, alternate or opposite or whorled. Spikes very slender; peduncled, axillary or terminal. Bracts minute, peltate. Flowers sessile or nearly sunk in a depression of rachis. Stamens 2; anthers extrorse, 2-celled. Ovary free; stigma globular. Drupe minute. Species 800, all tropics.

Leaves opposite or in threes and fours.

Stem and leaves pubescent.

Stigma below top of ovary; leaf elliptic . . ( (1) P. dindigulensis

Stigma terminal; leaf obovate . . . (2) P. Wrayi

Stem and leaves glabrous.

Stigma terminal; leaf obovate . . . (3) P. portulacoides

Leaves alternate.

Leaves glabrous.

Stigma oblique below top of ovary . . . (4) P. Maxwellana

Stigma terminal.

Leaves fleshy, quite round .

Leaves densely hairy

Leaves thin, ovate (weed)

(I) P. dindigulensis Miq. Syst. Pip. I22; Ill. Pip. I9, t. I3; C. DC. Journ. As. Soc. Beng. l.c. 290.

Erect, puberulous or not, I ft. tall, succulent, sometimes branched. Leaves opposite, below ternate, above elliptic to obovate-elliptic, pubescent, base narrowed or round, 5 to I.5 in. long; petioles $\cdot 2$ to $\cdot 4$ in. long. Spikes very slender, 3 to 4 in. long, glabrous on a shorter peduncle pubescent. Stigma oblique a little below the top of ovary. Hab. Limestone rocks, Pahang, Kota Glanggi Caves. Selangor, Batu Caves (Ridley). Distrib. S. India.

(2) P. Wrayi C. DC. Rec. Bot.Surv. Ind. vi. I; Journ. As. Soc. Beng. l.c. 290.

Stem decumbent, rooting puberulous; branches erect. Leaves opposite, puberulous on the edge on upper side ovate or rounded obovate, base acute, $\cdot 75$ in. long, $\cdot 3$ to $\cdot 4$ in. wide; petioles densely puberulous. Peduncles terminal. Spikes glabrous. Stigma terminal. Hab. Very rare on dead trees in forests, Perak, Batang Padang Valley (Wray).

(3) P. portulacoides A. Dietr. Sp. Pl, ed. vi. I, I72; C. DC. Journ. As. Soc. Beng l.c. 29I ; Wight, Icones, t. I922.

Succulent, glabrous herb. Leaves opposite, upper ones ternate 
obovate to elliptic rhomboid, base acute, I in. long, 75 in. across ; petioles $\cdot \mathrm{I}_{2}$ in. long. Peduncles $\cdot 5$ in. long; spikes slender, 2.5 in. long. Bracts round with a very short pedicel. Ovary turbinate; stigma terminal. Hab. Rare on limestone rocks, Selangor, Batu Caves (Ridley). Distrib. Mascarenes, S. India.

(4) P. Maxwellana C. DC. Rec. Ind. Bol. Survey, vi. I; Journ. As. Soc. Beng. l.c. 29 I.

Stem decumbent rooting at nodes. Leaves alternate subcoriaceous, elliptic blunt, base cuneate, edges at top minutely ciliate, $\mathrm{I} \cdot 5$ in. long, $\cdot 75$ in. wide; petioles $\cdot 25$ in. long. Peduncles terminal and axillary, 3 to $\cdot 4$ in. long. Spikes $\cdot 25$ in. long. Bracts orbicular, sub-sessile. Ovary obovate; stigma glabrous oblique. Hab. Perak, Maxwell's Hill, Thaiping Hills, in mountain forest (Ridley).

(5) P. malaccensis Ridl. Kew Bulletin, I895, p. I86; C. DC. Journ. As. Soc. Beng. l.c. $29 \mathrm{I}$.

Succulent herb, diffuse prostrate. Leaves ovate cordate, round, I.5 in. long, I in. wide, dark green to coppery brown, beneath silvery; petioles 5 in. long. Spikes solitary, terminal, $\mathrm{I} \cdot 5 \mathrm{in.}$ long; flowers sunk in pits. Bracts cuneate oblong rounded. Ovary globose; stigma penicillate, purple. Hab. Rare on rocks, Malacca, Batu Tiga (Derry).

(6) P. pellucida Korth, H.B.K. Nov. Gen. i. 64. Piper pellucidum Linn. Sp. Pl. i. I63. Peperomia exigua Miq. Syst. Pip. 77.

Annual branched, glabrous, bright green, up to 8 in. tall. Leaves alternate ovate or deltoid, cordate, thin $\cdot 75 \mathrm{in}$. long, $\cdot 5 \mathrm{in}$. wide; petioles $\cdot I$ in. long. Spikes very slender, $I \cdot 5$ in. long. Bracts round, sub-sessile. Ovary globose. Hab. Naturalised in gardens and waste ground. Common over nearly all the tropics, native of S. America. Singapore, Perak, Tringganu, Penang.

(7) P. kotana C. DC. Rec. Bot. Surv. Ind. vi. 2.

Creeping and rooting slender herb all hairy, stem and leaves both sides, about $\mathrm{I} \mathrm{ft}$. long, ascending to $8 \mathrm{in}$. tall. Leaves alternate, round, obovate, base narrowed acute, $\cdot 5$ to $I$ in. long, $\cdot 4$ to $\cdot 5$ in. wide; petioles $\cdot 2$ in. long. Peduncles $\cdot 5$ in. long; spikes very slender, 2 in. long. Bracts obovate sub-sessile. Stigma obliquely set. Hab. Local on rocks, Pahang, Kota Glanggi (Ridley). Johor, Pulau Tiuman, Juara Bay (Burkill).

\section{PIPER, Linn.}

Aromatic shrubs erect or climbing, rarely herbaceous; nodes dilated. Leaves with stipules on the margin of the petiole sheath. Spikes unisexual rarely bisexual, peduncled opposite a leaf. Flowers unisexual, sessile. Stamens 2 , rarely 3 to 4 , hypogynous; anthers usually 4-valvate. Bracts orbicular or oblong, often stalked. Ovary free or embedded in rachis; stigmas 2 to 6. Drupes globose or oblong or ellipsoid, pulpy-red or yellow, free 
sessile, stalked or more or less connate. Species I200, all tropical countries. In many cases both sexes are not known and the position of many, therefore, uncertain.

Section I. Muldera. Spikes solitary. Males sunk in a fleshy stipitate or sessile receptacle formed of the enlarged bract, distant. Drupe sessile, stigma sessile. Climber.

Section 2. Cubeba. Spikes solitary. Flowers crowded. Female bracts peltate. Fruit pedicelled. Climbers or erect.

Section 3. Chavica. Spikes solitary. Bracts orbicular peltate. Fruit very small, crowded sessile in dense cylindric or oblong spikes.

Section 4. Pseudochavica. Spikes solitary. Bracts peltate, orbicular. Fruits forming a long interrupted spike, much larger than in Chavica, pulpy separate, sessile. Erect or climbers.

Section 5. Eu-piper. Spikes solitary. Bracts adnate to rachis or with free margins. Fruit usually larger than previous sections, sessile in loose interrupted spike.

Section 6. Heckeria. Spikes several, umbelled flowers bisexual, erect shrub; leaves very large. Fruit very small.

Piper. §I. Muldeva. Climbers, usually very long. Spikes solitary. Flowers unisexual, often distant. Males sunk in a fleshy stipitate or sessile receptacle formed of the bracts. Drupe sessile; stigma sessile.

These generally creep up trees to a great height, flowering only and rarely at the top. The upper leaves are often different from the lower ones.

Receptacle glabrous outside, pubescent inside, sessile, ovary I.

Stamens 5

Stamens 8

Receptacle round; leaves elliptic-lanceolate

Receptacle round; leaves ovate, very fleshy

Receptacle pubescent inside and out.

Receptacle sessile, 2 -lipped with 3 to 4 ovaries

Receptacle stipitate, distant.

Receptacle round, 3 to 5 stamens .

Receptacle 2 -lipped, elliptic, 2 stamens :

Receptacle 2-lipped, reniform, 8 stamens

$\S 2$. Cubeba. Climbers or erect. Spikes solitary; flowers crowded.

Female flowers large bracts peltate. Fruit distinctly pedicelled.

Erect shrubby plants, hairy.

Leaves ovate, 5 in. wide, base equilateral.

Pedicel longer than fruit

Pedicel very short

Leaves all oblong, base unequally bilobed. Adult leaves glabrous; spikes 2 in. long . Adult leaves hairy.

Spikes II in. long

Spikes 2 in. long

Climbers, usually quite glabrous.

Stem very stout; leaves coriaceous. Leaves 6 to 8 in. by 3 to 4 in.

Leaves 3 by 2.75 in.
(I) P. pentandrum

(2) P. flavimarginatum

(3) P. firmum

(4) P. pachyphyllum

(5) P. polygamum

(6) P. Maingayi

(7) P. rarispicum

(8) P. schizonephros

um


Stems slender; leaves membranous.

Leaves oblong-ovate, base round

Leaves elliptic-ovate, base round

Leaves oblong-elliptic, base acute.

Female spike $1 \cdot 6$ in. long

Female spike $I_{4} 4$ in. long

Female spike 3 in. long

Female spike 4 in. long

Female spike 8 in. long

Leaves lanceolate acute at base

Leaves oblong-elliptic, base rounded unequal.

Leaf whitish beneath; bracts of female flowers obovate bracts oblong

Leaf not whitish beneath; bracts oblong rounded .

Leaves ovate acuminate, base acute.

Fruit spike 1.5 in. long .

Fruit spike 8 in. long

Leaves ovate acuminate, glabrous, base round, cordate

Stem and leaves pubescent

Leaves ovate, base round. Stems and leaves

(30) P. lanatum
§3. Chavica. Spikes solitary; bracts orbicular, peltate. Fruit very small, immersed in dense cylindric or oblong spikes, with little pulp.

Spikes 6 in. long or more, slender .

Stout climbing plant; stems hairy.

Glabrous, slender climbers.

Midrib of leaves hairy . . . (32) P. ramipilum

Leaves quite glabrous _ . . (33) P. miniatum

Spikes stout, cylindric, 3 in. long.

Leaves oblong, base rounded . . . (34) P. chaba

Leaves ovate-cordate, thinner . . . (35) P. Betle

Spike 3.5 in. long; leaves oblong-ovate, base round

Spike 5 in. long, cylindric, straight; leaves ovate-cordate; creeping herb

(36) $\mathbf{P}$. argyrites

(37) P. sarmentosum

§ 4. Pseudochavica. Spikes solitary. Bracts peltate or orbicular. Fruit in a long or short fleshy spike, globose or oblong sessile. Drupes partly immersed in rachis.

Erect plants.

Fruit-spikes 4 to 6 in. long, straight

Fruit-spikes $I$ in. long, curled into a circle .

Fruit-spikes $I^{\cdot} 5$ in. long, straight; styles short

Fruit-spikes I in. long, straight; styles long

Fruit-spikes 5 in. long, sub-globose; styles

Climbers.

$$
\text { long . . . . }
$$

(38) P. bøhmeriæfolium
(39) P. cyrtostachys

(40) P. oreophilum

(4I) P. stylosum

(42) P. penangense

(43) P. rufispicum

(44) P. minutistigmum

Fruit partly embedded, free part velvety
5. Eu-piper. Erect or climbing. Fruits separate usually in long solitary

Fruit glabrous, deeply embedded; style short, 4 -angled at top

§5. Eu-piper. Erect or climbing. Fruits separate usually in long solitary spikes.

Erect, glabrous plants.

Nerves 2 from base and 2 from midrib . (46) P. Kurzii

Nerves 8,2 from base and 4 from midrib : (47) P. erecticaule 
Leaves hairy beneath . . . . (48) P. subrubrispicum Climbers

Leaves velvety hairy $: \quad: \quad: \quad$ (49) P. velutinervium

Flowers close together, not whorled.

Leaves sparsely hairy, ovate . . . (50) P. acre

Branchlets puberulous, leaves ovatelanceolate alternate.

(5I) P. puberulirameum

Leaves puberulous beneath elliptic .

Plants quite glabrous.

Leaves ovate-cordate, spotted pink

Leaves ovate, base round equilateral, membranous

Leaves ovate, base round equilateral, subcoriaceous

Leaves ovate, base inæquilateral :

Leaves oblong or elliptic.

Leaf-bases equilateral, 5- to 7-nerved. Male spike 67 in. long

Male spike 75 in. long; nerves 5 to 7 Male spike 2.7 in. long; nerves 7 . Male spike $2 \cdot 7$ in. long; nerves 7 . Fruit-spike 4 in, long; nerves 5 . Fruit-spike 5 in. long Female spike 15.7 in. long; nerves 7 Leaves elliptic-oblong, nerves Io pairs

Leaf-bases unequal.

Rachis glabrous

Rachis hairy.

Leaf oblong-ovate, base round .

Leaf oblong-ovate base narrowed .

Leaf-base narrowed.

Leaves elliptic-lanceolate acuminate, 6-nerved

Leaves elliptic-lanceolate acuminate, 7-nerved

Leaves lanceolate : $: \quad \dot{*}$.

Leaves elliptic-oblong, long acuminate

Leaves oblong-elliptic

Spikes very long, slender; flowers in whorls.

Bracts very small glabrous

Bracts larger hairy

\$6. Heckevia. Erect shrub; leaves very large, spikes fascicled

(52) P. kotanum

(53) P. porphyrophyllum

(54) P. semangkoanum

(55) P. subfragile

(56) P. gymnocladum
(57) P. curtipetiolum
(58) P. magnibaccum
(59) P. flavispicum
(6o) P. obovantherum
(6I) P. subpenninerve
(62) P. longamentum
(63) P. conibaccum
(64) P. subsessililimbum
(65) P. rufibracteatum
(66) P. filipes
(67) P. flavibaccum

\section{§ I. Muldera.}

(68) P. gymnophylium

(69) P. eucalyptolimbum

(7o) P. lonchites

(7) P. Kunstleri

(72) P. Scortechinii

(I) P. pentandrum C.DC. Rec. Bot. Surv. Ind. vi. 25 ; Journ. As. Soc. Beng. l.c. 334 .

Glabrous. Leaves coriaceous, elliptic-lanceolate, acute acuminate, base equilateral acute, 7 -nerved, 4 to 5 in. long, $I$ to $I \cdot 5$ in. wide, lower ones $5 \cdot 25$ in. long, $3 \cdot 25$ in. wide; petioles $\cdot 5$ in. long. Peduncles glabrous as long as petiole. Male spikes $\mathrm{I} \cdot 5$ in. long, thick, densely flowered; rachis glandular asperulate when young, at length glabrous; receptacles sessile condensed elliptic, 2-lipped, hairy inside. Stamens 5, rarely 6. Female spikes thicker. Ovary free, ovate; stigmas 3. Berry globose, I in. through. Hab. Perak, upper (Wray, Scortechini). 
var. magnifolium. Leaves 5 in. long, 4.5 in. wide. Perak (Scortechini).

(2) P. flavimarginatum C. DC. Rec. Bot. Surv. Ind. vi. 26.

A stout woody climber with quite ovate leaves, sometimes round acute, base acute inæquilateral; nerves 3 pairs incurved, nervules numerous, conspicuous, fine, all inarching; 3 to 5 in. long, 3.5 in. wide; petioles 5 to 3 in. long. Peduncles glabrous, I in. long. Spikes glabrous, 4 in. long. Flowers rather distant. Receptacles sub-sessile, loose elliptic, 2-lipped. Stamens 8, anthers ovate, 4 -valved, shorter than the oblong filament. Female flowers and fruit unknown. Hab. Forests; climbing on trees, Singapore, Chan Chu Kang; Bukit Timah (Ridley); very common but rarely flowering.

(3) P. firmum C. DC. Prod. xvi. I. 242; Journ. As. Soc, Beng. l.c. 335. Muldera firma Miq. Ann. Mus. Bot. Lugd. Bat. i, I4o.

Glabrous. Leaves coriaceous lanceolate, or elliptic-lanceolate, acute, base acute, inæquilateral, 5 - or 6 -nerved, 3 in. long, I to $I \cdot 5$ in. wide; petioles $\cdot 25$ in. long. Peduncles $I$ in. long. Spikes I.25 in. long. Receptacles distant about I2, not stipitate but elevate, broad in fruit, $I$ in. across, hairy inside. Berry $\cdot I$ in. through. Hab. Rare. Perak, Tapah (Wray). Distrib. Sumatra, Java.

(4) P. pachyphyllum Hook. fil. F.B.I. v. 80 ; C. DC. Journ. As. Soc. Beng. l.c. 337 .

Glabrous. Leaves very fleshy, coriaceous, bright shining green elliptic or broadly ovate, 5 - to 7 -nerved, base narrowed; 4 to $5.5 \mathrm{in}$. long, 2 to 3 in. across; petioles 25 in. long. Peduncles over I in. long. Spikes in fruit nearly 2 in. long; rachis thick. Receptacles crowded, sessile, almost sunk; bracts forming a ring. Berry globose, $\cdot 25$ in. through. Hab. Very common in forests but flowers very rarely. Singapore, Bukit Timah; Garden Jungle. Malacca, (Griffith). Selangor, Ulu Gombak (Ridley).

(5) P. polygamum C. DC. Rec. Bot. Surv. Ind. vi. 27; Journ. As. Soc. Beng. l.c. 337.

Large climber, glabrous. Leaves coriaceous, elliptic, shortly acute-acuminate, base slightly unequal narrowed, 5 in. long, $2 \cdot 5$ in. wide, penninerved; nerves 3 pairs; petioles $\cdot 5$ in. long. Peduncles glabrous, I.Io in. long, slender. Female spikes nearly as long as leaf, minutely puberulous. Receptacles distant, sessile, transversely elliptic velvety outside, hairy inside with 3 or 4 ovaries included, sessile ovate, velvety on the top; stigmas 3 , linear. Fruit only one ripening, globose, I in. through. $H a b$. Forests, rare, Sungei Ujong (Stephenson). Perak, at $3500 \mathrm{ft}$. altitude (Wray).

(6) P. Maingayi Hook. fil. F.B.I. v. 80 ; C. DC. Journ. As, Soc. Beng. l.c. 336 .

Glabrous. Leaves coriaceous light shining green, elliptic-lanceolate, base inæquilateral, 5 -nerved; 3 to 4 in. long, I to 2 in. wide; 
petioles $x$ in. long. Peduncles 5 in. long; racemes $I \cdot 5$ in. long, very slender puberulous velvety. Receptacles stipitate, distant, velvety puberulous, rounded. Stamens 5, anthers minute. Berry globose. Hab. Forests, Singapore (Maingay). Malacca (Maingay). Selangor, Klang; Dusun Tua (Ridley).

(7) P. rarispicum C. DC. Rec. Bot. Surv. Ind. vi. 27; Journ. As. Soc. Beng. l.c. 336.

Glabrous. Leaves ovate to elliptic acute both ends, base in lower leaves rounded, 7 -nerved, $2 \cdot 75$ to $3 \cdot 25$ in. long, $\mathrm{I} \cdot 5$ to 2 in. wide; petioles $\cdot 2$ in. long. Spikes very slender, sub-terminal, 3 in. long, tomentose, pubescent. Receptacles stipitate elliptic. Stamens 2, anthers obovate. Hab. Hill forests, local. Penang, Government Hill; Road to Sungei Penang (Curtis).

(8) P. schizonephros C. DC. Prod. xvi. I, 24I; Journ. As. Soc. Beng. l.c. 337

Slender, glabrous. Leaves coriaceous elliptic-lanceolate, narrowed to both ends acute, 5-nerved, one pair from base, 4.75 in. long, 2 in. wide; petioles 4 in. long. Spikes slender, subterminal, 7 in. long. Flowers distant; rachis pubescent. Receptacles stalked, reniform. Stamens 8, anthers 4-valved. Hab. Malacca, Ching (Griffith). Penang Hill (Curtis).

§ 2. Cubeba.

(9) P. muricatum Bl. Verh. Bat. Nat. Gensoots. xi. 2I9, fig. I; Miq. Ill. Pip. 55, t. 55. P. muricatum var. peninsulare C. $D C$. Journ. As. Soc. Beng. l.c. 325.

A shrubby, hairy herb $2 \mathrm{ft}$. tall. Leaves membranous, oblongelliptic to nearly ovate, shortly acuminate, base narrowed blunt rounded, usually very unequal, hairy on both sides, but most so on the nerves of the underside; nerves 2 from base short, 2 to 4 above, ascending; 7 to 8 in. long, 4 to 5 in. wide; petioles hirsute, $\cdot 25$ to $1 \cdot 25$ in. long. Peduncles hairy, $\cdot 25$ in. long. Male spikes slender, $3 \cdot 5$ in. Iong. Bracts usually glabrous, oblong-obovate with a short, thick pedicel. Female spikes 2 to 4 in. long; stigmas 3 to 5, linear. Drupe ovoid-globose, yellow turning red, I2 in. through when dry; pedicel usually very short but sometimes as long as the drupe and slender. Hab. Forests. Common. Malacca (Griffith). Selangor, Kwala Lumpur; Ulu Gombak; Sungei Buloh; Semangkok Pass; Menuang Gasing (Kloss, a large roundleaved form with long fruit pedicels). Perak, Thaiping Hills. Distrib. Java, Sumatra, Borneo. Native name: Kerubut Paya.

This plant varies a good deal in the amount of hairiness, form of leaves and in the length of fruit pedicel. Most of our plants have the short thick pedicel of Miquel's type, but specimens occur with a long slender one. I am quite unable to separate these forms, even varietally. DeCandolle makes our plant a variety peninsulare, but I have met with forms identical with Miquel's figure and specimens. He gives two forms of it, pilistipes and pilosior Miq., but they seem all to occur together in the Selangor forests. 
(Io) P. Ridleyi C. DC. Rec. Bot. Surv. Ind. vi. I9; Journ. As. Soc. Beng. l.c. 327.

Stout shrubby plant 2 to $3 \mathrm{ft}$. tall, densely hairy. Leaves membranous, ovate acute to lanceolate-elliptic acutely acuminate, base round or slightly narrowed, penninerved, very hairy all over especially on nerves; 8 in. long, 3 to 5 in. wide; petioles .75 in. long, hairy. Spikes 2 to 3 in. long in flower to 4 in. long in fruit; peduncles $\cdot 25$ in. long, very hairy; rachis glabrous or hairy. Stamens 2. Stigmas 4, linear acute. Drupe globose, bright red; pedicel very short. Hab. Mountain forests from about $3000 \mathrm{ft}$. altitude upwards, Pahang, Telom. Selangor, Ginting Peras; Semangkok Pass. Perak, Thaiping Hills; Waterloo (Curtis); Ulu Kerling (Kunstler); Gunong Batu Putih (Wray); Temengoh; Bujong Malacca. Native Name: Kerubut Paya.

A form with lower flowers in spike bisexual and upper ones males was found at Ulu Kerling (Kunstler).

(II) P. malaccense C. DC. Rec. Bot. Surv. Ind. vi. I2; Journ. As. Soc. Beng. l.c. $3 \mathrm{I} 8$.

Erect shrublet, hairy when young at length glabrous. Leaves membranous, elliptic-lanceolate or obovate-oblong, sub-acute rather long acuminate base unequally rounded, penninerved, main nerves 3 pairs; very sparsely hairy on both sides and more so on nerves, 7 in. long, 3 in. wide; petioles rather thick, $\cdot 25$ in. long. Spikes nearly sessile or with a hairy peduncle $\cdot 25$ in. long, rather slender, 2 in. long, hairy. Bracts glabrous round. Flowers sometimes bisexual. Stamens I to 2. Ovary ovoid, glabrous; stigmas 4, linear acute. Drupe globose much longer than its pedicel. Hab. Damp forests, local, Johor, Sungei Tebrau. Malacca, Merlimau. Selangor, Sungei Buluh (Ridley). Native names: Poko Pimpin; Lada hitam jantan.

Near muricatum, but much less hairy; leaves very different in shape and spikes more slender.

(12) P. bipedale C. DC. Rec. Bot. Surv. Ind. vi. I9; Journ. As. Soc. Beng. l.c. 327 .

Erect, $2 \mathrm{ft}$. tall, hairy. Leaves membranous, hairy on nerves above and all over beneath, obovate-oblong acutely acuminate, base round, inæquilateral, penninerved; nerves 4 to 5 , upper ones ascending, lower ones thinner less so; $7 \cdot 8$ in. long, 2 to 8 in. wide ; petioles hairy, 47 in. long. Female spikes II in. long; rachis hairy. Bracts glabrous obovate; stigmas 3. Drupe ovate, globose acute; pedicel much shorter. Hab. Perak, at $300 \mathrm{ft}$. altitude (Wray).

I have not seen this species.

(I3) P. protractum C. DC. Rec. Bot. Surv. Ind. vi, I8; Journ. As. Soc. Beng. l.c. 326.

Erect, shrubby, densely hairy. Leaves oblong sub-acute FI.M P., 3 
acuminate, base cordate unequal penninerved; nerves 4 pairs, the two lower pairs much more slender than the others; hairy on both surfaces, especially on the nerves beneath, 6 in. long, 3 in. wide; petioles very hairy, $\cdot 25$ in. long. Spikes uni- or bi-sexual, about 2 in. long; peduncles short, hairy; rachis hairy; bracts glabrous obovate; when bisexual the male flowers above. Ovary glabrous. Drupe globose; pedicel as long. Hab. Woods in the south, Singapore, Jurong; Chan Chu Kang. Johor, Sungei Tebrau; road to Gunong Pulai th $^{\text {th }}$ mile; Castlewood. Negri Sembilan, Perhentian Tinggi; Gunong Tampin (Burkill).

(I4) P. ribesioides Wall. Pl. As. Rar. i. 79, t. 9; Cat 6637; C. DC. Journ. As. Soc. Beng. l.c. 322. P. sumatranum C. DC. Prod. xvi. (I), 343.

A strong creeper on trees. Leaves coriaceous, glabrous, oblongovate acute, base broad or blunt, often cordate, equally strongly 8 - or 9 -nerved, 6 to $8 \mathrm{in}$. long, 3 to 4 in. wide; petioles stout, 2 to $8 \mathrm{in.} \mathrm{long.} \mathrm{Peduncle} \mathrm{I} \mathrm{in.} \mathrm{long} \mathrm{in} \mathrm{flower.} \mathrm{Male} \mathrm{spikes;} \mathrm{bracts}$ glabrous, oblong. Stamens 2; rachis glabrous. Female spikes 3 in. long. Flowers rather distant; pedicels thick, $\cdot 25$ in. long. Stigmas 3. Drupe globose, large, red, pedicel nearly as long. Hab. Common in forests, Singapore, Reservoir woods. Malacca, Brisu (Derry); Bukit Panchur; Jus; Selandor (Cantley). Selangor, Semangkok; Rawang camphor forests. Negri Sembilan, Rantau (Cantley). Perak, Batu Togo and Thaiping Waterfall (Wray). Penang, West Hill (Curtis). Lankawi, Gunong Rayah (Curtis). Distrib. Tenasserim, Andamans, Sumatra. Native names: Akar Kalong Ular; Kalong Gajah; Lada Rimba.

(I5) P. pedicellosum Wall. Cat. 6646A; C. DC. Journ. As. Soc. Beng. l.c. 32I.

Climbing pepper with thick nodes, woody. Leaves coriaceous elliptic-ovate, base round or equally cordate or unequally 7 - to 9 -nerved, 3 in. long, $2 \cdot 75$ to $3 \mathrm{in}$. wide; petioles $\cdot 25$ to $\cdot 3$ in. long, rather thick. Male spikes unknown. Female spikes, peduncles - I5 in. long, glabrous; rachis thick, pubescent, hairy, $x$ in. long. Bract obovate-oblong. Ovary free; stigmas 4, rarely 3, ovate oblong acute. Drupe globose, small; pedicel $\cdot I$ in. long, puberulous. Hab. Forests, Singapore (Wallich); Chan Chu Kang. Pahang, Tahan River. Malacca, Ayer Panas. Selangor, Klang (Burkill). Perak, Larut (Kunstler). Distrib. Assam and Andamans.

This resembles $P$. ribesioides, but is very much smaller in all parts.

(16) P. selangorense C. DC. Rec. Bot. Surv. Ind. vi. I3; Journ. As. Soc. Beng. l.c. 3 I8.

Scandent glabrous, slender. Leaves rigid, membranous, oblongovate obtusely acuminate, base round equilong but one side wider, 5-nerved; midrib with many spreading nerves; 3 to 6 in. long, $\mathrm{x} \cdot \mathrm{S}$ in. wide; petioles $\cdot 23$ in. long. Peduncles 5 in. long, slender. 
Male spikes unknown. Female spikes nearly I in. long; rachis hairy. Bracts obovate $3 . I$ in. long with thick central pedicel. Ovary free, ovate; stigmas 3 , oblong blunt. Drupe $\cdot r_{3}$ in. long; stalk $\cdot x$ in. long. Hab. Mountain forests, Selangor, Semangkok, Sempang Mines (Ridley, I5567).

In a letter written to me in Herb. Singapore, DeCandolle writes: "No. 15567 is a new species, which $I$ describe as Selangorense. I 5569 is the same species, and your 2963 previously named by me magnibaccum in your herbarium." But in the Journ. As. Soc. Beng., l.c. later he quotes 2963 as magnibaccum and 15565 and 15569 as selangorense. All these plants seem to me identical, and do not fit the description of selangorense at all.

(I7) P. Klossii Ridl. Journ. Roy. As. Soc. S. Br. 82, p. I89.

Scandent, branches smooth rather soft, nodes not dilate. Leaves rigidly membranous, nearly chartaceous elliptic-ovate gradually blunt acuminate, base rounded or nearly, very slightly unequal, one side a little longer than the other; nerves I pair from base with 7 pairs from the midrib, horizontal and inarching with the side pair, glabrous above, sparsely hairy on the back, midrib elevate, thickly pubescent; 5 in. long, $2 \cdot 25$ in. wide; petioles .25 in. long, grooved. Peduncles $I \cdot 5$ in. long. Male flowers unknown. Female spikes in fruit 4 in. long, rather thick puberulous. Bracts cup-shaped. Drupe globose with a short point, $\cdot 2$ in. long when dry, pedicel much shorter, thick, shortly sunk in the rachis. $H a b$. Mountains, Selangor, Menuang Gasing, Ulu Langat (Kloss).

(I8) P. paucistigmum C. DC. Rec. Bot. Surv. Ind. vi. I4; Journ. As. Soc. Beng. l.c. 320 .

Slender creeper, glabrous. Leaves membranous, oblong-elliptic acutely acuminate equilateral, acute at base, 5-nerved; midrib with 2 ascending nerves; 4 in. long, $\mathrm{I} \cdot 27$ in. wide; petioles very slender, $\cdot 3$ in. long. Peduncles slender as long. Male flowers unknown. Female spikes nearly $\mathrm{I} \cdot 6$ in. long; rachis puberulous. Bracts ovate, $\cdot 039$ in. across. Ovary free; stigmas 2 or 3 ovate acuminate. Drupe red globose nearly $\cdot I$ in. through, pedicel shorter. Hab. Perak, Ulu Kerling on trees in bamboo forest (Kunstler).

(ig) P. Maxwellanum C. DC. Rec. Bot. Surv. Ind. vi. I5; Joum. As. Soc. Beng. l.c. 320 .

Climber, glabrous. Leaves membranous, elliptic-lanceolate, acutely acuminate equilateral and acute at base, 7 -nerved, midrib with one pair of nerves; $2.8 \mathrm{in}$. long, $\mathrm{I} \cdot 4$ in. wide; petioles slender, $\cdot 43$ in. long. Peduncles slender, 3 to $\cdot 4$ in. long. Male flowers unknown. Female spikes $I \cdot 4$ in. long; rachis hairy. Bracts obovate shortly pedicelled. Ovary ovate, free; stigmas ovate acute. Drupe globose, red, $\cdot 13$ in. through; pedicel shorter. Hab. Perak, Thaiping Hills, Maxwell's Hill (Wray).

I have not seen this species. 
(20) P. collinum C. DC. Rec, Bot. Surv. Ind. vi. I7.

Slender glabrous climber to $\mathrm{I} 3 \mathrm{ft}$. tall. Leaves membranous elliptic lanceolate acute, acuminate, base equal acute, penninerved; midrib with 4 pairs of nerves; 5 to $6 . I$ in. long, $I \cdot 9$ to 2.8 in. wide; petioles $\cdot 2$ in. long. Peduncles $I \cdot 2$ in. long. Male flowers unknown. Female spikes nearly 3 in. long; rachis hairy. Bracts obovate, sessile, 04 in. wide. Ovary free, ovate; stigmas 3, linear. Drupe ovate acute, $\cdot 2$ in. long; pedicel shorter. Hab. Perak, Goping, Limestone Hills (Kunstler).

I have not seen this species.

(2I) P. xanthocarpum C. DC. Rec. Bot. Surv. Ind. vi. I6; Journ, As. Soc. Beng. l.c. 324 .

Climber, glabrous. Leaves elliptic-lanceolate, acutely acuminate, base equal, glabrous above, puberulous beneath, 7 - to 9-nerved; midrib with I or 2 lateral nerves, 5 to 6 in. long, $2 \cdot 4$ in. wide; petioles glabrous, 24 in. long. Peduncles $I$ in. long. Female spikes, 4.5 in. long; rachis hairy. Bracts oblong, tip attenuate sessile, I in. long. Ovary ovate, free. Stigmas 3 or 4 , ovate acuninate. Drupe globose, nearly $\cdot$ I in. through, orange-colour, longer than the pedicel. $H a b$. Perak at $1000 \mathrm{ft}$. altitude (Wray).

I have not seen this species.

(22) P. mucronatum C. DC. Rec. Bot. Surv. Ind. vi. I5; Journ. As. Soc. Beng. l.c. 323.

A glabrous climber, rather woody; stem $\cdot I$ in. through. Leaves stiffly thin coriaceous, obliquely lanceolate acuminate, base narrowed blunt, equal-sided; nerves 2 pairs, one pair from base, one midway above, conspicuous elevate with conspicuous transverse nervules elevate beneath; $4 . I$ to 6 in. long, $I \cdot 6$ to $2 \cdot 25$ in. wide; petioles ' I to 23 in. long. Spikes opposite, axillary, solitary, 4 to 5 in. long, stout. Male unknown. Female spikes, rachis puberulous. Bracts linear-oblong, blunt at both ends adnate. Drupe elliptic, beaked, distant.$I$ in. apart, sessile in oval scars. $H a b$. Sungei Ujong (Cantley). Perak, Lenggong (Ridley).

(23) P. Burkillii Ridl. Joum. Roy. As. Soc. S. Br. 82, p. I89.

Slender climber; internodes jointed, joints slightly enlarged. Leaves membranous, glabrous, lanceolate acuminate, sub-acute, base usually narrowed and slightly unequal; nerves I pair by the edge from base, very fine, 2 from near base of midrib ascending, 4 or 5 pairs from side of midrib above, all very fine; 3 to 4 in. long, $\mathrm{I} \cdot 25$ to $\mathrm{I} \cdot 35 \mathrm{in}$. wide; petioles $.5 \mathrm{in}$. long or less. Male flowers unknown. Female spikes, peduncles ${ }^{2} 5$ in. long; spikes $\mathrm{I} \cdot 5$ to 2 in. long, hairy. Bracts very short, rounded. Ovary sunk in a pit; stigmas short, recurved sub-ovate, 3 or 4 . Fruit unripe, 
shorter than the pedicel, $\cdot \mathrm{I}$ in. long. Hab. Hill woods at $\mathrm{I} 600 \mathrm{ft}$. altitude. Negri Sembilan, Tampin Hill (Burkill).

(24) P. subalbicans C. DC. Rec. Bot. Surv. Ind. vi. I3.

Glabrous. Leaf membranous, pale whitish beneath, oblongovate acute acuminate, base inæquilateral, rounded on the longer, narrowed on the shorter side, 7 - to 9 -nerved, midrib 2 to 3 pairs; 4.8 in. long, 2.3 in. wide; petioles slender, 4 in. long. Peduncles very slender, $\cdot 47$ in. long. Male flowers unknown. Female spikes nearly $I .27$ in. long; rachis hairy. Bracts obovate, $\cdot I$ in. long, sessile above centre. Ovary free ovate; stigmas 3, ovate. Drupe elliptic longer than its stalk. Hab. Perak, Gunong Batu Putih (Wray).

\section{I have not seen this species.}

(25) P. larutanum C. DC. Rec. Bot. Surv. Ind, vi. I6; Journ. As. Soc. Beng. l.c. 324.

Scandent on tree trunks I5 ft. tall or more, glabrous. Leaves rigid, membranous, oblong-elliptic acutely acuminate, base unequal, round on long and narrowed on short side, penninerved with numerous lateral nerves from midrib; 5 to $6 \cdot I$ in. long, I.9 to 3.2 in. wide; petioles I4 in. long. Peduncles 67 in. long. Male flowers not known. Female spikes, white, $2 \cdot 2$ in. long; rachis hairy. Bracts adnate ciliate on edge, II in. wide, oblong rounded at both ends. Ovary free; stigmas 3 or more ovate acuminate. Drupes globose, I3 in. through, red, scattered among flowers. Hab. Perak, Larut (Kunstler).

I have not seen this species.

(26) P. Curtisii C. DC. Rec. Bot. Surv. Ind. vi. I4; Journ. As. Soc. Beng. l.c. 3 Ig.

Slender creeper, glabrous. Leaves membranous, ovate blunt acuminate, base round or very shortly acute, penninerved with 2 nerves close to base and about 6 fine pairs from midrib, rather paler beneath, $\cdot 4$ in. long, I. 5 in. wide; petioles 75 in. long. Peduncles in fruit, $\cdot 5$ in. long, slender; rachis hirsute, $\cdot 8$ in. long. Bracts glabrous, limb elliptic. Ovary free, glabrous; stigmas 3 or 4 , ovate-acuminate. Drupe globose, yellowish red, I2 in. through; pedicel shorter. Hab. Forests, Johor, Castlewood. Malacca (Cantley). Selangor, Kwala Lumpur (Curtis). Perak, Waterloo (Curtis); Larut (Kunstler); Tea Gardens, Thaiping Hill. Native name: Akar Siri Hutan.

(27) P. longibracteum C. DC. Rec. Bot. Surv. Ind. vi. I6; Journ. As. Soc. Beng. l.c. 323.

Long climbing pepper. Leaves chartaceous ovate acuminate, base short acuminate; nerves from base 5 to 7 ; midrib with numerous pairs inarching into side-nerve; 4 in. long, 2.5 to 2.75 in. wide; petioles slender, $\cdot 24$ in. long. Peduncles slender, $I \cdot 25$ in. 
long; rachis 4 in. long, very slender, glabrous. Flowers separate, very numerous. Bracts oblong-ovate, narrowed at base, sessile above the middle. Ovary free, glabrous; stigmas 4, ovate acuminate. Drupe small, globose; pedicel rather slender, considerably longer. Hab. Hill forests, Perak, Maxwell's Hill (Wray); Temengoh (Ridley).

(28) P. dindingsanum C. DC. Rec. Bot. Surv. Ind. vi. I2; Journ. As. Soc. Beng. l.c. 3I7.

Glabrous. Leaves membranous, ovate acute acuminate, base equilateral or repand sub-cordate, 5 - to 7 -nerved, 4.9 in. long, 2.6 in. wide; petioles 4 in. long. Peduncles .5 in. long. Spikes .6 in. long, hairy. Bracts glabrous, limb round, pedicel moderately long. Ovary free ovate; stigmas 3, linear. Drupe obovate, glabrous, I in. long, pedicel short. Hab. Dindings (Ridley). Rare.

This is very near $P$. caninum, and is possibly a variety of that but glabrous with shorter fruit pedicels.

(29) P. caninum Bl. Bijdr. Verh. Batav. Genoots. xi. 2I4, Fig. 26.

Slender climber; branchlets hairy especially in female plants. Leaves membranous, narrow lanceolate acuminate, I.5 in. long, $\cdot 2$ in. wide to 4 by $I$ in. in male, sparsely pubescent to thickly so, in female; ovate acuminate, base broad slightly unequal, 3 in. long, $I \cdot 5$ in. wide, in female; petioles $\cdot I$ in. long. Male spikes slender, $\cdot 5$ to $\cdot 75$ in. long; peduncles ' $I$ in. long. Stamens 2 . Female spikes thicker and blunter. Fruit spike $I \cdot 75$ in. long; peduncles 5 in. long; rachis hairy. Drupe ovoid-globose, bright red, I in. through on a short thick pedicel shorter than fruit. $H a b$. Common, low down on trees and stumps, Singapore, Garden Jungle; Selitar; Siglap. Dindings, Bukit Wok (Wray). Perak Gunong Bintang (Kunstler); Kelantan, Chaning. Lankawi, Bukit Penarak (Haniff). Distrib. Java. Native names: Chabai hutan; Lada Hantu; Lada Anjing; Akar Kalong.

The typical plant of Java has very much larger leaves than our form. A very narrow lanceolate-leaved plant, invariably male, and growing in the same locality as caninum, I have always believed to be a male form of it. It is the var. angustifolium of Miquel and Hooker of canimum, and a variety of bohmeriefolium, an erect Chavica, of C. DeCandolle. It was abundant in the Garden jungle.

(30) P. lanatum Roxb. Fl. Ind. i. I59; Wall. Cat. 6647.

Strong creeper; stems hairy. Leaves ovate acuminate, base round, very slightly cordate or oblique, hairy on both sides or nearly glabrous above when adult, 4 in. long, 2 in. wide; petioles hairy, .5 in. long. Male spikes unknown. Female spikes, peduncles rather thick, 5 in. long, rachis thicker, I.75 in. long, glabrous. Drupe globose ovoid, 'I in. long; pedicels distinct, shorter than fruit. Hab. Singapore. Johor, Pulau Tiuman (Burkill). Selangor, Menuang Gasing (Kloss). Dindings, Bukit Tungul. Penang 
(Wallich). Distrib. Malay isles. Native names: Akar Kalong; Chabei hutan.

Hooker makes this a variety of $P$. caninum, which it may be, but $C$, DeCandolle makes it a variety of bchmeriafolium, an erect plant of the Chavica section.

\section{§3. Chavica.}

(3I) P. febrifugum C. DC. Rec. Bot. Surv. Ind. vi. Io; Journ. As. Soc. Beng. l.c.

Stout scandent plant very hairy with rough hair. Leaves oblong, shortly acute, base unequally cordate, stiffly chartaceous above, glabrous beneath, hairy especially on the 7 pairs of nerves elevate beneath, sunk above with numerous transverse nerves and large reticulations, 9 in. long, $4 \cdot 75$ in. wide; petioles densely hairy, $\cdot 3$ in. long, shorter than basal lobes. Peduncles nearly glabrous, .2 in. long. Female spikes, slender, dense, 5.5 in. long; rachis hairy. Bracts very small, glabrous, round. Ovary half embedded in rachis. Stigmas 3, ovate acute. Hab. Very rare in forests, Sungei Ujong (Cantley). Perak, Ulu Batang Padang (a nearly glabrous form). Native name: Akar Sangkap. Use: Roots boiled, given in fever.

(32) P. ramipilum C. DC. Rec. Bot. Surv. Ind. vi. 3 .

Creeper, $20 \mathrm{ft}$. long, pubescent when young, glabrous when adult. Leaves stiff membranous, glabrous above; nerves pubescent beneath, hairs ramulose, ovate-elliptic acute acuminate, base cordate unequal, 7 -nerved from base, midrib with one pair of nerves above $; 4^{\circ} 7 \mathrm{in}$. long, $2 \mathrm{in}$. wide; petioles $\cdot 3$ in. long, sheathing half-way. Stipules glabrous confluent blunt. Peduncle pubescent, .8 to $.9 \mathrm{in}$. long, slender. Male spike narrow at top; rachis glabrous, 2.8 in. long. Bract glabrous round. Stamens 2. Female spikes .4 in. long. Ovary glabrous, base embedded in rachis; stigma I, orbicular. Drupe free except at base, globose. Hab. In hill forests. Johor, Bukit Soga (Ridley). Perak, Gunong Bulang (Kunstler); Gunong Keledang. Penang, Balik Pulau (Curtis).

(33) P. miniatum Bl. Verh. Bat. Genoots. xi. I66; C. DC. Journ. As. Soc. Beng. l.c. 303.

Climber on rocks. Leaves rather coriaceous elliptic-lanceolate, acuminate, base shortly narrowed, sometimes slightly inæquilateral ; nerves sunk above, prominent beneath, 3 very prominent, 2 slender near edge; 6 in. long, $2 \cdot 75$ in. wide; petioles thick, I2 in. long. Peduncle $\cdot 5$ to $I \cdot 5$ in. long. Male spikes slender, 6 in. long. Bracts very small, round. Female spikes nearly 'I in, thick. Fruit-spike nearly $\cdot 2$ in. thick, bright red. Drupes minute. Hab. On rocks and tree; common, Singapore, Chua Chu Kang; Toas; Chanchukang. Johor, Tanjong Kupang. Malacca, Bukit Bruang (Derry); Base of Mt. Ophir. Negri Sembilan, Tampin (Burkill); Bukit Tangga. Selangor, Semangkok Pass. Perak, Temengoh; 
Thaiping Waterfall. Penang, Batu Feringhi (Curtis). Lankawi. Distrib. Java. 83.

(34) P. chaba Hunter, As. Res. ix. 39I; Hook. fil. F.B.I. v.

A climbing glabrous pepper, rather fleshy. Leaves oblong, ovate or lanceolate acuminate, base round unequal, cordate; nerves at base 3 , with 2 pairs from midrib, 5 to 7 in. long, 2.5 to 2.75 in. wide; petioles $\cdot 25$ to 5 in. long. Peduncles 5 to $I$ in. long. Fruiting spikes cylindro-conic, widest at base, bright red, I to 3 in. long, $\cdot 25$ in. through. Drupes very small, globose sunk. Hab. Cultivated, Singapore, Bukit Mandai, a large-leaved form (Bakek Hutan), Malacca (Griffith, Maingay). Distrib. Malay isles. Native name: Bakek. Use: The dried fruits used as a substitute for Sirih in voyages, sold in all the bazaars.

Hunter gives the name and use as above (Bakee, Baci) for his $P$, siriboa and Chaba tadi for $P$. chaba.

(35) P. Betle Linn. Sp. Pl. i. 28; C. DC. Journ. As. Soc. Beng. l.c. 3II ; Bot. Mag. t. 3I 32 .

Glabrous climber. Leaves fleshy, ovate acuminate, base round or elliptic sometimes unequally bilobed, 6 in. long, 3 in. wide; nerves elevate beneath, about 5 to 7 ; petioles 5 to $\mathrm{I}$ in. long. Peduncles I in. long, male spikes cylindric, blunt. Female spikes 2 in. long, 25 in. thick, blunt grey. Ovary embedded in rachis. $H a b$. Cultivated extensively and often found in abandoned clearings. Native names: Sirih; Sirih China, with leaves light green; Sirih Malayu; Sirih Hudang, leaves dark green with the nerves red. Use: For chewing with betel-nut.

(35) P. argyrites Ridl. in C. DC. Rec. Bot. Surv. Ind. vi. 25; Journ. As. Soc. Beng. l.c. 333. P. nigrantherum C. DC. Rec. Bot. Surv. Ind. l.c. 20 ; Journ. As. Soc. Beng. l.c. 338.

A stout climber; stem I in. through. Leaves glabrous, oblongovate acutely acuminate, base round, slightly unequal, light green, with pale or white spots, plain green when adult, 7 -nerved, midrib emitting I pair of nerves; $6 \cdot 5$ in. long, $2 \cdot 4$ in. wide; petioles 4 in. long, sheathing to middle. Peduncles 6 in. long. Male spikes $3 \cdot 2$ in. long; rachis hirsute. Bract obovate. Stamens 2, reniform. Female plant unknown. Hab. Selangor, Batu Caves; Ginting Bidai (Ridley). Use: The wild tribes use the bark peeled off in strips for chewing with betel-nut.

Cultivated specimens from the Botanic Gardens, Singapore, were described by $C$. DeCandolle as $P$. nigrantherum, where it had been known as $P$. argyrites for many years.

(37) P. sarmentosum Roxb. Fl. Ind. Ed. Car. i. I62; C. DC. Journ. As. Soc. Beng. l.c. 308. Piper longum Hook. fil. F.B.I. l.c. 83, not of Linné.

Glabrous, creeping terrestrial herb about 8 in. tall. Leaves thin, dark green, ovate, deeply equally cordate, lobes round; 
nerves 7 radiating from base, dark green, 3 to $3 \cdot 5 \mathrm{in.}$ long, $\mathrm{I} \cdot 25$ to 3 in. across; petioles $\mathrm{I} \cdot 5$ in. long. Peduncles 5 to $\cdot 75$ in. long. Spikes short, dense, blunt, white cylindric, males 25 in. long; females about as long, thicker and up to 5 in. long. Drupes minute. Hab. Banks and cultivated ground, Singapore, Tanglin; Pulau Buru. Johor, Kota Tinggi. Malacca (Griffith), a pubescent form, the shoots and nerves beneath pubescent. Pahang, Pekan; Kwala Tahan (Seimund). Selangor, Langat. Penang, Pulau Betong (Curtis). Lankawi. Native name: Kadok. Distrib. Java.

\section{\$ . Pseudochavica.}

(38) P. bœhmeriæfolium Wall. Cat. 6654.

Erect shrub, with green smooth stems, $3 \mathrm{ft}$. tall, branched, internodes over I $\mathrm{ft}$. long in main stems, upper branches slender, I ft. long or more, entirely glabrous. Leaves thin membranous, lanceolate-oblong acuminate, base hardly narrowed very unequal, one side $\cdot \mathrm{I}$ in. wide, the other $\cdot 75$ in. wide at base; nerves 3 on the broad side, 2 on the narrow one with sub-parallel branched transverse nervules rather distant and inarching widely; 6 in. long, 2 in. wide; petioles $\cdot 25$ in. long. Male spikes cylindric, slender, I to 6 in. long, white on a peduncle 5 in. long. Bracts round, peltate shortly pedicelled. Stamens 2 . Female spikes 4 in. long. Fruits crowded, globose sessile red, under $\cdot I$ in. through when dry. $\mathrm{Hab}$. Forests. Pahang, Gunong Senyum (Evans). Negri Sembilan, Bukit Tangga. Perak, Larut (Kunstler, fide DC.); Gunong Inas (Yapp). Distrib. Sylhet, Burma.

DeCandolle's description, Journ. As. Soc. Beng., l.c. 305, hardly fits this plant, and he adds the totally distinct climbing Cubebas, $P$. lanatum and some forms of $P$. caninum as varieties.

(39) P. cyrtostachys Ridl. Journ. Roy. As. Soc. S. Br. 82, p. 189 .

An erect, glabrous herb hardly ever branched, about $2 \mathrm{ft}$. tall; stems zigzag, jointed, nodes not swollen, internodes 2 in. long. Leaves membranous, broadly lanceolate acuminate, acute, base very unequally cordate, one lobe often ${ }^{\prime}{ }_{5}$ in. longer than the other, rounded, penninerved, 2 main nerves on one side, one on the other from the base of the midrib; 4.5 in. long, I.75 in. wide; petioles $I \cdot I$ in. long. Male spikes slender, cylindric, blunt, I in. long on a $I \cdot 5$ in. long peduncle. Bracts round, glabrous. Stamens 2; filaments hardly longer than the bract; anther oblong-globose. Fruiting spikes, pedicels $I \cdot 5$ in. long; rachis about $I$ in. long, curled into a horse-shoe with numerous crowded drupes sessile in cup-shaped pits sub-globose with a short rounded stigma, orange yellow. $H a b$. Forests at $4000 \mathrm{ft}$. altitude. Perak, Gunong Berumbun near Telom (Ridley).

(40) P. oreophilum Ridl. Journ. Roy. As. Soc. S. Br. 82, p. 189 .

Erect, shrubby closely brown-hairy. Leaves lower ovate 
shortly acuminate, base cordate equally, upper oblong-lanceolate acuminate, base entire, rounded, sparsely hairy above; nerves hairy on both sides and conspicuous reticulations hairy beneath; main nerves from base 5 , above I pair ascending; 4 in. long, $I \cdot 75$ to 3 in. across; petioles hairy, $I$ in. long, sheathing $\frac{1}{3}$ of its length. Male spikes slender, .5 in. long; peduncles very slender as long, hairy. Bracts sub-orbicular edges undulate. Female spikes $\mathrm{I} \cdot 2$ in. long in fruit, rather thick. Ovary sunk in rachis; style distinct with two short recurved stigmas. Drupe pulpy, - I5 in. through, sunk in rachis for about a third, ovoid-conic with style-beak persistent. $H a b$. Mountains in 'woods at $4000 \mathrm{ft}$. altitude. Rare. Pahang, Gunong Tahan Gully (Ridley).

(4I) P. stylosum Miq. Ann. Bot. Mus. Lugd. Bat. i. I39; C. DC. Journ. As. Soc. Beng. l.c. 302.

Erect about I2 to $I_{5}$ in. tall, rough appressed hairy. Leaves membranous, broadly ovate, shortly acuminate, base narrowed, blunt, usually unequally, sometimes oblong lanceolate, base often unequal, glabrous above; nerves 5 from base, a pair from midrib, conspicuous hairy; 4 to 6 in. long, 2 to 5 in. wide; petioles $\cdot I_{5}$ in. long. Peduncles $-I$ in. long, hairy. Male spikes $\cdot 25$ in. long, white; rachis hairy; bracts orbicular. Stamens 2. Female or bisexual spikes $\cdot 25$ in. long. Ovary with a long style. Fruit spike 75 to I.25 in. long, thick, the drupes with conspicuous long styles, bright red. Hab. Common in forests, Johor, Castlewood; Kampong Simpai (Kelsall); Pulau Tiuman (Burkill). Pahang, Kota Glanggi; Tahan River. Negri Sembilan, Bukit Tangga. Selangor, Batu Caves; Sungei Buluh. Perak, Thaiping Hills; Temengoh; Kwala Wok (Wray); Goping (Kunstler); Bujong Malacca. Kelantan, Chaning woods. Distrib. Sumatra, Borneo.

Rather variable, especially in form of leaf. The hill range forms Temengoh, etc., are often very large.

(42) P. penangense C. DC. Prod. xvi. i. 353; Journ. As. Soc. Beng. l.c. 30I.

Glabrous shrublet $2 \mathrm{ft}$. tall, slender. Leaves thin membranous, lanceolate or elliptic-lanceolate acuminate, base acute, nearly equal or rounded, 5-nerved from base, I pair from midrib, slender elevate; 4 in. long, $I \cdot 5$ in. wide; petioles ' $I_{5}$ in. long. Peduncles $\cdot 2$ in. long. Male spikes 5 in. long. Female spikes very short, .25 in. long, on slender .5 in. long peduncles, ovate globose with few flowers. Drupe small, globose with a long conic style. Hab. Hill forests at $3000 \mathrm{ft}$. altitude upwards. Perak, Ulu Selama and Gunong Inas (Wray fide DC.). Penang, West Hill and Tanjong Bunga (Wallich, Curtis).

(43) P. rufispicum C. DC. Rec. Bot. Surv. Ind. vi. 4; Joum. As. Soc. Beng. l.c. 300.

Glabrous. Leaves stiff elliptic-lanceolate, acute attenuate, 
base narrowed on one side, sub-attenuate on the other unequal; nerves 6,3 on one side of midrib, 2 on the other; $2 \cdot 6$ to $3 \cdot 6$ in. long, $\mathrm{I} \cdot 25$ to $\mathrm{I} \cdot 4$ in. wide. Peduncles 5 in. long. Male spikes unknown. Female spikes cylindric, top round. Bracts sub-orbicular, sessile in centre. Drupe deeply embedded; style free, conic slender; stigmas 4, ovate acute. Hab. Perak at Ijuk (Gunong Hijau) (Scortechini).

I have not seen this species.

(44) P. minutistigmum C. DC. Rec. Bot. Surv. Ind. vi. 9; Journ. As. Soc. Beng. l.c. 3II.

A very large climbing pepper $36 \mathrm{ft}$. long, glabrous. Leaves rigid ovate, acutely acuminate, base round equally wide but one side longer, 9-nerved, midrib with one pair ; 4 in. long, $2 \cdot 8 \mathrm{in}$. wide ; petioles .6 in. long. Peduncles 2.3 to 2.8 in. long. Male flowers not known. Female spikes cylindric, 3.6 in. long, nearly $\cdot I_{3}$ in. thick; rachis velvety, puberulous. Bracts ovate round. Pedicels short and thick. Ovary deeply embedded convex and puberulous above; stigmas 3. Drupe 4-angled at top. Hab. Perak, Larut (Kunstler).

$I$ have not seen this species.

(45) P. globulistigmum C. DC. Rec. Bot. Surv. Ind. vi. 3.

Glabrous. Leaves rigid, oblong-elliptic-lanceolate acute, long narrowed, base unequal, shortest tapering, the other round, penninerved; nerves 3 pairs; 3.6 to 4.3 in. long, 75 to $\mathrm{I}$ in. wide; petioles $\cdot 2$ in. long. Peduncles $I$ in. long. Male spikes unknown. Female spikes cylindric, $2 \cdot 7$ in. long, $\cdot 03$ in. thick; rachis densely velvety. Bracts glabrous, orbicular with short central pedicel. Drupe partly embedded, free part round and densely velvety puberulous; stigma I, globular. Hab. Perak (Scortechini).

I have not seen this species.

\$ 5. Eupiper.

(46) P. Kurzii Ridl. Journ. Roy. As. Soc. S. Br. 82, p. I88.

Erect, shrubby, branched. Leaves thinly coriaceous, glabrous elliptic-lanceolate, base cuneate nearly æquilateral; nerves fine elevate, 2 from base, 2 stouter above, nervules nearly horizontal, numerous; 4 to 7 in. long, 2 to 3 in. wide; petioles $I$ in. long. Male spikes slender, $I \cdot 75$ in. long; peduncles $\cdot 75$ in. long. Bracts oblong rounded. Female spikes $I \cdot 75$ in. long; peduncles 5 in. long. Flowers not sunk; rachis hairy. Stigmas 3, thick round. Drupe small, sessile ellipsoid shortly pointed. Hab. Mountain forests usually lowland, Selangor, Batu Caves. Perak, Temengoh. Kelantan, Chaning woods. Distrib. Burma.

(47) P. erecticaule C. DC. Rec. Bot. Surv. Ind. vi. 22 ; Journ. As. Soc. Beng. l.c. 330.

Stem slender, fleshy flexuous. Leaves thin membranous 
elliptic-oblong lanceolate or ovate, base round or blunt (acute, C. DC.) unequal; nerves 2 from base and two pairs from the midrib (8-nerved, midrib with 5 nerves, 2 on one side, 3 on the other, DC.) transverse nervules sub-parallel flexed; 4 to 5.9 in. long, I. 75 to 2 in. wide; petioles 25 in. long. Peduncles $\cdot 27$ in. long. Male spikes 5 in. long (very young); rachis hairy. Bracts round short pedicelled. Stamens 3. Hab. Mountains, very rare and little known, Kedah Peak (Ridley). 23.

(48) P. subrubrispicum C. DC. Rec. Bot. Surv. Ind. vi.

Erect ? about $3 \mathrm{ft}$. I in. tall, long hairy. Leaf membranous, glabrous above, hairy below, round ovate obtusely acuminate, base equilateral, deep cordate 9 -nerved, midrib with one pair of ascending nerves; 5.9 in. long, 5.3 in. wide; petioles 2.4 in. long, hairy on back sheathing for 5.4 its length. Stipules pubescent. Peduncles hairy, 2.5 in. long. Male spikes $2.4 \mathrm{in}$. long, ${ }^{-15}$ in. through, blunt, white tinted pink; rachis glabrous. Bracts oblong-obovate alternate attenuate to lower end. Stamens 3; anthers reniform. Hab. Perak, Upper (Wray).

I have not seen this species.

(49) P. velutinervium C. DC. Rec. Bot. Surv. Ind. vi. 7; Journ. As. Soc. Beng. l.c. 308.

Erect ? lower portion rooting from nodes; young parts hairy. Leaves membranous, glabrous above, velvety, hairy on the nerves beneath, round ovate acute acuminate, base equally deep cordate, II-nerved; midrib with 2 opposite nerves; 8.6 in. long, 8 in. wide; petioles densely hairy, $\cdot 6$ in. long. Peduncles $\cdot 6$ in. long, hairy in male, glabrous in female. Male spikes I. 5 in. long, thick ; rachis hairy. Bracts glabrous, round with central pedicel. Stamens 2. Female spikes $2 \cdot 3$ in. long; rachis hairy. Ovary glabrous; stigmas 3 , rarely 4 , ovate-oblong. Drupe ovate-globose, yellowish red, ${ }^{\prime}{ }_{5}$ in. long. Hab. Among rocks, Perak, Larut Hills, I800 to $2000 \mathrm{ft}$. altitude (Kunstler). Distrib. Sumatra. 68.

(5o) P. acre Bl. Act. Bat. II, p. I85, Fig. I3; Enum. Pl. Jav.

Rather slender glabrous climber sparsely hairy, especially the nodes. Leaves firm in texture, ovate sharply acuminate base nearly round, base slightly narrowed, glabrous above except base of midrib, 5 elevate nerves from base pubescent beneath, a more slender pair near the edges inarching with transverse nervules; 3 to 3.5 in. long, $1 \cdot 5$ to 2 in. wide; petioles hairy, $\cdot 25$ in. long. Male spikes unknown. Female spikes, peduncles 25 in. long, hairy; rachis slender, 7 in. long, densely velvety tomentose. Bracts oblong. Ovary deep sunk. Fruits oval, separate in elliptic depressions fringed with long hairs. Hab. Mountain forests, Perak, Waterloo to Cottage, Thaiping Hills (Curtis). Distrib. Java. 
(5I) P. puberulirameum C. DC. Rec. Bot. Surv. Ind. vi. 7.

Branchlets puberulous. Leaves stiff, glabrous, ovate-lanceolate, acutely attentuate, base acute unequal slightly 5-nerved; midrib with I pair opposite nerves, $4 \cdot 8$ to $3 \mathrm{in}$. long, I in. wide; petioles puberulous, $\cdot 3$ in. long. Peduncles slender, glabrous, $3 \cdot 4$ in. long. Male flowers unknown. Female spikes $I \cdot 4$ in. long in fruit; rachis densely hirsute. Bract glabrous, round sessile. Ovary free, glabrous; stigmas 4, round, short. Drupe globose ovate, $\cdot 13$ in. long. Hab. Hill forests, Sungei Ujong (Cantley). Penang, Balik Pulau; West Hill (Curtis).

This species is close to P. Schmidtii Hook fil, of India.

(52) P. kotanum C. DC. Rec. Bot. Surv. Ind. vi. II ; Journ. As. Soc. Beng. l.c. $3 \mathrm{I} 6$.

Branches glabrous. Leaf rigidly membranous, glabrous above, velvety puberulous beneath, elliptic acutely acuminate, base inæquilateral acute on shortest, round on longer side, penninerved; midrib with 3 pairs of nerves; $4.8 \mathrm{in}$. long, 2 in. wide; petioles glabrous, $\cdot 3$ in. long. Male spikes unknown. Female spikes 2.5 in. long; rachis glabrous. Bract elliptic adnate to rachis free at edge only. Ovary free; stigmas 3 , triangular acute. Drupe globose, $\cdot$ in. through. Hab. Perak, Kota (Wray).

(53) P. porphyrophyllum N.E. Br. Gard. Chron. xxii. 438; C. DC. Journ. As. Soc. Beng. l.c. $3^{\mathrm{I}} 3$.

Slender climber. Leaves glabrous, velvety looking membranous, dark blackish green spotted rose and white ovate acute cordate, purplish beneath; nerves 5 , from base with numerous secondary nerves and reticulations; 4 to $6 \mathrm{in}$. long, 3 to $5.5 \mathrm{in}$. wide, upper leaves larger; petioles I to $\mathrm{I} \cdot 5$ in. long. Male spikes about 6 in. long; rachis hairy. Bract glabrous, oblong rounded. Stamens 3. Female spikes .I2 in. long. Ovary free; stigmas linear. Drupe ovate attenuate at top. $\mathrm{Hab}$. Common in forests on the ground and climbing up trees, rarely to be found in flower. Whole peninsula, Singapore, Bukit Timah; Garden Jungle, Selangor, Batu Caves; Petaling. Negri Sembilan, near Seremban (Napier). Dindings, Lumut. Perak, Thaiping Hills; Hermitage Hill. Tringganu, Bundi (Rostados). Penang (Wallich).

(54) P. semangkoanum C. DC. Rec. Bot. Surv. Ind. vi. 6; Journ. As. Soc. Beng. l.c. 304 .

Erect soft glabrous plant. Leaves thinly membranous, ovate acutely acuminate, base round equal-sided; nerves 3 from the base, 2 from the midrib, transverse nervules slender, distant, visible beneath; 4 in. long, 2 in. wide; petioles $\cdot 2$ in. long. Peduncles as long. Female spikes cylindric, 5 in. long. Bracts orbicular, sub-sessile at centre. Ovary free; stigmas 4, linear. Hab. Hill forests, Selangor, Semangkok Pass. Perak, the Cottage, Thaiping Hills (Ridley). 
(55) P. subfragile C. DC. Rec. Bot. Surv. Ind. vi. 9 .

Climber, glabrous. Leaves sub-coriaceous ovate, sliort, subacute, attenuate, base round nearly equal, 7 -nerved; midrib with one pair of nerves; $2 \cdot 2 \mathrm{in}$. long, I.4 in. wide; petioles $\cdot 2$ in. long. Peduncles $\cdot I$ in. long. Male spikes unknown. Female spikes $\cdot 4$ in. long; rachis hairy. Bracts round; pedicel central hairy. Ovary glabrous, lower part embedded in rachis. Hab. Perak, Kurau (Wray).

I have not seen this species.

(56) P. gymnocladum C. DC. Rec. Bot. Surv. Ind. vi.6; Journ. As. Soc. Beng. l.c. 304.

A straggling climber. Leaves thin, firmly membranous, ovate acute, pale beneath, base round unequal; nerves 7 from base with one pair from the midrib above, transverse nervules and reticulations conspicuous on both sides; 5.5 in. long, 2.6 in. wide; petioles $\cdot 25$ to $\cdot 4$ in. long. Male spikes slender, 75 in. long, on a slender peduncle as long. Female spikes 6.3 in. long. Bract round with short central pedicel. Ovary free. Stigmas 3 or 4 , ovate-oblong. Fruit-spike 2 in. long. Drupes sessile globose, close set, 'I in. long. Hab. Hill forests, Perak, Maxwell's Hill, Thaiping Hills (Ridley).

(57) P. curtipetiolum C. DC. Rec. Bot. Surv. Ind. 22 ; Journ. As. Soc. Beng. l.c. 330 .

Glabrous. Leaves membranous, elliptic-lanceolate, acute acuminate base aequilateral, 5-nerved, mid-nerve with I pair of side-nerves; 4.2 in. long, I in. wide; petioles $\cdot 2$ in. long. Peduncles glabrous, nearly $\cdot 22$ in. long. Male spikes $\cdot 67$ in. long; rachis hairy. Bract round, sub-sessile. Stamens unequal; filaments oblong, longer than ovate anthers. Hab. Perak, Gunong Inas (Wray).

I have not seen this species.

(58) P. magnibaccum C. DC. Bec. Bot. Surv. Ind. vi. 5, p. 30 I. (1iig. 139, p. 47.)

Climber, glabrous, stout. Leaves rather fleshy elliptic-lanceolate acuminate, often abruptly, base shortly narrowed acute or blunt; nerves prominent beneath, 5 to 7 from base, 2 slender ones outside, no visible secondary nerves, entirely glabrous; 6 to 7 in. long, 3 to 4 in. wide; petioles $\cdot 2$ in. long. Peduncles . I to .5 in. long. Male spikes slender, 75 in. long. Bracts ovate. Female spikes $I$ in. long, lengthening to Io in. Ovary narrowed to tip. Drupe $\cdot 25$ in. long, ovoid-conic. Hab. In hill forests climbing on trees, Pahang, Telom. Selangor, Semangkok Pass; Menuang Gasing (Kloss). Perak, Thaiping Hills; Gunong Kerbau (Robinson).

(59) P. flavispicum C. DC. Rec. Bot. Surv. Ind. vi. Io; Journ. As. Soc. Beng. l.c. 3I4.

Erect $2 \mathrm{ft}$. tall, glabrous. Leaves membranous elliptic-lanceo- 
late, long acuminate, base acute equal, 7 -nerved; midrib with I pair of ascending nerves; 5 to 5.9 in. long, $r \cdot 6$ to $2 \cdot I$ in. wide ; petioles $\cdot I_{3}$ in. long. Peduncles $\cdot 24$ in. long. Male spikes $I \cdot 25$ in. long; rachis glabrous. Bracts limb oblong-ovate. Stamens 3. Female spikes 2 to $2 \cdot 4$ in. long, yellow. Drupe free, ovate, ${ }^{\prime} 3$ in. long. Hab. Perak, Sungei Prya on a limestone hill (Kunstler).

(60) P. obovantherum C. DC. Rec. Bot. Surv. Ind. vi. 24; Journ. As. Soc. Beng. l.c. 332.

Glabrous. Leaves membranous elliptic, acute acuminate, base rounded slightly wider, 7-nerved, midrib with a pair of nerves; 5.4 in. long, 3.6 in. wide; petioles 47 in. long. Peduncles very

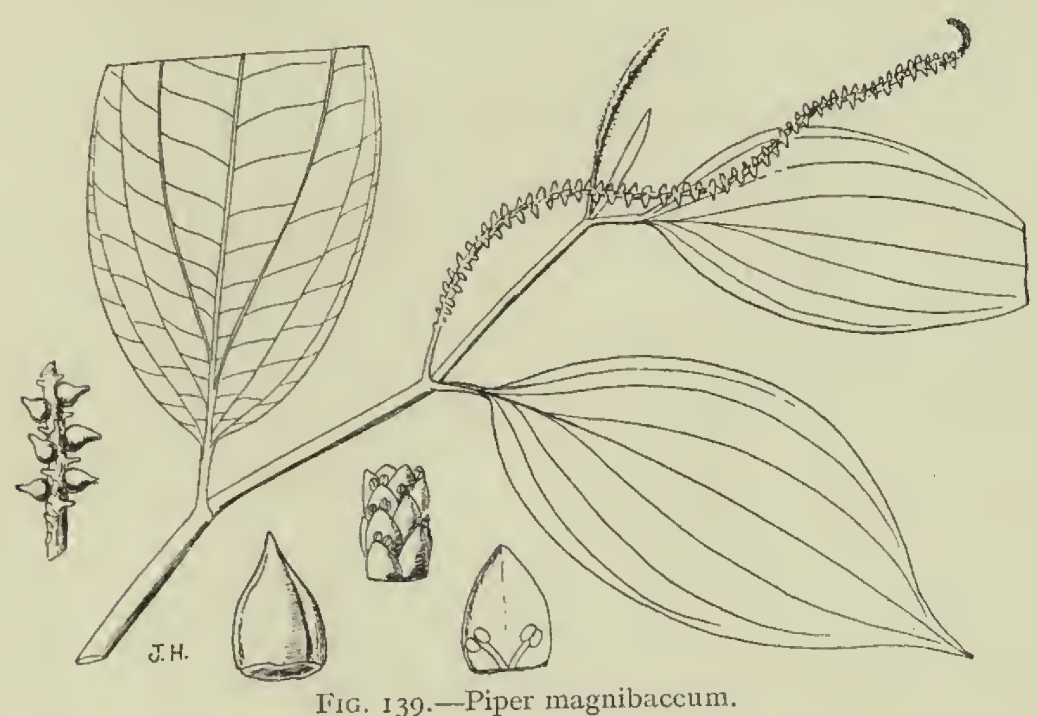

slender, nearly 73 in. long. Male spikes 2.7 in. long; rachis hairy. Bracts obovate-oblong, narrowed at lower end, blunt at tip, minutely ciliate on edge. Stamens 3 ; anthers obovate. $H a b$. Penang Hill (Ridley).

(6r) P. subpenninerve Ridl. P. nigrum var. subpenninerve C. DC. Journ. As. Soc. Beng. l.c. 3I4.

Glabrous climber. Leaves rather stiff elliptic-lanceolate, short acuminate, base cuneate; nerves 2 pairs ascending from base and one pair from midrib, one-third of way up, elevate, secondary nerves transverse, numerous, all elevate, 7 in. long, $3 \mathrm{in}$. wide; petioles thick, I to $\cdot 2$ in. long. Peduncles short, 2 in. long. Male and female flowers unknown. Spikes in fruit 4 in. long; rachis glabrous. Bracts very minute. Fruit ovoid narrowed to top, 2 in. long 
when dry, narrowed slightly at base, distant, sunk in rachis; stigmas 4. Hab. Selangor, Batu caves (Curtis). Dindings, Gunong Tungul. Perak, Hermitage Hill (Curtis). Distrib. Tenasserim, fide C. DeCandolle.

(62) P. longamentum C. DC. Rec. Bot. Surv. Ind. vi. 23; Journ. As. Soc. Beng. l.c. 33I.

Scandent? hairy. Leaves membranous oblong-ovate lanceolate acute, long acuminate equilateral, base acute, pubescent above and densely beneath 5 -nerved; midrib with two opposite nerves; 3.9 in. long, $\mathrm{T}^{\circ} 4$ in. wide; petioles $2.5 \mathrm{in.} \mathrm{long,} \mathrm{densely} \mathrm{hairy.} \mathrm{Male}$ spikes nearly 5.5 in. long, slender; rachis hairy. Bract round. Stamens 2; anthers ovate. Female spikes and fruit unknown. $H a b$. Perak, Larut, at I80o to $3000 \mathrm{ft}$. altitude (Kunstler).

I have not seen this species.

(63) P. conibaccum C. DC. Rec. Bot. Surv. Ind. vi. 4; Journ. As. Soc. Beng. l.c. 301 .

Stem stout glabrous. Leaves stiff, elliptic or ovate-lanceolate acute, base shortly cuneate acute, equal-sided; nerves 3 pairs, elevate beneath, nervules invisible; 4.7 to $5 \mathrm{in}$. long, 2 to $2.2 \mathrm{in}$. wide; petioles 4 in. long. Peduncles as long. Male flowers unknown. Female spikes $\mathrm{I}_{5.7}$ in. long, stout; rachis glabrous. Bracts glabrous; limb obovate attenuate below. Ovary narrowed to a long conic style; stigmas 3 to 5 . Hab. Hill forests, rare, Pahang, Semangkok Pass towards Tras (Ridley).

A very striking plant near $P$. magnibaccum, but the fruits are larger and the leaves smaller and stiffer.

(64) P. subsessililimbum C. DC. Rec. Bot. Surv. Ind. vi. 24.

Scandent, cirrhi ramulose. Leaves sub-sessile, glabrous, membranous obovate, elliptic-oblong acutely acuminate, base narrowed penninerved with Io pairs of fine nerves from midrib; $7 \cdot 3$ in. long, 2 in. wide; petioles ' $I$ in. long. Peduncles $\cdot 3$ in. long. Male spikes nearly $2.4 \mathrm{in.}$ long, $\mathrm{O} 07$ in. thick, yellow (young); rachis hairy. Bracts oblong-elliptic; pedicel short central. Female and fruit unknown. Hab. Perak, Goping (Kunstler).

I have not seen this species.

(65) P. rufibracteatum C. DC. Rec. Bot. Surv. Ind. vi. 2 I.

Glabrous. Leaves sub-coriaceous oblong-elliptic, short blunt attentuate, base inæquilateral, rounded both sides, 9-nerved; midrib with 2 nerves; $3 \cdot 6$ in. long, $I^{*} 4$ in. wide; petioles $\cdot 25$ in. long, sheath prolonged a little. Peduncles glabrous, I2 in. long. Male spikes I in. long; rachis glabrous. Bracts obovate subattenuate below densely red-pubescent; pedicel short and thick. Stamens 2 or 3. Hab. Malacca (Maingay I329).

I have not seen this species. 
(66) P. filipes C. DC. Rec. Bot. Surv. Ind. vi. 20 ; Journ. As. Soc. Beng. l.c. 320 .

Stalk and branches very slender, glabrous. Leaves membranous, oblong-ovate acutely attenuate, base round unequally wide, 5 -nerved, midrib with I pair of nerves; 3.6 in. long, I.6 in. wide; petioles very thin sheathing above base. Peduncle filiform, glabrous, nearly $I \cdot I$ in. long. Male spikes $\cdot 64$ in. long, white; rachis hairy; bracts glabrous, round, $\cdot 075$ in. across, short pedicelled. Stamens 3. Female and fruit unknown. Hab. Perak, Larut (Kunstler).

(67) P. flavibaccum C. DC. Rec. Bot. Surv. Ind. vi. 5 ; Journ. As. Soc. Beng. l.c. 303 .

Glabrous. Leaves rigid, membranous, oblong-ovate acutely narrowed, base unequal, narrowed on the shorter, rounded on the longer side, 4-nerved, 2 nerves on one side of midrib, one on the other; 3.9 to 4 in. long, I to 4 in. wide; petioles $4 \mathrm{in}$. long. Peduncles glabrous, slender, .8 in. long. Male spikes .8 in. long; rachis hairy. Bracts glabrous, limb round with a central short pedicel. Stamens 2. Female spikes shorter. Drupe free, globose, yellow. Hab. Perak, Gunong Batu Putih (Wray).

I have not seen this species.

(68) P. gymnophyllum C. DC. Rec. Bot. Surv. Ind. vi. 6 ; Journ. As. Soc. Beng. l.c. 307.

Glabrous. Leaves membranous, elliptic-lanceolate acutely acuminate, base acute slightly unequal, 6-nerved; midrib two on one side, one on the other; 6 in. long, $2 \cdot 2$ in. wide; petioles 4 in. long. Peduncles 47 in. long. Male spikes not seen. Female spikes nearly half as long as leaf; rachis fulvescent hairy. Bracts glabrous, round, sub-sessile at centre. Ovary free ovate. Stigmas 3 to 4 , linear. Drupe ovate, $-\mathrm{I}$ in. long. Hab. Perak, Bujong Malacca (Ridley).

Perhaps the female of $P$. eucalyptolimbum.

(69) P. eucalyptolimbum C. DC. Rec. Bot. Surv. Ind. vi. 23; Journ. As. Soc. Beng. l.c. 330.

Scandent glabrous. Leaves membranous, elliptic-lanceolate acute acuminate, base acute equilong, one side narrower, 7 -nerved; midrib with a pair of nerves; 5.3 in. long, $\mathrm{I} \cdot 6$ in. wide; petioles .24 in. long. Peduncles $3 \mathrm{I}$ in. long. Male spikes $2.6 \mathrm{in}$. long; rachis hairy. Bracts sub-ovate elliptic; pedicel short thick. Stamens 2 ; anthers elliptic. Female spikes and fruit unknown. Hab. Perak, Larut, 2800 to $3000 \mathrm{ft}$. altitude (Kunstler).

I have not seen this species. Perhaps the male of $P$. gymnophyllum C.DC.

(70) P. lonchites Wall. Cat. 6644 (in part); C. DC. Journ. As. Soc. Beng. l.c. 306.

Stiff glabrous climber, woody but slender; young parts pubesFL.M.P., 3. 
cent. Leaves lanceolate acuminate or ovate-lanceolate, base unequally rounded, thinly coriaceous, glabrous; nerves strong elevate, 5 from base, pubescent beneath, reticulations small yet visible; 3 to 4 in. long, I to $I \cdot 75$ in. wide; petioles ${ }^{\prime} I 5$ in. long. Peduncles 5 in. long or less, slender. Male spikes 2 to 3 in. long, very slender puberulous. Bracts glabrous round. Stamens 3. Female spikes up to 4 in. long, thicker. Drupes ovoid, small, - $x$ in. long when ripe on broad elliptic scars edged with hairs, hairy. $H a b$. On rocks at $2300 \mathrm{ft}$. altitude. Perak, Hermitage (Curtis). Penang, West Hill ; Experimental Nursery (Curtis, Wallich).

(7I) P. Kunstleri C. DC. Rec. Bot. Surv. Ind. vi. 21; Journ. As. Soc. Beng. l.c. 329 .

Erect to about $3 \mathrm{ft}$. tall, glabrous. Leaves membranous, elliptic-oblong acute and long-acuminate, base unequal; narrow on shorter, round on longer side, penninerved, midrib with 3 pairs nerves; 4.5 in. long, $\mathrm{x} \cdot 8$ in. wide; petioles .07 in. long. Peduncles 24 in. long. Male spikes .84 in. long; rachis hairy. Bracts orbicular, glabrous except central hairy pedicel. Stamens 3. Female and fruit unknown. Hab. Penang, rocky ground (Kunstler).

I have not seen this species.

(72) P. Scortechinii C. DC. Rec. Bot. Surv. Ind. vi. 8; Journ. As. Soc. Beng. l.c. 309.

Slender creeper I8 ft. long. Leaves glabrous membranous, oblong elliptic-lanceolate acutely acuminate, base narrowed unequally in male, equally in female, penninerved; midrib with 3 nerves on one, 4 on the other side; 4.8 to 6.5 in. long, $\mathrm{I} \cdot 4$ to $\mathrm{r} \cdot 8$ in. wide; petioles 5 in. long; sheath prolonged a little above base. Peduncles slender, $\cdot 6$ to $I$ in. long. Male spikes $2 \cdot 6$ in. long; rachis hairy. Bracts round, sub-obovate. Stamens 2. Female spikes 2.8 to $5 \cdot 9$ in. long. Ovary ovate; stigmas 3 , linear. Drupe sub-ovateglobose mucronate, .I3 in. long. Hab. Perak, Thaiping hills 2500 to $3000 \mathrm{ft}$. altitude (Scortechini and Kunstler); Goping, Limestone hills (Kunstler).

(73) P. leptonema Hook. fil. F.B.I. vi. 9I ; C. DC. Journ. As. Soc. Beng. l.c. $3 \mathrm{I} 6$.

Branching climber glabrous. Leaves membranours, ovate acute, base round, very slightly unequal; nerves 7 radiating from base; 4 in. long, 3 in. wide; petioles 25 in. long. Peduncles 5 in. long. Spikes slender. Bracts small glabrous. Male spikes very slender, 3 in. long, glabrous. Flowers in whorls and clusters separate. Stamens 3. Female spikes thicker up to 5 in. long. Flowers clustered very small. Ovary prolonged into a short thick style; stigmas 4 or 5 . Drupe oblong-ovate, small. Hab. Perak, Hermitage Hill (Curtis). Penang (Wallich, Maingay) "two miles from Government House." Distrib. Java. 
(74) P. longicaule C. DC. Rec. Bot. Surv. Ind. vi. II; Journ. As. Soc. Beng. l.c. 3 I5.

Spreading climber, glabrous, slender. Leaves rather stiffy membranous elliptic-lanceolate to nearly ovate shortly acute-acuminate, base quite round or shortly narrowed, slightly oblique; nerves from base 7; nervules transverse, slender broken up, all elevate; 4 to 5 in. long, 2.5 to 3 in. wide; petioles .75 to $I$ in. long. Peduncles I in. long, slender. Male spikes over 6 in. long. Female spikes slender, 3 to Io in. long; rachis hairy or glabrous. Flowers in distant whorls or clusters, often bisexual. Bracts large, adnate, ovate-oblong, hairy. Drupe ovate, narrowed at base, sub-acute, small. Hab. Forests, Malacca (Maingay). Perak, Tapah (Wray); Ulu Slim (Kunstler). Penang (Curtis). Distrib. India.

Probably a variety of the preceding. There is very little difference between this and $P$. leptonema, and they grow together in Penang. The difference in the bracts is the only one I see.

\section{\$6. Heckeria.}

(75) P. umbellatum Limn.Sp. Pl. 43. Pothomorphe subpeltata Miq. Syst. Pip. 213; Illustr. 29, t. 26.

Shrub about $4 \mathrm{ft}$. tall, glabrous except leaves. Leaves ovatereniform acute deeply unequally cordate, 6 to I2 in. long and about as wide, sub-glabrous above, pubescent tomentose; nerves 8 , radiating from base; petioles 4 to in. long. Spikes crowded on the top of axillary branchlets pendulous white, 2.5 in. long, rather thick. Flowers bisexual. Bracts peltate. Stamens 2 or 3 . Ovary free with 3 stigmas. Fruit minute. Hab. In rocky woods, common, Pahang, Kwala Tembeling. Selangor, Batu Caves; Ginting Bidai; Semangkok (common here). Negri Sembilan, Bukit Sulu (Cantley). Perak, Kamuning; Waterloo (Curtis); Thaiping Hills. Penang (Wallich); Kelantan, Kwala Aring (Yapp). Distrib. S. India, Ceylon, Malay isles, Africa and South America. Native name: Sigumber Urat.

\section{Cultivated only or Excluded Species.}

PIPER Nigrum Linn. Black Pepper. Lada hitam. Native of S. India, cultivated in Penang as early as 1796 .

P. LONGUm Limn. Cultivated in Java, and the dried fruit spikes imported here. The plants referred to this by C. DC. Journ. As. Soc. Beng., l.c. 3 Io are doubtless something else.

P. Clypeatum Wall. Cat. 6655 A. \& $B$. A climber on treetrunks with distichous orbicular-ovate cordate rounded subsessile leaves, hairy, $\mathrm{I} \cdot 5$ to $4.5 \mathrm{in}$. long, I to $4.5 \mathrm{in}$. wide. It is common all over the forests, but what it turns into no one has discovered. It is probably not a pepper, but a Ficus. 


\section{ORDER CXVI. CHLORANTHACE尼.}

Herbs (shrubs or trees). Leaves opposite, toothed; stipules small on the margin of petiole sheath. Flowers in terminal spikes (heads or panicled unisexual or bisexual), female and male cohering in a bract. Flowers without perianth (or females with a toothed limb adhering to ovary). Stamens I or 3 connate; filaments short and thick; anthers 2 -celled or if 3 stamens the side ones I-celled. Ovary I-celled; style very short; ovule I, orthotropous. Fruit a fleshy drupe. About 3 genera and 30 species, Asia, America.

\section{CHLORANTHUS, Swartz.}

Herbs. Flowers spicate simple or panicled bisexual. No perianth. Stamens I or 3. Stigma sub-sessile, truncate. Species Io, Asiatic. Gamble, Journ. As. Soc. Beng. lxxv. pt. i, 33.

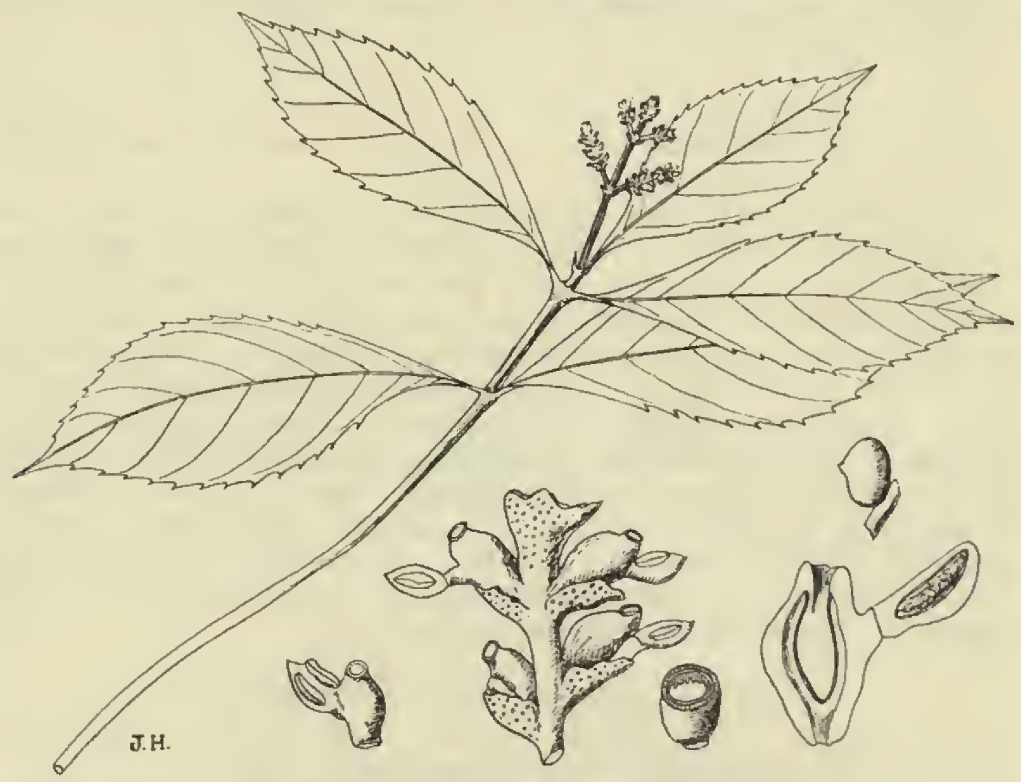

FIG. 140.-Chloranthus brachystachys.

Stamens 3, connate by the connectives; leaves shortly serrate; fruit white

Stamens I, 4-celled on a broad connective; leaves coarsely serrate; fruit bright red

(I) C. officinalis

(I) C. officinalis Bl. Enum. Pl. Jav. 79; Gamble, l.c. 33; Bl. Fl. Jav. iii, Fig. Io.

Shrublet about $2 \mathrm{ft}$. tall, glabrous. Leaves elliptic-lanceolate acuminate, narrowed to base shortly serrate, many-nerved, dark 
green membranous, 5 in. long, 2.5 in. wide; petioles $\cdot 25$ in. long. Peduncles slender, 2 in. long. Spikes usually 4 or 5 , slender, $\mathrm{I} \cdot 5$ in. long. Bracts sheathing ovate. Flowers very small, white. Stamens 3, connate by connectives. Drupe 5 in. through, pulpy, white. Hab. Common in damp spots in woods, Singapore, Bukit Timah; Jurong; Kranji. Johor, Batu Pahat; Gunong Pulai. Pahang, Pulau Tawar; Kwala Tembeling. Malacca, Batu Tiga. Negri Sembilan, Tampin Hill; Bukit Kandang (Cantley). Selangor, Batu Caves. Perak, Kwala Kangsa. Dindings. Tomoh (Machado). Penang Hill to $3000 \mathrm{ft}$. altitude (Curtis). Lankawi. Distrib. Indo-Malaya. Native names: Sigueh Putih; Sambau Paya.

A form on the top of Bukit Tangga in Negri Sembilan has stiffer ovate acute leaves, 6 in. long, 3 in. wide.

(2) C. brachystachys Bl. Fl. Jav. fasc. viii, I3, I4, 1. 2; Gamble, l.c. 34. (Fig. I40, p. 52.)

Glabrous undershrub about $2 \mathrm{ft}$. tall. Leaves stiffly membranous elliptic-lanceolate acute, base acuminate, coarsely serrate, 5 in. long, $2 \cdot 25$ in. wide, upper ones smaller; petioles $\cdot 2$ in. long. Peduncles 5 in. long. Spikes 5 in. long, dense. Stamen $I$; anther-cells 4. Drupe globose, 25 in. through, bright red. $H a b$. Mountain woods, not so common as the last, Pahang, Telom. Selangor, Sempang Mines; Menuang Gasing (Kloss). Perak, Bujong Malacca; Gunong Kerbau (Haniff); Batang Padang Valley (Wray). Penang Hill (all collectors). Distrib. India, China, Malaya.

C. inconspicuns Sw. is the species grown in pots by the Chinese for its fragrant leaves.

\section{ORDER CXVII. MYRISTICACEÆ.}

Trees, often large, usually more or less tomentose. Leaves alternate penni-nerved. Flowers unisexual, small, yellow, fragrant, in axillary panicles, cymes, umbels or fascicles. Perianth gamophyllous, inferior with 3 (or 2 or 4 ) lobes valvate. Androecium of 3 to 30 extrorse anthers, connate in a sessile or stipitate column or a disc. Ovary superior, sessile, I-celled; ovule I, erect. Stigma capitate or lobed. Fruit fleshy, splitting in 2 valves. Seed oblong or globose in a fleshy, entire or lacerate red or yellow aril (mace), albumen hard ruminate. Native names: Mendarah; Pendarah; Chendarah. About 235 species, chiefly Asiatic, also American and African (Gamble, Journ. As. Soc. Beng. lxxv. 205).

Anthers attached to a column of connate filaments.

Column sessile.

Anthers completely attached to column; aril entire or nearly so.

I. HORSFIELDIA 
Anthers free at the top; aril laciniate nearly to base

2. Gymnacranthera

Column stalked; aril laciniate to base

Anthers on the edge of a stalked disc; ari laciniate at tip

3. MYRISTICA

4. KNEMA

\section{HORSFIELDIA, Willd.}

Trees. Leaves usually large with conspicuous nerves. Male flowers in lax panicles, females in shorter and thicker panicles or racemes, from the axils of fallen or living leaves. Flowers usually very small, yellow, globose, fragrant, rarely sessile. Androecium sessile or nearly so; filaments combined into a column; anthers ro to 30 , completely attached to the column by thin backs. Stigmas in female very small, sessile. Fruit ovoid or globose. Pericarp thick. Seed testa thin. Aril scarcely laciniate. Species about 5I, India to New Guinea.

Anthers fully touching each other.

Perianth bivalved; leaves glabrous . . . (I) H. globularia

Perianth trivalved.

Sepals papillose inside; leaves glabrous - (2) H. canarioides

Sepals not papillose.

Male flowers elongate or oval.

Males large; leaves hairy beneath . . (3) H. superba

Males medium, oval globose; leaves hairy beneath large

Males medium; leaves glabrous, small :

Male flowers globose.

Leaves hairy, large; nervules impressed; inflorescence woolly, large

Leaves hairy, small; nervules indistinct; inflorescence pubescent, small . .

Leaves glabrous.

Flowers large; inflorescence pubescent.

Flowers small; inflorescence nearly glabrous

(4) H. flocculosa

(5) H. fulva

(6) H. grandis

(7) H. tomentosa

(8) H. Wallichii

(9) H. amygdalina

Anthers free at edge.

Perianth bivalved.

Flowers large; leaves oblong broad

Flowers small; leaves narrow lanceolate

(Io) H. majuscula

Flowers small; leaves oblanceolate

(I I) H. Irya

Flowers small; leaves oblong

(I 2) H. sucosa

Perianth trivalved.

(13) H. crassifolia

Branches with strong raised lines; leaves large. (I 4) H. brachiata

Branches without raised lines.

Leaves medium; inflorescence pubescent; fruit oblong : slightly pubescent.

Leaves inflorescence slightly pubescent; fruit globose .

(I5) H. Lehmanniana

Leaves small; inflorescence glabrous :

(I6) H. subglobosa

Male flowers unknown.

Fruits on long peduncles . - . (I8) H. racemosa

(I) H. globularia Warb. Monogr. Myrist. 288, t. xxi. ; Gamble, l.c. 207 . Myristica bivalvis Hook. fil. F.B.I. v. I07.

A glabrous bushy tree about $40 \mathrm{ft}$. tall. Leaves thin coriaceous, 
oblong or obovate-oblong, abruptly acuminate, base cuneate, dark shining green; nerves II to I8 pairs, thin; 7 in. long, 2 in. wide; petioles 3 in. long. Male panicles 3 to 4 in. long, spreading, pedicels 'I in. long. Perianth yellow, bivalved, $\cdot I$ in, long, glabrous. Androcium an obconic sessile bilobed cup of 20 to 30 linear anthers. Fruit sub-globose, $\cdot 5$ in. long, glabrous. Seed $\cdot 34$ in. long, aril complete. Hab. Singapore, one tree in the Botanic Gardens. Malacca, Bukit Naning (Cantley). Distrib. Java, Celebes, Amboina. Native name: Kedangga hutan hitam.

(2) H. canarioides Warb. Monog. Myrist. 294, t. xxi.; Gamble, l.c. 208. Myristica canarioides, King, Ann. Bot. Gard. Calc. iii. $304, t$. 134 .

Tree 60 to $70 \mathrm{ft}$. tall. Leaves coriaceous, elliptic-oblong to elliptic, acute shortly or blunt, base round or narrowed; nerves I2 to 15 pairs, faint; 5.5 to 7.5 in. long, 2.5 in. wide; petioles .25 in. long. Male panicles slender spreading, 6 in. long, manyflowered from axils of leaves and below; rachis puberulous. Perianth globose in bud very small, $\cdot 04$ in. long; lobes 3 to 5 cut nearly to base, acute. Androcium sub-sessile nearly annular; anthers Io. Female panicles 8 to 9 in. long. Fruit oblong-ovoid, blunt, slightly narrowed, 3 in. long. Pericarp thick. Seed 2 in. long. Aril slightly laciniate. $H a b$. In forests, Singapore, Sungei Jurong; Bukit Mandai; Stagmount. Malacca, Lubok Kedondong (Ridley). Perak, Ulu Bubong; Ulu Bera (Kunstler).

(3) H. superba Warb. Monog. Myrist. 295; Gamble, l.c. 209. Myristica superba Hook. fil. F.B.I. v. I05; King, Ami. Bot. Gard. Calc. 298, t. I24 bis, I25 bis.

A big tree upwards of Ioo ft. tall; young parts red-tomentose. Leaves stiffly coriaceous, densely tomentose when young, glabrous when adult, elliptic-lanceolate; midrib very stout; nerves $I_{5}$ to 30 pairs sunk above, strongly raised beneath; I2 to I8 in. long, 4.5 to 7 in. wide; petioles thick, 25 in. long. Male panicles large 6 in. long and wide, from scars of fallen leaves tomentose. Flowers in sub-umbellate clusters; perianth coriaceous obovoid elliptic, .2 in. long, yellow, teeth 3 to 4 . Androecium ovoid; anthers 20, connate. Female flowers on stout woody racemes, tomentose; perianth glabrous tubular, teeth 2 or 3 . Fruit ovoid-globose rough, yellow, very fleshy, 3 in. long, nearly 2 in. through. Hab. Forests, Singapore, Toas. Malacca, Jasin; Kesang Tua (Goodenough). Selangor, Ulu Selangor; Weld's Hill, Kwala Lumpur (Foxworthy). Perak, Gunong Batu Putih (Kunstler). Penang, Waterfall. Native name: Pendarah.

(4) H. flocculosa Warb. Monog. Myrist. 297. M. flocculosa, King, Ann. Bot. Gard. Calc. iii. 302, t. I3I.

Tree 40 to $70 \mathrm{ft}$. tall, Io to $20 \mathrm{in}$. through; branches thickly red-tomentose. Leaves stiffly coriaceous, oblong-lanceolate, acute or acuminate, base round or slightly cuneate at base, above hispid puberulous beneath, cinnamon tomentose; nerves $I_{5}$ to 20 pairs 
sunk above, elevate beneath, I6 in. long, $4 \cdot 5$ in. wide; petioles .5 in. long, very thick tomentose. Male panicles from the axils of fallen leaves, 6 in. long, 3 in. through, many-flowered; rachis and branches cinnamon-tomentose; pedicels slender, $\cdot I$ in. long. Perianth obovoid, thin glabrous; teeth 3 to 4 , shallow acute. Androcium sub-sessile obovoid truncate; anthers Io. Hab. Dense forests, rare. Perak, Ulu Kerling (Kunstler).

(5) H. fulva Warb. Monog. Myrist. 297; Gamble, l.c. 210. M. fulva, King, Ann. Bot. Gard. Calc. iii. 297, $t$. I24.

Tree 40 to $60 \mathrm{ft}$. tall, young parts red-tomentose. Leaves coriaceous elliptic-oblong, or obovate, tip acute, base narrow; nerves I2 to I4 pairs, rather stout, midrib puberulous; 6 to 7 in. long, 2.75 in. wide; petioles .5 in. long, red-puberulous. Male panicles from below the leaves many-flowered, spreading scurfy-tomentose, 2 to 3.5 in. long. Flowers sub-umbellate; pedicels slender, .07 in. long; perianth obovoid glabrous divided one-third into 3 teeth. Andrœcium sessile cylindric; anthers Io, connate. Female flowers not known. Fruit solitary on woody peduncles $\cdot 5$ in. long, ovoid, pointed glabrous, 75 in. long, yellow. Seed broad ovoid. Aril entirely covering seed. Hab. Forests, Malacca (Maingay). Perak, Goping (Scortechini).

var. paludicola Warb, l.c. M. paludicola King, Ann. Bot. Gard. Calc.l.c.t. I69. Leaves slightly puberulous beneath. Female flowers in short, thick, puberulous racemes, about 3 in. long. Perianth ovoid blunt bilobed. Fruit I in. long, $\cdot 75$ in. wide, yellow. Probably the female of $H$. fulva. Hab. Singapore, Selitar (Ridley). Perak, Goping, Larut (Kunstler).

(6) H. grandis Warb. Monog. Myrist. 30I; Gamble, l.c. $2 \mathrm{II}$. Myristica rubiginosa $K i n g, A n n$. Bot. Gard. Calc. iii. 302, $t$. I30.

A tree $30 \mathrm{ft}$. tall; branchlets stout, red-tomentose and ridged. Leaves coriaceous, rather thinly elliptic-oblong, blunt or shortly acute, glabrous above when adult, red-tomentose beneath; midrib tomentose on both sides; nerves and reticulations sunk above, strong elevate beneath; 9 to I2 in. long, 4 to 5 in. across; petioles very thick, tomentose, $\cdot 25$ in. long. Male panicles from below leaves densely tomentose, 9 in. long, with short branches. Cymules dense; pedicels very short. Perianth globose, 04 in. long; teeth triangular, 3 to 4 . Androcium sessile turbinate; anthers I3 to I5. $H a b$. Singapore, a single male tree in the Garden Jungle (Ridley). Distrib. Borneo.

(7) H. tomentosa Warb. Monog. Myrist. 302; Gamble, l.c. 2 I2. M. tomentosa Hook. fil. F.B.I. v. I05; King, Ann. Bot. Gard. Calc. 30I, $t$. I29.

Tree 20 to $30 \mathrm{ft}$. tall ; branchlets rusty tomentose, as are underside of leaves, petioles and inflorescence. Leaves thinly coriaceous, elliptic to oblanceolate acute, base cuneate or round; nerves Io to I2 pairs, slender; 8 to 9 in. long, 2 to 3 in. wide; petioles 
.25 in. long. Male panicles spreading, 4 in. long, 3 in. wide, rather lax; pedicels .04 in. long. Perianth glabrous depressed globose, nearly $\cdot I$ in. long in lax cymules, lobes 3 to 4 , triangular acute. Andrœcium sessile, globose; anthers Io to I5. Female in racemes of 8 to Io flowers. Fruit in short racemes of 3 to 5 , ovoid with a ridge on the suture about $I$ in. long, glabrous. Seed ovoid; aril fleshy entire, covering the whole seed. Hab. Rather common in forests, Singapore, Bukit Timah (Cantley). Johor, Kota Tinggi and Gunong Pantai. Malacca, Chabau to Jasin; Sungei Jerneh. Selangor, Weld's Hill; Ulu Selangor (Kunstler). Perak, Ulu Bubong and Ulu Kerling (Kunstler and Goping). Penang (Wallich), Waterfall, etc. Kedah, Yan. Native name: Manchong.

(8) H. Wallichii Warb. Monog. Myrist. 305; Gamble, l.c. 2 I3. M. Wallichii Hook. fil. F.B.I. v. I05; King, Am. Bot. Gard. Calc. iii. $203, t .132,133$.

Large tree I20 to I50 $\mathrm{ft}$. tall; youngest branchlets minutely red-tomentose. Leaves coriaceous, oblong-acute, base round or sub-cordate, glabrous above, red-tomentose beneath; nerves I6 to 22 pairs, stout, sunk above, elevate beneath; IO to I2 in. long, 3 to 4 in. wide, the terminal leaves smaller and more elliptic. Male panicles ro in. long, lax branches 3 in. long, woolly tomentose; pedicels short; perianth 05 in. long, glabrous globose; teeth triangular acute. Andrœcium sessile; anthers I5. Female flowers larger in shorter, stouter, few-flowered panicles. Perianth tomentose outside; teeth 3. Fruit ovoid, smooth, over 2 in. long, on short, stout peduncles. Hab. Forests, Singapore (Wallich), Chan Chu Kang; Garden Jungle; Bajau. Province Wellesley, Kubang Ulu (Curtis).

(9) H. amygdalina Warb. Monog. Myrist. 3ro; Gamble, l.c. 2I4. M. amygdalina Wall. Cat. 6797, Pl. As. Rar. i. t. go. M. sucosa King, Ann. Bot. Gard. Calc. t. I72, Figs. 2, 5, 6, 7 .

Tree $30 \mathrm{ft}$. tall, nearly glabrous. Leaves thinly coriaceous elliptic-oblong, shortly narrowed at both ends; nerves 8 to I2 pairs, very slender; 6 in. long, 2.5 in. wide; petioles $\cdot 5$ in. long, grooved. Male panicles lax branching, 3 in. long, puberulous. Perianth globose, 04 in. long, 2- to 3 -lobed; anthers I2 to I5. Fruit I.2 to I. 6 in. long; pericarp thick, fleshy. Seed ovate, aril complete or shortly laciniate at tip. Hab. Rare in lowland forests, Singapore, in forests near the Botanic Garden (Murton). Selangor, Sungei Buluh (Foxworthy). Penang Hill, to I50o ft. altitude (Curtis). Distrib. India, Burma, Andamans.

(Io) H. majuscula Warb. Monog. Myrist. 3I5; Gamble, l.c. 2I5. M. majuscula King, Ann. Bot. Gard. Calc. iii. 3Io, t. I43.

Tree about $50 \mathrm{ft}$. tall, glabrous except the puberulous tips and buds. Leaves coriaceous elliptic to elliptic-obovate, shortly narrowed at both ends; nerves Io to I5 pairs sunk above, elevate beneath, transverse nervules very inconspicuous; 6 to 9 in. long, 
3 to $3.5 \mathrm{in}$. wide; petioles $.5 \mathrm{in}$. long. Male panicles lax, spreading, 5 in. long, about 2 in. across, scurfy; cymules few-flowered; pedicels short; perianth globose, thick, glabrous, ${ }^{\circ} \mathrm{O}$ in. long; teeth triangular, 3 to 4 . Androcium nearly sessile trigonous; anthers Io to I3. Female panicles shorter, stouter, less branched. Perianth ovoid. Fruit yellowish-red, ovoid blunt, glabrous, $\mathrm{I} \cdot 8$ in. long, $I \cdot 6$ in. wide; pericarp thick. Seed ovoid, aril entire, covering the seed and overlapping at tip. Hab. Forests, Singapore, Bajau; Bukit Timah; Cluny Road. Perak, Thaiping Waterfall (Wray); Batang Padang (Kunstler).

(II) H. Irya Warb. Monog. Myrist. 37I, t. xxii.; Gamble, l.c. 2I5. M. Irya Gaerm. Fruct. i. I95, $t$. 4I. M. javanica $B l$. Rumphia, i, I90, t. 62. M. sphærocarpa Wall. Pl. As. Rar. 79, t. 89 .

Tall, rather slender tree with spreading branches, about $80 \mathrm{ft}$. tall, glabrous. Leaves membranous stiffly oblong-lanceolate, acuminate, base coriaceous; nerves Io to 20 pairs, slender, 9 in. long, 2.5 in. wide; petioles $\cdot{ }_{5}$ in. long. Male panicles lax, 3 in. long, scurfy or glabrous. Flowers minute, yellow, in small terminal clusters; pedicels short; perianth thin, bivalved. Andrcecium obovate; anthers 6 to Io. Female flowers fewer and larger, in smaller panicles. Fruit solitary or racemose globose, .8 in. through, glabrous; pericarp yellow, thick. Seed spherical. Aril thin, completely covering seed, lobes overlapping, tip often laciniate. Hab. Common in damp spots in forests, Singapore, Garden Jungle; Changi; Pulau Buru. Muar, Sungei Pauh (Fox). Malacca (Griffith, Maingay). Perak, Krian (Scortechini). Dindings, Bruas; Pulau Sembilan. Penang, Pulau Betong (Curtis). Setul. Distrib. Burma, Ceylon, Borneo, Java, Sumatra, Native names: Kandarah; Piango; Lempayan Paya.

(I2) H. sucosa Warb. Monog. Myrist. 322; Gamble, l.c. 3I7. M. sucosa King, Ann. Bot. Gard. Calc. iii. 301, t. I72 in part (Figs. I, 3, 8, 9).

Big tree up to Ioo ft. tall; branchlets and young leaves minutely tomentose, rest glabrous. Leaves coriaceous oblanceolate to obovate oblanceolate acute or acuminate, much narrowed to base; nerves 9 to I4 pairs, prominent and winged beneath; 7 to 8 in. long, 2 to 2.25 in. across; petioles 75 in. long. Male panicles lax, much branched, 6 in. long; branches scurfy; pedicels slender, .05 to 'I in. long. Perianth globular shorter puberulous, teeth 2 to 3 , triangular. Andrœcium sub-sessile globular; anthers ro. Female flowers in stout rigid puberulous panicles $I^{\circ} 5$ in. long. Perianth ovoid globose; teeth 3 . Fruit I to 3 in raceme ovoid or pearshaped, very succulent, glabrous, 2.4 to 2.8 in. long; pericarp thick. Seed ovoid, aril yellow covering the whole seed, slightly laciniate at tip. $H a b$. Forests to $3400 \mathrm{ft}$. altitude. Singapore, Garden Jungle. Malacca (Maingay). Perak, Goping; Ulu Bubong 
(Kunstler); Gunong Batu Putih (Wray); Batu Gajah (Foxworthy). Province Wellesley, Krian.

(I3) H. crassifolia Warb. Monog. Myrist. 323; Gamble, l.c. 217. M. crassifolia Hook. fil. F.B.I. v. Io8; King, Ann. Bot. Gard. Calc. iii. $308, t$. I40, I72, Fig. 4.

Big tree 40 up to Ioo $\mathrm{ft}$. tall; branchlets and buds puberulous. Leaves coriaceous, red-tomentose beneath when young, glabrous elliptic-oblong, blunt, cuneate at base; nerves I2 to I5 pairs, sunk above, prominent beneath; 6 in. long, 2 in. wide; petioles .5 in. long. Male panicles red-tomentose, above 4 in. long, lax with short branches. Flowers very small. Perianth bivalved. Androcium sessile flattened; anthers 6 to ro. Female flowers in short scurfy panicles, stout, 3 in. long, bivalved. Fruit yellow panicled ovoid; rachis and peduncles very thick, $\cdot 8 \mathrm{in}$. long. Seed ovoid; aril thin covering nearly the whole seed, apex laciniate. $H a b$. Forests, damp spots, Singapore, Bukit Mandai; Chan Chu Kang; Bukit Timah. Malacca (Griffith); Sungei Hudang (Derry). Perak (Kunstler). Distrib. Bangka, Borneo, Amboina.

(I4) H. brachiata Warb. Monog. Myrist. 325; Gamble, l.c. 3I5. M. brachiata King, Ann. Bot. Gard. Calc. 3II, t. II4. M. polyspherula Hook. fii. F.B.I. v. IoS in part.

Tree 50 to $60 \mathrm{ft}$. tall; buds pubescent. Leaves chartaceous, glabrous, oblong-lanceolate or elliptic-acuminate, acute or round at base; nerves I5 to 20 pairs, raised beneath, midrib scurfy; 6 to $8 \mathrm{in}$. long, 3.5 in. wide; petioles $\cdot 2$ in. long. Male panicles slender much branched, 5 in. long, 3 in. wide; rachis scurfy; pedicels .07 in. long; perianth shorter, globose; teeth 3 . Androcium sessile trigonous; anthers 9. Female flowers in stouter panicles. Pedicels thick. Fruit 6 to 8 together in woody cymes, ovoid, I.2 in. long; pericarp rather thin. Seed ovoid; aril covering the whole seed, tip laciniate. Hab. Forests, Singapore, Cluny Road. Malacca, Alor Gajah (Griffith). Perak, Larut (Kunstler).

(I5) H. Lehmanniana Warb. Monog. Myrist. 326; Gamble, l.c. 219. M. polysphertla Hook. fil. F.B.I. v. I08; King, Ann. Bot. Gard. Calc. 3I2, t. I46.

Tree 40 to $50 \mathrm{ft}$. tall. Leaves chartaceous oblong or oblonglanceolate, acuminate, base cuneate to round, glabrous except midrib beneath, scurfy; nerves Io to 15 pairs; 3 to 6 in. long, $\mathrm{I} \cdot 5 \mathrm{in}$. wide; petioles $\cdot 5$ in. long. Male panicles rusty tomentose much branched, 4 in. long, 3 in. wide, terminal cymules subumbellate; pedicels 04 in. long. Perianth globose, glabrous, teeth 3 , very small. Andrœcium sessile; anthers 9 to I2, ovate. Female panicles stout, few-flowered. Fruit 2 to 3 in a raceme, ovoid, $\cdot 8$ in. long. Seed ovoid, aril completely covering it. Hab. Common in forests, Singapore, Jurong; Chan Chu Kang; Bukit Timah. Malacca, Bukit Panchur and Merlimau (Derry). Perak, 
Ulu Bubong and Goping (Kunstler); Thaiping (Wray). Native names: Jankang Bukit; Menara or Pendara hijau or paya.

(r6) H. subglobosa Warb. Monog. Myrist. 328, t. xxi. M. subglobosa Miq. Fl. Bat. Supp. 383. M. Collettiana King, Ann. Bot. Gard. Calc. 3I3, t. I47.

Tree 50 to $70 \mathrm{ft}$. tall. Leaves stiffly chartaceous, ellipticoblong acuminate, cuneate or round at base, glabrous except slightly pubescent; midrib green above, brownish beneath; nerves $I 3$ to I7 pairs; 4 to 6.5 in. long, $I .5$ to 2.5 in. wide; petioles $\cdot 2$ to .5 in. long. Male panicles lax, scurfy, 3 in. long; pedicels .04 in. long; perianth globose, smaller with 3 acute triangular teeth. Androcium ovoid; anthers ro. Female panicles shorter, thicker. Fruit solitary or 2 or 3 in raceme ovoid-globose brownish yellow, I.25 in. through. Seed globose smooth, aril thick covering seed, red tinged yellow. Hab. Forests, not common, Johor, Road to Gunong Pulai. Perak, Larut to $2000 \mathrm{ft}$, altitude (Kunstler). Distrib. Sumatra.

(I7) H. Ridleyana Warb. Monog. Myrist. 23r; Gamble, l.c. 221. M. Ridleyana King, Ann. Bot. Gard. Calc. l.c. 33I, t. I45.

Tree 40 to $60 \mathrm{ft}$. tall, glabrous except the scurfy buds. Leaves chartaceous, lanceolate-acuminate, base cuneate; nerves 7 to ro pairs inconspicuous; 4.5 to 5 in. long, $\mathrm{I} \cdot 2$ in. wide; petioles $\cdot 25$ in. long. Male panicles scurfy or nearly glabrous, 2 in. long; branches short; pedicels .07 in. long. Perianth globose, teeth triangular acute 3 or 4 . Androcium sessile, trigonous; anthers 7 to Io. Female flowers in racemes $\cdot 8$ in. long. Fruit $I$ to 4 in a raceme, ellipsoid, 4 to $\cdot 8$ in. long; pericarp thick. Seed oval; aril thin entire covering seed. Hab. Forests, rare, Negri Sembilan, Pantai (Cantley). Perak, Ulu Bubong (Kunstler); Haram (Scortechini). Native name: Piango Jantan.

(I8) H. racemosa Warb. Monog. Myrist. 347; Gamble, l.c. 222. Myristica racemosa King, Ann. Bot. Gard. Calc. 328, $t$. I73.

Tree 40 to $50 \mathrm{ft}$. tall. Leaves thinly coriaceous, elliptic to elliptic-oblong sub-acute or short abrupt acuminate; base round or shortly cuneate; nerves 2 to 16 pairs, slender, prominent beneath; 6 in. long, $2 \cdot 75$ in. wide; petioles 5 in. long. Male and female flowers unknown. Fruit in lax racemes $5 \mathrm{in}$. long, oblongovoid pointed, $\mathrm{I} \cdot 75$ in. long, $8 \mathrm{in}$. through. Seed oblong-ovoid, pointed; aril completely covering it, tip fimbriate. $H a b$. Singapore, Bukit Timah (Ridley). Penang, Pass to Relau (Curtis).

The flowers are unknown. It is possibly a form of $H$. canarioides.

\section{Excluded SPECIES,}

H. sylvestris Warb. l.c. 337, t. xii. Myristica pendulina Hook. fil. F.B.I. v. 859. The only plant known here is one cultivated in Singapore Botanic Gardens. It is a native of Buru. 
2. GYMNACRANTHERA, Warb.

Trees medium. Leaves sub-coriaceous, glabrous, glaucous beneath. Panicles axillary; flowers fascicled pedicelled urceolate, 3- to 4-toothed. Androcium sessile, filaments forming a thick oblong column; anthers 6 to I2, elongate, lower part adnate to column by the back, tips free. Stigmas sessile, connate scarcely bilobed. Fruit rather small, globose or ovoid; aril laciniate nearly to base. Species II, India to New Guinea.

Flowers rerl-tomentose, 'I4 in, long

Flowers sub-glabrous, 'I in. long or less; leaves 6 to 8 in. long or less.

Leaf-nerves prominent beneath

Leaf-nerves faint beneath; leaves smaller .

(I) G. Murtoni

(I) G. Murtoni Warb. Monog. Myrist. 357, t. xx. Myristica Murtoni Hook. fil. F.B.I. v. I05; King, Ann. Bot. Gard. Calc. iii. 297 , t. I24 ter. M. ferruginea King, l.c. $298, t$. I25.

Tree about $60 \mathrm{ft}$. tall; branchlets densely rufous tomentose. Leaves stiffly coriaceous, elliptic-ovate, shortly abrupt-acuminate, base broad, round above glabrous shining beneath covered with deciduous red tomentum, beneath glaucous; nerves 20 to 22 pairs much elevate; 9 in. long, 3.5 in. wide; petioles 5 in. long, thick. Male panicles 2 in. long and wide, dense red-silky tomentose. Pedicels very short. Perianth $I_{5}$ in. long, tomentose, with 2 to 3 teeth urceolate. Andrœecium sessile, broad, ovoid; anthers 7 to Io, tips free. Female panicles very short, few-flowered. Fruit ovoid acute, densely red-tomentose, I in. long; pericarp stiff. Seed ovoid; aril deeply laciniate. Hab. Singapore (Wallich); Selitar; Sungei Morai; Bajau; Serangoon (Murton).

(2) G. Forbesii Warb. Monog. Myrist. 363, t. xx; Gamble, l.c. 224. Myristica Forbesii, King, Ann, Bot. Gard. Calc. iii. 396, t. $\mathrm{I} 37$.

Tree 60 to $80 \mathrm{ft}$. tall, 2 to $3 \mathrm{ft}$. through, glabrous except buds and inflorescence. Leaves thinly coriaceous oblong-lanceolate acuminate, base cuneate or rounded, glaucous beneath; nerves I3 to $I_{7}$ pairs, conspicuous; 6 to 8 in. long, 2 to 3.25 in. wide; petioles $\cdot 6$ in. long. Male panicles dense, 2 in. long; branches short, many-flowered, red-tomentose; pedicels long. Perianth urceolate, I $_{4}$ in. long; teeth 3 to 5 , nearly as long as tube, acute. Androecium sessile; anthers 6 to ro. Female panicles short, I in. long, dense; perianth hairy inside. Fruit 3 to I2 in raceme, narrow obovoid, I in. long, 5 in. through, pink or orange red. Seed ellipsoid; aril laciniate to base. Hab. Common in lowland forests, Singapore, Selitar; Garden Jungle. Malacca, Ayer Panas (Holmberg); Kesang Tua and Sungei Hudang (Goodenough). Negri Sembilan, Tampin (Goodenough). Perak, Tapah (Wray); Larut (Kunstler); Gunong Pondok (Kunstler). Province Wellesley, Krian. Penang Hill (Maingay). Distrib. Sumatra. 
(3) G. Farquhariana Warb. Monog. Myrist. $365, t . x x$; Gamble, l.c. 225. Myristica Farquhariana Wall. Cat. 6795; King, Ann. Bot. Gard. Calc. l.c. iii. 305, t. I36.

Slender tree about $60 \mathrm{ft}$. tall. Leaves sub-coriaceous, glabrous, glaucous beneath lanceolate acuminate, base cuneate; nerves indistinct, 6 to Io pairs; 4.5 in. long, $I \cdot 5$ to 2.25 in. wide; petioles .25 in. long. Male panicles rusty-puberulous, I. 5 in. long. Flowers numerous; pedicels slender, $\cdot 05$ in. long. Perianth ovoid inflate, 3- to 4-lobed, 08 in. long, puberulous both sides in cymules of 6 to I0. Androcium cylindric, sessile; anthers 7 to 8, narrow. Female panicles much shorter and denser; perianth 3- to 4-cleft.

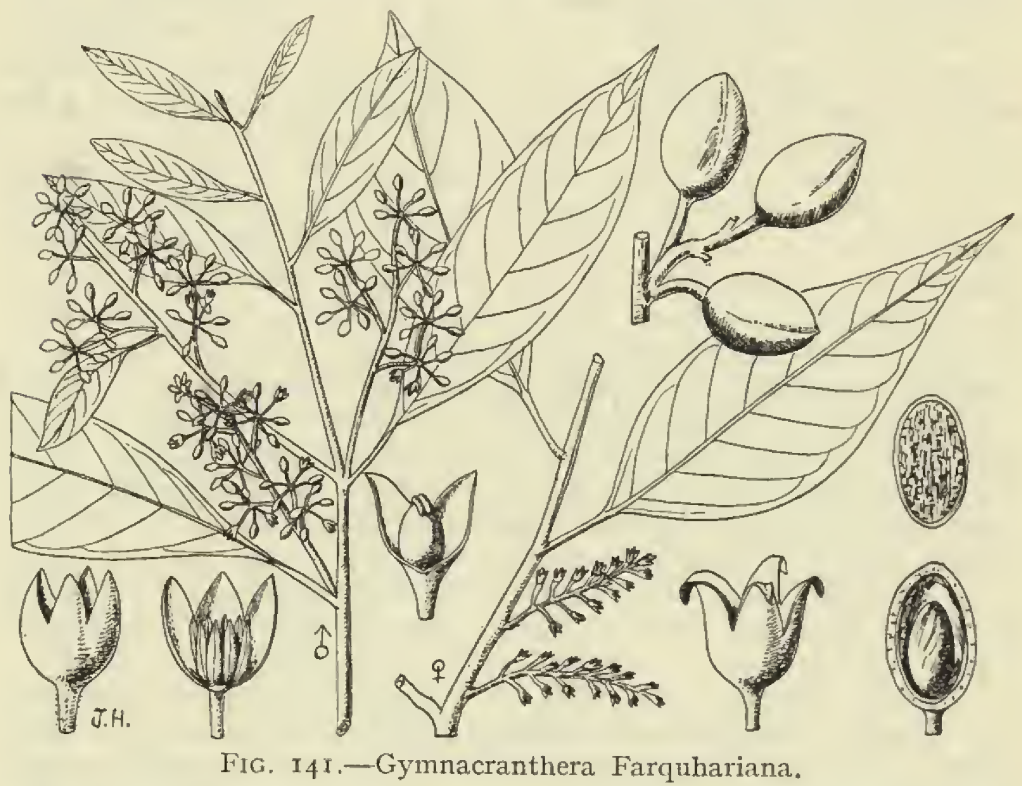

Fruit 2 to 5 in a raceme, ovoid pointed, I in. long, rufous-pubescent outside. Seed ellipsoid; aril as long as seed, laciniate yellow. $\mathrm{Hab}$. Common in forests. Singapore, Garden Jungle; Bajau; Chan Chukang. Johor, Batu Pahat; Tanjong Kupang. Malacca (Maingay). Selangor, Batu Tiga (Curtis). Perak, Goping (Kunstler); Thaiping (Wray). Penang Hill (Curtis).

This varies in size of leaves and panicles. A bigger form with wide leaves is var. major King. Var. Griffithii Hook. fil. and King, has more distinct nerves and a smaller globose-ovoid androecium. Malacca, Alor Gajah (Griffith).

3. MYRISTICA, Linn.

Trees often very large, usually glaucous beneath, often redtomentose. Inflorescence of cymes, umbels or few-flowered 
panicles axillary or from the axils of fallen leaves. Flowers rather large, urceolate or campanulate, pedicelled. Bracteoles persistent at base of perianth. Perianth 3 -toothed. Androcium stalked; filaments in a column produced beyond anthers 12 to 30 , connate. Stigmas connate bilobed. Fruit large oblong or ovoid; pericarp thick, fleshy; aril laciniate nearly to base. Species 80, India to Philippines, Australia and Polynesia.

The nutmeg of commerce, $M$. fragrans Linn, belongs to this genus, introduced from Banda and Amboina in I796, and cultivated as a small bushy tree in Penang and Singapore until 1866, when a disease destroyed the cultivation completely in Singapore and partly in Penang. Cultivation in Penang, however, continued till recently, Penang nutmegs and mace being considered the finest in the world. $M$. guattericefolia $D C$. a small tree with large lanceolate acuminate leaves and red-tomentose flowers grew in a hedge on Fort Canning, Singapore. It is a native of Labuan and the Philippines, probably introduced, and perhaps by Raffles, as it was within the area of his Botanic Gardens.

Inflorescence branching.

Perianth broad ovoid, $\cdot 25$ in. long; fruit 3 to 4 in. long

Perianth ovoir to globose.

Bracts broad; leaves lanceolate . . . (2) M. Maingayi

Bracts narrow; leaves linear to lanceolate : (3) M. gigantea

Bracts small; leaves oblong-lanceolate or oblong.

Male panicle sub-umbellate, I in. long; flowers ${ }^{\prime} \mathrm{I} 4 \mathrm{in}$. long

Male panicle 2 in. long; flowers $\cdot \dot{7}$ in. long :

(I) M. maxima

(4) M. iners

(5) M. malaccensis

Inflorescence not branching.

Leaves not glaucous beneath.

Flowers urccolate oblique

Flowers urceolate not oblique

Flowers long elliptic

Leaves glaucous beneath.

Anthers I 4 to I 8 ; fruit thinly woolly

Anthers Io to $\mathrm{I}_{4}$; fruit thickly woolly

(6) M. elliptica

(7) M. suavis

(8) M. cinnamomea

(9) M. crassa

(Io) M. Lowiana

(r) M. maxima Warb. Monog. Myrist. 385; Gamble, l.c. 228. M. bracteata King, Ann. Bot. Gard. Calc. iii. 286, t. Io7 (not of C. DeCandolle).

Tree about 50 to $70 \mathrm{ft}$. tall, I.5 to $2 \mathrm{ft}$. through. Leaves coriaceous oblong, shortly abrupt-acuminate, base rounded, glaucous beneath; midrib scurfy when young; nerves 20 to 30 pairs, raised beneath; I2 in. long, 4.5 in. wide; petioles thick, grooved, 5 in. long. Male flowers in panicles up to 7 in. long; branches distant, $\mathrm{r} \cdot 5$ in. long (lower ones). Flowers fascicled, $\cdot 25$ in. long, on slender pedicels 3 in. long, scurfy. Perianth urceolate, scaly tomentose; teeth broad, triangular 3. Fruit ellipsoid, red-pubescent, 3 to 
4 in. long, 2 in. wide, light yellow. Seed large; aril thin, bright red as long as the seed. Hab. Forests, Singapore, Bukit Timah. Perak, Larut (Kunstler). Penang Hill (Curtis). Distrib. Borneo.

(2) M. Maingayi Hook. fil. F.B.I. v. Io4; King, Ann. Bot. Gard. Calc. iii. 294, t. II4; Gamble, l.c. 228.

A lofty tree about $60 \mathrm{ft}$. tall; branchlets rusty-tomentose. Leaves coriaceous linear-oblong acute or acuminate, base round or cuneate, glabrous; nerves I6 to I8 pairs, prominent beneath, 6 in. long, I. 5 to $2 \cdot 25$ in. wide; petiole $\cdot 5$ in. long. Male flowers in red-tomentose umbellate cymes, I in. long; pedicels thick, $\cdot 2$ in. long. Bracteoles orbicular, $\cdot 2$ in. long. Perianth ovate, red-tomentose outside, teeth ovate acute. Andrœcium fusiform on a red-hairy column. Fruit oblong, 3 in. long, fleshy glabrous. Seed oblong; aril fimbriate at upper end. Hab. Forests, Malacca (Maingay); Bukit Jus (Derry). Perak (Scortechini). Penang, Moniot's Road (Curtis).

(3) M. gigantea King, Ann. Bot. Gard. Calc. iii. 288, $t$. IIo.

A tree Ioo to I50 ft. tall, 3 to $4 \mathrm{ft}$. through. Leaves coriaceous, narrow elliptic-oblong to lanceolate blunt, base very shortly acute, glabrous, light shining green, glaucescent beneath at first; nerves I 2 to I 8 pairs, faint, slightly raised beneath; 4 in. long, I. 5 in. wide; petioles $\cdot 2$ in. long. Male panicles rusty-pubescent, cymose I in. long. Bracteoles semi-annular; pedicels $\cdot I$ in. long. Perianth -I in. long, tomentose; anthers linear, Io, short tomentose. Fruit broad globose, about I in. long (unripe), tomentose. Seed ovoid; aril fimbriate nearly to base. Hab. Perak, Goping (Kunstler). Rare.

(4) M. iners Bl. Bijdr. 575; Rumphia, i. I84, t. 58; Gamble, l.c. 230 .

Tree. Leaves chartaceous oblong-lanceolate to oblanceolate acute or slightly acuminate, base narrow, glabrous; nerves I2 to I5 pairs, rather slender, little elevate, 5 in. long, I.5 in. wide; petioles $\cdot 25$ in. long. Male panicles short sub-umbellate, about $\mathrm{I}$ in. long; pedicels slender, $\mathrm{I}_{5}$ in. long. Perianth ovoid, $\mathrm{I}_{4}$ in. long, rusty puberulous outside; teeth three. Andrœcium slender, stalk as long as anthers, Io, puberulous. Female panicles 5 in. long, puberulous. Bracteoles large. Perianth campanulate tomentose, $\cdot 2$ in. long. Fruit oblong, 2.8 in. long, pericarp slightly tomentose. Seed $\mathrm{I} \cdot 6$ to 2 in. long; aril laciniate to near base: $H a b$. Rare at $3400 \mathrm{ft}$. altitude, in forests. Perak, Gunong Batu Putih (Wray). Distrib. Java.

(5) M. malaccensis Hook. fil. F.B.I. v. I04; Gamble, l.c. 230; King, Ann. Bot. Gard. Calc. iii. t. Io7 bis.

Tree. Leaves chartaceous oblong, base narrowed, tip acuminate blunt; nerves slender inarching at tips, I5 to 20 pairs, glabrous, 9 in. long, $3 \mathrm{in}$. wide; petioles 25 in. long. Male panicles 2 in. long, slender, glabrous; pedicels slender, ${ }^{\prime} 5$ in. long. Flowers 
half as long in sub-umbelled cymes. Bracteoles large reniform, edges ciliate. Perianth sub-globose coriaceous with three blunt shallow teeth. Androecium nearly sessile; anthers 7. Hab. Very rare and little known, Malacca (Maingay).

(6) M. elliptica Wall. Cat. 6798A; King, Ann. Bot. Gard. Calc. iii. t. II3; Gamble, l.c. 231.

Tree 60 to $80 \mathrm{ft}$. tall. Leaves chartaceous elliptic to linearoblong, shortly blunt-acuminate or acute, base cuneate, glaucescent beneath; nerves 8 to I 2 pairs, slender; 9 in. long, 3.5 in. wide; petioles 75 in. long, rather thick and rough. Male flowers in short umbels about 5 in. long; pedicels short; perianth $\cdot 3$ to 4 in. long, narrow tubular, divided half-way into 3 teeth, narrowovate acute, sometimes puberulous outside, yellowish. Androcium cylindric apiculate; stalk shorter; anthers Io. Female flowers urceolate, lobes ovate blunt. Fruit oblong, 3 in. long, pericarp leathery, pinkish yellow. Seed cylindric narrowed at tip; aril deep red laciniate. $H a b$. Common in low jungle. Singapore, Bukit Timah; Bukit Mandai; Garden Jungle. Johor, Tebing Tinggi; Gunong Pulai. Muar, Sungei Pauh (Fox). Malacca, Selandor (Cantley); Batang Malacca (Derry). Perak, Sungkai; Bikum Reserve (Burn-Murdoch) ; Ulu Bubong (Kunstler); Thaiping (Wray). Penang (Wallich); Penara Bukit (Curtis). Distrib. Sumatra, Borneo. Native names: Pala Hutan; Mumpato.

(7) M. suavis King, Amn. Bot. Gard. Calc. iii. 295, t. I2I; Gamble, l.c. 232.

Glabrous tree. Leaves coriaceous elliptic-lanceolate acute at both ends; nerves 20 to 25 pairs, prominent beneath, sunk above; 6 to 9 in. long, 2 to 2.4 in. wide; petioles .08 in. long, stout, grooved above. Flowers pale yellow, 2 to 4 together, in short thick woody racemes; pedicels 08 in. long. Bracteoles semi-orbicular. Male flowers, perianth narrow campanulate, cut half-way into three triangular acute recurved teeth, scurfy tomentose outside. Andrœcium cylindric short stalked; anthers 6 , linear. Female flowers similar but pedicels longer, teeth shorter; aril of seed extending to the tip deeply narrow laciniate. Hab. Malacca at Selandor (Cantley). Very rare.

(8) M. cinnamomea King, Amn. Bot. Gard. Calc. iii. 292, t. II6; Gamble, l.c. 232.

Tree 80 to $90 \mathrm{ft}$. tall. Leaves thinly coriaceous, lanceolate or oblong-lanceolate, acuminate both ends, shiny green above, cinnamon-brown beneath, minutely stellate-hairy; nerves I4 to 20 pairs, slender ; 6 in. long, 2 in. wide; petioles 75 in. long, pubescent. Male flowers red-tomentose in 8- to I4-flowered umbelled cymes, .75 in. long; pedicels slender, $\cdot 2$ in. long; perianth elongate ovoid tubular, $\cdot 2$ in. long, scurfy tomentose-brown. Fruit ellipsoid reddish yellow, minutely red-tomentose, 3 in. long. Seed cylindric, ellipsoid; aril thin, red, decply laciniate. Hab. Common in the F.M.P., 3. 
south, Singapore, Sumbawang; Sungei Buluh; Selitar. Pahang, Benchah, Kwala Lipis (Foxworthy); Rumpin (Foxworthy). Dindings, Bruas (Burn-Murdoch). Perak, Larut and Goping (Kunstler). Native name: Maiang Pahong.

The only wild species I have found in which the seed and aril have any spiciness.

(9) M. crassa King, Am. Bot. Gard. Calc. iii. 293, t. II7; Gamble, l.c. 234.

Tree 60 to $80 \mathrm{ft}$. tall, 2 to $3 \mathrm{ft}$. through. Leaves coriaceous, oblong or oblanceolate acute or slightly acuminate, glabrous, beneath sub-glabrous; nerves I5 pairs, strongly raised beneath, depressed above; 12 in. long, 4 in. wide; petioles 75 in. long, thick. Male flowers in many-flowered sessile, tomentose umbels on short woody peduncles; pedicels $\cdot 2$ in. long. Bracteoles ovate oblong. Perianth $\cdot 2$ in. long, tomentose urceolate constrict in middle, 3 cleft for one-third. Andrœcium narrow ovoid, stalk shorter. Fruit ovoid-globose pointed, base round, red-puberulous, 2.8 in. long, yellow. Seed ovoid; aril yellow laciniate extending to end of seed. Hab. Forests, Singapore, Sungei Morai; Gardens; Bukit Mandai. Malacca, Merlimau (Cantley). Negri Sembilan, Bukit Danan (Cantley). Perak, Thaiping Waterfall (Wray). Native names: Pala Bukit; Pala Hutan.

Cantley says this has the aroma of $M$. fragans.

(I0) M. Lowiana King, Ann. Bot. Gard. Calc. iii. 293, t. I20; Gamble, l.c. 235 .

Tree 60 to $80 \mathrm{ft}$. tall, 2 to $3 \mathrm{ft}$. through. Leaves stiffly coriaceous glabrous oblong, slightly narrowed at both ends; nerves 20 pairs, sunk above, fine elevate beneath; 9 in. long, 3 in. wide; petioles $x \cdot 25$ in. long, stout. Male flowers in dense, many-flowered axillary fascicles on short tubercles; pedicels slender red-tomentose. Bracteole ovate-round. Perianth ovoid, red-pubescent outside; teeth cut half-way down, 3, broad triangular. Androcium ellipsoid on a puberulous stalk; anthers Io to I4. Fruit ovoid, pointed both ends, red-tomentose, 2.5 in. long, ridged. Seed ellipsoid blunt at both ends; aril thin covering seed, sides widely areolate. Hab. Forests, not common. Muar. Malacca, Merlimau. Perak, Larut (Kunstler); Port Weld (Scortechini).

\section{KNEMA, Lour.}

Trees, rarely very large. Leaves chartaceous or coriaceous, often red-tomentose at first. Inflorescence of racemose or subumbellate clusters on thick tubercled peduncles from the axils of leaves or from fallen leaves. Flowers rather large for the Order, sub-globose or urceolate. Bracteoles persistent about the middle of the pedicel or above. Perianth 3 -toothed. Andrœcium stalked with a peltate round disc; anthers 8 to 20 attached to the edge. 
Style short, thick; stigmas connate in a bilobed often toothed or laciniate disc. Fruit oblong or ovoid, tomentose red-scurfy or eventually glabrescent; pericarp fairly thick. Aril laciniate at tip only. Species 38, India to Philippines.

Male flowers very large, red yellow, woolly outside, red inside.

leaves very large, thickly woolly when young; fruit thick woolly

Flowers moderate, 2 in. acruss; leaves smaller; fruit smaller

(I) K. Hookeriana

(2) K. Cantleyi

Flowers small, under $\cdot 2$ in. across.

Disc of androcium mammillate

Disc of androcium not mammillate.

Pedicel of male flower more than twice as long as perianth.

Anthers 40 to 45 ; leaves small.

Anthers under 20 on short filaments on edge of flat disc.

Anthers 9 to 12.

Leaves thinly coriaceous; nerves 7 to 14 pairs

Leaves membranous; "nerves 13 to 18 pairs

Anthers 8 to 18 .

Branchlets nearly giabrous; nervules obscure

Branchlets roughly pubescent; nerv: ules strong

Pedicel of male flower twice as long as perianth or less.

Leaves adult, glabrous beneath.

Leaves cordate; anthers Io to I2 .

Leaves cordate; anthers 6 to Io, disc very small . . . . .

Leaves not cordate; flowers in an umbel of 8

Leaves not cordate; flowers 3 to 4 in

Adult leaves 'stellate-hairy "beneath;

Leaves very large, silvery pubescent beneath; coriaceous; fruit 2 in. long or more

(I) K. Hookeriana Warb. Monog. Myrist. 25I, $t$, xxiv; Gamble, l.c. 237. Myristica Hookeriana Wall. Cat. 6802A; King, Am. Bot. Gard. Calc. iii. $325, t$. 163 .

A small tree up to $30 \mathrm{ft}$. tall; branchlets thick covered with dense brown wool. Leaves coriaceous, oblong-lanceolate or oblanceolate blunt or sub-acute, base round; young flaccid covered with thick brown wool; adult glabrous, glaucous beneath; nerves 20 to 30 pairs, prominent beneath, midrib stout; $2 \mathrm{ft}$. long, $4 \mathrm{in}$. across; petioles very thick, 5 in. long. Male flowers in clusters of 6 to 9 on thick tubercles densely woolly, 2 in. long. Perianth obovoid; teeth 3 , broad triangular, glabrous, bright pink inside. 
Androecium stalk conic; disc with 18 to 20 sessile anthers. Female teeth broader; ovary woolly. Fruit ellipsoid, 2 in. long, covered with dense yellow brown wool; pericarp crustaceous. Seed cylindric ovoid; aril thin covering it, red. Hab. Common in lowland forest, Singapore, Garden Jungle; Bukit Timah. Malacca (Griffith). Perak, Goping (Kunstler). Penang Hill (Curtis, Wallich). Lankawi, Gunong Raya (Haniff). Distrib. Sumatra.

(2) K. Cantleyi Warb. Monog. Myrist. 554, $t$. xxiv. Myristica Cantleyi Hook. fil. F.B.I. v. Iro; King, Ann. Bot. Gard. Calc. iii. $327, t$. 168 .

Tree 40 to $50 \mathrm{ft}$. tall; branchlets rather stout, dense woolly brown. Leaves coriaceous, oblong or oblong-lanceolate acute, base round, scurfily brown tomentose when young, especially on nerves, eventually glabrous; nerves $I_{5}$ to 20 pairs; 9 in. long, 2 to 4.5 in. wide; petioles rather thick, 5 in. long. Male flowers in sessile umbels on tubercles; pedicels thick, 2 in. long, all densely brown felted. Perianth globose-ovoid trigonous, brownwoolly outside, green inside, lobes 3 . Androecium with peltate disc surrounded by radiating anthers 13 to 15 on short filaments. Female in smaller clusters; stigma large with I2 or more lobes. Fruit ellipsoid blunt, red-tomentose, about I in. long. Seed obovate pointed; aril covering it. Hab. Forests, Singapore, Bukit Timah (Cantley). Selangor, Klang Gates (Burn-Murdoch); Weld's Hill; Menuang Gasing (Kloss). Perak, Larut (Kunstler); Thaiping (Wray). Penang, Pulau Betong (Curtis).

(3) K. intermedia Warb. Monog. Myrist. 564, t. xxv; Gamble, l.c. 239. M. intermedia Bl. Rumphia, i. I87; King, Ann. Bot. Gard. Calc. iii. 3I8, t. I54.

Small tree up to $50 \mathrm{ft}$. tall; young branches scurfy thin-tomentose. Leaves coriaceous, narrow oblong-lanceolate or oblong acute, rusty-pubescent when young, glabrous glaucescent beneath when adult, on branch ends small 4.5 in. long, I in. wide, to 8 in. long and 3.5 in. wide, finely reticulate with 12 to 22 nerves; petioles 5 in. long. Male flowers clustered 6 to 9 on tubercles; pedicels $\cdot 2$ in. long, scurfy-red. Perianth obovoid, teeth broad triangular, fleshy, white inside. Androecium pink, stalk short; anthers I2 to I5. Female similar but sessile; perianth obovoid. Ovary tomentose. Fruit ellipsoid minutely red-tomentose, $\mathrm{I} \cdot 6 \mathrm{in}$. long. Seed ellipsoid; aril completely covering it, laciniate or entire. Hab. Common in forests, Singapore, Bukit Timah; Garden Jungle; Changi. Johor, Tempayan River. Malacca, Pulau Besar (Fox); Merlimau (Derry); Selandor (Cantley). Perak, Batu Togoh (Wray); Haram Parah (Scortechini). Penang Hill (Curtis). Distrib. Java, Sumatra, Borneo, Natire name: Pendarah Kikeh.

The leaves vary much in size and shape in different parts of the tree, but the variety dubia Warb. Penang, Wallich 6810 is absolutely typical and the commonest form. Very woolly diseased flower tufts often occur on the branches. 
(4) K. Curtisii Warb. Monog. Myrist. 567, t. xxv; Gamble, l.c. 240. Myristica Curtisii King, Ann. Bot. Gard. Calc. iii. 326, t. 167 .

Small nearly glabrous tree, bark whitish. Leaves thinly coriaceous elliptic to nearly obovate, glaucous beneath; nerves 9 to I6 pairs; 2 to 3 in., rarely 5 in. long, $\mathrm{I} \cdot 25$ to 2.5 in. wide; petioles slender, 25 in. long. Male flowers 3 to ro in umbels on tubercles; pedicels slender, $\cdot$ I8 in, long. Perianth ovoid, trigonous, $I$ in. across, lobes broad, triangular, brown-scurfy. Andrœecium stalk obconic; anthers 40 to 45 , sessile on disc edge. Female flowers fewer; ovary tomentose; stigma 6-toothed. Fruit ellipsoid or ovoid, I.5 in. long, I in. through, pale greenish orange, redpuberulous. Seed ellipsoid; aril red, entire. Hab. Forests, Singapore, Bukit Mandai. Malacca, Batu Tiga. Negri Sembilan, Tampin Hill (Goodenough). Perak, Hermitage Hill (Curtis); Thaiping (Wray); Haram Parah (Scortechini). Penang (Curtis).

(5) K. Kunstleri Warb. Monog. Myrist. 568, t. xxv; Gamble, l.c. 24I. Myristica Kunstleri King, Ann. Bot. Gard. Calc. iii. 314, t. I49.

Tree I5 to $20 \mathrm{ft}$. tall. Leaves thin but stiff coriaceous, glabrous glaucescent beneath, elliptic to elliptic-oblong, short blunt acuminate at tip, base round or shortly cuneate; nerves 7 to I4 pairs, thin elevate, reticulations very fine; 4 to $6 \mathrm{in}$. long, I.25 to 2 in. wide; petioles 25 in. long. Male flowers 4 to 12 in umbels on tubercles; pedicels $\cdot 25$ in. long, rusty-puberulous pale yellow. Perianth globose trigonous lobes fleshy. Androecium, stalk short cylindric; anthers 9 to I2, horizontal with short filaments. Female flowers; stigma with short, spreading lobes. Fruit I to 3 together, ovoid globose, red-puberulous when young, after glabrous, 75 in. long. Seed ovoid; aril lobed at tip. Hab. Forests, Selangor, Kwala Lumpur. Perak, Ulu Bubong; Larut; Goping (Kunstler); Thaiping; Gunong Keledang (Ridley).

(6) K. malayana Warb. Monog. Myrist. 570, $t$. xxv.; Gamble, l.c. 242. Myristica glaucescens Hook. fil. F.B.I. v.; King, Ann. Bot. Gard. Calc. iii. 323, t. I6r (not of Jack).

Tree 50 to $70 \mathrm{ft}$. tall, Io to I $5 \mathrm{in.} \mathrm{through.} \mathrm{Leaves} \mathrm{membranous,}$ narrow, elliptic or oblong-lanceolate, sub-acute or blunt, base round glaucescent beneath glabrous; nerves I3 to I 8 pairs parallel, raised beneath; 4 to 6 in. long, I. 5 in. wide; petioles $\cdot 4$ in. long. Male flowers in sessile fascicles 5 to 8 , rusty-puberulous; pedicels slender, 5 in. long. Perianth globose, lobes ovate. Androeciumstalk thickened upwards; disc with Io to I2 anthers on edge. Female flowers fewer; stigma peltate, lobes 4 , acute. Firuit ovoid slightly narrowed at base, rusty puberulous, nearly .75 in. long. Seed ovoid, round; aril reniform fimbriate. Hab. Common in forests, Singapore, Cluny Road; Bukit Timah (Cantley). Johor, Bukit Tanah Abang (Kelsall). Malacca, Pulau Undang (Cantley); Ayer Panas. Pahang River, Kwala Berok, Selangor near Ulu 
Selangor (Kunstler). Perak, Tapah; Batang Padang (Wray); Goping; Chanderiang (Kunstler). Penang (Curtis). Distrib. Tenasserim. Native names: Chendarah Laut; Singgah Putih.

(7) K. Wrayi Warb. Monog. Myrist. 572, t. xxiv.; Gamble, l.c. 243. Myristica Wrayi King, Ann. Bot. Gard. Calc. 3I5, t. I5I. Tree 20 to $30 \mathrm{ft}$. tall, 4 to $6 \mathrm{in}$. through. Leaves thin coriaceous, narrow elliptic, acute, base round or sub-cuneate, dark green above, silver grey beneath; nerves I3 to 20 pairs, prominent beneath; 5 to 7 in. long, 2 to 3 in. wide; petioles 25 in. long. Male flowers many in rusty puberulous umbels on woody tubercles; pedicels slender, 2 in. long. Perianth globose, 3 - to 4-lobed, lobes ovate thick. Andrœcium, stalk short, disc sub-triangular; anthers I3 to I7 on short filaments. Fruit oblong-ovoid, glabrous, I.25 in. long, yellow tinged red. Seed ovoid, aril entire covering seed. Hab. Woods, low country, Singapore, Sungei Jurong. Johor, Tempayan River. Perak, Ulu Bubong; Kwala Dipang; Larut (Kunstler); Ulu Leding (Wray).

(8) K. conferta Warb. Monog. Myrist. 578, t. xxiv.; Gamble, l.c. 243. Myristica conferta King, Ann. Bot. Gard. Calc. iii. 365, t. I50.

Tree about 30 to $40 \mathrm{ft}$. tall; young parts rusty-tomentose. Leaves coriaceous, oblong, acute or acuminate, base round or slightly cordate, scurfy beneath when young, otherwise glabrous; nerves $I_{4}$ to 28 pairs, parallel elevate beneath; 5 in. long, 2 in. wide; petioles thick, I 5 in. long. Male flowers densely crowded axillary clusters 20 to 30 , rusty-pubescent. Pedicels $\cdot 2$ in. long; bracteole in middle. Perianth globose 3 -angled, . I4 in. across; teeth broad, triangular. Androcium stalk obconic; anthers 8 to I8 on short filaments. Female flowers larger, obovoid or urceolate, teeth short. Ovary tomentose. Fruit I to 2 , ovoid blunt, I.25 to 2 in. long, red-tomentose, yellow. Aril red. Hab. Common in woods, Singapore, Bukit Mandai; Changi. Malacca, Pulau Besar. Pahang River, Pulau Chengei. Perak, Thaiping (Wray); Ulu Bubong. Penang, Pulau Betong (Curtis). Distrib. Andamans, Borneo. Native name: Penara Batu.

var. Scortechinii Warb. M. Scortechini King, Ann. Bot. Gard. Calc. l.c. $315, t$. I53. Leaves longer and narrower and fruit smaller and globose. Perak, Goping (Scortechini); Gunong Batu Putih; Tapah (Wray).

(9) K. furfuracea Warb. Monog. Myrist. 58I, t. xxiv.; Gamble, l.c. 245. Myristica furfuracea Hook. fil. F.B.I. v. II2. King, Ann. Bot. Gard. Calc. iii. 3I8, t. I55.

Small tree about $30 \mathrm{ft}$. tall; young branches covered with reddish-tawny tomentum. Leaves coriaceous, narrow-oblong lanceolate acute or acuminate, base cordate, glaucescent beneath, glabrous except midrib red-tomentose beneath; nerves I8 to 36 , prominent; I3 in. long, 2.5 to 3 in. wide; petioles thick, 25 in. long. Male flowers 6 to 8 in rusty pubescent umbels on woody 
tubercles. Pedicels $\cdot 2$ to $\cdot 4$ in. long. Perianth trigonous subglobose, $\cdot 2$ in. across; teeth blunt, red inside. Andrœcium stalk obconic; anthers Io to $I_{3}$ on disc edge. Female flowers fewer obovoid. Ovary red-tomentose. Fruit ovoid or elliptic, densely rufous-tomentose, $2 \cdot 25$ in. long. Seed elliptic or oblong; aril covering it except at tip, where it is cut into 5 or 6 narrow lobes. Hab. Common in lowland woods. Singapore, Sungei Morai. Pahang River and Tahan River. Malacca, Tebong (Goodenough). Selangor, Ginting Bidai; Bukit Hitam. Perak, Goping; Ulu Kal and Larut (Kunstler). Penang Hill (Curtis). Distrib. Sumatra.

(Io) K. oblongifolia Warb. Monog. Myrist. 586, $t$. xxiv.; Gamble, l.c. 246. Myristica oblongifolia King, Amn. Bot. Gard. Calc. iii. 3r3, $t$. I48.

Shrub 8 to $\mathrm{I} 2 \mathrm{ft}$. tall, or small tree. Leaves membranous oblong or oblong lanceolate acute or short acuminate, base truncate cordate above, glabrous beneath, glaucous (red stellate-hairy when young); nerves 20 to 28 pairs; 7 to I4 in. long, 3.5 in. wide; petioles $\cdot 2$ in. long. Male flowers 4 to I2 in umbels on short tubercles; pedicels $\cdot 4$ in. long; perianth pale yellow " centre dark red," sub-urceolate, lobes broadly triangular. Androecium, stalk long cylindric, disc very small, anthers 6 to ro, sessile. Female flowers in peduncled umbels, ovoid, lobes ovate blunt; stigma bilobed. Fruit I to 2, obovoid covered with rusty-tomentum, I.5 in. long. Seed ovoid. Hab. Forests, Singapore, Garden Jungle; Bukit Timah. Johor, Tanjong Kupang; Bukit Tana Abang (Kelsall). Malacca, Bukit Sadanen (Derry). Selangor, Ginting Bidai; Semangkok. Perak, Thaiping Hills; Ulu Kerling and Goping (Kunstler). Penang (Curtis).

var. monticola King, l.c. Leaves smaller, 6 in. long, I.25 in. wide. Female flowers almost sessile. Mountains of Perak, at 3000 to $3500 \mathrm{ft}$. altitude, Thaiping Hills; Gunong Batu Putih (Wray).

(II) K. missionis Warb. Monog. Myrist. 602, t. xxv.; Gamble, l.c. 247. Myristica missionis Wall. Cat. 6788; King, Ann. Bot. Gard. Calc. iii. 32 I, $t$. I58.

Tree about $50 \mathrm{ft}$. tall. Leaves chartaceous, oblong-lanceolate or linear-oblong acute, base narrowed beneath glaucous; nerves I3 to I6 pairs, elevate both sides; 5 to 6 in. long, I.25 to $I \cdot 5$ in. wide; petioles I5 in. long. Male flowers about 8 , in rusty puberulous umbels on tubercles at first short lengthening to $\cdot 4$ in. long. Pedicels slender, $\cdot 2$ in, long. Perianth globose trigonous scurfypubescent, lobes triangular. Andrœcium, stalk short thick, disc with Io to 12 anthers. Female flowers similar; perianth urceolate. Ovary conoid, rusty-villous. Fruit sub-globose, rusty-pubescent at length glabrous, $\cdot 6$ in. long; pericarp thin. Seed sub-globose; aril fimbriate or entire at tip. Hab. Common in forests, Singapore (Wallich); Bukit Timah. Pahang River, from Kwala Pahang upwards. Malacca (Griffith, Maingay). Negri Sembilan, Tampin 
Hill (Goodenough). Selangor, Kwala Lumpur. Perak (Cantley). Penang Waterfall; Pulau Betong (Curtis), Kedah, Pulau Song Song. Perlis, Chupeng. Setul. Distrib. Tenasserim. Native name: Chendarah Padi.

(I2) K. geminata Warb. Monog. Myrist. 804, t. xxv.; Gamble, l.c. 247. Myristica geminata Miq. Fl. Ind. Bat. Suppl. 385; King, Ann. Bot. Gard. Calc. iii. 322, t. I60.

Large tree. Leaves chartaceous, oblong-lanceolate acuminate, short cuneate or round at base, beneath glaucous, golden rustytomentose when young; nerves 12 to I6 pairs; 4 in. long, I. 5 in. wide; petioles 25 in. long. Male flowers in 3- to 4 -flowered umbels on short tubercles; pedicel slender, $\cdot 24$ in. long. Perianth subglobose, red-puberulous, I in. long; lobes sub-acute. Andrœcium, stalk short, disc flat, anthers 9 to Io, sessile. Fruit usually in pairs, ellipsoid or ovoid, base narrow, 6 in. long, red-scurfy; pericarp thin. Aril slightly laciniate below tip. Hab. Rare, in lill forests, Johor, Gunong Pulai (King). Malacca, Jus (Cantley). Perak, Kurau (Scortechini). Penang (Curtis); near Crag Hotel. Distrib. Sumatra. Native name: Poko Ingank.

(13) K. laurina Warb. Monog. Myrist. 606, t. xxiv.; Gamble, l.c. 248. Myristica laurina Bl. Rumphia, i. I89, $t$. 6I.

Tree, $60 \mathrm{ft}$. tall. Leaves chartaceous-coriaceous, oblong or oblong-obovate acute or acuminate, base round or sub-cordate, glabrous above, stellate-hairy beneath, especially on midribs, and I2 to 24 pairs of nerves; 6 to 9 in. long, I.5 to 3 in. wide; petioles - I in. long, thickly tomentose. Male flowers in dense red-tomentose umbels, many-flowered; pedicels $I$ in. long. Bracts ovate below flower. Perianth obovoid, II in. long. Androcium long-stalked, disc small, concave; anthers erect, 6 to 9. Female flowers, ovary red-tomentose. Fruit ovoid or ellipsoid, I.2 in. long; pericarp leathery, red-tomentose. Seed ellipsoid; aril entire covering it. $H a b$. Common in forests, Singapore, Garden Jungle; Bukit Panjang; Bukit Mandai. Johor, Mount Austin. Malacca, Batu Tiga; Bukit Panchur (Derry); Sungei Hudang (Goodenough). Selangor, Kwala Lumpur. Perak, Larut; Goping (Kunstler). Penang, Pulau Betong (Curtis). Kelantan, Kwala Lebir (Gimlette). Distrib. Java, Sumatra, Borneo. Native names: Poko Deraham (Kelantan); Tenol; Chendarah Hitam. Use: Timber for house beams, durable.

(I4) K. retusa Warb. Monog. Myrist. 642, t. xxv.; Gamble, l.c. 249. Myristica retusa King, Ann. Bot. Gard. Calc. iii. 330, t. I7I.

Tree 40 to $60 \mathrm{ft}$. tall, $I_{5}$ to $20 \mathrm{in.} \mathrm{through.} \mathrm{Leaves} \mathrm{coriaceous,}$ stiff, oblong to obovate, blunt or retuse, base round sub-cordate, glabrous, shining deep green above, light brown with minute cinnamon hairs beneath; nerves I6 to 24 pairs, stout conspicuous beneath, midrib very prominent; 19 in. long, 8 in. across; petioles 
very thick, 75 in. long. Flowers unknown. Fruit 2 to 3 on short tubercles, ovoid apiculate velvety dark brown, 2 to 3 in. long. Seed narrow, obovoid; aril very small embracing base only, much fimbriate. Hab. Perak, Gunong Bubu at 500 to $600 \mathrm{ft}$. altitude (Kunstler). Rare.

\section{ORder CXVIII. MONIMIACER.}

Shrubs or trees. Leaves opposite (rarely alternate) entire (or serrate). Flowers uni- or bi-sexual, regular in cymes or racemes. Perianth inferior, globose, ovoid or depressed, 4-(to many-)toothed. Stamens 4 to $S$ in I- or 2 -series on a disc lining the perianth-tube, included. Carpels many or I, sessile on the disc or immersed; ovule solitary. Fruit a drupe enclosed in the disc or the receptacle. Species 250, chiefly S. American, but in all the tropics (Gamble, Journ. As. Soc. Beng. Ixxv. 250).

Stamens 4

Stamens 8

\section{MATTHঝЕA, Blume.}

Shrubs or trees. Leaves opposite entire. Flowers fascicled in leaf axils or below the leaves. Perianth turbinate with 4 minute lobes at the nearly closed mouth at length circumsciss, the top dehiscent. Stamens 4 on the flat receptacle; filaments very short; anthers ovoid, 2-celled. Carpels many on the flattened receptacles of the female flower; style short conical. Drupe fleshy, pedunculate, one or more on the enlarged receptacle. Species 3 (according to Miss Perkins), probably only one.

(I) M. sancta Bl. Amn. Mus. Bot. Lugd. Bat. 9o, t. x; Gamble, l.c. 25I. M. Iatifolia Perkins, Engl. Jahrb. xxv. 563. M. calophylla Perkins, l.c.

Slirub about $8 \mathrm{ft}$. tall with chartaceous light green leaves oblong acuminate; nerves impressed above, lightly elevate beneath, inarching far from edge, 6 to 9 pairs; 5 to 8.75 in. long, 2.5 to 3 in. wide; petioles 5 in. long. Flowers on pubescent pedicels, several in a fascicle, green, enlarging in fruit. Carpels very numerous, subulate pubescent. Drupe $\cdot 5$ in. long, olive-shaped, deep blue black, stalk 5 in. long, slender, 3 or 4 together, pendent $\mathrm{Hab}$. Dry woods. Singapore, Ang Mokio; Grarden Jungle; Bidadari. Johor, Bukit Soga. Pahang, Pramau River mouth. Malacca, Bukit Bruang. Perak, Gunong Haram (Scortechini); Thaiping (Kunstler), a tree 40 to $50 \mathrm{ft}$. tall.

I am quite unable to separate Miss Perkins' 3 species, and do not believe there is more than one here. Kunstler talks of it as a tree 40 to $50 \mathrm{ft}$. tall. All I have seen were stout few-branched shrubs usually under $8 \mathrm{ft}$. tall. 
2. KIBARA, Endl.

Shrubs or small trees. Leaves opposite, sub-coriaceous, entire or obscurely serrulate. Flowers unisexual in axillary cymes or panicles. Perianth ovoid, globular or hemispherical, nearly closed by 4 lobes in 2 series. Males erect; females inflexed, hooked; pedicels long. Stamens 5 to 8 in 2 rows; anthers I-celled opening by valves. Carpels many, free on the inside of the perianth; ovule I. Style very short. Fruit a sessile or stipitate drupe on the enlarged perianth-tube. Seed coniform, testa membranous. Species perhaps about 6 (I5 in Miss Perkins' monograph), but it is probable that most of the species may be reduced to I or 2 .

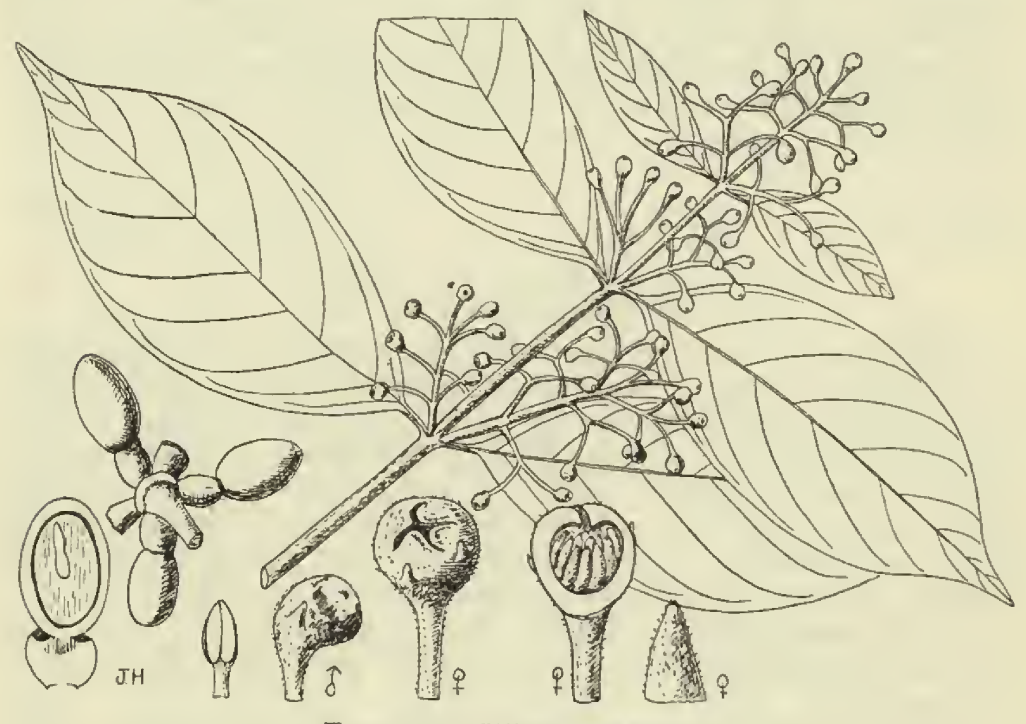

FIG. I42,-Kibara coriacea.

Leaves about 5 in. long; panicles nearly sessile, 2 in. long

Leaves stiff coriaceous, 7 in. long, 3.5 in. wide; panicles

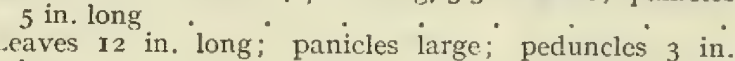
long 2 in. long; panicles large; peduncles 3 in.

(I) K. chartacea

(2) K. coriacea

(I) K. chartacea Bl. Ann. Mus. Bot. Lugd. Bat. ii. 89.

Shrub about $5 \mathrm{ft}$. tall. Leaves thinly coriaceous ovate or elliptic, short acuminate, base cuneate or round, edge entire, rarely obscurely serrulate; nerves 5 to 7 pairs; 5 in. long, 2.5 in. wide; petioles $\cdot 5$ in. long. Panicles I to 2 in. long, puberulous; pedicels rather slender. Perianth tube ovoid. Drupe ellipsoid, 4 in. 
long, orange; peduncle very thick. $H a b$. In forests. Malacca (Griffith). Pahang, Tanjong Api, Kwantan (Foxworthy). Negri Sembilan, Bukit Tumiang and Gunong Berumbun (Cantley). Perak, Tapah (Wray); Ulu Bubong (Kunstler). Penang, West Hill; Moniot's Road (Curtis). Distrib. Sumatra. Native names: Pakan Jantan; Pakan Kutang Tandok; Setubal Paya; Srian Putih; Susuh Ayam.

(2) K. coriacea Tul. Arch. Mus. Nat. Hist. Paris, vii. 404; Gamble, l.c. 255. (Fig. I42, p. 74).

Tree I5 ft. tall. Leaves stiffly coriaceous, elliptic, narrowed at both ends, 7 in. long, 3.5 in. wide; petioles $\cdot 5$ in. long. Panicles puberulous, stout, 5 in. long, lower branch 2 ; pedicels .25 in. long. Peduncle $\mathrm{r} \cdot 5$ to 3 in. long. Drupes ovoid acute. Hab. Perak, Sungei Rayah (Kunstler).

(3) K. serrulata Perkins, Engl. Jahrb. xxv. 575; Gamble, l.c. 256 .

Small tree or shrub. Leaves sub-coriaceous, oblong-ovate acuminate, base attenuate, glabrous, rarely slightly serrulate, I2 in. long, 6 in. wide; nerves inarching far from edge, 4 or 5 pairs; petioles I in. long. Panicles lax; peduncles 3.5 in. long in fruit, pubescent or puberulous in flower. Male flowers 05 in. long. Female flowers ${ } I$ in. long. Fruit greenish yellow, oblong. Hab. Forests, Malacca (Maingay). Negri Sembilan, Tampin. Perak, Ulu Bubong and Gunong Malacca (Kunstler). Penang Hill, to I200 $\mathrm{ft}$. altitude (Curtis). Distrib. Java.

\section{ORDER CXIX. LAURINEÆ.}

Trees or shrubs, often aromatic or (Cassytha) leafless twining parasites. Leaves alternate, rarely opposite or sub-opposite. Flowers regular, small uni- or bi-sexual in axillary clusters, racemes or panicles. Perianth inferior, tube short, lobes usually 6, imbricate. Stamens 6,9 or I2 in 2 - to 4 -series; filaments flat, those of inner row and sometimes of outer row with glands at base; anthers terminal, 2- to 4-celled, cells dehiscing by upturned lids, 4 th row of stamens often reduced to staminodes. In female flowers stamens reduced to linear or clubbed staminodes. Ovary I-celled, I-ovuled. Fruit a drupe supported on the more or less enlarged perianth-tube and lobes; pedicels also thickened. Species about Iooo, chiefly in hot regions; whole world. (Gamble, Journ. As. Soc. Beng. lxxv. I).

Trees or shrubs.

Stamens of 3 rd row when present extrorse.

Anthers 2-celled; stamens of three rows present fertile.

Fruit surrounded by enlarged perianth . I. CRYPTOCARYA 
Fruit seated on the enlarged perianth.

Perianth-lobes equal; fruit little en-

larged
Perianth-lobes unequal; fruit pedicel large fleshy, red

Stamens of rows I and 2 absent, 3 rd row sessile Stamens of row 3 absent, rows $I$ and 2 extrorse Anthers 4-celled, fertile; stamens 9.

Leaves usually opposite, usually trinerved; J.eaves alternate. fruiting perianth clasping drupe .

Fruiting perianth-tube enlarged, fleshy as is pedicel.

Fruiting pedicels hardiy cnlarged, lobes unequal

Fruiting perianth-tube hardly enlarged.

Perianth-lobes in fruit reflexed.

Perianth-lobes in fruit cup-like.

Fruiting pedicels short not enlarged, glands large

Fruiting pedicels long, clavate; glands small or o

Stamens all introrse.

Anthers 4-celled, fertile stamens 9 or more.

Involucre bracts deciduous; leaves sub-

Involucre bracts persistent in flower; leaves alternate or sub-opposite .

Anthers 4-celled, fertile stamens 6 ; bracts deciduous .

Anthers 2-celled; stamens 9 to I2

Parasitic leafless twiner; anthers 4 -celled

\section{BEIISCHMIEDIA \\ 3. Demaasia \\ 4. ENDIANDRA \\ 5. Micropora}

\section{CINNAMOMUM}

7. ALSEODAPHNE

8. Nothophase

9. Machilus

Io. Phøbe

II. STEMMATODAPIINE

\section{CRYPTOCARYA, R. Br.}

Trees or shrubs. Leaves alternate penni- or tri-nerved, coriaceous. Flowers small hermaphrodite in axillary or sub-terminal panicles. Perianth-tube turbinate or ovoid, lobes 6 . Stamens perfect, 9; Ist row opposite the 3 outer sepals, 2nd row opposite 3 inner petals, all introrse, 6 stipitate glands within and alternate, 3 rd row of 3 extrorse stamens, 4 th row 3 cordate stalked staminodes. Ovary sessile at base of tube; style exsert. Fruit enclosed in accrescent perianth-tube drupaceous, hard. Seed not separable. Species about 40, all tropics.

Leaves 3 -ribbed.

J.eaves elliptic-ovate, coriaccous, long acuminate.

Leaves orbicular-ovate very coriaceous, hardly acute often round

(1) C. densiflora

Leaves penni-nerved.

(2) C. Wrayi

Nerves hairy beneath; leaves large, panicles dense red-tomentose; flowers large for genus.

Leaves long acuminate; bracts conspicuous; fruit ovoid

Leaves blunt; bracts very inconspicuous; fruit ellipsoid

Leaves medium, panicles lax; flowers smail. Leaves elliptic; fruit globose . . .

(3) C. Griffithiana

(4) C. crassinervia

(5) C. impressa 
Leaves oblong acuminate; fruit flask-shaped

(6) C. rugulosa

Leaves slightly hairy beneath, glabrous when adult; reticulations conspicuous, elevate.

Glaucescent beneath minutely puberulous; fruit I in. long . . . . . .

Reddish beneath, puberulous when young; fruit 1.25 in. long.

(7) C. tomentosa

(s) C. ferrea

L.eaves glabrous, reticulations not elevate.

Leaves conspicuously blue glaucous beneath, bracts long linear.

(9) C. bracteolata

Leaves grey beneath; bracts small.

Leaves 3 in. across or more, blunt.

Panicles long, over 6 in. long; nervules prominent . . . . . .

Panicles under 6 in. long; nervules inconspicuous

\section{(Io) C. Scortechinii}

(II) C. areolata

Leaves hardly 2.5 in. across, acuminate.

Hardly glancous beneath; panicles narrow, puberulous

Leaves conspicuously white beneath; panicles spreading pubescent tomentose ${ }^{\circ}$ with

Leaves thin, panicles very slender with
slender branches . .

\section{(I 2) C. Kurzii}

(13) C. cæsia

(I4) C. tenuifolia

(I.5) C. enervis

(i6) C. bubongana

(17) C. argentea

Leaves narrow lanceolate; nervules inconspicuous.

Leaves oblong; branches angled

Near Kurzii but leaves smaller

(I) C. densiflora Bl. Bijdr. 556; Gamble, Journ. As. Soc. Beng. l.c. 39.

Tree 40 to $60 \mathrm{ft}$. tall, 15 to $20 \mathrm{in}$. through. Leaves coriaceous, dark green, glaucescent beneath, tripli-nerved, elliptic-ovate, cuspidate, base shortly narrowed, 5 in. long, 3 in. wide; petioles .25 in. long. Panicles yellow red-tomentose, I in. long. Bracts ovate caducous. Perianth-tube $\cdot 04$ in. long. Fruit globose-conic tip 5 to $\cdot 75$ in. through, green ribbed from the top when dry. Hab. Perak, Ulu Slim and Larut (Kunstler). Distrib. Java, Borneo.

(2) C. Wrayi Gamble, in Kero Bulletin, I910, p. I42; Joum. As. Soc. Beng. l.c. 40.

Small tree. Leaves thickly coriaceous ovate or orbicularovate, very short, bluntly acuminate or rounded, base truncate beneath glaucous, minutely reticulate and pubescent; nerves 3 from base; midrib with 2 to 4 above, all elevate, $2 \cdot 5$ to 3 in. long, $\mathrm{I} \cdot 5$ to 2 in. wide; petioles thick grooved, $\cdot 25$ in. long. Cymes rusty-pubescent, axillary and terminal $I \cdot 2$ in. long in flower, longer in fruit. Fruit depressed, globose obscurely ribbed, .75 in. through, black. Hab. Mountain forests, Perak, Gunong Bubu at $5000 \mathrm{ft}$. altitude (Wray).

(3) C. Griffithiana Wight Ic. t. I830; Gamble, Joum. As. Soc. Beng. l.c. 40.

Tree of large size; branchlets red-velvety. Leaves coriaceous, oblong or oblong-lanceolate cuspidate, base round or cuneate, 
glabrous; nerves and nervules sunk above except midrib tomentose, rusty-villous beneath eventually, except nerves glabrous glaucous; nerves 6 pairs; 8 in. long, 3.5 in. wide; petioles thick tomentose, .25 in. long. Flowers sub-sessile, numerous in dense red-tomentose sessile panicles I in. long. Bracts linear-lanceolate up to $\cdot 4$ in. long. Perianth-tube cylindric, .07 in. long, all tomentose. Fruit glabrous globose (cylindric when young) narrowed to a beak, .8 in. long, black. Hab. Common in forests, Singapore, Changi; Selitar; Teban. Muar, Biawak (Curtis). Malacca, Selandor (Cantley); Merlimau (Derry); Sungei Hudang. Selangor, Kwala Lumpur. Negri Sembilan, Bukit Tumiyiang (Cantley). Perak, Ulu Bubong and Ulu Kerling (Kunstler). Distrib. Tenasserim, Borneo. Native names: Laiang Chumpo Bukit; Medang Buaya; Rambahan Bukit; Tubo Buah.

(4) C. crassinervia Miq. Fl. Ind. Bat. i. 924; Gamble, Journ. As. Soc. Beng. l.c. $4 \mathrm{I}$.

Tree $60 \mathrm{ft}$. tall; branches red-tomentose. Leaves stiff coriaceous, elliptic or obovate-oblong to nearly orbicular, obtuse emarginate, rarely shortly acuminate above, glabrous with sunk nerves beneath, glaucous; nerves hairy tomentose, 6 pairs and reticulations tomentose; 6 to 9 in. long, 3 in. wide. Panicles redtomentose often thyrsoid, 4 in. long, 3 in. wide. Flowers sessile; bracts oblong or spathulate, small. Perianth-tube cylindric, tomentose, $\cdot 2$ in. long or less. Fruit ellipsoid, black, 8 in. long. Hab. Forest, Selangor, Sungei Buluh (Foxworthy). Dindings, Bruas (Burn-Murdoch). Perak, Goping and Thaiping (Kunstler). Distrib. Borneo, Sumatra. Native names: Medang Kelarah; Medang Miang.

Resembles C. Griffithiana, but has thicker, not cuspidate leaves and broader panicles with much smaller bracts.

(5) C. impressa Miq. Fl. Ind. Bat. I. i. 923; Gamble, l.c. 42.

Tall tree $80 \mathrm{ft}$. tall; branchlets finely red-tomentose. Leaves coriaceous, glabrous with 7 sunk pairs of nerves above, glaucous beneath with nerves and nervules raised and red-tomentose, elliptic short cuspidate, base cuneate, 5.5 in. long, 2.5 in. wide; petioles tomentose, .25 in. long. Panicles axillary and sub-terminal, spreading, 4 in. long, red-tomentose, numerous. Bracts small. Perianth-tube turbinate, $\cdot 04$ to $\cdot 2$ in. long. Fruit spherical, black, puberulous, 6 in. long. Hab. Forests. (I do not think rare, but tall, and difficult to get specimens of.) Singapore, Garden Jungle. Johor; Hulu Batu Pahat (Kelsall). Malacca (Griffith). Sungei Hudang; Bukit Sadanen (Derry). Perak, Gunong Batu Putih (Wray). Distrib. Sumatra. Native names: Munjuat; Medang Nau.

(6) C. rugulosa Hook. fil. F.B.I. v. Ir8; Gamble, l.c. 43.

Big tree 40 to $50 \mathrm{ft}$. tall, I2 to I8 in. through; branchlets redtomentose. Leaves coriaceous, oblong, oblong-lanceolate or ovate- 
oblong, acute or acuminate, base cuneate, glabrous above, with the nerves depressed, beneath greyish, nerves 4 pairs and reticulations elevate, red-tomentose; 3 to 5 in. long, 1.5 to 2.5 in. wide; petioles glabrous, 2 in. long. Panicles 2 to 3 in. long. Flowers very small, pale yellow crowded on the tips of the branchlets, all pubescent. Branches $\cdot 25$ in. long. Bracts small, oblong. Perianth-tube cylindric, $\cdot 075$ in. long; lobes as long. Fruit ovoid; flask-shaped, acute, I in. long, black. Hab. Forests, Malacca (Maingay, Derry). Dindings, Bruas, Lumut. Perak, Larut (Kunstler). Penang, Muka Head (Curtis). Native name: Medang Leang.

(7) C. tomentosa Blume, Ann. Mus. Bot. Lugd. Bat. I. i. 335; Gamble, l.c. 44 .

Big tree 30 to $50 \mathrm{ft}$. tall, Io to $\mathrm{I}_{5} \mathrm{in.}$ through; branchlets tawny-puberulous. Leaves chartaceous elliptic or oblong-lanceolate, shortly acuminate, base narrowed or rounded, glabrous above except midrib, grey beneath; nerves and reticulations tawny villous; 7 in. long, 3 in. wide; petioles glabrous, $\cdot 2$ in. long. Panicles lax, 4 in. long, 2.5 in. wide, grey puberulous, axillary and terminal; cymes corymbose; pedicels .04 in. long. Perianthtube funnel-shaped, 4 in. long; lobes as long, grey puberulous. Fruit ovoid or ellipsoid, I in. long, rather strongly ribbed when dry. Hab. River banks, Perak, Kinta River; Chanderiang; Batang Padang; Bernam River (Kunstler).

var. rugosa Gamble. Panicles with conspicuously rugose branches; leaves glabrous, and petioles very thick. Malacca, Sungei Hudang (Derry).

(8) C. ferrea Blume, Bijdr. 557 ; Gamble, l.c. 45.

A big tree 30 to $40 \mathrm{ft}$. tall, 8 to I2 in. through. Leaves chartaceous, oblong or oblong-obovate to lanceolate acuminate blunt, base cuneate, glabrous above, pubescent beneath, or glabrous except nerves, 4 pairs elevate, reticulations very small; 4 to 5 in. long, $I \cdot 5$ to $2 \cdot 75$ in. wide; petioles $\cdot 2$ in. long. Panicles axillary and terminal, 3 in. long, grey-pubescent, lower branches 2 in. long; flowers yellow, crowded at tips. Pedicels 04 in. long. Perianthtube funnel-shaped, 4 in. long, lobes shorter. Fruit ovoid-oblongcylindric, $\cdot 5$ in. long, $\cdot 25$ in. through, black. Hab. Forests, Singapore, Chua Chu Kang; Bukit Mandai. Johor, Pinerong (Cantley); Kwala Sembrong (Kelsall). Malacca, Sungei Hudang and Bukit Sadanen (Derry). Selangor, Ulu Selangor (Kunstler). Perak, Goping; Ulu Kerling (Kunstler). Penang, Pulau Betong (Curtis). Kelantan, Chaning Woods. Distrib. Java. Native names : Medang Merah; Medang Kuning.

(9) C. bracteolata Gamble, Kew Bulletin, I910, p. I44; Journ. As. Soc. Beng. l.c. 48.

Tree 50 to $70 \mathrm{ft}$. tall, Io to $\mathrm{I}_{5} \mathrm{in.}$ through. Leaves coriaceous, dark green above, bluish white beneath, ovate or elliptic-ovate cuspidate, base shortly cuneate; nerves 6 pairs sunk above, 
elevate beneath, reticulations fine, conspicuous beneath; 6 in. long, 3 in. wide; petioles 5 in. long. Flowers sub-sessile in panicles of cymes $I$ to $I \cdot 5$ in. Iong, axillary and terminal. Bracts and bracteoles linear to $\cdot 4$ in. long, very conspicuous. Perianth-tube funnel-shaped, $\cdot 2$ in. long, lobes oblong as long, dark brown. Fruit depressed globose, $\cdot 6$ in. long, beaked. $H a b$. Dense, rocky jungle, rare. Perak, Thaiping Hills up to I500 ft. altitude (Kunstler).

Easily recognised by its smooth leaves, white beneath, and long bracts.

(I0) C. Scortechinii Gamble, Kew Bulletin, I9Io, p. I43; Journ. As. Soc. Beng. l.c. 47.

Tree 50 to $70 \mathrm{ft}$. tall, Io to $\mathrm{I}_{5} \mathrm{in}$. through. Leaves coriaceous, dark green elliptic short or long abruptly acuminate, base narrowed; nerves 6 to 9 pairs inarching, reticulations fine, conspicuous; 6 in. long, 3 in. wide; petioles 4 in. long. Panicles lax, much branched, glabrous, 4 to I in. long, 3 in. across; peduncles 2.5 in. long. Flowers yellow, pubescent; pedicels 06 in. long. Perianth-tube funnel-shaped, 'I in. long; lobes ovate as long. Fruit oblongellipsoid truncate, I.2 in. Iong on much-thickened pedicels. $\mathrm{Hab}$. Forests up to $4000 \mathrm{ft}$. altitude. Sungei Ujong (Cantley). Perak, Thaiping; Ulu Kerling and Ulu Kal (Kunstler). Native name: Kayu Rangan. Use: Wood hard, flexible.

(II) C. areolata Gamble, Kew Bulletin, I9Io, p. I44; Joum. As. Soc. Beng. l.c. 48.

Big tree 40 to $50 \mathrm{ft}$. tall, $I_{5}$ to 20 in. through. Branches angled puberulous. Leaves deep green, glossy, ovate or ellipticovate (when young lanceolate), obtusely acuminate, cuneate at base, areolate reticulate both sides, glaucescent beneath; nerves 5 to Io pairs; 5.5 to 7 in. long, 3 to 3.25 in. wide (upper ones smaller); petioles $\cdot 3$ in. long. Panicles 3.5 in. long, rusty-pubescent, many-flowered. Flowers pale green, I4 in. long. Perianth-tube cylindric, lobes ovate, pubescent on both sides. Hab. Selangor near Ulu Selangor (Kunstler). Perak, Goping (Kunstler); Sungei Larut (Wray).

(I2) C. Kurzii Hook. fil. F.B.I. v. IIg; Gamble, Journ. As. Soc. Beng. l.c. 48.

Tree 30 to $40 \mathrm{ft}$, tall, 5 to 7 in. through, nearly glabrous entirely. Leaves chartaceous lanceolate to ovate-oblong acuminate, base cuneate dull dark green, greyish or slaty blue underneath; nerves 7 to I2 pairs with parallel nervules; 6 in. long, $2 \cdot 75$ in. wide; petioles $\cdot 25$ in. long. Flowers sub-sessile in axillary and terminal panicles about 2 in. long, puberulous, greenish yellow, - I in. long. Perianth-tube funnel-shaped, lobes ovate acute. Hab. Not rare in forests, Singapore, . Chan Chu Kang. Johor, Kota Tinggi. Pahang, Rumpin River (Foxworthy). Malacca, Bukit Bruang (Derry). Perak, Thaiping (Wray); Goping (Kunstler). Distrib. Tenasserim, Java, Borneo. Native name: Medang Ayer. 
(13) C. cæsia Bl. Ann. Mus. Bot. Lugd. Bat. i. 335; Gamble, l.c. 49 .

A fairly tall tree; branchlets and inflorescence softly tomentose. Leaves chartaceous ovate or elliptic-oblong, bluntly cuspidate, dull green above, violet glaucescent beneath; nerves slender, 7 to 8 pairs elevate beneath, midrib prominent flat angled puberulous, reticulations minute, conspicuous; 5 in. long, 2 in. wide or less; petioles 4 to $\cdot 5$ in. long, puberulous. Panicles lax, 4 in. long, many-flowered, tomentose-puberulous; flowers numerous, - I in. long, central ones sessile, laterals short-pedicelled. Fruit globose, rather fleshy, $\cdot 4$ in. long. Hab. Forests, Singapore, Chan Chukang; Bukit Mandai. Malacca, Sungei Hudang (Derry). Distrib. Andamans, Java. Native name: Kayu Grisek.

(I4) C. tenuifolia Ridl. Journ. Roy. As. Soc. S. Br. 82, p. Igo.

Tree. Leaves thin, nearly membranous, oblong, base very shortly narrowed abrupt acuminate, glaucous and glabrous except midrib and 9 pairs slender nerves pubescent, elevate beneath, lax reticulations and irregular nervules also elevate beneath; 7 in. long, 2.5 in. wide; petioles $\cdot 2$ in. long, pubescent. Panicles slender axillary, I to 4 in. long; branches slender pubescent. Bracts small linear-oblong. Flowers sessile. Perianth-tube $\cdot 04$ in. long, dilate upwards, lobes 6 , ovate, all hairy outside, lobes pubescent inside, pink. Stamens, rows I and 2 with ovate anthers and narrow filaments sparse hairy. Ovary conic. Hab. Forests, local, Selangor, Ulu Gombak (Ridley).

(I5) C. enervis Hook. fil. F.B.I. v. II9; Gamble, l.c. 50.

Leaves thin coriaceous, elliptic-lanceolate, caudate-acuminate, base narrow; nerves 6 to 8 pairs ascending obscurely glaucescent beneath; 3 in. long, $x \cdot 2$ in. wide; petioles $\cdot 2$ in. long. Panicles slender, axillary shorter than leaves. Fruit globose mammillate, faintly sulcate, 4 in. through. Hab. Malacca, Alor Gajah (Griffith).

A very doubtful plant. The leaves are not like those of a Cryptocarya, the nervules and reticulations being invisible.

(I6) C. bubongana Gamble, in Kerw Bulletin, I9Io, p. I44; Journ. As. Soc. Beng. l.c. 5o.

Large tree 50 to $70 \mathrm{ft}$. tall, 2 to $3 \mathrm{ft}$, through; branches angled. Leaves coriaceous elliptic or elliptic-oblong, shortly acuminate, base narrow, rounded, 6 in. long, 2.5 in. wide; nerves very prominent, 7 pairs, nervules slender transverse; petioles 5 in. long. Panicles lateral few-flowered, stout, about 2 in. long. Fruit globose, black, 4 in. through. Hab. Perak, Ulu Bubong (Kunstler).

A dubious plant, somewhat like $C$. areolata in the angled branches.

(I7) C. argentea Gamble, in Kere Bullelin, I9ro, p. I44; Journ. As. Soc. Beng. l.c. 5I.

Tree 30 to $70 \mathrm{ft}$. tall, 15 to $20 \mathrm{in}$. through; branchlets angled, puberulous. Leaves coriaceous, oblong or oblong-lanceolate, short

FI.MI.P., 3. 
blunt acuminate, base cuneate shortly, bright green above, silvery grey beneath, 4 in. long, 2 in. wide; nerves puberulous, 8 to Io pairs; nervules transverse, reticulations conspicuous, small; petioles $\cdot 2$ in. long. Panicles in young fruit 2 to 3 in. long. $H a b$. Perak, Batang Padang (Kunstler).

A dubious species near, and possibly a state of, C. Kurzii.

\section{BEILSCHMIEDIA, Nees.}

Trees or shrubs. Leaves alternate or opposite, usually coriaceous penni-nerved reticulate. Flowers rather small, bisexual racemose or panicled axillary to sub-terminal. Perianth-tube short, lobes 6. Stamens 9; anthers 2-celled, rows I and 2 introrse, 3 extrorse. Staminodes, $4^{\text {th }}$ row stipitate, cordate or ovate, glands 6 , stipitate between rows 2 and 3 . Ovary sessile, free. Fruit oblong, ovoid or globose; pedicels hardly thickened; perianth deciduous. Species 20, tropics.

Leaves very large, 12 in, long, very coriaceous.

Leaves oblong; perianth lobes ovate

Leaves obovate; perianth lobes oblong :

(I) B. insignis

Leaves coriaceous, about 6 in. long.

Leaves alternate; flowers rather large, glabrous

Leaves villous beneath more rounded

Leaves sub-opposite, rusty-villous; flowers rather large

Leaves opposite, glabrous shining; flowers very small

Leaves thin coriaceous or chartaceous.

Panicles dense, $I$ in. long

Panicles lax, spreading.

Nerves regular, panicle grey-pubescent

Nerves irregular; panicles reddish

Cymes short, '75 in. long; flowers campanulate, lobes long

(2) B. Kunstleri

(3) B. malaccensis

(4) B. Curtisii

(5) B. Scortechinii

(6) B. lumutensis

(7) B. Maingayi

(8) B. longipes

(9) B. perakensis

Flowers in very short bracteate racemes; bracts silky white, buds strobiloid

Flowers in very short glabrous bracteate racemes, glabrous; leaves lanceolate

(Io) B. tonkinensis

(II) B. penangiana

(1 2) B. brevipes

Species imperfectly known.

Leaves membranous elliptic

Leaves lanceolate willow-like chartaceous

Leaves coriaceous lanceolate

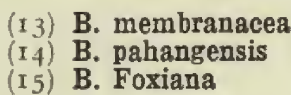

(I) B. insignis Gamble, Kew Bulletin, I9I0, p. I47; Journ. As. Soc. Beng. l.c. 53 .

Big tree 50 to $70 \mathrm{ft}$. tall, I.5 to $2 \mathrm{ft}$. through. Leaves stiff, coriaceous, oblong, oblanceolate acute, base narrow, glabrous; midrib prominent; nerves about 12 pairs slender but prominent; I2 in. long, $4.25 \mathrm{in}$. wide; petioles $\mathrm{I} .5 \mathrm{in}$. long. Panicles rather slender glabrous, 5 in. long; branchlets rather distant, $I$ in. long. Flowers few on terminal branchlets, green, glabrous. Perianthtube cup-shaped, lobes ovate blunt. Stamens white, villous. 
Fruit globose, reddish brown to black, $\mathrm{I} \cdot 5$ in. through. Hab. Low wet ground. Perak, Thaiping (Kunstler).

(2) B. Kunstleri Gamble, Kew Bulletin, I9Io, p. I47; Journ. As. Soc. Beng. l.c. 54 .

Big tree up to Ioo $\mathrm{ft}$. tall; stem 2 to $3 \mathrm{ft}$. tall; branchlets thick corky. Leaves very coriaceous, obovate or obovate-oblong, round or acute at tip, narrowed gradually to base, glabrous; nerves prominent about Io, reticulations conspicuous on both sides; I 2 in. long, 3 in. wide; petioles $\cdot 75$ in. long. Panicles 6 in. long, angled slightly puberulous; branches few, distant. Flowers

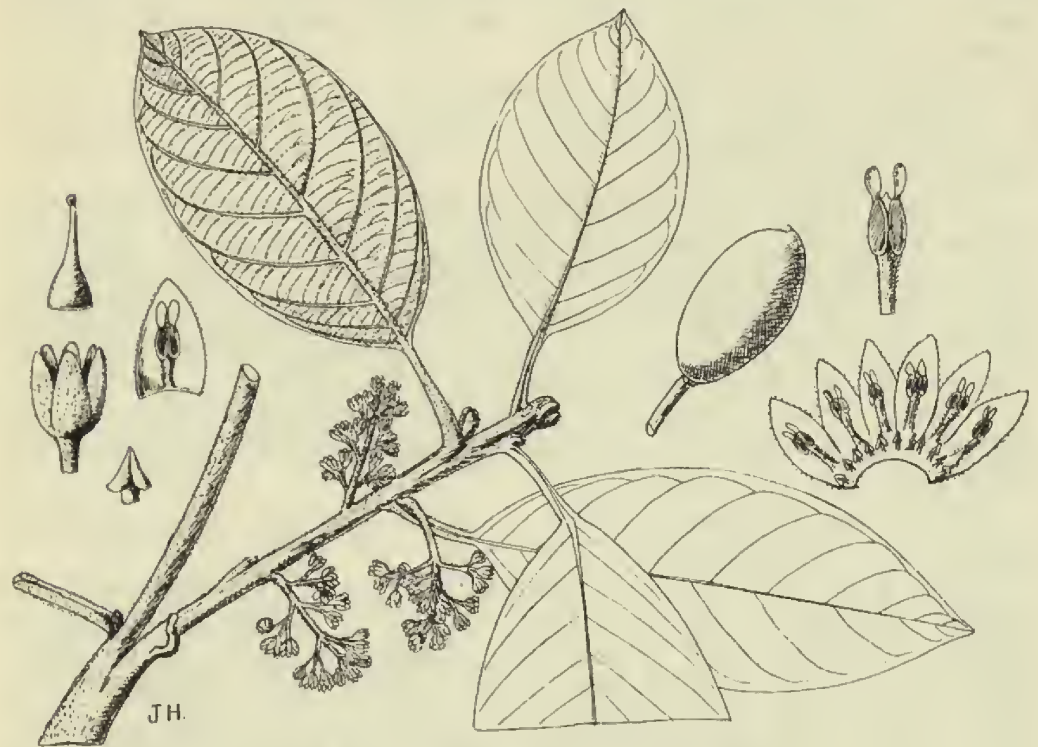

FIG. 143.-Beilschmiedia Curtisii.

I.5 in. long, velvety dark red. Perianth-tube very short, lobes oblong glandular glabrous. Fruit young obovoid. Hab. Low wet jungle. Singapore, Bukit Timah. Perak, Larut (Kunstler).

(3) B. malaccensis Hook. fil. F.B.I. v. I23; Gamble, Joum. As. Soc. Beng. l.c. 54.

Tree; young parts pubescent. Leaves coriaceous alternate glabrous elliptic blunt or acute shortly narrowed often unequally at base; nerves 8 to I2 pairs prominent, reticulations lax wide, 6 in. long, 3 in. wide; petioles .25 in. long. Panicles axillary lax, 2 in. long; branches stout purple pubescent. Perianth 25 in. long; tube very short, lobes oblong-linear purple, hairy, inside white. Fruit oblong. Hab. Forests, Singapore, Bukit Timah at the top; Garden Jungle. Malacca (Griffith and Maingay). 
Gamble gives the Garden Jungle plant as $B$. Curtisii, but its leaves are glabrous, and $I$ take it to be a narrow-leaved form of $B$. malaccensis.

(4) B. Curtisii Gamble, Kew Bulletin, I9Io, p. I48; Journ. As. Soc. Beng. l.c. 55. (Fig. I43, p. 83).

Tree about $60 \mathrm{ft}$. tall; branchlets thickly red-tomentose. Leaves stiff coriaceous elliptic acute, base narrowed unequal, glabrous above; nerves 8 to 9 pairs sunk above, elevate, redtomentose beneath, often entirely; 6 in. long, 3 to 4.25 in. wide; petioles tomentose, 5 in. long. Panicles 5 in. long; axillary tomentose. Bracts oblong-tomentose, $\mathrm{I}$ in. long, corymbose. Perianth-tube obconic, very short tomentose, lobes oblong, glabrous. Fruit oblong, black, $\mathrm{I}$ in. long. Hab. Penang Hill at $2000 \mathrm{ft}$. altitude (Curtis).

Resembles $B$. malaccensis, but is much more hairy.

(5) B. Scortechinii Gamble, Kew Bulletin, I9Io, p. I48; Journ. As. Soc. Beng. l.c. 56.

Tree; branchlets flattened, pubescent. Leaves coriaceous, oblong-lanceolate, acuminate acute, base attenuate, glabrous except midrib beneath rusty-puberulous when young, later glabrescent; nerves slender, I2 pairs elevate beneath, reticulations elevate; 6 in. long, 2 in. wide; petioles rusty-pubescent, I in. long. Flowers $\cdot I$ in. long in rusty-pubescent panicles, few-branched, 2 in. long. Perianth-tube campanulate, rusty-villous, lobes oblong. $H a b$. Mountain forests to $4000 \mathrm{ft}$. altitude. Perak, Thaiping Hills, Caulfield's Hill (Scortechini).

(6) B. lumutensis Gamble, in Kew Bulletin, I9Io, p. I48; Journ. As. Soc. Beng. l.c. 56.

Tree quite glabrous with slender branches. Leaves thin coriaceous elliptic to elliptic-oblong, acute or blunt, base shortly narrowed; nerves fine, 8 to Io pairs, reticulations very numerous and conspicuous; 5 in. long, $2 \cdot 25$ in. wide or less; petioles 25 in. long, rather slender. Panicles very slender, 4 or 5 branches, 3 in. long. Flowers few, very small, sub-globose, lobes short orbicular, glabrous except a villous ring at base of stamens. Hab. Dindings, Lumut (Ridley). Rare.

(7) B. Maingayi Hook. fil. F.B.I. v. I23; Gamble, l.c. 57.

Tree 40 to $60 \mathrm{ft}$. tall, $\mathrm{I}_{5}$ to $20 \mathrm{in}$. through. Leaves chartaceous, obovate or oblanceolate, abrupt acuminate, base narrowed red brown when dry; nerves 7 to 9 pairs distant elevate, reticulations wide, inconspicuous; 7 to 9 in. long, 3 to 6 in. wide; petioles $\cdot 25$ in. long, rather thick. Panicles dense, rusty-tomentose, $I$ in. long; rachis and branches stout. Bracts conspicuous ovate rustytomentose. Perianth-tube very short; lobes ovate. Fruit ellipsoid-obovoid, I.25 in. long, $\cdot 75$ in. through on thickened peduncle. $H a b$. Malacca (Maingay). Dindings, Lumut. Perak (Scortechini); Goping and Larut up to $2500 \mathrm{ft}$. altitude (Kunstler).

The fruiting specimens (Kunstler's) are a little doubtful. 
(8) B. longipes Hook. fil. F.B.I. v. I23; Gamble, l.c. 58.

Large tree 20 to $40 \mathrm{ft}$. tall, I5 to $20 \mathrm{in}$. through; young parts grey-pubescent. Leaves thin coriaceous, elliptic-lanceolate, acuminate, base cuneate; nerves Io to I4 pairs slender elevate beneath, glabrous above, puberulous beneath, reticulations distinct; 6 to 9 in. long, 3 to 3.5 in. wide; petioles .5 in. long. Panicles lax elongate ashy-pubescent, 4 in. long, 2 in. across; branches distant few with few-flowered cymules. Flowers white, centre yellow, 'I in. long, tube very short ovate, lobes round, tomentose inside and out. Fruit ovoid black. Hab. Malacca (Maingay). Perak, Sungei Larut (Wray).

(9) B. perakensis Gamble, in Ker Bulletin, I9Io, p. I49; Journ. As. Soc. Beng. l.c. 59 .

A shrub 4 to $6 \mathrm{ft}$. tall to a tree 30 to $40 \mathrm{ft}$. tall, 5 to 7 in. through; branchlets slender, pubescent. Leaves chartaceous alternate, elliptic to obovate, shortly acuminate, base attenuate, glabrous above, puberulous minutely on nerves, Io to I2 pairs, beneath elevate rather prominent; 5 to 7 in. long, 3 in. wide; petioles 25 in. long. Panicles slender pubescent, 4 in. long; branches few, very short, $\cdot 4$ in. long; cymules 3 -flowered. Perianth velvety, yellowish brown, $\cdot x$ in. long; lobes ovate pubescent. Fruit oblong or obovoid, black, 5 in. long. Hab. Dense forest, Perak, Ulu Bubong and Thaiping (Kunstler).

(Io) B. tonkinensis Ridl. Journ. Roy. As. Soc. S. Br. 82, p. Igo. B. glomerata Merrill var. tonkinensis Lecomte, Fl. Gen. de Cochinchine, v. 149 .

Tree with pale bark. Leaves glabrous, membranous obovate or oblanceolate blunt; nerves slender, inconspicuous; 3 in. long, $\mathrm{I} \cdot 5$ in. wide; petioles $\cdot 25$ in. long. Cymes lateral peduncled pubescent, 5- to 8-flowered, 75 in. long. Perianth campanulate, lobes linear-oblong, blunt, hairy outside and in, .25 in. long; pedicels ${ }^{-}{ }_{5}$ in. long. Stamens, row I, filaments hairy slender; anthers ovate, 2-celled; row 2, extrorse apparently sterile; row 3 absent. Staminodes small, ovate sub-sessile. Ovary conic; style rather long. "Fruit ellipsoid or obovoid, 5 in. long" (Lecomte). Hab. Setul. Distrib. Tonkin.

Quite an abnormal species, for, as my specimens are, the third row of stamens is quite wanting. The leaves as described above may be young. $B$. glomerata Merrill of the Philippines has thick coriaceous leaves, the var. tonkinensis Lecomte, oblanceolate thinly coriaceous leaves.

(II) B. penangiana Gamble, in Kew Bulletin, I9Io, p. I49.

Tree 30 to $40 \mathrm{ft}$. tall; branches white, shining. Leaves subcoriaceous elliptic or elliptic-lanceolate, blunt abruptly acuminate, base cuneate glabrous; nerves Io to 12 pairs faint irregular inarching far from edge; 4 in. long, I.75 in. wide; petioles $\cdot 25$ in. long, rather broad. Flowers in very short 5 in. axillary racemes with orbicular, silky-pubescent bracts enclosing I flower and 2 
lanceolate acuminate fimbriate bracts; pedicels thick and short. Perianth-lobes ovate, tube hardly any. Hab. Penang, Penara Bukit (Curtis).

(12) B. brevipes Ridl.

Glabrous tree. Leaves alternate crowded coriaceous lanceolate acuminate both ends; nerves about ro pairs elevate beneath, sunk above, reticulations lax visible on both sides; 4 in. long, $\mathrm{I} \cdot 25$ in. wide; petioles 25 in. long. Racemes axillary, I2 in. long, covered with ovate papery bracts; pedicels .05 in. long. Flowers glabrous as long. Perianth-lobes oblong not spreading, sub-equal. Stamens anther 2-celled. Fruit ellipsoid, blunt, narrowed at the base, 75 in. long, $\cdot 25$ in. through, on an enlarged peduncle ${ }^{\prime} I_{5}$ in. long with persistent spreading sepals $\cdot 05$ in. long. Hab. Pahang, Ulu Rumpin (Foxworthy). Native name: Medang Ayer.

This is perhaps nearest to $B$, tonkinensis Ridl.

(I3) B. membranacea Gamble, in Kew Bulletin, I9I0, p. I50; Journ. As. Soc. Beng. l.c. 60.

Small tree I5 to $20 \mathrm{ft}$. tall, 3 to $4 \mathrm{in}$. through; branchlets pubescent. Leaves membranous, elliptic to elliptic-ovate acute at tip, narrower unequally round at base, glabrous except midrib and nerves, 9 to II pairs, elevate beneath, reticulations fine, prominent; 3.75 to 6 in. long, 2 to 3.25 in. wide. Fruit oblong, black, $\cdot 5$ in. long; pedicel hardly enlarged. Hab. Perak (Kunstler).

A very little known plant.

(I4) B. pahangensis Gamble, in Kew Bulletin, I9Io, p. I50.

Small tree, glabrous. Leaves chartaceous, alternate, lanceolate or oblong-lanceolate acuminate, shortly blunt, base rather long attenuate; nerves fine not conspicuous, Io to I2 pairs, slightly elevate beneath; 4 to 5 in. long, I in. wide; petioles slender, $\cdot 2$ in. long. Panicles axillary, 5 in. up to 2.4 in. long, pubescent. Sepals narrow linear pubescent. Stamens in two whorls, outer filaments long. Ovary free, glabrous; stigma capitate. Fruit ellipsoid, blunt both ends, black with raised reddish dots. $H a b$. River banks, local, Pahang River, Kwala Triang, Lubu Lanjut; Kwala Tembeling. Kelantan River by the Jeram Panjang near Chaning. Native names: Medang Salau; Medang Tandok.

(I5) B. Foxiana Gamble, in Kere Bulletin, I9Io, p. I50; Journ. As. Soc. Beng. l.c. 6I.

Glabrous tree. Leaves coriaceous sub-opposite, prominently reticulate, lanceolate or oblanceolate, bluntly acuminate, long cuneate at base; nerves 7 pairs; 4 to 6 in. long, 2 to 2.8 in. wide ; petioles stout, -I in. long. Panicles much branched, 7.8 in. long; peduncles with oblong lenticles. Fruit ellipsoid pustular, $I \cdot 5$ in. long, 8 to $I$ in. through; pedicels slightly enlarged. Hab. Perak, Thaiping Hills, Birch's Hill (Fox). 


\section{DEHAASIA, Blume.}

Trees. Leaves alternate usually coriaceous often fascicled on branch-ends. Flowers small bisexual in axillary peduncled fewflowered panicles. Perianth-tube very short; lobes 6 , outer 3 shortest. Stamens 9, small, clavate, 2 -celled, 2 outer rows introrse, 3 rd extrorse with two large glands to each. Staminodes 4 th row small or o. Ovary sessile. Drupe oblong, black on a thick fleshy red peduncle. Species Io, Indo-Malaya.

Leaves large coriaceous, obovate; flowers $\cdot 2$ in. across Leaves small coriaceous; flowers hardly ' $I$ in. across.

Leaves broadly obovate; panicle large, many-flowered

Leaves oblanceolate blunt; panicle slender, small, few-flowered

Leaves stiff coriaceous lanceolate, not glaucous; panicles long lax

Leaves chartaceous lanceolate drying black
(I) D. microcarpa

(2) D. cuneata

(3) D. Curtisii

(4) D. lancifolia

(5) D. nigrescens

(I) D. microcarpa Bl. Rumphia, i. 162, t. 44; Gamble, Journ. As. Soc. Beng. l.c. 62 .

Tree 30 to $40 \mathrm{ft}$. tall or less. Leaves coriaceous, rather thinly, alternate elliptic-oblong to obovate acute or acuminate, base cuneate or narrowed gradually, glabrous; nerves prominent beneath, 9 to I5 pairs; Io to I6 in. long, 3.5 to 6.5 in. wide; petioles 5 in. long. Panicles 6 in. long, lax many-flowered from upper axils; branches I in. or less, angled, cymose at top. Flowers greenish white, -I2 in. long, tube short, lobes outer 3 triangular, inner ovate, blunt. Drupe oblong, I in. long, black; peduncle a little longer, red, very stout. Hab. Not rare, in forests, Singapore, Sungei Jurong; Bukit Mandai. Johor, Sungei Tebrau. Malacca (Maingay); Panchur. Perak, Gunong Kerbau (Haniff); Gunong Bubu and Goping (Kunstler); Trong (Wray). Distrib. Java, Sumatra, Borneo.

(2) D. cuneata Bl. Rumphia, i. I64, t. 46; Gamble, l.c. 64.

Tree 40 to $50 \mathrm{ft}$. tall, Io to $\mathrm{I} 5 \mathrm{in}$. through, bark white: young parts reddish-tomentose. Leaves coriaceous usually sub-whorled at top of branches obovate or oblanceolate acute or blunt, narrowed to base, glaucous beneath; nerves 8 to Io or more pairs sunk above, elevate beneath as are transverse nervules; 3 to 6 in. long, 2 to $3 \mathrm{in}$. wide; petioles 25 in. long. Panicles from upper axils 4 to 5 in. long, tomentose; peduncles long; branches numerous spreading lax; cymules few-flowered. Flowers very small, yellowish, tube very short, lobes ovate tomentose. Drupe ovoid-oblong, .75 in. long; pedicels cylindric, thick about as long. Hab. Selangor, Kwala Lumpur (Foxworthy). Perak, Larut, Thaiping (Wray, Kunstler). Dindings, Lumut. Pulau Rawei, Adang islands. Distrib. Burma, Java, Sumatra. Native name: Medang Ketanah. 
(3) D. Curtisii Gamble, in Kew Bulletin, I9Io, p. I5I ; Journ. As. Soc. Beng. l.c. 65.

Small tree; branchlets rough, white. Leaves coriaceous obovate, fascicled at branch ends obovate blunt or rounded, base long, narrowed, glaucous beneath; nerves fine, Io to I2 pairs, clevate both sides, reticulations minute; 3.5 to 4 in. long, $\mathrm{r} \cdot 25 \mathrm{in}$. wide; petioles $\cdot 2$ in. long. Flowers very small pubescent in slender cyme-panicles. Peduncles glabrous very slender, 2 in. long; branches very short, $\cdot 25$ in. long or less, tube cup-shaped, lobes ovate. Fruit ellipsoid, black, $\cdot 4$ in. long; pedicels clavate, $\cdot 2$ in. long. Hab. Selangor, top of Batu Caves (Kelsall). Penang, Rifle Range on the hill (Curtis). l.c. 66 .

(4) D. lancifolia Ridl. Journ. Linn. Soc. xxxiii. 320; Gamble,

Tree $25 \mathrm{ft}$. tall or bush; branches stout, dark. Leaves very coriaceous glabrous sub-fascicled at nodes; nerves conspicuous elevate both sides, 9 to I4 pairs rather slender inarching; reticulations wide conspicuous on both sides; 6 in. long, 3 in. wide; petioles stout, 25 in. long. Panicles 4 or more inches long, with long peduncles and few spreading rather slender branches pubescent. Flowers green, $\cdot 05$ in. long on pedicels as long, tube obconic, lobes nearly glabrous ovate, outer ones much shorter. Drupe elliptic, $\mathrm{I} \cdot 2$ to $\mathrm{I} \cdot 6$ in. long; pedicels cylindric not much thickened. Hab. Local on high mountains, open spaces, Pahang, Gunong Tahan, at 5000 to $6000 \mathrm{ft}$. altitude (Robinson).

(5) D. nigrescens Gamble, in Kere Bulletin, I9Io, p. I50; Journ. As. Soc. Beng. l.c. 64.

Glabrous tree 30 to $40 \mathrm{ft}$. tall ; branches white. Leaves chartaceous lanceolate or oblanceolate, long acuminate blunt, base narrowed; nerves fine and inconspicuous, 8 to ro pairs, 3 in. long, I in. across. Flowers few, small in slender panicles from the upper axils nearly 4 in. long; peduncles long; branches few, spreading. Perianth-tube cup-shaped, lobes small, all golden-pubescent, villous inside. Fruit obovate-ellipsoid, $\cdot 5$ in. long; pedicel clubbed about as long. Hab. Forests, Singapore, Garden Jungle. Selangor, Klang Gates (Ridley). Penang Hill (Curtis).

\section{ENDIANDRA, R. Brown.}

Big trees. Leaves coriaceous, minutely areolate all over. Flowers small, yellow bisexual in axillary and terminal panicles. Perianth-tube very short, lobes 6, sub-equal or inner smaller. Stamens of rows I and 2 absent, of 3 rd row 3, 2-celled extrorse, sessile, connivent over ovary; 4 th row staminodes 0 , or a fleshy ring; glands 6 or 0 at base of stamens. Ovary globose surrounded by tube. Fruit oblong or ellipsoid; pedicel slightly thickened. Species I5, Indo-Malaya, Australia. 
Leaves $2 \cdot 5$ to 3 in, long, elliptic

Leaves 4 to 5 in. long, lanceolate
Leaves 6 in. long, $2 \cdot 5$ in. across, el

(I) E. Maingayi

Leaves $6 \mathrm{in}$. long, $2{ }^{\circ} 5$ in. across, elliptic, pubescent beneath

Leaves 12 to $I_{5}$ in. long, 5 to 6 in. wide, glabrous

(2) E. Wrayi

(3) E. rubescens

(4) E. Kingiana

(5) E. praeclara

(I) E. Maingayi Hook. fil. F.B.I. v. I27; Gamble, Journ. As. Soc. Beng. l.c. 68 .

Tree 40 to $80 \mathrm{ft}$. tall, $\mathrm{I}_{5}$ to $20 \mathrm{in}$. through, glabrous. Leaves coriaceous elliptic, shortly blunt acuminate, base cuneate, minutely areolate both sides, glabrous shining dark green; nerves 8 to IO pairs, very fine inconspicuous and hardly elevate; 2.5 to 3 in. long, $\mathrm{I} .25$ to 2 in. wide; petioles $\cdot 25$ in. long. Panicles axillary or sub-terminal, lower ones very short, terminal 2 in. branches I in. long or less, glabrous or obscurely puberulous; pedicels -I in. long. Buds globose. Flowers waxy yellow. Perianth-tube very short, lobes $\cdot 08$ in. long, glabrous except a glandular cushion at base. Fruit oblong, black, $\cdot 5$ in. long, $\cdot 75$ in. through. Hab. Forests in lowlands. Malacca (Maingay). Selangor, Kwala Lumpur Gardens (Foxworthy). Perak, Goping and Ulu Kerling (Kunstler).

(2) E. Wrayi Gamble, Kew Bulletin, I9Io, p. I52; Journ. As. Soc. Beng. l.c. 70.

Small tree. Leaves coriaceous elliptic-oblong or oblanceolate, cuspidate acuminate blunt, base cuneate, minutely areolate, 4.5 to 5 in. long, I.5 in. wide; nerves 5 to 7 pairs, fine, very little raised; petioles $\cdot 2$ in. long. Racemes short axillary. Fruit oblong slightly narrowed both ends, blunt, $\cdot 75$ in. long, 3 in. through; pedicel slightly thickened. Hab. Perak, Upper at rooo ft. altitude (Wray).

(3) E. rubescens Miq. Fl. Ind. Bat. I. i. 918; Gamble, Journ. As. Soc. Beng. l.c. 70.

Tree. Leaves stiff thinly coriaceous, finely areolate all over, elliptic blunt, base cuneate; nerves 8 pairs sunk above, raised rather prominently beneath; 6 in. long, 2.5 in. across; petioles winged above, $\cdot 25$ in. long. Fruit oblong-ellipsoid blunt rusty brown, 2 in. long, $\cdot 6$ in. through. Hab. Perak, Relau Tujor (Wray). Distrib. Sumatra.

Specimen rather doubtful.

(4) E. Kingiana Gamble, in Kerw Bulletin, I9Io, p. I5I.

Tree 50 to $60 \mathrm{ft}$. tall, 2 to $3 \mathrm{ft}$. through; branchlets rustypubescent. Leaves coriaceous, rather stiff above glabrous, minutely areolate with sunk nerves, beneath softly red brown (when dry) pubescent, elliptic sub-acutely acuminate; nerves 5 pairs elevate strongly beneath; 5 to 6 in. long, 2.25 to 3.5 in. wide; petioles $\cdot 5$ in. long. Panicles dense, short, numerous, I.5 to 2 in. long, many-flowered, light tomentose brown. Pedicels very short or o. Perianth waxy-yellow, 'I in. long or less, pubescent. Hab. Perak, Larut, at 500 to $800 \mathrm{ft}$. altitude (Kunstler). 
(5) E. praeclara Gamble, in Kew Bulletin, I9I0, p. I52; JournAs. Soc. Beng. l.c. 69 .

Tree 60 to $70 \mathrm{ft}$. tall, I.5 to $2 \mathrm{ft}$. through. Leaves chartaceocoriaceous, large, finely widely reticulate both sides, glabrous; nerves sunk above, prominent beneath, 7 pairs, midrib stout; I2 to 15 in. long, 5 to 6 in. wide. Panicles rather lax glabrous, 4 in. long; branches 2.5 in. long; cymules few flowered. Flowers - I5 in. long, bright yellow on pedicels as long or shorter. Perianth. tube cup-shaped puberulous, lobes ovate glabrous. Fruit oblongellipsoid blunt, base narrowed dark red, 4 in. long, $\mathrm{I} \cdot 5$ in. through. Hab. Perak, Larut (Kunstler); Tupai (Wray).

\section{MICROPORA, Hook. fil.}

Tree; branchlets slender. Leaves alternate, conspicuously reticulate. Flowers small, bisexual in axillary racemes and panicles. Perianth-tube very short flat, lobes 6 , orbicular, equal. Stamens of rows I and 2, 6, exsert; anthers sessile, sub-quadrate opening by 2 circular pores, of $3 \mathrm{rd}$ and 4 th rows reduced to thick staminodes as large as fertile anthers and produced above them. Ovary ovoid, sessile; style very short; stigma minute. Fruit ovoid on the accrescent perianth. Species one.

(I) M. Curtisii Hook. fil. Ic. Pl. t. I547; Gamble; Joum. As. Soc. Beng. l.c. $7 \mathrm{I}$.

Small tree 40 to $60 \mathrm{ft}$. tall. Leaves coriaceous, elliptic subacute or blunt, base narrowed minutely reticulate both ends; nerves elevate beneath, 4.25 in. long, 2.25 in. wide; petioles 15 to 3 in. long. Racemes or panicles 75 in. long, pubescent. Flowers light yellow, 08 in. wide. Fruit ovoid rugose. Hab. Penang Hill, to Iooo $\mathrm{ft}$. altitude (Curtis, Kunstler). Very local.

The "Perak, Larut" locality given by Gamble is wrong, the labels are distinctly written "Penang" by Kunstler.

\section{CINNAMOMUM, Bl.}

Trees, rarely tall or shrubs, aromatic. Leaves opposite or sub-opposite or alternate, 3-ribbed (except Sect. Camphora), penninerved. Flowers small, bisexual in axillary and sub-terminal panicles, usually pubescent. Perianth-tube short enlarging in fruit, lobes 6, sub-equal. Stamens 9; anthers 4-(rarely 2-)celled, Ist and and rows introrse, 3 rd row extrorse or anther-cells on edge with 2 glands at base, 4th row of sagittate or cordate staminodes. Ovary free narrowed to style; stigma discoid. Drupe oblong on the cup-shaped enlarged perianth-tube; lobes more or less persistent. Species I40, Indo-Malaya, China, Australia, Polynesia.

§ I. Malabathrum. Leaves sub-opposite; nerves 3 , from near base.

Midrib without side nerves; nervules transverse.

Leaves glabrous when adult.

Panicles very short, slender, few-flowered. Leaves elliptic caudate acuminate

(I) C. gracilifforum 
Leaves ovate sub-acute

Leaves lanceolate acuminate blunt

(2) C. microphyllum

(3) C. vimineum

Panicles elongate silky puberulous.

Leaves oblong-lanceolate puberulous beneath with side nerves from outer pair

Leaves oblong, side-ribs reaching to top; nervules invisible

Leaves oblong cuspidate, side-ribs disappearing before tip

Leaves elliptic blunt or ovate; branches and leaves quite glabrous

Panicles hairy tomentose; leaf nervules transverse numerous, no distinct Trees. secondary ascending nerves.

Leaves silky pubescent beneath : .

Leaves large oblong with conspicuous transverse nervules

Leaves large, oblong blunt; nervules not conspicuous transverse .

Leaves 4 to $6 \mathrm{in}$. long, with branches densely hairy; panicles small.

Leaves 4 to 5 in. long, ovate woolly tomentose; panicles stout .

Leaves thick felted tomentose beneath, outer nerves with 3 to 8 secondary ones

Bush; leaves orange tawny beneath, acuminate

Leaves midrib with several pairs of secondary nerves ascending.

Leaves lanceolate acute, secondary nerves numerous

Leaves elliptic-oblong; secondary nerves 2 or 3 pairs

§ 2. Camphora. Tall trees. Leaves small, penninerved; stamens very small.

Leaves glaucous beneath; perianth glabrous .

Leaves not glaucous beneath; perianth villous inside

(4) C. paraneuron

(5) C. iners

(6) C. Ridleyi

(7) C. Deschampsii

(8) C. rhyncophyllum

(9) C. javanicum

(I0) C. Kunstleri

(Ir) C. mollissimum

(I2) C. velutinum

(I3) C. Scortechinii

(I 4 ) C. aureo-fulvum

(I5) C. cinereum

(16) C. puberulum

(I 7$)$ C. parthenoxylon

(I 8) C. inunctum

(1) C. graciliflorum Gamble, Kere Bulletin, I9Io, p. 218; Journ. As. Soc. Beng. l.c. 74 .

Tree; slender branches slightly puberulous. Leaves chartaceous opposite or sub-opposite, elliptic to lanceolate, glaucescent beneath, 3 nerves prominent beneath long cuspidate, base broad, very little narrowed, 3 to $5 \mathrm{in}$. long (cusp over I in. sometimes), $\mathrm{r} \cdot 5$ in. wide; petioles ' 5 in. long. Flowers few, 3 to 5 in., very slender racemes about $\mathrm{I} \cdot 5$ in. long. Pedicels very slender. Perianth glabrous outside, grey-pubescent inside, I in. long, tube campanulate. Fruit ovoid, 4 in. long, seated in the capsule, $\cdot 24$ in. across. Hab. Forests up to $4000 \mathrm{ft}$. altitude. Perak, upper at $3000 \mathrm{ft}$. altitude (Wray); Gunong Hijau, Thaiping Hills (Scortechini). 
(2) C. microphyllum Ridl. C. parvifolium Ridl. Journ. F.M.S. Mus. vi. 54 (not of Lecomte).

Tree or shrub; branches glabrous, black. Leaves coriaceous, glabrous ovate blunt shortly acuminate, base round, sub-opposite above; nerves 3 from close to base, nervules transverse obscure; $\mathrm{I} \cdot 5$ to 2 in. long, 75 to $\mathrm{I}$ in. wide; petioles $\cdot 2$ in. long. Cymes few-flowered lax axillary, $\cdot 75$ to $I$ in. long; peduncle and branches slender; pedicels $\cdot 2$ in. long. Flowers $\cdot 078$ in. long, tube short, lobes pubescent oblong blunt, silky inside. Stamens filaments linear glabrous, row 3, hairy. Staminodes conic. Hab. Mountains at $4200 \mathrm{ft}$. altitude. Perak, Gunong Kerbau (Robinson).

(3) C. vimineum Nees, Wall.Pl. As. Rar. ii. 76; Gamble, l.c. 80.

A small tree glabrous; branches slender. Leaves in distant pairs, thin coriaceous, lanceolate acuminate, base short, narrow, 4 in. long, I in. wide; petioles slender, 25 in. long. Panicles short, few-flowered on uppermost axils, very small. Fruit ovoid apiculate, 4 in. long; perianth cupule cup-shaped; pedicel enlarged, $\cdot 27$ in. long. $H a \bar{b}$. Very local at $2500 \mathrm{ft}$. altitude. A very aromatic plant. Pahang, Fraser Hill (Burkill). Penang (Porter), West Hill (Curtis).

The Penang specimens are very poor. In the Pahang ones, which I believe are the same, the panicle is pubescen $t r^{\circ} 75$ in. long, leaves larger, more coriaceous, flowers about 8 in a cyme, stamens 12. A bush, camphor-scented.

(4) C. paraneuron Miq. Fl. Ind. Bat. i. 895.

Tree 30 to $40 \mathrm{ft}$. tall, 8 to Io in. through. Leaves coriaceous oblong-lanceolate to ovate; nerves 3 , strongly elevate with inarching nerves from the outer 2 running to the edge, transverse nervules and reticulations conspicuous, back of leaf minutely puberulous, 8 to Io in. long, $2 \cdot 25$ to 3.5 in. wide; petioles .5 in. long. Panicles lax spreading, 6 in. long, minutely puberulous to glabrous. Sepals white silky. Stamens hairy at base, the glands cordate ovate acute. Fruit apparently small; calyx at base cupular fleshy lobed, the sepals ovate coriaceous, ribbed. Hab. Mountain forests. Selangor, Ginting Sempah; Bukit Kutu. Perak, Gunong Bubu and Kinta River (Kunstler); Gunong Batu Putih and Trong (Wray). Distrib. Sumatra.

Miquel's description is only of leaves, but it exactly fits this plant, which Gamble referred to iners, from which it differs in its nervation and pubescence beneath, and in the utterly different fruiting calyx. l.c. 76 .

(5) C. iners Bl. Bijdr. 570; Rumphia, i. 4I, t. I7, I8; Gamble,

Tree about $40 \mathrm{ft}$. tall with a short thick stem and large bushy top; branchlets glabrous. Leaves coriaceous, when young white, then red, finally deep green, elliptic or elliptic-oblong, variable 5 to 7 in. long, I.5 to 3 in. wide; nerves 3 , nervules and reticulations almost or quite invisible; glabrous beneath; petioles $\cdot 2$ in. long. Panicles about 6 in. long, lax. Flowers and pedicels silky, yellow within, I in. long, fœtid, tube very short; sepals ovate, 
sub-acute. Fruit ellipsoid, black, pulpy blunt, 4 to 6 in. long, cupule very short. Hab. Common in low-lying damp open country all over the peninsula. Distrib. Burma, Sumatra, Java and Borneo. Native names: Lelang; Kayu Manis hutan. Use: The bark is slightly aromatic, and occasionally used by Malays in curry, but the whole tree is nearly tasteless.

var. angustifolium Ridl. A much bigger tree, with narrow lanceolate leaves 7 in. long, $\mathrm{I} \cdot 5$ in. wide. Perhaps specifically distinct, but the flowers seem the same. Hab. River banks, Perak, Temengoh. Kelantan River (Ridley).

(6) C. Ridleyi Gamble, in Kew Bullctin, I910, p. 218; Journ. As. Soc. Beng. l.c. 77.

A short tree. Leaves chartaceous elliptic-lanceolate, long attenuate cuspidate blunt, base acute glabrous shining above, 4 to $6 \mathrm{in}$. long, $\mathrm{I}$ to $2 \cdot 25 \mathrm{in}$. wide; petioles $\cdot 2$ in. long. Panicles greytomentose slender spreading, 2 to $4 \mathrm{in}$. long. Flowers in small cymes on branchlet ends, I I in. long. Perianth villous inside, tube short lobes ovate. Fruit ovoid apiculate, $\cdot 4$ in. long, $\cdot 3$ in. through; cupule cup-shaped, 2 in. across. Hab. Singapore, a single tree on the Changi road near Changi (Ridley).

(7) C. Deschampsii Gamble, Kerw Bulletin, I910, p. 219; Journ. As. Soc. Beng. l.c. So.

Bushy tree with short, thick stem about $30 \mathrm{ft}$. tall (stem about 4 to $5 \mathrm{ft}$.) and I ft. through. Leaves variable oblong or ellipticovate, coriaceous or rigid coriaceous, base rounded; nerves 3 to 5 from base, dark green shining; 3 to 6 in. long, I.75 to 3 in. wide; petioles $\cdot 2$ in. long. Panicles lax spreading slightly puberulous; branches distant slender, $I_{5} 5$ in. long. Flowers ${ }^{\prime} 5$ in. long, silky. Drupes ellipsoid, $\cdot 5$ in. long, blunt, calyx coriaceous, 5 -lobed. Hab. Cultivated ground in low lands, Singapore, Botanic Gardens. Penang, roadsides (Deschamps).

I very much doubt if this Cinnamon is indigenous, but it does not appear to have ever been collected elsewhere.

(8) C. rhyncophyllum Miq. Fl. Ind. Bat. I, i. I85. (Fig. I44, p. 94).

Tree up to $50 \mathrm{ft}$. tall, $\mathrm{I} 2$ to $\mathrm{I} 8 \mathrm{in}$. through; branchlets grey puberulous. Leaves chartaceous, stiff, aromatic, elliptic to oblong abruptly cuspidate blunt, base narrowed, glaucous beneath and minutely silky, 4 to 5 in. long, 2 to $2 \cdot 25$ in. wide; petioles 25 in. long. Panicles lax sub-terminal, 5 in. long, branches 2 or less tomentose, rather thick. Flowers yellow, waxy, ${ }^{\prime} 5$ in. long (middle ones the largest) tomentose. Perianth-tube short; lobes ovate acute. Fruit ovoid truncate, $\cdot 4$ in. long, cupule $\cdot 25$ in. long, $\cdot 4$ in. across. Hab. Perak, Tapah (Wray); Larut (Kunstler). Distrib. Sumatra.

var. lampongum Miq. Fl. Ind. Bat. Supp. 358; Gamble, l.c. 79. Leaves more gradually narrowed to tip. Hab. Perak, Goping and Larut (Kunstler).

I am quite unable to separate these two plants. 
(9) C. javanicum Bl. Bijdr. 570; Rumphia, i. 42, t. I9; Gamble, Journ. As. Soc. Beng. l.c. 82 .

Shrub or tree; branchlets sub-quadrangular woolly-tomentose. Leaves chartaceous elliptic cuspidate and long narrowed to base, shining bright green, glabrous above, tomentose hairy beneath; nerves elevate both sides, but most beneath where thickly tomentose; transverse nervules conspicuous very numerous elevate beneath and sunk above in young plants, adult leaves quite glabrous,

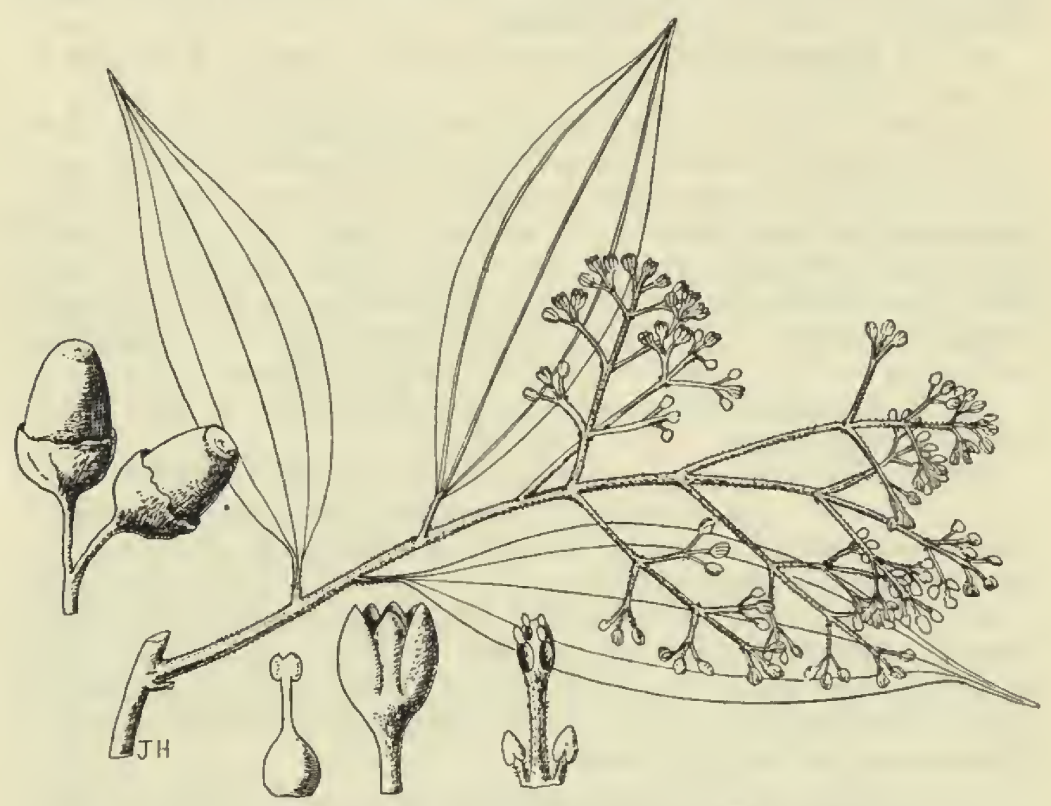

FIG. I44.-Cinnamomum rhyncophyllum var. lampongum.

7 in. long, 3 to $4 \mathrm{in}$. wide; petioles thick, $\cdot 25 \mathrm{in}$. long, tomentose. Panicles sub-terminal lax, stout, branches angled tomentose, 4 to $6 \mathrm{in}$. long, lowest branches 3 to $4 \mathrm{in}$. long. Pedicels stout. Flowers pubescent, up to $\cdot 2$ in. long; tube funnel-shaped, lobes oblong. Fruit sub-globose, fleshy, cupule thick, about I in. long. $H a b$. Not rare in southern woods, but very rarely in flower, very aromatic. Singapore, Garden Jungle; Bukit Timah; Changi. Johor, Pinerong (Cantley). Distrib. Java, Borneo.

(Io) C. Kunstleri Ridl. Journ. Roy. As. Soc. S. Br. 82, p. I9I.

Tree 30 to $40 \mathrm{ft}$. tall, 8 to $\mathrm{I} 2 \mathrm{in}$. through; branchlets hairy. Leaves oblong-elliptic blunt coriaceous, glabrous; nerves sunk above, pubescent hairy elevate beneath, nervules not parallel forked; 5 to 7 in. long, 3 in. wide; petioles thick, -25 in. long. 
Panicles slender, hairy, I to 3 in axils 3 to 6 in. long. Flowers yellow; pedicels as long, 08 in. long. Perianth-tube short, silky, lobes ovate blunt. Stamens, anthers outer row broad, inner row narrowed, all hairy. Hab. Wet jungle, Perak, Larut (Kunstler, $5568)$.

(II) C. mollissimum Hook. fil. F.B.I. v. I3I ; Gamble, l.c. 82.

Shrub $8 \mathrm{ft}$. tall or small tree, woolly on branches, petiole, leaves and inflorescence. Leaves chartaceous to coriaceous, elliptic to lanceolate cuspidate-acuminate, 4 to 4.5 in. long, 2 in. wide; petioles thick, $\cdot 25$ in. long. Flowers small, cream-colour, few in small panicles, 25 in. long, on slender pedicels 2 in. long, pubescent, tube campanulate, lobes ovate acute villous. Fruit ovoid, black blunt, 3 in. long on the enlarged thickened calyx $\cdot 2$ in. across; pedicel somewhat enlarged. Hab. Forests, Perak, Goping (Kunstler); Thaiping (Wray). Penang (Curtis).

(I2) C. velutinum Ridl. Journ. Roy. As. Soc. S. Br. 82, p. 190.

Small tree; branches, inflorescence, young leaves and petioles soft-velvety tomentose. Leaves opposite, above ovate to ellipticacuminate, base round slightly unequal or sub-acute coriaceous, soft pubescent tomentose both sides sometimes glabrescent above when adult; nerves 3 , prominent beneath, transverse nervules elevate, outer ones inarching; 5 in. long, I. 75 to 2 in. wide; petioles .25 in. long. Panicles axillary and terminal, woolly-tomentose, 2.5 to 4 in. long; branches I in. long or less. Flowers $I_{5}$ in. long; pedicels short thick, silky hairy within and without. Hab. High mountain woods, Pahang, Gunong Tahan, Teku woods (Ridley).

(13) C. Scortechinii Gamble, in Kere Bulletin, I910, p. 2I9; Journ. As. Soc. Beng. l.c. 83 .

Tree; branchlets sub-quadrangular, shortly tomentose, as are underside of leaves, petiole and inflorescence. Leaves coriaceous elliptic to elliptic-lanceolate acuminate, base cuneate, nerves 3 from above base, outer pair with raised secondaries running to the edge; 2.75 to 3 in. long, $I \cdot 25$ to $\mathrm{I} \cdot 5$ in. wide; petioles $\cdot 4$ in. long. Panicles axillary and terminal 2 in. long with few branches above and few rather large flowers in terminal cymules, pale green, $\cdot 2$ in. long; pedicels nearly as long. Perianth-tube short, lobes ovate, villous inside. Fruit ovoid. Hab. Mountain forests, Perak, Ulu Batang Padang, to $4900 \mathrm{ft}$. altitude (Wray, Scortechini).

var, selangorense; young parts and inflorescence very slender, red-tomentose; leaves distinctly areolate on both surfaces and eventually glabrous. Selangor, Ulu Kali (Burn-Murdoch).

(I4) C. aureo-fulvum Gamble, Kerw Bulletin, I910, p. 220; Journ. As. Soc. Beng. l.c. 84 .

A low bush; branchlets, underside of leaves, and inflorescence bright-orange tawny-tomentose. Leaves sub-coriaceous ellipticlanceolate, long-pointed acuminate, 3 in. long, $x$ in. wide; petioles slender, $\cdot 75$ in. long, pubescent. Panicles slender up to $\mathrm{I} \cdot 6 \mathrm{in}$. long; 
branches 4 in. long or less. Perianth-tube campanulate, 04 in. long, lobes oblong, all orange tawny. Hab. High mountains at $4000 \mathrm{ft}$. altitude, Selangor, top of Gunong Semangkok (Ridley).

(I5) C. cinereum Gamble, Kew Bulletin, I910, p. 220; Journ. As. Soc. Beng. l.c. 84 .

Tree 50 to $70 \mathrm{ft}$. tall, $\mathrm{I} 5$ to $20 \mathrm{in.}$ through; branches slender, glaucous. Leaves sub-coriaceous in distant pairs, lanceolate acute dark green, ashy grey beneath, base acute, primary nerves 2 from the midrib, $\cdot 15$ in. from base, not opposite, slender hardly elevate lateral ascending; nerves numerous faint minutely reticulate; 3 to 4.5 in. long, I to $I \cdot 5$ in. wide; petioles $\cdot 2$ in. long. Panicles long, lax; branches 3 in. long, remote; peduncles slender, 3 in. long in upper axils, grey hoary. Flowers few, cymose pale yellow. Perianth-tube slender, 078 in. long, lobes longer ovate villous inside. Hab. Mountain streams at $\mathrm{I} 200 \mathrm{ft}$. altitude. Perak at Thaiping, Waterfall Hill (Wray and Kunstler).

The secondary nerves of the leaves are not the usual transverse parallel unbroken nervules of most species, but irregular ascending and branched, especially in the upper part of the leaf.

\section{(16) C. puberulum Ridl.}

Leaves alternate elliptic-oblong, sub-acute base oblique narrowed, glabrous above; nerves beneath pubescent, 3, elevate beneath, 2 of which rise from the midrib at unequal heights, $\cdot 2$ in. from base or lower, transverse nervules irregular, arched and broken up, 2 or 3 nerves from upper part of midrib ascending; 4 in. long, I.75 in. wide; petioles 5 in. long or less pubescent. Panicles axillary short, $I \cdot 5$ in. long, red-velvety in bud, grey pubescent in flower, buds oblong grey-silky. Perianth-lobes oblong, blunt hairy on both sides. Stamens Ist row hairy, spathulate, of and row shorter. Hab. Pahang, Ulu Raub, Bentong (Foxworthy). Native names: Medang Kamangi; Teja.

Unfortunately, the stamens and pistils are much injured in the few flowers by dipterous larvae.

(I7) C. parthenoxylon Meissn. DC. Prod. xv. i. 26.

Lofty tree 30 to Ioo $\mathrm{ft}$. tall with whitish rough bark. Leaves red when young, adult sub-coriaceous dark green glaucous beneath, elliptic-ovate acute or acuminate, base acute or round; nerves pinnate slender, 3 pairs from the midrib; 2 to 4 in. long, I to I.75 in. wide; petioles slender, I to $I \cdot 25$ in. long. Panicles numerous slender, glabrous; peduncle $I$ to 2 in. long; branches 5 in. long, cymose at the top. Flowers few on each, $\cdot$ I in. across, light yellow. Perianth-tube funnel-shaped, glabrous, lobes oblong villous inside. Drupe globose, $\cdot 28$ in. across; perianth-tube enlarged, -I 8 in. across, tube funnel-shaped, $\cdot 2$ in. long. $\mathrm{Hab}$. Woods in hilly districts, Pahang, Fraser Hill (Burn-Murdoch). Dindings, Lumut and Pangkor. Perak, Gunong Bubu; Gunong Malacca (Kunstler); 
Gunong Batu putih (Wray). Province Wellesley, Permatang Bertam; Tasek Gelugur. Penang (Wallich, Curtis), common. Kedah Peak. Kelantan. Distrib. Mergui. Native names : Medang Kemangi; Kayu Gadis. Use: As a stimulant.

The Malacca (Maingay) locality is doubtful; the specimen was probably collected by Maingay in Penang. The tree usually flowers after change of leaves with only thin young ones. It often has obconic red-tomentose galls, .5 in. long, 4 in. wide, at the top in place of fruit.

(I8) C. inunctum Meissn. DC. Prod. xv. i. 25 ; Gamble, l.c. 85.

Big tree, bark pale corky. Leaves chartaceous alternate, ovate or elliptic, shortly acuminate, base shortly narrowed oblique not white beneath, drying dark (or pale), 4 in. long, 2.5 in. wide; nerves rather faint, 6 to 9 pairs, reticulations minutely areolate; petioles 5 to $I$ in. long. Flowers small, white in few-flowered axillary panicles $I$ to $I \cdot 5$ in. long; pedicels slender. Perianth funnel-shaped, lobes ovate-oblong, blunt, white-villous inside. Stamens very small; filaments very short villous, as long as anthers, lower cells elliptic. Fruiting branches very long, 3 in. long or more, slender; cupule funnel-shaped. Fruit pea-shaped, green. Hab. Local in forests, low lands, Malacca (Griffith); Tebong. Negri Sembilan, Tampin; Pajam (Foxworthy). Distrib. Burma. Native name: Medang Loso.

The Burmese plants have stiffer leaves, green when dry. My specimens are thinner and dark, quite like the specimen collected in Malacca by Griffith.

\section{Cultivated Species.}

Cinnamomum zeylanicum $\mathrm{Bl}$. Bijdr. 568. The true Cinnamon "Kayu manis" is not a native of our country but was introduced probably from Ceylon about 1806 and sparingly cultivated.

\section{ALSEODAPHNE, Nees.}

Trees or shrubs. Leaves alternate often crowded towards tips. Flowers small, yellow bisexual, in axillary or sub-terminal panicles. Perianth-tube short, lobes 6 , sub-equal, outer ones sometimes smaller. Stamens 9; anthers ovate oblong 4-celled, rows I and 2 introrse, row 3 extrorse; glands at base free from stamens (except A. pendulifolia). Staminodes $4^{\text {th }}$ row large, glabrous inside, stipitate ovate or cordate. Ovary ovoid; style slender; stigma peltate. Drupe ellipsoid or globose on enlarged perianth; pedicel enlarged and red as in Dehaasia or hardly enlarged.

Glands free from stamens of 3 rd row.

Leaves membranous.

Panicles glabrous; flowers very small . . (I) A. peduncularis

Panicles puberulous, grey; flowers larger . (2) A. Wrayi

Leaves coriaceous obovate.

Leaves small; drupe globose; pedicel hardly thickened. Shrub ‥ : : (3) A. bancana 
Leaves 9 in. Iong, very coriaceous; drupe big ellipsoid. Big tree.

Leaves very coriaceous, oblanceolate, grey beneath, large.

Drupe on flat top of perianth-tube, lobes persistent . . . . .

Drupe in cup-shaped perianth-tube, lobes not persistent .

Drupe very large woody brown scurfy oblong, $3^{\circ} 25$ in. long

Glands attached to filaments above base.

Leaves membranous pendulous; panicles subracemose

Duious a pendulifolia

(I) A. peduncularis Hook. fil. F.B.I. v. I44; Gamble, Journ. As. Soc. Beng. l.c. 89 .

Shrub or small tree, 9 to $\mathrm{I} 2 \mathrm{ft}$. tall; branchlets white. Leaves membranous more or less fascicled at branch tips, elliptic-lanceolate caudate acuminate, blunt, base narrowed, glabrous; nerves 6 to to pairs inarching in loops, raised beneath; 3.9 to 7.8 in. long, I. 2 to 2.8 in. wide; petioles slender, $\cdot 2$ in. long. Flowers minute, greenish yellow or purple in slender peduncles glabrous filiform, 2 to 3 in. long; branches very short, $\cdot 2$ in. long or more; cymules of 3 to 6 flowers. Perianth-tube very short, lobes ovate puberulous inside only. Stamens hairy, glands separate hairy. Drupe ellipsoid, I in. long, 5 in. through, black; pedicel fleshy red, subcylindric, $\mathrm{I}$ in. long. $H a b$. Common in forests, Pahang, Temerloh (Burn-Murdoch). Negri Sembilan, Gunong Berumbun (Cantley). Selangor, Kwala Lumpur; Petaling; Sungei Buluh; Ulu Selangor (Kunstler); Rantau Panjang (Kloss). Perak, Batang Padang and Ulu Bubong (Kunstler). Penang (Wallich). Native name: Gajus hutan.

In fruit, this much rescmbles a Dehaasia. Foxworthy sends specimens with very narrow lanceolate leaves, 6 in. long, I'5 in. wide, from Kwala Lumpur.

(2) A. Wrayi Gamble, Kew Bulletin, 1910, p. 220; Joum. As. Soc. Beng. l.c. 90.

Tree 40 to $50 \mathrm{ft}$. tall, Io to $\mathrm{I}_{5} \mathrm{in}$. through. Leaves membranous, elliptic-lanceolate, long-acuminate, base cuneate, glabrous; midrib and nerves Io to I2 pairs elevate beneath, nerves inarching; 4 in. long, I.5 to 2 in. wide; petioles 25 to 3 in. long. Panicles I.5 in. long, much branched puberulous on peduncle slender, nearly 2 in. long; cymules of 3 to 7 , rather large, green puberulous flowers. Perianth-tube cup-shaped, lobes oblong, glands free, glabrous. Stamens villous. Drupe globose black, 5 in. through; pedicel fleshy, dark red, 75 in. long. Hab. Perak, Kota (Wray); Larut and Goping (Kunstler).

(3) A. bancana Miq. Fl. Ind. Bat. I. i. 9I5; Gamble, Journ. As. Soc. Beng. l.c. 9I. A. decipiens Hook. fil. F. B.I. l.c. I45.

A bush about $5 \mathrm{ft}$. tall. Leaves coriaceous, fascicled at branchends obovate long-cuneate, sub-acute, dark green; nerves ro to 
I2 pairs sunk above, elevate beneath, all glabrous, reticulations rather conspicuous; 3 to 5 in. long, I. 5 to $2 \cdot 5$ in. wide; petioles - I to 5 in. long. Panicles 4 in. long, glabrous; branches few, short. Flowers rather small, yellow; pedicels slender, glabrous. Perianth-tube short, outer lobes shorter than inner, obovate blunt. Stamens hairy, glands white, glabrous. Fruit globose dark green with white spots, $\cdot 4$ in. through; pedicels hardly thickened, not coloured. Hab. Thick woods, Singapore, Garden Jungle; Bukit Timah; Chan Chu Kang. Distrib. Banca and Borneo.

(4) A. petiolaris Hook. fil. F.B.I. V. I45; Gamble, Journ. As. Soc. Beng. l.c. 9 r.

Big tree, branches thick. Leaves stiffly coriaceous, oblong to obovate-oblong, base narrow but blunt, shortly caudate-acuminate, glabrous and conspicuously reticulate both sides; nerves inconspicuous above, prominent beneath, 8 to I2 pairs; 9 in. long, 5 in. wide; petioles 1.5 in. long. Panicles stout, 7 in. long, rustypuberulous red in fruit. Flowers . I in. long, rusty-pubescent, tube funnel-shaped. Stamens nearly glabrous. Drupe oblongellipsoid, I.5 in. long, black, on much-thickened pedicel. Hab. Mountain forests, Pahang, Telom (Ridley). Distrib. Assam, Burma.

(5) A. paludosa Gamble, Kew Bulletin, I91o, p. 22I; Joum. As. Soc. Beng. l.c. 92.

Tree 80 to Ioo $\mathrm{ft}$. tall, 2 to $3 \mathrm{ft}$. through. Leaves very coriaceous, oblanceolate round, emarginate, long narrowed to base, glaucous beneath, 7 to 9 in. long, 3.5 to 3.75 in. wide; petioles thick, flat, $I \cdot 25 \mathrm{in}$. long. Fruiting raceme in uppermost axils stout, 6 in. long. Fruit ellipsoid, $\cdot 8$ in. long, enlarged pedicel obconic, I in. long, glaucous warty, with large persistent triangular perianth-lobes. Hab. Dense wet jungle, Perak, Larut (Kunstler).

The specimens are very incomplete. It is very near A. insignis, and I suspect the same species.

(6) A. insignis Gamble, Kew Bulletin, I9IO, p. 22I; Journ. As. Soc. Beng. l.c. 93 .

Tree 80 to roo ft. tall, 3 to $4 \mathrm{ft}$. through; branches stout. Leaves stiffly coriaceous oblong to oblanceolate, glaucous beneath, glabrous round, base long narrowed; midrib prominent on both sides, nerves I2 to I5 pairs, reticulations obscure but visible minute; 5 to $\mathrm{I}_{3} \mathrm{in}$. long, $2 \cdot 5$ to $3 \mathrm{in}$. wide; petioles $\mathrm{I} \cdot 25$ to $2.25 \mathrm{in}$. long. Panicles 4 in. long, stout puberulous. Perianth .I2 in. long, puberulous, light green, lobes outer, 3, shorter than inner. Stamens bright yellow rather slender. Fruit bright green, I.5 in. long, I in. through in a large rough pedicel cup 5 in. across; pedicel thick conic, I in. long; pedicels stout, 8 in. long. Hab. Dense lill forest, Perak, Thaiping, at 500 to rooo $\mathrm{ft}$. altitude (Kunstler).

(7) A. Ridleyi Gamble, Kere Bulletin, I910, p. 222; Joum. As. Soc. Beng. l.c. 94.

A high rather slender tree about $60 \mathrm{ft}$. tall. Leaves very coriaceous clustered on branch-ends elliptic-oblong or obovate, 
minutely reticulate, especially beneath; nerves elevate beneath, I2 to I5 pairs, midrib stout; tip blunt, base round or slightly narrowed, 9 in. long, 4 to 5 in. wide; petioles very stout, 2 in. long. Panicles from upper axils glabrous, 3.9 in. long; peduncles short, branches few. Bracts ovate acute, $I$ in. long. Flowers few, light yellow, tube short, lobes ovate. Drupes oblong, $3 \cdot 25$ in. long, $I \cdot 5$ in. through, brown scurfy, woody, on very stout pedicels and branches, 6 in. long, 4 in. through at top. Hab. Mountain forests, very rare, Selangor, Semangkok Pass about the I6th mile. A single tree seen (Ridley).

(8) A. pendulifolia Gamble, Kew Bulletin, I9Io, p. 222; Journ. As. Soc. Beng. l.c. 95.

A tree 60 to $70 \mathrm{ft}$. tall, ro to $I_{5}$ in. through. Leaves membranous, hanging down in the shape of an umbrella, obovate or oblanceolate, glabrous blunt; nerves ${ }_{5}$ to 20 pairs, slender; 9 in. long, 3 in. wide; petioles $I$ in. long. Flowers pale yellow, 2 in. across in long lax slender panicles 9 to $\mathrm{I} 2$ in. long; branches $\mathrm{I}$ in. or less distant, ending in 3 -flowered umbels; pedicels $\cdot 2$ in. long, slender. Perianth-tube fumnel-shaped, lobes ovate, silky inside. Fruit globose glabrous (very young). Hab. Dense bamboo forest, at 500 to $800 \mathrm{ft}$. altitude, Selangor (locality uncertain) (BurnMurdoch). Perak, Ulu Bubong; Ulu Kerling (Kunstler). Native name: Medang Payong.

\section{Dubious Species.}

A. CRASSIPES Hook. ful. F.B.I. v. I46; Gamble, Journ. As. Soc. Beng. l.c. 95. Tree? bark grey; shoots red-tomentose. Leaves thinly coriaceous elliptic-lanceolate acuminate, base cuneate long narrowed, glabrous drying yellow; nerves 6 to 8 pairs, very slender, looping within margin, secondaries and wide reticulations nearly as conspicuous, 4 in. long, 2 in. across; petioles slender, $\cdot 2$ in. long. Fruiting peduncles numerous, thickened upwards, woody. Fruit ellipsoid, 5 in. long, black shining; pedicel short, 25 in. thick, red. Hab. Malacca (Maingay).

Altogether doubtful, perhaps a Beilschmiedia.

A. Costalis Nees, Pl. As. Rar. ii. 72; Hook. fil. F.B.I. v. I46. Singapore (Wallich) is probably Litsea robusta $\mathrm{Bl}$.

A. LUCIDA Nees, l.c. Singapore (Wallich); leaves only, perhaps an oak.

8. NOTHOPHCEBE, Blume.

Trees or shrubs. Leaves alternate, not whorled. Flowers bisexual in axillary or sub-terminal panicles; cymules usually sub-umbellate. Perianth-tube very short, lobes 6 , outer smaller than inner. Stamens 9; anthers oblong, 4-celled villous; filaments short, rows I and 2 introrse, row 3 extrorse; glands 2, villous, round at base (rarely o). Staminodes very small ovate, 
clubbed, triangular. Ovary ovoid; style slender. Fruit ellipsoid or oblong-ovoid on the enlarged perianth-tube. Species I3, Malaya, Polynesia.

Leaves obovate, base cuneate; panicles nearly or quite glabrous.

Leaves chartaceous

Leaves membranous

Leaves large chartaceous oblanceolate.

Flowers rusty-tomentose; filaments distinct

Flowers rusty-tomentose; filaments o

Leaves large chartaceous, base cordate, auricled sessile

Leaves coriaceous, broad oblanceolate, base cuneate

Leaves coriaceous, narrow lanceolate, minutely reticulate "

(I) N. umbelliflera

(2) N. fruticosa

(3) N. Kingiana

(4) N. condensa

(5) N. panduriformis

(6) $\mathbf{N}$, reticulata

(7) N. angustifolia

(I) N. umbelliflora Bl. Ann. Mus. Bot. Lugd. Bat. i. 328; Gamble, Journ. As. Soc. Beng. l.c. 97.

Tree 40 to $50 \mathrm{ft}$. tall. Leaves chartaceous, elliptic to oblanceolate, cuspidate-acuminate, glabrous, long-cuneate at base and decurrent; nerves 6 to 8 pairs, looping within the edge, secondaries and reticulations fine, lax; 4 to 5 in. long, 2 to 3 in. wide; petioles 4 in. long. Panicles slender puberulous thyrsoid, lax 2 in. long. Flowers minute, pink, lobes very small ovate. Fruit oblongobovoid, dark purple, $\mathrm{I} \cdot 5$ in. long; perianth-tube and pedicel little enlarged. Hab. Forests, low country, Singapore, Chan Chu Kang; Bukit Timah. Malacca, Selandor; Brisu (Derry). Perak, Thaiping and Goping (Kunstler). Penang, Batu Feringhi; Pulau Betong (Curtis). Distrib. Tongka, Java, Sumatra, Borneo. Native names: Medang Ketanahan; Medang lengadi; Medang loso; Medang merah.

(2) N. fruticosa Gamble, Kew Bulletin, I9ro, p. 213; Journ. As. Soc. Beng. l.c. 98 .

Shrub 6 to $8 \mathrm{ft}$. tall, or a tree, bark white. Leaves membranous, lanceolate acuminate, base cuneate; nerves 8 to Io pairs, slender inarching in loops $\cdot 2$ in. from edge, transverse nervules few; 4 to 6 in. long, $I \cdot 25$ to $2 \cdot 25$ in. wide; petioles $\cdot 2$ in. long. Flowers minute, white, $\cdot 12$ in. across in very slender glabrous panicles from upper axils 2.5 in. long. Perianth-tube very short, lobes ovate gland-dotted. Stamens villous. Hab. Forests, Selangor, Ulu Selangor (Goodenough). Perak, Tapah (Wray); Ulu Bubong and Larut (Kunstler).

(3) N. Kingiana Gamble, Kew Bulletin, I910, p. 224; Journ. As. Soc. Beng. l.c. 99.

Tree 30 to $40 \mathrm{ft}$. tall, spreading, I.5 to $2 \mathrm{ft}$. through. Leaves thin, coriaceous, elliptic-obovate to lanceolate sub-acute or acuminate, base cuneate glabrous; nerves conspicuous elevate beneath; 6 to 7 in. long, 2.5 to 3 in. wide, variable; petioles short and thick. Flowers dark red or reddish yellow in rusty-tomentose panicles 4 in. long, branches 5 in. long. Cymes umbellate of 5 or 6 flowers 
on peduncles rather stout, $\cdot 2 \mathrm{I}$ in. long. Perianth lobes $\cdot \mathrm{I}_{5}$ in. long, rusty-tomentose, outer 3 lobes much smaller than inner, all thick. Fruit obovoid-oblong, club-shaped, dark red, 2 to 3 in. long, 75 in. through. Hab. Dense forests, Perak, Thaiping Waterfall (Kunstler, Wray).

var. glabrescens Gamble, l.c. Panicles very short, glabrous hardly sub-umbellate. Leaves obovate-elliptic, glands on 3 rd row of stamens often absent. Hab. Dindings, Lumut (Curtis).

(4) N. condensa Ridl. Journ. Roy. As. Soc. S. Br. 82, p. Igr.

Tree; leaves as in Kingiana but thinner oblanceolate, shortly cuspidate; nerves elevate beneath, 5 pairs; 5.5 in. long, 2.5 in. wide (or less); petioles $\cdot 25$ in. long. Panicles rather dense, $I \cdot 5$ to 2.5 in. long; branches very short, rusty-tomeritose. Flowers very small, under 'I in. long, tomentose on very short thick peduncles, umbellate; outer lobes much smaller than inner. Stamens, anthers glabrous sub-quadrate, nearly sessile; filaments practically none, base hairy. Staminodes glabrous except at base clubbed. Pistil short ovoid. Hab. Lankawi, Kesap (Haniff).

This is remarkable for its very small flowers.

(5) N. panduriformis Gamble, Joum. As. Soc. Beng. l.c. IOI. Alseodaphne panduriformis Hook. fil. F.B.I. v. I45.

Large spreading tree 40 to $50 \mathrm{ft}$. tall, I5 to $20 \mathrm{ft}$. through. Leaves chartaceo-coriaceous rather thin, glabrous broadly obovate blunt or apiculate, base cordate auriculate sessile or with short petioles; nerves prominent beneath, I2 to 20 pairs; 9 in. long, 6 in. wide. Panicles conspicuous, 4 to 9 in. Jong, 4 to $7 \mathrm{in}$. wide; flowers numerous orange-yellow rusty puberulous; peduncles -I5 in. long, outer lobes small triangular, inner ovate sub-acute, much larger. Fruit cylindric-oblong, black, $2 \cdot 75$ in. long, I in. through. Hab. River banks in low country; not rare. Pahang, near Pekan; Chenei River (Fox); Raub (Burn-Murdoch); Sungei Riau, Kwantan (Foxworthy). Malacca (Maingay); Panchur; Brisu (Derry). Selangor, Labu River; Semangkok Pass. Perak, Kurau; Chankat Serdang and Simpang (Wray); Ulu Bubong (Kunstler). Native names: Medang Hitam; Medang Keladi; Medang Ayer.

(6) N. reticulata Gamble, Kew Bulletin, IgIo, p. 214; Journ. As. Soc. Beng. l.c. Ioo.

Tree, glabrous, 40 to $50 \mathrm{ft}$. tall, 6 to ro in. through. Leaves chartaceo-coriaceous rather thin, densely minutely areolate, elliptic obovate or oblanceolate blunt or short cuspidate acuminate, base cuneate, 6 to 8 in. long, $2 \cdot 5$ to 3 in. wide; nerves fine but elevate both sides slightly, 9 to Io pairs; petioles 5 in. long. Panicles sub-terminal, spreading, 3 to 5.5 in. long (peduncles 2 in. long); branches I in. long or less with few small flowers in cymes $5 \mathrm{in}$. across; pedicels slender, all glabrous. Perianth-lobes ovate, 
outers smaller, .078 in. long. Stamens oblong, base hairy. Staminodes lanceolate villous. Drupe ellipsoid or ovoid light green with rusty warts $I \cdot 5$ in. long, I. 4 in. through; pedicels and peduncle woody thickened, 6 in. long. Hab. Mountain forests, Perak, Thaiping Hills, the Cottage, to $5000 \mathrm{ft}$. altitude (Kunstler and other collectors); Gunong Bubu (Wray). Selangor, Gunong Mengkuang Lebah (Robinson); leaves rather narrower and panicles 5.5 in. long.

(7) N. angustifolia Ridl. Joum. F.M.S. Mus. vii. 50.

Shrub $4 \mathrm{ft}$. tall. Leaves alternate coriaceous lanceolate acuminate, base narrowed; nerves very faint, ro pairs minutely inconspicuously areolate beneath; 3.5 in. long, I in. wide; petioles 2.5 in. long. Panicles sub-terminal, I.5 in. long, 5 in. across, pubescent. Flowers . I in. long, yellowish green, lobes ovateoblong, sub-equal. Stamens rows I and 2 slender, filaments hairy, row 3 with flat, glabrous oblong glands. Hab. Mountains, to $4000 \mathrm{ft}$. altitude. Rare. Kedah Peak (Robinson).

\section{MACHILUS, Nees.}

Trees; buds with imbricate scales. Leaves alternate minutely reticulate. Flowers small or medium bisexual in panicles from upper leaf axils. Perianth-tube short; lobes 6, sub-equal or outer smaller. Stamens 9; anthers 4-celled, rows $I$ and 2 with long filaments introrse, row 3, extrorse; anthers oblong narrowed, filaments slender, glands stipitate. Staminodes 4 th row cordate stipitate. Ovary sessile. Fruit globose or oblong; perianth hardly enlarged; pedicel not enlarged. Species 25. India, Burma, China, Japan.

(I) M. Scortechinii Gamble, Kew Bulletin, Igro, p. 226; Journ. As. Soc. Beng. l.c. I02.

Tree 40 to $50 \mathrm{ft}$. tall, $\mathrm{r} 8$ to $20 \mathrm{in.}$ through; branchlets tawny puberulous. Leaves chartaceous, obovate to oblanceolate, short cuspidate, glabrous; nerves elevate, 8 to Io pairs, nervules parallel transverse minutely areolate; 4 to 6 in. long, 2 to 2.75 in. wide; petioles slender, 5 in. long. Panicles 6 to ro in. long (peduncles 3 to 7 in. long), branches at end only, 2 in. long; dichotomous. Cymules sub-umbellate; pedicels $\cdot \mathrm{I}_{5}$ in. long, all softly grey-pubescent. Flowers dark yellow, .13 in. long; lobes ovate acute. Stamens slender; filaments silky-pubescent, rows I and 2, anthers ovate blunt, row 3 , anthers oblong, glands glabrous stipitate reniform. Hab. Mountain forests, Perak, Thaiping Hills at 3500 to $4000 \mathrm{ft}$. altitude (Kunstler and Scortechini).

Fruit being unknown, this plant is doubtful as to genus.

10. PHCEBE, Nees.

Trees or shrubs. Leaves alternate. Flowers bisexual in peduncled panicles from upper axils. Perianth-tube short, lobes 6 , 
sub-equal, 3 outer shorter, spreading in flower closing and enlarging afterwards. Stamens 9; anthers 4 -celled ovate, rows I and 2, anthers elliptic introrse, row 3, longer, more slender extrorse with 2 stipitate glands at base. Staminodes 4 th row stipitate cordate. Ovary globose. Fruit ovoid to globose in a cup of the enlarged perianth-lobes. Species 34, Indo-Malaya, America,

Leaves lanceolate nearly glabrous.

Leaves narrow long acuminate; flowers glabrous; filaments villous .

Leaves blunt acuminate minute reticulate; filaments glabrous

Leaves broad lanceolate cuspidate, silky beneath; branches silky, flowers hairy

Leaves obovate large coriaceous.

Flowers large, 4 in. across.

Leaves pubescent beneath; perianth tomentose. Leaves glaucescent not tomentose

Flowers under $\cdot 2$ in. across.

Leaves thickly coriaceous; perianth tawny pubescent .

Leaves thin coriaceous; perianth grey-tomentose

(I) P. lanceolata

(2) P. declinata

(3) P. tavoyana

(4) P. macrophylla

(5) P. Kunstleri

(6) P. opaca

(7) $\mathbf{P}$. cuneata

(I) P. lanceolata Nees, Syst. Laur. Iog; Gamble, Journ. As. Soc. Beng. l.c. I04; Wight, Ic. t. I82I.

A small tree; buds villous. Leaves chartaceous rather crowded at the branch ends, lanceolate long acuminate, base long cuneate glabrous; nerves Io to 15 pairs ascending; nervules and reticulations irregular, 7 in. long, $I \cdot 5$ in. wide; petioles slender, $I \cdot 5$ in. long. Panicles slender, peduncles 2 in. long; branches few. Bracts grey puberulous linear. Flowers $\cdot$ I in. long, pale yellow; lobes ovate, villous inside. Stamens villous. Fruit ovoid, 5 in. long, - I2 in. wide, black on the enlarged perianth. Hab. River banks on the east coast, Pahang, Tahan River (Ridley). Distrib. India to Java.

(2) P. declinata Nees, Syst. Laur. II4; Gamble, Journ. As. Soc. Bengal, l.c. I05.

Tree 30 to $40 \mathrm{ft}$. tall, 5 to $8 \mathrm{in}$. through, nearly altogether glabrous. Leaves chartaceo-coriaceous lanceolate or elliptic lanceolate acuminate, sub-acute or blunt; nerves 7 to Io pairs, very slender and inconspicuous, reticulation obscure, 4 in. long, I.25 in. wide; petioles $\cdot 25$ in. long, slender. Panicles slender, about 2 in. long with few distant branches and small .05 in. long flowers on pedicels I5 $_{5}$ in. long, generally all glabrous. Stamens glabrous except a tuft of hairs at base. Drupe globose, $\cdot 2$ to $\cdot 4$ in. through; pedicels and peduncles hardly enlarged. Hab. Forests, Singapore (Wallich); Changi. Selangor, Ulu Selangor (Kunstler). Penang, Balik Pulau; Penara Bukit (Curtis).

(.3) P. tavoyana Hook. fil. F.B.I. v. I43.

Tree. Leaves elliptic-lanceolate caudate acuminate base long narrowed membranous; nerves 9 to Io pairs, slender elevate be- 
beneath, slightly sunk above, pubescent beneath when young; 6 to Io in. long, 2 to 3.5 in. wide; petioles slender, $I$ in. long. Buds silky. Panicles slender, $I^{\prime} 5$ to 2 in. long, sub-glabrous with few short branches or one terminal cyme. Flowers few, 08 in. long, lobes orbicular ovate silky. Panicles in fruit, peduncles slender, 3 in. long; pedicels $\cdot 25$ in. long. Drupe ovoid, $\cdot 3$ in. long, black; perianth-lobes enlarged. Hab. Forests chiefly in the north. Perak, Temengoh (Ridley).

var. villosa. Leaves and flowers more villous; leaves shorter. Hab. Lankawi, Gunong Raya (Haniff). Kedah, Gurun, base of Kedah Peak (Haniff). Distrib. Burma, Mergui. Native name: Medang Rungkoi.

Gamble suggests $P$. pallida Nees for this, but it is not glaucous beneath, the nerves are not deeply sunk and the flowers are smaller. It seems much more to resemble $P$. tavoyana, but the two species are very near.

(4) P. macrophylla Blume Ann. Mus. Bot. Lugd. Bat. i. 326; Gamble, Journ. As. Soc. Beng. l.c. Io7.

Tree about $40 \mathrm{ft}$. tall, bushy. Leaves dark green, coriaceous obovate, short apiculate long narrowed to base, glabrous above, red-pubescent beneath; nerves and nervules and reticulations sunk above, elevate beneath, Io to I5 pairs; 9 to I 2 in. long, 4.5 to 6 in. long; petioles 5 in. long, tomentose (young leaves tomentose both sides). Panicles tomentose, 6 to 9 in. long; peduncles 5 to 6 in. long; branches 2 in. long. Flowers in short cymes 5 in. long. Perianth tomentose, $\cdot 2$ in. long, greenish yellow on short pedicels, lobes elliptic acute. Drupe dark blue olive-shaped, I.5 in. long; panicles thickened bright red. Hab. Wood in low country, Singapore, Garden Jungle; Bukit Mandai. Perak, Larut ; Chanderiang (Kunstler); Waterloo (Curtis).

(5) P. Kunstleri Gamble, Kere Bulletin, I910, p. 226; Journ. As. Soc. Beng. l.c. Io7.

Big tree 80 to Ioo $\mathrm{ft}$. tall, 2 to $3 \mathrm{ft}$. through; young parts puberulous. Leaves coriaceous obovate or elliptic-obovate blunt or short apiculate narrowed to base, glabrous above, glaucescent beneath and minutely puberulous, midrib and 8 to I2 pairs of nerves sunk above, elevate beneath, transverse nervules rather distant; visible beneath; 6 to 7 in, long, 3.5 in. wide. Panicles 7 in. long (peduncles 5 in. long), branches crowded at top, 2 in. long, all grey yellowish tomentose. Perianth $\cdot 2$ in. long, tomentose, light yellow, lobes oblong acute, outer smaller. Glands villous. Drupe ovoid bluish green; perianth-lobes persistent larger, Perak, Goping (Kunstler); Blanda Mabok (Wray). Distrib. Borneo.

Very like $P$. opaca, but the flowers are rather bigger and the panicle more lax.

(6) P. opaca Blume, Ann. Mus. Bot. Lugd. Bat. i. 327; Gamble, Journ. As. Soc. Beng. l.c. I08.

Tree 60 to $80 \mathrm{ft}$. tall, $\mathrm{I} 5$ to $20 \mathrm{in}$. through; branchlets redtomentose. Leaves coriaceous oblanceolate or obovate short 
apiculate blunt, glabrous shining above, base cuneate, glaucescent beneath; nerves 5 to 8 pairs, raised beneath, nervules slightly raised, parallel transverse ; 6 to 9 in. long, 3 to 3.5 in. wide; petioles $\mathrm{I}$ in. long. Panicles 9 in. long (peduncles 4 in. long); branches rather crowded, 2 to 2.5 in. long, all pubescent. Flowers I4 in. long on short thick pedicels, yellowish brown; lobes oblong acute. Glands glabrous. Fruit ovoid, 6 in. long, on the enlarged perianth. Hab. Woods and forests, Singapore, Pulau Ubin; Changi. Johor, Kwala Sembrong (Kelsall). Malacca, Bukit Sadanen; Merlimau (Derry, Maingay, Griffith). Perak, Gunong Bubu, at 800 to I50o ft. altitude, and Goping (Kunstler). Distrib. Java, Sumatra, Borneo. Native names: Medang Kasira or Kusirai; Medang Burong.

var. cuspidata Gamble, Joum. As. Soc. Beng. l.c. Leaves more acute; perianth-lobes ovate blunter. Hab. Perak, Ulu Kerling (Kunstler).

(7) P. cuneata Blume, Ann. Mus. Bot. Lugd. Bat. i. 9o8; Gamble, Journ. As. Soc. Beng. l.c. Iog.

Tree 60 to $80 \mathrm{ft}$. tall, ro to I5 in. through. Leaves rather stiffly thin coriaceous obovate or ovate-oblong short acuminate, base long cuneate, glabrous shining above dull minutely puberulous beneath; nerves 8 to 12 pairs rather strongly elevate, nervules conspicuous, reticulations obscure; 4 or 5 in. long, 2.5 to 3 in. wide; petioles 2 in. long. Panicles greyish puberulous; peduncles 4 in. long; branches $I .5 \mathrm{in}$. long, crowded at top. Perianth $I$ in. across yellow, lobes ovate, outer ones shorter acute, tomentose grey. Drupe ovoid or ellipsoid blue-black, 8 in. long; perianthlobes enlarged. Hab. Forests, Singapore, Changi. Pahang, Fraser Hill (Burkill). Perak, Thaiping Hills to $4000 \mathrm{ft}$. altitude; Goping (Kunstler). Province Wellesley, Kubang Ulu (Curtis). Distrib. Java.

\section{STEMIMATODAPHNE, Gamble.}

Tree. Leaves alternate membranous crowded on branch tips, large. Flowers in umbels in lax panicles from upper leaf axils; pedicels long. Perianth-lobes 6 , sub-equal, with raised ring at base. Stamens 9; anthers 4-celled ovate triangular sessile, glands on row 3, minute or o. Staminodes, row 4, triangular sessile. Ovary globose; style minute. Fruit a large globose drupe; perianth enlarged persistent; pedicel enlarged. Species $I$.

(I) S. perakensis Gamble, Journ. As. Soc. Beng. l.c. III.

Spreading tree 60 to $70 \mathrm{ft}$. tall, 2 to I 8 in. through. Leaves glabrous obovate long-acuminate, base cuneate; nerves raised beneath, sunk above, Io to 15 pairs, inarching, nervules prominent parallel sub-distant; 9 in. long, 5 in. wide; petioles $I$ in. long. Panicles puberulous, 3 in. long; pedicels 5 in. long, red. Perianth -I2 in. across, glabrous, lobes short, green. Drupe egg-shaped, 2 in. long, $\mathrm{I} \cdot 5$ in. through. Hab. Forests, Malacca, Batang Malaka (Derry); Chenana Putih (Cantley). Perak, Larut; Kwala Dipang; 
Ulu Bubong (Kunstler). Native names: Medang Kuning; Medang Ketanah. Use: Heart-wood black squares 6 to 8 in. A valuable timber.

\section{AC'TINODAPHNE, Nees.}

Trees or shrubs. Leaves whorled, usually coriaceous. Flowers small unisexual in axillary and terminal bracteate sessile or peduncled clusters or short racemes bearing bracteate umbellules of about 5 flowers. Bracts imbricate caducous. Perianth-tube short, lobes 6, sub-equal. Stamens in male 9; filaments slender, row 3 with glands, rows I and 2 eglandular, all introrse, 4-celled. Staminodes in female 9, rows $\mathrm{I}$ and 2 linear or spathulate, row 3 linear glandular. Ovary ovoid narrowed to style; stigma dilated. Drupe on the flat or concave perianth-tube much enlarged. Species 50 , Indo-Malaya to Japan.

Leaves large oblanceolate, 9 to 8 in. long, fruiting perianth flat.

Leaves in whorls of 12 or more, glabrous beneath

Leaves 6 to 10 in a whorl, hairy beneath .

Leaves 8 to 9 in. long.

Leaves obovate chartaceous glaucous, puberulous beneath

Leaves lanceolate glabrous, fruiting perianth a

Leaves obovate or oblong very coriaceous ; nerves few

Leaves $5 \mathrm{in.}$ long or less, lanceolate.

Leaves glabrous glaucous beneath; fruit-perianth flat

Leaves puberulous not glaucous beneath; fruitperianth a cup

Leaves villous beneath; fruit-perianth a cup .

Leaves elliptic-lanceolate acuminate.

Glaucous beneath, 3 to 5 in. long

Not glaucous beneath, 4 to $5 \mathrm{in.}$ long

Grey pubescent beneath, 3 to 4 in. long

Leaves elliptic-oblong, blunt glaucous beneath, 2 to 3 in. Iong

Leaves elliptic blunt minutely areolate, both sides bright green, 2 in. long

(I) A. sesquipedalis

(2) A. Maingayi

(3) A. glomerata

(4) A. montana

(5) A, obovata

(6) A. johorensis

(7) A. malaccensis

(8) A. Ridleyi

(9) A. pruinosa

(ro) A. concinna

(II) A. Hullettii

(I2) A. oleifolia

(13) A. gelonioides

Leaves elliptic-ovate glaucous beneath.

Leaves cuspidate acuminate, 4 in. long; pedicels short.

Leaves blunt at tip; pedicels very long slender .

(I4) A. cuspidata

(I 5) A. fragilis

(I) A. sesquipedalis Hook. fil. F.B.I. v. I5I; Gamble, Joum. As. Soc. Beng. l.c. II3.

Tree about 40 to $50 \mathrm{ft}$. tall, Io to $20 \mathrm{in}$. through; branches stout silky. Leaves whorled coriaceous oblanceolate short acuminate, long narrowed to cuneate base glabrous, shining above, silky villous beneath; nerves I5 to 20 pairs with midrib strongly elevate beneath; I4 to IS in. long, 3.5 to 4.5 in. wide; petioles stout villous, 5 in. long. Flower clusters on the branches between leaf-whorls I in. across. Peduncles of heads 2 in. long; bracts 
involucral orbicular, 4 , all villous. Umbellules of 5 flowers. Drupe globose orange or green, I in. through; perianth cup-shaped finally disc-shaped. Hab. Dense forests, Perak, Thaiping Hills (Curtis); Relau Tujor (Wray); Goping (Kunstler). Penang (Wallich); Waterfall; Pulau Betong (Curtis).

var. macrocarpa Gamble, Journ. As. Soc. Beng. l.c. II5. Tree 20 to $30 \mathrm{ft}$. tall, 3 to $4 \mathrm{in}$. through; branches scurfy. Leaves thinly coriaceous oblanceolate nearly quite glabrous, glaucous beneath, I 2 to $I 3$ in. long, 4 to 4.5 in. wide; nerves elevate, I2 to I3 pairs; petioles 2 in. long, thick. Heads much as in A. sesquipedalis. Hab. Pahang, Telom (Ridley). Perak, Larut (Kunstler). Distrib. Borneo.

I take this to be a variety of $A$. sesquipedalis rather than of the very hairy Maingayi, under which Gamble puts it.

(2) A. Maingayi Hook. fil. F.B.I. v. I5I; Gamble, Journ. As. Soc. Beng. l.c. II4.

Tree 60 to $80 \mathrm{ft}$. tall, Io to $15 \mathrm{in}$. through; branches browntomentose. Leaves dark green glabrous above, red-brown-tomentose beneath, stiff coriaceous in whorls of 6 to I2 oblanceolate to elliptic-oblong sub-acute, base long-cuneate; nerves io to 20 pairs with reticulations elevate beneath; 9 to I4 in. long, 3 to $4 \mathrm{in.}$ wide; petioles tomentose, 3 in. long. Flower-clusters $I$ in. through, between the leaf whorls; bracts orbicular 4 , and peduncles silky. Flowers 5 in a head. Drupe globose, yellow, 5 in. through on the flat perianth; pedicel villous, 'I in. Hab. Dense forest, Singapore, Pulau Ubin; Bukit Timah; Bukit Mandai. Malacca (Maingay). Perak, Tapah and Gunong Batu Putih (Wray); Goping (Kunstler).

The var. elliptica Gamble, Journ. As. Soc. Beng. l.c. cannot belong here, as the fruits are racemed.

(3) A. glomerata Nees, Syst. Laur. 597; Gamble, Journ. As. Soc. Beng. l.c. II6.

Tree 30 to $40 \mathrm{ft}$. tall, I2 to $\mathrm{I} 8 \mathrm{in}$. through; branchlets rustypubescent then glabrous. Leaves 4 to 7 in a whorl chartaceous, obovate, abruptly acuminate, base narrowed glabrous dark green above, glaucous beneath and nerves usually red-pubescent, I2 pairs, elevate beneath, minutely areolate both sides; 9 in. long, 3 in. wide; petioles 5 in. long, pubescent. Flowers yellow in peduncled or nearly sessile cymes in axils or between whorls, I in. long, I.5 in. wide, soft-tomentose. Umbels 5, flowers surrounded by boatshaped bracts $\cdot 2$ in. long. Fruit depressed, globose short apiculate, $5 \mathrm{in}$. long, yellow; perianth disc-shaped. Hab. Woods, Singapore, Bukit Timah; Bukit Mandai; Bukit Panjang. Perak, Larut (Kunstler). Distrib. Java, Sumatra.

(4) A. montana Gamble, Kerv Bulletin, I9Io, p. 3I2; Joum. As. Soc. Beng. l.c. II7.

Tree 50 to $70 \mathrm{ft}$. tall, I2 to $\mathrm{I} 8 \mathrm{in}$. through; branches slender, glabrous. Leaves chartaceous in whorls of 4 or 5 , bluish green, 
glaucous beneath lanceolate acuminate, base long narrowed; midrib and nerves 8 to Io pairs, elevate beneath, transverse nervules prominent; 8 in. long, $2 \cdot 25$ in. wide; petioles I in. long. Flowers in umbellules in pubescent racemes about 8 in. long; young fruits enclosed in a perianth-tube puberulous outside, villous inside. $\mathrm{Hab}$. Forests in the mountains, Perak, Larut, at 3000 to $3500 \mathrm{ft}$. altitude (Kunstler).

A very little known plant.

(5) A. obovata Bl. Ann. Mus. Bot. Lugd. Bat. i. 342; Hook. fil. F.B.I. i. I53.

Small tree; branches velvety. Leaves elliptic-oblong or obovate, very coriaceons, glabrous and glaucous beneath when adult; midrib very stout elevate both sides, nerves strongly elevate beneath, 5 to 6 pairs, transverse nervules parallel, very conspicuous (young leaves densely red-hairy on nerves beneath); 9 in. long, 6 in. wide; petioles I. 75 in. long. Flower-heads about I in. through; involucral bracts red-silky. Males large, clustered, females panicled. Fruit $\cdot 6$ to $I$ in. long, cup dilated, $\cdot 5$ in. across. Hab. Mountain forests, rare, Pahang, Teku woods, Gunong Tahan (Ridley). Distrib. Himalayas, Munnipore.

(6) A. johorensis Gamble, Kew Bulletin, I9Io, p. 3r3; Joum. As. Soc. Beng. l.c. II7.

A small tree; branchlets glabrous, tip and buds villous. Leaves coriaceous in whorls of 3 to 5 , glabrous, narrow lanceolate blunt, base long cuneate, grey beneath; nerves 4 to 7 pairs, inarching near edge, slender slightly elevate both sides; 5 to 5.5 in. long, $\mathrm{I} \cdot 5$ in. wide; petioles I in. long, slender. Flowers in sessile umbels between leaf-whorls. Drupe globose, black, $5 \mathrm{in}$. through on the flattened perianth-lobes, $\cdot 27$ in. across; pedicels thick, conic, $\cdot 3$ in. long. Hab. Hill forests, rare, Johor, Gunong Pantai (Ridley).

(7) A. malaccensis Hook. fil. F.B.I. v. I48; Gamble, Journ. As. Soc. Beng. l.c. II8.

Tree tall or small; branchlets rather stout tomentose. Leaves sub-coriaceous whorls of 4 to 7 , acuminate acute, base narrowed, glabrous above, red-tomentose beneath; nerves 8 to $\mathrm{x} 2$ pairs elevate, rather slender, reticulations obscure; 5.5 in. long, I.5 in. wide; petioles slender, $\cdot 25$ in. long. Flowers in numerous clusters .5 in. across, between the whorls tomentose; peduncles $I$ in. long. Fruit globose, shining reddish, 35 in. through; perianth flat, cup-shaped, - I in. across; pedicel short, thick. Hab. Forests in the south, Singapore, Garden Jungle; Bukit Timah (Ridley). Malacca (Maingay). Native name: Medang Kachigawei.

(8) A. Ridleyi Gamble, Kew Bulletin, IgIo, p. 3I2; Journ. As. Soc. Beng. l.c. II 8 .

Small tree; branches slender, glabrous. Leaves coriaceous not glaucous in whorls of 4 to 6 , lanceolate acuminate, base narrowed minutely areolate above, less beneath; nerves hardly visible 
above slender, slightly raised beneath, 6 to 8 pairs; $6 \cdot 7$ to 7 in. long, I.5 in. wide; petioles $\cdot 5$ in. long, rusty-pubescent. Flowers in sessile lateral umbels with chaffy deciduous scales; bracts orbicular. Drupe globose, nearly $4 \mathrm{in}$. through on the enlarged cup-shaped perianth. Hab. Hill woods, rare, Johor, Gunong Pulai (Ridley). Disirib. Borneo.

This resembles $A$. johorensis, but the leaves are minutely areolate, not glaucous beneath.

(9) A. pruinosa Nees, Wall. Pl. As. Rar. ii. 68; Gamble, Journ. As. Soc. Beng. l.c. IIg.

Tree 30 to $40 \mathrm{ft}$. tall; branchlets slender red-tomentose at tips. Leaves coriaceous in whorls of 4 to 6 , lanceolate, ellipticlanceolate, acute or acuminate, base shortly cuneate, shining, glabrous above, glaucous beneath (young); finely puberulous or glabrous beneath; midrib and nerves elevate slender; nerves 8 to Io pairs; nervules and reticulations very fine, visible beneath; 3 to 5 in. long, I.2 to 2 in. wide; petioles $\cdot 2$ in. long. Flowers in fascicles 5 in. long and wide, sessile or shortly peduncled, numerous between the whorls or in the whorls. Bracts caducous hispid. Drupe globose black, $\cdot 25$ in. through; perianth-cup $\cdot 15$ in. across; pedicels $\cdot 25$ in. long. Hab. Woods, Singapore, Changi. Malacca (Maingay). Perak, Waterfall Hill (Wray). Penang, Moniot's Road (Curtis, Wallich).

var. Kunstleri. Nearly entirely glabrous. Drupe globose, cupule shorter and thicker. Hab. Perak, Goping (Kunstler).

(Io) A. concinna Ridl. Journ. F.M.S. Mus. v. 44.

Leaves 4 to 5 in a whorl, thinly coriaceous, glabrous lanceolate acuminate; nerves 8 pairs slender, elevate beneath; paler and slightly glaucescent beneath, 4 to 5.5 in. long, I.75 in. wide; petioles $\cdot 24$ in. long. Heads 4 in. long, sub-sessile terminal or below leaves; bracts coppery, orbicular pubescent, outer lobes oblong blunt hooded, inner flat, all hairy outside; stigma in male conoid. Hab. Mountains, local, Selangor, Gunong Mengkuang Lebah (Robinson).

(II) A. Hullettii Gamble, Kew Bulletin, I9Io, p. 314; Journ. As. Soc. Beng. l.c. I20.

Tree about $30 \mathrm{ft}$. tall, bushy; stem $x \mathrm{ft}$. through. Leaves coriaceous in whorls of 3 to 5 oblanceolate, acuminate, base cuneate, glabrous above, light green, minutely areolate beneath glaucous, conspicuously areolate; nerves very fine, 5 to 6 pairs; 3 to 4 in. long, 75 to $x \cdot 2$ in. wide; petioles I $_{5}$ in. long. Flowers, male in axillary bracteate clusters; bracts deciduous leaving a very short peduncle. Flowers villous. Hab. Singapore Gardens.

A single tree on the bandstand, which died about Igrr. It was possibly not wild, but has been seen nowhere else. 
(I2) A. oleifolia Gamble, Kew Bulletin, I9Io, p. 3I3; Journ. As. Soc. Beng. l.c. I2I.

Shrub 6 to $8 \mathrm{ft}$. tall; branchlets slender tomentose. Leaves coriaceous in whorls of 4 to 8 , elliptic-oblong or lanceolate shortly acuminate or quite blunt, areolate above, glaucous beneath; nerves fine, 8 to Io pairs, elevate above, hardly beneath; 2.5 to 3 in. long, 75 to $I$ in. wide; petioles slender, $\cdot 25$ in. long. Flowers in dense tawny clusters 5 in. through, villous. Bracts orbicular deciduous. Fruit ovoid-oblong, $\cdot 27$ in. long; perianth-tube cupshaped, $\cdot 25$ in. across; pedicels villous. Hab. Mountains, about $5000 \mathrm{ft}$. altitude, Pahang, Kluang Terbang (Barnes). Perak, Gunong Bubu (Kunstler); Gunong Inas and Gunong Batu Putih (Wray); Gunong Berumbun, near Telom (Ridley). Distrib. Borneo.

var. glabra. Quite glabrous. Leaves stiff coriaceous, 4 in. long, I.5 in. wide, glaucescent beneath blunt, base round. Drupe black, 5 in. long; perianth-tube $\cdot 25$ in. wide; pedicels $\cdot 3$ in. long. Pahang, Gunong Tahan at $5000 \mathrm{ft}$. altitude (Ridley).

(I3) A. gelonioides Ridley.

Shrub with slender branches entirely glabrous except flowers and buds. Bud sheaths red-hairy. Leaves elliptic narrowed to a short blunt point and to the sub-acute or blunt base, bright green when dry not glaucous, conspicuously areolate all over; nerves faint, 7 pairs hardly visible beneath and very faint above; $2 \cdot 2$ in. long, 75 in. wide; petioles $\cdot 2$ in. long. Flower-heads small, fewflowered, about $\cdot 2 \mathrm{in}$. across in uppermost axils. Flower small, - I in. across, tube very short-hairy, lobes round, glabrous. Glands oblong, broad glabrous. Hab. Mountains, Gunong Kerbau (Robinson).

(I4) A. cuspidata Gamble, Kero Bulletin, I910, p. 3I4; Journ. As. Soc. Beng. l.c. I22.

Tree 40 to $50 \mathrm{ft}$. tall, 8 to $\mathrm{I} 2 \mathrm{in}$. through; branchlets rather thick, tips rusty-tomentose. Leaves coriaceous in whorls of 4 , elliptic or elliptic-obovate cuspidate acuminate, base narrow, glaucous, white beneath, above glabrous; nerves 8 to io pairs, slightly elevate beneath; 4 in. long, I'75 in. wide; petioles $I$ in. long, pubescent. Flowers in umbellules in very short rustypubescent racemes, 25 in. long. Bracts dry, hard ovate brown. Perianth light yellow. Hab. Rare, dense forests, Perak, Ulu Bera (Kunstler).

(I5) A. fragilis Gamble, Kew Bulletin, I9Io, p. 3I4; Joum. As. Soc. Beng. l.c. I23.

Tree 40 to $60 \mathrm{ft}$. tall, ro to $24 \mathrm{in}$. through; branchlets slender, minutely puberulous. Leaves coriaceous glabrous in whorls of 2 to 4 , ovate or elliptic-ovate blunt short acuminate, base acute beneath white, glaucous; nerves very faint, 5 to 6 pairs; $\mathrm{T} \cdot 5$ to 4 in. long, .75 to $\mathrm{I} \cdot 5 \mathrm{in}$. wide; petioles .75 in. long. Flowers in umbellules 
in slender peduncled pubescent umbels $\mathrm{I} \cdot 5$ in. long; pedicels very slender. Perianth reddish brown, tube short with a ring of golden hairs within, lobes ovate ciliate, glabrous inside. Fruit ovoid, 4 in. long on a saucer-shaped perianth-tube ${ }^{\prime} 5$ in. across; pedicels $\cdot 2$ in. long, cylindric. Whole fruit-panicle over I in. long. Hab. Perak, Ulu Bubong (Kunstler).

\section{LITSEA, Lour.}

Trees or shrubs. Leaves alternate or opposite or sub-opposite. Flowers unisexual in umbellules of 2 to $I_{5}$ (usually 6), surrounded by 4 to 6 involucral bracts orbicular concave, in axillary or lateral fascicles or racemes. Flowers shortly pedicelled or sessile; perianth-tube in males small or 0 , in females funnel-shaped, lobes 6. Stamens in males 9 to I2 (rarely more or less), rows I and 2 without glands, row 3 with 2 glands, cells 4 . Ovary o. Female flowers. Staminodes 9 to I2. Ovary globose or ovoid; style thick; stigma dilate. Fruit globose-ovoid, ellipsoid or cylindric on the perianth-tube enlarged in a cup, usually large, often thick. Seed I. Species I50 to 200, tropical and sub-tropical Asia, Australia, rarer in Africa and America.

Leaves alternate.

Flowers on tree-trunk on woody tubercles. Leaves tomentose beneath, 8 in. long. Leaves tomentose beneath, I 8 in. Iong Leaves glabrous, I 2 in. long; heads of umbellules 3 in. long

Flowers on branches; leaves hairy beneath.

Perianth-lobes none

Perianth-lobes 6 or more.

Umbellules in short clusters or racemes.

Leaves coriaceous obovate large.

Umbellules peduncled, racemes short .

Umbellules sessile, racemes 2 in. long .

Leaves sub-coriaceous lanceolate not large

Leaves chartaceous or membranous.

Leaves oblong-lanceolate; umbellules 2 to 3 together .

Leaves elliptic-lanceolate. Bush or tree

Leaves thin ashy beneath, 2 in. across. Small tree

Leaves elliptic-ovate. Very hairy shrub

Leaves elliptic sparsely pubescent ; umbellules densely clustered. Tree . Leaves cordate; umbels in racemes.

Umbellules in clusters or very short racemes.

Leảes glabrous or only slightly hairy beneath.

Leaves thin coriaceous broad (fruit unknown)

Leaves chartaceous elliptic ${ }^{\circ}$

Umbellules in short panicles of racemes .

(I) L. johorensis

(2) L. trunciflora

(3) L. magnifica

(4) L. tomentosa

(5) L. grandis

(6) L. artocarpifolia

(7) L. firma

(8) L. gracilis

(9) L. amara

(Iо) L. cinerascens

(II) L. hirsutissima

(I2) L. polyantha

(13) L. cordata

(I4) L. glabrifolia

(I5) L. petiolata

(I6) L. brachystachya 
Fruit oblong, 8 in. long; leaves coriaceous

(I 7$)$ L. angulata

Fruit 4 in. long; leaves sub-membranous, glaucous beneath .

Fruit $\cdot 6$ in. through; leaves chartaceous

Fruit 45 in. through; leaves coriaceous

Fruit moderate sized to large, cup margins entire.

Leaves elliptic; fruit cupule thick.

Fruit ovoid; leaves chartaceous .

Fruit ellipsoid-oblong; leayes coriaceous

Fruit cylindric-oblong ; leaves coriaceous obovate.

Leaves oblong; fruit cupule thick, cup- or saucer-shaped.

Leaves elliptic-oblong reticulate .

Leaves oblong-lanceolate, not conspicuously reticulate .

- Leaves oblong-obovate or oblanceolate, inconspicuously reticulate

Leaves elliptic-oblong, inconspicuously reticulate. .

Leaves sub-coriaceous, oblong or obovate, glaucous beneath.

Fruit-cup saucer-shaped large, 4 in. across.

Leaves pergamaceous oblongobovate; fruit-cup woody large

Umbels I to several, sub-terminai

Leaves elliptic cuspidate acuminate; racemes grey-pubescent

Leaves elliptic acute; racemes glabrous

Leaves more or less lanceolate.

Leaves lanceolate long-acuminate, areolate

Leaves oblanceolate, grey beneath.

Umbellules peduncled

Umbellules sessile

Leaves oblong-lanceolate, glaucous beneath; bracts densely grey puberulous .

Leaves elliptic-lanceolate or oblanceolate, glaucous beneath

Leaves ovate or elliptic, hardly $3^{\circ} 9$ in. long

Umbellules in elongate racemes.

Leaves narrow.

Racemes $\cdot 8$ in. long; leaves coriaceous

Racemes I in, long; umbel peduncles very short or 0 , glabrous

Racemes 3 in. long; peduncles ${ }^{\prime} 5$ in. long, slender, glabrous .

Racemes 3 in. long, puberulous .

Leaves broad.

Racemes glabrous, 6 to 8 in. long;

FL.M.P., 3. branches angular. .

(I8) L. spathacea

(19) L. Ridleyi

(2o) L. penangiana

(2I) L. castanea

(22) L. quercina

(23) L. cylindrocarpa

(24) L. Wrayi

(25) L. singaporensis

(26) L. perakensis

(27) L. pustulata

(28) L. patellaris

(29) L. fenestrata

(30) L. acrantha

(3I) L. Foxiana

(32) L. monticola

(33) L. Scortechinii

(34) L. ochracea

(35) L. oblanceolata

(36) I. Kunstleri

(37) L. claviflora

(38) L. Helferi var. ovata

(39) L. myristicæfolia

(40) L. Teysmanni

(4I) I. machilifolia

(42) L. panamonja

(43) L. Curtisii 
Racemes glabrous, 4 in. long, scurfy; fruit in a large woody cup.

Raceme puberulous, 4 in. long; fruit over I in. through; cup flat

Racemes pubescent or tomentose. Racemes short dense, 3 in long Racemes stout to 7 in. long

Leaves thin coriaceous.

Perianth-cup obconic

Perianth-cup flattened

Leaves opposite or sub-opposite.
(44) L. nidularis
(45) L. megacarpa
(46) L. sebifera
(47) L. Maingayi
(48) I. Noronhæe
(49) L. robusta

Large trees.

Leaves coriaceous rusty tomentose beneath.

Leaves many alternate, few, sub-opposite .

Leaves all opposite

(5o) L. ferruginea

Shrubs or small trees.

(5I) L. Griffithii

Leaves elliptic-lanceolate; umbels very few and small.

Leaves long-cuspidate

Tall tree.

Leaves blunt or acute; nerves 8 to 12 pairs

Leaves stiff chartaceous acute or acuminate;

Shrubs. nerves 6 to 8 pairs

Leaves grey pubescent beneath; stem

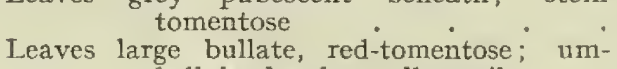
bellules heads small, sessile .

(52) L. sarawacensis

(54) L. gracilipes

(55) L. ujongensis

(56) L. sessilifiora

(I) I. johorensis Gamble, Kew Bulletin, I9Io, p. 315; Journ. As. Soc. Beng. l.c. I33.

A tree about $60 \mathrm{ft}$. tall, not stout, with conspicuous white bark. Leaves coriaceous, crowded towards branch ends, oblanceolate acuminate, long narrowed at base, reddish-tomentose beneath; nerves ro to I4 pairs, sunk above, raised beneath; 8 in. long, $2 \cdot 25$ in. wide; petioles 5 to $\cdot 8$ in. long. Umbellules tomentose, $\cdot 4$ in. long; peduncles on hard woody tubercles at base of trunk; bracts tomentose. Fruit ovoid truncate apiculate, halfenclosed in the hemispheric cup. Hab. Local in forests, Johor, Tanjong Bunga; Castlewood; Sedenah. Pahang, Temerloh (Burn-Murdoch).

(2) L. trunciflora Gamble, Kew Bulletin, I910, p. 316; Journ. As. Soc. Beng. l.c. I35.

Tree 40 to $60 \mathrm{ft}$. tall, 8 to I2 in. through; bark brown. Leaves coriaceous oblanceolate to obovate tomentose beneath; nerves I6 to 22 pairs, prominent beneath; I 8 in. long, 5 in. wide; petioles tomentose, 5 in. long. Umbels on pubescent peduncles, 4 in. long, in clusters on tubercles on the trunk nearly 2 in. across. Bracts orbicular minutely puberulous. Flowers yellow. Hab. Forests, not common, Malacca, Selandor (Cantley). Pahang, Gunong Senyum (Evans). Perak, Goping (Kunstler). Native name: Medang Kunyit. 
(3) L. magnifica Gamble, Journ. As. Soc. Beng. l.c. I52.

Small tree; bark white. Leaves thinly coriaceous oblanceolate, rounded acuminate, base long narrowed, 12 in. long, 3 in. wide ; nerves I5 to 20 pairs, sunk above, prominent beneath with nervules inconspicuous; petioles stout, short or none. Umbellules in very short racemes forming a head 3 in. across, on the trunk, peduncles $\cdot 3$ in. long, pubescent, grey. Umbellules 5 in. across with 7 to 9 flowers in male, 5 in female umbellules. Fruit ovoid truncate apiculate, 4 in. long; cup $\cdot 25$ in. across, edge regular, - $\mathrm{I}$ in. deep. Hab. Forests, Malacca, Nyalas (Derry); Batu Chengei (Cantiey), Penang, Waterfall (Ridley).

var. pahangensis. Leaves 4 in. wide more coriaceous; petioles .8 in. long. Hab. Pahang River and Tahan River, Kwala Tenok (Ridley). Malacca, Selandor (Cantley). Distrib. Sumatra. Native names: Medang Telor; Medang Kuning or Kunyit.

(4) L. tomentosa Bl. Bijdr. 566; Gamble, Journ. As. Soc. Beng. l.c. I32.

Tree 50 to $70 \mathrm{ft}$. tall, $\mathrm{I} \cdot 5$ to $2 \mathrm{ft}$. through; branches puberulous. Leaves softly chartaceous obovate or oblong-obovate sub-acute, base narrowed, glabrous when adult above, grey pubescent beneath; nerves prominent beneath, I2 to I5 pairs, as are reticulations; 5 in. long, 2.5 in. wide (young leaves thin, membranous, 8 in. long); petioles 5 to $8 \mathrm{in}$. long, tomentose. Umbellules in dense clusters axillary or below leaves, on a short stout peduncle 5 in. through. Bracts oblong, grey-pubescent. Perianth-lobes incomplete, small or absent. Fruit ellipsoid blunt, I.2 in. long, I in. through, cup irregularly toothed. Hab. Hilly woods, Perak, Goping (Kunstler). Penang, West Hill (Curtis). Distrib. Java.

(5) L. grandis Hook. fil. F.B.I. v. I62; Gamble, Journ. As. Soc. Beng. l.c. I36. (Fig. I45, p. II6).

Tree about 40 to $60 \mathrm{ft}$. tall, bushy, trunk short or up to Ioo ft. tall (Kunstler); branchlets brown-velvety. Leaves stiffly coriaceous obovate, usually blunt rounded, base cuneate; nerves I2 to 20 pairs, elevate beneath, as are transverse nervules, glabrous above, densely red-tomentose beneath, 6 to 7 in. long, 3.25 in. across ; petioles 5 to $\cdot 75$ in. long. Umbels very numerous in short racemes on the bare part or axils of branches tomentose; peduncles $\cdot 25 \mathrm{in}$. long. Bracts silky orbicular. Umbellules 5 in. across when open, about Io together, yellow. Perianth-lobes linear-oblong in male, lanceolate acute in female. Fruit ellipsoid, 7 in. long on a thin obconic tube. Hab. Common in open country, very floriferous, Singapore, Tanglin; Bukit Timah. Malacca (Maingay). Negri Sembilan, Bukit Bertam (Cantley). Perak, Goping and Ulu Bubong (Kunstler); Tapah (Burn-Murdoch); Gunong Batu putih (Wray). Penang Hill (Wallich, Curtis). Lankawi, Kesap (Haniff). Distrib. Burma, Java. Native names: Medang Busuk; Medang Daun Lebar. 
(6) I. artocarpifolia Gamble, Kew Bulletin, I9Io, p. 3I6; Journ. As. Soc. Beng. l.c. I37.

Tree. Leaves coriaceous obovate blunt or apiculate, glabrous above, pubescent beneath; nerves 20 pairs, elevate beneath, as are transverse nervules; 9 in. long, 4 in. wide; petioles grooved, .5 in. long. Umbels sessile or nearly so in a head I in. through on a stout pubescent raceme 2 in. long. Umbellules small. Bracts 5 , orbicular, enclosing 6 flowers. Perianth-lobes 6 to 8 , silky-villous on both sides. Stamens 9 to I5. Hab. Perak, Relau Tujor (Wray).

This is like L. grandis, but has hairy leaves and umbellules nearly sessile on long racemes.

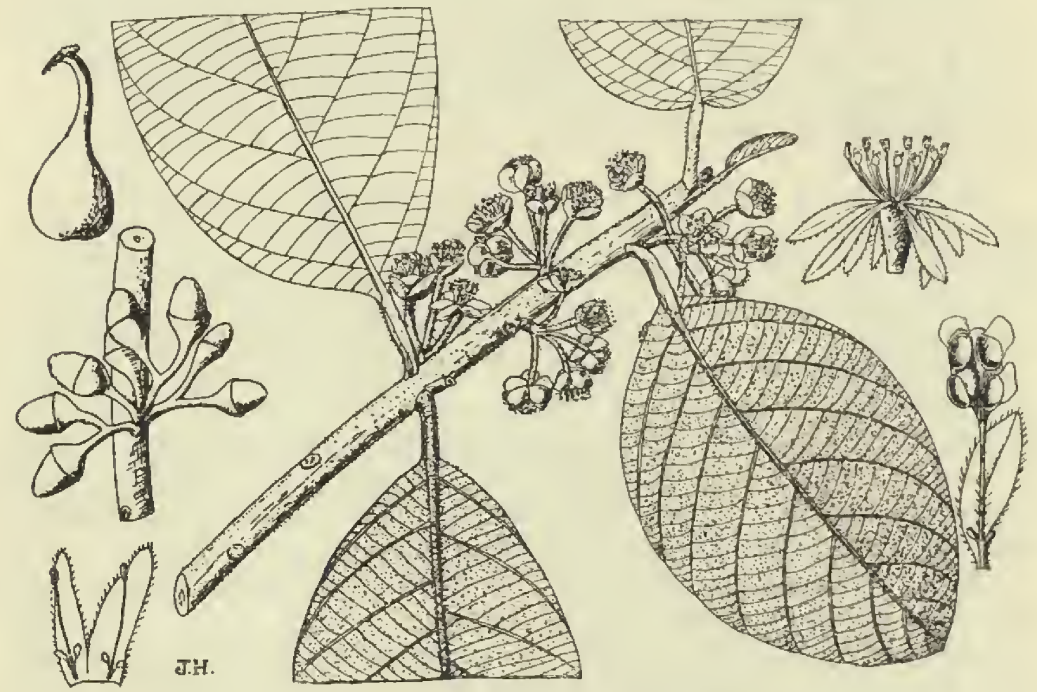

FIG. I 45--Litsea grandis.

(7) L. firma Hook. fil. F.B.I. v. I62; Gamble, Joum. As. Soc. Beng. l.c. 138 .

Tree 60 to $80 \mathrm{ft}$. tall, 2 to $3 \mathrm{ft}$. through; young parts brown puberulous. Leaves coriaceous, oblong-lanceolate blunt, base cuneate; nerves Io to I5 pairs and transverse reticulations redhairy beneath elevate; 3.5 to 4 in. long, 2 in. wide; petioles 5 in. long. Flowers in short racemes umbelliform. Umbellules 5 to 6 , about $\cdot 25$ in. across; peduncles slender, $\cdot 2$ in. long, red-pubescent, lobes oblong. Fruit ovoid-oblong truncate, $\cdot 3$ in. long, pink, cup shallow, $\cdot \mathrm{I}$ in. deep; pedicels $\cdot 2$ in. long. Hab. Woods, common, Singapore, Chua Chu Kang; Bukit Timah. Malacca (Maingay). Perak, Larut (Kunstler), tree Io ft. tall. Distrib. Sumatra, Borneo, Celebes. 
(8) L. gracilis Gamble, Kew Bulletin, I9Io, p. I39; Journ. As. Soc. Beng. l.c. I39.

Small tree with slender pubescent branches; buds silky. Leaves membranous, rather distant alternate, glabrous except midrib, sparse villous beneath; nervules slender, 8 to Io pairs; 4 to 4.75 in. long, I in. wide; petioles . $I$ in. long. Flowers in very small umbellules on very slender short I I in. long peduncles. Bracts membranous straw-coloured, villous outside ovate; flowers 3 ; lobes obovate, very thin, villous outside. Fruit obovoid apiculate; perianth-tube enlarged. Hab. Perak, Temengoh forests (Ridley).

(9) L. amara Bl. Bijdr. 563; Gamble, Joum. As. Soc. Beng. l.c. I40.

A bush or treelet about I2 to $15 \mathrm{ft}$. tall; branches red-pubescent. Leaves chartaceous alternate rather distant elliptic to lanceolate above, glabrous beneath rusty-villous often glaucescent; nerves 8 to I6 pairs, slightly elevate beneath, reticulations and nervules not elevate; 2.8 to 5.9 in. long, I. 2 to $2.8 \mathrm{in}$. wide; petioles ' I to $\cdot 4$ in. long, tomentose. Flowers in short-peduncled umbellules about 3 in. across containing 5 to 7 flowers. Perianth-tube short, villous within with long hairs, lobes thick unequal. Stamens 9 . Ovary ovoid; style curved thick; stigma large peltate lobed. Fruit ovoid apiculate, 3 in. long on the only slightly enlarged tube. Hab. Common over the whole peninsula from Singapore to Penang, Kedah and Lankawi and very variable. Generally in open country. Distrib. Burma, Malay isles, S. Siam. Native names: Medang Buluko; Medang Miyang.

var. fusco-tomentosa Meissn. DC. Prod. xv. i. Igo. Leaves rather stiffer and densely velvety-villous with long red or yellow hairs usually ovate, base round. Flowers hairy too, and stamens occasionally 2-celled. Hab. Forests, Johor, Kota Tinggi; Gunong Pantai. Malacca (Maingay, Griffith); Selandor; Merlimau (Cantley). Negri Sembilan, Gunong Angsi; Bukit Sulu (Cantley); Tampin. Selangor, Kwala Lumpur (Foxworthy). Perak, Tupai and Simpang (Wray); Gunong Hijau (Scortechini). Tringganu, Bundi (Rostados). Penang Hill (Curtis). Distrib. S. Siam. Native names: Jumpong; Kayu Liat; Kupong Sagah; Medang Bulut; Medang Krotan; Medang Sarang Tupai.

var. angusta Meissn. DC. Prod. xv. i. Igo. Leaves glabrescent often grey or silvery beneath, lanceolate or oblanceolate, usually $\mathrm{x} \cdot 5$ in. long, base narrowed. Hab. Pahang, Pekan. Malacca (Griffith); Sungei Hudang (Derry). Negri Sembilan, Bukit Tampin (Goodenough). Perak, Gunong Bubu (Kunstler). Penang (Wallich). Kedah, Alor Sta. Lankawi. Distrib. Burma.

var. attenuata Gamble, Journ. As. Soc. Beng. l.c. 142. Leaves oblong-lanceolate or oblanceolate acuminate, base narrow or round, often nearly 7 in. long, minutely rusty-pubescent beneath. $H a b$. Pahang River. Malacca, Batu Tiga (Derry); Selangor, Weld's 
Hill (Burn-Murdoch). Perak, Larut; and Ulu Bubong (Kunstler). Penang Hill. Native name: Medang Chenawa.

(I0) L. cinerascens Ridl. Journ. F.M.S. Mus. vi. I2.

Small tree with grey bark. Leaves thin lanceolate acuminate, base narrowed glabrous above, ashy beneath; nerves II pairs, slender, inconspicuous; $8 \mathrm{in}$. long, 2 to $2.5 \mathrm{in}$. wide; petioles $\cdot 1$ in. long. Flowers, female on very short peduncles 078 in. long. Umbellules 3, silky, 'I in. across. Sepals 6, oblong. Hab. Mountain forests at 2000 to $4000 \mathrm{ft}$. altitude, Pahang, Telom (Ridley). Selangor, Menuang Gasing (Kloss). Kedah, Gurun (Robinson).

Near Litsea amava var. attenuata, to which it was referred by Gamble. but very much more glabrous, with much larger leaves and smaller flowers,

(II) L. hirsutissima Gamble, Keto Bulletin, I9Io, p. 357; Journ. As. Soc. Beng. l.c. I42.

Shrub 6 to $8 \mathrm{ft}$. tall; branches and under-side and edge of leaves very hairy. Leaves membranous elliptic-ovate acute or cuspidate; nerves I2 to I5 pairs and nervules depressed above and elevate beneath; 6 to $6.5 \mathrm{in}$. long, 4 to $4.5 \mathrm{in}$. wide; petioles thick golden-hairy, 25 in. long. Umbellules on slender peduncles, 3 or 4 together; flowers 5 or 6 ; bracts hairy. Perianth nearly glabrous, glandular, lobes oblong. Stamens 9. Hab. Mountain forests, Perak, Goping and Thaiping (Kunstler); road to Gunong Hijau, to $2500 \mathrm{ft}$. altitude (Curtis).

var. geniculata Gamble, Journ. As. Soc. Beng. l.c. Branches zigzag. Leaves 3.4 to 4 in. long, ovate or orbicular sub-cordate. Hab. Perak, Goping (Kunstler).

This approaches $L$. amara var. fusco-tomentosa.

(I2) L. polyantha Jussieu, Ann. Mus. Bot. Lugd. Bat. vi. 2II; Gamble, l.c. I43.

Bushy tree I2 to $60 \mathrm{ft}$. tall; stem thick; young parts pubescent. Leaves chartaceous, elliptic to sub-orbicular blunt or sub-acute, base round or sub-acute, glabrous above, pubescent beneath; nerves 8 to I2 pairs raised beneath and red, nervules transverse numerous; 5 to 6 in. long, $2 \cdot 25$ to 4 in. wide; petioles $\cdot 5$ in. long. Umbellules generally numerous crowded, pubescent in dense clusters, $\cdot 5$ in. across. Umbellules 4 in. across when open. Fruit ovoid, .2 in. long; perianth cup small, flat; pedicels $\cdot 24$ in. long. $H a b$. Forests and open country, not rare, Pahang, Sungei Jelai (Machado); Kwala Tembeling. Perak, Gunong Pondok (Kunstler). Penang Hill and Balik Pulau (Curtis). Kelantan, Kota Bahru. Distrib. N. India, Burma, Java, China.

The leaves, which are smallest towards the branch ends, are variable. The Pahang form is less pubescent than usual.

(I3) L. cordata Hook. fil. F.B.I. v. I77; Gamble, Joum. As. Soc. Beng. l.c. I44.

Tree about 20 to $30 \mathrm{ft}$. tall. Leaves chartaceous, ovate or oblong-ovate sub-acute cordate, brown-tomentose beneath; nerves 
Io to I4 pairs elevate, as are reticulations and nervules; 4.5 to 8 in. long, 3 to 4.75 in. wide; petioles 5 in. long. Umbellules in racemes 2 to 4 in. long, or in panicles I. 5 in. long, lax puberulous, distant, 25 in. across; bracts ovate nearly glabrous. Fruit oblong acute, dark red then black, 75 in. long; perianth-cup small nearly flat, $\cdot I$ in. across; pedicels $\cdot 4$ in. long. $H a b$. Common; small tree in low country, Singapore, Kranji; Bukit Timah (Kunstler). Johor, Kota Tinggi; Bukit Murdom (Kelsall). Malacca, Sungei Udang (Goodenough). Selangor, Kerling (Goodenough). Perak, Kampar Road; Thaiping; Sungei Larut and Assam Kumbong (Wray). Distrib. Borneo, Sumatra.

(I4) L. glabrifolia Ridl. Journ. F.M.S. Mus. x. I52.

Tree, glabrous. Leaves alternate, thin coriaceous elliptic blunt, base shortly narrowed, glaucous beneath; nerves Io pairs, elevate beneath; 7 to 8 in. long, 3 in. wide; petioles 5 in. long. Umbellules in short, stout racemes, - I to $\cdot 2$ in. long; peduncles silky, $\cdot 2$ in. long. Involucre of 4 round, boat-shaped silky bracts, ' 15 in. long. Flowers 7 , pedicelled, $\cdot 25$ in. long and as wide; lobes linear-oblong, as long as the pedicels, silky. Stamens I2; filaments long slender hairy, inner 3 only with oblong stipitate glands. Pistillode cylindric with a 2 - to 3 -lobed stigma. Female flowers and fruit unknown. $H a b$. Pahang, Gunong Senyum (Evans).

(I5) L. petiolata Hook. fl. F.B.I. v. I7I; Gamble, Journ. As. Soc. Beng. l.c. I47.

Tree to $100 \mathrm{ft}$. tall, $2 \mathrm{ft}$. through, nearly glabrous. Leaves chartaceous deep green with yellow nerves aromatic glabrous; nerves 5 to 8 pairs; 3 to 4 in. long, 2 to 3 in. wide; petioles 5 to I in. long, slender. Umbellules $\cdot 25$ in. across, with very short -I in. long racemes; peduncles II in. long, puberulous. Flowers villous; lobes linear-oblong. Bracts orbicular concave almost quite glabrous. Fruit globose pulpy, $\cdot 3$ in. through; perianthtube flat, ' I in. across. Hab. Lowland woods, Singapore, Garden Jungle; Pulau Brani; Cluny Road; Gelang. Malacca (Maingay). Selangor, Kwala Lumpur. Perak, Goping; Batang Padang (Kunstler). Native name: Perawas. Use: In native medicine highly valued.

A very aromatic tree.

(I6) L. brachystachya Boerl. Handl. Fl. Ned. Ind. iii. I43; Gamble, l.c. I48.

Tree 40 to $50 \mathrm{ft}$, tall; stem ro to I5 in. through. Leaves thinly coriaceous glabrous elliptic-ovate blunt acuminate, base acute or rounded, bright shining green above, bluish green beneath; nerves 7 to 9 pairs, sunk above, elevate beneath, 4.5 in. long, 2.5 in. wide ; petioles slender, $\cdot 5 \mathrm{in}$. long. Umbellules $\cdot \mathrm{I}$ to $\cdot \mathrm{I} 5 \mathrm{in}$. across on racemes $I$ to $I \cdot 5$ in. long; pedicels $I$ in. long or less; bracts glabrous, outer orbicular, inner ovate green. Fruit globose or 
ellipsoid, $\cdot 3$ in. long, $\cdot 27$ in. through; perianth-tube little enlarged obconic. Hab. Perak, Relau Tujor and Matang Jambu (Wray); Larut (Kunstler). Distrib. Java.

(I7) L. angulata Bl. Bijdr. 563; Gamble, Journ. As. Soc. Beng. l.c. I49.

Tree 60 to $80 \mathrm{ft}$. tall; stem 2 to $3 \mathrm{ft}$. through; branchlets angular minutely puberulous. Leaves coriaceous elliptic-obovate blunt or sub-acute, base attenuate, dark green, glabrous; nerves 7 to I2 pairs, sunk above, raised beneath, nervules and reticulations very obscure; 3 to 5 in. long, 2 in. wide; petioles $\cdot 25$ in. long, slender. Umbellules of 6 flowers on grey peduncles $\cdot 2$ in. long on a raceme 4 in. long. Bracts 5, outer orbicular, glabrous, inner membranous puberulous fimbriate. Flowers 6. Fruit ovateoblong, dark red speckled white, tip green, 75 in. long, 5 in. through; perianth-tube flat, I 8 in. across. Hab. Lowland forest, not common, Selangor, Batu Caves. Perak, Larut (Kunstler). Distrib. Java.

(I8) L. spathacea Gamble, Kerw Bulletin, I910, p. 358.

Shrub or small tree $20 \mathrm{ft}$. tall; young parts puberulous. Leaves sub-membranous, elliptic-oblong or oblanceolate to obovate round to acute or cuspidate, base narrowed, glaucous beneath; nerves rather prominent, 9 to I2 pairs; 3 to 9 in. long, 2 to 4 in. wide; petioles $\cdot 2$ to $\cdot 8$ in. long. Umbellules $I$ to 3 in very short racemes with subulate bracts $\cdot 1$ to $\cdot 2$ in. long. Umbel bracts ovate-orbicular, densely tomentose outside; flowers 6 . Fruit ovoid apiculate, .47 to .6 in. long; perianth-cup short; lobes 2 to 5 . Hab. Forests, Selangor, Kwala Lumpur (Curtis). Negri Sembilan, Bukit Tumayiang and Bukit Klana (Cantley). Perak, Relau Tujor, and Sungei Larut (Wray); Maxwell's Hill (Wray, Scortechini). Penang (Curtis).

var. tomentosa Gamble, Joum. As. Soc. Beng. l.c. Thickly soft hairy all over except the upper side of the leaves. Hab. Perak, Ulu Selama (Scortechini). Native names: Kayu Tunkoi; Tunkoi Betina.

(I9) L. Ridleyi Gamble, Kew Bulletin, I9Io, p. 3I7; Journ. As. Soc. Beng. l.c. I53.

Small tree; young parts rusty-puberulous. Leaves chartaceous elliptic-oblong lanceolate-acute or acuminate, base long attenuate, glabrous above except midrib, minute areolate, beneath paler; nerves 7 to Io pairs, elevate pubescent; 7 in. long, 2.5 to 3 in. wide, nervules not transverse; petioles ${ }_{5} 5$ in. long. Umbellules few, I $_{5}$ in. long or less in short axillary racemes of 6 to I2 rusty-villous umbellules 4 in. across or less. Bracts 4 , ovate-oblong. Flowers 4 to 6 , lobes villous. Fruit globose, $\cdot 6$ in. through; perianth-tube obconic wrinkled, $\cdot 25$ in. long, 4 in. across. $H a b$. Local in lowland woods, Singapore, Changi; Garden Jungle; Bukit Mandai (Ridley). 
(20) L. penangiana Hook. fil. F.B.I. v. I7I; Gamble, Journ. As. Soc. Beng. l.c. I54.

Small tree; branchlets red-tomentose. Leaves stiffly coriaceous, elliptic-oblong, shortly acute, base long or shortly narrowed, glabrous shining above, bluish grey beneath and soft-tomentose when young; midrib stout; nerves 8 to ro pairs, elevate beneath; nervules and reticulations very faint; 6 to 6.5 in. long, 2.5 to $2.75 \mathrm{in}$. across; petioles I in. long. Racemes axillary very short, ' $I$ in. long. Umbellules 25 in. across; peduncles $\cdot$ I2 in. long. Bracts 4 , ovate tomentose. Flowers 4 to 6 , tube stout, villous inside, lobes oblong blunt villous outside. Fruit ellipsoid apiculate, $\cdot 45 \mathrm{in}$. long in a thick perianth-cup rugose with crenulate edge. Hab. Hill forests, at 2000 to $2400 \mathrm{ft}$. altitude. Pahang, Fraser Hill (Burkill). Perak, Gunong Batu Putih (Wray). Penang, Moniot's Road (Curtis, Philipps).

(2I) L. castanea Hook. fil. F.B.I. v. I7I; Gamble, Journ. As. Soc. Beng. l.c. I55.

Tree 60 to Ioo ft. tall; branchlets puberulous. Leaves stiffy chartaceous elliptic-ovate or obovate blunt or emarginate, base round, dark green, glabrous except the nerves beneath, 8 to 16 pairs, strongly elevate, sometimes puberulous; 4.5 to 7 in. long, 3 to 4 in. wide; petioles stout, 5 in. long. Racemes ${ }^{\prime} 5$ in. long of 6 to 8 umbellules, I 15 in. across on peduncles as long or longer. Bracts ovate-orbicular, quite tomentose. Flowers in umbellule 4 to 6 , villous outside; lobes spathulate. Fruit ovoid to cylindric ovoid, $\cdot 45$ to 8 in. long; perianth-tube cup-shaped, $\cdot 27$ in. tall, rough puberulous. Hab. Lowland woods, Malacca (Maingay), Bukit Bruang; Brisu (Derry). Selangor, Kwala Lumpur. Perak, Sungei Larut and Kota (Wray); Ulu Bubong and Larut (Kunstler). Native names: Medang Kunyit; Medang Bobokur.

(22) L. quercina Gamble, Kew Bulletin, rg10, p. 318; Journ. As. Soc. Beng. l.c. 156 .

Tree. Leaves coriaceous areolate elliptic or elliptic-ovate, blunt or emarginate, base round glabrous or minutely puberulous beneath; nerves 7 to 9 pairs, sunk above, raised beneath; 2.5 in. long, I' 25 in. wide; petioles ' 5 in. long. Umbellules on short racemes. Fruit ellipsoid-oblong, 5 in. long, $\cdot 20$ in. through. $\mathrm{Cup} \cdot 2$ in. long, $\cdot 25$ in. wide, enlarged pedicel very short and thick. Hab. Perak, Gunong Batu Putih (Wray).

Something like $L$. castanea, but the leaves are much smaller.

(23) L. cylindrocarpa Gamble, Kerw Bulletin, rgIo, p. 3I8; Journ. As. Soc. Beng. l.c. 157 .

Tree 40 to $130 \mathrm{ft}$. tall; stem I to $4 \mathrm{ft}$. through. Leaves coriaceous, dark green, glaucescent beneath, elliptic or oblong, minutely apiculate, base shortly cuneate; nerves 6 to I2 pairs, sunk above, strongly elevate beneath, nervules and reticulations nearly invisible; 4.5 to 6 in. long, 2 to 3 in. wide; petioles 4 in. long. Umbels $\cdot 25$ in. across in short racemes 5 in. long. Peduncles 
.2 in. long, pubescent. Bracts ovate-orbicular, puberulous. Flowers villous. Fruit cylindric-oblong about $I$ in. long, $\cdot 2$ in. through, dark red turning black; cup $\cdot 2$ in. deep; peduncle thick, short. Hab. Woods, usually in the lowlands, Perak, Larut (Kunstler). Province Wellesley, Krian; Nibong Tebal (Curtis). Dindings, Bruas (Burn-Murdoch). Penang, Batu hitam at I50o ft. altitude (Curtis). Distrib. Java, Borneo.

(24) L. Wrayi Gamble, Kew Bulletin, I9Io, p. 3I9; Journ. As. Soc. Beng. l.c. 158 .

Tree 50 to $80 \mathrm{ft}$. tall; stem $\mathrm{I} \cdot 5$ to $2 \mathrm{ft}$. through. Leaves chartaceous dark glossy green, glabrous elliptic or oblong, rather abruptly acuminate, base attenuate; nerves slender, Io to I3 pairs, invisible above; 3 to 4.75 in. long, $I .5$ to 2 in. wide; petioles .75 in. long. Umbellules on a raceme $\cdot 2$ in. long, puberulous with ovate caducous bracts; peduncles $\cdot I$ in. long. Involucral bracts 4 or 5 , villous or puberulous orbicular concave. Flowers 5 or 6 , villous. Fruit globose, tip conic, white, 4 in. through (not ripe); cup $\cdot 4$ in. across, $\cdot 2$ in. deep, green spotted white. Hab. Forests, local, Perak, Larut; Thaiping Waterfall (Wray, Kunstler).

(25) L. singaporensis Gamble, Kew Bulletin, I910, p. 358; Journ. As. Soc. Beng. l.c. I59.

Small slender tree about $30 \mathrm{ft}$. tall; stem 3 to 4 in. through. Leaves coriaceous oblong-lanceolate, long attenuate, tip blunt, light shining green above, pale glaucescent beneath; nerves 6 to I2 pairs, slender elevate beneath, reticulations and nervules faint; 6 to 9 in. long, 2 in. wide; petioles 75 in. long, rather stout. Umbellules in racemes .5 in. long, puberulous; pedicels . I in. long; bracts pubescent, thin orbicular. Flowers villous. Fruit depressed, globose white then red, .5 in. through. Cup wide, $\cdot 5$ in. across, .25 in. deep. Hab. Woods in the south, Singapore, Garden Jungle, Bukit Timah; Toas (Ridley). Distrib. Borneo.

(26) L. perakensis Gamble, Kew Bulleiin, I9Io, p. 359; Journ. As. Soc. Beng. l.c. 160 .

A big tree 20 to $40 \mathrm{ft}$. tall. Leaves sub-coriaceous, glabrous, glaucescent beneath; oblong to oblanceolate; nerves io to I2 pairs, slender, elevate beneath, reticulations distinct; 8 to I2 in. long, 4 in. wide or smaller; petioles 5 to $I$ in. long. Umbellules in axillary racemes $\cdot 25$ in. long, puberulous, $\cdot 2$ in. across. Raceme bracts lanceolate acuminate. Flowers 5, lobes oblong pubescent. Involucral bracts orbicular, 4. Fruit depressed, globose, 5 in. through; perianth cup 4 in. across, rather shallow. Hab. Forests, Singapore, Bukit Timah. Johor, Sungei Tebrau (Ridley). Perak, Larut and Goping (Kunstler).

(27) L. pustulata Gamble, Kew Bulletin, I9Io, p. 359; Journ. As. Soc. Beng. l.c. I6I.

A tree 20 to $30 \mathrm{ft}$. tall, Io to $15 \mathrm{in}$. through. Leaves ellipticoblong or nearly obovate, coriaceous, round at the tip, shortly narrowed or round at the base, glaucous beneath; nerves 8 to I2 
pairs, prominent, 7 to $9 \mathrm{in}$. long, $3.5 \mathrm{in}$. wide; petioles $\cdot 3$ to $\cdot 5$ in. long, stout. Umbellules in a raceme about 25 in. long. Fruit globose, $\cdot 5$ in. through, top round, cup at first enclosing it finally saucer-shaped, 25 in. wide; quite shallow and thin, wrinkled and pustular, as is the thickened pedicel. Hab. Dense forests, Perak, Larut Hills below $800 \mathrm{ft}$. altitude (Kunstler).

(28) L. patellaris Gamble, Kew Bulletin, I9Io, p. 360; Journ. As. Soc. Beng. l.c. I6r.

Tree 40 to $60 \mathrm{ft}$. tall, 8 to $\mathrm{I} 2 \mathrm{in}$. through. Leaves sub-coriaceous dark green, glaucous beneath, oblong or obovate shortly acuminate, base cuneate; nerves 8 to Io pairs elevate beneath, transverse nervules conspicuous fine; ro in. long, 4 in. wide; petioles 5 in. long. Racemes axillary, very short. Fruit globose, 5 in. through, red; perianth cup nearly flat, 4 in. across, wrinkled; pedicels short, thick. Hab. Dense forests up to $800 \mathrm{ft}$. altitude, Perak, Larut Hills (Kunstler).

This is perhaps a form of L. pustulata, but neither plant is well enough known to judge.

(29) L. fenestrata Gamble, Kew Bulletin, I9Io, p. 360 ; Journ. As. Soc. Beng. l.c. I62.

Big tree 80 to roo $\mathrm{ft}$. tall, 2 to $3 \mathrm{ft}$. through. Leaves subcoriaceous oblong or oblong-ovate, narrowed at base, sub-glaucous beneath; nerves strongly elevate, Io to I5 pairs; smooth above, minutely areolate beneath, I 2 to I 8 in. long, 5 in. wide; petioles I. 5 in. long, thick, wrinkled. Umbellules in dense clusters on the old wood, $\cdot 4$ in. across; peduncles puberulous, $\cdot 27$ in. long. Bracts orbicular puberulous outside. Flowers 6- to 7-pedicelled, lobes linearoblong, villous outside. Fruit globose, 8 in. through at first enclosed in the turbinate woody scurfy cup, at length the cup is I in. across, - 5 in. deep, brown woody, thick; fruit white turning purple pink. Hab. Dense forests up to $800 \mathrm{ft}$. altitude, Perak, Goping and Larut (Kunstler). Distrib. Sumatra.

(30) L. acrantha Ridl. F.M.S. Mus. x. I52.

Branches and petioles roughly bristly hairy. Leaves alternate, coriaceous areolate lanceolate acuminate, base narrowed, glabrous except the midrib and nerves appressed bristly hairy; nerves 7 pairs, elevate beneath, nervules parallel horizontal; 3 to 3.5 in. long, $\mathrm{I} \cdot 5 \mathrm{in}$. wide; petioles $\cdot 25$ in. long. Umbellules one or several on a short pseudo-terminal silky peduncle, 3 in. wide when expanded. Involucral bracts 4 , ovate, rounded silky. Flowers about 4 , pedicels silky, lobes 3 , ovate spathulate, 2 linear-oblong, all silky. Stamens 7; filaments glabrous, slender; anther oblong 4-celled. Pistillode conic with an elongate style and 3 minute stigmas. Female flowers and fruit unknown. Hab. Mountains, rare, Kedah, Gunong Bintang (Kloss).

(3I) L. Foxiana Gamble, Kew Bulletin, I9Io, p. 36r; Joum. As. Soc. Beng. l.c. I63.

Medium tree; branches angular. Leaves sub-coriaceous elliptic- 
oblong, acuminate, base short narrowed glaucous and pubescent beneath; nerves sunk above, prominent beneath, pubescent, I2 to I 6 pairs; 5 in. long, I.75 in. wide; petioles 6 in. long, pubescent. Umbellules $\cdot 3$ in. across; peduncles.$I$ in. long, puberulous in racemes, several together, $\cdot 2$ in. long. Bracts orbicular 4 . Flowers 5 or 6 , lobes oblong villous. Stamens 3 to ro in male. Hab. Penang, Moniot's Road (Curtis).

(32) L. monticola Gamble, Kew Bulletin, I9ro, p. 36I; Journ. As. Soc. Beng. l.c. I64.

Tree 40 to $50 \mathrm{ft}$. tall, 18 to 24 in. through; branches angled. Leaves coriaceous elliptic acute, base narrow, obscurely glaucous and pubescent beneath or quite glabrous; nerves 8 to I2 pairs, sunk above, elevate beneath, transverse nervules faint; 5 to 7 in. long, 2.5 in. wide. Umbellules 4 in. across; peduncles glabrous; racemes short puberulous. Involucral bracts 4 , orbicular glabrous, except the 2 inner ones ciliate on the edge. Flowers 5, densely golden tawny villous; lobes 6 . Stamens of males 8 to I3. Hab. Mountain forests at 4600 to $5500 \mathrm{ft}$. altitude, Perak, Thaiping Hills, Gunong Hijau (Kunstler).

This is very near $L$. Foxiana, but the leaves are not so long acuminate and hardly glaucous or pubescent, the racemes short, umbellules glabrous and flowers densely tawny villous.

(33) L. Scortechinii Gamble, Kerw Bulletin, I91o, p. 362; Journ. As. Soc. Beng., l.c. I64.

Probably a tree; branchlets red-puberulous. Leaves chartaceous, lanceolate or elliptic-lanceolate, acuminate, base long narrowed, glabrous above except the puberulous sunk midrib and nerves, 6 to ro pairs, beneath minutely areolate; nerves and midrib elevate puberulous; $6 \mathrm{in}$. long, 2 in. wide; petioles slender, $\cdot 3$ in. long. Umbellules small; peduncles $\cdot I$ in. long on racemes little longer. Bracts 5, membranous, edges fimbriate. Flowers 5, golden villous outside. Hab. Perak, Haram Parah (Arang Payah) (Scortechini).

(34) L. ochracea Boerl. Handl. Fl. Ned. Ind. I44; Gamble, Journ. As. Soc. Beng. l.c. I65.

Spreading tree 50 to $70 \mathrm{ft}$. tall, 2 to $3 \mathrm{ft}$. through. Leaves chartaceous oblong-lanceolate to oblanceolate short-acuminate, base long narrowed, bright green above, ashy beneath; nerves 7 to Io pairs, slender, slightly raised beneath and slightly puberulous; reticulations visible beneath; Io in. long, 3 in. wide or less. Racemes 'I5 in. thick; peduncles slender, $\cdot 2$ in. long, sub-corymbose, Io to I2 together. Umbellules $\cdot 2$ in. across. Bracts 4 , puberulous. Flowers yellowish white slightly puberulous. Drupe globose half enclosed in the cup-shaped tubercled grooved perianthtube $\cdot 4$ in. across, 2 in. high. Hab. Forests, Pahang, Kwala Tekam (Evans). Perak, Chanderiang and Goping (Kunstler). Distrib. Sumatra. 
(35) L. oblanceolata Gamble, Kerw Bulletin, I910, p. 362; Journ. As. Soc. Beng. l.c. I66.

Tree 30 to $40 \mathrm{ft}$. tall. Leaves chartaceous oblanceolate blunt abrupt short acuminate sub-glaucous beneath; nerves 8 to io pairs, sunk above, slightly raised beneath ; 8 in. long, 2.5 in. wide ; petioles $\cdot 25$ in. long. Racemes very short, $\cdot 24$ in. long or less; bracts ovate tomentose. Involucral bracts 4 , orbicular. Umbellules sessile pubescent. Flowers 4 to 5 ; lobes ovate blunt. Stamens 9 to I2. Hab. Damp forests, Perak, Larut (Kunstler).

Very near $L$. ochracea, but the leaves are oblanceolate, the racemes much shorter and the umbellules sessile.

(36) L. Kunstleri Gamble, Kew Bulletin, Igro, p. 363; Journ. As. Soc. Beng. l.c. I67.

Tree 50 to $60 \mathrm{ft}$. tall, I5 to $20 \mathrm{in.} \mathrm{through}$; branchlets angled and ribbed. Leaves chartaceous oblong or oblong-lanceolate, round or emarginate at tip, base short cuneate glaucous beneath; nerves I2 to I4 pairs, slender, elevate beneath, transverse nervules faint but visible beneath; ro in. long, 3.5 to 4 in. wide; petioles .5 in. long. Racemes often crowded,. in. long. Umbels $\cdot 24$ in. across; peduncles about ro together, ${ }^{\prime} 5$ in. long. Bracts usually 6 , outer orbicular, inner obovate. Flowers 7 , tube funnel-shaped, lobes oblong or obovate. Hab. Rare in rocky woods, Perak, Gunong Bubu and Gunong Pondok (Kunstler).

(37) L. claviflora Gamble, Kere Bulletin, I9Io, p. 363; Journ. As. Soc. Beng. l.c. I67.

Tree 30 to $40 \mathrm{ft}$. tall, 8 to Io in. through. Leaves chartaceous, elliptic lanceolate or oblanceolate short acuminate, base narrowed, dull green above, glaucous beneath; nerves sunk above, elevate beneath, 6 pairs; 6 in. long, 2.5 in. wide; petioles . 5 in. long, thick. Racemes under 'I in. long, hairy. Umbellules 2 to 3 together, $\cdot 27$ in. across; peduncles $\cdot 6$ in. long, puberulous thickened upwards. Flowers 5, lobes 6, oblong, gland-dotted. Hab. Dense forests, Perak, Thaiping (Kunstler).

(38) L. Helferi, Hook. fil. F.B.I. v. I72; var. ovata Gamble, Journ. As. Soc. Beng. l.c. I68.

Tree; branchlets slender. Leaves sub-coriaceous, ovate or elliptic acuminate or blunt, base shortly narrowed, glabrous glaucescent beneath; nerves slightly raised, as are reticulations, beneath puberulous, 3775 in. long, 2 in. wide; petioles thick, .25 in. long. Umbellules I to 3 on peduncles $\cdot 2$ in. long on axillary tubercles. Flowers 4 to 5, white. Stamens in male I2. Hab. Perak, Ulu Batang Padang (Wray).

Gamble makes this a variety of the Tenasserim or Andaman plant collected by and named after Helfer, but suggests that more complete specimens may show it to be specifically distinct.

(39) L. myristicæfolia Hook. fil. F. B.I. v. I72; Gamble, Journ. As. Soc. Beng. l.c. I69.

A glabrous tree up to $60 \mathrm{ft}$. tall; stem I2 to I 8 in. long. Leaves 
coriaceous, smooth above, elliptic-oblong or lanceolate, blunt, occasionally shortly acute, base rounded or shortly cuneate; nerves barely visible above, midrib sunk beneath, nerves 6 to I2 pairs, very faint, not elevate; 5 to 6 in. long, 2 to 2.5 in. wide; petioles stout, black, $\cdot 3$ in. long. Umbellules $\cdot 22$ in. across on peduncles $5 \mathrm{in}$. long in axillary fascicles 7 or 8 together on very short $\cdot$ I in. long racemes, entirely glabrous. Bracts 4 to 6 , reflexed. Fruit globose, 3 in. through in a thick fleshy clubbed cup, $\cdot 5$ in. long, including pedicel. Hab. Common in woods, generally in the low country, Singapore, Galang; Changi; Tanglin. Malacca, Pulau Besar and Malim (Griffith); Ayer Panas (Derry). Negri Sembilan, Tampin. Pahang, Telom Ridge at $4000 \mathrm{ft}$. altitude (Ridley). Penang, road to the spout. Distrib. Burma. Native names: Medang Asam; Medang baros; Medang bunga; Medang hitam; Medang K'layer; Medang Tahi Ayam.

(40) L. Teysmanni Gamble, Ker Bulletin, I910, p. 3I9; Journ. As. Soc. Beng. l.c. I7o.

Tree 50 to $70 \mathrm{ft}$. tall, $\mathbf{I}_{5}$ to $20 \mathrm{in}$. through. Leaves coriaceous, elliptic-oblong to obovate, blunt or cuspidate acuminate, base acute or round; nerves scarcely visible above, 8 to I2 pairs, elevate beneath, as are the small reticulations; 5 to 5.5 in. long, I.75 in. wide; petioles slender, $\cdot 5$ in. long. Umbellules $\cdot 24$ in. across, crowded on peduncles very short or none in racemes I in. long or less. Bracts puberulous, 4. Flowers villous. Fruit at first ovoid, then globose, 4 in. through, cup rather thin, 25 in. deep, saucershaped, 4 in. across, base broad; pedicels nearly cylindric, $\cdot 2$ in. long. Hab. Not common, Malacca, Merlimau (Ridley). Perak, Kota and Simpang (Wray); Larut (Kunstler). Distrib. Bangka, Borneo.

(4I) L. machilifolia Gamble, Kew Bulletin, I9Io, p. 310; Journ. As. Soc. Beng. l.c. I7I.

Tree 40 to $80 \mathrm{ft}$. tall; stem $\mathrm{I}_{5}$ to $20 \mathrm{in}$. through. Leaves coriaceous, oblong-lanceolate, long acuminate, base cuneate above, glossy bright green beneath, glaucescent, 3 to 7 in. long, I to 2 in. wide; petioles $\cdot$ I to $\cdot 2$ in. long. Umbellules glabrous, $\cdot 2$ in. across, glabrous; peduncles I $_{5}$ in. long, slender on lax racemes, 3 in. long. Fruit globose, $\cdot 4$ in. through in an orange-coloured cup 5 in. wide, 2 in. long, slightly narrowed at base; pedicels dilate upwards, $\cdot 25$ in. long. Hab. Low country, Singapore, Garden Jungle. Bukit Mandai. Malacca, Brisu (Derry). Negri Sembilan, Tampin Hill. Perak (Scortechini). Penang, Moniot's Road (Curtis).

var. angustifolia Gamble, Journ. As. Soc. Beng. l.c. I72. Leaves much smaller and narrower, more distinctly areolate, 5 in. long, I. $5 \mathrm{in}$. wide and slightly stiffer. Flowers smaller. Hab. Mountains, Selangor, Bukit Kutu (buds purple). Perak, Gunong Batu Putih (Wray); Gunong Haram (Scortechini); Goping and Larut (Kunstler). Native name: Medang Katuko. 
var. montana. Leaves very much shorter, 3 to 4 in. long. Inforescence short, I in. long, slightly puberulous. "Bark grey, a considerable tree." Pahang, Bukit Fraser (Sempang) (Burkill).

This varies very much in size of leaves according to altitude. The var. montana seems to be a very much condensed plant from high altitudes, and looks very different from the lowland long-leaved form.

(42) L. panamonja Hook. fil. F.B.I. v. I75; Gamble, Journ. As. Soc. Beng. l.c. I72.

Tree $40 \mathrm{ft}$. tall; branchlets puberulous. Leaves chartaceous elliptic-oblong short acuminate, base short cuneate, glabrous above, close, dense puberulous beneath; nerves io to I4 pairs, slender slightly elevate beneath; reticulations fairly wide; 5 in. long, I' 5 in. wide; petioles slender, $\cdot 25$ in. long. Racemes 3 in. long, puberulous; peduncles $\cdot I 5$ in. long. Umbellules $\cdot 2$ in. across; bracts puberulous. Flowers villous. Stamens, male flowers I2. Hab. Rare, Malacca, Hulu Chembong (Derry). Perak, Waterloo (Curtis). Distrib. India, Burma.

(43) L. Curtisii Gamble, Kew Bulletin, I9Io, p. 363; Journ. As. Soc. Beng. l.c. I73.

Tree 80 to Ioo $\mathrm{ft}$. tall; branches glabrous angled. Leaves chartaceous elliptic to elliptic-obovate, blunt or shortly acute, base shortly narrowed puberulous beneath; nerves $\mathrm{I}_{3}$ to $\mathrm{I}_{5}$ pairs, sunk above, elevate beneath, rather slender; $8 \cdot 5$ in. long, 3 in. wide (or less), petioles short, thick. Racemes 6 to 8 in. long with distant umbellules $\cdot 2$ in. across on pedicels $\cdot I 2$ in. long. Bracts 4 , glabrous or minutely puberulous. Perianth villous outside, funnel-shaped, lobes 6 to 9 . Stamens in males 9 to I4. Hab. Dense jungle, Perak, Goping (Kunstler). Penang Hill at I200 ft. altitude (Curtis).

(44) L. nidularis Gamble, Kew Bulletin, I9IO, P. 365; Journ. As. Soc. Beng. l.c. I74.

Tree 80 to roo $\mathrm{ft}$. tall, 3 to $4 \mathrm{ft}$. through. Leaves coriaceous, dark green above, glaucescent beneath, oblanceolate or ellipticobovate round at tip, long narrowed at base; nervules ro to I2 pairs, prominent beneath, reticulations prominent beneath; 8 in. long, 3 in. wide; petioles stout, $\cdot 25$ in. long. Racemes 4 in. long; peduncles $\cdot 2$ in. long. Umbellules $\cdot 25$ in. across. Bracts reflexed, all scurfy. Fruit flattened, globose, deep yellow, 5 in. across in a shallow $\cdot 2$ in. long woody green cup with incurved edges, $\cdot 2$ in. wide; pedicels obconic, $\cdot 2$ in. long, broad and thick. Hab. Dense jungle, Perak, Hulu Kenat (Scortechini); Larut (Kunstler). Penang Hill at $2000 \mathrm{ft}$. altitude (Curtis).

(45) L. megacarpa Gamble, Kew Bulletin, I9Io, p. 364; Journ. As. Soc. Beng. l.c. I75.

Big tree 40 to $60 \mathrm{ft}$. tall, Io to I5 in. through, glabrous. Leaves stiff coriaceous elliptic-oblong or obovate blunt and apiculate, base narrowed gradually rounded, dark green above, bluish beneath; nerves Io to 15 pairs distinct, slightly raised beneath; 6 to to in. 
long, 2.5 to 5 in. wide; petioles stout, $\mathrm{I} \cdot 5$ to $\mathrm{I} \cdot 75$ in. long. Racemes numerous, 4 in. long. Umbellules $\cdot 25$ in. across on short -I in. long peduncles, all puberulous. Fruit large, over I in. through, globose, yellow turning red; cupule rather flat saucer-shaped, - I in. deep, soft yellow; pedicels 2 in. long, thick. Hab. Forests; Singapore, Toas (Ridley). Selangor, Dusun Tua; Klang Gates (Burn-Murdoch). Perak, Sungei Larut and Tupai (Wray); Larut; Goping; Gunong Malacca (Kunstler). Province Wellesley, Sungei Daun (Curtis).

(46) L. sebifera Blume, Bijdr. 560; Greshoff, Nuttige, Ind. Pl. 9, t. 3; Gamble, l.c. I76. Lepidadenia Wightiana Nees, Wight, Ic. 1837 .

A large, handsome bushy tree with dark green leaves and silky buds. Leaves coriaceous lanceolate or ovate-oblong," acute or blunt glabrous (young, silvery tomentose beneath), I8 in. long, 5 in. wide or less; petioles 8 in. long. Racemes numerous, up to 3 in. long. Umbellules crowded on short peduncles under $\cdot I$ in. long, with large orbicular-ovate silky bracts. Involucral bracts ovate silky. Fruit depressed, globose, over I in. through, pink, cupule obconic, fleshy. Hab. Singapore town; Balestier Road (Goodenough). Rahman, Bukit Besar (Gwynne-Vaughan). Distrib. Java and Borneo. Native name: Malek.

Occasionally planted by the Javanese. I do not think it is wild in the peninsula.

(47) L. Maingayi Hook. fil. F.B.I. v. I75; Gamble, Journ. As. Soc. Beng. l.c. 178 .

Tree 80 to I20 ft. tall, 2 to $3 \mathrm{ft}$. through. Leaves coriaceous oblong or oblanceolate, abruptly acute, base narrowed, shining green; nerves Io to I2 pairs, deep sunk above and very prominent beneath, strongly inarching, 15 to $\cdot 2$ in. from the edge; transverse nervules few, conspicuous, often sunk above; Io in. long, 3.25 in. wide; petioles 2.5 in. long. Racemes up to $7 \mathrm{in.} \mathrm{long,} \mathrm{rather}$ stout puberulous. Umbellules scattered, peduncled, $\cdot 25$ to 3 in. long. Raceme bracts puberulous, boat-shaped. Involucral bracts 4 to 5, coriaceous, grey puberulous outside. Flowers 6 in an umbellule; perianth-tube hoary-villous on both sides. Stamens I2. Hab. Dense jungle, Malacca (Maingay). Perak, Goping (Kunstler).

(48) L. Noronhæ Blume, Bijdr. 56I; Gamble, Journ. As. Soc. Beng. l.c. I79.

A shrub 9 to $\mathrm{I}_{5} \mathrm{ft}$. to a tree $50 \mathrm{ft}$. tall, $8 \mathrm{in}$. through. Leaves thin, coriaceous, elliptic-oblong or obovate blunt, base narrowed glaucous beneath; nerves slightly sunk above, elevate beneath; 8 to $\mathrm{I}_{4}$ in. long, 6 in. wide; petioles $\mathrm{I}$ in. long. Racemes axillary or on old branches from the axils of fallen leaves, 3 in. long, tawnytomentose. Umbellules $\cdot 2$ in. across, tomentose on peduncles -I5 in. long, white. Involucral bracts orbicular, concave ciliate. 
Flowers in umbellule 5 or 6 . Perianth-tube very short or none in males, distinct in females; lobes oblong, 5 to 7 . Stamens 9 to I2. Fruit broader than long, red, seated on an obconic or cup-shaped tube $\cdot 6$ in. across. Hab. Forests, Selangor, Batu Caves. Perak, Kwala Dipang (Curtis); Goping and Chanderiang (Kunstler); Ulu Tupai (Wray).

var. hexandra Gamble, Journ. As. Soc. Beng. l.c. I8o. Leaves more coriaceous, rounded at both ends, red-tomentose on nerves beneath; nerves 20 pairs. Stamens 6. Hab. Selangor, Ginting Bidai (Ridley).

(49) L. robusta Blume, Bijdr. 560; Gamble, Joum. As. Soc. Beng. l.c. I $8 \mathrm{I}$.

Tree 80 to roo $\mathrm{ft}$. tall, 2 to $3 \mathrm{ft}$. through. Leaves chartaceous dark green, glabrous above, minutely puberulous beneath, ellipticoblanceolate acute, base narrowed and round at base or cuneate; midrib broad and flat; nerves sunk above, elevate beneath, I8 to 2 I pairs, reticulations and nervules raised beneath; I2 to I8 in. long, 5.5 to $8 \mathrm{in}$. wide; petioles I to I. 75 in. long, stout. Racemes 6 in. long; peduncles $\cdot I$ in. long. Umbellules $\cdot 25$ in. across, velvety puberulous all over. Flowers 7 , villous; perianth-tube villous; lobes 6 . Stamens I2. Fruit globose, 75 in. through, rose pink, cup at length flat, $\cdot I$ in. deep, $\cdot 8$ in. across, brown; pedicels very thick, $\cdot 5$ in. long. $H a b$. Forests, Singapore (Wallich). Selangor, Sungei Buluh; Batu Caves. Perak, Goping (Kunstler). Disirib. Burma, Java.

(50) L. ferruginea Blume, Bijdr. 56r; Gamble, Joum. As. Soc. Beng. l.c. 186.

Tree 60 to $80 \mathrm{ft}$. tall, 2 to $3 \mathrm{ft}$. through, upper branchlets redtomentose. Leaves coriaceous alternate obovate or oblong acute, base blunt, glabrous above except the midrib red-tomentose beneath, especially on the raised Io to I3 pairs of nerves; 5 to 7 in. long, 2 in. wide; petioles 4 in. long, rather thick tomentose. Racemes very short, $\cdot \mathrm{I}$ in. long lateral. Umbellules $\cdot 2$ in. across; peduncles red-tomentose, ${ }^{\prime}{ }_{5}$ in. long. Flowers yellowish densely dark tawny-tomentose; perianth-tube short, lobes ovate oblong ciliate. Stamens in males 12. Fruit globose, 4 in. through, cup saucer-shaped, $\cdot 4$ in. across, ' I in. deep. Hab. Forests, Singapore, Bukit Arang; Selitar (Ridley). Perak, Goping and Thaiping (Kunstler). Distrib. Java.

(5I) L. Griffithii Gamble, l.c. I87. L. Blumei Hook. ful. F.B.I. v. I60 (not of Nees).

Tree 40 to $60 \mathrm{ft}$. tall, Io to $\mathrm{I} 5 \mathrm{in}$. through. Leaves coriaceous opposite, occasionally alternate, oblong blunt or shortly acute, cuneate or rounded at base, glabrous except midrib above, redtomentose beneath; nerves raised beneath, 8 to $I_{5}$ pairs; 6 to Io in. long, 2 to 3 in. wide; petioles stout, $\cdot 25$ in. long. Umbellules .25 in. across on red-tomentose peduncles 3 in. long on a tomentose FI.M. P.. 3 
raceme I 8 in. long. Bracts tomentose. Fruit ovoid, 'I in. long, .5 in. through; perianth warted, cup-shaped, $\cdot 6$ in. wide, $\cdot 25$ in. deep. $H a b$. Woods in the low country, not rare, Singapore, Reservoir woods; Garden Jungle. Johor, Jaffaria (King). Malacca (Griffith). Selangor, Weld's Hill (Burn-Murdoch). Perak, Changkat Jerin (Wray); Ulu Bubong; Thaiping; Goping (Kunstler). Distrib. Sumatra.

(52) L. sarawacensis Gamble, Kew Bulletin, I9Io, p. 355; Journ. As. Soc. Beng. l.c. I82.

Small tree with slender branches, glábrous. Leaves chartaceous, opposite and sub-opposite, elliptic-lanceolate cuspidate, base narrowed acute; nerves 5 to 7 pairs, slender, sunk above, slightly elevate beneath; 4 to 4.5 in. long, I.5 to $x \cdot 75$ in. wide; petioles $\cdot 2$ in. long. Racemes very short, $\cdot$ in. long with a few umbellules $\cdot 05$ in. across on slender peduncles $\cdot 05$ in. long. Bracts orbicular, 4. Flowers 3 to 5 in an umbellule. Fruit ovoid apiculate on the obconic, glabrous cup. Hab. Rare in woods, Singapore, by the reservoir (Ridley). Disirib. Borneo.

(53) L. lancifolia Hook. fil. F.B.I. v. I59; Gamble, Joum. As. Soc. Beng. l.c. I82.

Bush or small tree about $20 \mathrm{ft}$. tall; branchlets slender. Leaves chartaceous, opposite, oblong to lanceolate, rather long acuminate, base cuneate, grey beneath (tomentose when young); nerves 8 to I2 pairs, sunk above, raised beneath; 3 to 5 in. long, I.5 to $I \cdot 75$ in. wide; petioles $I$ in. long, tomentose. Umbellules $\cdot I 5$ in. across, fascicled on a very short raceme; pedicels 'I5 in. long. Fruit ellipsoid apiculate, $\cdot 4$ in. long, $\cdot 2$ in. through. $H a b$. Lowland woods and forests, Singapore, Selitar; Bukit Panjang; Garden Jungle. Johor, Jaffaria (King). Selangor, Kwala Lumpur (Curtis). Perak, Ulu Bubong (Kunstler); Tapa and Relau Tujor (Wray); Pondok Tanjong (Cubit).

var. rufa. Leaves more tomentose and smaller. Hab. Perak, Ulu Bubong and Batang Padang (Kunstler). Distrib. India, Burma, Sumatra, Borneo.

(54) L. gracilipes Hook. fil. F.B.I. v. I59; Gamble, Joum. As. Soc. Beng. l.c. I84.

Tree 50 to $70 \mathrm{ft}$. tall, I5 to $20 \mathrm{in}$. through, nearly glabrous. Leaves stiff chartaceous opposite or sub-opposite elliptic to oblanceolate acute or shortly acuminate, base cuneate or round, glabrous; nerves 6 to 8 pairs, very faint above, visible beneath; 3 to 5 in. long, $\mathrm{I} \cdot 25$ to 2 in. wide; petioles 25 in. long. Racemes $\cdot 05$ in. long or less; peduncles slender, $\cdot 35$ in. long. Umbellules $\cdot 2$ in. across. Bracts 4, puberulous outside. Flowers 3 to 4, villous silky. Fruit cylindric-oblong, 5 in. long, green spotted white, on the obconic enlarged perianth. Hab. Woods, Johor, Tanjong Kupang (Ridley). Malacca (Griffith). Perak, Thaiping (Wray, Kunstler). Distrib. Borneo. 
(55) L. ujongensis Gamble, Kew Bulletin, I9I0, p. 366 ; Journ. As. Soc. Beng. l.c. 185 .

Small tree or shrub up to $20 \mathrm{ft}$. tall; branchlets rusty-tomentose. Leaves membranous to chartaceous, opposite, oblanceolate cuspidate acuminate, base cuneate or attenuate, base rounded, glabrous except midrib and nerves above, puberulous grey beneath; nerves to to I5 pairs and midrib red-tomentose; 7 to 8 in. long, 2.75 to 3 in. wide; petioles 15 in. long, tomentose or none. Umbellules in very short sessile axillary fascicles. Fruit ellipsoid, 4 in. long, $\cdot 2$ in. through; perianth-tube flat disc-shaped, $\cdot 2$ in. across; style persistent. Hab. Forests in hill districts, Malacca, Gunong Ledang, Mt. Ophir (Ridley). Negri Sembilan, Ayer Kuning; Gunong Berimbun and Bukit Sulu (Cantley). Perak, Gunong Batu Putih (Wray). Native names: Medang Kundo; Pendarah Padi; Puladan; Rukam Padang.

The Perak specimens have some of the leaves sessile and the nerves more prominent. These form the var. nervosa, Gamble, Journ. As. Soc. Beng. l.c.

(56) L. sessiliflora Hook. fil. F.B.I. v. I60; Gamble, Journ. As. Soc. Beng. l.c. I85.

Slender treelet ro $\mathrm{ft}$. tall, upper branchlets angled tomentose. Leaves chartaceous opposite oblong-lanceolate, shortly cuspidate, base narrowed, glabrous above except midrib, red hairy beneath; nerves $I 6$ to 20 pairs, like the nervules sunk above, elevate beneath; II to I 2 in. long, 2 to 4 in. wide; petioles thick, red-tomentose, $\cdot 24$ in. long. Flowers in dense sessile tawny pubescent umbellules .25 in. across. Fruit ovoid apiculate; perianth-tube funnelshaped. Hab. Mountain woods, Johor, Gunong Janeng (Kelsall). Penang Hill, Moniot's Road (Curtis, etc.). Distrib. Borneo and Sumatra.

\section{NEOLITSEA, Merr.}

Shrubs or small trees. Leaves opposite, whorled or alternate, triple-nerved usually areolate more or less lanceolate and glaucous beneath. Flowers in sessile umbels, axillary or on terminal racemes with bracts at the base. Involucral bracts 4. Flowers 5 to 7 . Perianth-lobes 4 . Stamens 6, rows $\mathrm{I}$ and 2 eglandular, row 3 glandular; staminodes in female 6, linear or linear-clavate. Ovary ovoid; style thick; stigma peltate. Drupe globose on the slightly enlarged discoid perianth-tube; pedicel somewhat enlarged. Species about 30, Indo-Malayan.

Leaves alternate
Leaves opposite or whorled.

Nerves and petioles rusty-villous, glaucous beneath.
Nes opposite or whorled.

Leaves densely villous beneath and on nerves above

Leaves glabrous (except young) prominently areolate both sides; umbellules racemed .
(I) N. zeylanica

(2) N. villosa

(3) N. mollissima

(4) N. kedahensis 
(I) N. zeylanica Merrill, Philipp. Journ. Sc. i. Suppl. 57. Tetradenia zeylanica Nees, Wall. Pl. As. Rar. ii. 64. Litsea zeylanica Hook. fil. F.B.I. v. I78. L. oblonga Nees, Wight, Ic.t. I845.

Shrub or treelet. Leaves coriaceous alternate, elliptic to ellipticovate or lanceolate-acuminate, often glaucous beneath; nerves 2 to 5 pairs, the lowest pair prominent from near the base, reticulations minutely areolate; 3 to 5 in. long, $I \cdot 25$ to $2 \cdot 25$ in. wide; petioles slender, $\cdot 5$ in. long (young leaves golden coppery-silky). Umbellules sessile tawny-puberulous in small axillary clusters. Fruit globose, green, $\cdot 2$ to nearly I in. through, cupule flat, $\cdot{ }^{5}$ in. across; pedicel clubbed, $\cdot 25$ in. long. Hab. Common in open sandy country, occasionally on mountains as on Mt. Ophir. The whole peninsula to Penang and Setul and Kelantan. Distrib. India, Ceylon, Burma, Siam, Philippines and Queensland.

The fruit is usually quite small, but a plant apparently otherwise identical in the Singapore Gardens had fruit nearly $I$ in. through.

(2) N. villosa Gamble, Journ. As. Soc. Beng. l.c. IgI. Litsea villosa Bl. Amn. Mus. Bot. Lugd. Bat. i. 349.

Tree 20 to $30 \mathrm{ft}$. tall, 2 to $3 \mathrm{in}$. through; branchlets tawny puberulous. Leaves opposite or sub-whorled, coriaceous, glaucous beneath, whorls of 5, lanceolate or oblong-lanceolate, long-acuminate, base shortly narrowed; nerves pubescent, 6 pairs sunk above, raised beneath; 4 in. long, $I \cdot 5$ in. wide; petioles slender, $\cdot 2$ in. long, pubescent. Umbellules sessile, 2 to 4 in a cluster, 'I5 in. through, silky-pubescent. Fruit globose red, $\cdot 5$ to $\cdot 75$ in. through. Perianth-tube flat and small; pedicel sub-quadrangular. Hab. High mountains, rare, at 4000 to $4200 \mathrm{ft}$. altitude, Perak, Larut Hills (Kunstler). Distrib. Amboina, Philippines.

(3) N. mollissima Gamble, Kew Bulletin, I910, p. 316; Journ. As. Soc. Beng. l.c. I92.

Small tree; branchlets red-woolly. Leaves coriaceous in pairs and whorled, lanceolate acuminate cuspidate, base acute, shining above, beneath brown hairy especially on the midrib and 4 pairs raised nerves; 3.25 to 5.25 in. long, I.25 to $I \cdot 5$ in. wide; petioles .25 in. long, tomentose. Umbellules sessile in heads $\cdot 15$ to $\cdot 2$ in. through, dense red-tomentose. Flowers 5. Hab. Mountains at $3400 \mathrm{ft}$. altitude, rare. Perak, Gunong Batu Putih (Wray).

(4) N. kedahensis Gamble, Kere Bulletin, I9Io, p. 367; Joum. As. Soc. Beng. l.c. 193 .

Tree; branchlets whorled rusty-villous. Leaves coriaceous whorled, lanceolate cuspidate acuminate, base shortly narrowed, glabrous above, strigosely villous beneath on the nerves 5 pairs, slender, finely areolate on both sides, 3 to 3.25 in. long, I.25 in. wide; petioles $I$ in. long. Umbellules in tufts on a hairy raceme terminal, 2 in. long, nearly $\cdot 2$ in. through. Bracts 4 , tomentose outside. Hab. On high mountains, local at $3000 \mathrm{ft}$. altitude, Kedah Pealk (Ridley). 
15. LINDERA, Thunb.

Shrubs or trees. Leaves alternate or sub-opposite, 3- to 5-ribbed or penni-nerved, chartaceous or coriaceous. Flowers unisexual in axillary peduncled or sessile umbellules. Bracts 2 to 4 . Flowers I to 6 or more; peduncles long or short; lobes 6 . Stamens 9 or 22 ; anthers all introrse 2- (rarely 4-)celled filaments slender. Ovary in female ovoid; style thick; stigma peltate. Fruit globose or ovoid seated on the slightly enlarged perianth-tube with persistent lobes; pedicel slightly thickened. Species about 60, China, Japan, India, N. America to Malaya.

Leaves penni-nerved; flowers in umbellules more than 9.

Trees.

Leaves ovate acuminate sub-coriaceous .

Leaves ovate acuminate thin glaucous beneath, lobes oblong .

Leaves obovate to oblanceolate, often roundtipped .

Leaves coriaceous lanceolate acuminate ; nerves I2 pairs . . . .

Leaves chartaceous lanceolate acuminate; nerves 7 to 8 pairs

Leaves membranous, lanceolate, glaucescent and pu berulous beneath; nerves 8 to I 2 pairs

Mountain shrubs.

Leaves stiff coriaceous.

Leaves lanceolate blunt, base cuneate ; flowers 5

Leaves lanceolate acuminate, base round,

flowers 9
Leaves more or less distinctly 3 -nerved; flowers I to 4 .

Leaves chartaceous ovate, cuspidate; flowers I. Small tree

Leaves distinctly tri-nerved, chartaceous.

Leaves caudate acuminate; flower I; lobes blunt. Bush . . . . .

Leaves acuminate; flowers 3 ; lobes acuminate.

Leaves ovate acuminate, 2 in. across; flowers 3 to 4 . Tree . Bushes.

Leaves stiff coriaceous. Bushes.
Leaves ovate to lanceolate acuminate, base narrowed.

Umbellules sessile, 3 -flowered
Leaves oblong-ovate, blunt or round, base shortly narrowed.

Umbellules 2 -flowered pedunculate
(I) L. malaccensis

(2) L. selangorensis

(3) L. Wrayi

(4) L. oxyphylla

(5) L. polyantha

(6) L. pipericarpa

(7) L. montana

(8) L. stricta

(9) L. caudifolia

(ro) L. bibracteata

(II) L. cæsia

(I 2) L. cinnamomea

(I) L. malaccensis Hook. fil. F.B.I. v. I83; Gamble, Journ. As. Soc. Beng. l.c. I94.

A slender tree about $40 \mathrm{ft}$. tall with spreading branches. Leaves sub-coriaceous, shining dark green, glabrous, ovate to 
elliptic-ovate, acuminate and cuspidate; nerves 5 to 7 pairs, raised beneath; 3.25 to 5 in. long, I. 5 to 3 in. wide; petioles .5 in. long. Umbellules numerous on a very short raceme; peduncles $\cdot 2$ in. long, sparsely puberulous or glabrous; umbellules $\cdot 2$ in, across. Flowers 9 or more. Fruit globose or ovoid, fleshy, $\cdot 25$ in. long; perianth hardly enlarged. Hab. Common in the low country, in woods, Singapore, Tanglin; Bukit Timah. Johor, Batu Pahat. Malacca (Griffith); Sungei Hudang; Brisu (Holmberg). Perak, Relau Tujor (Wray); Goping and Larut (Kunstler). Distrib. Sumatra, Borneo. Native names: Medang Paya; Serapu putih.

Griffith collected a form with umbellules on peduncles 3 in. long. It also occurred at Selitar in Singapore.

(2) L. selangorensis Ridl. Journ. F.M.S. Mus. v. 44.

Tree about $30 \mathrm{ft}$. tall. Leaves alternate, thin, glabrous (young ones silky) dark green, glaucescent beneath, ovate acuminate acute, cuspidate; nerves 6 pairs raised beneath; 5 to 6 in. long, 2.25 to 3 in. wide; petioles 4 in. long. Racemes $\cdot I$ in. long, axillary. Umbellules few on peduncles $\cdot 3$ in. long. Flowers 6 to II in umbel, glabrous except a few hairs outside, oblong-obovate, tip round. Hab. Mountain forests. Selangor, Gunong Mengkuang Lebah (Robinson); Sempang Mines, Semangkok Pass (Ridley).

Near $L$. malaccensis, but the leaves thinner, glaucous beneath; perianthlobes oblong rounded.

(3) L. Wrayi Gamble, Kew Bulletin, I910, p. 367; Journ. As. Soc. Beng. l.c. Ig6.

Small tree. Leaves chartaceous to membranous, alternate obovate to oblanceolate, round or acuminate, base narrowed, glabrous; nerves sunk above, elevate beneath, 8 to I4 pairs; 3 to 5 in. long, I.75 in. wide; petioles ${ }^{\prime} 5$ in. long. Racemes very short; peduncles $\cdot 2$ in. long. Umbellules $\cdot 2$ in. across; flowers about 8 . Fruit (young) ovoid, $\cdot 27$ to $\cdot 4$ in. long, on a much thickened pedicel. Hab. Mountain woods at 4000 to $7000 \mathrm{ft}$. altitude, Perak, Gunong Brumber Pahang at $7000 \mathrm{ft}$. altitude and Gunong Inas and Gunong Batu Putih (Wray); Bujong Malacca (Ridley); Pahang, Fraser Hill (Burkill).

(4) L. oxyphylla Hook. fil. F.B.I. v. I83; Gamble, Journ. As. Soc. Beng. l.c. I97.

Tree 30 to $40 \mathrm{ft}$. tall. Leaves thin coriaceous lanceolate acuminate, base cuneate, glabrous, pale beneath; nerves 12 pairs very fine, not elevate; 5 in. long, I.5 in. wide; petioles 3 in. long. Racemes I 8 in. long, red-pubescent. Umbellules $4 \mathrm{in.}$ across on peduncles rather thick, $\cdot 2$ in. long, puberulous. Flowers silky. Fruit globose-ovoid, $\cdot 2$ in. long (unripe) on small, flat perianth limb, pedicel ${ }^{1} 5$ in. long. Hab. Penang Hill (Wallich and Curtis).

A very floriferous tree. Apparently confined to this spot. 
(5) L. polyantha Boerl. Handl. Fl. Ned. Ind. iii. I47; Gamble, Journ. As. Soc. Beng. l.c. I97.

Medium tree; branches black angular. Leaves coriaceo-chartaceous, lanceolate acuminate, base acute; nerves 7 to 8 pairs, slightly elevate beneath; 4 to $4.5 \mathrm{in}$. long, I.25 in. wide; petioles $\cdot 2$ in. long. Racemes pubescent, 4 in. long. Umbellules $\cdot 2$ in. across. Bracts pubescent; peduncles $\cdot 2$ in. long, pubescent. Flowers 12 ; bracts 4, red-puberulous. Perianth lobes ovateoblong, villous. Drupe globose, 3 in. through. Hab. Perak, Bujong Malacca (Scortechini). Distrib. Java.

(6) L. pipericarpa Boerl. Handl. Fl. Ned. Ind. iii. I47; Gamble, Journ. As. Soc. Beng. l.c. Ig\&.

Tree 30 to $40 \mathrm{ft}$. tall, 6 to $8 \mathrm{in}$. through. Leaves membranous, alternate lanceolate or oblong-lanceolate, glaucescent beneath and puberulous; nerves 8 to I2 pairs, slender; 4 to $5 \mathrm{in}$. long, I.25 to $\mathrm{I} \cdot 75$ in. wide; petioles slender, 4 to 6 in. long. Umbellules small, -I in. across, fascicled on very short racemes; peduncles slender, -I2 in. long, puberulous. Bracts ovate puberulous. Flowers about 6 . Fruit globose, $\cdot \mathrm{I}$ to $\cdot 2$ in. through, black. Hab. Mountain forests at 3000 to $4000 \mathrm{ft}$. altitude, Pahang, Telom (Ridley); Fraser Hill (Burkill). Perak, Larut Hills at 3000 to $3500 \mathrm{ft}$. altitude (Kunstler and Scortechini).

(7) L. montana Ridl. Journ. F.M.S. Mus. vi. I72.

Bush. Leaves coriaceous, lanceolate blunt, base cuneate, densely close reticulate above, smooth beneath and glaucous; midrib prominent beneath; nerves very faint 4 pairs; 3 to $3.5 \mathrm{in}$. long, I to I. 5 in. wide; petioles thick, $\cdot 25$ in. long. Umbels $\cdot 12$ in. long, I or 2 on a short main peduncle 2 in. long, secondary peduncles as long, all glabrous; bracts orbicular. Flowers 5; lobes short oblong quadrate. Drupe oblong-ovoid, 4 in. long, black. Hab. High mountains on rocky slopes, Pahang, Gunong Tahan at 3300 to $5000 \mathrm{ft}$. altitude (Ridley).

(8) L. stricta Ridl. Joum. F.M.S. Mus. vi. I72.

Shrub. Leaves coriaceous, erect, lanceolate acuminate acute, base round; nerves Io, fine, reticulations conspicuous both sides; 3 to 4 in. long, I in. wide; petioles 5 in. long. Racemes few; umbels $\mathrm{I}$ in. long; peduncles 3 in. long; bracts ciliate on edge, otherwise inflorescence glabrous. Flowers 9 in umbellule. Drupe globose, I2 in. through, black; pedicels $\cdot 25$ in. long, rather thickened and cupped at top. Hab. High mountains, Pahang, Gunong Tahan at $5000 \mathrm{ft}$. altitude (Ridley).

(9) L. caudifolia Ridl. Journ. Roy. As. Soc. S. Br. 82, p. 192.

Small tree; branches slender. Leaves alternate, chartaceocoriaceous, lanceolate or elliptic-lanceolate, blunt caudate, base round or blunt ; nerves 6 pairs very fine and inconspicuous beneath; glaucous, glabrous minutely areolate-reticulate, $2 \cdot 25$ to $3 \mathrm{in}$. long, 75 to $I$ in. wide; petioles 'I in. long. Racemes axillary 
pubescent, $I$ in. long; bracts silky. Umbellules $\cdot 05$ in. across, I-flowered on peduncle $I$ in. long. Flowers minute. Perianthlobes white, 6 ; anthers 2-celled. Fruit small pea-shaped, black shining. Hab. Hill woods, Selangor, Semangkok Pass. Penang, Tiger Hill and road to Penara Bukit (Ridley).

The Selangor plant has much narrower leaves than the Penang one.

(Io) L. bibracteata Boerl. Handl. Fl. Ned. Ind. iii. I46; Gamble, Journ. As. Soc. Beng. l.c. I99.

Shrub ro to I5 ft. tall; branches slender, tips silky. Leaves chartaceous alternate, ovate long-cuspidate, base very shortly narrowed, finely areolate both sides, glaucescent beneath, triplinerved; nerves elevate, from base 3 , one pair near top from midrib; 4 in. long (cusp I in.), I.25 to I.5 in. wide; petioles $\cdot 2$ in. long, villous. Umbels sessile axillary, $\cdot 2$ in. across. Flowers I to 3 in umbel. Fruit globose, $\cdot 4$ in. through; perianth tube hardly enlarged; pedicels 4 in. long. $H a b$. Mountain woods at 2500 to $5000 \mathrm{ft}$. altitude, Perak, Thaiping Hills; Gunong Inas and Gunong Batu Putih (Wray); Hermitage (Curtis); Gunong Keledang (Ridley). Distrib. Java.

(II) L. cæsia Boerl. Handl. Fl. Ned. Ind. iii. I46; Gamble, l.c. 200 .

Small tree ro to $\mathrm{I}_{5} \mathrm{ft}$. tall, 2 to $3 \mathrm{in.} \mathrm{through;} \mathrm{branchlets}$ slender, tips villous. Leaves chartaceous, alternate, elliptic-ovate or lanceolate long-acuminate, base acute, glabrous above, glaucous beneath; nerves hairy on both sides, one pair from close to base, 2 pairs from midrib above, sunk above, elevate beneath; 3 to 4 in. long, I to I.5 in. wide; petioles velvety, $\cdot 2$ in. long. Umbellules red-hairy, sessile in clusters of about Io, $\cdot 25$ in. across. Flowers in umbels, 3. Hab. Mountain woods, Selangor, Sempang Mines; Gunong Mengkuang Lebah at $5000 \mathrm{ft}$. altitude (Robinson), a form with narrow lanceolate leaves. Perak, Thaiping Hills at 2500 to $4000 \mathrm{ft}$. altitude (Scortechini, Kunstler). Distrib. Java.

(r2) L. cinnamomea Ridl. Joum. F.M.S. vi. I73.

A tree. Branches slender. Leaves coriaceous, ovate acuminate, cuspidate, base cuneate, glaucous beneath, tri-nerved, basal pair $\cdot 25$ in. from base, above about 7 pairs; nervules horizontal very many, conspicuously areolate on both sides; 4 in. long, 2 in. wide; petioles $\cdot 5$ to $\cdot 75$ in. long, rather slender. Umbellules sessile, very small, 3 to 4 in a sessile head; bracts ciliate on edge. Flowers 4 , perianth with 4 lobes. Fruit ellipsoid acuminate, 5 in. long, -I2 in. through; pedicels $\mathrm{I} 2$ in. long, thick; perianth little enlarged. Hab. High mountains, Pahang, Gunong Tahan on banks of a stream at $5000 \mathrm{ft}$. altitude (Ridley).

(I3) L. rufa Gamble, Journ..As. Soc. Beng. l.c. 200.

Shrub $6 \mathrm{ft}$. tall, upper branchlets and young leaves copperyred, villous. Leaves coriaceous ovate to nearly lanceolate glabrous 
above, glaucous beneath, long-acuminate, base acute (young leaves coppery-red velvety), deeply and conspicuously areolate, trinerved with 2 pairs of nerves from upper part of midrib, 2 to 2.5 in. long, I to $I \cdot 5$ in. wide; petioles $\cdot 4$ in. long, tomentose. Umbellules sessile and shortly peduncled red-hairy in clusters of about 8. Flowers 3. Drupe ovoid, $\cdot 23$ in. long on the persistent perianth-lobes; pedicel thickened and lengthened. Hab. Mountains, Selangor, Gunong Semangkok; Gunong Mengkuang Lebah (Robinson). Perak, Gunong Brumber Pahang at $7000 \mathrm{ft}$. altitude; Gunong Bubu at $5000 \mathrm{ft}$. altitude; and Ulu Batang Padang at $4900 \mathrm{ft}$. altitude (Wray); Gunong Kerbau at $7000 \mathrm{ft}$. altitude (Haniff). Distrib. Borneo, Sumatra.

(I4) L. concinna Ridl. Journ. Roy. As. Soc. S. Br. 82, p. I92.

A bush glabrous except the tips of branches and young leaves. Leaves coriaceous, thick, oblong-ovate rounded or short blunt acuminate, base very shortly narrowed, glaucous beneath, triplinerved with numerous fine, close transverse nervules and small, prominent reticulations, $I \cdot 75$ to $2 \cdot 25$ in. long, $I$ to $I \cdot 25$ in. wide; petioles $\cdot I_{2}$ to $\cdot I_{5} \mathrm{in}$. long (velvety in young leaves as are nerves). Umbellules 4 or 5 together in the axils; peduncles . I in. long, hairy. Flowers 2, sessile, lobes oblong narrow, inner ones larger than outer. Stamens 9, filaments long, slender, very hairy; anther ovate. Drupe not seen; pedicels obconic hairy with lobes persistent. Hab. High mountains, Pahang, Gunong Tahan at $5500 \mathrm{ft}$. altitude (Robinson).

\section{CASSYTHA, Linn.}

Filiform, twining, yellow parasites. Leaves of minute scales or o. Flowers small, bisexual, capitate spicate or racemose. Perianth-tube globose or turbinate short, lobes 6 , outer 3 smaller. Stamens 9 or 6, 2 -celled, rows I and 2 introrse, row 3 extrorse with a pair of glands and 3 staminodes inside. Ovary free in tube ; style short. Drupe enclosed in the enlarged perianth-tube which bears the remains of the lobes at top. Species I5, chiefly Australian and S. African, one widely spread over Asia.

(I) C. filiformis Linn. Sp. Pl. 35; Gamble, Journ. As. Soc. Beng. l.c. 202.

Stem very long tangled, scrambling over bushes like Dodder, yellow. Flowers in dense spikes about $\mathrm{I}$ in. long; perianth 05 in. long. Drupe oblong, globose, $\cdot 25$ in. long, crowned with the lobes, white. Hab. Very common on the sea-coast, Singapore, Malacca, Pahang to Penang and Kelantan. Distrib. India, Africa, Malaya, Australasia, America.

A parasite on all kinds of bushes and small trees, including the nutmegs in Penang. 


\section{ORDER CXX. HERNANDIACE E.}

Trees or climbing shrubs. Leaves alternate, simple or pinnate. Flowers bisexual or unisexual, small, white, greenish or pink. Perianth superior; lobes in 2 valvate $3^{-}$to 5 -merous whorls or I imbricate 4- to 8-merous whorl. Stamens 3 to 5 in one whorl, anthers 2 -celled dehiscing by valves. Staminodes in $I$ to 2 whorls or o. Ovary inferior, I-celled, I-ovuled. Fruit winged or in an inflated cupule. Species about 35, tropics.

Leaves simple, peltate; fruit in a dilated cupule. Flowers unisexual. Trees

I. Hernandia

Leaves often lobed ovate; fruit with 2 long narrow wings. Flowers unisexual. Trees

Climbers with trifoliate leaves; fruit with "broad lateral wings. Flowers bisexual.

2. GYROCARPUS

3. Illigera

\section{HERNANDIA, Linn.}

Trees. Leaves alternate, ovate peltate 3 - to 7 -ribbed. Flowers unisexual, in involucres containing 3 flowers on branch-ends of a panicle, central flower female, laterals male. Involucral bracts 3 to 4 . Perianth-lobes in male 3 to 6 , in female 4 to 8 . Stamens as many; filaments usually with glands at base; anthers 2-celled, dehiscent by valves. Staminodes in females usually 4. Ovary inferior; style included; stigma dilate. Fruit a globular, black, stony nut enclosed in a white inflated involucre with an opening at the top. Species 8 to I2, tropics.

(I) H. peltata Meisn. DC. Prod. xv. I, 263; Gamble, Journ. As. Soc. Beng. l.c. 204.

Tall tree. Leaves ovate acute, base round, 3 to 7 in. long, 2 to $5.5 \mathrm{in}$. wide; petioles $4.5 \mathrm{in}$. long. Panicles $2 \mathrm{in}$. long, puberulous. Flowers yellowish. Fruit oblong or globose, .8 in. through, inflated involucre $3 \mathrm{in}$. through, open at the tip, creamy white. $H a b$. Rather rare, sea shores, Singapore (Wallich); Malacca, Pulau Nangka and Pulau Dodol (Cantley). Johor, Pulau Tinggi (Feilding). Dindings, Pangkor (Wray, Curtis). Distrib. E. Africa, Madagascar, Ceylon and S. India to Polynesia. Native name: Bua K'ras Laut.

\section{GYROCARPUS, Jacq.}

Tall trees. Leaves alternate, long-petioled, entire (or lobed). Flowers small, unisexual, very numerous, clustered on the ends of the branches in large dense cymes appearing after fall of leaves. Males very numerous. Calyx 4 -to 7 -lobed. Petals o. Stamens 4 to 7 , insert at base; anthers 2-celled dehiscing by valves; with many clavate glands alternating. Females few; calyx-tube adherent to ovary; $\operatorname{limb} 2$-lobed. Ovary I-celled, I-ovuled; stigma sessile. Fruit a bony nut with 2 long spathulate wings. Species 3 or 4 , seashores of tropics. 
(I) G. Jacquinii Gaertn. Fruct. ii. 92; Roxb. Cor. Pl. t. I.

Big tree. Leaves membranous, glabrous, round ovate acuminate, base broad, 5-nerved; midrib with 3 pairs of nerves; 4.5 to 6 in. long, 4 to 5 in. wide; petioles 3 to 5.5 in. long. Fruit ovoid, glabrous when ripe, slightly pubescent when young, 6 in. through ; wings glabrous, 3 in. long, $\cdot 5$ in. across. Hab. Seashores, rare. Penang, Pulau Badak (Curtis). Adang isles, on Pulau Tengah. Distrib. Tropical Asia.

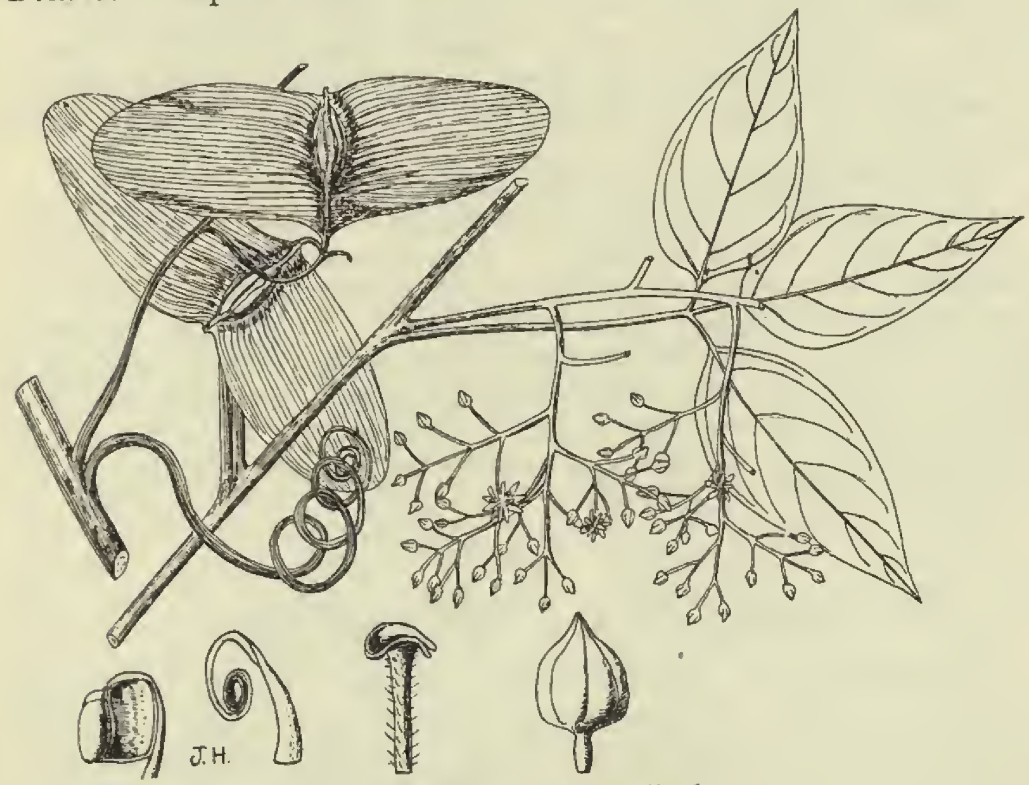

FIG. I46.--Illigera appendiculata.

\section{ILLIGERA, BI.}

Scandent shrubs. Leaves alternate; leaflets petioled, 3. Cymes elongate, lax. Calyx-tube constrict above ovary, lobes 5 , oblong valvate. Petals 5, oblong, as long. Stamens 5, epigynous, filaments with staminodes near base; anthers laterally valved. Ovary I-celled, I-ovuled; style filiform; stigma dilate sinuate. Fruit 2- to 4-winged, broad. Species 7, India to Philippines.

Nerves 2 to 3 pairs; panicle and flowers pubescent: fruit 2-winged

(1) I. appendiculata

Nerves 12 to I 4 pairs; panicles and flowers glabrous; fruit 4 -winged

(I) I. appendiculata $B l$. Bijdr. I, p. I53; King, Journ. As. Soc. Beng. lxvi. 343.

Climbers 40 to $80 \mathrm{ft}$. tall. Leaves, petiole 3 in. long; leaflets 
membranous, oblong tip, round, acute or acuminate, base cuneate or round, glabrous above, puberulous or glabrous beneath; nerves 2 to 3 pairs; 3 to $5 \cdot 5$ in. long, I. 75 to 4 in. wide; petioles $\cdot 2$ to - 6 in. long. Panicles lax, 5 to $I 5$ in. long, 3 or more in. across, pubescent. Flowers $\cdot 2$ in. long, rose-pink, in cymes on the branch ends. Calyx puberulous. Fruit narrow oblong, wings 2 broad truncate, rounded, 3 in. long, I.5 in. wide. Hab. Forests, Singapore, Bukit Timah. Malacca, Mt. Ophir (Lobb, Maingay), var. Kurzii with stiffer leaves; Selangor, Semangkok Pass; Batu Caves. Negri Sembilan, Bukit Sulu (Cantley). Perak, Larut at 800 to I000 ft. altitude, and Goping (Kunstler). Dindings, Pangkore (Curtis). Distrib. India, Burma, Java. Native name: Maralipit.

(2) I. lucida Teysm and Binn. Nat. Tijds. Ned. Ind. xxvii. 29.

A slender climber; branchlets angled. Leaflets membranous oblong, short, blunt acuminate, base round, minutely cordate, glabrous; nerves I2 to I4 pairs; 3.5 in. long, I.25 to 2.25 in. wide; petiolules ${ }^{\prime} 5$ in. long; petioles $I \cdot 5$ in. long. Panicle glabrous, lax, I2 in. long. Flowers glabrous, $\cdot 3$ in. across; sepals and petals with a patch of white hairs at base. Fruit 4-winged, I small, 3 large wings, tips narrowed blunt, 3 in. long, I in. wide. $H a b$. Not common, Johor, Batu Pahat. Perak (Scortechini, Curtis), Kamuning. Distrib. Java.

\section{ORDER CXXI. PRO'TEACE压.}

Trees or shrubs. Leaves usually coriaceous, usually alternate, entire or toothed. Flowers racemose (capitate or spicate) bisexual (or unisexual). Bracts small or large. Perianth inferior, 4-lobed, valvately connate in a tube, finally separating and recurved. Stamens 4, opposite the sepals, cells 2, dehiscing longitudinally. Disc of 4 hypogynous scales (or o). Ovary superior I-celled; style terminal; ovules I or many. Fruit a drupe (or nut, follicle or capsule). Seed solitary (or few). Genera 50. Species very numerous, chiefly Australia and S. Africa, a few in Asia and Africa and S. America (Gamble, Journ. As. Soc. Beng. 1xxv. 3, p. 339).

\section{HELICIA, Lour.}

Trees or shrubs. Leaves entire or serrate. Flowers in axillary (or terminal) usually pendent racemes, bisexual pedicelled usually in pairs. Perianth-tube slender; limb narrow ovate; in bud clubbed; in flower segments revolute to base, linear. Stamens long, anthers apiculate. Hypogynous scales free or connate. Ovary sessile; style slender, long. Fruit a green, hard drupe. Seeds I to 2. Distrib. Tropical Asia and Australia. 
Racemes glabrous; scales forming a cup.

Leaves petioled.

Petioles 4 to 5 in. long; leaves serrate above. Leaves large obovate; big tree Leaves lanceolate, small shrub

Petioles $\mathrm{I}$ in. long; leaves stiff, coriaceous; perianth thick

Leaves sessile or nearly so.

Leaves entire, base narrowed

Leaves serrate, base rounded

Racemes glabrous; scales free.

Leaves thin, very serrate.

Racemes densely rufous tomentose.

Leaves red tomentose beneath .

Leaves glabrous; lead-colour beneath, large

Leaves glabrous drying yellow .

Leaves glabrous drying black; racemes short

(I) H. aftenuata

(2) H. suffruticosa

(3) H. petiolaris

(4) H. Kingiana

(5) H. robusta

(6) H. Curtisii

(7) H. rufescens

(8) H. velutina

(9) H. excelsa

(I) H. attenuata Bl. in Ann. Sc. Nat. Ser. 2, I, 2I6; Gamble, Journ. As. Soc. Beng. l.c. 34 I.

Shrub 6 to Io $\mathrm{ft}$. to a tree 40 to $60 \mathrm{ft}$. tall, 3 to $\mathrm{S}$ in. through, glabrous. Leaves sub-coriaceous, obovate or oblanceolate, acute or acuminate, base long narrowed, entire or slightly serrate at tip; nerves 8 to Io pairs, slender, elevate beneath; 6.5 to $9 \mathrm{in}$. long, 3 to 5 in. wide; petioles 2 in. long. Raceme 6 in. long, yellowish white; perianth in bud clubbed very slender, .75 in. Iong; style and petals slender. Fruit ovoid, beaked, base narrowed, 75 in. long. Hab. Not rare, Pahang, Tahan River. Johor, Mt. Austin. Selangor, Kwala Lumpur (Curtis); Dusun Tua. Perak, Batu Togo and Tupai (Wray); Thaiping; Kinta River; Goping and Ulu Kerling (Kunstler); Penang (Jack); Telok Bahang; Waterfall (Curtis). Distrib. Java. Native names: Golang Paya; Gurang Bukit.

(2) H. suffruticosa Ridl. Journ. F.M.S. Mus. vi, I7I.

Shrub or little tree, bark pale, $2 \mathrm{ft}$. tall or upwards. Leaves lanceolate acuminate, base slightly narrowed, rounded with a few short teeth, coriaceous, glabrous; nerves 7 pairs, prominent beneath; 7 in. long, 3 in. wide; petioles thick, $\cdot 25$ to $\cdot 5$ in. long, geniculate. Raceme slender, 6 in. long. Flowers about 50 , white, $\mathrm{I} \cdot 4$ in. long. Hab. Pahang, Teku Woods, Gunong Tahan (Ridley).

The smallest Helicia I have seen. Plants only $2 \mathrm{ft}$. tall seemed adult.

(3) H. petiolaris Benn. in Horsf. Pl. Jav. Rar. 84; Gamble, Journ. As. Soc. Beng. l.c. 342 .

Tree 30 to $40 \mathrm{ft}$. tall, glabrous. Leaves stiff coriaceous, obovate blunt or sub-acute, base long cuncate, entire; nerves 7 to 8 pairs, sunk above elevate beneath; 7 to 9 in. long, 3.5 in. wide; petioles thick, I in. long. Raceme thick, angled rachis, 6 to II in. long. Flowers cream colour, bud linear clavate; perianth very thick, coriaceous. Fruit depressed-ovoid, pointed, .8 in. long and a little wider. Hab. Singapore (Wallich); Bukit Mandai; Changi. 
Selangor, Semangkok Pass; Kwala Lumpur (Goodenough). Perak, Ulu Kerling (Kunstler); Goping (Scortechini), Penang, cultivated (Jack). Native name: Gong.

(4) H. Kingiana Prain, Kew Bulletin, I9I2, p. 342; Gamble, Journ. As. Soc. Beng. l.c. 343.

Glabrous tree 60 to $70 \mathrm{ft}$. tall, Io to $15 \mathrm{in}$. through. Leaves coriaceous, obovate, round or sub-acute at tip, back long narrowed; nerves elevate, Io to I2 pairs; petioles $\cdot I$ in. thick or 0 . Raceme thick angled rachis; flowers cream colour, larger than in $H$. petiolaris. Style clubbed, I in. long. Fruit ovoid, I'5 in. Iong, shortly pointed both ends. Hab. Perak, Larut, at Ioo to Iooo $\mathrm{ft}$. altitude (Kunstler); Gunong Batu Putih (Wray).

Distinguished from $H$. petiolaris by its very short petiole and larger flowers and fruit.

(5) H. robusta Wall. Cat. 2702; Gamble, Journ. As. Soc. Beng. l.c. 344. H. javanica Bl. Bem. Pl. Horsf. Jav. 83, t. I8.

Tree about 30 to $60 \mathrm{ft}$. tall, glabrous. Leaves sub-coriaceous, obovate, blunt or shortly acuminate, dark shining green; nerves Io to I2 pairs, strongly elevate, sessile, base narrowed and rounded, edge serrate; 6 to 8 in. long, 4 in. wide. Racemes II in. long, rather stout, lax; flowers greenish white, $\cdot 6$ in. long in bud. Fruit globose apiculate, green. Hab. Forests in the south, Singapore, Garden Jungle; Bukit Timah. Pahang, Ulu Rumpin (Foxworthy). Johor, Bukit Tana Abang (Kelsall); Kota Tinggi. Malacca, Sungei Hudang. Selangor, Kwala Lumpur. Distrib. Java, Sumatra, Bangka. Native names: Medang Keladi; Medang Laiang; Putat Topi; Serantan Tua.

(6) H. Curtisii Gamble, Kev Bulletin, I913, p. 116; Journ. As. Soc. Beng. l.c. 348 .

Tree about $25 \mathrm{ft}$. tall. Leaves chartaceous oblanceolate acuminate long-attenuate, glabrous, strongly serrate except towards base; nerves 8 to Io pairs; 7 in. long, 2.5 in. wide; petioles 44 in. long, winged nearly to base. Raceme slender, 6 in. long, glabrous or minutely puberulous; pedicels slender; ovary villous; flowers small; style -25 in. long, very slender. Hab. Local, Penang, Penara Bukit (Curtis).

(7) H. rufescens Prain, Kew Bulletin, I912, p. 342; Gamble, Journ. As. Soc. Beng. l.c. 435.

Tree 60 to $80 \mathrm{ft}$. tall, I5 to $20 \mathrm{ft}$. through; branches dark redtomentose. Leaves sub-coriaceous, dark shining green above, red-tomentose beneath (becoming glabrous), edge entire; midrib prominent beneath, nerves I6 to 20 pairs; 5.9 to II in. long, $2 \cdot 4$ to 4 ill. wide; petioles I.2 in. long, tomentose. Racemes thick, red-tomentose, 6 in. long; pedicel 2 -flowered. Fruit subglobose, slightly flattened on both sides, acute both ends, redtomentose eventually glabrescent, $\mathrm{I} \cdot 2$ in. long. Hab. Thaiping Waterfall (Kunstler, Wray); Tupai (Wray). 
(8) H. velutina Prain, Kew Bulletin, I912, p. 343; Gamble, l.c. 346 .

Tree 50 to $70 \mathrm{ft}$. tall, Io to $\mathrm{I}_{5} \mathrm{in.}$ through; branchlets greypuberulous. Leaves chartaceous, oblanceolate, cuspidate acuminate, base cuneate, glabrous, glossy green; nerves I4 to I6 pairs prominently inarching beneath, nervules and reticulations prominent; 7 to 8 in. long, 3 in. wide; petioles ' I in. long, densely red-velvety; flowers densely congested. Perianth short and thick in bud. Hab. Rare and very little known; young racemes only collected, Perak, Gunong Bubu, at 2000 to $2500 \mathrm{ft}$. altitude (Kunstler).

(9) H. excelsa Bl. Ann. Sc. Nat. Ser. 2, i, 2I9; Gamble, l.c. 346; Wight, Ic. t. I90.

Tree 60 to $80 \mathrm{ft}$. tall, $\mathrm{I} 5$ to $20 \mathrm{in}$. through; buds rusty-tomentose. Leaves thinly coriaceous obovate or oblanceolate abruptly acuminate, base attenuate, entire (rarely serrate at tip) glabrous, 3 to 4 in. long, $1 \cdot 25$ to 2 in. wide ; petioles slender, 4 in. long, tomentose. Racemes crowded erect, 2 in. long, densely dark red-tomentose. Petals tomentose-red, very short; style slender, glabrous, $\cdot 2$ in. long. Fruit ovoid, $\cdot 4$ in. long, glabrous. Hab. Forests, Singapore, Chan Chu kang and Kranji. Malacca, Sungei Hudang (Derry). Perak, Goping and Ulu Bubong (Kunstler), Gunong Bubu (Scortechini).

var. salicifolia. Buds and racemes nearly glabrous. Leaves narrower, 6 in. long, $I \cdot 5$ in. wide. Flowers rather bigger, quite glabrous, Malacca, Sungei Hudang (Derry and Maingay). Perak, Goping (Kunstler); Simpang (Wray); Gunong Haram Parah (Scortechini). Distrib. Both forms, Burma.

var. Forbesii. Like salicifolia, but leaves 7 by 2 in. Racemes quite glabrous, 8 in. long, Perak, Larut (Kunstler). Distrib. Sumatra, Cambodia. Native names: Mata Kaok; Medang Obu.

(Iо) H. Scortechinii Gamble, Kew Bulletin, I9I3, p. II7; l.c. 348 .

Tree? branchlets slightly puberulous. Leaves chartaceous oblanceolate abruptly caudate acuminate, base cuneate, glabrous except a few hairs scattered on back, edge closely serrate in upper part; nerves 8 to Io, prominent beneath; 4.5 to 7 in. long, I.6 to 2.4 in. wide; petioles 4 in. long. Racemes I or twin minutely red-hairy, from axils of fallen leaves. Hab. Very rare and little known, Perak (Scortechini).

\section{ORDER CXXII. THYMELÆACEÆ.}

Trees or shrubs, sometimes lianes (rarely herbs). Leaves alternate or opposite, simple, entire. Flowers bisexual in axillary or terminal heads, racemes, umbels or spikes. Perianth regular, tubular or campanulate, 4 - to 5 -lobed, lobes imbricate, often with 
scales in the mouth. Stamens as many or twice as many adnate to the tube; filaments short. Disc annular or of scales or 0 . Ovary superior, I- to 2-celled; ovules I in a cell; style distinct; stigma capitate. Fruit a drupe or capsule. Seed $I$ in a cell. The bark usually very tough. Species about 360 , whole world (Gamble, Journ. As. Soc. Beng. 1xxv. (2), 256).

Ovary I-celled, I-ovuled; fruit a drupe.

Shrubs or small trees.

Leaves alternate, no disc, no perianth scales.

Leaves opposite, disc of $\mathrm{I}$ to 4 scales, no perianth scales

I. Daphne

2. WIKSTREMIA

Climbers.

Perianth lobes 5; stamens Io.

Leaves opposite; stamens in one row; scales Io 3. Linostoma

Leaves alternate; stamens in 2 rows; scales 5 . 4. ENKLEIA

Ovary 2 -celled; fruit capsular. Trees . . . 5. Aguilaria

\section{DAPHNE, Linn.}

Shrubs or small trees. Leaves alternate. Flowers bisexual in terminal or lateral heads (or racemes) often with involucral bracts. Perianth funnel-shaped or tubular; lobes 4, no scales in throat. Stamens in 2 rows of 4 each; filaments short. Ovary I-celled, I-ovuled; style short; stigma capitate. Fruit a fleshy drupe, globose or ovoid. Seed I. Species about 8o, Europe, Asia, N. Africa.

(I) D. pendula Sm. Pl. Ic. ined. ii. 34. D. composita Gilg. Pflanzenfam. iii. 6A, 238; Gamble, l.c. 257.

Shrub or small tree, 8 to I2 ft. tall. Leaves membranous, lanceolate acuminate both ends; nerves Io to I4 pairs, slender; nervules fine and conspicuous; 3 to $4.5 \mathrm{in}$. long, I to $2 \mathrm{in}$. wide, glabrous; petioles . I in. long. Flowers 5 to 7 in a head, sessile, densely white-hairy on a slender peduncle $I$ in. long with 2 suborbicular caducous pink bracts. Perianth tubular, 3 in. long, lobes short, white, densely hairy. Drupe black, $\cdot 2$ in. long. $H a b$. Mountain forests; a charming shrub. Selangor, Bukit Kutu; Menuang Gasing (Kloss). Perak, Ulu Batang Padang; Thaiping Hills, Birch's Hill (Wray, Kunstler, etc.); Bujong Malacca. Distrib. Burma, Sumatra, Java.

\section{WIKSTROEMIA, Endl.}

Shrubs or small trees with very tough bark. Leaves opposite. Flowers bisexual in axillary spikes, racemes or umbels, no bracts. Perianth-tube slender, elongate, lobes 4 , throat naked, greenish yellow. Stamens 8 in 2 rows, upper near mouth, lower in midtube; filaments short. Stigma capitate. Drupe fleshy, red. Species about 20, tropical Asia and Australasia. 
Leaves densely crowded, sub-coriaceous obovate,

I in. long

(I) W. viridiflora

Leaves in distant pairs, membranous.

Inforescence racemose lengthening axillary and terminal

Inflorescence umbellate not lengthening terminal,

(2) W. Candolleana

(3) W. Ridleyi

(I) W. viridiflora Meissn. in Denkschr. Regensb. Bot. Gesellsch. iii. 306 .

A little bushy shrub about $2 \mathrm{ft}$. tall. Leaves sub-coriaceous, crowded, oblong or obovate, round at tip, base cuneate; nerves

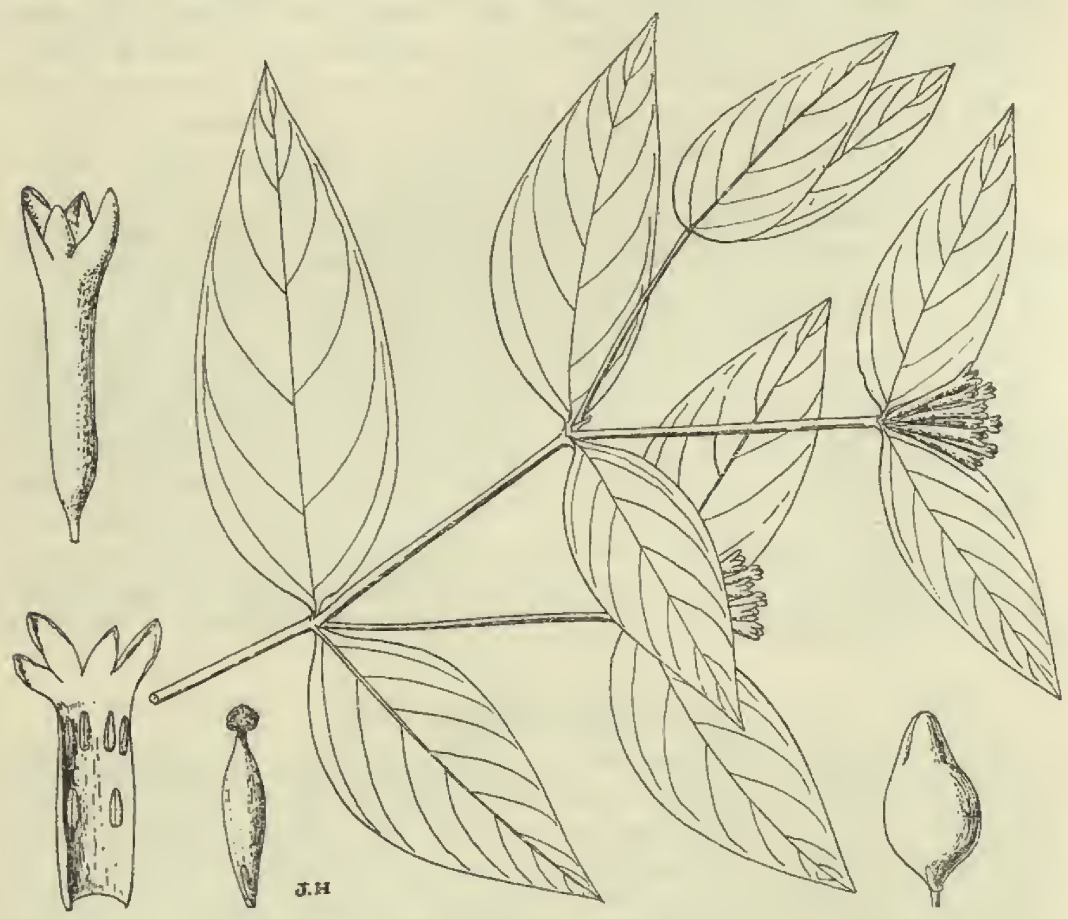

FIG. I47.-Wikstromia Ridleyi.

slender, numerous; I in. long, $\cdot 75$ in. wide or less. Flowers in very short terminal fascicles, bases hairy. Perianth-tube glabrous, yellow, 4 in. long, lobes short. Drupe ellipsoid, scarlet, $\cdot 2$ in. long. Hab. Dry spots, Penang Hill, Balik Pulau (Curtis). Lankawi, small islands (Curtis). Distrib. India, Philippines, China.

" Singapore, Lobb," must be an error. Lobb's specimens, no doubt, were from Penang.

(2) W. Candolleana Meissn. DC. Prod. xiv. 544; Gamble, Journ. As. Soc. Beng. l.c. 259.

A shrub or small tree 3 to $30 \mathrm{ft}$. tall, 2 to 3 in. through. Leaves FL,M.P., 3. 
scattered, sub-membranous, elliptic-ovate to lanceolate longacuminate, base acute or blunt, I to 3 in. long, $\cdot 5$ to $x \cdot 5$ in. wide; petioles $\cdot I$ in. long or less. Flowers in axillary and terminal peduncled racemes puberulous, gradually lengthening to $I^{\cdot} 5 \mathrm{in}$. long as the flowers fall, slender. Perianth $\cdot 35$ in. long, slender, greenish yellow. Drupe ellipsoid-ovoid, $\cdot 27$ in. long, red. Hab. Mountain woods up to $5500 \mathrm{ft}$. altitude. Variable in size and dimensions of leaves according to exposure and soil. Pahang, Kluang Terbang (Barnes); Telom; Gunong Tahan. Perak, Gunong Bubu (Wray); Thaiping Hills (Kunstler, Wray); Gunong Inas (Yapp and Wray), Kedah, Gunong Bintang. Distrib. Java. Native name: Chandan. Use: The heartwood as incense (Ridl. Journ. Roy. As. Soc. S. Br. xxxv. 80).

(3) W. Ridleyi Gamble, Kew Bulletin, I9I2, p. 200; Journ. As. Soc. Beng. l.c. 260 . (Fig. I47, p. I45.)

Shrub, little branched, 2 to $4 \mathrm{ft}$. tall. Leaves membranous, lanceolate acute or acuminate; nerves very fine and inconspicuous, 2.75 to 5 in. long, I to $I \cdot 6$ in. wide; petioles under $\cdot I$ in. long. Flowers in terminal umbels of 4 to 6 on very short peduncles. Perianth yellow, 5 in. long, lobes oblong, blunt. Drupe ellipsoid, .24 in. long, bright red. Hab. Sandy open country on the east coast chiefly, Pahang, Pekan. Tringganu, Pulau Ketam. Lankawi, Burau Bay (Robinson). Nalıve name: Deru Pelandok. Malay Poisons, Gimlette, p. I97.

This plant, brought from Penang in 1890 , ran wild for some time in Tanglin, Singapore. It has larger leaves and flowers than IV. Candolleana, and a shorter peduncle, and does not lengthen the inflorescence in flowering as $W$. Candolleana does. It is poisonous.

\section{LINOSTOMA, Wall.}

Erect shrubs or climbers. Leaves opposite or sub-opposite. Flowers bisexual in small panicled or umbelled cymes with conspicuous white floral leaves; bracts 2 , leafy. Perianth-tube cylindric; lobes 5 , scales Io in the tube mouth. Stamens Io, insert at mouth below scales; filaments exsert; anthers ovoid or oblong, blunt, connective enlarged. Disc annular lobed. Ovary stipitate, hairy; style filiform. Fruit ovoid enclosed in the enlarged urceolate perianth-tube. Species 6, 3 Indo-Malaya, 3 Brazil.

(I) L. pauciflorum Griff. Calc. Joum. Nat. Hist. iv. 234; Gamble, Journ. As. Soc. Beng. l.c. 261.

Very lofty, woody climber with pendent branches. Leaves chartaceous, glabrous elliptic or obovate blunt at top, round at base, I in. long, $5 \mathrm{in}$. wide, terminal leaves thin, conspicuously white (rarely rose pink). Flowers pendulous, light green, $\cdot 6$ in. long, slender. Fruit 5 in. long. Hab. Common in the south, Singapore, Garden Jungle; Changi Loyang; Bukit Timah. Malacca (Griffith). Dindings, Bangkor (Scortechini), Lumut. 
Penang, Muka Head (Curtis). Lankawi (Curtis). Perlis, Chupeng, floral leaves rose pink. Distrib. Burma, Sumatra, Singora. Native name: Babora.

\section{ENKLEIA, Griff.}

Softly woody climber. Leaves alternate. Flowers bisexual in heads on branches of a long terminal panicle with bracts and 2 small floral leaves eventually in fruit becoming large and acting as wings to the fruit. Perianth-tube tubular ovoid, constrict at throat; lobes 5 ; scales in mouth 5 . Stamens ro in 2 rows. Disc, a minute ring or 0 . Ovary sessile. Fruit a dry drupe ribbed. Species $I$.

(I) E. malaccensis Griff. Calc. Journ. Nat. Hist. iv. 234; Gamble, Joum. As. Soc. Beng. l.c. 262.

Branchlets, underside of leaves, inflorescence brown-red, tomentose. Leaves coriaceous, elliptic to nearly orbicular, subacute, base round; nerves numerous, parallel prominent beneath; 3.5 in. long, 2 in. wide; petioles .5 in. long. Panicles spreading, Io in. or more long with narrow brown floral leaves, 2 developing into stiff strongly reticulate brown leaves 2 in. long, I in. wide, at the base of a peduncle 2 in. long bearing the drupe. Flowers greenish brown tomentose, 25 in. long. Drupe ovoid fuscous, glabrous, ribbed and reticulate, beaked, $\cdot 25$ in. long. Hab. Common in forests in the south, Singapore, Garden Jungle; Bukit Timah. Malacca, Ayer Panas (Curtis); Sungei Hudang (Goodenough). Distrib. Burma, Siam. Native name: Akar Kapang.

\section{AQUILARIA, Lamk.}

Trees. Leaves alternate. Flowers bisexual in axillary or terminal umbels, white. Perianth-tube campanulate; lobes 5, silky, pubescent; scales in throat Io. Stamens Io, filaments short. Ovary sessile, villous, 2-celled; style short; stigma large, capitate. Fruit a flattened, woody or coriaceous obovate or oblanceolate capsule. Seeds I or 2, ovoid attached to the capsule by a long filiform appendage by which they hang from the bottom of the cell. Species about I2, India, China, Malaya.

Leaves glabrous.

Capsule obovoid woody; leaves $3.25 \mathrm{in.long}$
Capsule lanceolate long-beaked, coriaceous; leaves

4 in. long

Leaves tomentose beneath; capsule tomentose

(I) A. malaccensis

(2) A. rostrata

(3) A. hirta

(I) A. malaccensis Lamk. Dict. i. 49; Gamble, Journ. As. Soc. Beng. l.c. 264; Ridl. in Journ. Roy. As. Soc. S. Br. xxxv. 73.

A big tree 60 to $80 \mathrm{ft}$. tail ; buds silky. Leaves chartaceous, glabrous, shining, oblong-lanceolate, caudate-acuminate, base cuneate; nerves very fine, 8 to I2 pairs; 3.25 in. long, I in. wide ; petioles ' I in. long. Umbels axillary on short branchlets, 6 -flowered. 
Flowers white. Perianth-tube campanulate, puberulous, $I$ in. long; lobes ovate, $\cdot 07$ in. long. Capsule flat obovoid, woody, I in. long and nearly as wide, base much narrowed, glabrous. Seed ovoid, puberulous, beaked, orange, $2 \mathrm{in}$. long, hanging by a filiform basal appendage, orange colour, covered with red hair. Hab. All over the peninsula in forests, Singapore, Garden Jungle; Kranji. Johor, Castlewood. Pahang River, Kwala Luit. Malacca, Sungei Hudang; Brisu; Bukit Bruang (Derry). Negri Sembilan, Tampin. Perak, Kwala Kangsa (Sir Cecil Smith) ; Larut (Kunstler). Penang, Hill, Waterfall (Curtis); Balik Pulau. Distrib. Bangka, Java, Sumatra. Native names: Karas; Tuikaras; Tangkaras; Tabak (Sakai fide Skeat); Gaharu (a fine kind). Use: A celebrated incense wood valued at 400 dollars a picul.

First described by Garcia da Orta (" Historia Aromatum ") from Malacca in 1534 . The partly decayed heart wood is the part used.

(2) A. rostrata Ridl.

Tree; branchlets hairy. Leaves lanceolate, caudate acuminate, base shortly narrowed, sub-coriaceous, glabrous, smooth, grey when dry above; nerves very slender, numerous; 4 in. long; I.75 in. wide; petioles . I5 in. long. Fruit (hardly ripe) coriaceous, lanceolate long-beaked, base long narrowed, I in. long, '3 in. wide. Perianth persistent, tubular, 25 in. long, glabrous; lobes .05 in. long, oblong obtuse silky pubescent, split on one side. Hab. Very little known, Pahang, Wray's Camp, Gunong Tahan (Ridley).

The specimens are poor. It much resembles $A$. agallocha Lamk., especially in the perianth in fruit, but the beak of the fruit is very much longer in proportion to the body of the fruit.

(3) A. hirta Ridl. Joum. Roy. Soc. As. S. Br. xxxv. 73; Gamble, Journ. As. Soc. Beng. l.c. 265.

Small tree about $30 \mathrm{ft}$. tall; buds silky. Leaves sub-coriaceous, elliptic to elliptic-ovate, acuminate, base acute or round, glabrous above, tomentose beneath; nerves 20 to 30 pairs, fine; $5 \cdot 25$ in. long, $2 \cdot 3$ in. wide; petioles thick, I in. long. Umbels on axillary branches 8- to Io-flowered, grey tomentose; peduncles $\cdot 2$ to $\cdot 4$ in. long; pedicels $\cdot 2$ in. long. Flowers 5 in. long, tomentose. Capsule oblanceolate acute, narrowed at base, grey tomentose, leathery, I. 6 in. long, 6 in. wide. Seed ovoid, glabrous, beaked, black. Hab. Local in forests, Singapore, Bajau. Johor, Bukit Pengaram (Ridley). Native name: Chandan.

\section{ORDER CXXIII. ELÆAGNACEÆ.}

Shrubs (or trees) with copious brown or silvery scales. Leaves entire. Flowers small, bi- or uni-sexual in axillary spikes, fascicles or racemes. Perianth tubular; limb 2- to 4-lobed (in males sometimes of 2 membranous lobes). Stamens adnate to throat of 
tube as many as lobes (in males at base of perianth and twice as many). Ovary I-celled; style filiform; stigma lateral. Fruit a drupe or nut, covered with the thickened perianth-tube. Species about 16 , mostly temperate regions.

\section{EL压AGNUS, Linn.}

Shrubs (or trees) with silvery scales. Flowers bisexual, axillary in fascicles or racemes, tube campanulate or funnel-shaped; lobes 4, valvate. Stamens 4. Fruit a drupe. Species I2, Europe, Temperate and tropical Asia, Australia, N. America.

(I) E. latifolia Linn. Sp. Pl. I2I; Gamble, Journ. As. Soc. Beng. Ixxv. 268.

Bushy climber; branchlets and leaves beneath covered with rusty silvery scales. Leaves membranous to coriaceous elliptic or elliptic-lanceolate, very variable, 2 to 4 in. long, I. 2 to 2 in. wide. Flowers bisexual or male greenish white in fascicles or racemes $\cdot 8$ in. long, lengthening. Perianth campanulate, $\cdot 2$ to $\cdot 3$ in. long. Fruit ellipsoid, $\cdot 4$ to $\cdot 8$ in. long, orange with white spots; eatable. Hab. Penang Hill, on the roadside near the Bungalows. Distrib. Indo-Malaya, China.

A large mass of this has been here for many years, but I do not think it is indigenous.

\section{ORDER CXXIV. LORANTHACEÆ.}

Parasitic shrubs on trees or on other Loranths; much branched. Leaves usually opposite, coriaceous, sometimes o. Flowers bior uni-sexual, sometimes large and showy; racemose, spicate, fascicled or capitate, usually bracteate and with two or more bracteoles. Calyx small adnate to ovary; limb very short or o. Petals 3 to 8 valvate, free or connate in a tube. Stamens as many and opposite petals, and adnate to them; filaments slender or o; anthers opening by slits or rows or pores. Ovary inferior, I-celled; style short or long; stigma simple. Fruit a pulpy viscid drupe. Seed I with no distinct testa. Chiefly tropical, whole world (Gamble, Journ. As. Soc. Beng. 1xxv. iii. 350).

Flowers bisexual, often large,

Calyx-tube supported by a bract, no bracteoles.

Anthers basifixed

I. LoRANTHUS

Anthers dorsifixed .

2. LoXanthera

Bracts and 2 bracteoles. Anthers basifixed

3. Elytranthe

No bracts, bracteoles o to 4. Inflorescence a cone-shaped involucrate head

4. LEPEOSTEGERES

Flowers unisexual, very small.

Anthers 2-celled opening longitudinally.

Leafy plants; flowers in jointed spikes . . 5. Ginalloa

Leafless jointed; plants very small.

Flowers in axils of scales hairy at base; sepals 3 6. KoRthalsella 
Flowers I or more in a cup-shaped bract; sepals usually 2 .

Anthers opening by many pores; flowers in axillary threes or flattened heads.

Leafy or leafless and with flat jointed stems; anthers combined with perianth lobes

Leafy tomentose scurfy; anthers not combined with petals; flowers in small heads.

8. VISCUM

9. Nототиiхоs

\section{LORANTHUS, Linn.}

Parasitic shrubs. Leaves opposite or alternate, fleshy, coriaceous. Flowers in racemes, spikes or panicles axillary (rarely terminal) bracts small at base of calyx-tube, no bracteoles. Calyxlimb short, truncate. Corolla gamopetalous or petals free, lobes 4 to 6 ; tube often split down one side. Stamens as many as lobes; anthers basifixed; style filiform; stigma capitate. Fruit drupaceous crowned by persistent calyx. Seed albuminous in glutinous pulp. Tropics of Old World.

Petals free, 5 ; flowers in racemes or spikes.

Racemes involucrate at base

Racemes sunk in base of branchlet.

Leaves acute; petals rather thin

Leaves blunt; petals very thick

Racemes not involucrate nor sunk

Petals free, 4; racemes rusty-pubescent

Petals 4 ; Howers in sessile clusters.

Branches stout, 4 -angled; flowers large
Branches rather slender terete; flowers very small, yellow

Corolla gamopetalous.
Corolla 4 -lobed; young parts red-tomentose or scurfy.

Leaves oblong; flowers single or racemes fewflowered

(I) L. pulcher

(2) L. heteranthus

(3) L. crassipetalus

(4) L. pentapetalus

(5) L. coccineus

(6) L. productus

(7) L, Lobbii

Leaves elliptic, tomentose beneath; cymes dense, fascicled

Leaves elliptic, glabrous beneath when old; cymes lax, few-flowered .

Leaves elliptic or sub-orbicular, glabrous beneath when adult; cymes umbellate tomentose

Corolla 5-lobed.

Leaves densely orange-tomentose beneath

Leaves glabrous.

Racemes under 6 in. long, mealy; leaves

very thick
Racemes over I in. long, mealy pubescent; leaves very thick

Leaves coriaceous; racemes glabrous; corolla I. 6 in. long

Leaves very coriaceous, large; racemes glabrous;

Corolla 6-lobed. corolla 3 in. long, rose-pink. .

Pedicels I-flowered; corolla $3^{\circ} 9$ in. long .

Pedicels 2-flowered; corolla 2 in. long

(8) I. obtectus

(9) L. ferrugineus

(Io) L. malaccensis

(I I) L. estipitatus

(12) L. casuarinæ

(13) L. crassus

(I4) L. pentandrus

(15) L. Jongiflorus

(I6) L. grandifrons

(I 7) L. Scortechinii

(I8) L. Duthieanus 
(I) L. pulcher DC. Prod. iv. 295; Gamble, Journ. As. Soc. Beng. l.c. 352.

Big shrub 6 to $8 \mathrm{ft}$. tall or less; branches stout. Leaves opposite, very coriaceous, glabrous, lanceolate, oblong, or ovate long-acuminate, base round or acute; nerves 6 to to pairs, faint (sometimes invisible); 6 in. long, 2.5 in. wide or less; petioles thick, $\cdot 2$ in. long. Racemes I- to 4 -fascicled terminal, 6 in. long, densely floriferous nearly to base; pedicels very short with a long boat-shaped ovate bract at the base of the flower. Calyx urceolate, 'I in. long. Corolla 3 in. long, bright red; petals free linearoblong, recurved from middle, upper part hairy. Fruit subcylindric, truncate, $\cdot 25$ in. long, red. Hab. Usually rather low down on trees above $2000 \mathrm{ft}$. altitude. The low country form (Province Wellesley) has thin leaves and more nerves. Pahang, Tahan River. Perak, Thaiping Hills; Ulu Bubong (Kunstler). Province Wellesley, Tasek Gelugur. Penang (Porter, Phillips, etc.) at about $2500 \mathrm{ft}$. altitude. Adang Group, Rawei island. Setul (bract curiously gibbous).

var. Parishii Gamble, Journ. As. Soc. Beng. l.c. L. Parishii Hook. fil. F.B.I. v. 205. L. perakensis Engl. Nachtr. I29. Leaves lanceolate, 3 in. long, $\cdot 5$ in. wide, or larger. Selangor, Bukit Kutu. Distrib. Tenasserim, Siam.

var. sessiliflora Ridl. Leaves very coriaceous and fleshy ovate or elliptic; nerves very faint or quite invisible. Spikes 3 to 6 in. long, rachis stout, red; flowers quite sessile, red, rather shorter; bracts smaller, cucullate with a gibbous point, edge ciliate. Hab. Pahang, Gunong Tahan, at $5000 \mathrm{ft}$. altitude. Perak, Gunong Kerbau, at $4500 \mathrm{ft}$. altitude (Robinson).

This might almost be made a distinct species, but pulcher varies considerably in length of pedicels, shape of bract and thickness of leaves, according to altitude.

(2) L. heteranthus Wall. Cat. 537; Gamble, l.c. 353.

Big shrub with stout branches. Leaves coriaceous alternate, opposite, elliptic to linear-lanceolate, narrowed blunt at tip, base attenuate; nerves ro pairs but very faint, glabrous, midrib raised both sides; 3 to 5 in. long, I to I. 5 in. wide; petioles $\cdot 5$ in. long. Racemes I to 2, axillary and terminal about 6 in. long rising out of a shallow cup, red rather stout. Flowers solitary on distant pedicels $\cdot 5$ in. long or less with a boat-shaped bract $\cdot 05$ in. long at base of perianth. Calyx cylindric, 25 in. long; limb slightly spreading. Corolla slender, cylindric, 75 to I in. long, crimson; petals rather thin. Fruit urceolate, 4 in. long. $\mathrm{Hab}$. From sea level to $3400 \mathrm{ft}$. altitude. Pahang, Kwala Pahang; Pianggu, Endau (Evans). Perak, Temengoh (on Durian trees); Haram Parah (Scortechini); Gunong Batu Putih (Wray); Larut Hills (Kunstler). Kedah Peak. Distrib. Burma, Siam, Borneo, Java, Sumatra. 
(3) L. crassipetalus King, Journ. As. Soc. Beng. lvi. ii. 9I; Gamble, ibid, l.c. 354.

A stout shrub. Leaves coriaceous, stiff, alternate, elliptic or obovate blunt, base narrowed, glabrous; nerves invisible; 2 to 3 in. long, I to $\mathrm{T} \cdot 5$ in. wide; petioles $\cdot 3$ in. long. Racemes thick, 2 in. long, axillary stiff; flowers 8 or 9 ; pedicels very short or 0 ; bract ovate cochleate. Calyx cylindric, $\cdot 2$ in. long with rather a wide limb. Petals linear, very thick acute, 75 in. long. Hab. Not common, Selangor, Gunong Mengkuang Lebah (Robinson). Perak, Thaiping Hills at $5500 \mathrm{ft}$. altitude (Scortechini, etc.); Ulu Batang Padang (Wray).

(4) L. pentapetalus Roxb. Fl. Ind. (ed. Carey), ii. 2II; Gamble, Journ. As. Soc. Beng. l.c. 355; Bl. Fl. Jav. Loranthacea, 39, t.t. I4, $23 \mathrm{~A}$.

Bushy shrub moderately stout, glabrous. Leaves thinly coriaceous, opposite or alternate, ovate to ovate-lanceolate acute, narrowed or round at base; nerves very faint; 2.75 to 3 in. long, I to I.4 in. wide; petioles 5 in. long, slender, (plant dries black). Racemes I to 3 in axils 3 in. long, rather slender, entirely bright red; pedicels minute or o; bract oblique ovate. Calyx urceolate, -I in. long, minutely toothed. Corolla $\cdot 2$ in. long, very slender, base dilated and lobed, upper part narrower, slender, tip dilate. Fruit ellipsoid truncate, $\cdot 27$ in. long, crimson. Hab. Pahang, Pekan. Malacca, Serkam (Derry). Selangor, Ginting Bidai. Perak, Goping (Kunstler); Thaiping Hills (all collectors); Gunong Batu Putih (Wray). Penang Hill (all collectors). Distrib. India, Siam, Java, Sumatra, Borneo.

(5) L. coccineus Jack, Mal. Misc. i. 8; Gamble, Journ. As. Soc. Beng. l.c. 357.

A bushy shrub; branches moderately stout, scurfy tomentose at tips. Leaves thinly coriaceous, alternate, ovate or ovatelanceolate blunt, shortly narrowed at tip, base round or cordate; nerves 5 to 7 pairs, faint; 2 to 4 in. long, I to 2 in. wide; petioles 5 in. long. Racemes axillary, 2 in. long, flowered to base, rustytomentose; pedicels short, under . I in. long at right angle to rachis. Flowers erect parallel to rachis; bracts very small oblique above. Calyx cylindric, dilate at base. Petals linear narrow, .25 in. long, red-tomentose outside. Fruit flask-shaped, truncate, 3 in. long, red-brown. Hab. Common, Singapore, Bukit Mandai. Johor. Muar, Bukit Kayara. Malacca, Bukit Senggeh (Goodenough, Griffith). Pahang, Kwala Pahang. Selangor, Labu River. Perak, Thaiping Hills; Waterfall; Goping (Kunstler); Ulu Bubong (Kunstler). Penang Hill (all collectors). Perlis, Chupeng. Distrib. India, Borneo, Bangka.

(6) L. productus King, Joum. As. Soc. Beng. lvi. ii. 9I; Gambie, ibid. l.c. 357.

A stout shrub with thick 4 -angled branchlets, glabrous. Leaves 
opposite bluish green, coriaceous, lanceolate or ovate, shortly acuminate, base decurrent on petiole; nerves 3 to 8 pairs, visible when dry; 3 to 4.5 in. long, I. 5 to 2 in. wide (terminal ones smaller); petioles winged, $\cdot 5$ in. long. Flowers pale yellow sessile in axillary clusters; bracts short, tubular, crenate, ${ }^{\prime} 3$ in. long. Calyx tubular, short and broad. Corolla $\cdot 4$ to $\cdot 5$ in. long, base slightly enlarged. Fruit globose, $\cdot 25$ in. through. Hab. Rare, at 3000 to $4900 \mathrm{ft}$. altitude. Perak, Ulu Batang Padang (Wray); Larut at 3000 to $3600 \mathrm{ft}$. altitude (Kunstler).

(7) L. Lobbii Hook. fil. F.B.I. v. 204; Gamble, Journ. As. Soc. Beng. l.c. 358 .

Shrub with terete moderately slender brownish branches. Leaves thick, coriaceous, glabrous ovate-lanceolate, long acuminate, base round or acute; nerves 5 to 6 pairs, but rarely visible; 3 to $5.5 \mathrm{in}$. long, $\mathrm{x} .5$ to $2.5 \mathrm{in}$. wide; petioles very short and thick or 0 . Flowers minute, sessile, yellow on a cushion-like peduncle 6 to 20 in the axil. Calyx tubular, .07 in. long. Petals linear-oblong, puberulous, ${ }^{\prime} 3$ in. long. Fruit elliptic, brown, $\cdot I_{3}$ to $\cdot 2$ in. long, puberulous. Hab. Commonest at high altitudes, a common and slightly variable species, Singapore, Changi; Chan Chu Kang. Johor, Kukub. Pahang, Tahan River up to $550 \mathrm{ft}$. altitude, Selangor, Semangkok Pass; Gunong Mengkuang Lebah (Robinson). Perak, Goping; Thaiping Hills; Gunong Batu Putih (Wray); Ulu Bubong (Kunstler). Penang Hill, Balik Pulau Road (Curtis, Lobb, etc.). Kedah Peak.

Van Tieghem has made four species out of this common and hardly variable species, none of which is worth keeping up even as a variety.

(8) L. obtectus Wall. Cat. 534; Gamble, Joum. As. Soc. Beng. l.c. 357 . L. scurrula var. obtecta, Kurz and Hook. fil. F.B.I. v. 209.

Slender branched shrub; young parts and inflorescence thickly red-tomentose. Leaves chartaceous, opposite, ovate-lanceolate or elliptic-oblong, narrowed at tip, base round or cordate, rusty tomentose beneath when young, glabrous when adult; nerves 7 to 8 pairs, fairly conspicuous when dry; $I \cdot 5$ to 3 in. long, 4 to 2 in. wide; petioles $\cdot 2$ in. long. Flowers in axillary fascicles single or in short racemes, dense mossy-tomentose. Calyx-tube obovoid, $\cdot 2$ in. long. Corolla slender, scurfy-tomentose, curved, $\cdot 4$ to $\cdot 5$ in. long. Fruit pear-shaped, about 4 in. long. $H a b$. Not very common, Johor, Kota Tinggi. Malacca, Bruang and on Sonneratias in Mangroves (Griffith); Bukit Senggeh (Goodenough). Perak, Maxwell's Hill (Fox). Distrib. Burma and Trang.

(9) L. ferrugineus Roxb. Fl. Ind. ii. 207; Gamble, Journ. As. Soc. Beng. l.c. 360 ; Hook. Bot. Mus, i. 279 , t. 59 .

A slender branched bush; young parts and inflorescence and underside of leaves densely red-tomentose. Leaves opposite thinly 
coriaceous, elliptic blunt, base shortly narrowed or round; nerves 5 to 8 pairs, slender; I to 3 in. long, $\cdot 75$ to 2.5 in. wide; petioles - I5 to 2 in. long. Flowers in axillary fascicles of 2- to 6-flowered cymes densely rusty-tomentose. Calyx $\cdot 2$ in. long. Corolla $\cdot 8$ in. long, rather thick. Fruit ovoid-pear-shaped, densely tomentose, truncate. Hab. Very common. An orchard pest, growing on all kinds of trees, croton bushes, etc., Singapore. Malacca, Alor Gajah (Burkill). Pahang, Pekan. Negri Sembilan, Tampin. Selangor, Kwala Lumpur. Perak, Changkat Serdang (Wray), Penang (all collectors); Tringganu (Yapp). Distrib Sumatra.

(Io) L. malaccensis Hook. fil. F.B.I. v. 210; Gamble, Journ. As. Soc. Beng. l.c. $36 \mathrm{I}$.

Slender branched bush 2 to $3 \mathrm{ft}$. tall; branchlets scurfy-pubescent. Leaves thinly coriaceous, opposite, elliptic or ovate-elliptic, tip rounded, base round when young, thickly red-scurfy beneath eventually glabrous, except midrib; nerves 4 to 6 pairs slender; I to 2 in. long, $\cdot 25$ to I in. wide; petioles slender, $I_{5}$ in. long. Flowers in axillary about 5 -flowered lax cymes; peduncles $I$ in. long; pedicels about as long, slender, red-scurfy. Calyx pearshaped, very small. Corolla brown-scurfy, slender clubbed, $\cdot 4$ in. long. Fruit obconic, reddish-brown, $\cdot 3$ in. long, scurfy. Hab. Open places, sea level to $300 \mathrm{ft}$. altitude, Johor, Sedenah. Pahang, near Pekan. Malacca (Griffith). Selangor, Ginting Bidai. Perak, Larut (Kunstler). Penang Hill at 2000 to $2500 \mathrm{ft}$. altitude. Kedah, Alor Sta; Kedah Peak (Robinson and Kloss). Kelantan, Kota Bharu.

(II) L. estipitatus Stapf, Trans. Linn. Soc. ii. vol. iv. 22I; Gamble, Journ. As. Soc. Beng. l.c. 362 .

Branchlets slendır. Leaves thinly sub-coriaceous, sub-opposite, elliptic or sub-orbicular, blunt or emarginate, base short cuneate, glabrous when adult, densely red-tomentose beneath when young; nerves 3 to 4 pairs; I.5 in. long, $I$ to $I \cdot I$ in. wide; petioles $\cdot 25$ in. long, rather slender. Flowers in umbellate cymes; peduncles $\cdot 4$ in. long, red-tomentose; pedicels slender. Calyx ovoid subglobose. Corolla-tube very slender, curved, clubbed, nearly I in. long, red-scurfy. Fruit oblong truncate, glabrous, 3 in. long. Hab. Rare, Perak, Gunong Haram (Scortechini). Distrib. Borneo.

(12) L. casuarinæ Ridl. Trans. Linn. Soc. Ser. 2, iii. 342; Gamble, Joum. As. Soc. Beng. l.c. 362.

Pendent shrub, branches slender; young parts covered with red orange tomentum. Leaves opposite, fleshy, ovate-lanceolate acuminate, base round or sub-cordate beneath red-tomentose; nerves 5 or 6 pairs, obscure; 5 in. long, 2 in. wide; petioles 25 in. long. Flowers in axillary racemes $I$ in. long, orange-tomentose. Calyx-tube short, cylindric. Corolla curved, cleft on one side half-way, $x \cdot 75$ in. long; lobes 5 , linear, 5 in. long. Fruit lageniform rusty-tomentose. Hab. Local, Pahang on Casuarina trees at Sungei Meang, Pahang River (Ridley). 
(I3) L. crassus Hook. fil. F.B.I. v. 2I7; Gamble, Journ. As. Soc. Beng. l.c. 363 .

A stout shrub. Leaves very thick, coriaceous, opposite or alternate, elliptic-ovate-oblong to nearly orbicular, blunt acuminate, base round or narrowed; nerves 5 to 6 pairs visible when dry; 4 in. long, I.75 in. wide; petioles ${ }^{-} 5$ in. long. Racemes axillary, crowded scurfy, 5- to 6-flowered, up to 4 in. long. Calyx-tube globose or urceolate. Corolla straight, funnel-shaped, 67 in. long. Fruit ovoid-oblong, 4 in. long with persistent calyx limb. Hab. Singapore (Wallich), Botanic Gardens; Changi; Bukit Mandai; Kedah Peak (leaves red). Lankawi (Curtis).

(I4) L. pentandrus Limn. Mant. 63; Gamble, Journ: As. Soc. Beng. l.c. $364 ; \mathrm{Bl}$. Fl. Jav. Loranthacee, 33, t. Io.

A large stout plant; branches thick. Leaves thick coriaceous, glabrous, alternate lanceolate or ovate, elliptic to nearly orbicular, blunt or acute, base cuneate; nerves faint; 4 in. long, I.75 to 2 in. wide; petioles thick, II in. long. Racemes axillary, fascicled, usually short, scurfy, grey-pubescent. Calyx ovoid, 'I in. long. Corolla cylindric, base swollen, greenish outside, scurfy orange inside, 5 in. long. Fruit ovoid, 4 in. long, mealy. Hab. Common all over the peninsula. A pest in orchards and gardens, Singapore, Gardens; Changi. Malacca (Maingay); Pulau Besar. Pahang on Hibiscus tiliaceus, Sungei Meang. Selangor, Gunong Mengkuang Lebah (Robinson). Negri Sembilan; Tampin. Perak, Gunong Inas (Wray); Waterfall, Thaiping. Dindings, Pangkor. Province Wellesley. Penang (all collectors). Kedah Peak at 2800 to $4000 \mathrm{ft}$. altitude (Robinson). Setul. Kelantan, Kota Bharu.

(I5) L. longiflorus Desv. in Lamk. Encycl. iii. 598; Gamble, Journ. As. Soc. Beng. l.c. 365. L. bicolor, Roxb. Corom. Pl. 20, t. $\mathrm{I} 39$.

Large shrub. Leaves coriaceous, variable, ovate or elliptic blunt; nerves 6 to Io pairs, irregular; 3.6 to 6 in. long, $x \cdot 6$ to 2.8 in. wide; petioles stout,. to $\cdot 4$ in. long. Racemes axillary or on the old wood, solitary or fascicled, many-flowered, $I \cdot 6$ to 2.8 in. long. Corolla pink or red, lobes green, I. 8 in. long, slender, curved, clubbed at tip. Fruit oblong, 6 in. long. Hab. Very rare here, a common Indian plant. Malacca (Griffith), perhaps wrongly localised. Griffith collected it also in Assam, and the specimens in Kew herbarium have not his own tickets on them.

(I6) L. grandifrons King, Journ. As. Soc. Beng. lviii. 93; Gamble, ibid. l.c. 366 (Fig. I48, p. I56).

Big shrub. Leaves alternate, rarely opposite thick, coriaceous, broad, ovate, sub-acute; nerves about 6 pairs, very conspicuous, elevate beneath; 9 in. long, 475 in. wide; petioles stout, I in. long. Racemes 2 to 4 in. long; rachis stout, grey-puberulous. Calyx cylindric, I 8 in. long. Corolla cylindric, base inflate, 2 to 
3 in. long, puberulous, pink, tipped green. Fruit ovoid, greypowdery, 3 in. long. Hab. Not rare in open country. A very handsome plant, Pahang River up to Kwala Tembeling on Vitex vestita. Malacca, Batang Malaka (Derry). Selangor, Kwala Lumpur. Negri Sembilan, Seremban; Tampin (Burkill). Perak, Kinta River (Kunstler); Matang Jambu (Wray); Hulu Kwangsa (Scortechini). Distrib. Sumatra, South Siam. Native name: Mendalu Besar,

(I7) L. Scortechinii King, Journ. As. Soc. Beng. lvi. ii. 94; Gamble, ibid. l.c. 367 .

A big stout shrub, glabrous. Leaves coriaceous in whorls of 6 , elliptic-lanceolate; midrib very thick and prominent, nerves

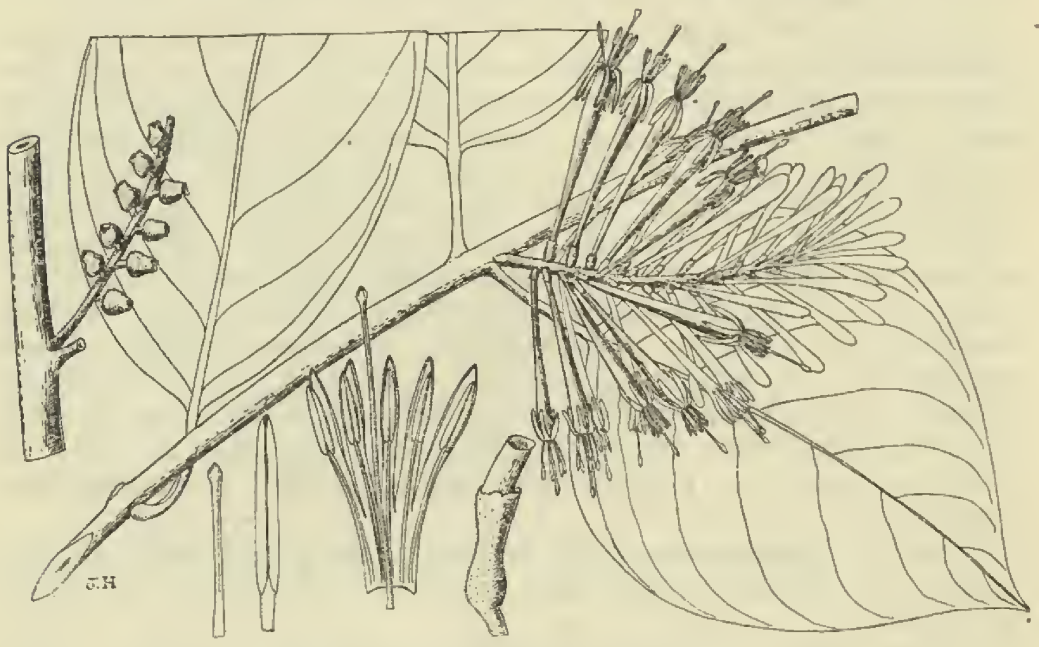

FIG. 148.-Loranthus grandifrons.

invisible; 9 in. long, 3 in. wide, Racemes 2 in. long on old wood. Corolla pale yellow, lobes greenish, cylindric, funnel-shaped upwards, 4.5 in. Iong; lobes reflexed, .25 in. long. Hab. Rare. Perak, Goping (Kunstler); Gunong Haram (Scortechini).

(I8) L. Duthieanus King, Journ. As. Soc. Beng. lvi. ii. 94; Gamble, ibid. l.c. 367 .

Glabrous; branches stout. Leaves alternate, opposite and whorled, elliptic-lanceolate, blunt, base cuneate, coriaceous; midrib and nerves 3 to 5 pairs visible when dry; 3 in. long, I in. wide; petioles 4 in. long. Racemes up to 2 in. long, slender, about 6 -flowered minutely puberulous, outer bract small ovate acute enclosing 2 flowers each with a shallow cup-bracteole. Calyx cylindric, I in. long. Corolla tubular, bright red inflate upwards 
2 in. long; lobes 6, spathulate. Hab. Rare. Singapore, Bukit Timah. Perak (Scortechini).

\section{LOXANTHERA, Blume.}

Shrubs. Leaves coriaceous. Flowers in short cymes from axils; bract ovate, embracing base of calyx-tube. Calyx cylindric ; limb irregularly cleft. Corolla very long contracted above base and above insertion of filaments; lobes 6, linear-spathulate, reflexed. Stamens 6; filaments slender; anthers linear, dorsifixed. Ovary cylindric; style filiform; stigma clubbed. Fruit as in Loranthus. Species 2, Malaya.

(I) L. speciosa Blume and Fisch. Fl. Jav. Loranthacea, ii. t. 20 and 23c; Gamble, Journ. As. Soc. Beng. l.c. 369. Loranthus speciosus King, ibid. lvi. ii. 95 (not of Bl.).

Glabrous. Leaves opposite, ovate or elliptic-ovate, acute or blunt, base narrowed blunt, coriaceous, nerves very obscure, midrib prominent; 3 in. long, I. 5 to 2.75 in. wide; petioles stout, .25 in. long. Cymes axillary or sub-terminal, about I in. long. Calyx $\cdot$ I $_{4}$ in. long, widely expanded at top. Corolla 5 in. long, red, narrowly funnel-shaped to stamens then constrict; lobes $\mathrm{I} \cdot 6 \mathrm{in}$. long, spathulate, twisted. Hab. Malacca (Griffith). Muar River (Curtis). Perak (Scortechini). Distrib. Java, Sumatra and Borneo,

\section{ELYTRANTHE, Blume.}

Bushy shrubs. Leaves opposite, coriaceous. Flowers few in spikes, racemes or pairs with one bract and two bracteoles often connate in a cup. Calyx-tube cylindric; limb small. Corollatube more or less cylindric or funnel-shaped; lobes 6 or 5 , reflexed. Stamens 6 or 5 ; anthers basifixed. Ovary enclosed in tube; style slender; stigma capitate. Fruit as in Loranthus. Species many, Indo-Malaya to New Zealand.

Flowers in spikes; bracts and bracteoles free, large. Glabrous; spike peduncled; flowers large, white.

Scurfy puberulous; spikes small, sessile; flowers

Flowers in racemes; bracts and bracteoles shorter

(I) E. albida

(2) E. Maingayi than calyx-tube.

Corolla 3 in. long.

Leaves ovate acuminate; corolla red tipped green . . .

Leaves ovate acuminate; corolla yellow . .

Leaves orbicular cordate; corolla red

Leaves ovate acute not cordate; petals linear acute

Corolla 2 in. long; leaves rather thin, lanceolate blunt; flowers red .

Corolla about I in. long; leaves lanceolate; corolla red.

Corolla slender; leaves coriaceous.

(3) E. formosa

(4) E. Kunstleri

(5) E. platyphylla

(6) E. tubæflora

(7) E. rubra

(8) E. avenis 
Corolla under I in. long.

Leaves oblanceolate; flowers 2 in a raceme, orange papillose

Leaves obovate; racemes of several flowers, pink and green

Leaves ovate or lanceolate acute.

Leaves puberulous pedicels and bracts .

Leaves glabrous; flowers green, yellow and black

Corolla-tube less than 4 in. long; leaves lanceolate.

Racemes clustered, 4- to 5 -flowered

Racemes nearly sessile fascicled, I- to $3^{-}$ flowered, red, very small .

Flowers in pairs in excavations of a thick peduncle.

Bracts moderate; bracteoles in a cup cleft opposite bract.

Leaves thin coriaceous, base round lanceolate; flowers red, lobes green

Leaves thick, base narrowed oblong-lanceolate; flowers red, lobes yellow .

(9) E. papillosa

(го) E. retusa

(I I) E. Lowii

(I2) E. globosa

(13) E. Barnesii

(I4) E. Robinsonii

(I) E. albida Bl. Fl. Jav. Loranthacee, t. 22; Gamble, Joum. As. Soc. Beng. l.c. $37 \mathrm{I}$.

Large stout shrub; bark grey. Leaves opposite, chartaceous to sub-coriaceous, ovate or oblong blunt, round or narrowed at base; nerves Io to I2 pairs, fine, distinct when dry; 4 in. long, 2 to 2.7 in. wide; petioles 5 in. long or less. Flowers in 2- to 6-flowered distichous spikes clustered on thickened nodes below the leaves; peduncles $\cdot 25$ in. long. Bracts ovate, boat-shaped, $\cdot 25$ in. long. Bracteoles 2, thinner as long. Calyx cupular short. Corolla $I \cdot 5$ in. long, cylindric, curved, white. Stamens, filaments crimson. $\mathrm{Hab}$. On high trees in forest, Singapore, Bukit Timah. Malacca (Griffith, Maingay). Perak, Gunong Batu Putih (Wray); Gunong Haram (Scortechini). Penang Hill (Curtis). Distrib. Southern Siam, Java, Sumatra, Borneo.

(2) E. Maingayi Gamble, Journ. As. Soc. Beng. l.c.372. Loranthus Maingayi Hook. fil. F.B.I. v. 222.

Small slender scurfy shrub. Leaves opposite, coriaceous, oblong, obovate blunt, base narrowed; midrib prominent, nerves invisible; 2.75 in. long, $\mathrm{I} \cdot 25$ in. wide; petioles $\cdot 25$ in. long. Spikes sessile, rusty-scurfy $\mathrm{I}$ or more axillary, 2 in. long. Bract oblong, blunt; bracteoles 2, acute. Calyx-tube .07 in. long. Corolla - 5 in. long, tube very short; lobes 6, linear acute. Hab. Rare and very inconspicuous, low down on small trees, Singapore, Krangi, in sandy woods by Mangroves (Ridley). Malacca (Maingay).

(3) E. formosa Don, Hist. Dichl. Pl. iii. 426.

A big shrub glabrous. Leaves opposite, coriaceous ovate or elliptic ovate to lanceolate acuminate blunt, round at base; nerves sunk above and elevate beneath 6 to 8 pairs; 6 in. long, I.5 to 2 in. wide; petioles thick, $\cdot_{5}$ in. long. Cymes umbelled on short - I in. long stout peduncles; pedicels as long; bracts and bracteoles 
ovate, spreading. Calyx $\cdot$ I in. long, thick, cylindric, cup wide. Corolla 3 in. long, gradually dilate upwards then constrict below the linear lobes, $\cdot 25$ in. long, scarlet crimson. Hab. On lofty trees, at 2000 to $6000 \mathrm{ft}$. altitude, Pahang, Tahan River. Selangor, Gunong Mengkuang Lebah (Robinson). Perak, Bujong Malacca (Curtis); Gunong Batu Putih (Wray). Distrib. Burma, Java.

(4) E. Kunstleri Gamble, Journ. As. Soc. Beng. l.c. 373. Loranthus Kunstleri King, ibid. lvi. ii. 95.

A large bushy shrub 4 to $5 \mathrm{ft}$. long, glabrous. Leaves opposite, coriaceous, ovate to ovate-oblong, acuminate, base round; nerves conspicuous sunk above, elevate beneath, 6 to Io pairs, midrib prominent both sides; 9 in. long, 4 in. wide. Cymes numerous, 5 -flowered, $\cdot 6$ in. long. Calyx-tube cylindric, $\cdot$ I 5 in. long. Corollatube 2 in. long, cylindric dilate slightly upwards, clubbed and angled in bud, golden-yellow, lobes 6 , sub-spathulate, 3 in. long, greenish, red inside. Fruit ovoid, $\cdot 5$ in. long, yellow, rather low down on trees. A splendid brilliant species. Hab. Pahang, Tahan River and Pahang River. Dindings, Telok Sera. Perak, Goping and Thaiping (Kunstler). Distrib. Borneo.

(5) E. platyphylla Gamble, Joum. As. Soc. Beng. l.c. 374. Loranthus platyphyllus King, ibid. lvi. ii. 97 (not Ridl.).

Glabrous; branches stout, 4-angled. Leaves coriaceous opposite, ovate round, base cordate; nerves 4 to 6 pairs from base mostly; 4.25 in. long, 4 in. wide; petioles hardly any. Racemes very short; flowers 4. Calyx cylindric truncate. Corolla cylindric, 6-angled, about 3 in. long; lobes linear-lanceolate, .8 in. long, red, tips green. Hab. Not common. Johor, Hulu Sembrong (Kelsall). Pahang, Rumpin River (Evans). Selangor, Ginting Bidai. Perak (Scortechini).

(6) E. tubæflora Ridl. Journ. Roy. As. Soc. S. Br. 86, p. 306.

Stems stout, pale emitting long creeping branches from the base, rooting at intervals. Leaves stiffly coriaceous, ovate to lanceolate acute, base round; nerves about 6 pairs usually invisible; 3 to 3.5 in. long, I.75 to 2.5 in. wide; petioles thick, .25 in. long. Racemes short, I in. long, about 8 -flowered; pedicels - $\mathrm{I}$ in. long. Bracts 3, lower one longest lanceolate, upper 2 ovate acute. Corolla 3 in. long, gradually dilate upwards, 5 in. across at mouth; lobes 6 , narrow-linear lanceolate acute, 75 in. long. Stamens 6, very narrow as long as corolla-lobes; anthers basifixed. Style longer; stigma ovoid. Hab. Mountains at $5500 \mathrm{ft}$. altitude, Perak, Gunong Inas (Yapp).

(7) E. rubra Ridl.

Branches rather slender. Leaves sub-opposite rather thin, chartaceous elliptic-lanceolate blunt acuminate, base narrowed; nerves slender conspicuous when dry, 3 pairs; reticulations visible, 3.5 in. long, $I .5$ in. wide; petioles $\cdot 4$ in. long. Cymes $\cdot 75$ in. long. Flowers sessile, about Io, red. Calyx cylindric; limb very obscurely 
lobed, I in. long. Corolla-tube gradually dilate upward, 3.75 in. long; lobes 6, narrow-linear spathulate, 4 in. long. Stamens 6. $H a b$. Setul (Ridley).

(8) E. avenis Don, Gen. Syst. Dichl. Pl. iii. 426.

Branches moderately stout below, slender at tips, rough. Leaves coriaceous, opposite, lanceolate, acute or blunt, base narrowed; nerves very obscure; 2.5 to 3 in. long, 75 in. across; petioles very short. Cymes short, 3 -flowered, numerous, I to 3 in an axil. Calyx cylindric, 07 in. long. Corolla very slender, .8 in. long, bright red. Hab. Mountains, Pahang, Kluang Terbang (Barnes). Perak, Thaiping Hills at $5000 \mathrm{ft}$. altitude; Gunong Bubu and Ulu Batang Padang (Wray). Kedah Peak at $3000 \mathrm{ft}$. altitude. Distrib. Java; Sumatra.

(9) E. papillosa Gamble, Kerw Bulletin, I9I3, p. 45; Journ. As. Soc. Beng. l.c. 375 .

Branches rather slender, round, brown. Leaves opposite, coriaceous oblanceolate, tip round; nerves invisible; $\mathrm{I} \cdot 25 \mathrm{in}$. long, $\cdot 3$ in. across; petioles 05 to $\cdot \mathrm{I}$ in. long or none. Flowers yelloworange in very short peduncled pairs I to 2 in an axil. Calyx-tube ovoid, $\cdot 07$ in. long, papillose. Corolla-tube cylindric, 6-angled, funnel-shaped in flower, $\cdot 3$ in. long, lobes 6 , papillose spathulate. $H a b$. Very rare, Singapore, Kranji (Ridley).

(Io) E. retusa G. Don, Gen. Syst. Dichl. Pl. iii. 325.

A stout shrub about $2 \mathrm{ft}$. tall. Leaves thickly coriaceous opposite obovate-elliptic, tip round, base narrowed; nerves 5 to 8 pairs very obscure; 2.5 to 3 in. long, I. 25 to 2 in. wide; petioles -I to $\cdot 2$ in. long. Racemes 5 to I in. long; flowers 5 to 7 . Bracteoles forming a 2-lobed cup. Calyx cylindric, 'I in. long, cylindric, dilate below rose pink; lobes linear green, tipped dark pink. Fruit ovoid, red at length black. Hab. On low trees usually by the sea; common. Singapore (Wallich); Changi on Rhodomyrtus; Pulau Tekong. Malacca on Melaleuca (Maingay); Top of Mt. Ophir (Hullett, Ridley) on Dacrydium. Pahang, Pekan; Kwantan (Foxworthy). Dindings, Lumut on Eusenia. Tringganu. Distrib. Java, Borneo. Native name: Dalu Dalu Hitam.

This emits suckers from the branches so that it creeps on the branches of the host.

(II) E. Lowii Gamble, Journ. As. Soc. Beng. l.c. 277. Loranthus Lowii King, ibid. lvi. ii. 98.

Branches rather slender. Leaves stiff coriaceous lanceolate or ovate, short acuminate, base round or slightly narrowed; nerves hardly visible; $\mathrm{I} \cdot 5 \mathrm{in}$. long, $\cdot 5 \mathrm{in}$. wide; petioles stout, $\cdot \mathrm{I}$ in. long. Racemes puberulous, hardly 4 in. long, of 2 to 4 flowers in axillary clusters. Calyx 'I4 in. long. Corolla curved, 6-angled, slightly inflate at lobes, $\cdot 4$ to $\cdot 6$ in. long; lobes 6 , sub-spathulate, tip thickened. Hab. Very rare and little known, Perak (Scortechini). 
(12) E. globosa Don, Gen. Syst. Dichl. Pl. iii. 426; Gamble, Journ. As. Soc. Beng. l.c. 377. Loranthus globosus Roxb. Fl. Ind. i. 550 , ii. I87, and L. ampullaceus Roxb. ibid., l.c. I89.

Usually quite glabrous. Leaves coriaceous opposite, alternate or 3 in a whorl, elliptic, ovate or lanceolate acuminate, base narrowed; nerves 5 to 6 pairs visible or not; 3 to 5 in. long, I.5 to 3 in. wide; petioles $I$ in. long. Racemes solitary or paired, $\cdot 5$ in. long; pedicels slender. Calyx urceolate, limb cup-shaped. Corolla . 4 in. long, angled cylindric dilate below the lobes in bud, campanulate when open with linear reflexed lobes, green and yellow, base black. Drupe ovoid, yellow, $\cdot 2$ in. long. Hab. Very common from sea level, Singapore, Tanglin. Malacca (Griffith). Perak, Tapa (Wray); Ulu Bubong. Tringganu. Penang Hill (Curtis and Wallich), Lankawi (Curtis). Perlis, Kanga.

var. puberula. Inflorescence. puberulous. Hab. Singapore. Perak, Kwala Kangsa (Wray); Ulu Bubong (Kunstler). Tringganu Pulau Ketam. Kelantan, Kwala Kelantan on Casuarinas. Distrib. India, Java, Sumatra, Borneo.

(I3) E. Barnesii Gamble, Kew Bulletin, I913, p. 45; Journ. As. Soc. Beng. l.c. 378.

Shrub, branches terete, rough. Leaves coriaceous, opposite, lanceolate or oblong-lanceolate, blunt acuminate, base round; nerves very faint; 3 in. long, $I$ in. wide; petioles thick, ${ }^{2} 5$ in. long. Racemes 5 in. long, clustered on the enlarged nodes in axils and ends of branches, 4- to 5-flowered; bracteoles nearly free. Calyxtube, ovoid, channelled. Corolla 4 in. long, slender, angled and dilate below, lobes linear acute, 6. Hab. Very rare, Pahang, K'luang Terbang (Barnes).

(I4) E. Robinsonii Gamble, Kew Bulletin, I9I3, p. 45 ; Journ. As. Soc. Beng. l.c. 379.

Straggling shrub. Leaves coriaceous, red above, green beneath, narrow-lanceolate acuminate at both ends; nerves indistinct, 2 to 3 pairs; 2.75 in. long, 4 in. wide; petioles 05 to $\cdot$ in. long. Racemes in sessile fascicles very small; bracteoles connate in a bifid lip. Calyx-tube ovoid, $\cdot 07$ in. long. Corolla bright orange red, clavate angled and dilate below the lobes; lobes linear-lanceolate, $\cdot 2$ in. long. $H a b$. Pahang, Gunong Tahan (Robinson).

(I5) E. diantha Gamble, Journ. As. Soc. Beng. l.c. 379. Loranthus dianthus King, ibid. lvi. ii. 96 .

Shrub $3 \mathrm{ft}$. high; branches terete, slender. Leaves opposite, thinly coriaceous, lanceolate, long-acuminate, base round; nerves 4 to 6 pairs with reticulations distinct when dry; 6 in. long, I to 3 in. wide; petioles $I$ in. long. Flowers in pairs in the excavations of a very short peduncle with an ovate acute bract and the bracteoles in a thick cup. Corolla narrow, tubular, curved, inflate and 6 -angled below the lobes, 2 in. long, red, lobes twisted oblanceo-

Fl.M. P. 3 . 
late green edged purple. Fruit globular, 45 in. through. Hab. Larut (Scortechini and Kunstler); Relau Tujor (Wray).

(I6) E. Wrayi Kew Bulletin, I9I3, p. 46; Journ. As. Soc. Beng. l.c. 386.

Stout terete branches. Leaves opposite, coriaceous, thick, oblong-lanceolate, blunt, base narrowed, reddish green, 6 in. long, $2 \cdot 75$ in. wide; midrib and 5 to 6 pairs of nerves conspicuous on both sides when dry. Flowers in pairs in a thick short axillary peduncle; bract broad ovate; bracteoles united in a truncate cup. Calyx-tube cylindric, - I in. long; $\operatorname{limb}$ tubular as long. Corolla 2 in. long; tube red, narrow, tubular angled, dilate below lobes; Iobes yellow, base green, narrow lanceolate acute. $H a b$. Rare, Perak, Upper (Wray).

\section{LEPEOSTEGERES; Blume.}

Parasitic shrubs. Leaves opposite or sub-opposite, coriaceous. Inflorescence of a sessile head surrounded by sheathing imbricate involucral bracts lengthening upwards. Flowers few or many, sessile on a flat receptacle. No floral bracts, bracteoles o to 4 . Calyx-tube short. Corolla elongate, sometimes cleft to base, slender, lobes 5 to 6 reflexed. Stamens 5 to 6 insert in corolla mouth; anthers basifixed. Fruit as in Loranthus. Species 6 or 7 , chiefly Borneo and Java.

Inflorescence 5 in. long; corolla-tube very narrow .

Inflorescence 2 in. Iong; corolla-tube stout

(I) L. Beccarii

(I) L. Beccarii Gamble, Joum. As. Soc. Beng. l.c. 38I. Loranthus Beccarii King, ibid. lvi. ii. 98.

Creeping glabrous, 20 to $30 \mathrm{ft}$. long; young branches 4-angled. Leaves ovate-lanceolate to ovate-oblong, 3 in. long, 2.5 in. wide; petioles 5 in. long. Inflorescence on old wood; heads coneshaped, 3 in. long; bracts I in. wide, rounded at tip, red. Flowers 3 in. long, very slender, about 20 , deep red. Fruit globose, 3 in. long. $H a b$. Mountain forests at 2000 to $5000 \mathrm{ft}$. altitude. Perak, Bujong Malacca; Thaiping Hills; Batang Padang (Kunstler). Distrib. Borneo.

(2) L. Kingii Gamble, Joum. As. Soc. Beng. l.c. 382. Loranthus Kingii Scort. King, ibid. Ivi. ii. 99.

Branches stout, terete. Leaves ovate-lanceolate acuminate, base round; nerves inconspicuous; 4 to 5 in. long, 2.25 to 2.75 in. wide; petioles 25 in. long, stout. Heads 4 -angled, I to $I \cdot 5$ in. long; bracts narrowed at tip, red, $\cdot 2$ in. across, keeled; flowers 4 to 6 ; bracteoles linear-lanceolate. Calyx-tube angular, 6-toothed. Corolla scarlet, 2 in. long, broad; lobes $\cdot 25$ in. long, lanceolate acuminate. Fruit ovoid, elongate. Hab. Pahang, Kwala Tenok, Tahan River. Johor, Kota Tinggi. Malacca, Bukit Sadanen; Selandor. Selangor, Sempang. Perak (Burkill), Thaiping Hills, Gunong Hijau (Scortechini); Ulu Batang Padang (Wray). 


\section{GINALLOA, Korth.}

Parasitic shrubs on trees; branches dichotomous, whorled, jointed at nodes with a sheath-like thickening above the nodes. Leaves opposite, coriaceous. Flowers very small unisexual in threes in terminal and axillary spikes; bracts connate. Perianth-tube in male 3-lobed, lobes triangular-ovate, in female oblong; lobes smaller. Stamens 3; anthers ovoid. Stigma sessile capitate. Ovary enclosed in tube I- or 2-ovuled. Drupe with leathery pericarp; lobes persistent. Seed ovoid. Species 9, Andamans, Ceylon, Siam.

(I) G. siamica var. Scortechinii Gamble, Journ. As. Soc. Beng. l.c. 383 .

Leaves ovate or oblong, sub-falcate, blunt, short acuminate, base unequally round or narrowed, 2 to $3 \cdot 2$ in. long, -8 to 2 in. across; ribs 3 , faint; petioles stout, $\cdot 27$ in. long. Spikes terminal, .2 in. long or more. Hab. Very rare, Perak (Scortechini):

\section{KORTHALSELLA, Van Tieghem.}

Leafless parasites; branches jointed, flat. Flowers in axils of scales at the joints unisexual surrounded by tufts of hair; perianthlobes 3 , persistent in female. Anthers 3,2-celled opening longitudinally but being connate with one central aperture. Ovary obovoid, Fruit obovoid. Species about 20, Indo-Malaya, Mascarenes and Polynesia.

(I) K. japonica Engl. and Prantl, Pfanzenfam. Nachtr. I38; Gamble, Joum. As. Soc. Beng. l.c. 384 .

Plant green, 2 to 4 in. tall; joints narrowed at base, $\cdot 2$ to .75 in. long, obovate, all in one plane keeled. Flowers minute in fascicled clusters in cup-shaped bracts at the top of the internodes. Drupe ellipsoid or ovoid, $\cdot 07$ to $\cdot 2$ in. long. Hab. Mountains. Parasitic on rhododendrons and other trees, Malacca, Mt. Ophir. Kedah Peak (Ridley). Distrib. India, China, Japan, Australia.

\section{ARCEUTHOBIUIM, Rich.}

Minute green parasites, usually with jointed stems, a cupshaped double bract at each node with I to more sessile flowers. Males shortly stalked; sepals 2 (or 3 ) ovate; anthers sessile on sepal. Females, ovary elliptic-ovoid; sepals 2, sub-acute. Fruit elliptic crowned by sepals. Parasitic on conifers. Species 5 to 6 , Europe, N. Asia, N. America.

(I) A. dacrydii Ridl. Journ. F.M.S. Mus. vi. I7o.

One inch tall, trichotomously branched; stems obscurely 4-angled, parasitic on Dacrydium Beccarii. Pahang, Gunong Tahan, at 3000 to $5000 \mathrm{ft}$. altitude (Ridley). 


\section{VISCUM, Linn.}

Parasitic shrubs dull green, on trees or on other Loranthacea; branches 2- to 3-chotomous, internodes often flattened. Leaves opposite, fleshy, coriaceous or reduced to small scales. Flowers unisexual, small, fascicled, solitary or in threes in axils or on the nodes; bracts small; bracteoles 2, free or connate in a cup. Perianth-tube adnate to ovary in female, solid in male; lobes 4, short, ovate or triangular. Stamens adnate to them. Ovary I-celled; ovules I or more; stigma sessile. Fruit a succulent, sticky drupe usually white. Species about 30, all regions.

Leafy shrubs parasitic on trees.

Leaves oblong coriaceous, upper branchlets terete

Leaves obovate, very thick, upper branchlets flat .

Leafless shrubs parasitic on Lovanthacece, brittle jointed.

Joints -25 in. wide; flowers fairly large

Joints I 3 in. wide; flowers very small

Joints 05 in. wide; flowers minute

(I) V. orientale

(2) V. Wrayi

(I) V. orientale Willd. Sp. Pl. iv. 737; Bl. Fl. Jav. Loranthacea, t.t. 24, 25; Gamble, Journ. As. Soc. Beng. l.c. 386.

A bushy mistletoe; branchlets terete, dichotomous or opposite. Leaves opposite, coriaceous, obovate or oblong or linear-oblong, blunt, base narrowed; nerves 3 to 5 from base; I.5 to 2.5 in. long, I to I.25 in. wide; petioles very short or o. Flowers in clusters of $I$ to 3 with 2 ovate bracts connate, very small. Drupe white, as large as a pea. Hab. Common. Parasite on Ficus Benjamina and other trees, Singapore, Gardens, etc. Malacca, Merlimau. Perak, Gunong Batu Putih (Wray); Thaiping Hills at $2000 \mathrm{ft}$. altitude.

var, ovalifolium Miq. Leaves larger up to 3 in. long. Flowers solitary in involucres and more numerous in fascicles, Malacca, Tanjong Kling. Perak (Scortechini). Penang Hill (Wallich). Kedah, Pulau Song Song (Curtis). Distrib. Indo-Malaya, China, Australia.

(2) V. Wrayi Gamble, Kew Bulletin, I9I3, p. 47; Journ. As. Soc. Beng. l.c. 387 .

Branches terete below, flattened in alternate directions above. Leaves yellowish green, opposite, thick coriaceous, obovate, tip round, base long-acuminate, I.5 in. long, $\cdot 75$ in. wide; nerves 5 , fine. Flowers in clusters of $I$ to 3 in an involucre of 2 connate bracts, middle one pedicelled. Drupe ovoid, pale green, 2 in. through. Hab. Mountains, Perak, Gunong Batu Putih (Wray). Kedah Peak.

(3) V. dichotcmum Don, Prod. Fl. Nepal. I42; Gamble, Joum. As. Soc. Beng. l.c. 388 .

Leafless much di-trichotomously branched parasite, dull green; branches terete, joints flat, narrowed above and more so at base, 
$\cdot 75$ to $\mathrm{I}$ in. long, $\cdot 25$ in. wide. Flowers small. Fruit globular, white, .2 in. through. Hab. Common, parasitic on $V$. ovalifolium and Loranthi. Hab. Johor. Malacca (Griffith). Perak, Simpang (Wray). Province Wellesley, Tasek Gelugur (Curtis). Distrib. India, Burma.

(4) V. articulatum Burm. Fl. Ind. 3II; Bl. Fl. Jav. Loranthacea, t. 24; Gamble, Journ. As. Soc. Beng. l.c. 389.

Bushy leafless parasite; branches terete, joints above flattened, longer and narrower than in $V$. dichotomum, $I \cdot 25 \mathrm{in}$. long, ${ }^{\prime} \mathrm{I}_{3} \mathrm{in}$. wide. Flowers very minute, often solitary; anthers adnate to base of perianth. Drupe yellowish, I in. through. The commonest species, parasitic on Loranthi, especially L. globosus. Hab. Singapore, Chan Chu Kang, etc. Pahang, Pekan. Malacca. Penang Hill (Kling). Setul. Kelantan, Kota Bharu. Tringganu (Yapp). Distrib. India, Java.

(5) V. flexuosum Gamble, Kew Bulletin, I913, p. 47; Journ. As. Soc. Beng. l.c. 389 .

Much branched bush 2 to $3 \mathrm{ft}$. high with very slender branchlets, linear, hardly flattened, $\mathrm{I}$ in. long, $\cdot 07$ in. wide or less. Flowers minute. Berry globular, white, 08 in. through. Hab. Parasitic on Loranthus, Singapore, Tanglin (Murton, etc.); Fresh Water Isle (Ridley).

Easily recognised by the extremely narrow branchlets.

\section{NOTOTHIXOS, Oliver.}

Hoary or tomentose shrubs parasitic on trees or Loranthacea, dichotomously branched. Leaves opposite, sub-coriaceous. Flowers minute in terminal spikes or sessile and in a row of 3 to 7 on a flattened receptacle, peduncled in the axils. Perianth-tube in male short and solid; in female adnate to ovary; lobes 4 (rarely 3 or 5 ) triangular. Stamens at base of sepals on the margins of a sinuate flat disc; anthers dehiscing introrse by pores. Ovary inferior, crowned by a fleshy disc. Drupe viscid. Seed oblong. Species about 5. Distrib. Ceylon, New Guinea, Australia.

(I) N. malayanus Oliv. Hook. Ic. Pl. t. I519; Gamble, Journ. As. Soc. Beng. l.c. 391 .

Young parts covered with greyish yellow tomentum. Leaves obovate, rounded at tip, base attenuate, scurfy beneath; nerves invisible, 3 from base; I to $\mathrm{I} \cdot 25$ in. long, .5 in. across; petioles .2 in. long. Heads 5 - to 7 -flowered, 05 in. long; flowers in I row, I or 2 male, the rest female. Perianth-lobes 4 . Stamens very minute; filaments very short; anthers broad ovate. Drupe ovoid-oblong. Hab. Rare, Penang, Telok Bahang (Curtis).

\section{Excluded Species.}

N. subaureus Oliver, Joum. Limn. Soc. vii. I03; Gamble, Journ. As. Soc. Beng. l.c. 390. Perak, Logon (Scortechini). Logon is in Australia, where Scortechini formerly collected. 


\section{Dubious Species.}

Nallogia Gaudichaudiana Baillon, Bull. Soc. Linn. Rar. ii. 985 , and Hist. Pl. xi. 478. A glabrous tree with alternate membranous leaves and axillary male flowers in racemes, 5-lobed; anthers dehiscing laterally. Malacca (Gaudichaud).

I cannot guess what this was.

\section{ORDER CXXV. SANTALACEÆ.}

Trees, shrubs (or herbs) many parasitic on branches or roots of other plants. Leaves alternate, opposite, scale-like or o. Flowers small, usually uni- or bi-sexual. Perianth superior or inferior, 3- to 8-lobed. Stamens as many as and opposite to lobes attached to tube. Disc epigynous or perigynous. Ovary I-celled, inferior; ovules 2 to 3 ; style short; stigma entire or lobed. Fruit a drupe (or not). Seed globose or ovoid, rugose or grooved. Species about 240. Whole world (Gamble, Journ. As. Soc. Beng. lxxv. (2), 269).

Climbing shrubs, parasitic; flowers minute .

Leafless parasites with minute flowers

I. Henslowia

Spiny trees; flowers in dense pendent spikes.

Drupe large, pear-shaped

2. Phacellaria

3. SCLEROPYRUM

\section{HENSLOWIA, Blume.}

Parasitic, scandent shrubs usually climbing over bushes. Leaves alternate, fleshy, more or less obovate, narrowed to the petiole and decurrent. Flowers very minute, unisexual (occasionally bisexual), the males in fascicles of cymes or heads or racemose, the females solitary or in small clusters, yellow or green. Male perianth flat, 5- to 6-lobed, valvate. Stamens 5 or 6 insert on the lobes and opposite them; filaments short and thick; anthers introrse. Disc epigynous. Female perianth tubular, globose or oblong, lobes as in male. No stamens, but sometimes staminodes. Ovary inferior, I-celled, 2- to 4-ovuled; stigma sub-sessile. Drupe oblong or ovoid, black or red; exocarp pulpy; endocarp bony, ridged or rugose, protruding $\delta$ to to hard plates into fissures in the lobed seed. Species about 20, Indo-Malayan and Chinese.

A very difficult genus, as the plants seem to vary much, especially in form and size of leaves in different parts, and the specimens preserve badly. They require study in the field. The rugosities of the fruit described here are not visible in fresh fruit, and are taken from dried plants.

Drupe large, $\cdot 5$ in. long.

Leaves broad obovate, 5 -ribbed

Leaves narrow oblanceolate, hardly I in. long.

Drupe not more than 4 in. long, ovoid or ellipsoid.

Leaves 3- to 5-ribbed; drupe 5, furrowed; flowers in axillary umbels .

(I) H. Ridleyi

(2) H. minor

(3) H. umbellata 
Leaves 3 - to 5 -ribbed; drupe unknown; male flowers racemose

Leaves 3-ribbed; drupe smooth ; furrowed:

Leaves 9-ribbed; drupe obscurely furrowed; petiole very thick

Drupe flask-shaped, $\cdot 3$ in. long, smooth; leaves 3 -ribbed, $x$ in. long

Drupe very small, globose.

Flowers fascicled; leaves obovate or orbicular,

green
Drupe short racemes .

Drupe 05 in. through; flowers 1 to 2 in axils, minute

Drupe 'I in. through; whole plant yellow; $a$ small bush erect; flowers nearly sessile on tubercles.

(4) H. philippinensis

(5) H. Wrayi

(6) H. plurinervis

(7) H. Reinwardtiana

(8) H. Lobbiana

(9) H. monticola

(Io) H. varians

(I I) H. buxifolia

(I) H. Ridleyi Gamble, Kew Bulletin, I9I2, p. 20I; Journ. As. Soc. Beng. l.c. 270.

Climbing shrub, rather stout. Leaves coriaceous, obovate or orbicular, tip round, base abruptly narrowed to petiole, glabrous; nerves 3 , the outer ones branched to make 5, nervules obscure; $\mathrm{I} \cdot 5$ to 2.5 in. wide; petioles 3 in. long or very short passing into blade at the top. Flowers rather large for genus, in slender racemes up to $\cdot 8$ in. long, $\cdot 3$ in. through. Hab. Mountains, Pahang, Gunong Tahan (Robinson); K'luang Terbang (Barnes). Selangor, Sempang mines (Ridley).

(2) H. minor Ridl. H. Ridleyi Ridl. Journ. F.M.S. Mus. vi. I70 (not of Gamb!e). (Fig. I49, p. I68.)

A slender climber. Leaves elliptic blunt oblanceolate or obovate; nerves 3 ; coriaceous, greenish yellow, young ones red, - I in. long, 5 in. wide; petioles . I2 in. long. Male flowers in short axillary racemes usually 2 together, yellow; perianth flat, lobes 4 , acute, I in. across. Female flowers solitary on a very short peduncle, red. Fruit 5 in. long, ellipsoid, red then black. Seed indistinctly 5-ribbed. Hab. Pahang, Gunong Tahan at $5500 \mathrm{ft}$. altitude, climbing on bushes (Ridley).

(3) H. umbellata Bl: Mus. Bat. Lugd. Bat. i. 243. Tupeia umbellata Bl. Fl. Jav. Loranthacee, $t$. xxvii, H. varians Gamble, Journ. As. Soc. Beng. l.c. 27I (not of Blume).

Climbing parasite, I5 to $20 \mathrm{ft}$. long. Leaves stiffly coriaceous, oblong-obovate, rounded, narrowed to the petiole and decurrent; nerves 3 ; I to $2 \cdot 5 \mathrm{in}$. long, I to $I \cdot 5 \mathrm{in}$. wide; petioles $\cdot 2 \mathrm{in}$. long or less. Flowers very small, green in few-flowered umbels. Perianth infundibuliform, lobes 5, ovate acute. Fruit ovoid, .25 in. long, on peduncles about . I5 in. long; endocarp rugose, 5-grooved. Hab. Not rare. Usually in sandy places near the sea, Singapore, Chan Chu Kang; Changi. Johor, Tanjong Kupang. Pahang Kwantan (Foxworthy). Malacca, Iringgit; Bukit Bruang. Negri Sembilan, Tampin. Dindings, Lumut. 
Perak, Larut (Kunstler). Province Wellesley, Tasek Gelugur. Penang Hill (Kunstler). Lankawi, Kwah (Curtis). Perlis, Chupeng. Kelantan, Chaning. Distrib. Malay islands, Trang. Native names : Api-Api; Benalu; Bendalu-Bendalu; Akar Sutubal; Akar Simpah Ulat; Telinga Kra (these names are also applied to other species); Akar Ara Ara Batu.

(4) H. philippinensis DC. Prodr. I4, 63I.

Leaves obovate-oblanceolate, rounded, long narrowed at base; nerves 3 with 2 from the outer pair slender; I to I.75 in. long, I in. wide; petioles slender, $\cdot 2$ in. long. Male flowers in slender
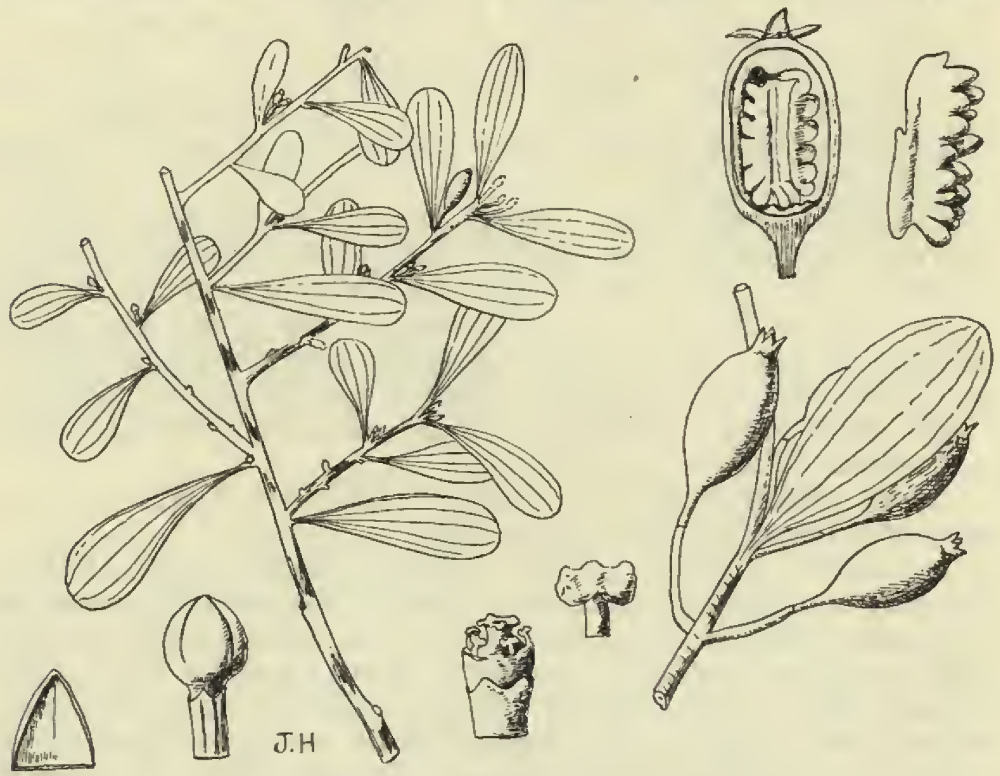

FIG, I 49.-Henslowia minor.

racemes 2 to 5 together in the axils, 4 in. long, shortly pedicelled. $H a b$. Malacca (Cuming 225).

Perhaps a form of $H$. umbellata $B 1$, with the flowers racemose and not umbelled. A specimen from Penang Hill (coll. King) closely resembles it; it was distributed with typical umbellata. Hooker in Fl. Brit. Ind., suggests this plant is $H$. varians $\mathrm{Bl}$. or $H$. spicata $\mathrm{Bl}$., but the latter is practically undescribed.

(5) H. Wrayi Gamble, Kew Bulletin, I9I2, p. 201 ; Journ. As. Soc. Beng. l.c. 272.

Climber Io to I5 ft. long. Leaves elliptic-obovate to orbicular, narrowed or rounded at the tip, decurrent to petiole at base; nerves 3 , prominent (when dry), nervules obscure; I to 3 in. long, $\cdot 75$ to $\mathrm{I} \cdot 75$ in. wide; petioles $\cdot 2$ in. long. Flowers in short 
fascicles of racemes $\cdot 2$ to $\cdot 25$ in. long. Males slender, 3 - to 4 flowered; females thicker; flowers fewer. Tube in male very short, lobes triangular greenish yellow. Drupe ellipsoid-obovoid, -4 in. long, smooth. Hab. Perak, Sungei Larut and Relau Tujor (Wray); Larut (Kunstler).

Hervey's Malacca specimens referred here by Gamble are, I think, $H$. umbellata.

(6) H. plurinervis Boerl. Handl. Fl. Ned. Ind. iii. I8I; Gamble, Journ. As. Soc. Beng. l.c. 272.

Climber. Leaves coriaceous, ovate blunt, base narrowed into the broad petiole; nerves 9 , from base, nervules o; I. 5 to $3 \mathrm{in}$. long, I. 25 to 2 in. wide; petioles 2 to 4 in. long, thick, flat. Racemes .8 in. long, 2 or 3 together. Drupe oblong-globose, 3 in. long; endocarp rugose, green tinted dull red. Hab. Mountains at 2500 to $5500 \mathrm{ft}$. altitude. Pahang, Gunong Tahan (Robinson). Malacca, Mt. Ophir (Maingay). Perak, Gunong Batu Putih (Wray). Disirib. Sumatra.

Gamble has a little doubt as to whether this is Boerlage's species. It is anyway a very distinct plant in its numerous nerves and broad flat petiole.

(7) H. Reinwardtiana Bl. Mus. Bot. Lugd. Bat. i. 244. Tupeia Reinwardtiana $\mathrm{Bl}$. Fl. Jav. Loranthacee, $t$. viii.

Climber $I_{5}$ to $30 \mathrm{ft}$. long, slender. Leaves obovate; nerves 3 , fairly conspicuous; I in. long, $5 \mathrm{in}$. wide; petioles $\cdot I$ in. long. Flowers solitary or racemose, very small, with numerous imbricate bracts at base. Perianth tubular with short ovate lobes; stigma 5-lobed. Fruit flask-shaped, smooth, 3 in. long. Seed with no protuberance of the endocarp into the albumen. Hab. On a large tree in dense forest at Ioo ft. altitude. Perak, Larut (Kunstler). Distrib. Sumatra, Borneo.

Gamble's careful notes and dissections of this curious species have been very useful in describing this. The fruit, as he shows, is quite unlike that of other Henslowias.

(8) H. Lobbiana DC. Prod. xiv. 631; Gamble, Journ. As. Soc. Beng. l.c. 273.

Climbing shrub. Leaves obovate to orbicular, rounded; nerves 3 or more, slender, with branches; I to $2 \mathrm{in}$. long, 5 to $2 \mathrm{in}$. across; petioles rather broad, $\cdot 2$ in. long. Flowers . I in. long, in fascicles of very short racemes about $\cdot 2$ in. long. Drupe globose, 2 in. long, furrowed and wrinkled. Hab. Singapore, Changi. Pahang, mouth of Pahang River. Malacca (Griffith, Maingay). Penang Hill (Lobb, Maingay). Disirib. Malaya.

(9) H. monticola Gamble, Kew Bulletin, IgI2, p. 201 ; Journ. As. Soc. Beng. l.c. 274.

Leaves coriaceous, obovate-spathulate, truncate or emarginate; nerves 3 , outer forked making $5 ; \cdot 75$ in. long, 5 in. across; petioles $\cdot I$ in. long. Flowers bisexual in short axillary fascicles of racemes 
of few flowers. Drupe blue black, $\cdot 07$ in. through, rugose. $H a b$. Mountains, rare. Perak, Ulu Batang Padang at $4900 \mathrm{ft}$. altitude (Wray).

(I0) H. varians Bl. Mus. Bot. Lugd. Bat. i. 244, P1. xliii.

Shrub; branches slender. Leaves elliptic-subspathulate blunt slightly narrowed at top, I.5 in. long, 5 in. wide, sub-membranous; petioles $\cdot 2$ in. long. Flowers minute, solitary or two or three on very short axillary peduncles. Drupe ellipsoid, globose, 05 in. when dry, rugose. Hab. Rare. Kedah Peak at $3500 \mathrm{ft}$. altitude (Robinson and Kloss). Distrib. Borneo.

(II) H. buxifolia Bl. Mus. Bot. Lugd. Bat. i. 224; Gamble, Journ. As. Soc. Beng. l.c. 274. Osyris rotundata Griff. Ic. Pl. As. $t$. 627 , Fig. 2 .

Small erect yellow shrub with twining branches. Leaves fleshy, yellow elliptic-obovate or spathulate blunt or sub-acute, $\mathrm{I} \cdot 5$ in. long, 5 in. wide, upper ones much smaller; petioles $\cdot \mathrm{I}$ in. long. Flowers minute, sessile or very shortly pedicelled on the top of a very short peduncle. Drupe very small, under $I$ in. long, dark red becoming shining black. Hab. Dry open woods, usually near the sea, often a little conspicuous yellow bush, not climbing at all, Singapore, Kranji; Bajau. Johor, Tana Runto. Pahang, Pekan. Malacca, Tanjong Kling (Griffith). Perak, Larut (Kunstler). Tringganu, Bundi (Rostados). Kelantan, Kota Bharu. Penang, Pulau Inajah (Curtis). Distrib. Bangka, Borneo.

2. PHACELLARIA, Benth.

Leafless parasites with fascicled stems. Flowers minute, unisexual, scattered on the branches, solitary or a number together, sessile or sunk in the branch, ebracteate. Perianth male, tube solid; female adnate to ovary; lobes 4 to 8 , valvate; stamens 4 to 5 on the base of the lobes; filaments short, thick; anthercells divergent below. Disc flat. Ovary inferior; style short; stigma entire or 3-lobed; ovules 3. Fruit pulpy, flat. Seed flattened, with 5 grooves. Species 5, Indian and I Malay Peninsula.

(I) P. malayana Ridl.

Stems crowded, flattened, seldom branched, 3 to 4 in. long, - I in. wide, scurfy-red when young. Flowers sessile solitary or 3 to 4 together. Males and females mixed, sunk in the rachis; males cushion-shaped with 4 valvate triangular lobes. Females tubular, $I$ in. long; petals as in male. Fruit $\cdot 22$ in. long with one 5-grooved, flat seed. Hab. Rare, parasitic on a Loranthus at $5000 \mathrm{ft}$. altitude, Selangor, Gunong Mengkuang Lebah (Robinson).

\section{SCLEROPYRUM, Arnott.}

Small trees or shrubs with white bark and strong spines. Leaves alternate, sub-coriaceous. Flowers unisexual in short dense hanging spikes yellowish green. Perianth-tube of male solid, of 
female enclosing and adnate to the ovary; lobes 4 - to 5-valvate. Stamens 4 to 5 ; filaments bifid with an anther-cell on each arm dehiscing transversely. Ovary inferior; ovules 3 ; style short; stigma large, peltate. Fruit a pear-shaped pulpy drupe crowned by the perianth-lobes. Seed I, globose. Species 3 or 4 , IndoMalaya.

\section{Leaves glabrous}

Leaves tomentose beneath

(I) S. Maingayi

(I) S. Maingayi Hook. fil. F.B.I. v. 235; Gamb'e, Journ. As. Soc. Beng. l.c. 276.

Tree 40 to $60 \mathrm{ft}$. tall. Leaves ovate or oblong-ovate, glabrous, blunt or acuminate, base acute or round; nerves 4 to 5 pairs elevate; 6 in. long, 3 in. wide; petioles 25 in. long. Male spikes 2 in. long, rachis pubescent; of hermaphrodite flowers much longer; 7 in. long in fruit. Drupe pear-shaped, I in. through. Hab. Pahang, Sungei Tahan. Malacca, Merlimau (Cantley, Maingay). Penang, Pantai Acheh (Curtis).

(2) S. Ridleyi Gamble, Kew Bulletin, rgr2, p. 202; Journ. As. Soc. Beng. l.c. 276.

Small tree Io to $20 \mathrm{ft}$. tall; bark white; branchlets, inflorescence and underside of leaves white-tomentose. Leaves thick, membranous, ovate to oblanceolate acute or abruptly acuminate, bullate above; nerves 6 to Io, elevate beneath; 4 to 7 in. long, $\mathrm{r} \cdot 5$ to 3.5 in. across. Flower-spikes tomentose; males 2.25 in., females 9 in. long. Perianth-tube cylindric, green-woolly, lobes cream-colour, $\cdot 2$ in. long. Drupe pear-shaped, 3 in. long with a long base dilate at top to I in. through, green. Hab. Dry woods, chiefly near the sea, Singapore, Gardens; Changi; Selitar (Ridley).

\section{ORDER CXXVI. OPILIACE 2 .}

Shrubs (sometimes scandent). Leaves alternate, rather fleshy, petioled. Flowers very small in short axillary spikes bisexual. Perianth campanulate or tubular, 4- to 5-lobed. Stamens as many as perianth-lobes and opposite to them. Disc fleshy, yellow, lining the tube or forming 4 or 5 lobes alternate with the stamens. Ovary superior I-celled, I-ovuled; style cylindric or none; stigma capitate. Drupe red with a hard seed. Species about 20, Asiatic.

These plants have been referred to Olacinece by many authors, but appear to be really more closely related to the Santalacea.

Cymes panicled, slender; sepals free nearly to base.

Stamens exsert

i. Champereia

Flowers racemose or spicate, tubular or campanulate.

Stamens not exsert.

Disc of 4 or 5 lobes

Disc lining the perianth-tube

2. CANSJERA

3. LEPIONURUS 


\section{CHAMPEREIA, Griff.}

Glabrous shrubs or small trees. Leaves fleshy membranous. Flowers in panicles of small cymes usually bisexual, but males occur; sepals 5. Stamens 5. Disc hypogynous, annular or lobed. Ovary immersed in disc. Stigma sessile. Drupe ellipsoid, blunt. Species I or perhaps 2 or 3, Burma and Malaya.

(I) C. Griffithii Hook. fil. F.B.I. v. 236; Gamble, Journ. As. Soc. Beng. lxxv. ii. 277.

A pale-barked shrub about $6 \mathrm{ft}$. tall. Leaves ovate-oblong or lanceolate; nerves 5 to 6 pairs; 3 to 4 in. long, $\cdot 75$ to 3 in. wide. Panicles slender lax, $6 \mathrm{in.}$ long or less, shorter in fruit. Flowers - $\mathrm{r}$ in. wide, pale green, on pedicels $\cdot 2$ in. long, all scattered and few. Drupe orange-yellow, pulpy, $\cdot 5$ in. long. Hab. Common in open woods, Singapore, Changi; Chan Chu Kang. Johor, Bukit Sialu. Malacca (Griffith). Pahang, Pekan. Selangor, Klang Gates; Sungei Buluh. Dindings, Lumut. Perak, Ulu Kerling (Kunstler); Penang, Waterfall; Telok Bahang (Curtis). Lankawi (Haniff). Distrib. Burma, Andamans, Malay isles to Formosa. Native name: Buah Chemperai.

\section{CANSJERA, Jussieu.}

Climbing shrubs. Leaves few-nerved. Flowers in dense axillary spikes; perianth tubular, 4- to 5-lobed. Stamens as many and opposite; anthers small, oblong. Staminodes (disc lobes) 4 to 5, alternate ovoid. Ovary ovoid-conic; style cylindric; stigma 4-lobed. Fruit oblong or globose. Species 4 or 5, all closely allied, India, Cambodia, Malaya.

(I) C. zizyphifolia Griff. Notula, iv. $360, t .537$, Fig. I.

Leaves rather fleshy ovate, base round; nerves 2 from near base and three pairs from midrib; 3 in. long, $\mathrm{I} \cdot 5$ in. wide; petioles - I in. long. Spikes 5 in. long, glabrous. Flowers very small. Drupes globose, red. Hab. Rare, Malacca, Woods near Pringgit (Griffith). Distrib. Borneo.

This species is referred by most authors to $C$. Rheedii, but that has woolly spikes and large pubescent flowers.

\section{LEPIONURUS, Blume.}

Shrubs. Inflorescence spicate axillary. Bracts large caducous. Flowers separate or clustered; perianth urceolate, 4-lobed. Stamens 4. Disc fleshy yellow lining the tube. Ovary oblong conic. Stigma 4-lobed. Drupe red. Species 2, Asiatic.

Spikes dense; bracts ovate sub-acute

Spikes lax; flowers distinct; bracts ovate cuspidate.

(I) L. sylvestris

(2) L. oblongifolius

(I) L. sylvestris Bl. Bijdr. II 48 ; King, Journ. As. Soc. Beng. lxiv. ii. I05.

Shrub about $2 \mathrm{ft}$. tall. Leaves oblong to elliptic shortly 
acuminate, base cuneate; nerves 7 to 9 pairs; 4 to 6.5 in. long, 3.5 in. wide; petioles $I_{5}$ to 35 in. long. Spike dense, up to I.25 in. long. Bracts ovate, longer than flowers. Flowers shortly pedicelled, green. Drupe 5 in. long, oblong, red. Hab. Common in woods. Singapore, Garden Jungle; Changi. Johor, Castlewood. Malacca (Maingay). Selangor, Ulu Gombak. Perak, Larut (Kunstler). Distrib. Java, Borneo.

(2) L. oblongifolius Mast. in Hook. fil. F.B.I. i. 583. var. angustifolius Ridl.

A slender twiggy plant. Leaves thin lanceolate acuminate at both ends; nerves 6 pairs; 4.5 in. long, 1.5 in. wide; petioles very short, winged nearly to base. Racemes very slender, about I in. long. Bracts ovate cuspidate. Flowers distant, very small ; pedicels filiform, longer. Perianth campanulate, globose, dirty yellow, lobes oblong. Hab. Perak, Gunong Kerbau (Robinson). Distrib. Of type form Sikkim and Assam.

Masters and King both confused L. sylvestris with this distinct plant, which is apparently a bigger, more branched plant, and has more slender distant spikes, more distinctly globose flowers and cuspidate bracts.

\section{ORDER CXXVII. BALANOPHORACEÆ.}

Red or yellow parasites on roots with tuberous rhizome and leaves reduced to scales or bract-like. Flowers small in uni- or bi-sexual spikes. Perianth of male of 3 to 8 valvate lobes or absent. Stamens I or many; filaments free or connate. Perianth of female tubular or lobed or absent. Styles I or 2. Ovary globose or ellipsoid, I to 3 locular. Fruit minute, I-seeded. Species about 40, tropics generally, Europe and New Zealand.

Style I; female flower naked

I. BALANOPHORA

Styles 2; female flower with tubular perianth.

2. RHOPALOCNEMIS

\section{BALANOPHORA, Forst.}

Firm fleshy red or yellow herbs with a large tuberous warty rhizome. Peduncles cylindric with large scale-leaves or yellow sub-foliaceous ovate leaves. Spikes uni- or bi-sexual, ovoid or cylindric, dense-flowered. Male perianth stipitate, lobes 3 to 6 , ovate or oblong. Stamens 3, or many, filaments connate; anthers bilocular or connate into a 3 or many locellate mass. Females minute, no perianth, sessile or on the stalks of fleshy cellular bodies (spadicels). Ovary ellipsoid, I ovule; style hair-like. Seed minute. Species I5, tropical Asia and Australia.

Spikes unisexual, thick, red.

Anther-cells 5, horse-shoe-shaped

Anther-cells more than 5 linear.

Rhizome branched, red pustular, anther-cells 20

Rhizome tuberous, brown tessellate; anthercells 12
(I) B. gigantea

(2) B. multibrachiata

(3) B. globosa 
Spikes unisexual, tall, yellow; sepals in 2 dissimilar pairs

Spikes bisexual, slender, yellow

(4) B. truncata

(5) B. insularis

(I) B. gigantea Wall. Cat. 7249; Fawcelt, Trans. Linn. Soc. Ser. ii. (2), $235, t .33$, Figs. 6,7 .

Rhizome tuberous tessellate, lobed, dark orange subterranean. Peduncles 4 in. tall covered with numerous ovate or lanceolate blunt scales, deep red. Male spike cylindric-conic. Flowers dense in small pits; pedicels white. Sepals linear-oblong, truncate, about I in. long, white tipped deep red. Stamen-column white, cells horse-shoe-shaped, 5. Female spike ovoid round-topped, short-peduncled. Hab. In dense mountain forests. Selangor, Semangkok Pass at roots of a fig tree. Perak, Ulu Batang Padang; Kinta (Kunstler); Gunong Kerbau (Haniff). Distrib. Burma, Tonkin.

(2) B. multibrachiata Fanecett, Trans. Linn. Soc. Ser. ii. (2), $236, t .34$, Figs. I5 to I8.

Rhizome dichotomously branched, scarlet, tessellate and papillose. Flowering branches erect about I in. tall, 5- to 6-lobed at top. Male spike about 2 in. long, short-stalked, lax-flowered with a few scale-leaves. Sepals 4, linear-oblong, blunt, $\cdot$ I in. long. Stamen column short; anther-cells 20, linear straight. Female spike oblong-globose, 75 in. Iong, 35 in. wide, short peduncled. Hab. Selangor, Bukit Fraser (Sempang) (Burkill). Perak and Pahang, Ulu Batang Padang; Telom; Gunong Irau (Kloss and Robinson). Distrib. Sumatra.

The brilliant scarlet branching rhizome, largely above ground, looks like scarlet coral.

(3) B. globosa Jungh. Nov. Act. Acad. Cats. Nat. Cur. xviii. Fig. 2.

Tuber subterranean irregular, 6 in. through or less, brown, yellow inside, tessellate, branches short, cone-shaped, lobed, Plants unisexual; peduncles 75 to $I$ in. long, thick with numerous coriaceous ovate scales, dark red. Male spike $\cdot 75$ in. long, shortly protruding from scales, red, rachis stout with horse-shoe-shaped bracts. Flowers sunk in pits, very small. Sepals 5, oblong truncate. Stamen-column ellipsoid with I2 linear cells. Female spike ellipsoid-globose top broad round, 75 in. long, hardly projecting beyond scales. Hab. Mountains, parasitic on roots of conifers, invisible when out of flower. Malacca, Mt. Ophir. Pahang, Gunong Tahan (Robinson); Kluang Terbang (Barnes). Selangor, Semangkok Pass. Perak, Ulu Batang Padang; Telom. Distrib. Java,

(4) B. truncata Ridl. Journ. Limn. Soc. xli. 296.

Rhizome tuberous as large as the fist, subterranean, tessellate and papillose not pustular. Male flower stems 4 to 8 in. tall, slender, dirty yellow. Scale leaves 3 or more at base, lanceolate 
or oblong, blunt. Flower spike lax, 2 to 3.5 in. long. Flowers sessile, .25 in. across, outer lobes 2 , transverse oblong; inner 2 linear-oblong, much smaller, yellow. Stamen-column white, cells linear, very numerous. $H a b$. Dense forests at 3000 or $4000 \mathrm{ft}$. altitude. Selangor, Menguang Gasing (Kloss). Perak, Ulu Batang Padang, parasitic on a big liane (Ridley).

(5) B. insularis Ridl. Journ. Roy. As. Soc. S. Br. xlv. 218.

Rhizome $2 \mathrm{in}$. through, nodular warted. Stems I or more with a small volva split into 4 or 5 round lobes at base, 3 to 3.5 in.

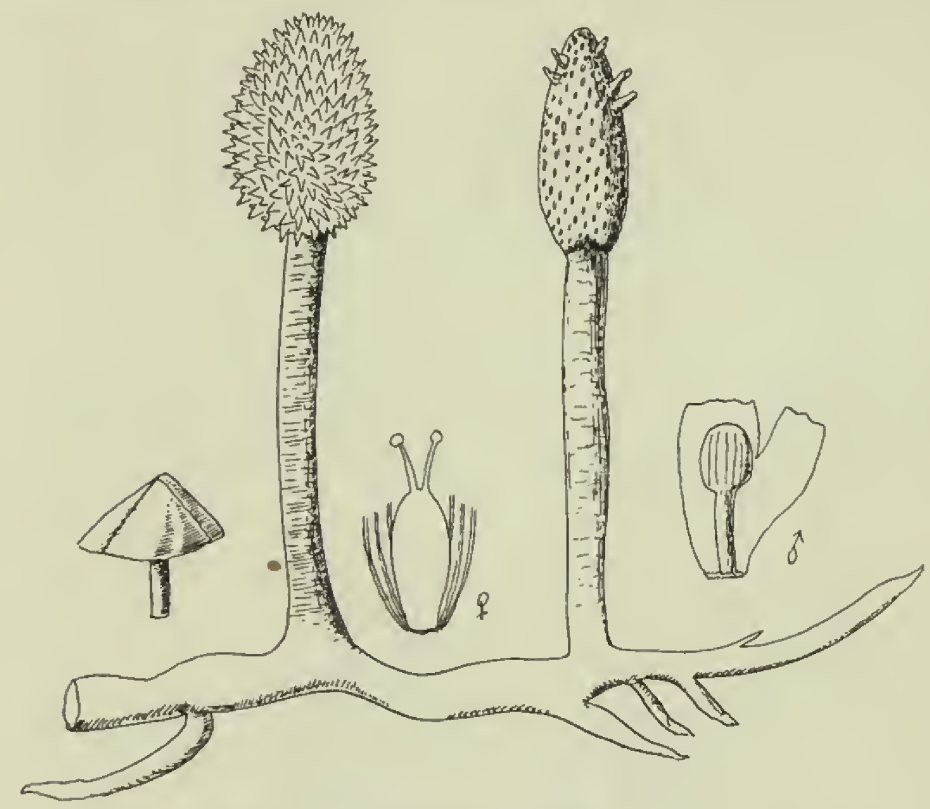

FIG. 150.-Rhopalocnemis ruficeps.

long, slender, lemon-yellow. Scale-leaves oblong-linear, blunt, .5 to .75 in. long, .25 in. wide. Spike with scattered male flowers at base; tip ovoid ellipsoid female. Male flowers very small. Sepals oblong-truncate, upper and lower ones larger than lateral ones. Stamen-head transversely oblong, cells 7 to 8 , hexagonal. Female flowers shortly stalked with numerous obovate spadicels. Ovary obovoid. Seed dust-like. Hab. Pahang, Pulau Aur (Feilding). Perak, Lenggong (Ridley). Distrib. Christmas Island.

\section{RHOPALOCNEMIS, Jungh.}

Fleshy parasitic rhizomatous herbs. Spikes unisexual, sessile or stalked, no scale leaves. Flowers very numerous, minute and 
covered at first by conic stalked umbrella-like red bracts, deciduous. Male (funnel-shaped) or of 4 oblong truncate lobes connate at base. Female tubular (or bilobed). Styles 2; stigmas discoid. Seed small, globose. Species 2, I Java and Himalayas, I Malay Peninsula.

(I) R. ruficeps Ridl. Kew Bulletin, I9I4, p. I88 (Fig. I50, p. I75).

Rhizome elongate terete, over 6 in. long, $\cdot 2$ in. through, orange brown, yellow inside. Stem terete, 3.5 to 3.75 in. long, yellow streaked brown. Head ovoid to cylindric, $\mathrm{I}_{5} 5$ in. or more long, rose pink; bracts bright, red-stalked, cone-shaped, 4- to 6-angled. Male flowers. Sepals 4 shortly connate at base. Stamens 3, connate with about 8 linear cells in an oblong head. Female flowers flat elliptic tubular, all mixed with very numerous filiform hairs. Hab. In dense forest at 2500 to $4000 \mathrm{ft}$. altitude, Perak, Thaiping Hills. Penang, Penara Bukit (Ridley).

\section{ORdER CXXVIII. EUPHORBIACEÆ.}

Trees or shrubs, more rarely herbs, a few twining, frequently laticiferous. Leaves simple (except Bischofia) and usually entire, generally alternate. Flowers unisexual on the same, or separate, spikes, racemes or panicles, often on different plants. Calyx of two or more lobes. Petals usually absent. Stamens free or connate, few or very numerous. Pistillode in male often present. In female flowers, ovary superior, 3-celled, rarely 2-celled. Ovules I or 2 in a cell. Styles 3 or 2, often divided. Fruit a capsule of 3 bivalved cocci separating from a persistent axis, or a drupe or berry with I to 3 cells. Seed laterally attached to the middle of the cell, albuminous (rarely exalbuminous). Species about 3000 , chiefly tropical, rare in cold countries.

Among the cultivated plants to be seen in gardens and plantations are a great variety of cultivated Crotons (Codiaeum) from the Papuan region, Tapioca, Kayu ubi, Cassava or Manioc (Manihot aipi Pohl) from South America and Para Rubber (Hevea braziliensis Mull. Arg.) introduced in 1876 .

A. Cells of ovary 2-ovuled.

i. Euphorbier. Male flowers of one pedicelled stamen numerous surrounding a single-pedicelled female, all enclosed in a cup-like involucre. . . .

I. EUPHORBIA

Flowers separate

ii. Buxinex. Apetalous, sepals 4 in male, 6 in female.

Herbs, trees or shrubs; flowers in axillary

$$
\text { clusters }
$$

2. Buxus

iii. Phyllanthex.

Flowers petaliferous.

Calyx valvate, stamens in a column.

Fruit a drupe; ovary 2 -celled

Fruit capsular; ovary 3 -celled

3. BRIDELIA

4. Cleistanthus 
Calyx imbricate; stamens free.

Shrubs (or trees). Female flowers large. Disc 5-lobed

Herb, flowers small. Disc of Io glands - ix axillary fascicles.

Flowers solitary or in axillary fascicles.
Fruit dry capsular of 3 bivalved cocci

Herb; styles small in excavated top

of ovary
Herbs, shrubs or trees; styles free or united below; disc present, of

Scales or a ring petaloid lobes styles long united

Shrubs or trees; styles long united
in a column, rarely free; disc o

Fruit of 6 cocci; epicarp fleshy white .

Fruit baccate of 3 to 6 hard cocci in a fleshy epicarp.

Sepals 4; stamens 4 ; fruit large; tree Sepals 5 to 6 ; stamens 3 ; fruit large.

Tree; leaves linear
Male flowers turbinate or hemispheric, lobes minute; fruit small;

shrubs or treelets . or discoid,
lobes minute; fruit medium; shrublets

Flowers axillary clustered.

Big trees or shrubs; leaves large stiffly coriaceous.

Leaves alternate; petals o; fruit 2-celled

Leaves opposite; petals 'o; capsule tricoccous; flowers racemose.
5. ACTEPHILA
6. ANDRACHNE

7. Agyneia

8. Phyllanthus

9. Phyllanthodendron

Io. GLOCHIDION

iI. Flueggia

I2. Cicca

I3. Eмblica

If. BREYNIA

I5. Sauropus

I6. DRYPETES

i7. LONGETIA

iv. AntIDEsmine. Trees; flowers in large racemes or in spikes.

Fruit drupaceous; disc circular pulvinate or conic; seeds laterally flattened reticulate; filaments long

Fruit drupaceous; seed not flattened; anthers sub-sessile flowers in cat-

Fruit capsular dehiscent; flowers in catkins; filaments long seed with an

Fruit capsular or baccate; seed with an

aril ; flowers racemose
Fruit a thin white hoary capsule $4^{-}$
valved.

I8. Antidesma

19. DaphNiphyllum

20. Aporosa

2I. Baccaurea

22. SCORTECHINIA

Fruit of 2 broad-winged cocci; flowers in catkins .

23. Hymenocardia

B. Cells of ovary I-ovuled.

Shrub habit of Actephila. Petals 5.

Cells of ovary I-ovuled

24. Actephilopsis

v. JATROPHE.E. Inflorescence of terminal di- or tri-chotomous cymes.

Flowers apetalous. Big tree . . 25. ElATERIOSPERMUM

Flowers petaliferous.

Trees; stamens free . . . . 26. Aleurites

Shrubs, inner or all stamens connate $\quad 27$. JATROPHA

Fl.M.P., 3 . 
vi. Galeariex. Inflorescence axillary or if terminal not dichotomous cymes; male flowers petaliferous.

Stamens opposite sepals; fruit drupaceous.

Racemes of very small flowers long

slender terminal
Flowers yellow in axillary fascicles or cymes. . . . . 29. Microdesmis

vii. Crotonez. Stamens strongly incurved in bud alternate with the sepals.

Shrubs or small trees often glandular; flowers in small racemes; fruit capsular . . . 30. CROTON

viii. Chrozophore. Stamens erect in bud; petals present.

Inner or all stamen-filaments united.

Pistillode on the top of the column - 3I. TRIGONOPLEURA

Pistillode absent.

Stamens 3 to 5 ; sepals not accrescent in fruit Stamens all free.

Trees or shrubs; flowers small in long racemes; anther-cells pendulous from a thickened connective . .

Anther-cells connate.

Trees or shrubs; flowers rather large racemose, no pistillode .

Shrubs; flowers small on long slender pedicels; pistillode capillary . $\quad 36$. ERISmanthus

ix. Acalyphex. Shrubs or trees, rarely herbs; calyx valvate in bud, apetalous.

Stamens free and unbranched.

Anther-cells 2, cells diverging from base, not flexuous.

Shrubs or small trees

Annual herb
Anther-cells 2, flexuous, shrubs or herbs

Anther-cells diverging from apex.

Shrubs or small trees

Anther-cells 2 parallel.

Stamens 3 to 5; flowers in small heads, axillary

Stamens 4 to ro; flowers small, green, racemose; sepals not accrescent

Stamens 5 to I5; flowers large, pink; sepals accrescent, pink

Stamens 2 to 4 ; male flowers in globose heads, very small.

Stamens 20 to very many on or round a large central disc.

Stamens surrounding a central disc; shrub or treelet stellate-pubescent :

Stamen-receptacle glandular lobed; stamenconnective broad, buds globose bursting irregularly.

Stamens I4 to I7: panicles axillary.

Stamens very numerous; panicles terminal

37. Claoxylon

38. Micrococca

39. ACALYPHA

40. Ceelodepas

4I. Cladogynos

42. ALCHORNEA

43. Epiprinus

44. Cephalomappa

45. Caelodiscus

46. Blumeodexdron

47. BOtr YOPHORA 
Stamens receptacle not lobed or glandular.

Racemes long; capsule 3-celled . .

Panicles long lax; sepals and bracts glumaceous, glabrous . . .

Panicles short rather dense redhairy. Capsule 2-celled .

Flowers racemose or panicles short, compact.

Capsule small, slightly 3-lobed

Capsule large, strongly 3 -winged

Anthers 3-or 4-celled.

Racemes stout hairy; anther-cells very unequal; connective broad long. Trees.

Fruit indehiscent

48. Wetria

49. KunstlerodendRoN

50. Melanolepis

5I. Mallotus

52. Coccoceras

Racemes not stout.

Stamens 50 to 60 , cells equal, connective not enlarged. Capsule dehiscent; styles long bifid .

Stamens 30 or fewer, sometimes I to 3 , connective not enlarged.

Stamens not on a receptacle

Stamens on a clavate receptacle

\section{PтусHOPYXis}

54. Cleidion

55. MaCARANGA

56. ENDOSPERMUM

$x$. DALECHAMPIEx. Twining shrubs usually with stinging hairs.

Racemes bisexual; disc o; female calyx

of 3 sepals; styles 3 fimbriate
Racemes unisexual; disc lining male calyx female calyx 5 sepals

Style large globose, 3 -lobed .

Sepals 4- to 6-lobed; stamens 8 to 30.

Fruit with three long wings . . 60 . Pterococcus

xi. Ricinez. Stamen-filaments numerous connate often in bundles.

Shrub. Ieaves palmate, serrate; racemes

terminal bisexual . . 6r. Ricinus

57. CNesmone

58. Tragia

59. Spherostylis

Shrub. Leaves narrow willow-like; racemes axillary; stamens in a globose head

Shrub or tree; leaves elliptic-oblong; racemes axillary; stamens in six bundles. . . 63. Polydragma

xii. Gelonieze. Stamens numerous 5 to 60 on a receptacle.

Filaments united with a large pistillode; fruit echinate ${ }^{2}$.

Filaments free; pistillode minute or o.
Woody shrubs; flowers in clusters, leaf opposed small; leaves entire

Shrubby: flowers in axillary racemes;

leaves toothed or lobed $:$ 66. BALIOSPERMum

64. Chætocarpus

65. Gelonium

xiii. HippomaneÆ. Flowers in uni- or bi-sexual axillary or terminal spikes, racemes or panicles.

Shrubs or trees.

Calyx laterally compressed of 2 sepals.

Racemes axillary; stamens I 2 to I 5 .

Racemes terminal; stamens 6 or fewer

Calyx not compressed, 3-lobed.

Spikes axillary unisexual

\begin{tabular}{c} 
bisexual \\
Herb with very short leaf opposed bisexual \\
spikes \\
\hline
\end{tabular}

67. Pimeleodendron

68. Homalanthus

6o. Exccecaria

7o. Sapium

7I. Sebastiana 


\section{EUPHORBIA, Linn.}

Herbs or shrubs, milky. Leaves simple alternate, or opposite. Inflorescence of one female and many male flowers in a small 4 - to 5-lobed turbinate or campanulate perianth-like involucre, lobes with thick glands in the sinuses; glands often with a petallike white or coloured limb. Male flowers of a pedicelled stamen; anther-cells globose. No perianth (except species 2). Female flowers a solitary pedicelled 3-celled, 3-ovuled ovary; styles 3 , free, or combined simple or bifid. Capsule of 3 bivalved cocci separating from a columella and dehiscing. Species about 600, whole world. Stems thick, fleshy spiny angled; leaves few and
small
Shrub $2 \mathrm{ft}$. tall; leaves fleshy numerous, no spines
Herbs, shrubby only at base; leaves numerous thin . Leaves alternate below, pandurate, half red . Leaves opposite entire, stem stout
(I) E. antiquorum
(2) E. synadenium
Slender herbs, annuals.
Erect. Flowers in axillary heads
Prostrate. Involucres very small, I ' or 2 axillary.
(3) E. heterophylla
(4) E. Atoto
(5) E. hirta
(6) E. thymifolia

(I) E. antiquorum Limn. Hort. Cliff. Ig6; Hook. fll. F.B.I. v. 256 ,

Shrub or short tree, branches 3- to 6-angled, branchlets with 3 to 5 sinuate wings thick and fleshy green. Spines stipular in the sinuses. Leaves few and small, obovate-oblong tip rounded, deciduous. Involucres ternate in short cymes in sinuses. Styles 2-lobed. Hab. Limestone rocks, Lankawi, Kwah, and Pulau Hujong Duri (Curtis). Perlis, Bukit Lagi, Tebing Tinggi (Ridley). Distrib. India. Use: Hard woody part of the stem used in medicine under the name of Tras Sudu.

This plant is also cultivated occasionally. There was formerly in the Old Malacca residency garden a very large tree of this plant believed to date from Dutch occupancy.

(2) E. synadenium Ridl. Journ. Roy. As. Soc. S. Br. 6I, p. 36.

Shrub about $2 \mathrm{ft}$. tall. Branches rather succulent, brown. Leaves alternate oblanceolate spathulate sub-acute or blunt, fleshy dark green; nerves invisible; 4 in. long, $I \cdot 5$ in. wide; petioles $\cdot 5$ in. long. Involucres solitary unisexual. Male on a peduncle $\cdot \mathrm{I} 2$ in. long with 2 ovate purple-pink bracts; involucre pink, lobes thick semi-orbicular, green. Glands Io, truncate oblong laciniate pink. Stamens solitary surrounded by a calyx of about 8 white linear lobes. Female involucre smaller, with 2 pink lobes, glands flat incurved green. Pistil surrounded by a 
laciniate green calyx. Ovary sub-globose stipitate. Styles 3, subulate. Hab. Rocky woods, local, Selangor, Langat (Ridley). Penang Hill near the Waterfall (Curtis, Ridley). Native name: Poko Sesudu Bukit.

I have only seen this plant about $2 \mathrm{ft}$. tall. Mohammed Haniff reports it as growing to 6 to $8 \mathrm{ft}$.

(3) E. heterophylla Linn. Sp. Pl. 453. E. cyathophora Murr. in Comm. Gotting vii. 8 I.

Succulent herb $3 \mathrm{ft}$. tall with erect branches, glabrous. Leaves alternate, opposite above, elliptic-lanceolate, narrowed to the base, 3 in. long, I in. wide, and pandurate with 5 points; leaves round the inflorescence narrow lanceolate. Upper leaves dark green, the lower half bright red. Involucres crowded in the uppermost axils campanulate, I in. long. Stamens long projecting. Capsule smooth trilobed sub-globose top flattened. Hab. Seashores and waste ground. A garden escape now quite established at Tanjong Katong, Singapore. Native of tropical America.

(4) E. Atoto Forst. Prodr. n. 207; Hook. fil. F.B.I. v. 248.

Succulent plant shrubby at the base, about $2 \mathrm{ft}$. tall, glabrous with erect branches. Leaves opposite fleshy elliptic-oblong blunt entire, base rounded, I. 25 in. long, 4 in. wide; petioles very short, hardly .05 in. long. Inflorescences several in pairs terminal or in uppermost axils, 5 in. long, including peduncle. Involucres turbinate, lobes triangular, glands with a very minute limb. Styles bifid. Capsule 08 in. long, trilobed sub-globose, brown, punticulate. Seed whitish globose. Hab. Sandy seashores, common. Singapore, Galang; Tanjong Katong; Changi. Johor, Tana Runto. Malacca, Tanjong Kling (Maingay, Griffith). Pahang, Rumpin; Sungei Meang. Dindings, Pulau Rumpia, Sembilan islands (Kloss). Perak (Scortechini). Penang, Batu Feringhi and Telok Bahang (Curtis). Pulau Adang. Distrib. Tropical Asia to Polynesia. Native name: Jelutong Laut.

I found a plant in Perlis, near Kanga, in which the bracts are very narrow acuminate, the petioles longer, glands linear clubbed, no visible limb, and capsule pubescent; in some respects resembling $E$. hypericitolia, but the leaves are not serrate, and gland limb minute or none. The leaves are much affected by a fungus, which may account for its variation from typical $E$. Atoto.

(5) E. hirta Linn. Amoen. Acad. iii. II4. E. pilulifera Linn. l.c. II5; Hook. fil. F.B.I. v. 250.

Herb, simple or branched from the base, 9 to I2 in. tall, hairy. Leaves opposite oblong-lanceolate, blunt at both ends, obliquely cordate, edges serrate; nerves I pair; hairy beneath, above scabrid hairy, 6 in. long, 25 in. wide; petioles very short. Inflorescence of many flowers in sessile or peduncled heads 25 in. through; 
peduncles 25 in. long or less, hairy. Involucres minute, limb of glands narrow or wanting. Fruit very small globose, hairy. Seeds pale brown angled rugulose. $\mathrm{Hab}$. Common weed in waste ground, Singapore, Tanglin. Malacca (Griffith). Selangor, Rantau Panjang (Kloss); Salak (Seimund). Kelantan, Kwala Lebir. Distrib. All warm countries: Native names: Ambin Jantan; Kurumak Susu; Gelang Susu.

(6) E. thymifolia Burm. Fl. Ind. II2; Thes. Zeylan. t. I05, Fig. 2 ; Hook. fil. l.c. $25^{2}$.

A much branched ustually prostrate herb forming a tuft about 8 in. across, glabrous or somewhat hairy. Leaves opposite oblong, base inæquilateral, tip round, edge at tip serrate, glabrous, I I in. long, 05 in. wide; petioles very small. Stipules fimbriate with a long point. Involucres I or 2 axillary very small, lobes short ciliate, glands stipitate. Capsules small pubescent on a short stalk. Seeds transversely grooved. Hab. Common in paths and gravelly spots, Singapore, Tanglin; Pasir Panjang. Malacca (Griffith); Merlimau (Cantley). Perak, Thaiping (Wray). Native name: Segan Padang.

\section{Cultivated Species.}

E. NERIIFolia Linn. Hort. Cliff. Ig6 part; Hook. fil. F.B.I. v. 255. Shrub or small tree, fleshy; branches jointed obscurely 5-angled, stipular thorns from small tubercles. Leaves subterminal obovate or sub-spathulate. Involucres in small peduncled cymes from sinuses, hemispheric. Styles undivided. Native name: Sesudu. Use: Leaves after extraction of latex by punctures preserved in syrup as a sweetmeat.

E. Tirucalli Limi. Hort. Cliff. I97. Small tree I2 to $20 \mathrm{ft}$. tall, trunk 6 to Io in. through, brown. Branches cylindric green, very milky. Leaves very small, caducous. Hab. Introduced probably from India, a native of Africa. Use : Latex inserted into cuts in bullocks to form the elevated recognition marks.

E. pulcherrima Willd. Allg. Gartenz. ii. 27. Poinsettia pulcherrima Grah. Edinb. N. Phil. Journ. xx. 4I2. Cultivated for ornament.

\section{BUXUS, Linn.}

Trees or shrubs. Leaves small opposite, coriaceous entire. Flowers in very short dense axillary racemes, apetalous. Male flowers 4 in 2 rows imbricate. Stamens as many opposite them; anthers dorsifixed. Female flowers, sepals 6, 2 outer smaller. Ovary 3-celled; styles 3; ovules 2 in a cell. Capsule ovoid 3-valved. Styles persistent, endocarp splitting from exocarp. Seeds oblong black. Species 20, temperate and tropical regions.

(I) B. rupicola Ridl. Joum. Roy. As. Soc. S. Br. 59, p. I66.

Shrub; bark pale corky. Leaves elliptic-oblanceolate blunt, base narrowed stiffly coriaceous, $2 \cdot 25$ to 3 in. long, 75 to $I$ in. 
wide; petioles $\cdot 25$ in. long, winged to base. Male flowers on pedicels $\cdot I$ in. long. Sepals triangular ovate blunt. Female flowers terminal on racemes I2 in. long. Styles short thick recurved. Hab. On bare rocks by the sea, Lankawi, Dayong Bunting (Curtis).

\section{BRIDELIA, Willd.}

Shrubs or small trees. Leaves alternate entire. Flowers small or minute in axillary spicate clusters bracteate, sessile or very shortly pedicelled. Calyx 5-cleft, lobes valvate. Petals much smaller. Disc broad pulvinate or adnate to calyx in male; conical truncate membranous enclosing ovary in female. Stamens 5; filaments connate below with a pistillode on the columnar base, free above spreading. Ovary I-(rarely 3-)celled; ovules 2 in a cell. Styles 2 forked; Drupe with I or 2 one-seeded cocci or pyrenes. Species 3o, tropics of Africa, Asia, Australia.

Flower-clusters in axils of stipular bracts.

Female disc bristly.

Leaves red-pubescent beneath .

Leaves glaucous glabrous beneath

Flower-clusters without stipular bracts.

Disc glabrous.

Leaves lanceolate glaucous beneath .

Leaves ovate or elliptic not glaucous.

Glabrous beneath

Leaves tomentose or pubescent beneath.

Fruit sub-globose

Fruit elliptic.

Leaves softly red-tomentose beneath

Leaves minutely pubescent beneath. Flowers small, female petals red-hairy Flowers minute; petals glabrous

\section{(I) B. stipularis \\ (2) B. retusa}

(3) B. tomentosa

(4) B. ovata

(5) B. pustulata

(6) B. cinnamomea

(7) B. Griffithii

(8) B. penangiana

(I) B. stipularis Bl. Bijdr. 597; Hook. fil. F.B.I. v. 270.

A large bush about I2 ft. tall; branchlets velvety tomentose (red when dry). Leaves thinly coriaceous elliptic blunt, bases broad above glabrous, beneath red-tomentose; nerves 9 to Io pairs and small reticulations conspicuously elevate beneath; I.5 to 3.5 in. long, I to I.5 in. wide, the terminal shoot-leaves smaller; petioles I I to $\cdot 2$ in. long, tomentose. Heads of flowers axillary on the ends of shoots. Bracts and stipules ovate hairy. Calyx - I in. long, lobes lanceolate acute glabrous enlarging to $\cdot 2$ in. long in fruit. Petals orbicular. Disc pulvinate in male, urceolate in female with a ring of bristles at base. Drupe oblong 4 in. long, green turning black. $H a b$. Open country, often near streams, common. Singapore, Macpherson Road; Galang. Johor, Batu Pahat. Muar (Curtis). Pahang, Pulau Rumput, Pahang River. Malacca, Merlimau (Cantley, Griffith, Maingay). Selangor, Port Swettenham (Burkill). Perak (Scortechini). Penang (Wallich). Distrib. India, Malay islands, Philippines. Native names: Chindarai Gajah; Kenidei Babi. 
I do not remember ever to have seen this plant scandent, as Hooker says it is. 268.

(2) B. retusa Spreng. Syst. Veg. iii. 48; Hook. fil. F.B.I. v.

Large tree. Leaves elliptic-oblong, tip and base round glabrous sub-coriaceous; nerves I3 to I5 pairs with numerous transverse parallel nervules and fine not elevate reticulations; sub-glaucous beneath, 4 to 6 in. long, 2.5 to 3.5 in. wide; petioles $\cdot 2$ in. long. Flower-heads $\cdot \mathrm{I}_{2}$ in. wide. Flowers as large as in $B$. stipularis on short silky pedicels. Calyx-lobes ovate acute, tube and back of lobes silky. Petals in males orbicular crenate; in females oblong-sub-spathulate toothed. Fruit globose purple black the size of a pea. Hab. Lankawi, Dayong Bunting (Robinson). Distrib. India, Siam.

I have only a spray in female flower, and it differs slightly from the Indian ones in being more glabrous with silky bracts and pedicels.

(3) B. tomentosa Bl. Bijdr. 597; Hook. fil. F.B.I. v. 27 I.

A small tree. Branches slender shortly rough-hairy. Leaves thinly coriaceous elliptic-lanceolate acuminate blunt, base shortly narrowed blunt, above glabrous except midrib, beneath grey hairy on the ro pairs of nerves, midrib and reticulations, 4 in. long, I. 2 in. wide; upper leaves on shoots I.5 in. long, 5 in. wide; petioles $I$ in. long hairy. Heads of flowers axillary on ends of shoots I5 in. through. Bracts glabrous, edges ciliate. Flowers very small. Calyx-lobes triangular acute. Petals much smaller, sub-flabelliform. Disc circular. Female flowers slightly larger. Petals minute. Disc glabrous. Fruit sub-globose black, 'I in. through. Hab. Damp open spots; common. Singapore, Tanglin; Bukit Timah; Garden Jungle. Johor, Bukit Muar (Feilding). Malacca, Bukit Panchur (Cantley); Sungei Hudang (Goodenough); Chabau (Griffith). Negri Sembilan, Tampin. Selangor, Batu Caves; Kwala Lumpur. Dindings, Pangkor. Perak, Thaiping Waterfall, and Kampar (Kunstler). Province Wellesley, Tasek Gelugur. Penang Hill (Curtis). Kelantan, Chaning Woods (Ridley). Lankawi, Kwah (Curtis). Distrib. Indo-Malaya. Native name : Kenidei jantan.

(4) B. ovata Decne. Nouv. Ann. Mus. Par. iii. 484. B. Curtisii Hook. fil. F.B.I. v. 273. B. pedicellata Ridl. Journ. Roy. As. Soc. S. Br. 59, p. 167 .

Small tree, glabrous. Leaves elliptic round at tip and base; nerves ro pairs slender, reticulations close and conspicuous; 3.5 in. long, $\cdot 2$ in. wide; petioles $I$ in. long. Heads of few flowers. Bracts small triangular acute. Calyx-lobes deltoid-lanceolate acute glabrous. Petals ovate or obovate. Disc saucer-shaped. Female flowers as in male, but calyx more shortly divided. Disc edge crenulate. Fruit pulpy black, 2 in. long; pyrenes hemispherical. Hab. Open country in the north. Penang, Batu 
Feringhi and Telok Bahang (Curtis). Lankawi (Ridley). Perlis, Bukit Lagi. Distrib. Timor, Australia.

(5) B. pustulata Bl. Bijdr. 597; Hook. fil. F.B.I. v. 27 I.

Tree about $60 \mathrm{ft}$. tall. Branchlets thick pustular. Leaves coriaceous elliptic-oblong to ovate sub-acute, base round or cuneate above glabrous beneath the midrib and 8 pairs of nerves sparsely hairy; young leaves with reticulations also hairy beneath and midrib above; 5 to $6 \mathrm{in}$. long, 2 to 3 in. wide; petioles $\cdot 25$ in. long, glabrous. Heads $\cdot 2$ in. wide. Bracts ovate acute ciliate. Flowers yellow. Calyx-lobes triangular-ovate acute. Petals scalelike emarginate, very small in females. Styles 2 -forked at tip. Drupe globose stalked black, 'I2 in. long. Hab. Forests, Singapore Garden Jungle; Sungei Jurong. Johor, Kota Tinggi ; Castlewood. Malacca (Maingay, Griffith); Selandor (Cantley). Selangor, Kwala Lumpur. Perak, Goping (Kunstler). Penang, Penara Bukit; Waterfall (Curtis). Native names : Kenidei Gajah; Kenidei hutan.

(6) B. cinnamomea Hook. fil. F.B.I. v. 273.

A thorny shrubby climber Io to ${ }_{5} \mathrm{ft}$. long with pale bark and short stout thorns on the lower part of the stem. Branchlets hairy. Leaves sub-coriaceous elliptic blunt or sub-acute, base slightly narrowed above, glabrous except base of midrib, beneath covered with coppery hairs; nerves 8 pairs; 3.5 in. long, $\mathrm{x} \cdot 5$ in. wide; petioles $\cdot 2$ in. long, woolly. Heads of flowers $\cdot 2$ in. through. Bracts woolly. Calyx $\cdot \mathrm{I}_{2}$ in. long, glabrous dark red on a pedicel as long, lobes ovate-lanceolate. Petals obovate. Disc thick flat. Drupes unknown. Hab. Open jungle, Perak, Ulu Bubong, Batang Padang district and near Gunong Mesan in Kinta (Kunstler). Distrib. Borneo.

A very distinct plant reduced by Jablonsky in Pflanzenreich, p. 74, to $B$. Griffithii, from which it is very different.

(7) B. Griffithii Hook. fil. F.B.I. v. 272.

Scandent shrub with long branches; branchlets hairy or glabrous pustulate. Leaves thinly coriaceous elliptic-oblong acuminate, base shortly narrowed; nerves 8 pairs elevate beneath, puberulous, midrib above often hairy at the base; 3 to 4 in. long, $\mathrm{I} \cdot 5$ to $2 \mathrm{in}$. wide; petioles hairy, $\mathrm{I}$ in. long. Heads of flowers $\cdot 2$ in. wide. Bracts minute. Calyx-lobes ovate pubescent or glabrous yellow, tube villous. Petals minute entire in female, sometimes lobulate in males. Male flowers, stamens 5, tube short. Pistillode of 2 carpels glabrous. Disc large pulvinate entire. Female flowers, disc crenulate. Ovary ovoid glabrous. Styles short. Fruit unknown. Hab. Johor, Kota Tinggi (Ridley). Malacca, Alor Gajah (Griffith).

(8) B. penangiana Hook. fll. F.B.I. v. 272. B. minutiflora Hook. fil. l.c. 273 .

Tree 20 to $30 \mathrm{ft}$. tall, glabrous. Leaves sub-coriaceous elliptic 
oblong, shortly cuspidate or acuminate, base shortly cuneate; nerves 9 pairs, midrib and nerves beneath sparsely hairy; 2 to 4.5 in. long, 75 to $2 \cdot 5$ in. wide; petioles $\cdot I$ in. long. Heads $\cdot r$ in. through, flowers small. Bracts pubescent. Sepals ovate pubescent. Petals broad oblong crenate very small. Disc flat saucer-shaped in male. Style forked at tip. Drupe ovoid acuminate, style forming a beak, black, ${ }^{\prime} 5$ in. long. Hab. Perak, Pondok Tanjong (Burn-Murdoch); Ulu Kerling (Kunstler). Penang Hill (Curtis); Ayer hitam (Haniff). Distrib. Mergui, Malay islands.

\section{CLEISTAN'THUS, Hook. fil.}

Trees or shrubs. Leaves alternate, usually thinly coriaceous, entire. Flowers smaller minute in axillary clusters or spikes, sessile or females pedicelled. Calyx 5-lobed valvate. Petals as many minute. Disc in male flat or pulvinate, in female conic or turbinate. Stamens 5, filaments in a column in centre of disc with a pyramidal or 3 -lobed pistillode at the tip, free and spreading above. Ovary 3-celled usually hairy. Styles 3, bifid; ovules 2 in a cell. Capsule sub-globose or depressed of 3 cocci, dehiscing. Seeds exarillate. Species IIo, Africa, Indo-Malaya.

Flower-clusters in the axils of 2-winged bracts

Flower-clusters with no 2-winged bracts.

Flowers elongate, pedicelled; fruits on long slender pedicels.

Flowers sessile or nearly so.

Leaves glabrous glaucous beneath.

Leaves ovate abruptly caudate.

Leaves lanceolate elongate acuminate.

Leaves membranous

Leaves coriaceous shining : .

Leaves glabrous not glaucous.

Calyx pubescent or hairy.

Leaves membranous greenish yellow

Leaves coriaceous not greenish yellow.

Petals hairy

Petals glabrous.

Leaf-base round

Leaf-base acute

Flower-clusters minute on very slender

panicled branches. Calyx glabrous.

Leaves membranous

Leaves coriaceous.

Leaves lanceolate acuminate. ․ . (I I) C. heterophyllus

Leaves ovate abruptly caudate

Flower-clusters not minute
branchlets.

Stipules persistent aculeate

Stipules caducous.

Leaves rounded at base; nerves not inarching, glaucescent beneath (I4)
(I) C. bracteosus

(2) C. pedicellatus

(3) C. glaucus

(4) C. membranaceus

(5) C. nitidus

(6) C. flavescens

(7) C. hirsutopetalus

(8) C. podocarpus

(9) C. glandulosus
(I 2$)$ C. gracilis

(13) C. siamensis

C. parvifolius 
Leaves narrowed blunt at base; nerves inarching, glabrous, not glaucescent glabrous.

Leaves acute, at base glabrous.

Leaves membranous moderate size .

Leaves coriaceous very large
Leaves thinly coriaceous, 4 in. long

Leaves puberulous or tomentose beneath.

Leaves glaucous beneath.

Petiole very stout tomentose.

Petioles not stout or tomentose.

Nerves Io to 15 pairs.

Nerves 5 to 8 pairs.

Leaf-base acute

Leaf-base round.

Tipround or shortly acuminate

Tip caudate

Leaves grey papillose beneath; nerves 6 pairs

Leaves not glaucous beneath.

Pubescence minute closely appressed.

Nerves 13 to 20 pairs, coppery beneath .

Nerves 8 to ro pairs, silky pubescent beneath

(I 5) C. albidiscus

(I6) C. decurrens

(I 7) C. macrophyllus

(I8) C. sumatranus

Nerves 6 pairs, sparsely hairy on midrib beneath

Pubescence rufous dense.

Leaves cuspidate or acute, base narrowed.

Leaves cuspidate, base broad more densely pubescent, larger .

(19) C. lanuginosus

(2o) C. hirsutulus

(2I) C. prætermissus

(22) C. polyphyllus

(23) C. Maingayi

(24) C. Kingii

(25) C. myrianthus

(26) C. pseudomyrianthus

(27) C. ellipticus

(28) C. perakensis

(29) C. rufus

(I) C. bracteosus Jabl. Pfanzenreich, l.c. 4I.

Small tree; branchlets red-villous. Leaves coriaceous glabrous above, red-tomentose beneath, elongate-lanceolate or oblong acuminate, base acute; nerves I2 to I6 pairs, nervules obscure, not parallel; Io to I 2 in. long, 2.5 to 3.75 in. wide; petioles thick, .6 to .75 in. long. Flower heads spicate; rachis villous. Bracts concave as long as flowers or longer, fleshy, hairy on the back or not. Male flowers glabrous. Petals ovate. Female flowers. Petals obovate spathulate. Pistillode glabrous. Disc irregularly toothed. Capsule 5 in. long on a stipes half as long, glabrous, 3-lobed crimson turning black. Hab. Perak (Scortechini, Wray); Kota Bharu and Goping (Kunstler).

I have not seen this species.

(2) C. pedicellatus Hook. fil. F.B.I. v. $28 \mathrm{I}$.

A small tree quite glabrous. Leaves coriaceous drying nearly black elliptic-oblong or oblong blunt caudate, base round or shortly narrowed; nerves 3 to 5 pairs slender, nervules and very small reticulations conspicuous on both sides; 3.5 to 4.5 in. long, $I .5$ to 2.25 in. wide; petioles ${ }^{\prime} 5$ in. long. Heads of 6 or more flowers, bracts very small. Flowers on pedicels 25 in. long, stout. Calyx-lobes ovate, thick. Petals spathulate dentate. Disc crenu- 
late in male. Capsule 5 in. long on a pedicel 5 in. long, all glabrous. $H a b$. Forests, Perak, Thaiping (Wray). Penang Hill at 700 to Iooo ft. altitude (Hullett, Curtis).

(3) C. glaucus Jabl. Pfanzenreich, l.c. 25.

Tree 30 to $40 \mathrm{ft}$. tall, glabrous except the extreme tips of branches hairy. Leaves thin coriaceous elliptic cuspidate acuminate, base round; nerves 7 pairs, very faint; 2 to 3 in. long, 5 to I in. wide; petioles very short. Stipules setaceous, very abundant and persistent on the slender flowering shoots. Male flowers not seen. Female flowers in very small heads. Calyx hairy outside, lobes ovate. Petals orbicular or rhomboid. Disc annular. Ovary pilose. Capsule 3-lobed. Hab. Forests, Dindings, Lumut (Ridley). Perak, Goping, Limestone Hills (Kunstler).

(4) C. membranaceus Hook. fil. F.B.I. v. 278 . C. stipulatus Hook. fil. l.c. $28 \mathrm{I}$.

Tree with spreading branches $I 5$ to $30 \mathrm{ft}$. tall, 4 to 8 in. through; branchlets slender pubescent-hairy. Leaves membranous, glabrous elliptic, oblong or oblong-lanceolate, obtusely acuminate or cuspidate glaucous beneath; nerves Io to 15 pairs, very slender and faint; $\mathrm{I}$ to 4 in. long, 4 to $\mathrm{I} \cdot 5$ in. wide; petioles $\cdot 05$ in. long. Stipules acicular persistent, $\cdot \mathrm{I}$ to $\cdot 25$ in. long. Flowers very small pale green in small clusters. Bracts minute. Calyx-lobes ovate, glabrous in male, hairy in females. Petals in males obcuneate, in females rhomboid. Disc in male pulvinate lobed, in female a short crenulate cup. Capsule $\cdot 3$ in. long, lobed sub-globose hairy. $H a b$. Dense forests at 300 to $500 \mathrm{ft}$. altitude. Perak, Larut (Kunstler). Penang, Balik Pulau and Waterfall (Curtis).

(5) C. nitidus Hook. fll. F.B.I. v. 280.

Tree. Branches slender closely pubescent. Leaves coriaceous glabrous, oblong-lanceolate or oblanceolate caudate-acuminate, edges undulate, base caudate shining above, glaucescent beneath; nerves 8 to I2 pairs slender; 4 to $6 \mathrm{in}$. long, I to $\mathrm{I} \cdot 25$ in. wide; petioles $\cdot 8$ in. long, densely red-woolly. Heads small, $\cdot I$ in. through; flowers few, sessile. Calyx-lobes ovate acute densely hairy. Petals in male flabellate crenulate, in female obovate. Disc in male pulvinate, in female tubular densely hairy. Pistillode in male hairy, lobed. Styles 3, bifid. Capsule round-oblong slightly 3 -lobed, red hairy, 25 in. long. Hab. Hill forests, Penang, Waterfall (Curtis).

var. Curtisii Ridl. C. Curtisii Jabl. Pfanzenreich, l.c. 22. Branchlets densely red velvety. Leaves all 3 in. long, $I$ in. wide. Penang, Batu Feringhi (Curtis). Native name: Sabasal Batu.

The specimens labelled Singapore, Lobb, were no doubt collected in Penang.

(6) C. flavescens Jabl. Pfanzenreich, iv. I47; viii. I9.

A small tree I5 ft. tall; branchlets glabrous. Leaves membranous or thinly coriaceous elliptic, 2 to 6 in. long, I to 2.5 in. 
wide, acuminate, base acute, glabrous or with sparse minute hairlike scales on midrib and nerves; nerves 7 to Io; petioles slender, - I to $\cdot 2$ in. long. Flower clusters of few male or female flowers. Bracteoles ovate. Male flowers sessile. Calyx rusty-pubescent, lobes deltoid. Petals sub-quadrate. Female flower; petals flabelliform. Disc sub-crenulate. Ovary globosely ovoid, densely hairy. Capsule pale brown appressed hairy, 25 in. long. Hab. Perak, Goping (Kunstler), Gunong Keledang (Ridley).

(7) C. hirsutopetalus Gage, Kere Bulletin, I9I4, p. 239.

Tree about $30 \mathrm{ft}$. tall, glabrous. Leaves coriaceous narrowly ovate-elliptic or lanceolaté sub-caudate acuminate, base round or sub-cuneate with two small swellings at petiole; nerves 6 to 8 ; $2 \cdot 75$ to $7 \cdot 25$ in. long, 3 to $I \cdot 3$ in. wide. Stipules lanceolate caducous. Flower clusters of few male or female flowers. Bracteoles ovate or lanceolate. Male flowers unknown. Female flowers sessile. Calyx hairy. Sepals deltoid or lanceolate. Petals obovate entire, hairy outside. Disc annular membranous toothed. Ovary ovoid hairy. Capsule sub-sessile on a short stout obconic pedicel hairy at the base, smooth light brown, $\cdot 3$ in. long. Seed sub-orbicular-ovoid. Hab. Negri Sembilan, Bukit Tumiang (Cantley). Penang, Penara Bukit (Curtis).

(8) C. podocarpus Hook. fil. F.B.I. v. 28I.

Tree 50 to $70 \mathrm{ft}$. tall, Io to ${ }_{5} 5$ in. through. Branchlets pubescent tomentose. Leaves thinly coriaceous, glabrous lanceolateoblong to oblong-acuminate, base cordate; nerves elevate 8 to Io pairs, nervules transverse conspicuous; 6 to 9 in. long, 2 to 3 in. wide; petioles 25 in. long, glabrous. Flowers few in heads nearly $\cdot 2$ in. wide. Male flowers not seen. Female flowers, calyxlobes ovate-triangular villous-tomentose outside. Petals cuneate. Disc with crenulate edge. Capsule stoutly stipitate, $\cdot 5$ in. through when ripe, broader than long, deeply 3-lobed entirely rusty-villous. $H a b$. Rocky open jungle at 300 to $500 \mathrm{ft}$. altitude. Perak, Larut (Kunstler).

(9) C. glandulosus Jabl. Pfanzenreich, I8.

Small tree glabrous. Leaves elliptic acutely cuspidate, base acute; nerves fine about ro pairs, nervules and lax reticulations elevate beneath; 3 to 3.5 in. long, I to I.5 in. wide; petioles wrinkled, $\cdot 2$ in. long. Stipules lanceolate setaceous. Flowers few in small clusters. Sepals ovate acute pubescent outside. Petals widely spathulate or fan-shaped. Disc upper part free, Io-lobed, lobes between the petals broad rounded, lobes in front of the petals, small narrower. Stamen-tube short. Pistillode conic, glabrous. Female flowers and fruit unknown. Hab. Hill forest, Perak, Gunong Keledang (Ridley).

(Io) C. malaccensis Hook. fil. F.B.I. v. 277 .

Glabrous except the flowering shoots, red-tomentose. Leaves thinly coriaceous, elliptic-oblong or lanceolate, caudate-acuminate, 
base acute; nerves 4 to 6 pairs slender; 6 in. long, $2 \cdot 1$ in. wide; petioles $\cdot 15$ in. long. Heads on lateral branches 05 in. through. Bracts orbicular, hairy. Male flowers, sepals ovate, in females lanceolate acute. Petals in males spathulate, in females rounded. Disc in male pulvinate, in female tubular. Ovary hairy. Fruit glabrous, $\cdot 3$ in. long. Seed trigonous-ovoid brownish black, back convex, base blunt, tip acute. Hab. Singapore, Chan Chu Kang; Selitar (Ridley). Malacca (Maingay).

(II) C. heterophyllus Hook. fil. F.B.I. v. 276 . C. læevis Hook. fil. l.c. 277.

A small glabrous tree $30 \mathrm{ft}$. tall. Leaves coriaceous of two forms, the larger on the main branches elliptic to elliptic-lanceolate caudate-acuminate, nerves prominent beneath 4 to Io pairs; 5 to 6 in. long, 2 to 3 in. wide; small leaves on flowering sprays lanceolate, .5 to $.75 \mathrm{in}$. long, I to $\cdot 2 \mathrm{in}$. wide; petioles of large leaves $\cdot 25$ in. long. Flowers minute on very small clusters on very slender axillary and terminal branchlets 3 to 6 in. long. Calyx-lobes ovate acute in male, blunt in female. Petals narrow. Disc urceolate in female. Ovary hairy with long erect hairs. Styles 3 bifid. Fruit globose lobed, I·35 in. long, pink, exocarp completely separating. Seed ellipsoid brown, $\cdot 25$ in. long, keeled. Hab. Forests, rather scarce, Singapore, Changi; Bajau (Ridley); Botanic Gardens (Murton). Malacca (Maingay); Bukit Bruang (Curtis). Pulau Tiuman, Juara Bay (Burkill). Native name: Jarak Pipit.

(I2) C. gracilis Hook, fil. F.B.I. v. 277. C. dasyphyllus Williams, Bull. Herb. Boiss. v. 3 I.

A small bush about $4 \mathrm{ft}$. tall with very slender twigs. Leaves coriaceous elliptic caudate, base blunt, dark shining green, glaucescent beneath; nerves about 3 pairs faint; 2 to 3 in. long, 75 to I.25 in. long; petioles.$I$ in. long. Flowers few in small heads, male and female together. Calyx-lobes lanceolate. Petals in male minute linear, in female elliptic. Pistillode on stamen column hairy. Disc in female conoid. Capsule $\cdot 5$ in. long, glabrous. Seeds ovoid-oblong, back convex, keeled. Hab. Perak (Scortechini). Lankawi isles (Robinson); Kwah (Curtis).

var. parvifolia; leaves elliptic-ovate, $\mathrm{I} \cdot 5$ in. long, $5 \mathrm{in}$. wide. $H a b$. Limestone rocks, Pahang, Kota Glanggi. Kedah (Kunstler). Lankawi, Kwah (Curtis). Perlis, Tebing Tinggi (Ridley).

The small-leaved form is the commonest and forms an elegant little compact bush. Kunstler gives the Kedah plant as 15 to $25 \mathrm{ft}$. tall. The form from Kwah, the type of Williams' C. dasyphyllus, is a round-leaved form with a very marked cusp.

(I3) C. siamensis Craib, Kere Bulletin, r913, p. 7I. C. penangensis Jabl. Pflanzenreich, l.c. $2 \mathrm{I}$.

Shrub 6 to $15 \mathrm{ft}$. tall (Siam), branchlets red-tomentose. Leaves chartaceous lanceolate acuminate, base narrowed blunt; nerves 8 pairs slender; 3 in. long, $\mathrm{I}$ in. wide (in Siamese specimens 6 in. 
long, 2 in. wide); petioles very short. Stipules setaceous from a broad base. Flowers 4 or 5 together. Bracts small setaceous, glabrous. Sepals ovate blunt glabrous. Petals transversely oblong, cuspidate acuminate or tricuspidate. Ovary white-hairy. Capsule .25 in. long, glabrous. Hab. Penang, Waterfall (Curtis); Balik Pulau (Ridley). Distrib. Siam.

(I4) C. parvifolius Hook. fil. F.B.I. v. 28r.

Small tree 30 to $40 \mathrm{ft}$. tall, 4 to 8 in. through, glabrous, branches short. Leaves thin coriaceous elliptic-lanceolate shortly bluntly acuminate, base shortly narrowed blunt, glaucescent beneath; nerves ro to I2 pairs very obscure. Male flowers unknown. Female flower sessile apparently solitary. Bracts minute. Calyxlobes deltoid-lanceolate. Petals obovate-spathulate, tip crenulate or retuse. Capsule $\cdot 25$ in. through, sub-globose, 3-lobed, sessile hairy at base and tip and in the furrows, light brown. Hab. Top of limestone hills at 500 to Iooo ft. altitude, Perak, Goping (Kunstler).

(I5) C. albidiscus Ridl. Kew Bulletin, I923, p. 360.

Small tree, branches and leaves glabrous. Leaves Ianceolate acuminate, base blunt thinly coriaceous, beneath glaucescent; nerves about Io pairs very fine inarching within the margin; 2 in. long, 75 in. wide; petioles $\cdot r$ in. long or less. Stipules setaceous, base broader. Male flowers unknown. Female flowers 2 or more from axillary tufts of red-brown hairy bracts. Pedicels filiform, . I2 in. long. Sepals lanceolate acute, valvate. Petals much broader, ovate, tip rounded. Ovary glabrous almost entirely concealed by a cylindric white papillose disc. Hab. Pulau Terutau at Telok Hudang (Haniff).

This seems allied to $C$. parvitolius Hook. fil., of which the female flowers and fruit only are known, but in that the nerves of the leaves are not inarching, and the bracts are glabrous; the shape of the petals is also different.

(I6) C. decurrens Hook. fil. F.B.I. v. 278.

A many-stemmed shrub or treelet Io to $12 \mathrm{ft}$. tall with arched branches, glabrous except the tomentose flowering branches. Leaves sub-coriaceous or chartaceous oblong-elliptic or broadly lanceolate to obovate, base decurrent on petiole; nerves 5 to 7 pairs; 3 to 7 in. long, " 75 to $2 \cdot 5$ in. wide; petioles $I$ in. long. Flowering branches 5 to 3 in. long, tomentose with very small lanceolate leaves 5 in. long. Bracts red-woolly at the tip, oblong nearly as long as the flowers. Male flowers sub-sessile. Sepals lanceolate. Petals very shortly clawed obcuneate, tip truncate or round. Disc fleshy, broad-ringed adherent to upper part of calyx-cup. Pistillodes stout bluntly trifid. Female flowers white. Sepals narrow triangular-lanceolate. Petals elliptic. Disc very short, sub-lobed. Ovary hairy. Capsule glabrous when ripe, sub-globose, slightly lobed, tip depressed, 4 in. long. Hab. Dense jungle, near Limestone rocks, Perak (Scortechini); Goping (Kunstler). Penang, Batu Feringhi (Curtis). 
(I7) C. macrophyllus Hook. fil. F. B.I. v. 278.

Tree; branchlets stout glabrous. Leaves thin coriaceous, oblong-obovate shortly cuspidate, base narrowed; nerves 7 pairs, slender elevate beneath; 6 to 7 in. long, 3.25 to 4.25 in. wide; petioles $\cdot I$ in. long. Flowers sessile in small clusters. Male flowers pedicelled glabrous. Sepals lanceolate. Petals clawed sub-quadrate toothed. Disc lining the calyx smooth. Female flowers, sepals ovate coriaceous. Petals sub-quadrate crenate. Disc crenulate with an erect toothed tube at length 5-cleft. Styles 3 bifid, arms flabellate. Capsule $\cdot 3$ in. long, brown rounded, on a short stout pedicel 25 in. long. Hab. Forests, Kranji; Bukit Timah (Ridley). Perak (Scortechini); Goping (Kunstler).

(I8) C. sumatranus Müll. Arg. in DC. Prodr. xv. (2), 504; Jabl. Pflanzenreich, I3, Fig. 2, A to $\mathrm{E}$.

Shrub or small tree quite glabrous. Leaves thinly coriaceous elliptic cuspidate-acuminate, base acute; nerves faint 3 to 4 pairs; 4 in. long, $I \cdot 75$ in. wide; petioles $\cdot I 2$ in. long. Flowers in small heads under $I$ in. across on slender branches with smaller leaves. Bracts ovate glabrous or pilose on backs. Calyx-lobes lanceolate acute glabrous. Petals cuneate-spathulate. Disc in female cylindric. Ovary pilose. Styles 3, bifid. Capsule 3-lobed, sparsely pilose in the grooves, 3 in. long. Hab. Johor, Pinerong (Cantley). Distrib. Malay islands.

(I9) C. lanuginosus Jabl. Pfanzenreich, l.c. 26, Fig. 3, f.

Branches densely red-tomentose, rather stout. Leaves oblonglanceolate acuminate, base gradually narrowed, glaucous beneath, thinly coriaceous glabrous; nerves 8 pairs slender elevate, nervules conspicuous beneath irregular; 9 in. long, $2 \cdot 75$ in. wide; petioles $\cdot 2$ in. long, red-tomentose. Stipules lanceolate setaceous at tips, .25 in. long, glabrous, persistent. Heads woolly-tomentose, white, -4 in. through. Bracts lanceolate acute ciliate, woolly on the back. Male flowers shortly pedicelled. Calyx-lobes lanceolate quite woolly outside. Petals rhomboid. Disc adnate to receptacle. Female flowers, calyx-lobes triangular acute. Petals ovate denticulate. Disc urceolate. Ovary pilose. Capsule unknown. $H a b$. Malacca, Mt. Ophir (Hullett), very rare.

(20) C. hirsutulus Hook. fil. F.B.I. v. 278.

Tree 30 to $40 \mathrm{ft}$. tall, branches spreading, stem 6 to Io in. through; branchlets velvety. Leaves chartaceous obovate-oblong, caudate, base round, beneath pubescent and glaucous; nerves II to I5 pairs; 4 to 7 in. long, I to I.5 in. wide; petioles very short. Stipules setaceous. Flowers in small clusters minute cream-colour. Calyx villous, 'I in. wide, lobes ovate. Petals in male bifid or flabellate crenate. Disc pulvinate crenulate, in female glabrous tubular. Capsule sessile deeply 3-lobed pubescent, .5 in. long, red. Hab. Forests, Singapore, Bukit Timah. Malacca, Bukit Kandang (Cantley). Pahang, Kwala Tenok (Ridley). 
Selangor, Batu Caves (Burkill). Perak, Goping (Kunstler); Sungei Larut (Wray).

In the plant from the Batu Caves the petals are not bifid, but broadly flabellate.

(2I) C. prætermissus Gage, Kew Bulletin, I9I4, p. 240.

Shrub. Branchlets straw-colour, pustulate. Leaves membranous elliptic-lanceolate, long acuminate, base acute, dark brown when dry; nerves 3 to 4 pairs with midrib hairy; $3 \cdot 25$ to 5 . I in. long, I.25 to 2 in. wide. Flower-clusters axillary and on short spiciform twigs, male or female. Bracts minute ovate acute. Male flowers not seen. Female flowers sessile. Sepals deltoid or lanceolate. Petals shortly clawed, sub-spathulate obovate, crenulate. Disc glabrous. Ovary ovoid hairy. Styles united at base shortly bifid. Capsule sessile, $\cdot 25$ in. long to 3 in. through, glabrous black polished. Seeds mottled brown and yellow, base blunt excavate. Hab. Forests, Dindings, Gunong Tungul (Ridley).

(22) C. polyphyllus Williams, Bull. Herb. Boiss. v. 3I. C. trichocarpa Ridl. Journ. Roy. As. Soc. 59, p. I67.

Small tree or bush, very glaucescent, young parts hairy. Leaves elliptic acute or acuminate coriaceous, base round; nerves 6 pairs elevate, hairy as are reticulations; $\mathrm{I} \cdot 25$ to $\mathrm{I} \cdot 75 \mathrm{in}$. long, $75 \mathrm{in}$. wide; petioles ' I in. long, hairy. Stipules and bracts acuminate setaceous silky-hairy. Male flowers pedicelled, $\cdot 25$ in. wide. Sepals narrow lanceolate-triangular silky. Petals obovate-spathulate, pubescent. Disc annular sinuate. Female flowers larger. Sepals narrower long acuminate silky. Petals sub-spathulate silky. Ovary silky-hairy. Style arms 3, bifid. Capsule 25 in. long, deeply 3 -lobed appressed hairy. Hab. Open heaths in the north, Perak, Trong (Kunstler). Penang Hill. Kedah, Alor Sta. Lankawi, Kwah (Curtis). Perlis, Chupeng (Ridley). Setul. Adang isles, Rawei (Ridley).

(23) C. Maingayi Hook. fil. F.B.I. v. 280.

Tree ?; branches red-tomentose. Leaves chartaceous elliptic or oblong-lanceolate caudate, base narrowed rounded minutely cordate; nerves 6 to 8 pairs elevate and hairy beneath as are reticulations; 3 to 4 in. long, I to 2 in. wide; petioles $\mathrm{I} \cdot 06 \mathrm{in}$. long, red-tomentose. Stipules lanceolate acuminate or setaceous red-hairy. Flowers few in small heads. Sepals lanceolate acuminate hairy. Petals obovate entire. Disc of male lining the tube, of female urceolate hairy. Capsule about 3 in. long and wide, tomentose. Hab. Malacca (Maingay); Ayer Keroh (Ridley). Perak (Scortechini).

(24) C. Kingii Jabl. Pflanzenreich, l.c. 40.

Tree or shrub 6 to $60 \mathrm{ft}$. tall; branchlets twiggy glabrous. Leaves sub-coriaceous ovate gradually acuminate, base round or acute; nerves 6 pairs; $3 \cdot 5$ to $6 \cdot 25$ in. long, I. 6 to 3 in. wide,

Fl.M.P., 3 
glabrous above, grey papillose beneath; petioles 20 to $\cdot 25$ in. long, thick. Flower clusters few of male or female flowers only. Males unknown. Female perianth only seen in fruit. Sepals lanceolate glabrous. Petals broad sub-spathulate-obovate, clawed crenulate. Capsule glabrous, 4 in. long, stipitate. Hab. Perak, Larut (Kunstler); Sungei Siput (Burkill).

(25) C. myrianthus Kurz. For. Fl. ii. 370; Hook. fil. F.B.I. v. 275 .

Small bushy tree 20 to $50 \mathrm{ft}$. tall, or large shrub, young parts coppery puberulous. Leaves coriaceous oblong-lanceolate acuminate, base rounded; nerves 13 to 20 pairs, above dark green, shining, beneath copper-coloured from a very thin tomentum; 6 in. long, 2.5 in. wide; petioles coppery, -25 in. long. Heads of flowers small, $\cdot 2$ in. through. Bracts blunt ovate villous. Calyx-lobes ovate acute coriaceous. Petals fan-shaped crenate. Ovary globose. Capsule stipitate sub-globose, shortly trilobed, $\cdot 3$ in. long. Exocarp brown separating from the hard endocarp; columella thick angled. Seed ovate, cotyledons folded not complicate. Hab. Edges of woods, especially by streams, Singapore, Stagmount; Jurong; Kranji Road (Ridley). Selangor, Ayer Kuning (Burn-Murdoch). Distrib. Burma, Java, Borneo, Philippines, Papua.

(26) C. pseudomyrianthus Jabl. Pfanzenreich, l.c. 4I.

Small tree; branchlets glabrous or red pubescent. Leaves coriaceous elliptic acuminate slight silky-pubescent beneath; nerves 8 to ro pairs; 3.25 to 7 in. long, $\mathrm{I} \cdot 5$ to 2.5 in. wide; petioles -I8 to $\cdot 2$ in. long, wrinkled. Flower heads axillary. Bracts glabrous, keeled ovate. Male flowers not seen. Female flowers sessile. Calyx-lobes triangular thick glabrous. Petals narrow oblong-lanceolate. Ovary ovoid glabrous. Styles 3, bifid. Capsule 3-lobed stipitate. Seeds cordate striate; cotyledons crisped and irregularly complicate. Hab. Perak, Sungei Larut (Wray).

Allied to $C$. myrianthus but the cotyledons irregularly complicate.

(27) C. ellipticus Hook. fil. F.B.I. v. 28I.

A tree 30 to $40 \mathrm{ft}$. tall, 8 to Io in. through, young parts redpubescent. Leaves coriaceous glabrous, stiff elliptic blunt or shortly acute acuminate, paler beneath; nerves 7 pairs; 4 to 4.5 in. long, $I \cdot 5$ in. wide; petioles $\cdot 2$ in. long. Heads of flowers $\cdot 25$ in. through. Bracts rusty-villous ovate. Male flowers; sepals rufous-tomentose at tip. Petals fan-shaped crenulate glabrous. Disc lining calyx-tube. Pistillode short columnar hairy. Female flowers, sepals as in male. Petals obovate-spathulate entire. Capsule on a stout stalk glabrous, '5 in. through, sub-globose trilobed. Seeds elongate ovoid, back convex keeled, base cordate excavate. Hab. Dense rocky jungle near water, Perak, Larut (Kunstler); Trong (Wray); Asam Kumbang (Wray); Thaiping (Burn-Murdoch). 
(28) C. perakensis Gage MSS. C. vestitus var. perakensis Jabl. Pflanzenreich, iv. 32.

Shrub 5 or $6 \mathrm{ft}$. tall ; twigs red-tomentose as are the young leaves. Leaves sub-coriaceous thin, elliptic-lanceolate or oblanceolate, long-acuminate, base narrowed acute, above glabrous, beneath thinly cinnamon-red-pubescent; nerves 6 pairs, thin moderately prominent beneath; 3.5 to 5 in. long, $\mathrm{I} .5$ in. wide; petioles densely red-tomentose beneath, sometimes glabrescent, $\cdot 08$ in. long. Flower clusters axillary sub-globose. Flowers few. Bracts minute, ovate red-tomentose. Male flowers sessile. Sepals lanceolate. Petals obcuneate, cream-colour. Disc lining calyx cup. Pistillode columnar lobed. Female flowers unknown. Capsule 3-lobed, black glabrous, $\cdot 25$ in. long. Hab. Woods, Singapore, Garden Jungle (Ridley). Muar (Curtis). Perak (Scortechini). Penang, Waterfall (Curtis).

I have seen no type of $C$. vestitus (true), a Bornean species, but it is described as having a round-based ovate leaf, and is certainly different from Jablonsky's variety perakensis.

(29) C. rufus Gehrm. Engler's Bot. Jahrb. xli.; Beibl. 95, 2. Bridelia rufa Hook. fil. F.B.I. v. 273.

Shrub 8 to $\mathrm{I} 2 \mathrm{ft}$. tall, bark rough; branchlets densely redtomentose. Leaves thinly coriaceous, glabrous above except redtomentose nerves; in young leaves, red-hairy beneath on nerves, elliptic-lanceolate cuspidate, base rounded; nerves 8 pairs elevate beneath; 5 to 6 in. long, 2 to 3 in. wide; petioles $\cdot I$ in. long, red tomentose. Flowers sessile in small heads 'I in. across. Bracts red-tomentose ovate. Male flowers. Sepals lanceolate glabrous except the red-tomentose tips. Petals small round. Pistillode in male hairy. Female flowers, sepals as in male. Petals oblongspathulate, sub-crenulate. Disc toothed. Ovary ovoid hairy. $H a b$. Penang at roo to $400 \mathrm{ft}$. altitude (Kunstler).

I am by no means sure that this is not a state of $C$. perakensis, but it is much more tomentose, the leaves thicker and rounded at the base.

\section{ACTEPHILA, Bl.}

Shrubs or small trees. Leaves simple alternate. Flowers axillary in imbricating bracteolate heads or racemes. Calyx 5-fid nearly to base. Petals 5 much smaller attached outside the disc. Stamens 5 surrounding a trifid pistillode, filaments free or united only at base. Disc cup-shaped or annular, edge crenulate. Ovary sessile sub-globose trilocular, locules 2-ovuled. Styles 3, minute. Capsule dry, loculicidal or cocci breaking into 2 valves, bearing a central columella, I- or 2 -seeded. Seeds triquetrous, back convex with 2 plane lateral surfaces meeting at an acute angle; albumen scanty or o, cotyledons contort, fleshy. Species about 1o, East Asia and Australia. 
Sepals in female flowers large ovate, $\cdot 6$ in. long .

Sepals and petals minute.

Leaves thin elliptic-lanceolate entire; flowers green

Leaves thinly coriaceous broadly elliptic entire

Leaves thick obovate crenulate; flowers orange

\section{(I) A. ovalis}

(2) A. javanica

(3) A. excelsa

(4) A. aurantiaca

(I) A. ovalis Gage, Rec. Bot. Surv. Ind. ix. (2), 2Ig. Dimorphocalyx ovalis Ridl. Journ. Roy. As. Soc. S. Br. 59, p. I78.

Shrub, glabrous, shoots yellow pubescent. Leaves thinly coriaceous opposite or sub-whorled at the ends of the branches lanceolate acutely acuminate, base cuneate, blunt, obscurely undulate glabrous except for a few hairs at the base; nerves I4 pairs, in loops well within the margin; 3 to 6 in. long, I. 2 in. wide; petioles - I to - I2 in. long. Male flowers not known. Female flowers solitary on capillary pedicels $I .5$ in. long. Sepals 5 , ovate obtuse light green, $\cdot 6$ in. long, $\cdot 5$ in. wide. Ovary conic pubescent; styles 2, unbranched free to base. Capsule globose black, covered with small white hairs 5 in. through. Hab. Woods in the north, Lankawi, Kwah (Curtis). Perlis, Bukit Telor Jambu, Kanga (Ridley).

(2) A. javanica Miq. Fl. Ind. Bat. i. (2), 356.

Shrub 2 or $3 \mathrm{ft}$. tall, glabrous. Leaves thin coriaceous ellipticlanceolate, bluntly acuminate narrowed at base, entire; nerves about Io pairs, elevate beneath; 6 in. long, $2 \cdot 75$ to 3 in. wide; petioles $I$ in. long. Sepals coriaceous oblong. Petals in males broad rhombic-ovate, base cuneate, in females cuneate-obovate emarginate. Stamens, filaments connate at base. Female flowers larger than males. Disc 5-lobed. Styles short, thick bifid. Stigmas capitate. Capsules sub-globose slightly trilobed, 5 in. through on pedicels I in. long. Seeds mottled. Hab. Forests, Singapore (Wallich); Garden Jungle. Selangor, Batu Caves (Ridley). Penang, West Hill (Curtis). Distrib. Java, Borneo.

(3) A. excelsa Miill. Arg. in Linnaa, xxxii. 78; Hook. fil. F.B.I. v. 282.

A shrub 4 to $8 \mathrm{ft}$. tall. Leaves broadly elliptic-lanceolate to obovate, thinly coriaceous acute or acuminate, base cuneate thinly coriaceous glabrous; nerves 6 to I2 pairs; 6 to 8 in. long, 3 in. wide; petioles 5 in. long. Male flowers several in an axil. Bracts broadly ovate. Calyx sub-campanulate. Sepals oblong-ovate or broadly lanceolate, minutely hairy. Petals narrowly sub-spathulate. Disc annular crenulate. Stamens free. Female flowers several together or solitary, rather larger; perianth as in male. Ovary sub-globose glabrous. Capsule $\cdot 75$ to ${ }^{*} \cdot 5$ in. through, cocci breaking into 2 valves, pericarp crustaceous. Seeds triquetrous, back very convex. Hab. Woods and rocky spots, especially near limestone. Singapore, Sungei Morai. Selangor, Batu Caves; Kwala Lumpur (Curtis). Perak, Larut (Kunstler); Tambun (Ridley). 
(4) A. aurantiaca Ridl. Kew Bulletin, I923, p. 360.

Low shrub, glabrous. Leaves thinly coriaceous obovate or oblanceolate to elliptic shortly blunt acuminate, base narrowed blunt, edge crenulate; nerves ro pairs inarching far from edge in wide arches, reticulations wide; 8 in. long, 3 in. wide; petioles .5 in. long. Flowers in small clusters en the stem, orange. Sepals linear-oblong, 5. Petals broadly obovate denticulate. Disc of 5 flat lobes covered with hairs. Ovary conic glabrous. Capsule sub-globose trilobed, 6 in. long on peduncles 5 in. long. Hab. Forests, Kelantan, Chaning Woods (Ridley).

\section{ANDRACHNE, Linn.}

Herbs or low shrublets. Leaves alternate, membranous rather small. Flowers monœcious pedicelled. Males very small clustered in the axils. Sepals 5 or 6 . Petals much smaller, 5 or 6 . Discglands 5 or 6 bifid linear. Stamens 5, filaments long, free. Pistillode small. Female flowers larger. Ovary 3-celled, 2 ovules in a cell. Styles bifid. Capsule small of 3 bivalved cocci. Seeds rugose, triquetrous. Species I6, Europe, Asia, Africa and America.

Much branched. Leaves lanceolate long-narrowed to base, nearly glabrous

Much branched. Leaves small elliptic-Ianceolate, base shortly cuneate, very hairy

Little or not branched. Leaves elliptic-lanceolate, base shortly cuneate, sparsely hairy

(1) A. australis

(2) A. hirta

(3) A. calcarea

(I) A. australis Zoll. Flora, xxx. 663. A. fruticosa Hook. fil. F.B.I. v. 284; Ic. Pl. t. 4074 (not of Decaisne)

A shrublet I to $2 \mathrm{ft}$. tall, with long spreading branches shortly closely hairy. Leaves membranaceous glabrous above, hairy on the midrib and nerves beneath, lanceolate narrowed to both ends; nerves 6 pairs inarching within the margin; I.5 to 3 in. long, .5 to $I$ in. wide; petioles slender, I in. long. Flowers axillary, I or 2 together. Males $I$ in. wide on slender pedicels. Sepals spathulate blunt hairy outside. Petals similar but narrower, glabrous. Stamens 5, free. Disc of 5 deep-cleft lobes, lobules linear. Rudimentary pistil very small. Female flowers much larger. Sepals and petals ovate blunt pilose. Ovary sub-globose, hairy. Styles 3, bipartite to base. Capsule sub-globose grooved .25 in. wide. Seeds semi-ovoid grooved. Hab. Perak, Larut, at 300 to $500 \mathrm{ft}$. altitude (Kunstler). Distrib. Java, Philippines, Timor Laut.

(2) A. hirta Ridl. Kew Bulletin, I923, p. 36r.

Shrubby much branched plant, 12 in. or more tall, hairy all over. Leaves elliptic-lanceolate blunt or sub-acute, base shortly cuneate, densely hairy on both sides; nerves 4 pairs faint; I to I. 25 in. long, 4 to .6 in. wide; petioles 4 in. long, hairy. Male flowers minute; pedicels hairy, $\cdot I$ in. long, filiform. Sepals oblong 
blunt hairy. Petals much smaller spathulate glabrous. Stamens 5; filaments thick narrowed upwards. Disc lobes linear acute long. Pistillode short oblong blunt. Female flowers $\cdot 2$ in. wide. Sepals coriaceous hairy outside. Capsule $\cdot I$ in. long, hairy round semiovoid. Seeds grey transversely rugose. Hab. Perlis, Tebing Tinggi near Kanga (Ridley).

(3) A. calcarea Ridl. Kew Bulletin, I923, p. 362.

Shrublet under I $\mathrm{ft}$. tall, stems slender pubescent, little or not branched. Leaves membranous, glabrous or sparsely hairy beneath, elliptic or elliptic-lanceolate blunt mucronulate, base shortly narrowed; nerves faint, 4 pairs; $I \cdot 25$ in. long, $\cdot 6$ in. wide; petioles hairy, 3 to $\cdot 4$ in. long. Flowers $I$ or 2 in axils. Males $I$ in. across on filiform hairy pedicels $I_{5}$ in. long. Sepals oblong hairy. Petals narrow lanceolate. Stamens 5, filaments free slender. Disc deeply cut into linear lobes. Pistillode rather large. Female flower .25 in. wide. Sepals ovate hairy on the back. Ovary glabrous. Styles bifid. Capsule I in. long, light brown. Seeds oblong, grey transversely rugose. Hab. Limestone rocks, Selangor, top of Batu Caves (Ridley). Lankawi, Dayong Bunting (Robinson). Distrib. Siam.

\section{AGYNEIA, Vent.}

Herbs erect, branched. Leaves small entire alternate. Flowers minute apetalous. Males in axillary clusters; females solitary larger. Bracts numerous, stipule-like. Male flowers, sepals 6, gland-dotted thick with white edges. Disc 6-lobed. Stamens 3, central, filaments connate; anthers sessile on them. Pistillode o. Female flowers. Disc o. Sepals acute not edged with white. Ovary ovoid truncate; ovules two in a cell; styles very short sunk in top of ovary. Capsule splitting into 2-valved cocci. Species 2, Mascarene, Indo-Malaya.

(I) A. bacciformis Jussieu, Tent. Euphorb. 24; Hook. fil. F.B.I. v. 285 .

Plant I2 in. tall, glabrous, stems angled. Leaves fleshy sessile oblong-obovate to linear-lanceolate, blunt or acute, 5 in. long, - I in. wide. Stipules minute ovate or lanceolate-acute. Flowers pedicelled minute. Females $\cdot$ I2 in. across. Sepals ovate acuminate. Capsule I3 in. long, globose ovoid nearly terete. Hab. Sandy spots, Singapore, Tanjong Katong. Pahang, Kwala Pahang (Ridley). Distrib. Mauritius, India, Java.

\section{PHYLLANTHUS, Linn.}

Shrubs or shrublets, rarely herbs. Leaves membranous alternate, entire distichous very small to 4 in. long. Flowers small in axillary clusters, apetalous. Males, sepals 4 to 6 , imbricate in 2 series. Stamens 3 to 6 filaments free or united. Pistillode o (except in $P$. pulcher minute). Disc various. Female flowers as 
in male. Ovary 3 - or 4-celled; ovules 2 in a cell. Styles free or connate, usually bifid. Fruit of 3 or more crustaceous cocci. Seeds trigonous. Species over 300 , all tropical countries.

Herbs, occasionally wiry at base; leaves distichous small.

Quite herbaceous; leaves oblong or elliptic obovate; capsule smooth

Slightly woody at base; leaves linear-oblong; capsule echinate .

Strongly woody at base; leaves coriaceous; capsule smooth

Nine inches to $2 \mathrm{ft}$. tall with long branches, leaves close set very narrow

Leaves linear or oblong-linear; flowers pedicellate

Leaves cuneate-obovate; flowers sub-sessile

Dwarf shrubs I to $2 \mathrm{ft}$. tall; leaves distichous, 5 in. long; flowers pedicellate solitary.

Sepals ovate-lanceolate usually deep red, lacerate. . .

Sepals obovate, tips toothed i in. or more Shrubs or small trees; leaves $I$ in. or more
long.

Capsule small $\cdot$ i in. through or less, fleshy.

Pedicels very short.

Leaves elliptic blunt, $\cdot 2$ in. long, glabrous

Leaves ovate, base broad pubescent beneath .

Pedicels slender rather long - P.

Capsule $\cdot 25$ in. through, dehiscent. Pedicels short under ' $I$ in. long.

Flowers very small sub-sessile; leaves $\mathrm{I}$ in. long, oblong-lanceolate acuminate . . . . .

Flowers small sub-sessile; leaves 4.5

Pedicels 'I in. long; leaves sub-coriaceous glaucous beneath desiscent, i to $\dot{5}$

Capsules long-ped
in. long.

Leaves ovate-lanceolate glaucous beneath, 4 in. long . -

Leaves lanceolate glaucous beneath, 2 in. long

Leaves ovate pale beneath, $\dot{1}_{5} \mathrm{in.}$ long

Leaves oblong, glaucous beneath, I' 25 in.

long
Capsule very large, I in. long, valves thin. Leaves inæquilateral lanceolate longacuminate, 4 in, long

(I) P. Niruri

(2) P. urinaria

(3) P. chamæpeuce

(4) P. simplex

(5) P. maderaspatensis

(6) P. pulcher

(7) P. filicifolius

(9) P. erythrocarpus

(Io) P. reticulatus

(II) P. frondosus

(I2) P. coriaceus

(I3) P. campanulatus

(I 4) P. elegans

(15) P. gracilipes

(16) P. Hamiltonianus

( 17 ) P. Hullettii

(I8) P. gomphocarpus

(r) P. Niruri Limn. Sp .Pl. 98r; Hook. fil. F.B.I. v. 298.

Glabrous weedy herb I2 in. tall. Leaves distichous oblong or elliptic-obovate sub-sessile, tip and base round, 25 in. long, $\cdot$ in. wide; petioles minute or none. Stipules subulate, base broad. Males flowers solitary or in pairs nearly sessile, very minute. 
Female flowers twice as large. Sepals in males orbicular. Anthers 3 , sessile on a short column. Disc of minute glands. Females, sepals oblong-obovate, edges broad white. Disc annular lobed. Styles bifid. Capsule minute depressed globose, hardly lobed. Hab. Waste ground, paths, common; Singapore, Tanglin. Malacca (Griffith). Province Wellesley, Prai Docks (Burkill). Lankawi, Kwah (Curtis).

(2) P. urinaria Linn. Sp. Pl. 982 ; Hook. fil. F.B.I. v. 293.

Herb, glabrous wiry at the base, 6 to $\mathrm{I} 2$ in. tall; stem angled. Leaves herbaceous sessile distichous imbricate oblong to linear oblong rounded at both ends, glaucous beneath, $\cdot 25$ in. long, $\cdot 08$ in. wide. Stipules acuminate. Flowers very minute axillary subsessile, .08 in. wide. Sepals orbicular in male, oblong in female. Disc in male of glands, in female narrowly lobed. Stamens very shortly united. Capsule globose minutely echinate. Hab. Waste grounds, paths, etc., common; Singapore. Malacca (Griffith). Selangor, Kwala Lumpur. Penang. Native name: Ambin Buah.

(3) P. chamæpeuce Ridl. Trans. Linn. Soc. ser. 2, vol. iii. p. 325.

A small shrub 8 in. tall with a stout woody stem; branchlets strict. Leaves distichous sessile coriaceous oblong mucronate, edges pubescent; nerves conspicuously elevate. Flowers minute, shortly pedicelled. Bracts linear acuminate nearly ${ }^{\prime} \mathrm{I} 2$ in. long, much longer than the flowers. Sepals 6 obovate blunt, thin, median line thicker. Stamens 3 nearly completely free; filaments very short. Ovary sub-globose; stigmas 3 -lobed sessile. Capsule very small globose. Seeds 3, trigonous brown, backs wrinkled. Hab. On rocks in rapid streams ; Pahang, Tahan River; Kelantan River, Jeram Panjang (Ridley).

Gage considers this as only $P$. urinaria, and it might be a remarkable modification of that species, from which it differs in its stout woody stem 'I in, through, and coriaceous acute narrower leaves.

(4) P. simplex Retz. Obs. v. 29; Hook. fil. F.B.I. v. 295.

Stem slender, woody below with slender erect branches 9 in. to over $2 \mathrm{ft}$. tall. Leaves distichous sub-sessile linear or oblonglinear slightly narrowed, but blunt at both ends; midrib prominent beneath, nerves very conspicuous; .5 in. long, 08 in. wide. Stipules peltate sagittate. Male flowers minute on capillary pedicels 08 to $\cdot I$ in. long. Female flowers on stouter and longer pedicels, in tufts of 2 males to a female, or above females solitary. Sepals oblong. Stamens free. Disc of large round glands in male, annular in female. Styles short free recurved. Capsule globose smooth or echinate, 08 in. through. Hab. Grassy meadows; Pahang, Pulau Tawar. Perak, Kwala Kenering. Province Wellesley, Tasek Gelugur (Curtis). Perlis, Kanga (Ridley).

(5) P. maderaspatensis Linn. Sp. Pl. 982; Hook. fil. F.B.I. V. 292 .

Herb glabrous, I to $2 \mathrm{ft}$. tall, branched. Leaves sub-sessile 
cuneate-obovate glaucous beneath, $\cdot 25$ to $\mathrm{I}$ in. long, $\cdot \mathrm{I}$ to $\cdot 25 \mathrm{in}$. wide. Stipules peltate. Male flowers axillary minute sessile. Sepals round or obcuneate. Disc of glands. Female flowers larger pedicelled. Fruit $\cdot 2$ in. wide or less. $H a b$. Seashores, rare, Pahang, Kwala Pahang (Ridley). Distrib. Africa, India, Java to Australia.

(6) P. pulcher Wall. Cat. 7908; Hook. fil. F.B.I. v. зот. Reidia glaucescens Miq. Fl. Ind. Bot. i. (2), 374; Hook. Bot. Mag. t. 5437 .

Shrub about $2 \mathrm{ft}$. tall. Branches pubescent on one side. Leaves distichous glaucous imbricating close-set broadly oblong, glaucous beneath oblique sub-sessile, $\cdot 25$ to $\cdot 75$ in. long, - I2 to 6 in. wide. Stipules lanceolate acuminate. Flowers solitary, .25 in. wide, pendent on slender red pedicels 65 in. long. Sepals ovate lacerate deep red with dark centre, or white or yellow with red base. Stamens 4, anthers sessile. Disc of 4 reniform glands in males, of females annular crenate; styles spreading, 6. Hab. Stream banks, but in some spots an escape from cultivation; Singapore, Tanglin, and probably Malacca (Maingay) escapes; Pahang, Pekan; Pulau Tawar and Temengoh, river banks; Sungei Jelai (Machado). Selangor, Klang River near Klang Gates. Penang (Wallich); Kedah (Kunstler). Kelantan, Chaning. All wild. Distrib. Siam, Java. Native name: Kanka Bona.

(7) P. filicifolius Gage, Kerw Bulletin, I9I4, p. 24I.

Small shrub, glabrous. Leaves bifarious on the branches obliquely obovate inæquilateral membranous, acute at base, one side round, the other sub-cuneate, beneath glaucous; nerves faint 4 or 5 pairs; $\cdot 3$ to $\cdot 5$ in. long, $\cdot 25$ in. wide; petioles minute. Stipules minute triangular acute sub-scarious. Male flowers in upper axils solitary from bracteolate tubercles, pedicels filiform, $\cdot 5$ in. long. Sepals 4 , deeply cut down, obovate, tip irregularly toothed. Glands 4, fleshy reniform peltate alternating with them. Stamen-column very short; anthers 2 minute. Female flowers solitary; pedicels stiffer than in males. Sepals 5 to 7 , obovate. Disc shortly cup-shaped, edge thickened. Ovary sub-globose, 3-lobed; styles 3 deeply bifid. Capsule light brown, I in. through, styles persistent, cocci rounded. Seeds triquetrous, red-brown. Hab. Lankawi, Kwah (Curtis).

Allied to $P$. pulcher, but with the sepals less deeply laciniate.

(8) P. dalbergioides Wall. Cat. 7934.

Small shrub, glabrous; branchlets angled. Leaves elliptic sub-acute, base rounded, shortly narrowed, coriaceous; nerves parallel, Io pairs, reticulations visible on both sides; 2 in. long, I in. wide; petioles ' I in. long, slender. Stipules very small lanceolate acuminate. Bracts similar. Male flowers very small. Sepals 6, ovate round, glabrous. Stamens 6, anthers globose. 
Female flowers solitary sub-sessile very small. Sepals 6 , rounded. Fruit shortly pedicelled globose, .08 in. through; sepals little enlarged oblong. Hab. Perak, Goping (Kunstler). Distrib. Burma.

(9) P. erythrocarpus Ridl. Kew Bull. I923, p. 362.

Tree. Branchlets pubescent. Leaves thin sub-membranous ovate blunt, base rounded, or sub-emarginate, above glabrous except base of midrib, beneath pubescent on the nerves, densely on the midrib; nerves 7 pairs, nervules conspicuous, reticulations large; I to 2 in. long, 6 to $\mathrm{I} \cdot 4$ in. wide; petioles $\cdot 05$ in. long. Stipules lanceolate acuminate persistent. Flowers in tufts on slender lateral branches usually 4 or 5 in. long, pubescent, appearing racemose from fall of leaves. Bracts several lanceolate acuminate. Male flowers minute shortly pedicelled; pedicels pubescent. Sepals imbricate, 5, oblong blunt, pubescent outside. Stamens 5; anthers oblong deeply grooved between the cells; filaments free to base, short cylindric. Disc saucer-shaped minutely lobulate. Capsule sub-sessile globose red, $\cdot 25$ in. through, glabrous, crowned with the very short styles. Seeds 4 , black triquetrous. Hab. Woods by limestone rocks; Selangor, Batu Caves (Ridley).

(ro) P. reticulatus Poir, Encycl. v. 298. Glochidion microphyllum Ridl. Joum. Roy. As. Soc. S. Br. 59, p. I72.

A tree (or scandent shrub) glabrous or pubescent. Leaves small elliptic-oblong, tip round, blunt or acute, I to 2 in. long, .25 to .5 in. wide; nerves 7 pairs slender; petioles very short. Flowers few together axillary and pseudo-racemose; racemes slender, 3 in. long or less; pedicels slender, $\cdot I$ in. long. Sepals 5 or 6 rounded. Stamens 5 in 2 series, outer free, inner 3 connate. Ovary globose, 5- to 8-celled: Stigmas 2, very minute 2-lobed. Fruit -I2 in. through, sub-globose, top flattened, not lobed, 8- to I6-seeded. Hab. Open country; Malacca town (Maingay, Ridley). Kedah, Alor Sta. Perlis, Kanga (Ridley). Distrib. India, China, Malay islands, Africa.

The racemes are lateral branches with suppressed or fallen leaves.

(II) P. frondosus Wall. Cat. 7932; Hook. fil. F.B.I. v. 292. P. Kunstleri Hook. fll. l.c.

A shrub 4 to $6 \mathrm{ft}$. tall with slender spreading branches glabrous, rarely puberulous. Leaves oblong or oblong-lanceolate acuminate, bright green, membranous, those of flowering branchlets $\mathrm{I}_{5} 5 \mathrm{in}$. long, 5 in. wide, older ones 2 in. long, I in. wide; nerves about 6 pairs slender; petioles very short. Flowers numerous sub-sessile in minute axillary clusters very small, yellow; pedicels very short. Male flowers, sepals 6, inner series slightly larger than outer, broadly oblong blunt. Stamens 3, filaments connate or separable; anthers lanceolate, connectives produced at tip. Disc of 6 oblong toothed lobes. Female flowers as in male. Ovary globose, glabrous or rarely pubescent. Styles 3 forked. Capsule sub-globose lobed dehiscent, 3 in. through. Seed reniform, back convex, inner 
faces acute, faintly reticulate, $\cdot 25$ in. long. Hab. Abundant in forests from sea level to $4000 \mathrm{ft}$. altitude. Johor, Batu Pahat. Pahang, Tahan and Pahang River woods. Malacca, Mt. Ophir. Selangor, Kwala Lumpur; Bukit Hitam; Semangkok Pass. Perak, Temengoh; Goping (Kunstler); Thaiping Hills (Long). Dindings Lumut. Penang (Wallich, Kunstler); Batu Feringhi (Curtis).

var. rigidus Ridl. Base of stem bare, leafy branches at the top. Leaves coriaceous elliptic lanceolate, blunt narrowed to base, 3 in. long, I.5 in. wide; male flowers fewer and larger. Hab. Mountains, Kedah Peak (Robinson). A stiff-leaved mountain form. Distrib. Of species Lingga, Carimon islands. Native name: Cherek Hantu.

(I2) P. coriaceus Wall. Cat. 7946; Hook. fil. F.B.I. v. 292.

Slender tree $I_{5} \mathrm{ft}$. tall, quite glabrous. Leaves coriaceous elliptic acuminate, base narrowed; nerves about Io pairs, nervules nearly as prominent; 4.5 in. long, I.75 in. wide; petioles very short. Male flowers in minute axillary clusters glabrous. Sepals ovate blunt. Stamens lanceolate; filaments very short. Disc glands in male 2 crenate. Ovary globose; style columnar. Hab. Hill forests, local. Perak, Goping (Kunstler 716). Penang (Maingay). Distrib. Siam.

(I3) P. campanulatus Ridl. Kew Bulletin, I923, p. 362.

Shrub. Leaves sub-coriaceous lanceolate, base narrowed, tip acuminate beneath glaucescent; nerves 6 pairs faint; 3 in. long, $I$ in. wide; petioles very short. Male flowers in very short axillary racemes, - I in. long, with lanceolate acute bracts; pedicels slender, $\cdot I$ in. long. Sepals 6 , inner whorl broader than outer, oblong blunt, $\cdot r$ in. long. Stamens 3 , filaments connate; anthers free erect lanceolate blunt. Disc of obovate broad toothed lobes. $H a b$. Mountains, Kedah Peak at $2000 \mathrm{ft}$. altitude (Bell and Haniff).

This is near $P$. frondosus, but differs in its coriaceous leaves, glaucescent beneath and flowers twice as large on distinct pedicels in short racemes.

(I4) P. elegans Wall. Cat. 7926; Hook. fil. F.B.I. v. 300. P. glaucifolia Ridl. Journ. Roy. As. Soc. S. Br. 6I, p. 59 .

A shrub with slender branches, glabrous. Leaves ovatelanceolate rarely oblique, acuminate acute, base round, membranous, glaucous beneath; nerves 5 pairs inconspicuous; 3 to 4 in. long, $I$ to $I \cdot 5$ in. wide; petioles $I$ in. long. Male flowers minute in numerous small clusters of racemes on the lower part of the branches below the leaves. Racemes $\cdot I$ in. long, covered with ovate acuminate pink bracts on one side. Pedicels capillary, pink. Sepals 4, rose-pink oblong fimbriate. Stamens 4 ( 2 fide Hooker) connate. Female flowers on the leafless ends of the branches solitary in the axils of lanceolate acuminate bracts; pedicels $I \cdot 25$ in. long, capillary. Sepals triangular-lanceolate fimbriate green. Capsule smooth, green, 5 in. long. Hab. Stream banks, Pulau Adang islands, Rawei (Ridley). Distrib. Tenasserim. 
(15) P. gracilipes Milll. Arg. Linnaa, xxxii. 47. P. concinna Ridl. Journ. Roy. As. Soc. S. Br, 59, p. I7I.

Shrublet about $4 \mathrm{ft}$. tall; branchlets hairy (red when dry). Leaves oblong-lanceolate to ovate-lanceolate usually inæquilateral, base broad rounded unequal, tip acuminate acute, glabrous above except the midrib beneath paler downy; 2.5 in. long, $\cdot 75$ in. wide; petioles $\cdot 05$ in. long, hairy. Stipules lanceolate acuminate glabrous, .05 in. long. Male flowers in small axillary tufts with numerous pale ovate bracts, tipped red; pedicels filiform, $\cdot 25$ in. long. Sepals triangular with long cilia crimson, $\cdot 05$ in. long. Stamens 4. Female flowers solitary in the upper axils, $\cdot 25$ in. wide; pedicels 2 in. long, hairy. Sepals longer and narrower than in male. Fruit globose pale green woolly, $\cdot 25$ in. long. Seed reniform black. Hab. Open woods. Lankawi, Telaya Tujoh, Burau (Curtis, Robinson, Ridley). Terutau (Robinson). Distrib. Java, Sumatra.

(I6) P. Hamiltonianus Müll. Arg. Linnea, xxxii. 48; in DC. Prod. xv. (2), 425; Hook. fil. F.B.I. v. 304. P. secundiflora Ridl. Journ. Roy. As. Soc. S. Br. 59, p. I7o. P. perlisensis Ridl. l.c. I7I.

Shrub; branchlets crowded at top of branches, glandular pubescent with white hairs. Leaves distichous elliptic acute unequal sided, herbaceous pubescent on both sides, paler beneath and more thickly pubescent, $\mathrm{I} \cdot 25 \mathrm{in}$. long, $\cdot 5$ in. wide; petioles $\cdot 08$ in. long. Stipules lanceolate subulate. Male flowers solitary or in tufts of 2 or 3 together minute; pedicels filiform, I2 in. long. Sepals purple triangular acuminate lacerate. Stamens 4 . Capsule globose dark brown, scurfy, $\cdot \mathrm{I}$ in. long. Hab. Open country, Perlis, Kanga (Ridley). Distrib. Assam, Himalayas, Burma.

(I7) P. Hullettii Ridl. Kew Bulletin, I923, p. 363 .

Shrub, Branches red, scurfy. Leaves membranous coriaceous, glabrous oblong oblique sub-acute, base narrowed, grey beneath, nerves faint, 7 pairs; $\mathrm{I} \cdot 5$ in. long, $\cdot 5$ in. wide; petioles $\cdot 08$ in. long, red, scurfy. Stipules very short lanceolate acuminate scurfy. Male flowers $\cdot I$ in. across, dark red on filiform pedicels - II in. long, hairy. Sepals 4, connate ovate red with white laciniz, hairy on the back. Stamens 4, filaments very short; anthers sub-globose. Female flower ${ }^{-} 5_{5}$ in. across, pedicels 4 in. long, scurfy hairy. Sepals 5, oblong-lanceolate blunt, fimbriate, with a raised central nerve, dull red. Disc of 5 fleshy oblong quadrate truncate lobes. Ovary semi-ovoid, 6, grooved. Styles 6, short lying on ovary. Hab. Mountains, Malacca, top of Mt. Ophir (Hullett).

A striking plant with the habit of $P$. frondosus, but the leaves are much smaller and blunt.

(I8) P. gomphocarpus Hook. fil. F.B.I. v. 301.

Shrub, 6 to $8 \mathrm{ft}$. tall; branchlets pubescent. Leaves membranous, glabrous obliquely ovate or ovate-lanceolate acuminate, base acute or cuneate, very unequal; nerves 6 pairs very slender, 
3.5 in. long, $I .75$ in. wide; petioles under $I$ in. long. Male flowers minute, II in. wide, panicled on short capillary pedicels. Sepals pale red ovate fimbriate. Female flowers large solitary, 3 in. wide; pedicels $I \cdot 5$ to 2 in. long. Sepals toothed. Stigmas minute. Capsule I in. long, sub-globose, trilobed, lobes inflated, light green, valves thin, on pedicels $I \cdot 5$ to 2 in. long. Seeds curved trigonous rugose small. Hab. Hilly jungle, Negri Sembilan, Gunong Angsi (Ridley); Bukit Tangga. Perak, Chanderiang; Larut and Kota Bharu (Kunstler). Distrib. Siam.

\section{PHYLLANTHODENDRON, Hemsl.}

Shrubs or small trees. Leaves alternate thinly coriaceous, large. Flowers in small axillary tufts. Bracts numerous ovate acute glabrous. Male flowers small pedicelled. Sepals 5 or 6 . Petals much smaller linear setaceous. Stamens 5 in a column. Pistillode conic. Disc. o. Females larger, longer pedicelled, perianth as in males but sepals usually larger keeled. Ovary ovoid glabrous or pubescent adnate to sepals at base. Styles 3, bifid. Fruit large bladdery, dehiscent. Species 6, Malay Peninsula, Cambodia, Siam, China.

Erect shrub. Leaves elliptic, 5 to $6 \mathrm{in.} \mathrm{long,} \mathrm{thin} \mathrm{.} \mathrm{.}$

Climbing shrub. Leaves stiff glaucous, 2 to 3 in. long, oblong-elliptic

(I) P. dubium

(I) P. dubium Gage, Rec. Bot. Surv. Ind. ix. (2), 219. Cleistanthus? dubius Ridl. Journ. Roy. As. Soc. S. Br. 59, p. I68. Glochidion flavum Ridl. l.c. p. I73.

Erect shrub. Glabrous, bark dark brown; branchlets often zigzag. Leaves thinly coriaceous elliptic to elliptic-lanceolate acuminate, base narrowed; nerves conspicuous, 5 to 8 pairs in arching; (drying dark brown above, red-brown beneath), 5 to 6 in. long, 2 in. wide; petioles thick, $\cdot I_{2}$ in. long. Male flowers $\cdot 12$ in. long on pedicels . I2 in. long. Capsule 5 in. through on a short stalk. Hab. Forests. Perak, Thaiping Hills. Dindings, Telok Sera (Curtis). Kedah Peak (Ridley, Robinson). Lankawi, Gunong Raya (Curtis); Kwah (Ridley); Sungei Batu Asap (Haniff).

(2) P. coriaceum Gage Rec. Bot. Surv. Ind. ix. (2), 2I9. Cleistanthus? minutiflorus Ridl. Journ. Roy. As. Soc. S. Br. 59, p. I69.

Climbing shrub 30 to $40 \mathrm{ft}$. long, branches at first puberulous. Leaves oblong-elliptic coriaceous glabrous glaucous; nerves very conspicuous, 7 to Io pairs; 2.5 to 3 in. long, I.5 in. wide; petioles thick, I in. long. Male flowers in very small clusters, pedicels slender. Sepals 6, imbricate, base lanceolate, tip filiform. Petals 6, very small, spathe-like. Stamens 3, connate in column. Female flowers larger. Sepals 6. Ovary globose hairy; stigmas 3, short. Hab. Limestone rocks, Pahang, Kota Glanggi (Ridley). Perak, Goping (Kunstler). Distrib. Annam, Siam.

Dr. Keith describes this as a climbing shrub hanging on boles of trees. 
10. GLOCHIDION, Forst.

Trees or shrubs. Leaves alternate, shortly petioled sub-coriaceous. Flowers small in axillary clusters, apetalous without disc, scales or glands. Male flowers; sepals 6, rarely 5, in 2 series, imbricate. Anthers 3 to 8 , connate in an ellipsoid or oblong column, cells linear, connective produced into separate points or connate in an umbonate head. Pistillode o or minute between the anthers. Female flowers of 6 short imbricate sepals, or tubular and unequally toothed or cleft. Ovary 3- to I5-celled. Styles connate in a globose, columnar or conic column lobed or toothed at tip, in $\S$ Glochidiopsis 3 , free. Ovules 2 in a cell. Capsule of 3 or more 2-valved cocci, often with twice as many lobes as cells, globose, or orbicular, depressed or intruded at tip, cocci crustaceous. Seed hemispherical or laterally compressed. Species I20, chiefly Asiatic. tip.

i. Euglochidion. Styles confluent in a column lobed or notched at the

Capsule not, or very indistinctly, lobed.

Capsule fleshy pink, 8- to Io-celled; leaves rounded.

Capsule brown coriaceous; style short columnar.

Leaves oblong acuminate glabrous.

Flowers glabrous

Flowers hairy $\quad . \quad$ :

Cymes few-flowered sessile; flowers

Capsule brown pubescent; ' leaves glaucous beneath

Capsule trilocular, trilobed, small.

Leaves coriaceous tomentose beneath; capsules in heads 2 in. across

Leaves not or hardly pubescent membranous.

Whole plant glabrous; cymes peduncled.

Whole plant glabrous; clusters and flowers sessile.

Branches and capsules pubescent

Leaf-nerves beneath pubescent; capsule slightly so .

All pubescent; capsule obconic :

Leaves and branches glabrous.

Flowers in sessile fascicles

Flowers in peduncled cymes; fruits angled, densely hairy

Leaves and branches hairy; fruit round, glabrous 6- to 8-

Capsule where known 6-to 8 -celled and lobed,
Style columnar longer than perianth, notched or bifid.

Branches winged; style clubbed

Branches not winged; style columnar.

Plant pubescent.

Leaves ovate-elliptic, I to $2 \mathrm{in.} \mathrm{long} \mathrm{.}$

(I) G. littorale

(2) G. brunneum

(3) G. pedunculatum

(4) G. glaberrimum

(5) G. obscurum

(6) G. superbum

(7) G. microbotrys

(8) G. glomerulatum

(9) G. singaporense

(Io) G. Kunstlerianum

(I I) G. trilobum

(๘2) G. Maingayi

(13) G. goniocarpum

(I4) G. arborescens

(I 5) G. tetrapteron

(I6) G. villicaule 
Leaves elliptic-oblong, 2 to $3.25 \mathrm{in}$. long glabrous except twigs.

Plant glabrous except twigs.

Style short thick hardly longer than perianth, clubbed or swollen.

Leaves glaucous beneath .

(I7) G. coronatum

(I8) G. leiostylum

Leaves not glaucous beneath.

Branches and flowers pubescent; flowers small

Quite glabrous : fowers not large '

Style globose, 5 to 6 cleft

Style shortly conic with very small points.

Capsule 5-lobed

Capsule 6-lobed

Style of 5 or 6 minute points

ii. GLochIDIopsis. Styles free to base filiform

Leaves glaucescent, pubescent beneath

Leaves hairy beneath

\section{(19) G. insulare}

(20) G. Wallichianum

2I) G. perakense

(22) G. macrostigma

(23) G. nanogynum

(24) G. desmocarpum

(25) G. lævigatum

(26) G. sericeum

(27) G. stylosum

(I) G. littorale Bl. Bijdr. 585; Hook. fil. F.B.I. v. 308.

A shrub about $6 \mathrm{ft}$. tall quite glabrous. Leaves coriaceous elliptic or obovate rounded, base acute or round; nerves fine, 5 pairs; I.5 to 3 in. long, I to $I \cdot 5$ in. wide; petioles $\cdot 05$ in. long. Male flowers on peduncles 25 in. long. Sepals elliptic. Anthers 5 or 6 . Female flowers larger, on stout and short pedicels. Sepals broad. Ovary Io- to I2-celled sub-globose, glabrous or pubescent. Style conical truncate. Capsule fleshy pink orbicular depressed, $\cdot 5$ in. through, Io- to I4-lobed when dry; pedicel $I$ in. long, thick. Hab. Tidal swamps. Singapore, Chan Chu Kang; Kranji; Bukit Mandai. Johor, Tebrau River; Jambu Larang (Feilding). Pahang, Pekan. Distrib. South India, Ceylon, Borneo, Sumatra, Java.

(2) G. brunneum Hook. fil. F.B.I. v. 312.

Tree glabrous, branchlets stout angled, thinly stiff coriaceous oblong shortly cuspidate or oblong-lanceolate acuminate, base rounded, often unequal; nerves 8 pairs; 4.5 to 6 in. long, $x \cdot 75$ to 2 in. wide; petioles $I_{5}$ to 2 in. long. Flowers minute on the bracteolate ends of a stout peduncle $\cdot I$ in. long. Male flowers yellow, pedicelled. Sepals oblong blunt thick. Anthers 5 or 6 , connectives blunt. Females sub-sessile. Ovary hairy, $4^{-}$to 6-celled. Style cylindric stout 5-toothed. Capsule globose brown, glabrous faintly 4 - to 6 -lobed, 25 in. through, crowned with the cylindric style. Hab. Damp low-lying spots, Singapore, Tanglin; Bukit Timah; Galang. Malacca (Maingay).

(3) G. pedunculatum Ridl. Kerw Bulletin, I923, p. 364.

Branches glabrous. Leaves membranous obliquely oblong shortly abruptly blunt cuspidate, base cuneate quite glabrous; nerves 8 pairs, slender; 4.5 in. long, 1.75 in. wide; petioles $\cdot 2$ in. long. Cymes pubescent, hairy on a glabrous peduncle 3 in. long. Bracts and stipules lanceolate acuminate pubescent. Male flowers unknown. Female flowers on short thick pedicels. Sepals oblong 
blunt, thickly pubescent. Ovary hairy semi-ovoid. Style conic hairy. Stigma pulvinate lobed. Fruit unknown. Hab. Forests, Singapore, Bukit Timah (Ridley).

The habit of this is quite like that of G. brunnerun and G. glaberrimum.

(4) G. glaberrimum Ridl. Kew Bulletin, I923, p. 363.

Shrub or tree Io to $15 \mathrm{ft}$. tall, glabrous. Leaves obliquely oblong bluntly shortly acuminate, base very shortly narrowed; nerves 9 pairs faint; 4 in. long, $I \cdot 5$ in. wide; petioles $\cdot 2$ in. long. Stipules rigid lanceolate acuminate acute. Male flowers not seen. Female flowers sub-sessile or with a short thick pedicel several in an axil. Sepals coriaceous ovate acute. Ovary ovoid. Style long stout clubbed with 3 broad lobes. Capsule orbicular flattened not lobed, $\cdot 25$ in. wide (ripe ?). Hab. Perlis, Kanga (Ridley).

Allied to $G$. brunneum, but the inflorescence is not peduncled and the style much longer.

(5) G. obscurum Bl. Bijdr. 585; Hook. fil. F.B.I. v. 3 I7.

Shrub 6 to $8 \mathrm{ft}$. tall to a tree 30 to $40 \mathrm{ft}$. tall and 6 to $\mathrm{I} 2 \mathrm{in}$. through; branches finely tomentose. Leaves distichous oblong blunt, base unequal ; nerves about 6 pairs sub-coriaceous; glabrous above except midrib, entirely grey-pubescent beneath, I.5 to 2 in. long, $\cdot 5$ to $\cdot 75$ in. wide; petioles very short. Flowers few together, male and female. Males on slender pubescent pedicels $\cdot 2$ in. long. Sepals oblong blunt, pubescent outside, 08 in. long. Anthers 3 (rarely 4 or 5) in a globose column. Females solitary among the males. Sepals short blunt recurved. Ovary globose 6- to 7-celled tomentose. Style columnar, 5 to 6 together tomentose. Capsule globose brown not lobed tomentose, 3 in. through on a pedicel $\cdot 5$ in. long. Hab. Common in woods and thickets. Pahang, Pekan, and Pahang River banks. Selangor, Kwala Lumpur. Perak, Sungei Rayah and Goping (Kunstler); Ulu Temengoh. Province Wellesley, Permatang Bertam. Penang (Wallich); Waterfall and Government Hill, $300 \mathrm{ft}$. altitude (Curtis). Distrib. Siam, Sumatra, Java, China.

(6) G. superbum Baill. Etudes Gen. Euphorb. 638.

A little-branched tree 20 to $30 \mathrm{ft}$. tall, 8 to ro in. through; branchlets stout densely tomentose. Leaves thickly coriaceous glabrous with sunk reticulations, above midrib hairy, beneath all tomentose; nerves Io pairs conspicuous as are reticulations; oblong acuminate or round-tipped, base round or cordate, 6 to 9 in. long, 3 to 4 in. wide; petioles $I$ in. long or less. Flowers small pink in dense clusters. Males on filiform pedicels $\cdot 2$ in. long, all glabrous. Sepals linear-oblong. Anthers 3, connectives acute. Female flowers sessile in the same head or shortly pedicelled. Sepals oblong hairy. Ovary 3-celled, hairy. Style forming a short hairy cone, 3-cleft. Capsules pedicelled entire, 3-lobed pink pubescent, nearly 2 in. through, in heads often 2 in. through. 
$H a b$. Open country secondary jungle. Common, Singapore, Tanglin; Selitar; Jurong. Malacca (Hervey); Ayer Panas (Cantley); Bukit Bruang (Derry). Perak, Relau Tujor (Wray); Ulu Bubong (Kunstler). Penang Hill (Wallich, Curtis, Kunstler). Distrib. Borneo, Java. Native names: Guramong Betina; Tamango.

(7) G. microbotrys Hook. fil. F.B.I. v. 2I9.

A tree 30 to $50 \mathrm{ft}$. tall, stem Io to $15 \mathrm{in}$. through, glabrous. Leaves elliptic or ovate-oblong sub-acute shortly cuspidate thinly coriaceous, rich glossy green drying black; nerves 6 to 8 pairs, slender; $3 \cdot 25$ to 4 in. long, I.75 to 2 in. wide; petioles.$I$ to $\cdot I 5$ in. long. Flowers in peduncled cymes; peduncles $\cdot 5$ to $\cdot 75$ in. long. Male and female flowers mixed all pedicelled. Male flowers very minute, .05 in. long. Outer sepals broad ovate, inner nearly round. Anther-column broad, connectives blunt. Female perianth as in male. Ovary globose glabrous; style faintly 4- to 6-lobed, very short. Capsule sub-sessile, $\cdot^{2} 2$ in. through, turbinate globose glabrous, 3-lobed, 6-ribbed, green, flat at tip, drying black. Hab. Rocky creeks and forest, Singapore (Kunstler); Changi; Chan Chu Kang; Pulau Ubin (Ridley). Perak, no locality (Kunstler).

(8) G. glomerulatum Boerl. Fl. Nederl. Ind. iii. 276 . Phyllanthus glomerulatus Mull. Arg. DC. Prod. I5, ii. 293.

Glabrous tree with slender branches. Leaves thinly coriaceous drying black lanceolate-elliptic acuminate; nerves 6 pairs slender; 3 in. long, $I \cdot 5$ in. wide; petioles slender, ' $I$ in. long. Flowers in small clusters sessile yellow. Bracts very small oblong lanceolate. Male flowers minute. Anthers 3, connate, connectives prolonged blunt. Female flowers sessile; sepals 5 or 6 broadly ovate blunt. Ovary glabrous. Styles very short. Capsule white, globose, 3-lobed, 6-ribbed, 'I in. through, puberulous. Hab. Rare, Perak Goping (Kunstler). Distrib. Sumatra.

Near $G$. microbotrys, but the fruits are sessile and the style more minute.

(9) G. singaporense Gage, Rec. Bot. Surv. Ind. l.c. $22 \mathrm{I}$

Tree or shrmb, branchlets yellow-brown muriculate. Leaves obliquely oblong-ovate or oblong-elliptic, shortly sub-caudate acuminate, base unequally cuneate above shining glabrous except the hairy base of the midrib, beneath minutely pustular, midrib and nerves 9 pairs sparsely hairy; I. 4 to $4 \cdot I$ in. long, $\cdot 75$ to 2 in. wide, more or less hairy. Flowers mixed in minute axillary heads. Bracts ovate more or less ciliate. Male flowers, pedicels filiform, -I2 in. long, sparsely hairy. Sepals 3, oblong-ovate, sub-acute, sparsely setulose outside. Petals smaller nearly or quite glabrous. Anthers 3, connectives forming an umbo. Female flowers subsessile. Sepals lanceolate hairy outside. Petals narrower. Ovary sub-conic, 3-celled, hairy. Style trifid. Capsule on a pedicel $\cdot \mathbf{r} 2$ in. long, depressed sub-globose, 3-lobed, - $\mathrm{I}$ in. long, 'I2 in. wide, velvety pubescent, cocci rounded; style minute trifid. Seeds obliquely

FI.M.P., 3 
triquetrous. Hab. Singapore, Reservoir; Bajau; Pulau Damar; Botanic Gardens (Ridley). Malacca and Sungei Ujong (Cantley).

(Io) G. Kunstlerianum Gage, Rec. Bot. Surv. Ind. l.c. 220.

Shrub 6 to $9 \mathrm{ft}$. tall; branches yellowish brown, sometimes sparsely pubescent. Leaves oblong-lanceolate thinly coriaceous acute or caudate-acuminate, base rounded slightly unequal, above dark, beneath, midrib ferruginous pubescent and scabrid with hair bases; nerves Io to I2 pairs; I. 5 to 3.5 in. long, $\cdot 3$ to I. 25 in. wide ; petioles more or less red pubescent, 05 in. long. Flowers in axillary heads. Male flowers pedicelled; bracteoles imbricate triangular, $I$ in. long, pedicels half as long. Sepals 6 or 7 in two rows, widely ovate. Petals 3 or 4 , narrower. Stamens 3, connectives forming a cone. Female flowers sessile. Sepals more or less red pubescent, broadly ovate. Petals ovate. Ovary above ferruginous-tomentose. Styles 3 , thick conic diverged. Fruit suborbicular, 3-lobed, $\cdot I$ in. long, ${ }^{\prime} 5$ in. wide, slightly pubescent. Seeds smooth triquetrous. Hab. Singapore (Kurz, Anderson). Johor, Serom (Ridley). Selangor, Kwala Lumpur (Curtis). Perak, Ulu Kerling (Kunstler).

(II) G. trilobum Ridl. Kerw Bulletin, I923, p. 364.

Tree. Branchlets finely pubescent. Leaves membranous or sub-coriaceous obliquely oblanceolate blunt acuminate glabrous above except midrib and nerves 7 pairs, fine pubescent beneath, 4.25 to 5 in. long, $I \cdot 5$ to 2 in. wide; petioles ${ }^{-} 5$ in. long. Male flowers in pubescent fascicles of 8 ; pedicels slender, $\cdot{ }^{2} 2$ in. long, pubescent. Sepals, outer whorl linear-oblong blunt recurved pubescent, inner ones similar but glabrous spreading. Anthers shorter 3, forming a cone. Female flowers unknown. Capsules about I2, in a cluster on a short pubescent raceme on pedicels $\cdot 2$ in. long pubescent, obcordate trilobed top, depressed pubescent, - I5 in. across. Style pulvinate short. Sepals short oblong. Seeds 3, shining red, backs rounded. Hab. Woods. Singapore, Botanic Gardens (Ridley). Negri Sembilan, Tampin (Burkill).

Allied to $D$. microbotrys, but that is quite glabrous and has a longer peduncle and shorter pedicels.

(I2) G. Maingayi Gage, Rec. Bot. Surv. Ind. l.c. 22I.

Shrub or tree, glabrous. Leaves coriaceous elliptic blunt, base round; nerves 8 pairs; 5 to 7 in. long, 2.75 to 3 in. wide; petioles $I$ in. long, thick. Flowers in a head 5 in. through, on a stout peduncle $\cdot 2$ in. long. Male flowers, pedicels $\cdot I$ in. long. Sepals 6, obovate, outer ones setulose outside. Stamens 5, connectives forming an umbo. Female flower pedicels half as long as male. Calyx cup-shaped with 5 sub-triangular teeth. Ovary subglobose or sub-pyriform, tip obtuse or sub-acute, 5-cleft half exsert from calyx. Capsule (unripe) sub-globose 4-locular. Hab. Singapore, Bukit Timah (Ridley). Malacca (Maingay).

Near G. goniocarpum Hook. fil., but the stigma is sessile. 
(I3) G: goniocarpum Hook. fil. F.B.I. v. 309.

Tree 20 to $30 \mathrm{ft}$. tall, glabrous. Leaves thinly coriaceous elliptic-oblong, acuminate or acute, base unequal; nerves 6 or 7 pairs, slender; 4 to 6 in. long, I.5 to $2 \cdot 5$ in. wide; petioles . I in. long. Flowers clustered in axils, all shortly pedicelled. Males; outer sepals hairy, inner glabrous. Anthers 5. Females; pedicel stout. Sepals broad ovate blunt hairy. Style stout columnar 3- to 6-cleft pubescent. Ovary 5- to 6-celled. Capsule sub-globose pubescent brown, obscurely 5 -lobed flattened at both ends, 4 in. through, with enlarged rounded sepals at base. Hab. Singapore (Kunstler); Botanic Gardens, a shrub $6 \mathrm{ft}$. tall (Ridley).

(I4) G. arborescens Bl. Bijdr. 584. G. sclerophyllum Hook. fil. F.B.I. V. 3I 4 .

Shrub; branchlets rather thick pubescent. Leaves stiffly coriaceous broad ovate or oblong acute, base round or sub-cordate usually inæquilateral, glabrous above except base of midrib, pubescent beneath; nerves I2 pairs prominent beneath; 4 to 6 in. long, 2 to $2 \cdot 5 \mathrm{in}$. wide; petioles $I$ in. long. Flowers very small. Males on slender pedicels $I$ in. long from a short thick raceme. Sepals oblong. Anthers 5. Females densely hairy. Style subcylindric hairy. Ovary hairy or glabrous. Capsule small globose depressed $4^{-}$to 5-lobed. Style short conical. Hab. Malacca, Bukit Bruang (Griffith). Lankawi, Terutau at Telok Wau (Robinson). Distrib. Java.

(I5) G. tetrapteron Gage, Rec. Bot. Surv. Ind. l.c. 223.

Tree or shrub, branches 4 -winged minutely pubescent. Leaves lanceolate acuminate apiculate, base unequally rounded or broadly cuneate membranous, above sparsely pubescent or muriculate with hair-bases and midrib only pubescent, beneath midrib and I2 pairs of nerves pubescent; $3 \cdot \mathrm{I}$ to $4 \cdot 75 \mathrm{in}$. long, 75 to $\mathrm{I} \cdot 25 \mathrm{in}$. wide; petioles short pubescent. Flowers in small axillary heads. Bracts triangular minute. Male flowers on pedicels 'I in. long. Sepals and petals oblong-ovate or obovate sub-equal sparsely pubescent outside. Anthers 3, connectives forming a narrow cone. Female flowers sub-sessile, perianth 6-toothed pubescent outside. Ovary sub-orbicular 3-celled tomentose; style long columnar clubbed more or less pubescent trifid. Capsule pedicelled orbicular 6-lobed, more or less pubescent, $\cdot I 2$ in. long, 2 in. wide, 3 -celled, top depressed; style persistent. Seeds smooth oblique triquetrous. $H a b$. Mountain forests, Semangkok Pass (Ridley).

(I6) G. villicaule Hook. fil. F.B.I. v: 326.

Shrub 4 to $6 \mathrm{ft}$. tall. Branchlets hairy with short rough hairs. Leaves thinly coriaceous ovate elliptic or oblong acuminate acute or blunt, base round, midrib above hairy; nerves 6 pairs and nervules hairy; I to 2 in. long, 75 to $I$ in. wide; petioles very short. Male flowers few, shortly hairy pedicelled. Sepals lanceolate hairy. Anthers 3 to 5, large, with large free connectives. 
Female flowers minute sessile. Ovary pubescent, 3- to 4-celled. Style slender longer than perianth, swollen above the middle and narrowed to the tip, 2- to 3-toothed. Capsule 5 in. through, 6 to 8 , lobed hairy top depressed pink. Seed reniform brown shining. Hab. Heaths and open country, Negri Sembilan, Tampin; Johol (Ridley). Perak (Scortechini). Kedah, Alor Sta. Kelantan, Kota Bharu (Ridley). Distrib. Burma, Yunnan, Annam.

(I7) G. coronatum Hook. fil. F.B.I. v. 326. Bradleia coronata Wall. Cat. 7857. Phyllanthus penangensis Müll. Arg. in DC. Prod. xv. (2), 3Io.

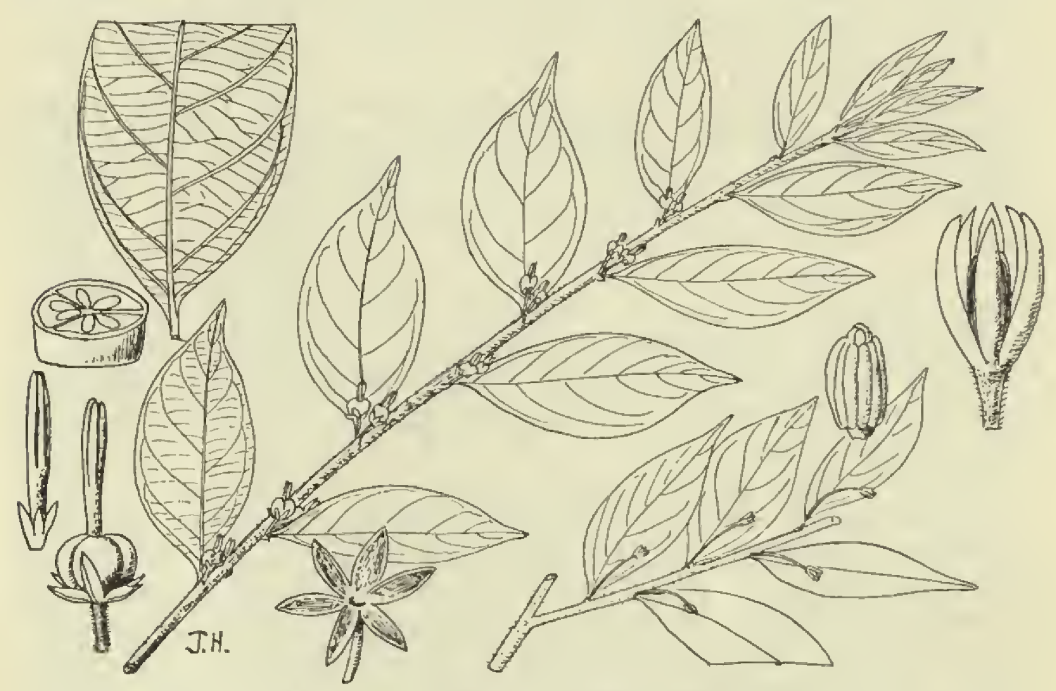

FIG. I5 T.-Glochidion leiostylum.

Shrub 8 to $\mathrm{I} 2 \mathrm{ft}$, tall. Branchlets roughly short-hairy. Leaves chartaceous, sub-sessile elliptic-oblong acuminate, base rounded often unequal, glabrous above except the midrib, sparsely hairy and glaucescent beneath midrib and nerves densely hairy; nerves 6 to 8 pairs; 2.5 to 3.25 in. long, $I \cdot 25$ to $I \cdot 75$ in. wide; petioles hairy, hardly any to $\cdot I$ in. long. Male flowers white minute; pedicels hairy. Stamens 3, connectives umbonate. Female flowers few in dense axillary clusters sessile. Sepals very small lanceolate lairy. Style cylindric, I I in. long, 3-cleft at the top, yellow. Capsule 3 - to 6-lobed, hoary tomentose, $\cdot 3$ in. through, purpleviolet. Seeds red. Hab. Rocky jungle; Negri Sembilan, Bukit Tangga. Perak, Larut (Kunstler). Penang (Wallich, Kunstler); Waterfall (Burkill); Batu Feringhi (Curtis). Distrib. Mergui.

(I8) G. leiostylum Kurz, For. Fl. ii. 345; Hook. fll. F.B.I. v. 324. (Fig. I5I.) 
Tree. Branchlets glabrous or pubescent. Leaves thinly coriaceous, smooth glabrous dark green above, drying black above. red-brown beneath, glabrous, ovate-elliptic acuminate or oblonglanceolate, base round or shortly acute; nerves 6 pairs slender; 2 to $2.5 \mathrm{in}$. long, 5 to $I$ in. wide; petioles under $\cdot I$ in. long. Flowers in small tufts. Male flowers pedicelled, pedicels 25 in. Iong. Anthers 3. Female flowers few clustered, sessile. Sepals lanceolate acute, glabrous or puberulous. Ovary villous. Style long cylindric, 3-lobed at tip, bright orange-yellow. Capsule orbicular flattened at top and bottom, 6- to 8-lobed glabrous red, 2 in. through, on a short stout pubescent pedicel, with enlarged sepals; style long persistent considerably enlarged, eventually caducous. Seeds chestnut-red shining with round backs and an acute angle on inner face. Hab. Low-lying damp ground on forest edges. Common, Singapore, Chanchu Kang; Jurong. Malacca (Griffith). Selangor, Kwala Lumpur. Perak, Changkat Mentri (Kloss). Penang, Batu Feringhi. Lankawi, Kwah (Curtis), Terutau (Robinson). Distrib. Burma, Siam. Native name: Ubah Vechil.

Hooker says style very minute in capsule. It is remarkably large until the fruit is almost quite ripe, when it appears to fall off.

(Ig) G. insulare Hook. fil. F.B.I. v. 3Io.

Branchlets long slender densely red-hairy. Leaves membranous elliptic-lanceolate acuminate, base acute, glaucous beneath with midrib hairy; nerves 7 pairs fine; 2 in. long, I in. wide; petioles tomentose, 'I in. long. Male flowers small on capillary pedicels .2 in. long. Sepals linear oblong glabrous. Anthers 4 to 6. Female flowers short-pedicelled. Sepals very short tomentose all over. Style short columnar trifid glabrous. Ovary villous, 3-celled. Hab. Penang (Wallich, 7875). Rare, not seen since.

(20) G. Wallichianum Miill. Arg. Linnaa, xxxii. 67; Hook. fil. F.B.I. v. 3I5. G. Curtisii Hook. fil. l.c. 327.

Tree? Branchlets hoary-pubescent. Leaves thinly chartaceous elliptic-oblong shortly blunt acuminate, base narrowed oblique; nerves 8 or 9 pairs elevate beneath with midrib and nervules hoary pubescent; 2.5 to 6 in. long, I to 2 in. wide; petioles -I in. long. Male flowers sometimes very numerous in small tufts; pedicels filiform, $\cdot 2$ in. long, hoary pubescent. Sepals oblong blunt pubescent. Anthers 3, connective short conic. Female flowers, sepals very short triangular pubescent. Ovary small, pubescent, $3^{-}$to $4^{-c e l l e d}$. Style turgidly columnar with 3 or 4 broad apiculate lobes. Hab. Forests at I200 ft. altitude; Penang (Wallich) ; Cooly lines, Government Hill (Curtis).

(2I) G. perakense Hook. fil. F.B.I. v. 3I 7 .

Tree $20 \mathrm{ft}$. tall, glabrous, branches black. Leaves thinly coriaceous oblong-lanceolate to lanceolate sub-acute, base narrowed; nerves slender, 5 or 6 pairs; 3 to 4 in. long, I to I.5 in. wide; 
petioles ${ }^{\prime}$ to ${ }^{\prime} 5$ in. long. Flowers grey brown and dark yellow, in clusters. Male flowers on slender pedicels $\cdot 2$ in. long. Sepals broad oblong. Anthers 3. Female flowers among the males, or in clusters by themselves; pedicels short and thick. Sepals small, ovate blunt. Ovary villous globose; style thick cylindric short villous top round. Capsule depressed globose 3-celled subglabrous obscurely 6 -lobed, 5 in. through. Sepals oblong spreading ; pedicels -2 in. long. Hab. Hill forests, Perak, Thaiping and Sabatang (Wray); Sungei Batang (Kunstler). Penang, West Hill at I000 ft. altitude (Curtis). Perlis, Bukit Telor Jambu, Kanga (Ridley). Native name: Telungoh.

(22) G. macrostigma Hook. fil. F.B.I. v. 313.

Small tree $30 \mathrm{ft}$. tall, glabrous. Leaves elliptic-oblong subacute, base oblique acute; membranous drying black; glaucous beneath; nerves 5 to 6 pairs very slender; 2 to 3.5 in. long, I.5 in. wide; petioles very short. Flowers few in short racemes with numerous ovate acute bracts; pedicels slender, $\cdot 2$ in. long. Male flowers; sepals oblong. Anthers 5, connective hemispheric. Female flowers 6-lobed pubescent. Style very large globose 5- or 6 -cleft, suddenly contracted into a very short base, narrower than the globose 5- to 6-celled ovary. Hab. Hill woods, Penang Hill at 500 to $2000 \mathrm{ft}$. altitude (Curtis, Ridley).

(23) G. nanogynum Hook. fil. F.B.I. v. 318.

Shrub or large tree, quite glabrous. Leaves thin dark redbrown when dry, elliptic, oblong, or elliptic-lanceolate blunt acuminate, base round or slightly narrowed, often oblique; nerves slender, 6 pairs; 3 to $3 \cdot 25$ in. long, I to $I \cdot 25$ in. wide; petioles 'I in. long. Flowers very small in small axillary clusters. Sepals oblong blunt. Anther-column cylindric. Ovary in female flowers minute villous covered by the depressed trigonous style. Capsules very small, $\cdot 2$ in. wide, orbicular depressed with 6 lobes, pubescent greyish white. Hab. Malacca (Maingay, Griffith). Selangor, Batu Caves. Perak. Penang (Wallich and all collectors). Native name: Semak Suai.

(24) G. desmocarpum Hook. fil. F.B.I. v. 318.

Small bushy tree about $30 \mathrm{ft}$. tall, branchlets pubescent. Leaves elliptic-oblong, blunt, base very shortly acute, glabrous entirely or midrib and nerves 7 or 8 pairs pubescent beneath; 4 in. long, I.5 to 2 in. wide; petioles hardly $\cdot I$ in. long. Male flowers minute clustered. Sepals ovate tomentose. Anthers 3. Ovary pubescent. Style hemispheric, 3-lobed. Capsules clustered shortly pedicelled orbicular depressed, 6- to 8-lobed, pale green hoary-pubescent, $\cdot 2$ in. wide; style forming a short central point. Seeds orange. Hab. Wet lowland spots, river-banks, Singapore, Pulau Damar. Malacca (Griffith). Selangor, Kwala Lumpur, Perak, Changkat Serdang (Wray); Goping (Kunstler). Penang (Herb. Hooker), Government Hill (Ridley). Native names: Ubah hitam; Samak Serai. Use: Bark used for tanning. 
(25) G. lævigatum Hook. fil. F.B.I. v. 319.

Tree 40 to $50 \mathrm{ft}$. tall; stem 8 to $\mathrm{x} 2$ in. through, glabrous, or twigs pubescent. Leaves chartaceous, thin, glaucescent beneath, obliquely elliptic or ovate cuspidate or acuminate, base narrowed; nerves 6 pairs slender; 2 to 3.5 in. long, $\cdot 75$ to I. 5 in. wide; petioles -I in. long. Stipules triangular-lanceolate coriaceous. Flowers very small in tufts. Male flowers on slender pedicels. Sepals linear-oblong. Anthers 3. Female flowers; sepals oblong blunt. Ovary globose glabrous, 5-celled; style of 5 to 6 minute points. Capsule $\cdot 3$ in. through, orbicular flattened, 6 - to Io-Iobed, glabrous, pedicelled. Hab. Common in open country. Singapore, Tanglin; Changi; Toas; Bukit Timah (Hullett). Malacca, Sungei Hudang (Derry, Griffith). Penang (Wallich); Highlands (Curtis). Lankawi, Kwah. Distrib. Tenasserim.

var. cuspidatum Ridl. Tree from I2 to $25 \mathrm{ft}$. tall and 4 to $5 \mathrm{in}$. through. Leaves ovate or ovate-lanceolate cuspidate mucronulate, base cuneate, not glaucescent beneath; nerves 7 pairs inarching within the margin; 3 to $4.5 \mathrm{in}$. long, I.5 to I. 75 in. wide. Capsule very dark red rather bigger, 6-lobed. Stigma larger. Hab. Selangor, Sungei Buluh (Ridley); Telok forest reserve, Klang (Burkill). Perak, Larut (Kunstler).

I have seen no flowers of this, and it may be specifically distinct.

(26) G. sericeum Hook. fll. F.B.I. v. 326. Glochidiopsis sericea $B l . B i j d r .588$.

Small tree, branches pubescent. Leaves chartaceous oblong blunt, base round, puberulous above at least on midrib, glaucous puberulous beneath; nerves 7 to 8 pairs, slender; 3 to 4 in. long, $I .25$ to $I .5$ in. wide; petioles 05 in. long, pubescent. Flowers all pedicelled very small. Males; sepals 6 . Anthers 3 . Females; sepals 2 or 3. Ovary globose, villous, 3 -celled. Styles 3 , villous bifid. Capsule I5 in. across, 3-lobed, shortly pedicelled pinkish. Seeds 6 in 3 pairs, bright red. Hab. Common on edges of woods and thickets. Whole peninsula to Perak. Singapore, Tanglin; Bukit Mandai; Thompson Road (Hullett). Johor, Genuang; Tanjong Kupang. Malacca, Ayer Panas (Griffith). Pahang, Pulau Tawar. Negri Sembilan, Burunang (Cantley). Selangor, Ulu Gombak; Semangkok Pass to $4000 \mathrm{ft}$. altitude (Ridley). Perak, Goping (Kunstler); Tapah (Wray). Distrib. Java. Native name: Kenidei Bukit.

(27) G. stylosum Ridl. Kew Bulletin, I923, p. 364.

Small tree; young parts hairy. Leaves coriaceous not glaucescent beneath obliquely lanceolate-oblong acuminate, base broad, slightly narrowed at tip, glabrous above except midrib, 'hairy on 7 pairs of nerves and midrib beneath; 3 to 3.5 in. long, $x \cdot 5$ in. wide; petioles hairy, $\cdot$ I in. long. Male flowers few in axillary fascicles on short pubescent pedicels $I$ in. long. Bracts ovate pubescent. Sepals oblong sub-equal hairy on the back. Female flowers sessile; sepals ovate acute pubescent. Ovary hairy. Styles very long 
glabrous filiform free, $\cdot 2$ in. long. Capsule puberulous, $\cdot 25$ in. long, rounded. Seeds sub-reniform, backs rounded, bright red. Hab. Mountains, Semangkok Pass (Ridley).

Allied to G. sericeum, but not silky pubescent, rather sparsely hairy, leaves coriaceous, more lanceolate and styles much longer.

\section{FLUEGGIA, Willd.}

Shrubs. Leaves small distichous alternate. Flowers minute axillary pedicelled, apetalous, males numerous clustered, females solitary. Male flowers; sepals 5, sub-petaloid imbricate. Stamens 3 to 5 , with as many disc glands; filaments free. Pistillodes 3, large with recurved tips. Female flowers as male but disc annular. Ovary I- to 3-celled; styles elongate recurved 3-bifid. Fruit globose, epicarp fleshy breaking irregularly or into 2 -valved cocci. Species 6, Old World tropics.

(I) F. microcarpa Bl. Bijdr. 580; Hook. fil. F.B.I. 328. F. virosa Baill. Etud. Euphorb. 593, $t$. xxvi. Fig. 39.

A bush about 5 or $6 \mathrm{ft}$. tall. Leaves elliptic or obovate, base narrowed, tip rounded chartaceous; nerves 5 or 6 pairs; I in. long, $\cdot 5$ in. wide; petioles $\cdot I$ in. long. Flowers very small in dense tufts with numerous bracts, pedicelled, 08 in. wide; pedicels slender, ${ }^{2} 2$ in. long. Sepals round or oblong. Stamens 3 to 5, filaments long. Pistillodes 3 united at the base, with simple or lobed tips. Ovary ovoid. Fruit fleshy white, - I in. through. Seeds 3 to 6. Hab. Open country, edges of rivers, Pahang, Pekan and other places on Pahang River; Tahan River. Perak, Temengoh; Ulu Tupai (Wray); Tampan (Wray); Sungei Rayah (Kunstler). Kedah (Kunstler). Kelantan River, Chaning. Tomoh (Machado). Penang, common near the Gardens. Lankawi, Kwah (Curtis). Distrib. Old World tropics, Africa, Asia, Australia.

\section{CICCA, Linn.}

Tree. Leaves thin distichous. Flowers minute in dense clusters axillary or racemed. Sepals 4 (rarely 5). Stamens 4, free, anthers oblong. Styles 4, free. Fruit fleshy with 3- to 4-celled bony endocarp. Species I, Asiatic.

(I) C. disticha Limn. Mantiss. I24. Phyllanthus distichus Miill Arg. Linnaea, xxxiv. 75; DC. Prod. xv. (2), 424; Hook. fil. F.B.I. v. 304 .

Tree about $I_{5}$ to $20 \mathrm{ft}$. tall, with erect branches at top; branchlets slender. Leaves distichous thin, obliquely ovate acute, base rounded, tip acute, 2 in. long, I in. wide, light green; petioles $\cdot I$ in. long. Flowers very small in slender racemes 2 in. long from the thick branches. Sepals orbicular pink at base. Disc of male of large glands; of females annular crenate. Fruit yellow-green, I in. long, globose fleshy acid, obscurely 6-lobed depressed at both ends. Hab. In gardens. Cultivated only. Distrib. Asia. Native name: Chermela. Use: Fruits for pies. 


\section{EMBLICA, Gaertn.}

Trees. Leaves narrow linear close set. Flowers densely fascicled along the branches. Male flowers; sepals 5 to 6 . Disc 0. Filaments united in a column, connective produced. Female flowers, styles 3 , united below twice bifid. Fruit fleshy indehiscent large, cocci bony, 3. Species II, Indo-Malaya, South America.

(I) E. pectinata Ridl. Phyllanthus pectinatus Hook. fil. F.B.I. v. 290 .

Tree about 40 to $50 \mathrm{ft}$. tall, bark red-flaky; branchlets scurfy red-tomentose slender. Leaves distichous close-set linear-oblong blunt coriaceous glaucous beneath, edges recurved, nerves very inconspicuous, $\cdot 2$ in. long, $\cdot 08$ in. wide. Flowers very small in small tufts; pedicels slender, I I in. long. Sepals 6, oblong-ovate, with a gland at the base of each. Anthers 3 in a ring on the top of a column. Ovary sub-globose with 6 recurved stigmatic arms. Fruit I in. long, globose green fleshy smooth, acid, with 3 bony 2-valved cocci but indehiscent. Hab. Edges of woods, common in the south; Singapore, Bukit Timah; Bukit Mandai; Sumbawang. Johor, Bukit Soga. Malacca (Griffith); Tanjong Kling (Cantley); Sungei Hudang (Derry); Selandor (Cantley); Perak, Tapah (Wray); Batang Padang district (Kunstler). Native name: Malaka. Use: Fruits eaten cooked.

\section{BREYNIA, Forst.}

Shrubs or small trees. Leaves small alternate. Flowers minute solitary or axillary in clusters. Male flowers; calyx turbinate or hemispheric truncate rim often thickened and lobulate, opposite the minute inflected round lobes. Stamens 3; filaments united in a column; anthers adnate to column. No pistillode. Female flowers; calyx hemispheric turbinate or rotate, lobes short broad, in fruit often enlarged and saucer-shaped. Ovary globose, truncate or depressed at tip, fleshy 3 -celled; ovules 2 in a cell. Styles 3 , united in a short column or sessile 2 -lobed or stigmas immersed in a depression. Fruit succulent, red, globose or depressed at tip indehiscent with 3 to 6 trigonous cocci. Species I2, Africa, Asia, Polynesia.

Small tree hairy

Trees or shrubs glabrous; leaves glaucous beneath. Calyx of female greatly enlarged in fruit.
Leaves oblong blunt, $\cdot 75$ in. long
Leaves ovate, $2 \cdot 25$ in. long
(2) B. angustifolia
(3) B. coronata

(I) B. discigera

Calyx hardly enlarged in fruit; flowers solitary.

Leaves cuneate at base; female calyx hemispheric

Leaves rounded at base; female calyx turbinate

Flowers cymose, 3 together

(I) B. discigera Müll. Arg. in DC. Prod. xv. (2), 440; Hook. fil. F.B.I. v. 33I.

A small tree $I_{5} \mathrm{ft}$. tall or shrub shortly roughly hairy all over. Leaves chartaceous elliptic-ovate sub-acute sparsely hairy above,

(4) B. rhamnoides

(5) B. reclinata

(6) B. Keithii 
grey hairy beneath; nerves 6 pairs; .75 in. long, .5 in. wide; petioles $\cdot 05$ in. long. Flowers solitary. Male flowers; calyx turbinate edge entire, pubescent. Staminal column fusiform. Female flowers; calyx saucer-shaped, lobes short, purple-pink. Ovary turbinate top convex. Fruit globose, $\cdot 2$ in. through; calyx slightly enlarged, an elevated ring on the top. $H a b$. Not rare in woods and thickets to $2500 \mathrm{ft}$. altitude, Singapore, Bukit Timah; Ang Mo Kio; Reservoir Woods. Malacca, Gunong Mering, Mt. Ophir. Negri Sembilan, Bukit Tangga at top, $2400 \mathrm{ft}$. altitude, Perak, Temengoh; Kwala Kangsa (Ridley); Simpang (Wray). Penang (Wallich); Western Hill; Waterfall (Curtis). Distrib. Siam.

(2) B. angustifolia Hook. fil. F.B.I. v. 330.

Shrub 8 to Io $\mathrm{ft}$. tall, glabrous. Leaves oblong tip and base rounded, base slightly unequal, membranous glaucous beneath; nerves very faint, 4 pairs; $\cdot 75$ in. long, $\cdot 25$ in. wide; petioles . 08 in. long or less. Flowers shortly pedicelled, very small, yellow. Male calyx campanulate, 6-lobed, lobes retuse. Female flowers broad, funnel-shaped, lobes 6 , round apiculate. Style stout with 3 recurved 2 -lobed arms. Fruit red, $\cdot 25$ in. through, calyx wider, much enlarged distinctly lobed purple. Hab. Rocky hill jungle. Perak, Ulu Batang Padang (Ridley); Larut (Kunstler). Distrib. Siam.

(3) B. coronata Hook. fil. F.B.I. v. 330.

Small tree, I5 to $20 \mathrm{ft}$. tall, stem 3 to 4 in. through, glabrous. Leaves thickly membranous glaucescent beneath, ovate blunt, base round; nerves conspicuous, 5 or 6 pairs; $2 \cdot 25$ in. long, I. $x$ in. wide; petioles 08 in. long. Flowers solitary axillary, reddish yellow. Males; calyx hemispheric, edge toothed. Stamens included. Females rather larger broadly funnel-shaped. Ovary included, broadly cuneiform truncate with 3 minute stigmas. Fruit globose, 3 in. through, cherry-pink with a ring on the top, 6 -valved; cocci 6 , enlarged; calyx $\cdot 2$ in. wide. $H a b$. Common in hill forests, Johor, Kwala Kahang (Kelsall). Negri Sembilan, Bukit Tangga. Selangor, Kwala Selangor; Old Fort and Ulu Gombak (Ridley); Rantau Panjang (Kloss). Perak, Ulu Ledang (Wray); Larut and Goping (Kunstler). Penang, Bagian Jennal (Curtis). Lankawi (Curtis). Native names: Chuma padang; Rumang panas.

(4) B. rhamnoides Miill. Arg. in DC. Prod. xv. (2), 440 (excluding vars.); Hook. fil. F.B.I. v. 330.

Small tree 5 in. through, quite glabrous. Leaves membranous glaucous beneath elliptic-ovate or round blunt, base cuneate, $\mathrm{I}$ in. long, $\cdot 75$ in. wide; petioles slender, $\cdot 08$ in. long. Flowers pedicelled. Males; calyx turbinate mouth of tube entire or obscurely lobed. Females; calyx shortly 6-lobed hemispheric. Ovary exserted. Fruit globose, 'I2 in. through, red, enlarged calyx 
quite small. Hab. Open country thickets; Singapore, Eskbank, Tanglin (Hullett); Pulau Buru. Negri Sembilan, Bukit Sulu (Cantley). Perak (Scortechini); Ulu Temengoh. Dindings, Lumut. Penang (Wallich). Distrib. India, China, Malay isles. Native name: Suruyian.

(5) B. reclinata Hook. fil. F.B.I. v. 33I.

Erect shrub, about $6 \mathrm{ft}$. tall, glabrous, branches spreading. Leaves coriaceous deep above, glaucous beneath; nerves 4 to 6 pairs; I to $I \cdot 5$ in. long, 5 to $\cdot 75$ in. wide; petioles very short. Flowers solitary, yellow decurved. Male calyx hemispheric, mouth crenate. Female calyx turbinate shortly 6-lobed. Fruit bloodred small, globose, I5 in. through, calyx very slightly enlarged. $H a b$. Common in thickets, edges of woods, Singapore, Tanglin; Changi; Pulau Ubin. Pahang, Kwala Pahang. Malacca, Mt. Ophir; Sungei Hudang (Derry); Pulau Besar (Griffith); Malaka Pindah (Cantley). Negri Sembilan, Gunong Berimbun (Cantley). Tringganu, Bundi (Rostados). Kelantan, Kwala Lebir (Gimlette). Distrib. Sumatra, Java. Native names: Poko Ambin Kra; Sumbar; Saga (Kelantan), Hujan Panas (lit. warm rain, i.e. drops of blood spilt in a fight), referring to the little blood-red fruits. Name also applied to B. rhamnoides.

(6) B. Keithii Ridl. Journ. Roy. As. Soc. S. Br. 59, p. I74.

Shrub, glabrous. Leaves membranous drying black, glaucous beneath elliptic blunt sub-acute, $\cdot 75$ to $I$ in. long, $\cdot 5$ in. wide; petioles .12 in. long. Male flowers turbinate. Female flowers on short lateral branches, 3 together, cymose shortly pedicelled, minute. Bracts linear setaceous. Calyx cupular entire. Fruit globose, I2 in. through, pedicel as long terminated by 3 short setaceous styles; calyx split into 5 unequal ovate-triangular acute lobes, more than half as wide as the fruit. Seeds 2 in a cell, yellowish white pubescent. Hab. Open country in the north. Kedah, Alor Sta. Setul at Bukit Bunga (Ridley). Distrib. Siam.

\section{SAUROPUS, B1.}

Small shrubs or shrublets. Leaves alternate distichous membranous. Stipules minute. Flowers small axillary apetalous, solitary or clustered. Male flowers; calyx saucer-shaped, urceolate or turbinate, 6-lobed. Stamens 3 , filaments connate in a very short trigonous column; anthers sessile on the angles of the column. Pistillode o. Female flowers; calyx 6-cleft persistent accrescent. Ovary ovoid, top round or concave, 3 -celled; ovules 2 in a cell. Styles 3 sessile depressed spreading with 3 recurved arms. Fruit globose, depressed, epicarp fleshy or coriaceous 6 -valved or dehiscing irregularly with 6 trigonous crustaceous cocci. Species 20, Indo-Malayan. 
Plants glabrous.

Leaves ovate, $6 \mathrm{in}$. long, $3 \mathrm{in}$. wide

(I) S. spectabilis

Leaves elliptic-lanceolate, 4 in, long. Styles depressed with 2 incurved arms

Leaves $2 \cdot 5$ in. long or less.

Leaves elliptic blunt; flowers in short racemes .

Leaves ovate-oblong acuminate; flowers in clusters (cult)

Leaves I in. long, obovate-oblong blunt, glaucous beneath

Plant densely hairy .

(2) S. forcipatus

(3) S. sumatranus

(4) S. albicans

(5) S. parvifolius

(6) S. Llanosii

(I) S. spectabilis Miq. Fl. Ind. Bat. Suppl. 446. S. macrophyllus Hook. fil. F, B.I. v. 333 .

Glabrous shrub, stems flexuous. Leaves membranous ovate acuminate; nerves 6 to 7 pairs; 6 in. long, 3 in. wide; petioles - I in. long or less. Flowers axillary from tubercles bearing bracts shorter than the petioles; pedicels stout, I in. long. Male flowers - I in. wide; pedicels slender. Calyx-lobes 5, oblong blunt rather deeply cut. Stamens 3, filaments very short. Female flowers; pedicels stout, $\cdot 5$ in. long. Calyx leathery, $\cdot 25$ in. wide, lobes rounded. Fruit on a lengthened pedicel, depressed globose, as big as a cherry-stone. Hab. Dense thickets at base of limestone cliffs, Selangor, Batu Caves (Ridley). Distrib. Assam, Sumatra.

(2) S. forcipatus Hook. fil. F.B.I. v. 334.

Shrub; branches black, nearly terete with a low ridge on one side, quite glabrous. Leaves thin elliptic or oblong-lanceolate acuminate, base acute; nerves 6 pairs; 3 to 5 in. long, $x \cdot 5$ to 2 in. wide; petioles $\cdot I$ in. long. Male flowers 3 in. wide on filiform pedicels as long, lobes 6 , minute rounded incurved into the centre. Anthers oblong. Female flowers in the same axil as male, 5 in. wide; pedicel short and stout. Sepals linear-oblong, spreading. Ovary oblong; styles (or stigmas) 3, depressed, divided in two arms like forceps. Hab. Perak (Scortechini).

(3) S. sumatranus Miq. Fl. Ind. Bat. Suppl. 446.

Shrub glabrous, branches rather slender flexuous with a low rib on each side, angled. Leaves membranous elliptic narrowed to the blunt tip and slightly at the base; nerves 4 pairs, faint; $2 \cdot 25$ to 3 in. long, I in. wide; petioles . $I$ in. long or less. Flowers in racemes $I$ in. long with ovate persistent bracts. Male flowers unknown. Female flowers $\cdot{ }^{2}$ in. across; pedicels ${ }^{\prime} I_{5}$ in. long. Calyx-lobes round rather deeply cut. Ovary sub-globose. Stigmas very short papilliform, 5. Hab. Lowland woods, Selangor, Klang Gates (Ridley). Distrib. Sumatra.

I have seen no type or specimen from Sumatra, but Miquel's description suits this plant.

(4) S. albicans Bl. Bijdr. 596; Hook. fil. F.B.I. v. 332. S. indicus Wight Ic. $t$. I952.

A shrub about 2 to $6 \mathrm{ft}$. tall, branching from near the base. Leaves membranous ovate-oblong or lanceolate blunt or acute 
base round, dark green above with a whitish central patch, glaucous beneath, 2 in. long, - I in. wide; petioles hardly any. Flowers small on short racemes $\cdot I$ in. long. Males $\cdot I$ in. wide, claretcolour. Calyx saucer-shaped with 6 short angles. Females larger, cup-shaped, purple. Calyx-lobes emarginate. Capsule with fleshy thick white or pink epicarp, 75 in. through. Hab. Gardens and waste ground; a popular vegetable. Singapore, Government Hill (Schomburgk). Malacca (Griffith, Hullett, Cuming). Perak, Goping (Kunstler). Penang. Kelantan near Kota Bharu. Distrib. IndoMalaya. Native names: Assin-Assin; Chekop.

The male flower is at first green, and becomes more and more spotted with pink, until it is quite dark pink by the time the dark red stamens have shed their pollen. The female flower is cup-shaped and purple.

(5) S. parvifolius Ridl. Journ. Roy. As. Soc. S. Br. 59, p. I75.

A slender branched shrub, $3 \mathrm{ft}$. tall; branchlets angled pubescent. Leaves alternate obovate to oblong blunt, base cuneate herbaceous glaucous beneath, $\cdot 75$ in. long, 5 in. wide; petioles slender, $\cdot$ I in. long. Stipules linear-subulate. Male flowers on very short racemes covered with ovate acute bracts on pedicels . I2 in. long. Perianth $\cdot_{2}$ in. long. Sepals flat with 6 oblong blunt lobes, pubescent beneath. Stamens 3. Females solitary in a terminal axil larger than males. Sepals oblong truncate. Styles short bifid recurved. Capsule $\cdot 25$ in. through, globose whitish thin-walled. Hab. Open country, Kedah, Alor Sta (Ridley). Lankawi (Robinson).

(6) S. Llanosii Gage, Rec. Bot. Surv. Ind. l.c. 223. Phyllanthus Llanosii Müll. Arg. Flora, xlviii. 387. Glochidion Llanosii Müll. Arg. Limnaa, xxxii. 68.

Small bush 2 or $3 \mathrm{ft}$. tall, very hairy all over. Leaves distichous crowded oblong shortly blunt acuminate, base usually broad, subsessile, I.I to $I \cdot 75$ in. long, $\cdot 2$ to $\cdot 75$ in. wide, pustulate and sparsely hairy above, closely hairy beneath. Stipules setaceous. Male flowers in small axillary tufts under $\cdot I$ in. across, hairy on the back and the short pedicel, glabrous above. Female flowers unknown. Capsule globose bright orange-yellow, glabrous globose, .25 in. through, crowned with the small incurved bifid stigmas. Hab. Open heaths, Lankawi (Curtis). Perlis, Ginting Kabok (Ridley). Distrib. Siam, Philippines.

\section{DRYPETES, Vahl.}

Trees. Leaves alternate entire or crenulate, base often inæquilateral. Flowers axillary racemed or clustered, apetalous pedicellate. Male flowers; sepals 4 to 6 broad imbricate. Stamens few or many inserted round a flattened disc; filaments free, short. Pistillode minute or 0 . Female flowers as in male but disc annular or 0 . Ovary 2- to 4-celled. Styles long or o. Stigmas dilate 
fleshy or connate into a peltate disc. Fruit sub-globose or ovoid indehiscent; pericarp thick 2-celled. Seeds I in a cell. Species I40, Africa, Indo-Malaya and Tropical America.

Leaves very coriaceous, $2 \mathrm{ft}$. long, base cordate

(I) D. pendula

Leaves coriaceous, $\mathrm{I} \mathrm{ft}$. long or less.

Leaves oblong unequally narrowed at base, I ft. long

Leaves oblong or elliptic lanceolate; nerves strongly elevate.

Base blunt unequal

Base acute equal

Leaves ovate caudate-acuminate, tip serrate
Leaves thin lanceolate acuminate, base unequal; nerves not prominent

(2) D. longifolia

(I) D. pendula Ridl. Kew Bulletin, I923, p. 365. Cyclostemon longifolius Hook. fil. F.B.I. v. 34 I (not of Blume).

Tree about 40 to $60 \mathrm{ft}$. tall with very long pendent branches. Leaves rigidly thick coriaceous shining green, red when young linear-oblong, unequal-sided, base unequally cordate; nerves 20 to 30 pairs; I to $2 \mathrm{ft}$. long, 4 to Io in. wide; petioles $5 \mathrm{in}$. long, very thick. Male flowers many in a cluster over I in. through, shortly pedicelled, 5 in. wide. Sepals 5, glabrous round concave. Stamens numerous round a flat disc. Stigmas 3, bifid. Fruit 2 to 2.5 in. through, globose slightly trigonous orange slightly tomentose. Hab. Lowland woods; not rare, Singapore, Garden Jungle ; Selitar. Selangor, Kwala Lumpur. Perak, Larut (Kunstler). Penang Hill (Maingay, Curtis). Native name: Garligo Salak. leaves.

A very striking tree from its very long pendent branches and large shining

(2) D. longifolia Pax. Pflanzenreich, iv. I47, Xv. 245.

Tree 30 to $40 \mathrm{ft}$. tall. Leaves coriaceous oblong to elliptic lanceolate slightly oblique at the narrowed base, bluntly acuminate; nerves 6 to 8 pairs prominent beneath; 9 to $\mathrm{I} 2$ in. long, 2 to 2.5 in. wide; petioles stout, -25 in. long. Flowers .5 in. across in axillary tufts from bare part of branches. Bracts short broad; pedicels $\cdot 2$ in. long, puberulous. Male flowers; sepals 4 or 5 , round orbicular velvety outside, edges denticulate ciliate. Disc concave villous. Stamens 30 to 50 . Female flowers; sepals as in male, disc annular. Ovary bilocular, densely pubescent. Stigmas transversely oblong sessile. Drupe sub-globose, 75 to I in. through, pubescent. Hab. Forests; Malacca (Maingay). Selangor, Weld's Hill (Burn-Murdoch). Distrib. South India, Ceylon, Andamans, Malay islands to Philippines.

(3) D. nervosa Pax Pflanzenreich, iv. I47, p. 244. Cyclostemon nervosus Hook. fil. F.B.I. v. 342 .

Tree 30 to $40 \mathrm{ft}$. tall, stem 8 to $\mathrm{I} 2 \mathrm{in}$. through; branchlets tomentose. Leaves oblong-lanceolate caudate-acuminate coriaceous glabrous except the midrib beneath, base unequal rounded; nerves I2 to I5 pairs, sunk above, elevate beneath; 8 to I2 in. 
long, 2 to 3 in. wide; petioles 2 in. long. Flowers in axillary clusters, sessile, about $\cdot 25$ in. wide. Sepals round concave fulvous tomentose. Stamens very many. Disc deeply sunk villous. Ovary fulvous tomentose; stigmas semi-circular. Fruit 5 in. through, dark brownish green. Hab. Open jungle on limestone hills 400 to $600 \mathrm{ft}$. altitude, Perak, Goping (Kunstler).

(4) D. Curtisii Pax PAlanzenreich, l.c. 250. Cyclostemon Curtisii Hook. fil. F.B.I. v. 343.

A small tree, glabrous. Leaves elliptic-lanceolate acuminate narrowed to base, not inæquilateral, thinly coriaceous; nerves Io pairs, sunk above, prominent beneath, and finely reticulate; 6 to Io in. long, I.5 to 2 in. wide; petioles 25 to 3 in. long. Male flowers unknown. Female flowers solitary axillary very shortly pedicelled. Calyx patelliform fringed with coarse hairs. Fruit (unripe) 5 in. through, 2-celled, cells 2 -ovuled glabrous; stigmas 2, small hemispheric. Hab. Hill forest, Penang, Moniot's Road at $2500 \mathrm{ft}$. altitude (Curtis).

(5) D. perakensis Gage, Rec. Bot. Surv. Ind. l.c. t. 223.

Shrub or small tree glabrous. Leaves coriaceous ovate caudateacuminate, base sub-cuneate, entire or near the tip bluntly serrate or undulate; nerves 6 to 9 pairs; 4.75 to 8 in. long, $2 \cdot 6$ to 3 in. wide; petioles 5 to $I$ in. long. Male flowers in small heads. Bracts ovate-triangular minutely silky; pedicels $\cdot I$ in. long. Sepals 2, imbricate, ovate sub-orbicular, - I in. long and wide. Petals 2, smaller. Disc quadrate or oblong, edge raised. Stamens 20 , surrounding the disc; anthers oblong-ovate, 4-celled. Female flowers in few-flowered heads. Pedicels thick more or less silky. Sepals acute fulvous pubescent outside. Disc sub-cupular or ring-shaped hairy. Ovary glabrous 2-celled ovoid longitudinally grooved; ovules 2 in a cell. Stigmas 2 , sessile oblong or semilunar. Fruit drupaceous of 2 cocci ovoid glabrous bilobed, $\cdot 6$ in. long and wide, $\cdot 4$ in. thick, pericarp thin coriaceous. Seeds 2. Hab. Perak, Larut, and Gunong Bubu (Kunstler) ; B'landa Mabok (Wray).

Near $D$. Curtisii, but the leaves ovate and twice as long as wide. I have not seen this species.

(6) D. riparia Ridl. Kew Bulletin, I923, p. 365.

A small tree, young branches pubescent, lower parts whitebarked. Leaves thinly coriaceous, glabrous lanceolate acuminate entire base narrowed acuminate slightly unequal; nerves very slender, Io pairs slightly elevate beneath, as are the nervules and reticulations; 7 in. long, I.5 to 2 in. wide; petioles light brown rugose and pubescent, $\cdot 3$ in. long. Flowers not seen. Drupe globoseoblong bisulcate 2 -celled, yellowish pubescent, $\cdot$ I in. long; pedicel stout axillary, $\cdot \mathrm{I}$ in. long. Sepals rounded hairy. Hab. River banks, Kelantan, banks of the Lebir River at Jeram Panjang (Ridley).

Near D. sumatrana Pax, but the leaves are bigger and not crenulate, the fruits larger and pubescent. 


\section{LONGETIA, Baill.}

Glabrous trees. Leaves opposite coriaceous entire. Flowers small axillary apetalous, males in racemose cymes, females few in sessile spikes. No disc. Male flowers; sepals 4 to 6 , membranous oblong imbricate. Stamens 4 , opposite sepals, inserted round a conical pistillode, filaments free. Female flowers; sepals 4, broad fleshy embracing the ovary imbricate. Ovary 3-celled; ovules 2 in a cell. Styles free thick not divided. Capsule of 3 bivalved cocci, leaving a central column when fallen. Seeds oblong with an aril. Species 6, Malay Peninsula and New Caledonia.

Leaves oblong to obovate, 4 by 2 in., thin coriaceous.

Leaves elliptic, 2 by ' 75 in,, stiff coriaceous .

(I) L. malayana

(I) L. malayana Pax Pfanzenreich, iv. I47, xv. 29I. Choriophyllum malayanum Benth. in Hook. Ic. Pl. t. I2So; Hook. fil. F.B.I. v. 344 .

Medium or big tree, buds pubescent. Leaves oblong, linearoblong or obovate blunt narrowed at the base to the stout petiole, bright green, midrib prominent; nerves very fine numerous; 3 to $4 \mathrm{in}$. long, I to 2 in. wide; petioles $I_{5}$ in. long. Male cymes I to I.5 in. long, much branched lax, several together, flowers white, I in. wide, sessile or pedicelled. Stamens as long as petals. Female; sepals acute. Capsule $\cdot 75$ in. long, pyriform sub-angled; epicarp of valves separating from the crustaceous endocarp. Hab. Dry spots, often near the sea; Singapore, Sungei Buluh; Serimbun. Johor, Tana Runto. Malacca (Griffith). Pahang, Renchong and Pekan (Ridley). Dindings, Penang, common up to $3000 \mathrm{ft}$. altitude, West Hill (Maingay, Curtis). Kedah, Pulau Song Song. Distrib. Borneo.

(2) L. montana Pax, l.c. 29I. Choriophyllum montanum Ridl. Journ. Linn. Soc. xxxviii. 322.

A shrub. Leaves opposite coriaceous elliptic, base narrowed, tips retuse shining above, paler beneath, 2 in. long, $\cdot 75$ in. wide; nerves faint more conspicuous above; petioles ' $I$ in. long. Flowers yellow. Capsule globose not angled; cocci 3 , bivalved, 5 in. long. Seed $\cdot 25$ in. long, chestnut-red polished, elliptic, sub-oblique; aril bilobed with sub-acute triangular lobes half covering the seed. Calyx small, lobes ovate acute. Hab. High mountains; Pahang, Gunong Tahan (Robinson and Ridley).

I have seen no flowers of this plant.

\section{ANTIDESMA, Linn.}

Trees or shrubs. Leaves entire alternate, stipulate. Flowers small or minute in slender axillary or terminal simple or panicled spikes or racemes, apetalous. Male flowers; calyx 3- to 5-, rarely 6- to 8-lobed. Disc entire or lobed. Stamens 2 to 5 inserted on or round the disc, anthers lunate or didymous, connective thickened, 
cells globose. Pistillode minute or o. Female flowers; calyx as in male. Disc shortly annular or pulvinate. Ovary celled; stigmas 2 to 4 , bifid; ovules 2 . Fruit a compressed drupe crowned with sub-lateral or terminal stigmas. Species about 70 , Africa, Asia and Australia.

Stipules foliaceous, large.

Inflorescence simple.

Leaves oblong or oblong-ovate.

Leaves hairy beneath

Leaves glabrous, branches tomentose.

Leaves glabrous, branches glabrous
Leaves lanceolate, male spikes very slender

Inflorescence panicled.

Leaves lanceolate glabrous . . . (5) A. alatum

Stipules small lanceolate.

Racemes simple.

Leaves quite glabrous.

Leaves oblong-lanceolate, 9 to $\mathrm{I}_{4}$ in. long

Leaves lanceolate, I. 4 to 3.5 in. long.

Leaves elliptic cuspidate, 6 in. long; male spikes very slender .

Leaves hairy or pubescent.

Leaves lanceolate ceolate caudate.

(I) A. Kunstleri
(2) A. tomentosum
(3) A. pachystachys

(4) A. stipulare

(6) A. pendulum

(7) A. gracillimum

(8) A. Helferi

(9) A. salicinum

(Io) A. hirtellum

(II) A. longipes

(I 2) A. persimile

Racemes in a panicle of from 2 to 5 .

Stamens 4 to 8 .

Leaves orbicular-obovate, 3 in. long; spikes 5 in a panicle.

Leaves oblong or oblong-lanceolate.

Branchlets red-tomentose

Branchlets velvety not red.

Leaves 8 in. long; nerves sunkabove, very prominent beneath

Leaves 6 in. long; nerves not conspicuous.

Stipules lanceolate acuminate.

Stipules ovate-lanceolate.

Stamens 3 .

Leaves oblong-lanceolate " caudate stipules ovate-lanceolate

Stipules linear or filiform.
(I3) A. ghoesembilla
(I4) A. cruciforme

(I 5) A. phanerophlebium

(16) A. velutinosum

(I 7$)$ A. montanum

(18) A. cuspidatum

Leaves coriaceous glabrous; stipules linear acuminate.

Leaves pubescent beneath; stipules linear :
Leaves quite glabrous; stipules filiform

(I9) A. coriaceum
(20) A. perakense
(2I) A. leucocladon

(I) A. Kunstleri Gage, Rec. Bot. Surv. Ind. l.c. 225.

Shrub $9 \mathrm{ft}$. tall, branch tips red-tomentose. Leaves oblongovate or oblong-lanceolate thiniy coriaceous, caudate acuminate, mucronate, base sub-cuneate, glabrous above, sometimes pubescent

Fl. M. P., 3. 
beneath with midrib and II to I3 pairs of nerves hairy; 6.25 to 9.5 in. long, $\mathrm{I} \cdot 25$ to 3.5 in. wide; petioles .85 to $\mathrm{I}$ in. long. Stipules leafy obliquely ovate or lanceolate, 5 to $I \cdot 5$ in. long. Spikes simple, or branched axillary and terminal, longer than half the leaf, more or less red tomentose. Bracteoles ovate, hairy outside. Male flowers sessile. Sepals widely ovate sparsely hairy. Disc annular, 4-lobed. Stamens 4. Pistillode minute, sub-clavate. Female flowers pedicelled. Calyx cup-shaped 4-fid nearly to base, lobes ovate tomentose outside, bearded within at base. Disc annular. Ovary oblong-ovoid. Stigma sessile, 4- to 5-rayed. Drupe ovoid bi-convex, $\cdot 25$ in. long, pericarp (dry) reticulate. Hab. Mountain forests. Perak, Larut (Kunstler, Scortechini); Maxwell's Hill (Ridley); Gunong Inas (Wray).

(2) A. tomentosum Bl. Bijdr. II26. A. Kingii Hook. fll. F.B.I. v. 356 .

Shrub to a treelet $25 \mathrm{ft}$. tall, branchlets rusty tomentose. Leaves sub-coriaceous sub-sessile oblong to broadly obovateoblong, shortly cuspidate, base narrowed blunt or cordate, tomentose beneath; nerves 20 pairs; 8 to II in. long, 3 to 4 in. wide. Stipules lanceolate, I in. long. Male spikes rather stout, $4.5 \mathrm{in}$. long; rachis tomentose; flowers in small clusters, very small. Sepals 5, hairy ovate acute. Stamens 5. Disc glabrous. Female spikes 4 to 6 in. long, stout tomentose. Sepals 4 , ovate acute tomentose. Ovary tomentose. Fruits 5 in. long, sub-sessile falcate-ovoid deeply reticulate red. Hab. Hill forests, Johor, Sungei Tebrau; Bukit Soga. Pahang, Pulau Tawar; Tahan River; Telom (Ridley). Perak, Larut and Goping (Kunstler); Gapis Pass (Curtis). Distrib. Sumatra, Java, Borneo.

(3) A. pachystachys Hook. fil. F.B.I. v. 355.

Stout shrub 6 to I2 ft. tall, nearly glabrous. Leaves thinly coriaceous obovate or oblong-lanceolate, shortly cuspidate, base round or acuminate; nerves I 7 to 20 pairs parallel, elevate beneath; I 2 to 18 in. long, 4 to $6 \mathrm{in}$. wide; petioles very stout, $25 \mathrm{in.} \mathrm{long.}$ Stipules lanceolate-acuminate, $I \cdot 25$ in. long, 3 in. wide at base. Male spikes solitary, filiform, Io to I2 in. long, pendulous glabrous. Flowers sessile, 08 in. wide. Calyx cupular bluntly 4- to 6-lobed half-way. Stamens 4 or 5, short. Disc hairy. Pistillode clavate. Female spikes not known. Fruiting raceme, $\mathrm{I} \cdot 5$ in. long (base 2.5 in. long, bare). Fruits flattened ovoid-oblong, 5 in. long, white tinged red; pedicels very short, 08 in. long. Calyx acutely 6-lobed. Hab. Forests; Perak, Larut (Kunstler). Penang (Wallich).

(4) A. stipulare $B l$. Bijdr. II25. A. amboinense Miq. Ann. Mus. Bot. Lugd. Bat. i. 2I8. A. stenophyllum Gage, Rec. Bot. Surv. Ind. l.c. 25.

Shrub or treelet $15 \mathrm{ft}$. tall, young parts pubescent. Leaves thinly coriaceous lanceolate or oblong-lanceolate acuminate, base 
narrowed blunt, quite glabrous; nerves I4 pairs slender, elevate beneath inarching; $\cdot 75$ in. long, 2 to 2.5 in. wide; petioles $\cdot 4$ in. long, thick. Stipules ovate acute, base round shortly petioled, $\cdot 8$ to $\cdot 9$ in. long, 5 in. wide, persistent. Male racemes slender simple or little branched, 2 in. long. Flowers very small sessile. Calyx cup-shaped, very shortly lobed, red. Stamens 5, rarely 4 , insert in the disc. Pistillode minute glabrous. Female racemes over 12 in. long. Sepals as in male. Stigmas 3, I entire, 2 bipartite. Drupe $\cdot 4$ in. long, elliptic flattened (when dry), tip decurved; pedicels $\cdot I$ in. long. Hab. Forests; Selangor, Ulu Gombak; Ginting Sempah (Ridley). Johor, Gunong Pulai (Ridley). Perak, Larut (Kunstler).

I have not seen types of Gage's A. stenophyllum, but his description exactly fits this plant.

(5) A. alatum Hook. fil. F.B.I. v. 358.

A small tree 20 to $30 \mathrm{ft}$. tall, 4 to 5 in. through, bark whitish, glabrous except tips of branches puberulous. Leaves membranous or sub-coriaceous oblanceolate or lanceolate to elliptic cuspidate acuminate, base long narrowed; nerves very faint; 3 to 4 in. long, I to $\mathrm{I} \cdot 5$ in. wide; petioles $I$ in. long. Stipules elliptic-ovate cuspidate, .25 to .5 in. longr persistent. Male spikes slender puberulous, 5 to .75 in. long, panicled. Flowers very minute. Sepals 5, hairy. Disc pulvinate glabrous. Stamens 5. Female spikes solitary, ovary glabrous. Disc wider than calyx. Drupe ovoid, $\cdot 25$ in. long, red, slightly flattened when dry, shortly pedicelled. Hab. Not rare; in woods up to $3000 \mathrm{ft}$. altitude, Singapore, Changi; Bukit Timah; Jurong. Johor, Sungei Tebrau; Gunong Pantai. Malacca (Griffith). Pahang, Temerloh. Negri Sembilan, Tampin Hill (Goodenough). Selangor, Langat, Dindings, Telok Sera; Sungei Segari. Perak, Thaiping Hills; Tapah (Wray); Gunong Batu Putih (Wray); Larut, at I500 to $3000 \mathrm{ft}$. altitude (Kunstler).

(6) A. pendulum Hook. fil. F.B.I. v. 356.

Shrub 6 to $8 \mathrm{ft}$. tall, glabrous, branches stout. Leaves subcoriaceous oblong-lanceolate or oblanceolate bluntly cuspidate, base narrowed acute or rounded; nerves Io to I4 pairs, slender, ascending parallel; 9 to $\mathrm{I}_{4}$ in. long, 3.25 to 3.75 in. wide; petioles thick, $\cdot 25$ in. long. Stipules lanceolate acuminate. Spikes slender sub-terminal pendulous, 6 to I8 in. long. Male flowers distant, very small. Sepals 4 to 6 , orbicular hairy. Stamens 4 . Disc glabrous lobed. Pistillode clubbed. Female flowers; ovary gibbous glabrous. Stigmas very small. Fruit-raceme slender, I8 in. long or less. Drupes flattened rugose, 3 in. long, red. Hab. Dense rocky forest, Johor, Gunong Pantai. Perak, Temengoh (Ridley); Thaiping Waterfall (Wray); Goping (Kunstler).

(7) A. gracillimum Gage, Rec. Bot. Surv. Ind. l.c. 227.

Small tree; branchlets glabrous. Leaves lanceolate shortly blunt acuminate mucronate, base round or sub-cuneate, thinly 
coriaceous glabrous; nerves 8 pairs; $\mathrm{I} \cdot 4$ to 3.5 in. long, "75 to $\mathrm{I} \cdot 5$ in. wide; petioles $\cdot 05$ to $\cdot \mathrm{I}$ in. long. Stipules deciduous lanccolate subulate, 08 in. long. Spikes slender, $\cdot 3$ in. long, puberulous, 2 to 5 on axillary tubercles. Bracts widely ovate or triangular. Male flowers sessile. Calyx 4 - to 5 -fid, lobes broadly ovate, outside sparsely pubescent. Stamens 4 to 5 . Disc annular 4 -lobed. Pistillode conspicuous clubbed. Female flowers sub-sessile. Calyx cup-shaped, 4- to 5-lobed, lobes widely lanceolate sparsely pubescent, bearded at base inside. Disc annular. Ovary obliquely ovoid glabrous. Stigma $4^{-}$to 5-rayed, sessile terminal. Fruit (unripe) shortly pedicelled ovoid bi-convex. Hab. Hill forests, Perak, Thaiping Hills, Maxwell's Hill; Gunong Inas (Wray).

I have not seen this species.

(8) A. Helferi Hook. fil. F.B.I. v. 357.

Tree $60 \mathrm{ft}$. tall, quite glabrous. Leaves thinly coriaceous elliptic cuspidate, base cuneate; nerves faint, ro pairs, not inarching; 6 in. long, 2.5 in. wide; petioles I5 in. long, thick. Stipules small lanceolate blunt caducous, pubescent. Male spikes axillary filiform simple green or pale pink pubescent, I.5 in. long. Flowers few distant sessile. Bracts minute hairy. Sepals ovate sub-acute hairy. Stamens 3, rising from a small hairy disc. Female spikes longer. Flowers shortly pedicelled. Sepals ovate hairy. Drupe pink and white, oblong not flattened, with a few large reticulations $\cdot 2$ in. long; style terminal; pedicels thick, $x$ in. long, hairy. Hab. Swampy woods, Kelantan, Glam Woods, Kota Bharu (Ridley). Perak, Jungle near water, Chanderiang (Kunstler).

The type is only in female flower, and very imperfect, but I think this is the same. The ovary is hairy and stigmas 2 , bilobed.

(9) A. salicinum Ridl. A. salicifolium Hook. fil. F.B.I. v. 366 (not of Miquel).

Shrub about $8 \mathrm{ft}$. tall; branchlets slender puberulous velvety. Leaves thinly coriaceous lanceolate long-acuminate, narrow, base narrowed blunt, glabrous except the midrib, sometimes puberulous above; nerves about 7 pairs slender, inconspicuous inarching; 4 in. long, 5 in. wide; petioles 2 in. long or less, puberulous or glabrous. Stipules Ianceolate acuminate, 'I in. long. Male spikes solitary very slender, 2.5 in. long, glabrous. Flowers scattered very small glabrous, pedicelled. Sepals ovate rounded. Stamens 2 or 3 . Female spikes 2 or 3 together, 2 in. long. Pedicels rather long. Bracts acute. Sepals lanceolate acute. Ovary glabrous, ovoid narrowed at both ends. Style prominent; stigmas rather long recurved. Drupe ovoid acute at both ends, not flattened when dry. Hab. Mountain torrents, Pahang, Tanjong Antan, Pahang River and Tahan River banks; Kwala Lipis (Machado). Negri Sembilan. Banks of Jelei River, Johol. Selangor, Klang Gates. Perak, Plus River (Wray); Temengoh. Dindings, Bruas 
(Burn-Murdoch). Kelantan, Jeram Panjang, Kelantan River (Ridley).

var. latior. Leaves wider; nerves more prominent, 3.5 in. long, I in. wide; petioles longer. Hab. Johor, Gunong Janeng (Kelsall). Distrib. Borneo.

A. salicifolium Miq., is based on specimens collected in Priaman Sumatra by Diepenhorst. Leaves and fruits only are described. A leaf specimen in Herb. Kew has much wider leaves than $A$. salicinum and the description of the fruit does not fit this plant.

(Io) A. hirtellum Ridl. Kew Bulletin, I923, p. 360.

Small tree I5 ft. tall; branchlets and young parts yellowish hairy. Leaves thinly coriaceous above, glabrous except midrib, beneath glabrous elliptic cuspidate, base blunt unequal; nerves II to I2 pairs slender; 8 in. long, $3.5 \mathrm{in.}$ wide; petioles $-\mathrm{I}$ in. long, hairy. Stipules lanceolate caudate, $\cdot 5$ in. long, hairy. Flowers unknown. Fruiting racemes from bare part of boughs on trunk, slender, simple, 20 in. long, pubescent. Bracts very small lanceolate hairy. Pedicels distant very slender, 4 in. long. Sepals ovate acute densely hairy. Drupe ovoid-oblong flattened, sparsely hairy, reticulations few strong. Stigma terminal. Hab. Mountain forests; Perak, Bujong Malacca (Ridley).

(II) A. longipes Hook. fil. F.B.I. v. 335 .

Shrub or treelet Io to $15 \mathrm{ft}$. tall, stem I to 2 in. through. Leaves membranous oblong-obovate, base round or cordate, glabrous above, pubescent beneath; nerves 15 to 20 pairs, elevate beneath; 9 to I2 in. long, 4 to 6 in. wide; petioles pubescent, $\cdot 2$ in. long. Stipules $\cdot 2$ in. long, lanceolate hairy. Male flowers unknown. Female racemes slender pubescent peduncled, 9 in. long; pedicels very short. Sepals 4, ovate acute pubescent minute. Disc glabrous. Ovary tomentose, stigmas acute. Fruit raceme pendulous; peduncles 6 in. long, raceme 6 to 9 in. long, pubescent; pedicels filiform, $\cdot 5$ in. long. Drupe flat ovoid falcate rugose, edges sharp, red. Hab. Dense rocky jungle, Perak, Goping (Kunstler). Distrib. Borneo.

(I2) A. persimile Kurz, Journ. Bot. (1875), xiii. 330. A. perserula Hook. fil. F.B.I. v. 365 .

Shrub, young parts hairy. Leaves coriaceous oblong-obovate shortly cuspidate, base slightly narrowed rounded, glabrous above, appressed hairy on the midrib and I5 pairs of elevated nerves; ro in. long, 4 in. wide; petioles thick, 22 in. long, hairy. Stipules lanceolate long acuminate hairy, 4 in. long. (Male flowers on a filiform raceme 3 in. long, tomentose. Sepals 3 or 4 widely ovate acute. Stamens 3 to 5. Ovary in female densely fulvous tomentose, stigma terminal.) Fruiting racemes io in. long, hairy. Drupe ovoid falcate flattened, prominently reticulate when dry, dull red on one side, white on the other, .5 in. long, glabrous or nearly so; 
pedicels - I in. long. Hab. Pahang, Gunong Senyum (Evans). Distrib. Nicobars.

No specimen of the type occurs in Europe. Neither Hooker nor Pax saw one, Kurz only obtained the plant in male and female flower with very young fruit. His description fits this plant as far as it will go. The words in brackets are from his description.

(13) A. ghoesembilla Gaertn. Fruct. ix. I39, t. 39; Hook. fil. F.B.I. v. 357 .

A bush or a small tree, 30 to $40 \mathrm{ft}$. tall, 6 to 8 in. through, tomentose or glabrous. Leaves thin membranous orbicularobovate or oblong rounded at both ends, glabrous above; midrib hairy beneath, nerves 5 pairs, slender; 3 in. long, I.5 in. wide; petioles $I_{5}$ in. long. Stipules small lanceolate acuminate. Spikes I in. long in panicles of 5 , tomentose, peduncles $\cdot 25$ to $\cdot 5$ in. long; rachis of spike tomentose. Male flowers separate, sessile. Sepals 5 to 7 , tomentose. Stamens 4 to 7 , filaments long filiform. Disc 5 -lobed. Female flowers; sepals as in male but acute. Ovary pubescent. Stigmas minute. Drupe sub-globose (flattened when dry and reticulate) red, ${ }^{\prime} 2$ in. long, shortly pedicelled. $\mathrm{Hab}$. Open sandy country, Pahang, Renchong, Pahang River; Kwala Tekam (Evans). Malacca, Tanjong Kling; Bukit Sabukor in the Melaleuca forest (Derry). Perak, Matang (Wray); Hermitage Hill; Goping (Kunstler). Penang (Phillips); Waterfall (Curtis). Kelantan, Kamposa. Perlis, Kanga. Setul, a common shrub in paddy fields. Distrib. India, Siam, Malay isles, China, Australia. Native names: Gunchiak; Balong Ayam.

(r4) A. cruciforme Gage, Rec. Bot. Surv. Ind. l.c. 226.

A small tree; branchlets at first red-tomentose. Leaves coriaceous glabrous, hairy beneath narrowly oblong or oblonglanceolate caudate-acuminate, base sub-cuneate or round; nerves I4 to I 8 pairs; $6 \cdot 25$ in. long, $I .5$ to 3 in. wide; petioles 5 to $\cdot 9$ in. long, red-tomentose all over. Spikes solitary axillary one-third or one-fourth the length of the leaves. Male spikes small redtomentose. Bracteoles narrow lanceolate red-tomentose outside; flowers sessile. Calyx 4-angled ovoid acute in bud, 4-fid and cruciform when open, lobes lanceolate sparsely on edge. Stamens 4 . Disc orbicular glabrous. Female flowers shortly pedicelled. Calyx as in male. Disc annular. Fruit obliquely ovoid, $\cdot 2$ in. long. Stigma terminal. Hab. Perak, Gunong Batu Putih (Wray).

Near $A$. pendulum Hook. fil., but leaves four times longer than broad and spikes shorter and red-tomentose.

(I5) A. phanerophlebium Merrill, Philipp. Journ. Sc. xi. 59.

Shrub 6 to $8 \mathrm{ft}$. tall (or tree), branches closely velvety hairy. Leaves thinly sub-coriaceous oblong, abruptly cuspidate, base rounded (or shortly narrowed); nerves sunk above, prominent beneath, 9 or Io pairs inarching within the edge, pubescent on 
both sides, reticulations similar; 8 in. long, 4 in. wide; petioles thick, $\cdot 2$ in. long. Stipules lanceolate long-acuminate, hairy, .2 in. long. Racemes 3 on an axillary, velvety peduncle 3 in. long, racemes slender, 3 to 4 in. long, velvety. Male flowers unknown. Female flowers, bracts linear-lanceolate acuminate. Calyx cupular pubescent outside, truncate or shortly 3- to 4-lobed, lobes toothed. Ovary glabrous; stigma terminal. Drupe on a pedicel 08 in. long, not flattened, $\cdot 2$ in. long. Hab. Johor, Kwala Sembrong (Kelsall). Perak, Sunkai (Kunstler). Distrib. Borneo.

(16) A. velutinosum Bl. Bijdr. II25; Hook. fil. F.B.I. v. 356.

A small tree about I5 ft. tall. Branches thickly tomentose. Leaves sub-coriaceous glabrous above except the midrib, tomentose beneath on the midrib, nerves and nervules, oblong or oblonglanceolate acute or acuminate, base round; nerves I2 to I5 pairs, elevate beneath, transverse nervules conspicuous beneath; 6 to 8 in. long, $2 \cdot 25$ to 4 in. wide; petioles $\cdot 25$ in. long. Stipules narrowed lanceolate acuminate. Male spikes solitary or 3 in a panicle, dense, tomentose, 3 in. long. Bracts lanceolate tomentose. Flowers shortly pedicelled. Calyx-lobes 5 to 8 , tomentose. Stamens 5 to 8 , long-projecting. Female spikes 4 in. long, tomentose. Ovary obliquely globose tomentose. Style lateral. Stigmas long-forked. Drupes small obliquely globose reticulate when dry pink glabrous, $I_{5}$ in. long on slender hairy pedicels ${ }^{\prime} I_{5}$ in. long. Hab. Lowland woods, very common, whole peninsula. Singapore, Changi; Pulau Ubin (Hullett). Johor, Pinerong; Batu Pahat. Pahang River and Tahan River. Malacca, Selandor (Cantley); Hulu Chembong (Derry). Negri Sembilan, Bukit Kandang and Bukit Sulu (Cantley); Tampin (Goodenough). Selangor, Kwala Lumpur (Curtis); Batu Caves. Perak, Ulu Bubong (Kunstler). Dindings, Gunong Tungul. Province Wellesley, Permatang Bertam. Penang, Pulau Betong; Waterfall (Curtis). Kedah, Yan. Lankawi, Gunong Raya (Curtis).

var. lancifolia Hook. fil. l.c. 357. Leaves lanceolate acuminate, base long narrowed, 6 in. long, $I \cdot 5$ in. wide. Hab. Penang, Western Hill (Curtis). Lankawi, Gunong Raya (Curtis).

var. orthogyne Hook. fil. l.c. 357. Ovary fusiform erect straight; stigmas terminal. Hab. Malacca (Griffith). Distrib. Burma, Siam, Sumatra, Java. Native names: Mempunai Bukit; Sutupo Bukit; Burubah Rimbah.

(I7) A. montanum Bl. Bijdr. Ir24. A. Moritzii Mïll. Arg. Linnaa, xxxiv. 69; DC. Prod. xv. (2), 252.

Small tree about $40 \mathrm{ft}$. tall, branchlets softly tomentose. Leaves oblong or elliptic-lanceolate acuminate, base round or acute; nerves 8 pairs prominent beneath inarching, midrib and nerves pubescent on both sides; 4.5 to 6 in. long, I.75 to 2 in. wide; petioles very short, under $\cdot I$ in. long, pubescent. Stipules ovatelanceolate acuminate, Male spikes tomentose, $\mathrm{I} \cdot 25$ in. long, 
racemed or panicled 2 or 3 in. long, tomentose; flowers shortly pedicelled. Calyx tomentose with 5 short ovate lobes. Disc pubescent. Stamens 5. Female spikes solitary, 3 in. long. Flowers scattered pedicelled. Calyx cupular 5-lobed, hairy. Ovary glabrous. Stigmas short. Drupe sub-globose, $x$ in. long; pedicel as long red. Hab. Common in lowland woods. Johor, Tebing Tinggi; Serom; Kwala Sembrong (Kelsall). Malacca (Griffith) ; Merlimau (Derry). Pahang, Pekan. Perak, Larut (Kunstler) ; Batu Togoh (Wray). Province Wellesley, Bukit Juru; Tasek Gelugur. Kedah Peak; Alor Sta. Penang (Porter, Kunstler); Balik Pulau. Adang group, Rawei island. Lankawi, Burau Bay. var. oblanceolata Ridl. Leaves thin oblanceolate, Io in. long, 3.5 in. wide, Perak, Goping (Kunstler).

var. rigida, leaves stiff; nerves sunk above, female spikes panicled. Hab. Negri Sembilan, Bukit Tangga. Selangor, Kwala Lumpur (Ridley). Distrib. India, Siam, Malay isles. Native names: Gunchian or Gunchiak.

(I8) A. cuspidatum Müll. Arg. Limnaa, xxxiv. 65; DC. Prod. xv. (2), 252; Hook. fil. F.B.I. v. 360. A. rotatum Mïll. Arg. DC. Prod. l.c. 256.

Tree. Branchlets pubescent. Leaves thinly coriaceous oblonglanceolate caudate-acuminate, base narrowed blunt glabrous shining on both sides; nerves 8 pairs; 6 to 9 in. long, 2 to 3 in. wide; petioles 5 in. long, pubescent. Stipules short ovate-lanceolate subulate. Spikes racemose. Males 6 or more in a raceme, slender. Flowers scattered pedicelled, whole raceme 3.5 to 6 in. long, spikes 3.5 in. long or less. Bracts as long as the flowers. Sepals 4 to 5 , villous round. Disc lobed. Stamens 3. Female spikes usually solitary, 4 in. long. Flowers pedicelled tomentose. Sepals lanceolate acute hairy. Ovary glabrous. Fruit pedicelled obliquely. round ellipsoid; stigmas sub-lateral, $\cdot 2$ in. long. Hab. Lowland woods, common, Singapore, Changi; Bukit Timah; Garden Jungle. Johor, Tempayan River. Pahang, Temerloh; Telom. Malacca, Ching (Griffith); Merlimau (Goodenough); Brisu (Derry). Negri Sembilan, Gunong Berumbun (Cantley); Bukit Tangga. Selangor, Ulu Selangor and Bukit Bintang (Goodenough). Perak, Relau Tujor (Wray); Thaiping Waterfall (Wray). Penang, Balik Pulau and the Hill. Kedah, Yan; Alor Sta. Perlis, Chupeng (Ridley).

var. leiodiscus. Male flowers rather smaller and disc glabrous. Otherwise quite resembling $A$. cuspidatum. Hab. Perak, Larut (Kunstler, Scortechini). Native name: Petaling Tujok.

A. rotatum Mïll. Arg. DC. Prod. xv. (2), 256 is based upon a specimen in Leman's herbarium from Griffith's collection. Pax in the Pflanzenreich, p. II 7, keeps the species separate, giving Griffith's 4923 as A. rotalum. A plant from Leman in the Kew herbarium is from Griffith's 4923. Under $A$. cuspidatum he quotes Leman, Maingay $x_{34} \mathrm{I}$, and Griffith, Ching, but 4923 is the plant from Ching. Pax separates $A$. rotatum from cuspidatum, and puts it in another section on account of the flowers being different, but neither the specimens nor his description show any real difference. I concur with Hooker in keeping all under $A$. cuspidatum. 
(I9) A. coriaceum Tulasne, Ann. Sc. Nat. 3 Ser. Xv. 204. A. fallax Müll. Arg. Linn. xxxiv. 68; DC. Prod. xv. (2), 253; Hook. fil. F.B.I. v. 359. Aporosa Griffithii Hook. fil. F.B.I. v. 353 .

Tree 20 to $30 \mathrm{ft}$. tall, glabrous. Leaves coriaceous shining on both sides oblong or oblong-ovate or acuminate; nerves 9 pairs; 3.5 to 5.5 in. long, 1.5 in. wide; petioles .25 to .5 in. long, rather slender. Stipules linear acuminate. Male spikes panicled redtomentose, .5 in. long, whole panicle $I .5$ in. long. Flowers sessile scattered. Sepals 4 to 5 , pubescent. Stamens 3 to 4 . Disc cupular lobed. Female spikes shorter thicker, 7 or 8 in a panicle with ovate bracts at base, all red-tomentose. Ovary glabrous. Styles rather short recurved. Drupe orbicular, compressed when dry, red, $\cdot 25$ in. wide. Hab. Lowland woods. Common up to $4000 \mathrm{ft}$. altitude. Singapore, Bukit Timah; Tanglin; Garden Road. Johor, Kwala Sembrong (Kelsall); Pinerong (Cantley). Malacca (Maingay); Panchur. Selangor, Batu Caves; Fraser Hill (Semangkok) at $4000 \mathrm{ft}$. altitude (Burkill); Gunong Mengkuang Lebah (Robinson). Perak, Thaiping Waterfall (Wray, Kunstler); Kinta (Wray). Province Wellesley, Bukit Juru. Penang Hill (Wallich), West Hill (Curtis), Batu Feringhi. Distrib. Borneo. Native names: Buras-Buras hitam; Mata Punai.

(20) A. perakense Pax and Hofm. Pflanzenreich, l.c. II7.

Tree or shrub. Branches densely velvety pubescent, becoming glabrous. Leaf oblong-ovate shortly abrupt-acuminate membranous, midrib above and nerves beneath pubescent; 4.5 to 7.5 in. long, $I \cdot 5$ to $2 \cdot 75$ in. wide; petioles tomentose, $\cdot I$ to $\cdot 2$ in. long. Stipules linear. Male inflorescence simple or branched at base, I.5 to 2 in. long, ashy pubescent dense flowered. Bracts linear, pedicels longer. Calyx tripartite nearly to base pilose inside, less so outside, lobes broadly ovate, toothed. Stamens 3 , inserted in excavations of the disc. Pistillode small sunk in disc. Hab. Perak (no collector or locality given).

I have not seen the type. It is doubtless one of the preceding species.

(2I) A. leucocladon Hook. fil. F.B.I. v. $35^{8}$.

Small tree or shrub 8 to $25 \mathrm{ft}$. tall, branches white, shoots puberulous or glabrous. Leaves membranous oblanceolate or oblong caudate-acuminate, base blunt or acute; nerves 9 to Io pairs; 5 to 6 in. long, $I \cdot 5$ in. wide, glabrous; petioles very short. Stipules filiform. Male spikes panicled, very slender filiform tomentose. Flowers sessile minute. Calyx 4-lobed, lobes short rounded. Disc tomentose. Female spikes solitary or paired. Ovary tomentose or glabrous. Stigmas long recurved. Fruit .5 in. long, ovoid, very shortly pedicelled, style persistent long with little-curved stigmas. Hab. Open low jungle, Perak, Sungei Rayah and Larut (Kunstler). Penang (Wallich). 


\section{DAPHNIPHYLLUM, Bl.}

Shrubs or trees. Leaves alternate entire long petioled. Flowers in axillary racemes apetalous small. Male flowers; sepals 3 to 8 , or the calyx 4-toothed or discoid. Stamens 5 to I8; filaments short free or none; anthers large erect. Female flowers; calyx of the male. Disc o or of 4 to 6 scales or glands. Ovary imperfectly 2-celled. Styles or stigmas short thick recurved entire. Drupe oblong usually I-seeded. Seed with a membranous testa. Species II, Tropical Asia.

Leaves oblong-lanceolate, 6 to ro in. long, 3 to 4 in. wide.

Shrub; flowers red and yellow

Tree. Flowers white

Leaves lanceolate acuminate, $\dot{5}$ in. long, $\dot{I} \cdot 5$ in. wide.

Leaves stiff coriaceous elliptic-oblanceolate, 3 in. long, $\mathrm{I} \cdot 25 \mathrm{in}$. wide

(I) D. laurinum

(2) D. bancanum

(3) D. lancifolium

(4) D. Scortechinii

(I) D. laurinum Baill. Gen. Euphorb. 565, t. 2I, Figs. 25 to 27 ; Hook. fil. F.B.I. v. 353.

A large shrub, glabrous. Leaves fleshy coriaceous, dark green oblong or oblong-lanceolate acuminate or acute, base narrowed; nerves I4 pairs conspicuous beneath; 6 to Io in. long, 3 to 4 in. wide; petioles 3 in. long, thickened at the ends. Racemes 2 to 3 in. long. Flowers distant on slender pedicels red and yellow. Male calyx disciform, lobes triangular acute, $\cdot 05$ in. wide. Stamens 7 to Io; anthers laterally çompressed, not apiculate. Female racemes 2 in. long; pedicels 25 in. long. Fruit ellipsoid, 5 in. long. $H a b$. Seashores and open spots. Singapore, Changi; Kranji; Siglap (Ridley). Johor, Pinerong. Malacca, Bukit Bruang (Cantley); Ching. Negri Sembilan, Bukit Dusun Paya and Bumban (Cantley). Selangor, Kwala Lumpur. Perak, Chanderiang; Goping and Ulu Bubong (Kunstler). Penang. Setul heath. Distrib. Siam, Sumatra. Native names: Majis; Ruas-Ruas jantan; Mumpat Padang; Murabuju Pipit; Rupa.

(2) D. bancanum Kurz. Tidsch. Nederl. Ind. xxvii. 5I.

Tree 30 to $50 \mathrm{ft}$. tall. Leaves dark green coriaceous shining lanceolate or oblong acute, base slightly narrowed; nerves 9 pairs; 6 to 9 in. long, I.75 to 3 in. wide; petioles $I \cdot 5$ to $3 \cdot 5$ in. long. Male flowers white in axillary racemes $\mathrm{I} \cdot 5$ in. long; pedicels $\cdot 25$ in. long. Calyx with 5 ovate-triangular acute lobes. Stamens 8. Female flowers in longer racemes. Styles 2. Fruit obovoid, .25 in. long (not ripe). Hab. Open country. Selangor, Kwala Lumpur near the Museum (Ridley). Perak, Goping (Kunstler). Setul Heath. Lankawi, Kwala Burah (Haniff). Distrib. Bangka.

Herbarium specimens of this closely resemble those of $D$. laurinum, but whereas that is a scrambling bush with yellow and red flowers, this is a tree with white flowers. 
(3) D. lancifolium Hook. fil. F.B.I. v. 354.

Tree 40 to $60 \mathrm{ft}$. tall, stem $\mathrm{I} \cdot 5$ to $2 \mathrm{ft}$. through. Leaves coriaceous glossy dark green, lanceolate acuminate at both ends; nerves Io pairs very fine and inconspicuous on both sides, nervules and reticulations fine outside on both sides; 4.5 to 5 in. long, $\mathrm{I} \cdot 5$ in. wide; petioles slender, I in. long. Fruit pale green, $\cdot 25$ to .3 in. through, ellipsoid rugose, on racemes I to 3 in. long; pedicels .5 in. long. Style short excentric bilobed. Hab. Mountain forests, Perak, Thaiping Hills, Gunong Hijau, at 4500 to $4600 \mathrm{ft}$. altitude (Kunstler, Scortechini).

(4) D. Scortechinii Hook. fil. F.B.I. v. 354.

Shrub 5 to $7 \mathrm{ft}$. to tree Io to I $5 \mathrm{ft}$. tall, stem 8 to ${ }_{5} 5$ in. through. Leaves stiffly coriaceous, very glossy, bright gireen above, bluish green beneath, elliptic to oblanceolate, tip round, base narrowed or rounded; nerves numerous faint, with many nervules and reticulations as conspicuous; 2 to 3 in. long, 75 to $I \cdot 25$ in. wide; petioles $\cdot 25$ to $\cdot 5$ in. long. Male flowers umbelled in short racemes I. 5 in. long; pedicels $\cdot 2$ in. long or shorter. Sepals 4 , very small oblong blunt. Stamens 8; filaments very short. Fruit in racemes 2 in. long or less on pedicels $\cdot 25$ in: long, ellipsoid, about $\cdot 35$ in. long, $\cdot 25$ in. through, green. Hab. On rocks on mountains or in dwarf jungle at 3000 to $5300 \mathrm{ft}$. altitude. Selangor, Gunong Mengkuang Lebah (Robinson). Perak, Gunong Inas (Yapp); Gunong Batu Putih (Kunstler); without locality (Scortechini).

\section{APOROSA, B1.}

Trees never very large, or shrubs. Leaves alternate sometimes toothed, penni-nerved. Flowers minute, apetalous. Males very minute in axillary catkin-like yellow spikes. Females sessile or short pedicelled in very short bracteate spikes. Male flowers; sepals 4 (or 3 to 6 ) imbricate membranous. Stamens $I$ to 5 in centre of flower; filaments filiform. Pistillode minute or none. Female flowers; sepals larger. Ovary 2-, rarely 3-celled. Stigmas small plumose, short simple or 2- to 4-cleft, rarely elongate. Fruit globose yellow or red, ellipsoid or ovoid, splitting into 2 to 4 valves from base upwards or irregularly; epicarp usually fleshy, cells glabrous or hairy inside. Seeds oblong or sub-orbicular. Species about 40, tropical Asia.

Stipules large persistent lunate.

Tree glabrous; leaves 8 to 18 in. long in. long,
Branchlets pubescent; leaves 6 in.

linear-oblong glabrous
Leaf-veins beneath and branches tomentose; leaves II in. long; nerves sunk above

Stipules small inconspicuous.

Leaves on back and branches tomentose or hairy.

Leaves oblong cuspidate; nerves sunk above

(ז) A. Benthamiana

(2) A. falcifera

(3) A. lunata

(4) A. bracteosa 
Leaves sinuate toothed or crenulate.

Leaves elliptic-oblong, 7 to 8 in. long, 3 to 4 in. wide

Leaves elliptic-lanceolate, 3 to 4.5 in. long, I. 75 in. wide.

Leaves with entire edges.

Leaves coriaceous, 6 in. Iong; female spikes .75 in. long

Leaves membranous, $\dot{8}$ to ro in. long; female spikes $\cdot$ I 5 in. long

Leaves quite glabrous.

Leaf-edge sinuate toothed; drying yellow

Leaf-edge undulate; drying black .

Leaf-edge entire.

Leaves large, 6 to $9 \mathrm{in}$. Iong, thinly coriaceous.

Leaf-base rounded; petiole short

Leaf-base acute; petiole longer

Leaf-base acute stiff coriaceous, drying yellow

Leaves small rather thin, 3 to 6 in. long.

Leaves sub-coriaceous; flowers distichous on a slender raceme.

Fruits oblong, $\cdot 5$ in. long

Fruits ovoid, $\cdot 25$ in. long

Leaves stiff small; flower spikes dense . Leaves lanceolate acuminate membranous Leaves oblong cuspidate membranous

(5) A. pseudoficifolia

(6) A. globifera

(7) A. nervosa

(8) A. confusa

(9) A. microcalyx

(1 o) A. nigricans

(1 I) A. stellifera

(12) A. arborea

(13) A. aurea

(I) A. Benthamiana Hook. fil. Ic. Pl.t. 1583 .

Tree 60 to $80 \mathrm{ft}$. tall, I 2 to I5 in. through, glabrous. Leaves coriaceous linear-oblong shortly acuminate, base round cordate, nerves prominent beneath, I 8 to 20 pairs; 8 to I 8 in. long, 2 to 5 in. wide; petioles $\cdot 25$ to I in. long, thickened at the tip. Stipules persistent coriaceous shining semilunar, $\cdot 75$ in. long. Male spikes cylindric blunt, 25 in. long. Sepals 4, ovate. Stamens 2 ; filaments long filiform. Female spikes stout, I in. long, tomentose. Styles long depressed bifid. Ovary hairy. Fruit ellipsoid, $\cdot 5$ in. long, glabrous red. Hab. Forests; Singapore, Bukit Timah; Changi; Chan Chu Kang; Tanglin. Malacca, Brisu (Derry); Selandor. Negri Sembilan, Tampin (Goodenough). Selangor, Langat. Perak, Larut. Penang, Penara Bukit and Waterfall (Curtis). Native name: Klempiti.

(2) A. falcifera Hook. fil. F.B.I. v. $35^{2}$.

Tree 40 to $60 \mathrm{ft}$. tall, stem 6 to Io in. through; branches black tomentose. Leaves thin coriaceous elliptic or linear-oblong, subacute or acuminate, base round cordate; nerves slender, elevate beneath, Io pairs, inarching; 6 in. long, 2 in. wide; petioles ${ }^{\prime}{ }_{5}$ in. long, thick tomentose. Stipules sickle-shaped acuminate, ${ }^{\prime} \mathrm{I}$ in. long. Male spikes thick tomentose, 5 in. long, brown. Stamens filaments long filiform. Female spikes. Fruit ovoid, 5 in. long, very shortly pedicelled. Hab. Forests. Singapore, Jurong; Toas; Kranji. Selangor, Ulu Selangor (Kunstler). Perak, Larut; Batang Padang district (Kunstler). Distrib. Borneo. 
(3) A. Iunata Kurz, Journ. As. Soc. Beng. xlii. (2), 239.

Tree $50 \mathrm{ft}$. tall, stem ro to $\mathrm{I}_{5} \mathrm{in}$. through. Leaves stiffly coriaceous glabrous above, midrib hairy beneath, linear-oblong, base cordate above shining with nerves and nervules deeply impressed, beneath tomentose or glabrous except midrib hairy, nerves and nervules sunk above strongly elevate; II in. long, 3 to $5 \mathrm{in}$. wide; petioles I in. long, thickly tomentose. Stipules persistent at tips of branches large lunate round, $5 \mathrm{in}$. wide, coriaceous. Male spikes 5 in. long, yellow. Female spikes densely tomentose. Sepals 5 or 6 , linear-oblong blunt tomentose. Stigmas 3 or 4 , stout bifid. Fruit pink globose tomentose, $\cdot 2$ in. through. Hab. Forests; Singapore, Jurong. Pahang, Bukit Duri (Fox). Perak, Larut; Chanderiang and Gunong Bubu (Kunstler). Penang Hill (Ridley, Curtis). Distrib. Sumatra.

(4) A. bracteosa Pax and Hoffm. Pflanzenreich, l.c. 95.

Small tree, branchlets tomentose. Leaves coriaceous, above glabrous except the tomentose midrib, beneath midrib and nerves tomentose oblong long-cuspidate, base rounded or slightly narrowed; nerves sunk above, elevate beneath, I3 pairs, inarching; 6 to 7 in. long, 2 to $2 \cdot 25$ in. wide; petioles tomentose thick, $\cdot 2$ in. long. Stipules linear-oblong blunt. Male spikes fascicled, yellow tomentose, $\cdot 25$ in. long. Bracts crowded hemispheric obtuse pubescent concave. Sepals 3 or 4 , oblong pilose. Stamens 2 or 3 . Female spikes $\cdot 2$ in. long. Sepals 4 , ovate acute glabrous. Fruit ellipsoid narrowed to tip, 4 in. long, glabrous. $H a b$. Forests; Singapore, Bukit Timah. Penang, Highlands and Penara Bukit (Curtis). Distrib. Borneo, Sumatra. Native name: Sebasih Jantan.

(5) A. pseudoficifolia Pax, Pfanzenreich, iv. I47; xv. 94. A. ficifolia Hook. fil. F.B.I. v. 346 (in part).

Shrub 6 to Io ft. tall. Branches stout rusty villous. Leaves coriaceous glabrous above except the hairy midrib, beneath redhairy on the midrib, nerves and reticulations, elliptic or oblong acute or acuminate, base narrowed, edge sinuate toothed; nerves 8 to I2 pairs, sunk above, prominent beneath, as are reticulations; 7 to 8 in. long, 3 to 4 in. wide; petioles 25 in. long, thick redtomentose. Male flowers unknown. Female flowers sessile in small axillary tomentose clusters. Ovary villous. Stigmas 4, depressed broad, 2-lobed plumose. Fruit globose pale green with dark red cheeks, $\cdot 25$ to $\cdot 6$ in. through, villous. Hab. Hill forests; Perak, Thaiping Hills, Waterfall to Tea Gardens (all collectors). Penang Hill (Wallich, Curtis); Penara Bukit.

(6) A. globifera Hook. fil. F.B.I. v. 347.

Small tree 20 to $30 \mathrm{ft}$. tall, stem 5 to 7 in. through. Branchlets rather thick red-tomentose. Leaves thinly coriaceous, light green, greenish yellow beneath, elliptic or lanceolate blunt acuminate crenulate undulate, glabrous above except the tomentose midrib, hairy beneath; nerves 7 pairs strongly elevate red-hairy beneath, 
sunk above, inarching; 3 to 4.5 in. long, I to I.75 in. wide; petioles red-tomentose, $I$ in. long. Male flowers unknown. Female flowers sessile axillary. Fruit globose pubescent yellow with red cheeks, $\cdot 3$ in. through. Styles 3 . Seeds brown convex, $\cdot 25$ in. through. $H a b$. Low wet ground in dense jungle; Perak, near Gunong Mesah, and Gunong Bubu range (Kunstler), Upper Perak (Wray).

(7) A. nervosa Hook. fil. F.B.I. v. 350.

Small tree. Branches pubescent. Leaves coriaceous elliptic or oblong shortly acuminate or blunt, base round or cuneate, glabrous above, hairy on the midrib, nerves and nervules beneath; nerves 7 pairs elevate beneath, as are the nervules; 6 in. long, 3 to 3.5 in. wide; petioles 5 to $I$ in. long, hairy. Male spikes rather thick, 5 in. long. Sepals 4 , ovate tomentose. Stamens 2. Female spikes $\cdot 75$ in. long, pubescent. Sepals very small. Ovary densely tomentose. Stigmas depressed, 4-partite. Fruit globose glabrous, 4 in. long. Hab. Forests; Singapore, Toas. Malacca (Maingay). Penang, West Hill $2500 \mathrm{ft}$. altitude (Curtis). Native name: Jinjenta.

(8) A. confusa Gage, Rec. Bot. Surv. Ind. l.c. 229.

Tree 40 to $60 \mathrm{ft}$. tall, stem 8 to $\mathrm{I} 2 \mathrm{in}$. through, or often much smaller. Branchlets more or less pubescent. Leaves elliptic or oblanceolate, caudate-acuminate, base sub-cuneate or rounded, membranous glabrous above, hairy on the midrib and Io to I2 pairs of elevate nerves; 8 to Io in. long, 2.5 in. wide; petioles .25 to 4 in. long, tomentose. Male spikes unknown. Female spikes 2 to 4 together in an axil $I_{5}$ in. long, tomentose. Flowers pedicelled. Sepals 5 or 6 , triangular tomentose. Ovary 3-locular, pubescent; stigmas 3, sessile, connate in a funnel-shaped disc. Fruit sub-triquetrously globose or oblong pubescent yellow, 5 in. long on a pedicel $\cdot 25$ in. long. Hab. Lowland forests; Singapore, Garden Jungle; Bukit Timah; Bukit Mandai (Ridley). Pahang (Machado). Perak, Goping; Chanderiang and Ùlu Bubong (Kunstler). Distrib. Sumatra.

(9) A. microcalyx Hassk. Bull. Bot. Soc. France, vi. 7r4; Hook. fil. F.B.I. v. 346.

Shrub or small tree I $5 \mathrm{ft}$. tall, branchlets pubescent or tomentose. Leaves coriaceous bright light green, quite glabrous except midrib above sometimes hairy, elliptic-ovate blunt, base cuneate, edge undulate or obscurely toothed; nerves 6 to 8 pairs, forming large loops prominent beneath; 4 to 6 in. long, I.5 to 2 in. wide; petioles $\cdot 25$ in. long. Male spikes sessile, 2 to 4 in an axil $\cdot 5$ in. long; rachis and bracts hairy. Sepals 3 or 4, glabrous. Stamens I or more. Female spikes thicker tomentose, I5 in. long. Ovary hairy. Stigmas short recurved 2-lobed. Fruit ellipsoid glabrous narrowed to base 4 in. long. Hab. Common in open country; Pahang, along the river, Renchong, Pulau Manis and Kwala Tembeling; Kwala Lipis (Ridley). Malacca, Brisu; Panchur; Gadek 
(Burkill). Negri Sembilan, Bumban (Cantley). Selangor, Ulu Selangor (Kunstler). Perak, Ulu Bubong; Goping; Kota Bharu (Kunstler). Province Wellesley, Tasek Gelugur (Curtis). Penang. Kedah, Alor Sta. Perlis, Kanga. Adang Group, Pulau Rawei. Distrib. Borneo, Java, Philippines. Native names: Buburas padi; Buburas Merah; Pelangi; Jujamo.

(Io) A. nigricans Hook. fil. F.B.I. v. 347.

Small tree about $20 \mathrm{ft}$. tall, stem 6 to 8 in. through, whitish. Leaves coriaceous deep green (drying black), glabrous or with a few sparse hairs on the back, oblong or elliptic-oblong acuminate, base narrowed, edges undulate; nerves 7 to 8 pairs, inarching; 6 to 7 in. long, 2 to 3 in. wide; petioles 25 in. long. Male spikes very dense, yellow, flowers in spirals. Sepals 3 to 6 , oblong truncate incurved. Stamens 5 or more. Female spikes short. Fruit globose glabrous, yellow, epicarp thick, 4 in. long; stigmas 2, short depressed 2-partite; septum hairy. Hab. Lowland forest; Singapore, Bukit Mandai; Bukit Timah. Pahang, Sungei Jelei (Machado); Kwala Lipis. Pahang River, Pulau Tawar. Selangor, Bukit Kutu (Goodenough). Perak, Tapah (Wray); Larut (Kunstler). Penang Hill, and Telok Bahang (Curtis). Native name: Banuan.

(II) A. stellifera Hook. fil. F.B.I. v. 352 .

Tree I5 to $30 \mathrm{ft}$. tall, glabrous. Leaves thinly coriaceous oblong cuspidate-acuminate, base round or shortly acute drying pale green; nerves to pairs slender elevate beneath; 7 to 9 in. long, 3 to 4 in. wide; petioles $\cdot 2$ in. long. Male spikes rather slender cylindric, $\mathrm{I} \cdot 5$ in. long. Sepals 4 , ovate pubescent. Stamens 2, shorter. Female spikes glabrous short; flowers few sessile. Ovary glabrous. Stigmas connate in a 6-rayed disc. Fruit ellipsoid, glabrous, 75 in. long, 4 in. through, yellow. Seeds 3 , aril crimson. Hab. Forests; Selangor, Damasara Hill, Kwala Lumpur. Perak, Larut and Gunong Bubu (Kunstler). Penang up to $\mathrm{I} 800 \mathrm{ft}$. altitude (Kunstler); Penara Bukit; Waterfall; Telok Bahang (Curtis). Native name: Damak paya.

(I2) A. arborea Müll. Arg. DC. Prod. xv. (2), 470. Daphniphyllum Kingii Hook. fil. F.B.I. v. 354 .

Tree 30 to $40 \mathrm{ft}$. tall, stem $\mathrm{I}_{5}$ to $20 \mathrm{in}$. through, glabrous. Leaves elliptic, thinly coriaceous dark green, shortly blunt acuminate cuspidate, base cuneate, edge undulate; nerves I2 pairs, elevate beneath inarching; 9 in. long, $3.5 \mathrm{in}$. wide; petioles rather slender, I in. long. Male spikes fascicled; flowers in distant clusters. Bracts triangular acute ciliate. Sepals 4 or 5, oblong pubescent. Stamens 2. Pistillode distinct. Female flowers; sepals triangular acute puberulous. Ovary pubescent. Stigmas 3, bipartite. Fruit in paired axillary racemes $I \cdot 5$ in. long, ellipsoid narrowed at base, .25 in. long, glabrous. Seeds usually 3 , oval or obovate. Hab. Dense jungle 300 to $800 \mathrm{ft}$. altitude, Perak, Larut (Kunstler). Distrib. Sumatra and Java. 
(I3) A. aurea Hook. fil. F.B.I. v. 35I.

Bush 6 to $8 \mathrm{ft}$. tall, to a tree 30 to $40 \mathrm{ft}$. tall, stem ro to $5 \mathrm{in}$. through. Leaves coriaceous shining, drying golden green, ellipticoblong to lanceolate, acuminate, base acute, glabrous; nerves 5 or 6 pairs slender, elevate beneath, sunk above; 6 to 7 in. long, 2 to 3 in. wide; petioles slender, I in. long. Male spikes 3 or 4 together, rather stout, I in. long, glabrous. Sepals 4, round glandular. Female spikes short; flowers sessile. Ovary flask-shaped glabrous. Styles long bifid. Fruit globose yellow tinted pink, $\cdot 25$ in. through, glabrous. Seeds orbicular plano-convex grooved on ventral surface. Hab. Johor, Gunong Janeng (Kelsall). Pahang, river at Pigang. Malacca, Batang Malaka; Bukit Bruang (Derry). Negri Sembilan, Tampin Hill (Goodenough); Gunong Talan and Bumban (Cantley). Dindings, Simpit. Selangor, Ulu Kerling (Kunstler). Perak, Gunong Bubu; Ulu Bubong and Larut (Kunstler), Penang Hill. Kedah, Yan. Lankawi, Gunong Raya (Haniff). Native names: Tambon Chichat; Rambai Chichut; Marimbong; Mubagon; Sebasah hitam; Nipis Kulit Minyak.

(I4) A. Prainiana King, in Gage, Rec. Bot. Surv. Ind. l.c. 228.

Small tree I8 to $30 \mathrm{ft}$. tall, glabrous. Leaves elliptic-ovate to widely lanceolate acuminate-caudate, base cuneate, thinly coriaceous drying pale green; nerves about 6 pairs slender inconspicuous; $5 \cdot 25$ to $6 \mathrm{in}$. long, $2 \cdot 75$ in. wide; petioles slender, $\cdot 2$ to .25 in. long, swollen at the top. Male spikes 3 to 8 , crowded in an axil, 2.75 in. long, slender, with distant clusters of minute sessile flowers. Calyx of 4 lobes oblanceolate or sub-spathulate. Stamens 2 or 3 , shorter. Pistillodes minute. Female racemes 5 in. long of few distant short-pedicelled flowers. Sepals 4, ovate. Ovary ovoid glabrous. Stigmas 3, sessile obscurely bifid. Fruit oblongovoid yellow smooth, 5 in. long, crowned by the minute stigma, 3 -celled. Seed plano-convex. Hab. Open woods, common; Singapore, Tanglin; Garden Jungle; Selitar. Johor, Castlewood. Pahang, Sungei Tenok, Tahan (Ridley). Malacca, Bukit Bruang (Derry); Brisu (Holmberg). Negri Sembilan, Gunong Bumban (Cantley). Selangor, Bukit Tungul (Burn-Murdoch). Perak. Penang, Government Hill; Balik Pulau. Native names: Tambasak; Kuku Balam; Chemantong Gajah; Petaling Tandok; Masokam putih.

(I5) A. symplocoides Gage, Rec. Bot. Surv. Ind. l.c. 229. Baccaurea symplocoides Hook. fil. F.B.I. v. 376.

Tree 30 to $40 \mathrm{ft}$. tall, stem 8 to $\mathrm{I} 2 \mathrm{in}$. through, glabrous. Leaves chartaceous glossy light green, elliptic or ovate-lanceolate caudateacuminate, base blunt; nerves about 6 pairs slender; 3 to 4.5 in. long, I. 5 to 2 in. wide; petioles slender, $\cdot 25$ in. long. Male flowers unknown. Female racemes on branchlets 5 in. long. Flowers scattered pedicelled glabrous. Sepals 4 or 5, equal oblong very small. Ovary oblong-cylindric truncate. Stigmas 2, very short. 
Fruit-racemes over I in. long. Fruit ellipsoid glabrous smooth, $\cdot 3$ in. long, yellow; epicarp thin. Seeds oblong. Hab. Forests; Singapore, Chua Chu Kang; Garden Jungle; Selitar. Johor, Castlewood. Negri Sembilan, Kupayiang (Cantley). Perak, Goping; Batang Padang and Gunong Bubu (Kunstler). Penang, Waterfall (Curtis).

(16) A. Miqueliana Müll. Arg. in DC. Prod. xv. (2), 474. A. microsphæra Hook. fil. F.B.I. v. 350.

Shrub Io $\mathrm{ft}$. tall to a tree $40 \mathrm{ft}$. tall, stem 5 to $8 \mathrm{in}$. through, glabrous. Leaves coriaceous lanceolate caudate-acuminate, dull deep green, base cuneate; nerves 6 to 8 pairs, very slender and inconspicuous; 3 to 4.5 in. long, I to I.5 in. wide; petioles 22 in. long. Male spikes slender sulphur-yellow, 7 to 8 together, I in. long. Sepals 5, oblong ciliate. Stamens I to 3. Female spikes tomentose under $\cdot 2$ in. long. Ovary glabrous. Stigmas 2, very short, 2 cleft. Fruit $\cdot 25$ to $\cdot 3$ in. long, globose glabrous, yellow. Seed orbicular compressed, aril thin yellow, Hab. Forests in low ground, Johor, Mt. Austin (Ridley). Perak, Goping; Larut and Batang Padang district (Kunstler). Distrib. Sumatra. Native name: Sukam Merah.

The specimens referred by Hooker to A. Planchoniana Baill., collected in Perak by Kunstler, are of this species.

(I7) A. frutescens Bl. Bijdr. 5I4. A. fruticosa Miill. Arg. in DC. Prod. xv. (2), 475 .

Shrub or tree 20 to $30 \mathrm{ft}$. tall, stem 4 to $6 \mathrm{in}$. through; branchlets pubescent. Leaves membranous lanceolate acuminate or elliptic cuspidate, base blunt or narrowed, drying pale greenish ; nerves slender, 8 or 9 pairs; 3 to 5 in. long, I. 25 to $I \cdot 5$ in. wide; petioles $\cdot I_{5}$ to .25 in. long, slender. Male spikes solitary axillary, .25 in. long. Sepals 3 to 4 . Stamens 2 or 3 . Female flowers shortly pedicelled. Ovary ovoid blunt. Stigmas 2 to 4 , reniform. Fruit globose deep yellow glabrous, 75 in. through. Stigmas flat on the top. $H a b$. Forests; Singapore, Garden Jungle; Selitar; Bukit Timah (Ridley). Johor, Kota Tinggi. Pahang, Labong, Endau (Evans). Negri Sembilan, Linsum. Perak, Gunong Mesah (Kunstler). Province Wellesley, Kubang Ulu (Curtis). Lankawi, Gunong Raya (Haniff). Distrib. Java and Sumatra.

(I8) A. Maingayi Hook. fil. F.B.I. v. 348.

A small slender tree with twiggy branches glabrous, young parts pubescent about $20 \mathrm{ft}$. tall. Leaves elliptic-oblong caudateacuminate, base acute, membranous; nerves 5 to 7 pairs elevate beneath, midrib pubescent; $2 \cdot 75$ to 3 in. long, .75 to $I \cdot 75$ in. wide; petioles very short pubescent. Male spikes yellow, five together, pubescent, $\cdot 2$ in. long. Sepals 4 , hairy. Stamens 2. Female spikes very short; flowers several sessile. Ovary villous. Stigmas very short 2-lobed fimbriate. Fruit ellipsoid yellow, or salmon-red, $\cdot 5$ in. long, narrowed at both ends. Seed covered by a yellow aril. Hab. Lowland forest; Singapore, Garden Jungle; F1.M.P., 3. 
Malacca (Maingay); Sungei Hudang (Goodenough); Brisu (Derry); Mt. Ophir (Hullett). Negri Sembilan, Tampin Hill (Goodenough). Selangor, Petaling; Kwala Lumpur. Perak, near Ulu Kerling (Kunstler). Kedah Peak (Ridley).

var. penangensis Ridl. Leaves stiffer, sometimes narrow-lanceolate, Penang, Penara Bukit; Moniot's Road (Curtis); Waterfall (Haniff). Native names: Tampoi pachat; Agas-agas; Lampai.

\section{BACCAUREA, Lour.}

Trees medium-sized or small. Leaves alternate coriaceous rarely crenate-serrate. Flowers in simple or compound racemes or raceme-like panicles, apetalous. Males usually hoary. Disc o, or of obscure glands. Sepals 4 or 5, unequal imbricate. Stamens 4 to 8 ; filaments free short. Pistillode pubescent orbicular or an irregularly cleft column, sessile or stipitate. Female flowers larger. Sepals 4 to 6 , linear or oblong. Ovary ovoid or globose, 2- to 3-celled; stigmas 2 to 5 , small sessile free or connate into a short style, rarely one peltate stigma. Fruit ovoid, globose or fusiform, 2- to 4-celled, pericarp leathery or coriaceous. Seeds broad with a fleshy often coloured coat. Species 30, tropical Asia, Africa, Polynesia.

Flower spikes on trunk; leaves medium or small in terminal tufts.

Fruit fleshy indehiscent fusiform.

Leaves elliptic acute

Leaves obovate-sub-rhomboid

Fruit ovoid-globose dehiscent

Flower spikes on branches scattered; leaves scattered on branches.

Leaves moderate size, $x \cdot 5$ to 2.5 in. wide, glabrous.

Fruit $\cdot 4$ in. long, glabrous.

Rachis faintly pubescent

Rachis tomentose

Fruit .5 in. long, glabrous; leaves elliptic-lanceolate caudate, 3.5 by I. 5 in.

Fruit I in. long, glabrous; leaves elliptic-lanceolate, 6 by 2.5 in.

Leaves moderate-sized, pubescent beneath on the nerves.

Bracts ovate; racemes lax

Bracts lanceolate; racemes dense : :

I.eaves large, glabrous.

Base of leaf rounded.

Leaves ovate

Leaves oblong; stipules inconspicuous:

Fruit $\cdot 5$ in. long; pericarp thin crustaceous Fruit large; pericarp very thick

Leaves obovate-oblong; stipules large oblong Leaves narrowed at base.

Flower-spikes solitary or in pairs, pubescent .

Flower-spikes fascicled very long slender, glabrous
(r) B. parviflora
(2) B. Scortechinii
(3) B. Wrayi

(4) B. leucodermis

(5) B. Kingii

(6) B. minor

(7) B. Wallichii

(8) B. bracteata

(9) B. reticulata

(Io) B. Maingayi

(II) B. Hookeri

(I 2) B. malayana

(I 3$)$ B. macrophylla

(I . f) B. Griffithii

(15) B. lanceolata 
Leaves large pubescent.

Fruit dehiscent.

Leaves with numerous very prominent nerves, pubescent beneath

Leaf-nerves hairy beneath

(I6) B. polyneura

Leaves with nerves not conspicuous.

Fruit globose; pericarp very thick woody .

Fruit pear-shaped .

(I7) B. Kunstleri

(18) B. latifolia

(I9) B. pyriformis

Fruits indeliscent baccate, fruiting spikes very long; female flowers large.

Leaves oblanceolate narrowed to base .

Leaves elliptic, base rounded cordate

Doubtful, resembles $B$. Motleyana with membranous leaves

(x) B. parviflora Mïll. Arg. DC. Prod. xv. (2), 464, partly Hook, fil. F.B.I. v. 368 . B. singaporica Pax and Hoffm. Pflanzenreich, l.c. 54 .

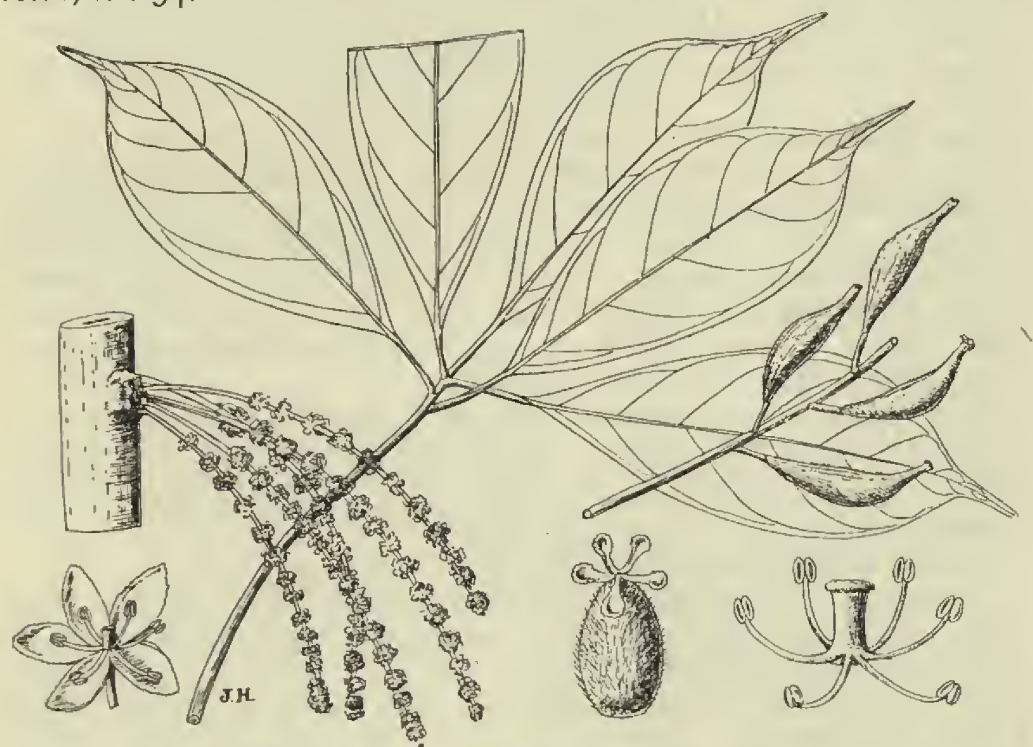

FIG. I52.-Baccaurea parviflora.

(20) B. brevipes

(21) B. Motleyana

(22) B. pubescens 
deep claret-colour, acid, I in. long. Seed one. Hab. Lowland woods; common. Singapore, Garden Jungle; Changi (Hullett); Toas. Johor, Mt. Austin; Bukit Tanah Abang (Kelsall). Malacca, Brisu; Ayer Panas (Derry); Bukit Sadanen. Negri Sembilan, Bukit Payong (Cantley). Selangor, Kwala Lumpur; Semangkok Pass; Ulu Selangor (Goodenough). Perak, Larut and Batang Padang district (Kunstler); Tapah (Wray); Sungkai (BurnMurdoch). Penang (Wallich); Telok Bahang (Curtis). Kedah, -Alor Sta. Distrib. Sumatra, Tonka. Native names: Setambon Merah; S. Lalang or Jantan. Use: The wood is extremely hard and yellow, and the little tree forms strong knotted clubs, used as walking-sticks.

The male spikes are borne on tubercles on the upper part of the stem and are scented like cowslips. It is not rare to find them on the branches also, especially in Penang. They are generally yellow, but I found them red in the Semangkok Pass. The female spikes are quite at the base of the same tree, very numerous, so that the fruit spikes form a large mass on the ground.

Pax's $B$, singaporica is from description a fruiting specimen of this species.

(2) B. Scortechinii Hook. fil. F.B.I. v. 368.

Small tree; branchlets hairy. Leaves sub-membranous obovate sub-rhomboid cuspidate, base acute; nerves 7 to 8 pairs slender; 5 to 6 in. long. Males very slender white-tomentose. Flowers shortly pedicelled minute. Female racemes 4 to 6 in. long. Sepals $\cdot 3$ in. long, hairy. Ovary ovoid silky contracted into a stout style with 3 recurved bifid stigmas. Fruit oblanceolate-obovoid, .5 in. long. $H a b$. Perak (Scortechini).

This appears to have the same habit as $B$. parviflora with the leaves in tufts at the tips of the branches. Hooker says racemes from the branches, though in the specimens I have seen at Kew they all appear to have been from the stem as in $B$. parviflora, but $B$. parviflora does sometimes have racemes from the branches.

(3) B. Wrayi King, Hook. fil. F.B.I. v. 374.

Tree 60 to $80 \mathrm{ft}$. tall, thick; branchlets hairy. Leaves thin, riptic-lanceolate or oblanceolate cuspidate-acuminate, base acute, glabrous or midrib sparsely hairy beneath; nerves 7 to 9 pairs slender, transverse nervules fine; 6 to 7 in. long, 2.5 in. wide; petioles pubescent, 5 to $I$ in. long. Stipules broadly ovate, villous. Male flowers unknown. Female racemes villous-tomentose, rather stout, from trunk, pedicels very short. Sepals -I3 in. long, linear-oblong blunt tomentose. Ovary ovoid hairy. Stigmas 3, depressed bifid. Fruit-racemes 6 to I 2 in. long, stout tomentose; pedicels $I$ to $\cdot 25$ in. long. Fruit $I$ to $I \cdot 5$ in. long, ellipsoid bright red, 3-celled; pericarp thick. Seeds 1.5 in. long, ovate acute compressed. Hab. Perak, Thaiping Hill Gardens (Wray); Larut (Kunstler). Penang, Waterfall (Curtis). Adang islands, Rawei island. Use: Fruit eaten by Malays.

(4) B. leucodermis Hook. fil. MSS.

Small tree Io to I5 ft. tall, shrubby. Branchlets white. Leaves thinly coriaceous, glabrous lanceolate equally narrowed to both 
ends; nerves 6 pairs inarching inconspicuous; $4 \cdot 25$ in. wide; petioles slender, $\mathrm{I}$ in. long. Flowers unknown. Fruiting spikes I.25 in. long. Capsule dark yellow, oblong narrowed to the base with 2 ribs with very short stigma, 4 in. long, $\cdot 2$ in. through; pedicels $\cdot I$ in. long. Hab. Dense jungle, Perak, Kinta (Kunstler). Johor, Castlewood (Ridley).

Rare; the specimens are very poor.

(5) B. Kingii Gage, Rec. Bot. Surv. Ind. l.c. 23I. B. sp. A. Hook. fil. F.B.I. v. 373 .

Tree 40 to $50 \mathrm{ft}$. tall, glabrous, bark almost black. Leaves thin chartaceous elliptic or lanceolate acuminate, base slightly narrowed; nerves 4 to 6 pairs very slender, nervules faint; 3 to 4 in. long, $I \cdot 5$ to $2 \cdot 75$ in. wide; petioles slender, $I$ in. long. Male racemes on branches 5 to $I$ in. long, tomentose; flowers clustered on very short branchlets. Bracts very small ovate. Sepals 4 , ovate blunt tomentose outside. Stamens 4. Female spikes I in. long; flowers distant entirely tomentose. Sepals ovate blunt. Ovary ovoid tomentose. Stigma peltate pustular. Fruit-racemes 2 in. long, tomentose. Fruit obovoid 4-angled, 25 in. long, sparsely hairy. Hab. Forests, Singapore, Bajau; Bukit Timah. Perak, Tapah (Wray) ; Larut and Goping (Kunstler). Penang (Kunstler); Government Hill (Curtis).

Allied to $B$. minor, but the nervules are irregular and the fruit is ovoid.

(6) B. minor Hook. fil. F.B.I. v. 370.

Tree 20 to $30 \mathrm{ft}$. tall, shoots pubescent; branchlets slender. Leaves glabrous thinly coriaceous, dark green, nerves yellow; drying yellow-green ovate or ovate lanceolate acuminate-caudate, base narrowed; nerves 5 to 6 pairs, elevate beneath; 3 to 3.5 in. long, $I .5$ in. wide; petioles slender, .5 in. long. Male racemes .5 to $I$ in. long. Flowers yellow very small crowded, sessile on very short side-branches with a persistent bract at the tip. Sepals 4 , ovate pubescent. Stamens 4, short. Female racemes from branches 3 to Io in. long, brown-tomentose. Sepals oblong blunt, I 2 in. long, tomentose. Ovary globose tomentose. Fruiting racemes 6 to Io in. long, brown-tomentose. Capsule sub-globose dehiscent minutely velvety dark yellow, 3 in. through; pericarp coriaceous, splitting in 3 valves. Seeds 3 , rarely 4 , globose in yellow aril, suspended by placenta after fall of pericarp. Hab. Forests; Singapore, Bukit Timah; Bukit Mandai, Garden Jungle, Perak, Batang Padang; Dipang; Larut and Ulu Bubong (Kunstler).

(7) B. Wallichii Hook. fil. F.B.I. v. 375 .

A tree 30 to $40 \mathrm{ft}$. tall, stem I2 to I5 in. through, glabrous. Leaves thinly coriaceous pale, elliptic-lanceolate or oblanceolate bluntly caudate acuminate, base long-acute; nerves 5 to 7 pairs, elevate beneath; 5 to 6 in. long, $2 \cdot 5$ in. wide; petioles slender, $\mathrm{I} \cdot 5$ in. long. Male flowers unknown. Female racemes $I$ to 2 in. long, slender pubescent. Bracts very broad short. Sepals $\cdot 25$ in. long, linear-oblong blunt finely pubescent. Ovary ellipsoid densely 
tomentose, 3-celled; stigma sessile peltate, obscurely 3-lobed papillose. Fruit-racemes slender, 4 in. long; pedicels very short. Fruit globose glabrous, red, 5 in. through. $H a b$. Open jungle on low hills, Singapore, Selitar; Bukit Timah; Ang Mo Kio. Malacca (Maingay); Brisu (Derry). Negri Sembilan, Tampin; Bukit Sulu (Cantley). Selangor, Batu Tiga. Perak, Larut (Kunstler). Penang (Wallich). Distrib. Borneo. Native names: Gintek Merah; Lolai paya; Mutali; Setambun betina.

(8) B. bracteata Miill. Arg. in DC. Prod. xv. (2), 466; Hook. fil. F.B.I. v. 372 .

Tree 20 to $40 \mathrm{ft}$. tall, 6 to $\mathrm{I} 5 \mathrm{in}$. through, shoots rusty pubescent. Leaves coriaceous elliptic-oblong, or elliptic-ovate or lanceolate, acute, base rounded or acute, black dotted beneath; nerves 5 to 7 pairs elevate beneath, midrib and nerves pubescent; 4 to 6 in. long, $I \cdot 75$ to 3 in. wide; petioles pubescent, $I$ to $I \cdot 25$ in. long. Male panicles 2 to 3 in. long, pubescent; flowers $I$ in. wide in clusters on short branches ${ }^{\prime} 5$ in. long. Bracts broadly ovate concave longer than flowers. Sepals 3 to 5 oblong, very unequal yellow. Stamens 4 to 6 . Pistillode columnar. Female racemes lax. Sepals $3 \mathrm{in}$. long, linear-oblong blunt. Ovary ovoid villous contracted into a short style with 3 bifid stigmas. Fruit globose glabrous dark red, 75 in. through, dehiscent; pericarp thick coriaceous. Seed aril yellow. Hab. Common in woods, Singapore, Bukit Timah; Changi; Tanglin. Johor, Kota Tinggi. Pahang, Pekan. Malacca, Alor Gajah (Griffith); Merlimau (Cantley). Perak, Ulu Bubong (Kunstler); Sapetang (Wray). Distrib. Borneo. Native name: Tampoi Kra Paya.

(9) B. reticulata Hook. fil. F.B.I. v. 373.

Tree, shoots hairy. Leaves coriaceous elliptic-oblong or lanceolate acuminate, base narrowed; nerves 8 to I2 pairs elevate, transverse nervules and reticulations conspicuous beneath, no black-dotting; 4 to 4.5 in. long, 2 to 2.25 in. wide; petioles 2 in. long, tomentose. Male panicles slender tomentose, 2 in. long; flowers in short branches. Bracts longer oblong blunt. Sepals 5, ovate. Stamens very short, 5. No pistillode. Female and fruit unknown. Hab. Lowland woods. Singapore, Tanglin; Selitar; Kranji. Johor, Kota Tinggi. Malacca (Hervey, Griffith, Maingay). Perak (Scortechini). Distrib. Sumatra.

This is very like $B$. bracteata, but the leaves are more distinctly reticulate, not black-dotted; flowers more abundant and rather smaller and bracts longer.

var. velutina. Leaves large ovate, base round, 6 in. long, $4 \mathrm{in}$. wide; midrib and nerves beneath thickly softly hairy; petioles 3 in. long, with branches velvety. Inflorescence velvety. Hab. Pahang, Fraser Hill, borders of Selangor, $4000 \mathrm{ft}$. altitude (Burkill).

(Io) B. Maingayi Hook. fil. F.B.I. v. 370.

Tree 25 to $30 \mathrm{ft}$. tall; branchlets scurfy. Leaves glabrous coriaceous broadly ovate acute or elliptic, base round broad subcordate; nerves prominent beneath, 6 to 7 pairs; 7 or 8 in. long. 
Male spikes axillary red-tomentose, I to 3 in. long, panicled; flowers pedicelled in tufts small tomentose. Sepals 4 to 6 , very unequal. Stamens 5 or 6 . Fruiting spikes 6 in. long, scurfy. Capsule globose; pericarp crustaceous hairy within, 6 in. through. Hab. Lowland forest, Singapore, Garden Jungle. Malacca (Maingay). Perak, Larut (Kunstler).

(II) B. Hookeri Gage, Rec. Bot. Surv. Ind. l.c. 232. Baccaurea B. Hook. fil. F.B.I. v. 373 .

Tree 50 to $70 \mathrm{ft}$. tall, stem Io to $5 \mathrm{in}$. through. Leaves coriaceous ovate sub-acute, base rounded, edge minutely indented with hairy glands in the notches, above glabrous beneath, very minutely scurfy on the II pairs of nerves when young, nerves parallel conspicuous; 6 to 7 in. long, 3 to 3.5 in. wide; petioles I.5 to 2 in. long. Flowers unknown. Capsules in long racemes 7 or 8 together from a bough, racemes 9 in. long, puberulous, ovoid 3-celled dark green oblong-ovoid, $\cdot 5$ in. long; stigma sessile minute trifid. Calyx of 4 or 5 ovate lobes. Seeds oblong, 25 in. long. Hab. Forests, lowland wet ground. Singapore, Bukit Mandai; Chan Chu Kang (Ridley). Perak, Larut (Kunstler).

(I2) B. malayana King, Hook. fil. F.B.I. v. 374. Hedycarpus malayanus Jack, Trans. Limn. Soc. xix. II8.

A big tree 60 to $80 \mathrm{ft}$. tall. Leaves coriaceous glabrous broadly elliptic-oblong or lanceolate blunt, base acute or round; nerves 7 to Io pairs strongly elevate; 6 to ro in. long, 4 in. wide; petioles I to 2 in. long. Panicles spike-like slender, $3 \cdot 25$ in. long, solitary or fascicled on the branches, pubescent. Bracts at base of cymes ovate glabrous. Male flowers in short velvety cymes $I$ in. long, pedicelled. Sepals 5, very small triangular-ovate velvety. Stamens Io; filaments very short. Fruit-raceme short; pedicels .25 to 5 in. long. Capsule ellipsoid, 2 in. long, or sub-globosely ovoid appressed white-tomentose 2- to 3-celled, dehiscent; style minute with 3 recurved bifid stigmas; pericarp very thick woody, .25 to $\cdot 3$ in. thick. Seed I in. long, orbicular in 2-celled fruit, sub-trigonously oblong in 3-celled fruit, pulp white sweet. Hab. Forests and in cultivation; Pahang, Tahan Woods. Malacca (Maingay). Perak, Goping and Larut (Kunstler). Native name: Tampoi. Use: Fruit eaten.

(I3) B. macrophylla Miill. Arg. in DC. Prod. xvii. 460.

Tree 60 to $80 \mathrm{ft}$. tall, stem 8 to I2 in, through. Leaves coriaceous elliptic or obovoid-oblong, blunt or shortly cuspidate acuminate, base shortly narrowed; nerves Io to I2 pairs strongly elevate beneath; 7 to I 2 in. long, 4 to 5 in. wide; petioles 3.5 in. long. Stipules coriaceous, broad oblong blunt, $\cdot 25$ in. long on terminal bud. Male racemes 2 to 3 in. long. Flowers very small, sessile on the tips of very short branchlets. Sepals 4, rounded pubescent sub-equal. Female racemes from stem. Sepals oblong blunt. Fruit 75 to I in. long, yellow splitting irregularly. Seed flat curved with orange aril. Hab. Forests, Singapore, Selitar. 
Selangor, Semangkok Pass. Perak, Goping (Kunstler); Kota (Wray); Batang Padang district (Kunstler). Penang (Wallich). Distrib. Borneo. Native name: Tampoi Tunga or Tungnau.

(I4) B. Griffithii Hook. fil. F.B.I. v. $375^{\circ}$.

Tree 20 to $60 \mathrm{ft}$. tall, stem 15 to 20 in. through, shoots sparsely stellate-pubescent. Leaves coriaceous elliptic-oblong or ellipticlanceolate acuminate narrowed to a blunt base; nerves 8 pairs elevate beneath; 4 to Io in. long, 2 to 4 in. wide; petioles 2 to $2 \cdot 25$ in. long. Stipules oblong coriaceous. Male racemes fascicled on the branches, 3 to 5 in. long, compound or simple. Sepals oblong hairy. Stamens 5 or 6 . Female racemes from the trunk tomentose, 3 in. long; flowers in clusters. Bracts ovate acute. Sepals ovate-oblong tomentose. Ovary ovoid hairy. Stigmas short recurved hairy. Fruit globose glabrous, I.25 in. through; pericarp woody thick. Hab. Forests, Singapore, Selitar. Johor, Pulau Tinggi (Burkill). Malacca (Griffith). Perak, Larut; Gunong Bubu (Kunstler); Tapah (Wray). Penang, Waterfall (Curtis).

(I5) B. lanceolata Miull. Arg. DC. Prod. xv. (2), 457; Hook. fil. F.B.I. v. 368 .

Tree 20 to $40 \mathrm{ft}$. tall, stem 6 to Io in. through. Leaves thin coriaceous oblong or oblong-lanceolate bluntly acuminate, base blunt, acute; nerves 8 pairs slender; 6 to ro in. long, 2.5 to 5 in. wide; petioles slender, 2 in. long. Male racemes from trunk fascicled in large clusters, 7 in. long, slender. Flowers waxy yellow pedicelled clustered. Sepals 4, oblong pubescent. Stamens 4, shorter with interposed glands. Female flowers rather larger, - 12 in. wide. Sepals glabrous except the edge. Fruit 2 in. long, ellipsoid. Hab. Forests; Singapore, Selitar; Bukit Timah. Pahang River. Selangor, Batu Caves. Perak, Ulu Bubong; Chanderiang; near Ulu Kerling (Kunstler). Penang Hill (Curtis). Kedah, Gerun (Bell and Haniff). Distrib. Sumatra, Borneo, Java,

(I6) B. polyneura Hook. fil. F.B.I. v. 369 .

Tree 60 to $80 \mathrm{ft}$. tall, stem 2 to $3 \mathrm{ft}$. through. Leaves coriaceous oblong blunt, base cordate, tip acute; nerves to to I4 pairs and transverse nervules pubescent and prominent beneath; 4 to 6 in. long, 2 to 2.5 in. wide; petioles 4 to .5 in. long. Male racemes on branches clustered, short. Sepals 4 or 5 , rounded ovate, very unequal, pubescent. Stamens 4 or 5. Pistillode globose. Female racemes 8 to $\mathrm{I} 2$ in. long, tomentose; pedicels $\cdot 25$ in. long, jointed below the flower. Sepals ovate or oblong unequal, hairy. Ovary hairy. Stigmas subulate recurved. Fruit I in. long, ovoid nearly glabrous; pericarp crustaceous, dehiscent. Hab. Forests, Malacca (Griffith, Maingay). Negri Sembilan, Bukit Sulu (Cantley). Perak, Larut (Kunstler). Native name: Ginteh Merah.

(17) B. Kunstleri Gage, Rec. Bot. Surv. Ind. l.c. 230.

Tree $60 \mathrm{ft}$. tall, branches velvety tomentose. Leaves coriaceous, glabrous above except the midrib and nerves, velvety tomentose beneath, elliptic-oblong, tip round, base cordate; nerves I2 pairs 
with transverse nervules prominent beneath and sunk above; 6 to 7.5 in. long, 3.5 to 4 in. wide; petioles densely velvety, 3 in. long. Male panicles on the branches, I in. long, tomentose in axillary fascicles. Bracts large oblong, tomentose. Flowers sessile. Petals 4 , ovate, tomentose. Stamens 5 or 6 . Pistillode minute, tomentose. Female flowers in racemiform panicles, central flowers larger than lateral ones. Sepals 5 or 6 , oblong-ovate. No disc. Ovary ovoid, tomentose. Stigmas sessile, trifid, fimbriate. Fruiting racemes 7.5 in. long, pubescent. Capsules globose pubescent, $\cdot 5$ in. through, dehiscing into 3 valves, hairy inside; pedicels .25 in. long, pubescent; sepals 5 , ovate blunt. Seed 3 , suspended from the top of the column. Hab. Lowland forests. Singapore, Garden Jungle; Toas; Tanjong Gol; Selitar. Perak (Kunstler). Native name: Rambai hutan.

(I8) B. latifolia King, in Hook. fil. F.B.I. v. 373 .

Tree 50 to $60 \mathrm{ft}$. tall, branches sub-stellately puberulous. Leaves coriaceous elliptic or elliptic-oblong cuspidate or acute, base acute or blunt, tomentose with soft hairs beneath; nerves Io to I2 pairs, elevate; 6 to 8 in. long, 3 to 5 in. wide; petioles half as long as blade. Male panicles from the youngest branches hoary pubescent, 2 to 4 in. long. Bracts 13 in. long, concave hoary, caducous ovate acuminate. Flowers ${ }^{\circ} 05$ in. wide, pale yellow. Sepals 4 or 5, broad. Stamens as many. Fruiting racemes from the old wood, 6 to 8 in. long, rachis hoary pubescent ; pedicels $\cdot 25$ to 5 in. long, woody, with 2 or 3 broad short bracteoles jointed below calyx. Capsule 75 in. through, globose, glabrous; pericarp very thick woody. Seeds with orange aril. Hab. Singapore, Garden Jungle (Ridley). Perak, Larut (Kunstler).

(I9) B. pyriformis Gage, Rec. Bot. Surv. Ind. l.c. 233. B. platyphylloides Pax and Hofm. Pfanzenreich, 68. Baccaurea F.G. Hook. fil. F.B.I. v. 375 .

Tree about $60 \mathrm{ft}$. tall, branchlets pubescent. Leaves thinly coriaceous drying dark colour, elliptic ovate or obovate acute, base sub-cuneate, edge slightly undulate; nerves 6 to 8 pairs, pubescent; 4 to 5.5 in. long, 2 to 2.5 in. wide; petioles $\mathrm{I} \cdot 5$ in. long. Male panicles raceme-like slender tomentose, I in. long, dense. Bracts lanceolate tomentose. Flowers 8 to I2 in a bract, sub-sessile minute. Sepals 4 , ovate tomentose. Stamens 4. Pistillode subcylindric tomentose. Female panicles stouter; flowers solitary in bracts, sessile. Sepals as in male. Ovary triquetrous ovoid, tomentose; stigma sessile 3-lobed, fimbriate. Fruiting spikes stout, 2 in. or more long. Capsules sessile obovoid pubescent, I in. long, 5 in. through; pericarp woody. Hab. Lowland woods, Singapore, Garden Jungle (Cantley, Murton, etc.). Chan Chu Kang; Kranji (Ridley). Malacca (Maingay); Merlimau (Derry); Ayer Panas (Goodenough). Penang, Pantai Acheh (Curtis).

The B. platyphylla Pax, l.c. 67 , seems from description to be the same thing. It appears to be distinguished by the less pubescent leaves and the smaller (probably younger) fruit. 
(20) B. brevipes Hook. fil. F.B.I. v. 372 .

Tree $I_{5}$ to $20 \mathrm{ft}$. tall. Leaves sub-coriaceous obovate-oblong acute or shortly acuminate narrowed to base; nerves prominent, I2 or more pairs elevate beneath and with the midrib hairy, glabrescent when old; 6 to Io in. long, 3 to 5 in. wide; petioles 2 in. long. Male racemes slender, 6 to 9 in. long. Flowers 08 in. across in small fascicles with a lanceolate long-acuminate bract to each fascicle longer than the flowers. Sepals 5, yellow, rounded oblong puberulous. Stamens 5, short. Female racemes from the stem, 6 to 9 in. long, stouter tomentose. Flowers sessile. Bracts as in male. Sepals $\cdot I$ in. long. Ovary ovoid villous. Stigmas broad depressed bilobed. Fruit $\cdot 5$ in. through, globose white pubescent indehiscent. Seeds enclosed in a violet or blue aril. Hab. Woods and open forest, common. Pahang, Kwala Tembeling; Tahan River. Malacca, Ayer Panas (Goodenough); Malim Road (Maingay); Bukit Naning (Cantley). Negri Sembilan, Tampin Hill (Goodenough). Bumban (Cantley). Selangor, Dusun Tua; Ulu Gombak; and Sungei Buluh (Ridley). Perak, Larut (Kunstler); Ulu Bubong (Kunstler); Tapah (Wray). Penang Bukit Erskine (Curtis); Waterfall (Curtis). Kedah, Yan. Distrib. Borneo. Native names: Karaes; Rambai Ayam Rantau or hutan; Poko Mawas; Mata Ayam; Tajam Moleh.

(2I) B. Motleyana Müll. Arg. DC. Prod. xv. (2), 46I; Hook. fil. F.B.I. v. 37 I.

Tree usually $60 \mathrm{ft}$. tall, stem 9 to I2 in. through, bark whitish. Leaves coriaceous oblong-elliptic sub-acute, base round, above glabrous, beneath shortly hairy, especially on the midrib, nerves and nervules; nerves Io to II pairs, slender elevate beneath; 8 in. long, $3 \cdot 5$ in. wide; petioles $\mathrm{I} \cdot 5$ in. long, hairy-tomentose. Male racemes 3 in. long, tomentose from the boughs. Flowers several on very short branches, I in. long. Sepals 4, oblong hairy blunt. Stamens 4. Female racemes pubescent, I2 in. long; flowers scattered, larger greenish yellow on short pedicels. Bracts long lanceolate. Sepals not expanding oblong blunt hairy, I I in. long. Ovary ovoid-oblong pubescent; stigmas short. Fruit baccate, I in. long, ellipsoid rounded at both ends, buff-colour, pubescent indehiscent. Seeds thin green, testa membranous, surrounded by a transparent white sweet aril. Hab. Cultivated ground, orchards. The Rambeh, cultivated all over the peninsula. I found it appar. ently wild at Telom in Pahang. Distrib. Sumatra. Use: The fruit much resembles the Langsat in appearance, is usually acid, but sweet forms are found which are excellent eating.

(22) B. pubescens Pax and Hofm. Pfanzenreich, l.c. 6I.

Tree, branches velvety pubescent. Leaf 6 to 7 in. long, 3.25 to 5 in. wide, broadly ovate or oblong shortly acuminate, base round cordate repand-crenulate membranous, above shining glabrous, beneath paler; nerves 5 to 7 pairs, pubescent beneath, with hairy glands on the edge. Male flowers unknown. Female 
racemes on the trunk or older branches 13 in. long, densely pubescent. Bracts triangular acuminate, 05 in. long; pedicels.$I$ in. long. Sepals 5, ovate or oblong blunt pubescent on both sides. Ovary 3 -celled tomentose. Stigmas bifid papillose. Hab. Singapore (Wawra).

I have not seen this. I cannot see any clear distinction between it and $B$. Molleyana except that Pax describes the leaves of this plant as membranous.

22. SCORTECHINIA, Hook. fil.

Trees. Leaves alternate coriaceous; petioles thickened at the top. Flowers minute in lax axillary and sub-terminal panicles, pedicelled apetalous. Male flowers; sepals 4 or 5 , round imbricate. Stamens 4 or 5 , alternating with hairy disc glands; filaments stout free; anthers broad, cells diverging a little. Pistillode 3-lobed, hairy. Female flowers; sepals 4. Ovary 2- or 3-celled. Stigmas 4, minute. Fruit a I-celled elliptic-oblong crustaceous hoary white capsule dehiscing by 4 elliptic-lanceolate valves. Seed I, elliptic-oblong. Species 3 or 4 , Borneo, Papua.

(I) S. Kingii Hook. fil. F.B.I. v. 366; Ic. Pl. I706.

A tree 40 to $60 \mathrm{ft}$. tall, stem I2 $_{2}$ to $I_{5}$ in. through. Leaves coriaceous drying brown elliptic to obovate, base cuneate; nerves 5 pairs elevate beneath inarching; 3 to 6 in. long, $x \cdot 5$ to $2 \cdot 5$ in. wide; petioles 5 in. long. Panicles 2 to 6 in. long, spreading. Male flowers .08 in. wide. Sepals rounded. Stamens short. Female flowers; sepals sub-acute. Fruit erect, I to I.5 in. long, covered with white appressed tomentum. Seed rounded on both ends on a long spermophore. Hab. Open old jungle; Malacca (Griffith, Maingay); near Merlimau (Derry). Perak, Larut (Kunstler). Native name: Tembatu.

\section{HYMENOCARDIA, Wall.}

Shrub or small trees. Leaves alternate entire. Flowers apetalous. Males solitary in the bracts of a catkin spike. Females in short axillary racemes. Male flowers; calyx irregularly $4^{-}$to 6 -lobed. Stamens 4 to 6 ; filaments free or united below in a column, anthers large. Pistillode small or as long as filaments. Female flowers; sepais narrow. Ovary 2-celled flattened; ovules 2 in a cell. Styles long entire papillose all over. Capsule flat of 2 flat broad wing-like cocci separating from central axis; pericarp crustaceous. Seeds usually $I$ in a coccus, flat. Species 5, IndoMalaya, Africa.

(I) H. punctata Wall. Cat. 3549; Hook. fil. F.B.I. v. 377. H. Wallichii Tul. Ann. Sc. Nat. 3; Ser. xv. 256.

Bush 4 to $6 \mathrm{ft}$. tall, shoots and leaves beneath pubescent, and dotted, lepidote. Leaves ovate or oblong blunt rounded at the base, thinly coriaceous; nerves 4 to 5 pairs, the lowest from the base of the leaf; 2 in. long, I. 25 in. wide; petioles $\cdot 2$ in. long, pubescent. Male spikes 5 in. long, I to 3 together, yellow puberulous and glandular. Flowers minute. Capsule broadly obcordate 
glabrous, 75 in. wide, .5 in. long, shortly petioled. Hab. Hill forests, rare. Pahang, Telom (Ridley). Distrib. Burma', Siam, Sumatra.

\section{ACTEPHILOPSIS, Ridl.}

A shrub glabrous except the buds. Leaves alternate elliptic cuspidate, crenulate. Male flowers minute pedicelled in dense axillary fascicled racemes. Bracts minute ovate. Sepals 5 oblong. Petals 5 oblong broader. Stamens 3; anthers sub-sessile. Disc of 5 lobes. Pistillode minute. Female flowers in a lax sub-terminal raceme, bracts leafy lanceolate. Sepals 5 ovate. Petals 5 fleshy; ovary glabrous trilocular; ovules I in a cell. Styles 3 , very short. Capsule rounded deeply 3-lobed glabrous. Seeds rounded yellow marbled with brown. Species I.

(I) A. malayana, Ridl. Kew Bulletin, I923, p. 36r.

Bark whitish. Leaves thinly coriaceous, base narrowed; nerves Io to II pairs, 8 in. long, 75 in. wide; petioles $\cdot 25$ to $\cdot 75$ in. long. Female racemes 6 to 8 in. long. Bracts $\cdot 5$ in. long, ${ }^{\prime} 5$ in. wide. Capsule 5 in. across. Hab. Forests, Pahang, Kwala Tembeling (Ridley). Perak, Gunong Kerbau (Haniff). Penang, Ayer Hitam (Curtis).

\section{ELATERIOSPERMUM, Bl.}

A big tree. Leaves alternate jointed on the long petiole entire coriaceous. Flowers medium-size in spreading di- or tri-chotomous panicled cymes apetalous; central flowẹr of each cyme a sessile female. Male flowers; sepals 4 to 6 , broad imbricate. Stamens Io to 20 or more on a villous receptacle; filaments very short free; anthers linear-oblong, cells parallel, connective gland-tipped. Female flower; sepals 6, imbricate. Disc elevate pubescent. Staminodes many within the disc. Ovary ovoid tapering into a short thick style, 2- to 4-celled; ovules I in each cell. Stigmas 3, dilated crescent-shaped. Capsule large of 2 bivalved cocci. Seed large oblong with a thin crustaceous chestnut-brown testa. Species I, Malayan.

(I) E. Tapos Bl. Bijdr. ii. 62I; Hook. Ic. Pl. t. I294; F.B.I. v. 382 .

Big tree often over Ioo ft. tall, stem 2 to $3 \mathrm{ft}$. through. Leaves linear-oblong sub-acute, base shortly narrowed; nerves $\mathrm{I}_{5}$ pairs slender, reticulations very fine and conspicuous; 6 to 7 in. long, 2 in. wide; petioles 2 to 2.75 in. long. Panicles 4 in. long from the upper axils spreading. Flowers waxy cream-colour. Males $\cdot 2$ in. wide; females 3 in. wide. Sepals oblong thin. Ovary pubescent. Capsule 2 in. long, oblong smooth, I.5 in. through. Seed I.25 in. long, sub-trigonous, tip, sides and base rounded. Hab. Mountain forests, Malacca (Griffith, Maingay); Selandor (Cantley); Bukit Sabukor (Derry). Selangor, Batu Caves; Weld's Hill, Kwala Lumpur (Burn-Murdoch). Perak, Waterloo (Robertson-Glasgow); Larut, Goping and Ulu Bubong (Kunstler). Dis- 
trib. Sumatra, Java. Native name: P'rah. Use: The seed is eaten, and furnishes an important food supply to the Sakais.

\section{ALEURITES, Forst.}

Trees with stellate or simple tomentum. Leaves alternate entire or 3- to 7 -lobed; petioles biglandular at the top. Flowers white in lax terminal panicled cymes. Male flowers; calyx subglobose bursting into 2 or 3 valvate lobes. Petals 5, longer. Stamens 8 to 20 on a conic receptacle, five outer ones opposite the petals with small glands between them. Female flowers; perianth as in male. Ovary 2- to 5-celled; ovules I in a cell. Styles with 2 linear stout arms. Fruit large fleshy. Species 4, Asia and Pacific.

A. cordata Müll, a Chinese and Japanese shrub with large white flowers and ovate cordate leaves was formerly in cultivation in the Botanic Gardens, Singapore, but only one or two plants.

(I) A. moluccana Willd. Sp. Pl. iv. 590; Hook. fil. F.B.I. v. 384 .

Tree about $60 \mathrm{ft}$. tall, stem I5 to $20 \mathrm{in}$. through. Leaves ovate or ovate-lanceolate, 3 to 6 in. long, $2 \cdot 5$ to 3 in. wide and larger leaves strongly trilobed, 8 in. long, 9 in. wide; petioles $2 \cdot 5$ to 6 in. long. Panicles dense, 4 in. long and a little wider. Flowers very numerous, white scurfy puberulous. Calyx $\cdot I$ in. long, splitting into 2 or 3 lobes, puberulous. Corolla longer, 5 in. across. Fruit 2 to $2 \cdot 5 \mathrm{in}$. long, sub-globose fleshy olive coloured, putamen very hard and thick. Seeds I or 2. Hab. Sea-coasts, wild and often planted. Singapore (planted). Malacca (Griffith and Maingay). Perak, Ulu Kerling and Gunong Pondok on limestone rocks at I000 to I500 ft. altitude (Kunstler). Penang Coast (Curtis). Kelantan, Kwala Lebir. Distrib. Malay and Polynesian islands. Native names: Buah Keras; Camiri Nuts; Candle Nuts; Singapore Nuts. Use: For oil for burning.

The seeds are common in sea-drift, and the plant is typically a seashore plant; in inland stations it is usually planted.

\section{JATROPHA, Linn.}

Shrubs or small trees or herbs often glandular. Leaves alternate, entire or digitately lobed. Stipules often ciliate. Flowers in terminal cymes, the central one in the cyme or fork usually female. Male flowers; sepals 5, imbricate often petaloid. Petals 5 , contort free or connate. Disc entire or of 5 glands. Stamens many; filaments of all or only the inner ones connate. No pistillode. Females, perianth as in male. Ovary 2- to 4-celled; ovules I in a cell. Styles connate below bifid, lobes entire or bilobed. Capsule of 2 to 4 bivalved cocci; endocarp crustaceous or bony. Seeds ovoid or oblong. Species about 70 , chiefly American, two of which have established themselves here.

Shrub 6 to $8 \mathrm{ft}$. tall; leaves 3 - to 5 -lobed; flowers yellow

Shrub 2 to $3 \mathrm{ft}$. tall; leaves 3 - to 5 -lobed, serrate; flowers dark red

(I) J. curcas

(2) J. gossypifolia 
(I) J. curcas Linn. Sp. Pl. Ioo6; Hook. fil. F.B.I. v. 383.

Shrub about 6 to $8 \mathrm{ft}$. tall, branched, bark grey, glabrous except the shoots. Leaves membranous orbicular cordate, entire or $3^{-}$to 5 -lobed, base retuse, 4 to $6 \mathrm{in}$. long and wide; petioles $2 \cdot 5$ to 5 in. long. Cymes pubescent or glabrous, 4 in. wide, on peduncles 2.5 in. long. Flowers $\cdot 25$ in. wide. Petals light yellow, connate. Disc-glands 5, two larger than the others. Fruit oblong, I to $\mathrm{I} \cdot 5$ in. long, yellow. Seeds oblong black. Hab. Cultivated ground, used as a hedge plant. Native name: Jarak B'landa. Distrib. Tropics.

(2) J. gossypifolia Lim. Sp. Pl. I006; Hook. fil. F.B.I. v. 383; Bot. Reg. t. 746 .

Shrubby plant 2 or $3 \mathrm{ft}$. tall. Leaves membranous, 3- to 5-lobed purple, lobes glandular serrate, 4 in. long and wide; petioles 3.5 in. long, glandular hairy. Cymes 2 in. long on peduncles 4 in. long. Bracts glandular hairy. Flowers 5 in. wide. Petals free, ovate red. Disc lobed. Fruit oblong, 2 -lobed with flat top, 5 in. long, $\cdot 3$ in. through, brown. Hab. Waste ground; a garden escape; Singapore, Jurong. Distrib. A native of Brazil, now established in Burma, and many other countries.

28. GALEARIA, Zoll. and Mor.

Shrubs or treelets. Leaves alternate, entire, base often unequal-sided. Flowers small or minute in long slender terminal racemes. Male racemes fascicled. Female racemes solitary. Male flowers; calyx 5-toothed or lobed. Petals 5, short concave and tips inflexed induplicate-valvate, keeled inside. Stamens Io; filaments very short. Pistillode usually hairy. Female flower, perianth as in male. Ovary 2- to 3-celled; ovules $I$ in a cell. Styles short, slender bifid. Fruit pulpy transversely oblong or broadly obcuneate or reniform (rarely large globose). Seeds testa membranous. Species I2 to I5, Malayan, Tenasserim, Siam.

Racemes stout; buds oblong; petals boat-shaped; fruit large globose

(I) G. Maingayi

Racemes slender; buds sub-globose; fruit small flattened laterally.

Petals hood-shaped; stamens glabrous.

Petals hairy; pedicels short

Petals glabrous; pedicels long

Petals glabrous; flowers sub-sessile.

Petals oblong boat-shaped; anthers glabrous.

Branchlets glabrous.

Female flowers solitary in bract

Female flowers several in a bract

Branchlets red-pubescent.

Leaves $4 \cdot 5$ in. long, ovate-oblong .

Leaves 6 in. long, lanceolate-elliptic

Leaves 7 in. long, oblong

Petals orbicular concave; anthers hairy. Pedicels short; bracts subulate .

Petals elliptic concave.

Pedicels long slender; bracts subulate Pedicels very short; bracts subulate.

(2) G. Lindleyana

(3) G. affinis

(4) G. phlebocarpa

(5) G. Ridleyi

(6) G. Wallichii

(7) G. minor

(9) G. Finlaysonii

(9) G. fusca

(Io) G. fulva

(II) G. pedicellata

(I 2) G. subulata 
(I) G. Maingayi Hook. fil. F.B.I. v. 377 .

Leaves coriaceous glabrous elliptic shortly acuminate, base acute; nerves 8 pairs inarching, transverse nervules and reticulations conspicuous on both sides; 7 in. long, 3 in. wide; petioles $\cdot 25$ in. long. Male racemes $5 \mathrm{in}$. long on a peduncle $6 \mathrm{in}$. long, puberulous. Flowers $I$ in. long; pedicels slender longer. Calyx cupular with 5 teeth. Petals oblong puberulous on edges and midrib within, tomentose. Stamens tomentose; anthers glabrous. Pistillode columnar truncate tomentose. Firuit fleshy capsular rugose pale green with 3 longitudinal wings extending from top to base 2- or 3 -locular, over I in. long. Hab. Malacca (Maingay). Very rare.

The stout raceme and the large fruit are quite unlike any other of our species.

(2) G. Lindleyana Miill. Arg. Linnaa, xxxiv. 205; DC. Prod. xv. (2), I037; Hook. fil. F.B.I. v. 379.

Branchlets sparsely deciduous shortly hairy. Leaves coriaceous glabrous and rigid when adult, sparsely hairy on midrib and nerves beneath, elliptic bluntly cuspidate, base acute or round; nerves 6 to 8 pairs prominent; 6 in. long, $2 \cdot 25$ in. wide; petioles 18 in. long. Male racemes about I2 in. long, pubescent. Flowers in tomentose clusters with short thick tomentose pedicels. Petals hooded hairy. Stamens quite glabrous. Pistillode cylindric with a truncate hairy dilated top. Hab. Hill forests. Penang (Wallich, Porter); West Hill at $4500 \mathrm{ft}$. altitude (Curtis). Kedah Peak (Robinson and Kloss).

(3) G. affinis Hook, fil. F.B.I. v. 379; Bennettia affinis Br. in Bennett. Pl. Jav. Rar. 25 I.

A small tree, branchlets covered with short dark brown hair. Leaves sub-coriaceous, silvery shining beneath, brown hairy on midrib and nerves, oblong or elliptic shortly acuminate, base rounded or slightly narrowed; nerves about 6 pairs strongly elevate and inarching; 5.5 to 7 in. long, I.75 to 2.75 in. wide; petioles ' I in. long, hairy. Male racemes I to $2 \mathrm{ft}$. long, hairy. Bracts lanceolate acuminate hairy short. Flowers green, in distant clusters with very short hairy pedicels. Petals quite glabrous. Stamens glabrous. Pistillode hairy columnar. Hab. Woods, common. Singapore, Bukit Timah; Changi; Bajau. Johor, Tempayan River; Gunong Janeng (Kelsall). Pahang River, Pulau Jellam. Malacca, Mt. Ophir (Maingay). Selangor, Batu Caves; Dusun Tua; Sungei Buloh; Rantau Panjang (Kloss). Kedah, Yan; Alor Sta. Adang islands, Pulau Rawei. Native name: Rambei Pontianak.

(4) G. phlebocarpa Hook. fil. l.c. Bennettia phlebocarpa Br. Benn. Pl. Jav. Rar. 25 I.

A shrub. Leaves sub-coriaceous elliptic or oblong-lanceolate or ovate acuminate or cuspidate, base rounded; nerves 8 pairs prominent inarching; 6 to 9 in. long, 2 to 4 in. wide; petioles - $\mathrm{I}$ in. long. Male racemes glabrous, over I2 in. long. Flowers in 
small clusters sub-sessile. Petals narrow glabrous, edges ciliate. Stamens glabrous. Female spike shorter and thicker. Fruit white, glabrous transversely oblong, rugose when dry. $H a b$. Forests, Singapore (Wallich); Bukit Timah; Garden Jungle; Pulau Damar. Johor, Road to Gunong Pulai; Kwala Sembrong (Kelsall).

Wallich's type has the rachis pubescent. This species has the largest leaves of any of our species.

(5) G. Ridleyi Gage, Rec. Bot. Surv. Ind. l.c. 235.

Shrub. Leaves thinly coriaceous oblong-ovate acute or caudateacuminate, base acute; nerves 7 to 8 pairs; 2.25 to 6 in. long, .75 to 2 in. wide; petioles slender, $\cdot I$ in. long. Male racemes very slender, minutely puberulous or glabrous. Bracts lanceolate minute. Flowers 6 together in a bract, pedicelled. Calyx cupshaped, 5-toothed, teeth triangular. Petals 5 oblong-ovate, crested in centre. Stamens ro glabrous. Female racemes as in male, but flowers solitary in the bracts. Sepals lanceolate pubescent outside, with a hairy crest in the centre inside. Ovary sub-globoseovoid tomentose. Stigmas 2 to 3 sessile bifid, branches filiform. Fruit ovoid, $\cdot 25$ in. wide, puberulous. Hab. Johor, Gunong Janeng and Simpai (Lake and Kelsall). Selangor, Dusun Tua (Ridley).

Near $G$. Wallichii, but the female flowers solitary in the bracts.

(6) G. Wallichii Hook. fll. F.B.I. v. 379; Bennettia Wallichii Br. in Benn. Pl. Jav. Rar. 25I.

Small tree, branchlets glabrous or nearly angled. Leaves coriaceous oblong-elliptic or elliptic-lanceolate acuminate cuspidate glabrous; nerves 6 pairs elevate beneath; 6 to $7 \cdot 5$ in. long, I.5 to 2.5 in. wide; petioles $I_{5}$ in. long. Male racemes I $_{2}$ in. long, glabrous, rachis angled. Bracts short subulate. Flowers clustered on short thick pedicels. Petals ovate blunt or rounded, quite glabrous. Stamens glabrous. Fruit $\cdot 5$ in. wide, $\cdot \mathrm{r}$ in. long, rugose (fide Müller). Hab. Lowland woods, Singapore, Changi (Hullett); Bedok. Distrib. Tongkah, Tenasserim.

(7) G. minor Gage, Rec. Bot. Surv. Ind. l.c. 234.

Small tree. Branchlets red-pubescent. Leaves membranous or thinly coriaceous ovate-oblong acuminate, base sub-cuneate; nerves 6 or 7 pairs, red-pubescent; 4.5 in. long, I.75 in. wide; petioles I I in. long, more or less red-pubescent. Male racemes very slender, 4 to 12 in. long, sparsely red-pubescent. Bracts lanceolate hairy. Flowers 3 in a bract. Pedicels 05 in. long. Male flowers; sepals 5, radiating pubescent outside, crested in the centre inside. Petals 5, ovate concave, glabrous, centre inside crested, tip hooded and bearded. Stamens Io, glabrous. Pistillode thick, tomentose. Female flowers not seen. Fruiting racemes 6 in. long. Capsule sub-reniform, -25 in. wide; pedicels $\cdot I$ in. long. Hab. Pahang, Pulau Jellam, Pahang River (Ridley). Sungei 
Ujong (Cantley). Perak, Gunong Mesah and Goping (Kunstler). Distrib. Sumatra.

Distinguished by its short racemes and small leaves. Forbes gives it as $4 \mathrm{ft}$. tall in Sumatra.

(8) G. Finlaysonii Hook. fil. F.B.I. v. 380 ; Pax, Pfanzenreich, iv. I47, p. Ioo. Bennettia Finlaysonii R. Br. in Horsfield Pl. Jav. Rar. $25 \mathrm{I}$.

Branches angled red-pubescent. Leaves sub-coriaceous lanceolate-elliptic sub-caudate acuminate, base inæquilateral; nerves 7 pairs with reticulations prominent beneath, midrib pubescent beneath at base; 6 in. long, I.5 in. wide; petioles .08 in. long, thick, pubescent. Male spikes red pubescent, 6 in. long (very long, according to Pax). Bracts minute. Pedicels slender long. Calyx pubescent. Petals boat-shaped glabrous. Stamens glabrous. Pistillode silky. Hab. Singapore (fide Pax). Penang (Finlayson, Wall. Cat. 8585B).

(9) G. fusca Ridl.

Branches flexuous angled red, black hairy. Leaves glabrous except nerves and midrib beneath, oblong shortly acuminate, base cuneate oblique; nerves 6 pairs, very prominent beneath, as are the large reticulations; 7 in. long, 3 in. wide; petioles hairy, $\cdot$ I in. long. Male raceme over 5 in. long, rather stout black-hairy. Bracts subulate. Flowers in threes. Pedicels short thick hairy. Sepals ovate pubescent. Petals oblong concave glabrous. Stamens quite glabrous. Pistillode bearded at the tip. Hab. Negri Sembilan, Gemas (Burkill, 6375).

This resembles $G$. fulva, but has entirely different petals quite glabrous.

(Io) G. fulva Müll. Arg. Linnaa xxxiv. 205; DC. Prod. xv. (2) I037; Hook. fil. F.B.I. v. 378. G. Jackiana Hook. fil. v. 378.

Shrub, branches densely red-brown-tomentose. Leaves ellipticlanceolate, shortly acuminate, base blunt, glabrous except midrib on both sides and nerves 8 or 9 pairs elevate beneath, sparsely hairy; 4 to 8 in. long, I.5 to $2 \cdot 25$ in. wide; petioles tomentose very short. Racemes 12 in. long or less, tomentose. Bracts often long subulate. Male flowers clustered minute brown pedicelled. Petals orbicular concave ciliate at tips. Anthers hairy. Female racemes shorter stouter; flowers scattered larger tomentose. Ovary ovoid tomentose. Young fruit transversely oblong velvety pale. Stigmas very short. Hab. Forests, Singapore, Chua Chu Kang. Malacca, Mt. Ophir. Perak, Ayer Kuning near Thaiping (Burn-Murdoch); Tapah. Dindings, Lumut (Ridley). Penang (Wallich, Phillips), Western Hill (Curtis); Telok Bahang; Penara Bukit. Kedah, Yan. Native name: Ekor Tupai.

(II) G. pedicellata Hook. fil. F.B.I. v. 378. Bennettia pedicellata Br. in Bennett, Pl. Jav. Rar. 25I.

Small tree Io ft. tall. Branchlets sparsely hairy. I-aves FI.M.P., 3. 
glabrous above hairy on the nerves beneath, oblong or elliptic to obovate-oblong acuminate, base rounded or narrowed; nerves 8 pairs; 6 to I2 in. long, $2 \cdot 5$ to 3.5 in. wide; petioles very short. Male racemes puberulous, I2 to I6 in. long; pedicels slender pubescent, much longer than the flowers, $\cdot 25$ in. long, in fascicles of 5 or 6 . Petals broad elliptic-oblong concave glabrous, edges ciliate. Anthers hairy. Hab. Hill woods. Penang (Wallich); Penara Bukit (Ridley).

Near G. fulva, but the plant is rather less hairy and the male pedicels are longer and more slender. The petals are more distinctly oblong.

(12) G. subulata Mïll. Arg. in DC. Prod. xv. (2), 1039. Hook. fil. F.B.I. v, 379 .

Shrub I5 to I8 ft. tall, shortly red-tomentose-hairy. Leaves coriaceous elliptic-oblong acuminate, base rounded or narrowed; nerves very prominent beneath, 7 to 8 pairs hairy, inarching; 6 to Io in. long, $2 \cdot 5$ to 4 in. wide; petioles thick, hairy, I5 in. wide. Female racemes thick, densely red-hairy. Flowers scattered. Pedicels short stout pale tomentose. Bracts subulate as long. Sepals lanceolate acute. Petals rounded all pale greenish tomentose. Ovary pale tomentose ovoid. Stigmas slender subulate bifid. Fruiting raceme 9 in. long. Fruit broadly oblong-ovoid transversely grooved, pale tomentose, $\cdot 3$ in. wide, $\cdot 25$ in. long; pedicels $\cdot \mathrm{I}$ in. long. Hab. Perak, Larut; Goping (Kunstler). Penang, Waterfall (Ridley).

The Penang plant has narrower leaves than the Perak one, lanceolate cuspidate, 7 in. long, $T \cdot 5$ in. wide. This species is based on a specimen from Penang in Sonder's collections; neither Hooker nor I have seen it. The description above is based on the Perak plant.

\section{MICRODESMIS, Planch.}

Small tree. Leaves alternate entire or toothed. Flowers minute in axillary clusters. Male flowers; sepals 5, imbricate. Petals small twisted imbricate. Stamens Io in 2 series on a fleshy receptacle, free; anthers erect. Pistillode columnar. Female flowers; perianth as in male. Ovary fleshy, 2- to 3-celled at base.

Styles short bifid. Capsule fleshy dehiscent. Seed I arillate. Species 2, I African.

(I) M. casearifolia Planch. in Hook. Ic. Pl. under t. 758 . Miill. Arg. in DC. Prod. xv. (2), I04I; Hook. fil. F.B.I. v. 380.

Small tree about $I_{5} \mathrm{ft}$. tall. Branchlets and young leaves puberulous. Leaves thinly coriaceous, oblong-lanceolate or lanceolate acuminate or cuspidate, edge often crenulate; nerves 4 pairs, slender; 4 to 6 in. long, $\mathrm{I} \cdot 25$ to 2 in. wide; petioles 08 in. long, pubescent. Flowers pubescent yellow, about Io in a fascicle; pedicels slender, 08 in. long. Male flowers very small. Sepals oblong. Petals round pubescent. Stamens apiculate. Fruit ellipsoid acute fleshy, orange-yellow, 3 in. long. dehiscing. Seed 
ellipsoid, aril crimson-red. Hab. Woods and forests all over the peninsula, Singapore, Garden Jungle; Changi. Johor, Pulau Tiuman (Burkill). Malacca (Griffith), Bukit Bruang; Chabau (Cantley). Negri Sembilan, Bukit Sulu (Cantley). Selangor, Kepong (BurnMurdoch). Perak, Ulu Bubong (Kunstler); Chankat Mentri (Kloss). Province Wellesley, Bukit Juru. Penang (Wallich) Waterfall. Kedah, Alor Sta. Lankawi islands. Perlis, Kanga. Adang islands, Pulau Rawei. Distrib. Tenasserim, South China, Borneo. Native names: Chateng; Chereh Rambeh; Kenidei Badak; Sigoniah.

\section{CROTON, Linn.}

Shrubs or small trees. Leaves alternate (rarely opposite or whorled) biglandular at base. Flowers small solitary or clustered in a terminal raceme with small bracts. Male flowers; calyx 4-, 5- or 6-lobed imbricate or sub-valvate. Petals as many. Disc glands as many opposite the sepals. Stamens indefinite on a hairy receptacle, free, incurved in bud. Female flowers; sepals more ovate than in male; petals smaller or none. Ovary 2- or 3- to 4-celled; ovules I in a cell. Styles long and slender, 2- to 4-cleft. Capsule of three 2-valved cocci. Seeds smooth, testa crustaceous. Species very many, about 500; in all hot countries. Seeds of all strongly purgative and dangerous.

The "Crotons" of Gardens do not belong to this genus, but to the genus Codiceum of Papua and Polynesia.

Sarmentose shrub; racemes long; fruit globose hard scurfy

Erect shrubs or small trees; racemes short.

(x) C. caudatum

Leaves silvery scaly beneath.

Racemes stout, 4 to $6 \mathrm{in}$. long; leaves 4 to 6 in. long, thin coriaceous.

Racemes 2.5 in. long; leaves $x$ to 3.5 in. long, coriaceous.

Racemes $\mathrm{I}$ in. long; leaves 5 to 7 in. long, thin chartaceous

Leaves not silvery beneath, glabrous entire.

Racemes glabrous; fruit rather small.

Racemes scaly .

Racemes tomentose

Racemes short glabrous; fruit large, .75 in. long .

Leaves small, 2 to 4 in. long, obovate oblong crenate; fruit small .

Leaves beneath and stem densely stellate hairy

(I) C. caudatum Geisel Croton, Monog. 73, var. malaccanum Hook. fil. F.B.I. v. 389 .

Sarmentose shrub, forming large bushes. Branches and racemes stellate-hairy, rough. Leaves thinly coriaceous, ovate or oblong acuminate, base cordate or acute, edge serrulate with stalked 
glands, scabrid stellate-hairy on both sides; nerves 3 to 5 from base, with one pair from the midrib and transverse nervules; $2 \cdot 25$ to 4 in. long, I to I.5 in. wide; petioles 25 to I in. long, racemes 4.5 in. to over $I \mathrm{ft}$. long. Male flowers $\cdot 2$ in. wide. Sepals ovate hairy. Petals as long linear-oblong, edges woolly, centre long white-woolly. Stamens I8 to 30 . Female flowers few at base of raceme. Sepals ovate hairy. Ovary densely hairy. Styles bifid filiform. Fruit globose brown, 75 to $I$ in. long, scurfy obscurely 6-ribbed, hard, endocarp $\cdot 25$ in. thick, woody. Seed $\cdot 5$ in. long. Hab. Common in open country and borders of woods; very conspicuous from the bright red of the withering leaves; Singapore, Chan Chu Kang; Crarden Jungle; Sungei Morai. Pahang, Pekan. Malacca, Jus and Selandor (Cantley); Bukit Sabukor (Derry). Selangor, Kwala Lumpur. Dindings (Curtis). Kelantan, Kamposa; Kota Bharu. Distrib. Mergui, of type Indo-Malaya. Native name: Akar Tuku Takal.

A specimen from Bukit Timah, Singapore, collected by Hullett is described as a small tree, and has some of the leaves lanceolate, and one broad with three acute points.

(2) C. argyratum Bl. Bijdr. 602; Hook. fil. F.B.I. v. 385 .

Small tree Io to $40 \mathrm{ft}$. tall, stem 7 to Io in. through; branches scaly. Leaves thinly coriaceous, elliptic or ovate-lanceolate, acute or acuminate, base blunt, silvery scaly beneath; nerves 6 pairs slender; 4 to 6 in. long, 2 to 2.5 in. wide; petioles I in. long. Racemes 4 to 6 in. long, scaly. Male flowers cream-colour, small. Stamens Io to I2 villous. Female flowers larger; sepals linearoblong. Ovary scaly. Styles slender bifid. Capsule oblongglobose or obovoid, 75 in. long, obscurely 3-lobed, scaly. Seeds plano-convex shining light brown, ${ }^{5} 5 \mathrm{in}$. long. Hab. Forests and woods common. Singapore, Changi (Hullett); Batu Putih. Johor, Bukit Soga, Batu Pahat. Muar, Biawak (Curtis). Pahang, along the river, Pulau Tawar, Pulau Chengei; Kota Tongkat (Evans). Malacca (Griffith); Ayer Panas and Bukit Panchur (Derry). Negri Sembilan, Port Dickson. Selangor, Bukit Telaga, Semangkok Pass. Perak, Larut (Kunstler). Penang Hill (Curtis). Distrib. Burma, Sumatra, Java, Borneo. Native names: Cherit Badak; Mungke; Simmungke.

(3) C. erythrostachys Hook. fil. F.B.I. v. 39 I.

Low shrub; branches, underside of leaves, petioles and inflorescence dotted with red stellate hairs. Leaves coriaceous smooth and shining above, ovate-oblong or linear-oblong acuminate, edges glandular serrulate, base rounded or blunt; nerves 6 pairs, fine; I to $3.5 \mathrm{in}$. long, 3 to $I \cdot 5$ in. wide; petioles very short to .6 in. long. Racemes 2.5 in. long, hairy. Male flowers pedicelled hairy, I in. wide. Sepals ovate hairy. Petals oblong. Stamens I2. Female flowers one or two at base of raceme, hairy. Petals subulate. Ovary depressed hairy. Styles very slender bifid. 
Capsule 3 to 5 in. through, globose hairy. $H a b$. On rocks at $3000 \mathrm{ft}$. altitude. Very local. Malacca, Mt. Ophir on the Padang Batu near the camping ground (Cuming, Griffith, Lobb and all collectors). Selangor, Bukit Kutu (Ridley).

(4) C. Cumingii Mill. Arg. DC. Prod. xv. (2), Ior.

Straggling shrub with slender branches. Leaves at the ends of shoots clustered, thin chartaceous, oblong-lanceolate or oblongovate or rhomboid acuminate with blunt base, beneath thickly covered with silvery peltate scales with some red ones; nerves 6 or 7 pairs inarching well within the margin; 5 to 7 in. long, I.5 to 3 in. wide; petioles .75 in. long. Racemes very short, I in. long. Male flowers small covered with scales, 08 in. wide. Sepals ovate. Stamens short, I2 to I5. Female flower rather bigger. Styles slender bifid. Capsule I5 in. long, scaly. Seeds ellipsoid slightly flattened on one side, $\cdot \mathrm{I}$ in. long. Hab. Rocks usually limestone. Johor, Pulau Tiuman (Burkill). Pahang, Kota Glanggi. Perak, Temengoh; Tambun; Gunong Pondok (Kunstler). Lankawi near the lake; Dayong Bunting (Robinson). Kelantan, Gunong, Kota Bharu. Perlis, Chupeng. Distrib. Siam, Philippines.

(5) C. Griffithii Hook. fil. F.B.I. v. 392.

Shrub, 4 to $6 \mathrm{ft}$. tall or a tree up to $40 \mathrm{ft}$. tall (fide Kunstler), glabrous. Leaves fleshy coriaceous elliptic or oblong blunt acuminate, base round, edge frequently undulate, drying brownish yellow; nerves about Io pairs ; 4 to 9 in. long, 2.5 to 4 in. wide; petioles $x$ in. long. Racemes 6 to 9 in. long, glabrous. Males with females 2 or 3 together pedicelled, ' I in. wide, woolly inside. Stamens 8 to 15 . Females larger scaly. Disc of 5 large glands. Ovary 3-lobed stellate-tomentose and white scaly. Styles bifid. Capsule globose depressed trilobed, 25 in. through. Seeds sub-globose. Hab. Woods and forests. Common. Singapore, Selitar; Bukit Mandai; Changi. Johor, Batu Pahat; Bukit Murdom (Kelsall). Malacca (Griffith). Negri Sembilan, Ayer Kuning (Cantley). Selangor, Klang Gates; Kwala Lumpur. Perak, Goping (Kunstler) Tapa; Relau Tujor (Wray). Penang, back of West Hill (Curtis). Native names: Chalang Paya; Poko Mawai.

(6) C. confusum Gage, Rec. Bot. Surv. Ind. l.c. 237.

Shrub or tree up to $30 \mathrm{ft}$. tall, bark white. Leaves thin subcoriaceous glabrous drying grey elliptic acuminate or cuspidate, base round or sub-acute; nerves 5 pairs inarching; 4 to 6 in. long, 3 to $3.5 \mathrm{in}$. wide; petioles i to $2 \mathrm{in}$. long, slender, scaly. Male flowers small, under -I in. long; pedicels short slender. Petals oblong hairy. Stamens ro. Female flowers; sepals glabrous, ovate acuminate. Ovary hairy. Styles slender bifid. Capsule .25 in. wide, sub-globose trilobed. Seed globose. Hab. Woods and forests, Singapore (Wallich 7754); Garden Jungle (Murton), Selitar; Bukit Timah. Johor, Tebrau. Malacca, Mt. Ophir. 
Negri Sembilan, Bukit Klana (Cantley). Perak, Larut (Kunstler). Distrib. Siam. Native name: Lidai api.

(7) C. lucidum Gage, Rec. Bot. Surv. Ind. l.c. 236.

Shrub or small tree. Leaves thinly coriaceous elliptic-ovate or lanceolate caudate-acuminate, base blunt rounded or sub-cuneate, edge very obscurely serrate undulate glabrous except a few sparse hairs on the midrib and nerves beneath; nerves 9 pairs, very slender: 4 to 5 in. long, $I \cdot 5$ to 2 in. wide; petioles stellate-hairy, .25 to $\mathrm{I} \cdot 5 \mathrm{in}$. long. Racemes terminal fascicled tomentose (glabrous or minutely stellate scaly). Flowers male at top, a few females at base. Male flowers; sepals 5 lanceolate tomentose (or red-scaly) bearded inside near tip. Petals 5 oblong. Disc annular. Stamens II, hairy below. Female flowers; sepals 5 oblong-ovate. Petals minute, scale-like. Disc annular. Ovary ovoid triquetrous densely red stellate-tomentose; styles bifid, arms filiform. Hab. Johor, Gunong Pulai and between Kota Tinggi and Gunong Pantai (Ridley).

(8) C. tiglium Linn. Sp. Pl. I004; Hook. fil. F.B.I. v. 393.

Bush or small tree, glabrous. Leaves membranous ovate acuminate serrate, base round very shortly narrowed, 3- to 5-nerved, 4.5 in. long, $3 \cdot 75$ in. wide; petioles $I \cdot 5$ in. long, slender. Racemes 2 to 3 in. long. Male flowers stellate-hairy. Sepals nearly glabrous, tips bearded. Petals narrow, edges woolly. Receptacle villous. Stamens glabrous. Disc glands 5 small. Female flowers; sepals villous at base. No petals. Capsule oblong 3-lobed green or whitish somewhat trigonous, $\cdot 75$ in. long. Seed $\cdot 5$ in. long, oblong, dark grey. Hab. Cultivated ground, Malacca (Maingay) cultivated. Kelantan (Gimlette). Distrib. Indo-Malaya and China. Native names: Chengkian; Chemkian. Use: As a purgative and in poisoning (see Gimlette, "Malay Poisons and Charm Cures," ed. ii. I45).

(9) C. heteropetalum Müll. Arg. in DC. Prod. xv. (2), $62 x$. C. ardisioides Hook. fil. F.B.I. v. 393.

A robust shrub or tree quite glabrous. Leaves oblong or linear or obovate-oblong narrowed to the base, tip blunt, edges boldly crenate, glabrous; nerves fine; 2 to 4 in. long, 5 to I. 5 in. wide; petioles $I$ to $I$ in. long. Racemes slender, 4 in. long; flowers scattered. Sepals glabrous in males with bearded tips, in females ovate blunt. Stamens I2. Ovary depressed stellate-tomentose; styles bifid. Capsule I2 in. through, globose smooth. Hab. Johor, Sempang River (Ridley). Malacca (Griffith). Distrib. Borneo.

(I0) C. calcicolum Ridl. Kerw Bulletin, I923, p. 360.

Shrub $8 \mathrm{ft}$. tall. Branches stellate-hairy. Leaves membranous chartaceous, elliptic-oblong acute, base narrowed blunt rounded very shortly bilobed, edge minutely glandular, above nearly glabrous when adult except midrib, beneath stellate-hairy; nerves I2 or I3 pairs slender elevate beneath (young leaves velvety beneath); 
7 to Io in. long, 3.75 to 3 in. wide; petioles densely stellate-hairy, $2 \cdot 2$ in. long. Male inflorescence unknown. Female raceme 5 to 6 in. long, stout densely stellate-hairy; pedicels stout hairy, I in. long. Sepals ovate-triangular, $\cdot I$ in. long, densely hairy outside. Ovary densely hairy. Styles slender bifid to near the base glabrous. Capsule $\cdot 3$ in. long, cocci thin woody, shortly densely pubescent. Seed ovoid rounded at both ends, black, 25 in. long. Hab. Limestone rocks, Selangor, Kanching (Ridley). Distrib. Borneo (Beccari 3134).

\section{TRIGONOPLEURA Hook. fil.}

Tree. Leaves alternate coriaceous, oblong entire. Flowers small in axillary clusters. Male flowers; sepals 5, broadly oblong coriaceous imbricate. Petals longer obovate villous on both sides. Disc of 5 glands round the base of the staminal column. Stamens 8 , filaments united in a column, tips free; anthers united to the hairy connective. Pistillode on top of column. Female flowers unknown. Capsule small 3-lobed hoary; epicarp separable, cocci bony separating from a columella with 3 hyaline wings. Seeds solitary broad oblong dorsally compressed, testa black, aril large pale. Species 2, Malayan.

(I) T. malayana Hook. fil. F.B.I. v. 399; Ic. Pl. I753.

Large tree 40 to $60 \mathrm{ft}$. tall. Leaves 4 to $6 \mathrm{in}$. long, I.5 to $\mathrm{I} \cdot 75$ in. wide; acuminate, base blunt; nerves 7 pairs; petioles ' $I$ in. long. Flowers ro in a cluster hoary, about $\cdot 25$ in. across when expanded. Sepals blunt unequal. Petals small coriaceous, hairy. Capsule 5 in. through. Hab. Hill forests. Perak, Ulu Bubong (Kunstler). Penang Hill near the Cooly lines at I200 ft. altifude (Curtis, Maingay). Distrib. Philippines.

Maingay's specimens have Malacca tickets to them, but the plant probably came from Penang.

32. TRIGONOSTEMON, BI.

Shrubs (or small trees). Leaves alternate at the ends of the branches or stem. Racemes axillary elongate. Male flowers; sepals 5, imbricate. Petals 3 or 5 . Anthers sessile or filaments united in a column with free spreading tips; anther-cells united by their bases, each cell often with a thick crested connective. Female flowers; perianth of male, or with no petals. Disc usually entire. Ovary 3-celled; ovules $I$ in a cell. Styles bifid or twice bifid. Capsule of 3 bivalved cocci. Seeds ovoid or globose. Species 20, tropical Asia.

Stamens 5 .

Tree; leaves elliptic-lanceolate broad

Low shrub; leaves narrow lanceolate acuminate

(I) T. indicus

Stamens 3 .

Shrubs glabrous (except young parts); bracts minute.

(2) T. salicifolius 
Leaves oblanceolate, over I $\mathrm{ft}$. long; petioles very short.

Racemes over I $\mathrm{ft}$. tall

Leaves broad elliptic, 6 to 7 in. long; petioles 3 in. long; racemes 6 in. long

Shrub villous with long bracts

Small tree glabrous; racemes very short, $\mathbf{I}$ in. long

(3) T. longifolius

(4) T. malaccanus

(5) T. villosus

(6) T. lævigatus

(I) T. indicus Mïll. Arg. in Linnaa, xxxiv. 214; in DC. Prod. xv. (2), II07; Hook. fil. F.B.I. v. 398.

Bushy tree $30 \mathrm{ft}$. tall, glabrous. Leaves sub-coriaceous shining elliptic-lanceolate or oblanceolate acuminate, base narrowed blunt; nerves I 5 to 20 pairs, slender faint ; 6 in. long, $2 \cdot 25$ in. wide; petioles .5 to 2 in. long. Racemes 2 to 3 in. long, slender glabrous, uppermost flower female $\cdot 25$ in. wide. Male flowers small. Sepals orbicular-ovate toothed. Petals rounded glabrous. Stamens 5, anthers bifid at top. Female flowers larger, red. Ovary tomentose. Styles bifid. Disc in all urceolate 5-partite. Capsule hairy. Hab. Hill woods. Perak (Scortechini). Penang (Maingay, Porter, Curtis). Distrib. Sumatra.

(2) T. salicifolius Ridl. Kew Bulletin, I923, p. 360 .

Shrub 2 to $3 \mathrm{ft}$. tall, glabrous. Leaves coriaceous narrow lanceolate long acuminate, base shortly narrowed blunt; nerves I4 pairs very faint, widely inarching; 6 to 6.5 in. long, $\cdot 5$ to $\cdot 75$ in. wide; petioles slender, 5 to $I \cdot 5$ in. long. Racemes axillary, 2 in. long, few-flowered. Bracts small, ovate blunt; pedicels thick, - I in. long. Sepals coriaceous round, edge ciliate. Petals much longer broad round imbricate, deep crimson-purple, fleshy. Whole flower 25 in. wide. Staminal column short; anthers 5 oblong bifid at top. Disc short cupular. Female flower, sepals short coriaceous. Ovary pubescent 3-lobed. Styles short bifid, hornshaped. Capsule oblong-ovate thinly woody, epicarp greyish black pustular, 25 in. long, glabrous. Hab. Limestone rocks, Selangor, Kanching (Ridley).

This is allied to $T$. indicus Müll., differing in its narrow willow-like leaves and very short disc.

(3) T. longifolius Baill. Etudes Gen. Euphorb. 34I, t. II, Fig. I2; Hook. fil. F.B.I. v. 396; Pax, Pfanzenreich, iv. I47; iii. 88, Fig. 28.

Shrub 6 to $\mathrm{I} 2 \mathrm{ft}$. tall, shoots golden-hairy. Leaves sub-sessile lanceolate or oblanceolate acuminate narrowed at base, glabrous, edge obscurely toothed at tip; nerves I 5 to 20 pairs; 9 to I4 in. long, 2 to $2 \cdot 25$ in. wide; petioles 3 in. long or less, very thick. Racemes I5 in. long, pubescent. Flowers numerous in tufts. Bracts short subulate hairy. Male flowers 2 in. wide. Sepals broad hispid, one much the largest. Petals ovate round, dark purple glabrous. Disc urceolate. Stamens 3 with large appendages. Ovary hispid. Capsule flattened globose, trilobed with a groove down the centre of each lobe $\cdot 5$ in. across, hairy. Hab. Woods, 
Singapore, Stagmount; Reservoir; Kranji. Johor, Batu Pahat; Jaffaria (King). Malacca (Griffith). Perak, Ulu Temengoh; Bujong Malacca; Gunong Bubu (Kunstler); Kenering (Wray). Province Wellesley, Krian. Penang (Wallich); Waterfall (Curtis). Kedah, Yan. Lankawi (Robinson); Burau Bay. Distrib. Tenasserim, Sumatra.

(4) T. malaccanus Müll. Arg. in Flora, xlvii. 482; DC. Prod. xv. (2), IIIO; Hook. fil. F.B.I. v. 396.

Glabrous woody shrub. Leaves lanceolate long-acuminate, base rounded, edges entire or crenate; nerves 15 to 20 pairs; 6 to 9 in. long, $x \cdot 5$ to 2 in. wide; petioles $\cdot 25$ to 6 in. long, thickened at the tip. Racemes slender, 6 to Io in. long, glabrous. Flowers scattered. Bracts - I in. long, subulate. Male flowers minute clustered pedicelled. Sepals coriaceous pubescent. Petals broadly obovate dark purple. Anthers with papillose connectives. Female flowers solitary, much larger. Pedicels stout pubescent, 2 in. long. Sepals oblong erect, 3 short pubescent, 2 much larger with a broad thin rounded edge. No petals. Ovary hairy. Hab. Forests. Johor, Pulau Tiuman, Tanjong Duatak (Burkill); Genuang. Malacca (Griffith). Negri Sembilan, Tampin (Ridley).

The Pulau Tiuman plant has linear bracts $\cdot 25$ in. long. The leaves of this plant are very variable. At the top of the shoot is a cluster of short and shortly petioled leaves with some twice as large on long petioles.

(5) T. villosus Hook. fil. F.B.I. v. 397. T. tomentellus Pax, Pflanzenreich, iv. 147 , p. 89.

Small shrub, branches brown-tomentose. Leaves membranous elliptic acuminate entire, base shortly narrowed blunt, nerves about I2 pairs sunk above, elevate beneath, and with the midrib and nervules hairy, a few hairs on the base of the leaf above; 4 to 6 in. long, I.I to $2 \cdot 25$ in. wide; petioles $I$ in. long, hairy. Racemes axillary brown-tomentose. Bracts lanceolate acuminate, .25 in. long, hairy. Male flowers clustered, small. Sepals oblong villous. Petals obovate-oblong. Disc glands 5, erect. Stamens 3 , anthers with crested connectives. Female flowers 5 in. wide. Sepals lanceolate villous. Ovary globose hairy. Style arms filiform. Hab. Forests. Malacca, Gunong Mering, Mt. Ophir. Selangor, Kwala Lumpur (Curtis); Sungei Buloh. Perak (Scortechini, Kunstler); Tapah (Wray); Ipoh (Curtis).

(6) T. lævigatus Müll. Arg. in Flora, xlvii. 538; DC. Prod. XV. (2), IIII.

Small tree glabrous. Leaves thinly coriaceous elliptic to lanceolate cuspidate blunt, edges slightly undulate, nerves 6 to 8 pairs, slender elevate beneath; 5 to 6 in. long, 2 in. wide; petioles .2 to .25 in. long. Male flowers very small, $\cdot 2$ in. wide, about 8 in a silky pubescent raceme $I$ in. long, axillary. Pedicels glabrous, -I in. long. Sepals 5, 3 outer small, inner concave. Petals 5, coriaceous, all ovate blunt. Stamens 3 , column very short or 0 . 
Female flowers; sepals 5 oblong. Petals o. Disc saucer-shaped. Ovary 3-celled, hairy. Styles 3, simple. Hab. Hill woods, Johor, Bukit Murdom, Batu Pahat (Kelsall). Penang, back of West Hill (Curtis). Lankawi islands (Robinson). Distrib. Borneo.

\section{DIMORPHOCALYX, Thwaites.}

Shrubs or small trees. Leaves alternate entire, coriaceous. Flowers few in axillary and terminal racemes or females subsolitary. Male flowers; calyx cupular or 5-toothed or lobed. Petals 5, longer and broader. Disc-glands 5, alternate with petals. Stamens ro to 20 on a columnar receptacle, filaments stout free or inner ones connate; anther-cells on a thick connective. No pistillode. Female flowers; sepals 5, imbricate enlarging greatly in fruit. Petals 5. Ovary 3-celled; styles erect bifid. Capsule of 3 bivalved crustaceous cocci. Seeds ovoid. Species about 8, Indo-Malaya.

Leaves entire.

\section{Leaves 6 in. long, 2 in. wide}

Leaves 4 in. long, $I$ in. wide

Leaves crenulate, 6 to $7 \mathrm{in.} \mathrm{long,} 2.5 \mathrm{in}$. wide
(I) D. malayanus

(2) D. Kunstleri

(3) D. capillipes

(I) D. malayanus Hook. fil. F.B.I. v. 404.

Shrub Io to I5 $\mathrm{ft}$. tall, bark white. Leaves sub-membranous glabrous elliptic or elliptic-oblong blunt acuminate; nerves fine, 8 pairs; 4 to 6 in. long, $I \cdot 75$ to 2 in. wide; petioles $\cdot 2$ in. long, slender. Male flowers white in slender branched cymes. Calyx with 5 short blunt teeth. Stamens Io, central ones united in a column with 5 free ones at the base. Disc of large glands. Female flowers; ovary glabrous. Capsule $\cdot 5$ in. through, deeply 3 -lobed; sepals broadly oblong sub-equal. Seeds sub-globose, dark mottled, $\cdot 5$ in. long. Hab. Malacca (Griffith). Penang, Waterfall (Kunstler and Curtis).

(2) D. Kunstleri Hook. fil. F.B.I. v. 405.

Shrub Io to $15 \mathrm{ft}$. tall or small tree. Leaves coriaceous ellipticoblong acuminate or lanceolate, narrowed at base, pale beneath; nerves very faint, 7 or 8 pairs; 3 to 4 in. long, $I .5$ in. wide ; petioles .25 in. long. Male cymes sub-terminal short, 6- to 8-flowered, I in. long; pedicels $I$ in. long. Flowers campanulate white, 3 in. wide. Calyx cupular 5 -toothed. Petals oblong. Stamens about I3; 5 at the column base, 8 at the top. Capsule ' $I$ in. long, globose, 3-lobed; sepals oblong, tip rounded, $\cdot 2$ in. long. Hab. Hill woods, Penang (Kunstler); Batu Feringhi and Waterfall (Curtis).

(3) D. capillipes Hook. fil. F.B.I. v. 404.

Leaves oblanceolate acuminate, base long narrowed truncate crenulate; nerves fine, 6 pairs; 6 to 7.5 in. long, 2.5 in. wide; petioles none to $\cdot I$ in. long. Racemes elongate capillary, 4 to 7 in. long; flowers few. Bracts foliaceous oblong, 5 to .75 in. long. 
Flowers not known. Capsule $\cdot 5$ in. through hoary; cocci globose, smooth thinly crustaceous; sepals oblong-lanceolate, $\cdot 5$ in. long. $H a b$. Singapore (Lobb).

This has not been collected anywhere since, and, like all Lobb's collection, the locality given is doubtful.

\section{AGROSTISTACHYS, Dalz.}

Trees or shrubs glabrous, rarely with the raceme pubescent. Leaves alternate coriaceous entire or serrate. Flowers in axillary or extra axillary bracteate erect racemes or spikes. Male flowers few or many in each bract. Calyx globose splitting into 2 to 5 valvate lobes. Petals 8 , shorter. Disc-glands very large, alternating with the petals. Stamens 8 to I3 on a convex receptacle filaments nearly free; anthers versatile, cells pendulous from a thickened connective. Pistillode 2 - to 3 -fid or none. Female flowers solitary pedicelled. Calyx $5^{-}$to 6-lobed. Petals longer. Ovary 3-celled; ovules one in a cell. Styles short thick entire or bifid. Capsule of 3 bivalved cocci. Seeds globose shining. Species 6 or 8, tropical India.

Racemes when young not cone-shaped of imbricating bracts; leaves coriaceous.

Shrub up to $2 \mathrm{ft}$. tall. Raceme pubescent . Big shrub branched $2 \mathrm{ft}$. tall; racemes glabrous.

Racemes when young conoid.

Leaves membranous

(x) A. sessilifolia

(2) A. bormeensis

(3) A. Gaudichaudii

(I) A. sessilifolia Pax and Hoffm. Pfanzenreich, iv. I47, vi. p. I02. A. longifolia var. malayana Hook. fil. F.B.I. v. 40\%. Sarcoclinium sessilifolium Kurz. Flora, I875, p. 3 I.

Unbranched shrub, stem about I2 in. high with a whorl of leaves at the tip. Leaves coriaceous oblanceolate shortly cuspidate decurrent on the petiole to the base; nerves 23 pairs parallel ascending; I5 in. long, 2.75 in. wide. Racemes slender erect, I 2 in. long, puberulous. Bracts ovate concave pubescent. Male flowers; sepals 2, sparsely pubescent. Petals 4. Disc glands 4. Stamens 8; anthers widely divaricate. Female flowers on different plants and clusters more distinct. Sepals rounded crenulate. Petals rounded obovate. Ovary 3 -lobed hairy. Capsule 3 -lobed, $\cdot 3$ in. through. $H a b$. Lowland woods, Singapore, Garden Jungle; Selitar, common. Malacca (Griffith); Bukit Bruang (Derry); Selandor. Perak, Waterfall, Thaiping (Wray). Native name: Julong-Julong.

This is very distinct from $A$. bomeensis, Becc., which Hooker combines with it as varieties of the Indian $A$. longifolia. A. sessilifolia is a dwarf shrub, usually quite unbranched, with erect pubescent spikes above the terminal tuft of leaves, and is not at all resinous. A. borneensis is a resinous muchbranched big shrub with more slender racemes in the axils of the distant lower leaves, not at all pubescent. The shape of the leaves and the venation are also quite different. 
(2) A. borneensis Becc. Nelle Foreste di Borneo, p. 33r. A. latifolia Pax and Hoffm. Pflanzenreich, iv. I47, l.c. p. Ioo. A. longifolia var. latifolia Hook. fil. F.B.I. v. 407.

Big spreading shrub 3 to $\mathrm{I} 2 \mathrm{ft}$. tall, shoots gummy. Leaves stiffly coriaceous oblanceolate or lanceolate, shortly acute, base long narrowed and decurrent on the petiole, midrib stout; nerves about 20 pairs prominent and stout; I6 in. long to base of petiole, 3 to 4.5 in. wide. Racemes extra-axillary gummy, males 3.5 in. long. Flowers 7 or 8 in a short oblong rounded concave coriaceous bract - I in. long. Sepals 2, nembranous. Petals 5, rounded retuse clawed. Stamens ro. Disc of 5 large glands. Female racemes 6 in. long or more. Sepals 5, with glandular margins. Discglands large. Ovary trilobed. Styles short recurved bifid. Hab. Dry woods, Dindings, Gunong Tungul; Pulau Rumpia, Sembilan isles (Kloss); Perak (Scortechini); Larut (Kunstler). Kedah Peak (Robinson). Use: The gum was formerly used in varnishing the sheaths and handles of krises.

(3) A. Gaudichaudii Müll. Arg. in Linncea, xxxiv. I44; in DC. Prod. xv. (2), 725. A. filipendula Hook. fil. F.B.I. v. 407. A. Maingayi Hook. fil. F.B.I. v. 406.

A tree 40 to $60 \mathrm{ft}$. tall, stem 6 to 8 in. through. Leaves membranous oblanceolate acuminate narrowed to the base; nerves I2 to 20 pairs slender; I 8 in. long, 5 in. wide; petioles 3 in. long, winged to the base. Male racemes in bud cylindric-conoid with round ciliate bracts, when developed slender pendent racemes 4 to 7 in. long, with distant ovate-oblong or ovate-lanceolate blunt, ciliate bracts, $I$ in. long. Flowers 5 or 6 in a bract; pedicels longer capillary. Sepals ovate-oblong. Petals obovate thin white. Disc-glands 4 or 5 , orange colour. Stamens 8 or 9 ; filaments long and slender. No pistillode. Female racemes numerous very slender, 4 to 6 in. long. Bracts oblong blunt, I-flowered; pedicels 5 to $I$ in. long. Sepals 4 . Staminodes filiform. Ovary 3-lobed. Styles entire. Disc orange crenulate. Capsule 3-lobed, $\cdot 75$ in. long, hoary. Hab. Sandy woods, Singapore, Changi (Hullett). Johor, Batu Pahat. Selangor, Batu Caves; Sepang. Perak, Thaiping Hills; Chanderiang (Kunstler). Lankawi, Terutau (Robinson). Native name: Julong Jantan.

A. Maingayi, Hook. fil., is a poor specimen of what appears to be this species. A. Gaudichaudii, Müll. Arg., is based on a plant collected by Gaudichaud in Penang, which I have not seen. Pax, who has seen it, identifies with it a specimen of $A$. flipendula collected by me at the Batu caves, and puts $A$. filipendula under the section Sarcoclinium, in which the racemes when in bud are not in the form of cylindric cones, but $A$. filipendula has these cones when the racemes are young, and $A$. Maingayi and $A$. filipendula are specimens in that state. 
35. OSTODES, B1.

Trees or shrubs. Leaves alternate toothed or entire. Flowers in lax terminal and lateral panicled racemes, rarely in axillary fascicles. Males fascicled or cymose. Females in separate racemes or solitary in the male cymes. Male flowers; sepals 5, broad unequal imbricate. Petals longer, 5 or 6 . Disc of 5 glands or none. Stamens 8 to 30 on a convex or columnar receptacle; anthers dorsifixed. No pistillode. Female flowers; perianth as in male. Ovary 3-celled. Styles short bific. Capsule subglobose 6-ribbed, almost bony, at length breaking up into 3 bivalved cocci. Seeds ovoid. Species Io, tropical Asia.

Racemes axillary; petioles long.

Male cymes or racemes short, few-flowered axillary

Male panicles long short-branched terminal; flowers numerous in clusters.

Panicles long dense from the trunk

(I) 0. muricata

(2) O. macrophylla

(3) O. appendiculata

(I) O. muricata Hook. fil. F.B.I. v. 40 I.

Shrub or treelet 6 to I5 ft. tall, glabrous. Leaves coriaceous elliptic-oblong or lanceolate acuminate entire or broadly serrate; nerves slender, Io to I2 pairs; 6 to ro in. long, 3 to 4 in. wide; petioles $\mathrm{I} \cdot 5$ to $2.5 \mathrm{in}$. long. Male flowers $\cdot 25$ in. wide, white, pink or crimson in small axillary cymes; pedicels slender, $\cdot 5$ in. long. Bracts small ovate. Calyx-lobes round. Petals oblong. Stamens short 20 to 30. Female flowers solitary. Capsule 75 in. long; peduncles 5 to $I$ in. long; valves black echinate thick. Seeds $\cdot 3$ in. long, ellipsoid brown. Hab. Hill jungle. Dindings, Pulau Sembilan; Lumut, Sungei Segari. Perak, Larut (Kunstler); Gunong Keledang. Penang, Waterfall (Ridley).

var. minor Hook. fil. Leaves ovate-lanceolate, 4 to 7 in. long, $\mathrm{I} \cdot 75$ in. wide; petioles shorter, cymes shorter. Penang (Lobb, Kunstler, Curtis).

(2) O. macrophylla Benth.Gen. Plan, iii. 299; Pax, Pfanzenreich, l.c. 88. Tritaxis macrophylla Miill. Arg. Flora, xlvii. 482. (Fig. I53, p. 270.)

Tree 30 to $40 \mathrm{ft}$. tall, I5 to $20 \mathrm{in.} \mathrm{through.} \mathrm{Leaves} \mathrm{thinly}$ coriaceous oblong or oblong-lanceolate serrate acuminate; nerves 20 pairs; I2 in. long, 6 in. wide; petioles 4 in. long (leaves close to the inflorescence much smaller, 3 to 7 in. long, $\cdot 2$ to $\cdot 5$ in. wide); petioles I in. long or less, and scurfy. Panicles I ft. or more long, slender scurfy. Flowers pedicelled scurfy in compact distant clusters on short branches light yellow. Male flowers irregular. Sepals concave round scurfy. Petals oblong glabrous. Stamens I2 to 15 , outer ones free, the rest in a column. Disc urceolate lobed hairy. Female flowers larger. Ovary hairy. Stigmas 3, bifid half-way. Hab. Open woods, Singapore, Chua Chu Kang; Bukit Panjang. Malacca, Ayer Panas (Griffith); Merlimau (Derry, 
Cantley); Batang Malacca and Bukit Sadanen (Derry). Pahang, Rumpin River (Evans); Semantan Road (Burn-Murdoch). Perak, Larut (Kunstler); Waterloo (Curtis); Hermitage Hill. Distrib. Borneo, Java. Native names: Chindara hantu; Kasumba jantan; Julong putih; Julong Rambei Ayam; Chungah Padi.

(3) O. appendiculata Hook. fil. F.B.I. v. 4OI.

Tree 40 to $60 \mathrm{ft}$. tall, $\mathrm{I} \cdot 5$ to $2 \mathrm{ft}$. through. Leaves coriaceous glabrous oblong cuspidate, base acute or blunt; nerves I2 to I5 pairs, prominent beneath, nervules and reticulations conspicuous; I 8 in. long, 6 in. wide. Panicles from the trunk, I2 in. long, densely flowered, branches 2.5 in. long at base, very short at tip, closely pubescent all over. "Bracts short silky. Male flowers white Sepals 5 , round coriaceous, silky white, $\cdot I$ in. long. Petals longe.

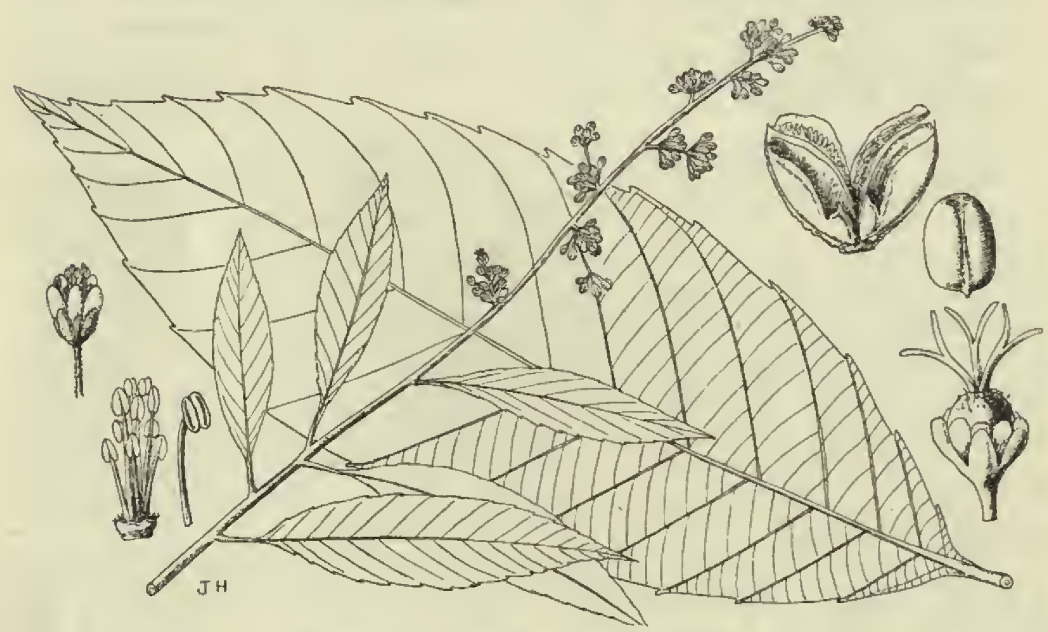

F1G. I53.-Ostodes macrophylla.

erect, tips recurved, villous at the back with 2 waved appendages at base. No disc. Stamens 7; filaments free long silky. Female flowers and fruit unknown. Hab. Dense jungle on limestone at 500 to rooo ft. altitude, Perak, Goping (Kunstler).

\section{ERISMANTHUS, Wall.}

Shrubs. Leaves sub-sessile oblong, base cordate unequally chartaceous. Flowers axillary. Males on long capillary pedicels from the bracts of a short sub-sessile cone, petaliferous small. Females solitary in separate axils on long pedicels. No disc. Male flowers; sepals 4 or 5, reflexed. Petals half the size. Stamens I2 on a conical hairy receptacle terminated by a capillary pistillode ; filaments very short; anthers large. Female flowers larger. Sepals 5, elliptic-oblong foliaceous enlarging in fruit. Ovary 
3-lobed, 3-celled hairy. Styles very long united below, bipartite, arms hairy filiform. Capsule of 3 sub-globose hairy cocci. Seeds sub-globose. Species 2, the other one Chinese.

(I) E. obliqua Wall. Cat. 80II; Müll. Arg. in DC. Prod. xvii. II38; Hook. fll. F.B.I. v. 405 .

A shrub to a treelet $25 \mathrm{ft}$. tall, hairy. Leaves glabrous cuspidate serrate, edge serrate; nerves about Io pairs; 6 in. long, 2.5 in. wide; petioles red, $\cdot I$ in. long or less. Stipules linear hairy, $\cdot 2$ in. long. Male cone $\cdot 25$ in. long, bracts hairy; pedicels hairy, .5 in. long; flowers pink, $\cdot 05$ in. wide. Female flowers; peduncle fairly stout hairy, I in. long with two lanceolate bracts at top. Pedicels $\cdot 3$ in. long. Sepals acute hairy, $\cdot 3$ in. long. Style arms $\cdot 3$ in. long. Capsule $\cdot 5$ in. through. Seed mottled. Hab. Forests. Malacca, Bukit Besar, Mt. Ophir. Pahang River at Tanjong Antan. Perak, Kwala Kenering; Kwala Dipang (Kunstler). Penang (Wallich); Hill; Waterfall (Curtis). Native name: Kusep Kuludu.

\section{CLAOXYLON, A. Juss.}

Shrubs or small trees (rarely herbs). Leaves alternate, membranous, long-petioled oblong or ovate, toothed or entire. Flowers small or minute in axillary or lateral spikes or racemes. Male flowers; calyx sub-globose 3 to 4 valvate segments. Petals and disc none. Stamens many on or around a central receptacle often mixed with glands or long linear scales; filaments free, cells divaricate. No pistillode. Female flowers; calyx as in male. Disc none or of 5 petal-like hypogynous scales alternate with the carpels. Ovary 3-celled; ovules $I$ in a cell. Styles short entire fringed. Capsule of 3 bivalved cocci (or coriaceous indehiscent). Seeds sub-globose, aril red. Species about 40, Old World tropics.

I,caves broad ovate or elliptic-lanceolate; racemes rather long

Leaves lanceolate narrowed at both ends; racemes rather long

Leaves elongate oblanceolate; racemes short

Leaves large oblong acuminate, base blunt; racemes short

(I) C. indicum

(2) C. longifolium

(3) C. Wallichianum

(4) C. Kingii

(r) C. indicum Hassk. Bogor, 235; Müll. Arg. in DC. Prod. xv. (2), $782 ;$ Hook. fil. F.B.I. v. 400.

A big shrub softly pubescent all over. Leaves broadly ovate, base round, 6 to 7 in. long, 475 in. wide, or lanceolate or ellipticlanceolate, base acute, edge entire or toothed, 6 in. long, 2 in. wide ; sparsely hairy or glabrous above, softly tomentose beneath; nerves 6 to 8 pairs; petioles 2 to 4 in. long, softly tomentose. Racemes pubescent slender, 4.5 to 5 in. long. Male flowers minute, green tomentose in small clusters shortly pedicelled. Sepals oblong acute, hairy outside, reflexed. Stamens numerous, glabrous, 20 to 30 mixed with filiform scales. Female flowers solitary on longer 
pedicels. Capsule 3 -lobed, green, $\cdot 3$ in. through. Seed sub-globose, aril red. Hab. Woods. Singapore, Grange Road and Sophia Road (Hullett); Bukit Panjang. Malacca, Mt. Ophir. Selangor, Ginting Bidai. Perak, Thaiping Hills at $5000 \mathrm{ft}$. altitude; Batu Togoh (Wray). Penang, Glugor. Perlis, Chupeng. Distrib. IndoMalaya.

This plant is very variable in the amount of pubescence and the form of the leaves. The commonest form has nearly, rarely quite, glabrous leaves ovate or oblong very shortly narrowed at the base, nearly entire. The Chupeng (Perlis) plant is densely tomentose on both sides of the leaves. Another form from Perlis has very strongly toothed rhomboidal leaves.

(2) C. longifolium Mïll. Arg. in DC. Prod. xv. (2), 78r; Hook. fil. F.B.I. V. 4II.

Shrub or small tree $\mathrm{I} 2 \mathrm{ft}$. tall, glabrous except young parts and inflorescences. Leaves thin elliptic-oblong or lanceolate, base acute, toothed or nearly entire; nerves 5 pairs; 4 to 6 in. long, I.75 to 3 in. wide; petioles $I \cdot 5$ in. long. Racemes slender pubescent, 6 in. long. Nale flowers pedicelled tomentose few together in tomentose tufts. Sepals ovate tomentose outside. Stamens 40 to 50 with long villous scales intermixed. Female racemes shorter. Capsule trilobed mealy, bilobed or globose when only I or 2 seeds are developed, $\cdot 3$ in. through. Hab. Woods and forests, a smaller plant than C. indicum. Singapore, Bukit Panjang; Bukit Mandai; Pulau Ubin (Hullett). Johor, Gunong Pulai. Malacca, Bukit Batu Tiga (Derry). Dindings, Lumut Pahang, Gunong Berumbun. Penang (Wallich); Pulau Betong (Curtis). Distrib. Java and Sumatra.

var. brachystachys Hook. fil. l.c. More slender and weaker. Leaves thinner; petioles up to 4 in. long. Racemes 2 or 3 in. long, with the flowers longer petioled and more scattered; pedicels up to 25 in. long. Hab. Woods, Singapore, Pulau Ubin (Hullett); Kranji; Chan Chu Kang. Dindings, Pangkor. Penang, Penara Bukit (Curtis).

(3) C. Wallichianum Müll. Arg. in DC. Prod. xv. (2), 78r.

Small tree 15 .to $20 \mathrm{ft}$. tall, stem 2 to 4 in. through; branchlets hairy. Leaves thin purplish beneath and when young glabrous except midrib and 7 pairs of fine nerves beneath, oblanceolate or obovate acuminate, long-narrowed to base, sinuate serrulate, 6 to Io in. long, $x \cdot 2$ to 3 in. wide; petioles 5 in. long. Racemes I to 2 in. long, slender with few minute scattered flowers pubescent purplish, shortly pedicelled. Stamens about 30. Scales on receptacle few, minute. Capsule glabrous, $\cdot 5$ in. through, deeply lobed. $H a b$. Hill woods, Perak, Thaiping Hills at 3000 to $4000 \mathrm{ft}$. altitude (Kunstler, Curtis). Penang (Wallich); Richmond Pool (Curtis).

(4) C. Kingii Hook. fil. MSS. Claoxylon, sp. I3 Hook. fil. F.B.I. l.c. $4 \mathrm{I} 4$.

Shrub 3 to $6 \mathrm{ft}$. tall, shortly rather sparsely hairy all over. 
Leaves oblong acuminate, base very shortly narrowed, entire rather thick minutely hairy; nerves 9 pairs ascending, midrib stout; Io to II in. long, 4 in. wide; petioles 2 to 3.25 in. long, stout. Racemes I in. long (not fully developed). Stamens 60 to 70 , filaments short; anthers long for the genus. Receptacle glabrous. Hab. Perak, Larut at 2000 to $2500 \mathrm{ft}$. altitude (Kunstler).

Hooker suggests that this is a variety of $C$. longipetiolatum, Kurz, but the flowers are larger.

\section{MICROCOCCA, Benth.}

Annual herbs. Leaves alternate, herbaceous, small, ovate serrate; petioles long slender. Racemes slender lax. Flowers minute. Males; calyx globose splitting into 3. Stamens 5 to 30; filaments as long as the anthers. No pistillode. Females; sepals larger, 3 or 4 . Disc-glands linear alternate with carpels. Ovary 3-locular. Styles free laciniate. Capsule tricoccous (rarely 2 or 4 coccous), thinly crustaceous. Seeds sub-globose. Species ro, African and Indian.

(I) M. mercurialis Benth. Niger Flora, 503. Claoxylon mercurialis Thw. Enum. 27I; Hook. fil. F.B.I. v. 4I2.

Herb I ft. or more tall with rather sparse long white hairs. Leaves ovate acute, base round or acute, crenate; nerves ascending 5 pairs, nervules and reticulations visible; I to $I \cdot 5$ in. long, $\cdot 5$ in. wide; petioles slender, 4 in. long. Racemes slender, $1 \cdot 5$ in. long. Females solitary with several males. Sepals 4 or 5 glabrous oblong. Stamens 3 to IO, or numerous in a globose head; anthers nearly sessile. Female flowers with 3 linear scales, alternating with carpeis. Capsule 'I2 in. through, sparsely hairy or glabrous 3-lobed. Cocci globose. Seeds red-brown, deeply foveolate. Hab. Waste ground. Singapore, Rochor; Bajau; Pulau Ubin. Pahang, Pekan (Ridley). Penang, Sepoy lines and fort (Curtis). Distrib. Africa, India.

\section{ACALYPHA, Linn.}

Herbs, shrubs (or trees). Leaves alternate toothed or crenate (rarely entire). Flowers minute in axillary or terminal racemes. Male flowers very minute with small bracts. Females at the base of the male spikes or in separate spikes, often in the axil of large accrescent leafy bracts. No disc nor pistillode in males. Sepals 4. Stamens often 8 on a convex receptacle; filaments free; anthercells divaricate flexuous. Ovary 3-celled; ovules $I$ in a cell. Styles filiform long, and laciniate or fimbriate. Capsule very small of 3 bivalved cocci. Seeds sub-globose. Species 220, tropics and sub-tropics of both hemispheres.

Herbs hairy; leaves herbaceous.

Female flowers few in cuneiform bracts . . . (I) A. indica

Female flowers numerous; bracts minute : : (2) A. fallax

Shrub glabrous; leaves sub-coriaceous . . . (3) A. siamensis

FL.M.P., 3. 
(I) A. indica Linn. Sp. Pl. I003; Hook. fil. F.B.I. v. 4 I6.

A herb I ft, tall or more, pubescent. Leaves membranous ovate rhomboid, base cuneate, edges serrate, I to $2.5 \mathrm{in}$. long, .5 to $I^{\prime} 75$ in. wide; petioles slender, 2 to 4 in. long. Racemes shorter than petiole, I to 3.25 in. long. Male portion very slender, .25 in. long with minute flowers crowded together sessile. Female flowers in cuneiform toothed bracts I to I2 on a raceme. Bracts -I5 in. long, green. Capsule very small hairy concealed in the bract. Hab. Waste ground, a common weed. Singapore, Gelang; Pulau Ubin (Hullett). Province Wellesley, Krian. Penang, Balik Pulau Road (Curtis). Kelantan, Kota Bharu (Yapp). Distrib. Africa, India and Malay islands. Native name: Rumput Lislis.

(2) A. fallax Müll. Arg. in Limnaa, xxxiv. 42; in DC. Prod. xv. (2), 87I; Hook. fil. F.B.I. v. $4 \mathrm{I} 6$.

Herb, pubescent, 6 to 18 in. tall, branched. Leaves rhombic or ovate-lanceolate sub-acute crenate-serrate sparsely hairy all over, 2 in. long or more, $\mathrm{I}$ in. wide; petioles slender, 2 in. long. Spikes I to $2 \mathrm{in.} \mathrm{long,} \mathrm{hairy,} \mathrm{axillary} \mathrm{sessile} \mathrm{or} \mathrm{peduncled.} \mathrm{Males}$ in a minute terminal head or spike; females below numerous. Bracts I-flowered toothed, 05 in. long, hairy. Capsule hairy, - I in. long. Seeds globose smooth. Hab. Waste ground, Perlis, Tebing Tinggi (Ridley).

(3) A. siamensis Gage, Rec. Bot. Surv. Ind. l.c. 239.

Bush about $4 \mathrm{ft}$. tall with slender twigs, glabrous except inflorescence. Leaves coriaceous rhomboid narrowed to blunt base, bluntly serrate, tip blunt; nerves 5 pairs slender with a pair from the leaf base; I to $2.5 \mathrm{in}$. long, 25 to I. 25 in. wide; petioles under - I in. long. Racemes slender, puberulous, $x \cdot 25$ in. long, upper part male, with 2 or 3 female flowers at the base. Male flowers minute in small tufts. Sepals ovate acute ciliate. Stamens about Io; filaments hairy, scales lanceolate acuminate. Female flowers enclosed in large herbaceous bract. Capsule covered with long processes, ' $I$ in. long. Hab. Sandy open country in the north and on the east coast, Pahang River, Pekan and further north; Labong, Endau (Evans). Malacca, Pulau Sabang (Burkill). Perak, Ulu Temengoh; Grit. Tringganu, Bundi (Rostados). Kelantan, Bagan Estate (Macgill); Kwala Lebir. Distrib. Siam. Native name: Tumput. Use: Leaves for making tea.

\section{CeELODEPAS, Hassk.}

Small trees. Leaves alternate oblong, toothed or entire. Flowers in axillary spicate clusters apetalous, females few at the base of the spikes. No disc. Male flowers; calyx globose splitting into 3 or 4 valvate segments. Stamens 4 to 8 ; filaments dilate from base upwards; anthers terminal. Pistillode minute. Female flowers; calyx cupular often enlarged in fruit, lobes 4 to Io 
imbricate. Ovary 3-celled; ovules I in a cell. Styles 2- to multifid, lobes toothed or lacerate, fimbriate. Capsule of 3 bivalved cocci stellate-pubescent. Seeds sub-globose. Species 6, IndoMalayan.

Leaves serrate, some nearly entire.

Branchlets glabrous; leaves 6 to 9 in. long.

Female sepals not glandular.

Female sepals glandular

Branchlets tomentose; leaves serrate, 6 in. long :

Branchlets tomentose; leaves entire, 3 to 4 in. long

(I) C. Wallichianum Benth. Hook. Ic. Pl. i. I288; Hook. fil. F.B.I. v, 4r9. C. subcordatum Gage, Rec. Bot. Surv. Ind. l.c. 239.

Tree, wood very hard, glabrous. Leaves coriaceous, broad oblong-lanceolate serrate or nearly entire, acuminate, base round; nerves 9 pairs; 6 to Io in. long, I.5 to 3 in. wide; petioles $\cdot 2$ in. long. Spikes tomentose short, I in. long. Male flowers minute in distant clusters, $\cdot \mathrm{I}$ in. wide. Sepals ovate. Stamens 6; filaments oblanceolate suddenly contracted at the tip with a small anthers. Pistillode thick, truncate. Female calyx tomentose shortly lobed. Styles thick multifid, lobes papillosely fringed. Hab. Woods, Dindings, Pangkor (Curtis). Penang (Porter); Penara Bukit (Curtis).

I fail to see any difference between C. Wallichianum and Gage's C. subcordatum. The Wallichian specimens (Porter's) have quite entire leaves, and those of Curtis, also from Penang, are more or less serrate, but this occurs also in C. glanduligerum.

(2) C. glanduligerum Pax, Pfanzenreich, iv. I47, p. 270.

Small tree about I5 to $20 \mathrm{ft}$. tall; young parts red-tomentose. Leaves coriaceous oblong cuspidate, bluntly serrate, base round; nerves I2 pairs slender conspicuous on both sides, elevate beneath with conspicuous transverse nervules; 6 to 9 in. long, 3 in. wide ; petioles scurfy, $\cdot 25$ in. long, thick. Spikes orange-colour slender grey-tomentose, 6 in. long. Male flowers few together, very minute, sessile in distant clusters. Sepals 4, ovate, stellate-hairy. Stamens 6; filaments very short triangular much smaller than the anthers. Pistillode columnar conic. Female flowers pedicelled, 5 or 6 together. Stigmas deeply and finely cut up, laciniate. Capsule trilobed orange-colour, 5 in. through, cocci rather woody, tomentose on a stout pedicel 5 in. long; axis stout strongly angled. Seed globose light brown smooth, 25 in. long. Hab. Lowland woods, Singapore, Garden Jungle; Bukit Timah; Kranji (Ridley). Malacca (Griffith). Native name: Santai Paya.

This tree has often the inflorescence modified into a mass of buds and branches 6 in. long and orange coloured.

(3) C. longifolium Hook. fil. F.B.I. v. 420.

Tree 20 to $30 \mathrm{ft}$. tall, stem 2 to 3 in. wide, branchlets tomentose. Leaves linear-lanceolate acuminate sub-serrate, base rounded; 
nerves 13 pairs elevated, as are transverse nervules beneath; 6 in. long, $I \cdot 5$ in. wide; petioles thick tomentose, $\cdot 2$ in. long. Spikes I to 3 in. long, stout tomentose. Male flowers very minute in small distant clusters sessile. Calyx cup-shaped hairy with 3 to 5 short blunt lobes. Stamens 4 or 5 ; filaments connate below in a fleshy cup, free part of filament triangular; anthers rather large. Hab. Dense rocky jungle, Perak, Larut at 500 to Iooo $\mathrm{ft}$. altitude (Kunstler).

(4) C. ferrugineum Hook. fil. F.B.I. v. 420.

Branches, petioles and capsules all rusty tomentose. Leaves linear-oblong, bluntly acuminate, base round entire, when young scurfy-tomentose, adults with a little scurf on the midrib; nerves 8 pairs elevate beneath, as are the transverse nervules; 3 to 4 in. long, I to $\mathrm{I} \cdot 5$ in. wide; petioles $\cdot 25$ in. long. Racemes very short. Male flowers minute. Sepals 5, broad villous. Stamens with very short stout filaments thickened in the middle. Female flowers; calyx very thick globose stellate-tomentose 3-lobed. Stigmas large densely branched. Fruit young globose. Hab. Malacca (Griffith).

\section{CLADOGYNOS, Zipp.}

Shrub, covered except upper side of leaves with white tomentum. Leaves alternate large, strongly toothed. Peduncles axillary solitary or paired. Male flowers very small, sessile in a small globose head. Calyx 2- to 4-lobed. Stamens 3 to 5, usually 4, filaments longer than sepals; anthers dorsi-fixed. Female flowers larger, I- or 2 -pedicelled below the males. Sepals 5 to 7 , lanceolate and foliaceous, enlarging after flowering. Disc of alternating glands. Ovary 3- or 4-celled; ovules solitary. Styles connate at base, 3 or 4 times cleft, papillose. Capsule 3-lobed. Seeds globose. Species I, Cochinchina to Philippines.

(I) C. orientalis Spanoghe Limnaa, xv. 349; Pax, Pfanzenreich, iv. I47, p. 265, Fig. 4I. Adenochlena siamensis Ridl. Journ. Roy. As. Soc. S. Br. 59, p. I8o.

Woolly shrub 3 to $5 \mathrm{ft}$. tall. Leaves alternate lanceolate acuminate, base round sub-peltate, strongly coarsely toothed, glabrous above, stellate-white-tomentose beneath; nerves 5 to 9 pairs; 7 in. long, 4 in. wide; petioles I to 2.5 in. wide, white-woolly. Nale flowers in small heads, one or more on short stout axillary peduncles, ${ }^{\prime} 5$ in. long. Heads ${ }^{\prime} 2$ in. wide. Flowers many, sessile. Sepals ovate acute hairy. Stamens 4, glabrous, filaments longer than sepals; anthers elliptic. Pistillode cylindric, blunt. $H a \bar{b}$. Open country in dense thickets near limestone rocks, Lankawi, Terutau (Curtis). Perlis, Ginting Kabok, Kanga (Ridley). Distrib. Cochinchina, Siam, Malay isles. 
42. ALCHORNEA, Swartz.

Shrubs or trees pubescent. Leaves alternate entire or toothed, stipellate and usually glandular at the base. Flowers in terminal or axillary spikes or racemes simple or panicled apetalous. No disc. Male flowers; calyx globose splitting into 2 to 4 valvate segments. Stamens 6 to 8 or indefinite; filaments free or connate at base. No pistillode. Female flowers; sepals 3 to 6 , imbricate. Ovary 2- or 3-(rarely 4-) celled. Styles linear often very long entire or bifid. Capsule of 2 or 3 bivalved cocci crustaceous. Seeds sub-globose. Species about 50, all tropics, rarest in Asia.

Leaves stipellate; styles filiform.

Hairy on branches and leaves beneath.

Female racemes several, 6 in. long

Female racemes solitary, $1 \cdot 5$ in. long

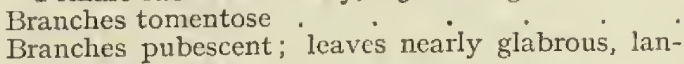
ceolate dentate

Leaves elliptic not stipellate; whole plant glabrous; styles flattened

(I) A. villosa

(2) A. tiliæfolia

(3) A. adenophila

(4) A. rhodophylla

(5) A. javensis

(I) A. villosa Mïll. Arg. in Limnaa, xxxiv.; in DC. Prod. xv. (2), g02; Hook. fil. F.B.I. v. 420.

Bush, pubescent or tomentose all over except the upper side of the leaves. Leaves membranous ovate acuminate serrulate, base round with 2 short subulate stipels; nerves 7 pairs, I or 2 pairs from the base, above midrib and nerves pubescent; 3 to 6 in long, I.5 to 3 in. wide; petioles.$~ I$ in. long in small leaves to $4 \mathrm{in}$. long in large ones. Male racemes slender axillary, 3 in. long, pubescent hairy. Flowers minute in distant clusters. Sepals 2 or 3 . Stamens 8 . Female racemes terminal, 6 in. long, stout, $I$ to 6 in a panicle. Flowers much larger, including the stipes .5 to .75 in. long. Sepals and bracts about I2 lanceolate acuminate, hairy. Ovary glabrous; styles twice as long, 3 linear connate about half-way. Capsule globose, slightly 3-lobed, glandular glabrous, 3 in. through. Seed oblong plano-convex pustular shining brown, - 5 in. long. Hab. Common in woods and thickets. Singapore, Reservoir woods; Bukit Mandai. Johor, Castlewood; Kota Tinggi. Malacca, common (Griffith); Bukit Sabukor; Ayer Panas; Ching. Negri Sembilan, Gunong Berumbun (Cantley). Perak, Temengoh; Thaiping (Wray).

var. glabrata Hook. fil. l.c. Almost completely glabrous, young parts, midrib beneath, and inflorescence only being pubescent. Hab. Penang, foot of the Hill (Curtis). Disirib. Sumatra and Java. Native names: Ramin bukit; Ramin hitam or Bulan; Sumin Jantan. Use: Bast for string.

(2) A. tiliæfolia Müll. Arg. in Linncea, xxxiv. I68; Hook. fil. F.B.I. v. 42 I.

Shrub; branches and young parts pubescent; young leaves tomentose. Leaves membranous ovate serrate or nearly entire, 
base rounded acuminate, glabrous above, hairy on the nerves beneath; nerves 3 from base, midrib (central nerve) with 4 pairs of nerves; stipels 2 at base, ' $I$ in. long, lanceolate; 8 in. long, 4.5 in. wide; petioles 4 in. long, pubescent. Male racemes 2 to 4 in. long, pubescent. Bracts lanceolate subulate. Flowers very small, in clusters of 4 or 5, pubescent, buds globose, bursting irregularly. Female spikes below males, I. 5 in. long. Sepals subulate lanceolate pubescent. Ovary minutely tubercled. Styles free to the base. Capsule 5 to $\cdot 6$ in. long, 3-lobed, puberulous green with purple tubercles, Hab. Pahang, Labong, Endau (Evans). Distrib. India, Siam, Cochinchina.

(3) A. adenophila Pax and Hoffm. Pflanzenreich, l.c. 25 I.

Shrub ?, young branches ashy velvety. Leaves ovate cuspidate acuminate, base blunt or obscurely cordate, glandular-toothed, membranous, nerves from base 3 to 5 , above 5 or 6 , above glabrescent, beneath pilose; 4 to 5.5 in. long, $I .75$ to 3 in. wide; petioles slender tomentose, 5 to 2.5 in. long. Male flowers unknown. Female racemes paniculate, 6 in. long; rachis velvety-pubescent. Sepals usually 6, with large glands alternating. Ovary shortly pubescent warty. Styles shortly connate. Hab. Perak (Scortechini).

(4) A. rhodophylla Pax and Hofm. Pfanzenreich, iv. I47, p. 249. A. discolor Hook. fil. F.B.I. v. 42I (not of Endlicher).

Shrub, about 8 or Io ft. tall; branchlets finely pubescent. Leaves lanceolate or elliptic-lanceolate long-acuminate, base longnarrowed, serrate glabrous purple beneath; nerves 6 to 7 pairs, and I pair from base, transverse nervules parallel ; 4 to 5 in. long, I to I.75 in. wide; petioles $\cdot 2$ in. long; stipels at base of blade lanceolate. Male racemes slender, 2 to 4 in. long, axillary puberulous. Sepals 3, stamens 8. Female raceme terminal. Styles 3, connate half-way. Capsule $\cdot 25$ in. through, glabrous, slightly 3-lobed. Hab. Thin hill-woods; Pahang, Telom (Ridley). Penang Hill (Wallich, Curtis and all collectors); Balik Pulau (Curtis).

(5) A. javensis Müll. Arg. in Linncea, xxxiv. I70; in DC. Prod. 905; Hook. fil. F.B.I. v. 422.

Glabrous shrub. Leaves oblong-lanceolate or oblanceolate narrowed to base, no stipels; nerves Io pairs slender, transverse nervules parallel; 6 to $S$ in. long, 2 to 3 in. wide; petioles none to $\cdot 5$ in. long. Male spikes terminal about $\&$ together slender, 7 in. long; flowers minute in distant clusters. Sepals 2 or 3 , ovate. Stamens 6 or 8 ; filaments connate at base. Female spikes shorter, stouter. Flowers very shortly pedicelled. Sepals 6, broad. Ovary 3-lobed puberulous. Style arms twice as long as ovary. Capsule 3-lobed glabrous. Hab. Woods, Singapore, Serangoon; Changi. Malacca, Ayer Panas (Griffith); Selandor and Chabau (Cantley); Machap Tebong Road (Derry). Distrib. Burma, China, Malay islands. Native names: Julong Jantan; Rabu Kumbang. 


\section{EPIPRINUS, Griff.}

Shrub. Leaves alternate, entire. Flowers in dense thick spike-like pubescent racemes terminal apetalous. Male flowers crowded, pink, with females scattered at base of raceme. Calyx globose, 2- to 4-lobed. Stamens 5 to I5; filaments free; anthers large oblong, dorsi-fixed. Pistillode thick, 3-lobed. Female flowers pedicelled. Sepals 5 or 6 , much enlarged and pink in fruit, alternating with minute naked or biglandular scales. Ovary 3-celled; ovules I in a cell. Styles 3, connate in a long stout column bifid and palmately lobed. Capsule large of 2 or 3 sub-globose bivalved cocci. Seeds sub-globose. Species 2, I in Cochinchina.

(I) E. malayanus Griff. Notula, iv. 487; Müll. Arg. in DC. Prod. xv. (2), Ioz4; Hook. fil. F.B.I. v. 464.

Shrub about 8 or $9 \mathrm{ft}$. tall, young parts scurfy. Leaves coriaceous elliptic or lanceolate, shortly acute acuminate, glabrous, base narrowed; nerves very stout beneath, 5 pairs; 6 to I2 in. long, 3 to $4 \mathrm{in}$. wide; petioles $2 \mathrm{in}$. long; the leaves at the base of the inflorescence are frequently reduced to $2 \mathrm{in}$. long and nearly sessile. Racemes 2 or 3 in. long, very thick. Male flowers - I in. wide, rose pink. Female flowers larger. Fruit yellowish, I.5 in. wide, 75 in. long; sepals lanceolate acuminate, $I \cdot 75$ in. long, .5 in. wide at base, dark pink. Hab. Thick forests. Malacca (Griffith), Kesang; Brisu; Selandor; Bukit Bruang (Derry). Negri Sembilan, Bukit Tumayiang, Bukit Sulu and Bukit Berumbun (Cantley). Selangor, Klang Gates; Semangkok Pass at $2500 \mathrm{ft}$. altitude; Dusun Tua. Perak, Trong (Wray); Larut (Kunstler). Penang, Pass țo Relau (Curtis). Kedah, Yan woods. Distrib. Sumatra. Native names: Balong Hijau; Chendur; Chindra; Jarak hitam; Munot.

\section{CEPHALOMAPPA, Baill.}

Trees, more or less tomentose. Leaves thinly coriaceous alternate. Male flowers apetalous in panicled heads. Female flowers solitary. Male calyx turbinate shortly 3 - to 5-lobed, lobes valvate. Stamens 2 to 5 on a thick common stalk on the calyx tube; filaments free; anthers dorsified. Pistillode columnar. Female flowers; sepals 5 or 6 imbricate. Ovary 3-celled. Styles short, thick connate at base. Stigmas paimate or bifid. Fruit 2- or 3-lobed, covered with short, thick conic-cylindric processes. Species 2, Malay Peninsula and Borneo.

(I) C. penangensis, Ridl. Kew Bulletin, I923, p. 368 .

Tall tree; branchlets velvety-scurfy. Leaves elliptic or obovate cuspidate, base blunt narrowed, edge sparsely toothed, thinly coriaceous; nerves 7 pairs elevate beneath with distant transverse nervules, pubescent scurfy, rest dotted with scurfy spots; 6 to 8 in. long, 3 to 4 in. wide; petioles tomentose strongly thickened 
at the tip, $\cdot 5$ to $I$ in. long. Panicles axillary, $I$ in. long, stellatetomentose. Male heads $\cdot 2$ in. through; peduncles $\cdot 25$ in. long. Stamens 5, free nearly to base. Female flowers . I in. long, woolly; sepals acuminate. Style I ? Capsules 25 in. wide, red-tomentose, processes conic-cylindric. Hab. Hill woods, Penang, West Hill (Curtis).

Curtis notes one specimen as a tall tree, the other as a large shrub. Allied to $C$. Beccariana, Baill., but leaves much larger and toothed and with larger male heads.

\section{CaLlodiscus, Baill.}

Shrubs or small trees with stellate pubescence. Leaves opposite, broad ovate or orbicular. Flowers bracteate in axillary spikes or racemes, apetalous small. Males clustered in bracts. Females solitary. Male sepals 3, valvate. Stamens 20 or more free, surrounding a naked receptacle; anthers oblong. No pistillode. Female flowers; sepals 3, narrow. Ovary 2- to 5-lobed; ovule I in a cell. Styles entire stout. Capsule of 3 velvety or spiny bivalved cocci. Seeds sub-globose. Species 5 or 6 , Indo-Malayan.

Branches, leaves and inflorescence densely stellatetomentose

Upper side of leaves glabrous, branches shortly tomentose

(I) C. montanus

(2) C. subcuneatus

(I) C. montanus Miill. Arg. in DC. Prod. xv. (2), 759; Hook. fil. F.B.I. v. 425 .

Shrub or treelet 18 to $25 \mathrm{ft}$. tall, softly tomentose all over. Leaves ovate-cordate to oblong-lanceolate acuminate, sinuatetoothed, stellate-hairy on both sides; nerves 5 pairs, nervules transverse; 7 to 9 in. long, 2.75 to 6 in. wide; petioles 1.5 to 3 in. long. Racemes short and stout, 3 to 5 in. long. Male flowers sub-sessile in remote clusters 2 or 3 . Sepals 3 , ovate-lanceolate. Stamens about 25; filaments slender hairy. Female flowers on stouter racemes. Capsule depressed trilobed tomentose, 4 in. through. Hab. Woods, Dindings, Lumut. Penang (Porter, Wallich, Kunstler and all collectors). Native name: Glam Chicha.

(2) C. subcuneatus Gage, Rec. Bot. Surv. Ind. l.c. 240.

Tree 30 to $36 \mathrm{ft}$. tall, tomentose. Leaves opposite very unequal, thinly coriaceous, ovate-cordate acuminate, base sub-cuneate or round, edge undulate, above glabrous, beneath pubescent; nerves 5 pairs elevate, as are nervules and reticulations beneath; 5 to ro in. long, 2 to $3.25 \mathrm{in}$. wide; petioles pubescent, I to I.25 in. long. Male flowers in spikes or racemiform spikes $\cdot 5$ to $I^{\cdot} 5 \mathrm{in}$. long, tomentose. Calyx sessile ovoid-tomentose, at length $3^{-}$to 4-lobed. Discs 2, I extra-staminal cup-shaped lining the base of the calyx; the other intra-staminal. Stamens 40 to 60 glabrous. Fruit racemes solitary fulvous tomentose. Capsule trigonous depressed, sub-globose, stellate-tomentose covered with many 
short spines; style terete with 3 fimbriate arms. Seeds globose ovoid. Hab. Woods, Selangor, Dusun tua (Ridley). Perak (Scortechini, Kunstler). Kedal, Gerun near Kedah Peak (Robinson). Langkawi (Curtis).

\section{BLUMEODENDRON, Kurz.}

Trees. Leaves alternate or opposite or whorled coriaceous, spikes and panicles axillary solitary or fascicled. Females shorter than males. Flowers apetalous, in bud globose. Male flowers; calyx ellipsoid, 3- to 4-cleft. Stamens I4 to 35, free, filaments long; anthers globose; connectives broad. Receptacle raised pulvinate glandular-lobed among the filaments. No pistillode. Female flowers; sepals 3 to 5. Disc annular. Ovary 2- or 3celled; styles linear-subulate papillose within, connate at base. Capsule large. Seeds large.

Spikes short fascicled.

Leaves thinly coriaceous elliptic, 7 in. long

Leaves stiffly coriaceous ovate blunt, 8 in. long

Panicles elongate; leaves elliptic cuspidate coriaceous, 4 in. long.

(I) B. concolor Gage, Rec. Bot. Surv. Ind. l.c. 244.

Tree, glabrous. Leaves opposite thinly coriaceous shining green, ovate cuspidate acuminate, base cuneate entire with 2 to 4 minute ovate glands, trinerved with 3 pairs of nerves from the midrib and 2 marginal ones from the base, nervules transverse; 7 in. long, 3.25 in. wide; petioles slender dilate at tip, 3 in. long. Male flowers numerous on racemes $\cdot 25$ in. long with short thick peduncles articulate with the pedicels. Sepals ovate deflexed. Stamens numerous, anther-cells oblong. Female flowers fascicled at the nodes; pedicels 5 in. long from tubercles. Buds globose. Sepals 3, widely ovate. Disc hemispherically turbinate fleshy. Stamens 22 to 25. Hab. Forests. Rare. Dindings, Pangkor (Curtis), female. Lankawi, Gunong Raya (Haniff).

Allied to $B$. Kurzii, but the leaves are much thinner and transverse nervules fewer and the stamens 22 to 25 .

(2) B. Kurzii J. J. Smith, Mededeel, Dept. Landbouw. x. 463. Mallotus Kurzii Hook. fil. F.B.I. v. 427.

Tree 50 to $70 \mathrm{ft}$. tall, stem Io to $15 \mathrm{ft}$. through, glabrous. Leaves stiffly coriaceous, elliptic-ovate, base round, tip shortly blunt cuspidate; nerves prominent, 6 pairs, transverse nervules very many close; 8 in. long, 6 in. wide; petioles $I \cdot 5$ to 2 in. long, thickened at both ends. Male flowers clustered in short cymes over $\cdot 2$ in. long. Calyx globose, 'I in. long, 2- or 3-valved. Receptacle convex covered with tumid glands. Stamens 20 to 30 , filaments rather long; anthers nearly orbicular, connectives broad. Female flowers unknown. Capsule globose, $2-$ to 3 -coccous, $x$ to $\mathrm{I} \cdot 5$ in. wide, brown-glossy, fibrous woody. Seeds purple covered 
with a thick spurious aril. Hab. Perak, Limestone rocks near Gunong Mesah (Kunstler).

(3) B. vernicosum Gage, Rec. Bot. Surv. Ind. l.c. 244. Mallotus vernicosus Hook. fil. F.B.I. v. 443.

Apparently a tree quite glabrous. Leaves alternate, stiffly coriaceous elliptic ovate, bluntly acuminate polished above, drying brown with a yellow edge; nerves 7 pairs; 4 in. long, 2 in. wide; petioles $I$ in. long. Male racemes and panicles solitary or in pairs, axillary. Buds globose long-pedicelled. Sepals 4 . Stamens 30 to 40.

This was sent from the Botanic Gardens, Singapore, in 1882 by Cantley under the name of Kayu Karanji (which is the name of Dialium spp.). There is no clue as to whether it was wild or cultivated, and I have never seen anything more of the plant in the Botanic Gardens or anywhere else.

47. BOTRYOPHORA, Hook. fil.

A large tree. Leaves alternate coriaceous elliptic or oblonglanceolate caudate entire. Male panicles long puberulous terminal with horizontal branches. Flowers in bud globose. Calyx bursting irregularly. Stamens in a globose mass very numerous; anthers peltately attached to a central receptacle; connectives broad, disc-shaped with 2 minute oblong cells pendulous from their margin. Female flowers and fruit unknown. Species I, Perak, Peninsular Siam.

(I) B. Kingii Hook. fil. F.B.I. v. 476 .

Tree 40 to $50 \mathrm{ft}$. tall, stem 3 to I2 in. through; branchlets knotted. Leaves sub-coriaceous, base blunt; nerves elevate beneath, I6 to $I 8$ pairs; 8 to $I 3$ in. long, 3.5 to 3.75 in. wide; petioles thickened at both ends, slender, 3 in. long. Panicles 9 in. long. Flowers $\cdot 25$ in. wide, crimson or (Kunstler) half yellow, half red waxy. Stamens yellow. Hab. Near the coast, in sandy soil, Perak, Larut (Kunstler). Distrib. Tapli (Peninsular Siam).

\section{WETRIA, Baill.}

Tree. Leaves bistipulate, shortly petiolate sub-coriaceous large narrowed to the base. Racemes long axillary many-flowered. Male flowers solitary fascicled, females solitary; all apetalous. Male flowers; calyx 3 to 4-partite. Stamens 25 to 30 , nearly free to base, on a convex receptacle. No pistillode. Female flowers; sepals 5. Ovary 3 -locular. Styles shortly connate elongate linear bifid. Capsule 3-lobed, cocci bivalved. Seeds globose. Species 2, Malayan.

(I) W. trewioides Baill. Etud. gen. Euphorb. 407. Trewia macrophylla Bl. Bijdr. 6I2.

Tree, young parts and inflorescence pubescent, otherwise glabrous. Leaves thinly coriaceous oblanceolate sub-acute, base gradually narrowed, edge glandular serrate; nerves horizontal parallel, about 30 pairs; 6 to 8 in. long, 2 to 3 in. wide; petioles 
thick, $\cdot I$ in. long. Male flowers in a long slender raceme. Tiemale inflorescence axillary slender, racemes occasionally branched with few racemose branches, 7 to 12 in. long, puberulous. Bracts small ovate cuspidate in pairs. Flowers scattered; pedicels 25 in. long, pubescent. Sepals lanceolate acuminate, 05 in. long, ciliate on the edge. Ovary globose densely hairy. Styles 3, plumose deeply bifid. Capsule 5 in. long, cocci thinly woody, epicarp thin brownscurfy. Seed sub-globose shining black, $\cdot 25$ in. long. Hab. Woods by limestone rocks, Pahang, Kota Glanggi (Ridley). Distrib. Java, Sumatra, Borneo.

\section{KUNSTLERODENDRON, Ridl.}

Trees. Leaves large, long-petioled. Racemes or panicles lax with slender branches sub-terminal. Male flowers small numerous clustered. Calyx in bud globose. Sepals 3 or 4. Stamens 20 to 50 , filaments filiform, free to base, not on a receptacle or glandular disc; anther-cells separated by a broad connective. No pistillode. Female flowers and fruit unknown. Species 3, Malaya.

Leaves elliptic-lanceolate narrowed to base ; inflores-

cence panicled .
Leaves ovate cuspidate, base blunt; inflorescence racemed .

(I) K. sublanceolata Ridl. Mallotus ? Kunstleri King, in Hook. fil. F.B.I. v. 443 .

Tree, 40 to $60 \mathrm{ft}$. tall, stem 6 to $\mathrm{I} 2 \mathrm{in}$. through, quite glabrous except the inflorescence. Leaves coriaceous alternate, ellipticlanceolate acute or acuminate, serrate; nerves 15 to 20 pairs, slender prominent, midrib stout; 8 to I2 in. long, 6 in. wide; petioles $I$ to 3 in. long. Male panicles axillary spreading, 6 to Io in. long and as wide; branches slender and stiff finely pubescent. Flowers in distant clusters $\cdot 25$ in. across, 4 - to 6 -flowered. Bracts glumaceous. Sepals 3, glumaceous ovate coriaceous. Stamens 20 to 30 . Female flowers and fruit unknown. Hab. Open hilly jungle. Perak (Scortechini); Goping (Kunstler).

(2) K. cuspidata Ridl.

Tree, glabrous. Leaves ovate abruptly cuspidate (cusp I in. long), base very shortly cuneate; nerves 5 pairs prominent beneath, nervules horizontal transverse; 9 to II in. long, 3.5 to 5 in. wide; petioles 3.5 in. long, geniculate at top. Panicles racemiform, 6 in. long. Branches few, I in. long. Flowers in distant clusters. Bracts ovate cuspidate, pedicels as long. Male flowers; buds .08 in. long, globose. Sepals 4 . Stamens about 50 , filaments slender. Hab. Dindings, Telok Sera (Ridley 79Ix).

50. MELANOLEPIS, Reichenb and Zoll.

A tree. Leaves alternate large broad, palminerved. Flowers in panicles of racemes. Male flowers 3 to 5 in a bract. Females 
solitary in a bract. Male calyx globose splitting into 3 or 5 lobes. No disc. Stamens 200 to 250 free on a convex stellate-hairy receptacle; anthers dorsifixed oblong emarginate at tip, connective appendages sub-globose purple. No pistillode. Female flowers; sepals 5. Disc annular crenate. Ovary 2-(rarely 3-)locular. Styles free divaricate papillose. Capsule 2-(rarely 3-)lobed, splitting into 2 bivalved cocci. Seed sub-globose foveolate, pseudo-aril purple. Species I, Cambodia, Formosa, Malay islands to Melanesia.

(I) M. multiglandulosa Rchb. fil. and Zoll. Linnaa, xxviii. 324. Mallotus moluccanus Mïll. Arg. in Linnaa, xxxiv. I85. Melanolepis moluccana Pax and Hoffm. Pflanzenreich, iv. I47; vii. I42, Fig. 20.

Tree, about $30 \mathrm{ft}$. tall. Leaves thin ovate-cordate coarsely toothed, tip acuminate, above glabrous when adult, beneath with scattered stellate hairs; young leaves, shoots, and inflorescence scurfy and stellate-hairy all over; nerves 5, radiating from the base, the midrib with 3 or 4 pairs of nerves, transverse nervules parallel; 6 to 9 in. long, 6.5 to Io in. wide; petioles glabrous, 6 in. long. Panicles in terminal axils several erect densely tomentose, 6 or 7 in. long. Male flowers 25 in. wide. Female flowers crowded on longer pedicels nodding. Capsule $\cdot 25$ in. long, tomentose $\cdot I_{5}$ in. long. Hab. Forests, Pahang, Kwala Semantan. Selangor, Kwala Lumpur. Perak, Kampong Kota (Wray). Kelantan, Chaning (Ridley). Native name: Jarak Kayu.

\section{MALLOTUS, Lour.}

Small trees or shrubs. Leaves opposite or alternate entire, toothed, or 2-lobed, sometimes peltate, often gland dotted. Flowers small or minute in axillary or terminal simple or panicled spikes or racemes. Petals and disc usually none. Male flowers clustered, females solitary in the bracts. Male flowers; calyx globose or ovoid, 3- to 5-fid. Stamens 20 to 30 or more, crowded on a convex or flat receptacle; filaments free; anthers dorsifixed globose or oblong parallel separated by a wide connective. No pistillode. Female flowers; calyx spathaceous or 3- to 6-lobed. Ovary 2- to 4-celled. Styles free or connate below entire plumose or papillose. Capsule of 2 or 3 , rarely 4 , bivalved cocci, smooth, tubercled or echinate. Seeds ovoid, oblong or globose. Species Ioo, all Asiatic but 2 African.

§i. Echinocroton. Leaves 3-nerved from base usually opposite not peltate. Fruit hairy often spiny.

Leaves glandular-glandulose beneath, orbicular-ovate .

Leaves pubescent beneath, ovate or elliptic:

Leaves scabrid-pilose beneath, very unequal Leaves glabrous. Leaves elliptic cuspidate sub-serrate .

(I) M. tiliæfolius

(2) M. leucocalyx

(3) M. dispar

(4) M. bracteatus 
Leaves elliptic narrowed to base, entire long cuspidate

Leaves lanceolate, entire base round, acuminate

Leaves oblanceolate shortly sub-cordate

Leaves obovate toothed, base cuneate

Leaves ovate caudate-acuminate; bracts red-glandular, nerve axils hairy
(5) M. Wrayi

(6) M. lancifolius

(7) M. brevipetiolatus

(8) M. cuneatus

(9) M. smilaciformis

§ii. Echrsus, Leaves alternate, peltate granulose-glandular beneath. Capsule echinate or woolly; stamens 45 to roo.

Shrubs; racemes long pendent, fruit woolly.

Leaves red-tomentose beneath

Leaves white-tomentose beneath . .

Tree; panicles of slender racemes, fruit echinate.

Leaves shortly white-tomentose beneath .

Leaves not white beneath; racemes 3 in. long

(Io) M. macrostachyu

(II) M. barbatus

(r2) M. cochinchinensis

(13) M. puberulus

\$iii. Stylanthus. Leaves alternate peltate.

Stamens I 7 to 42 ; female calyx spathaceous.

Leaves orbicular-ovate glaucous beneath : (I 4 ) $\boldsymbol{M}$. floribundus

Leaves thin oblong to elliptic, not glaucous. (I 5) M. acuminatus

§iv. Diplochlamys. Leaves alternate or opposite, not glandular above Capsule echinate. Stamens 150 to $25^{\circ}$.

Spikes very short. Capsule I in. through; nerves 7 pairs . . .

Spikes long; capsule 75 in. through; nerves Io to 12 pairs

(I6) M. subpeltatus

(1 7 ) M. Griffithianus

$\S$ v. Philippinexsis. Leaves alternate glandular beneath.

Capsule not spiny; stamens 40 to 50.

Trce, glabrous; male racemes slender
Tree, branches stellate-tomentose; leaves pale beneath; male racemes panicled

Scandent shrub, stellate-tomentose; leaves hairy beneath.

Capsule $\mathrm{I}$ - or 2 -seeded, red-tomentose .

(18) M. leucodermis

(I9) M. philippinensis

(2o) M. repandus

$\S$ vi. AXENFELDIA.

Leaves alternate or if opposite unequal. Capsule spiny. Stamens 20 to 30 .

Leaves alternate.

Leaves sparsely hairy beneath; racemes simple $\dot{0}$ es glabrous beneath; racemes simple

Leaves glabrous beneath; racemes simple
Leaves large softly hairy beneath; racemes panicled

Leaves opposite unequal.

Leaves small coriaceous slightly unequal .

Leaves large, one very much smaller

(2I) M. Porterianus

(22) M. oblongifolius

(23) M. Kingii

(24) M. penangensis

(25) M. anisophyllus

(r) M. tiliæfolius Müll. Arg. in Limnaa, xxxiv. rgo; in $D C$. Prod. xv. (2), 969 .

Bush about 8 to ro $\mathrm{ft}$ tall, yellowish or white-tomentose. Leaves alternate or opposite unequal orbicular or triangularovate acuminate, base rounded truncate or cordate, generally entire, scabrid but glabrous above, white stellate-pubescent beneath, and granular-glandulous, 4 in. long, 3.5 in. wide; nerves 5 pairs; petioles 2 in. long, tomentose. Male racemes 5 in. long, 
tomentose, axillary and terminal. Sepals 3 to 5 lanceolate or elliptic acute pubescent all over. Stamens 80 to Ioo, connectives broad emarginate at top. Female sepals lanceolate-ovate connate at base. Ovary trilocular, densely tubercled and stellate-hairy. Styles connate at base plumose. Capsule 3-lobed hairy and spiny. Seeds globose. Hab. Open country, Johor, Pulau Tiuman (Kloss). Pahang, Pekan (Ridley).

(2) M. leucocalyx Mïll. Arg. in DC. Prod. xv. (2), 270.

Shrub or treelet about $\delta$ to $15 \mathrm{ft}$. tall ; branchlèts densely tomentose. Leaves rather thin opposite elliptic acuminate, margins undulate serrate, narrowed towards the base, blunt, not peltate or cordate, glabrous above, tomentose beneath; nerves 8 or 9 pairs, elevate beneath; 6 to 7 in. long, 3 to 3.25 in. wide; petioles tomentose, $2.5 \mathrm{in}$. long. Racemes sub-terminal velvety-tomentose. Bracts elongate lanceolate acuminate tomentose, $I$ in. long, 2 to 3 in. long. Male flowers; sepals 3 or 4, oblong-lanceolate acute hairy outside and glandular. Stamens 30 to 35 , connectives broad. Female flower; sepals 3 ovate acuminate pubescent. Ovary softly spiny; spines hairy. Styles 3 , connate half-way papillose. Capsule trilobed densely covered with soft hairy spines. Hab. Open country in the north. Kedah, Alor Sta (Ridley). Distrib. Philippines.

(3) M. dispar Miull. Arg. in DC. Prod. xv. (2), 97I; Pax, Pflanzenreich, l.c. 152 .

Shrub or treelet about 8 to $I_{5} \mathrm{ft}$. tall, tomentose. Leaves thin chartaceous lanceolate-elliptic to ovate-elliptic acuminate, narrowed and blunt at base, edge crenate-serrate, above glabrous, beneath hairy on the midrib and 8 pairs of nerves and the nervules; 5 or 6 in. long, 2 to 3 in. wide; petioles tomentose, 75 in. long. Stipules lanceolate acuminate tomentose, -25 in. long. Male racemes slender tomentose, 4 in. long. Flowers small tomentose in remote clusters of 4 or 5 . Bracts lanceolate acuminate, little longer. Sepals 3, oblong. Stamens 35 to 50 on a discoid receptacle. Frmale racemes stouter, 2 to 3 in. long, tomentose. Flowers solitary; bracts lanceolate tomentose, $I_{5}$ in. long. Sepals 3 or 4 , lanceolate acute tomentose. Ovary densely tomentose with dark processes. Styles 3, very shortly connate plumed. Capsule trilobed, $\cdot 4$ in. through, shortly tomentose with a few scattered black subulate processes. Hab. Foot of limestone cliffs, Johor, Pulau Tiuman (Burkill). Selangor, Batu Caves, abundant. Perak, Lenggong (Ridley). Distrib. Java, Sumatra.

This is very near $M$. leucocalyx, but less tomentose, and the fruits are less armed with spines. It is an abundant bush or small tree at the foot of limestone rocks and conspicuous for its young red leaves.

(4) M. bracteatus Hook, fil. F.B.I. v. 436.

Nearly glabrous except the inflorescence, a slight pubescence on the young parts. Leaves thin glabrous elliptic cuspidate- 
acuminate, sinuately subserrate, base slightly narrowed, blunt; nerves 8 pairs; 6 to 7 in. long, 3 in. wide; petioles 25 to 5 in. long, slender. Male racemes slender, stellate-pubescent, 2 to 3 in. long. Flowers very small few in a cluster. Bracts longer than the ovoid buds densely silky tomentose. Sepals 3, ovate. Stamens 30 to 40 ; anther-cells globose separated by a broad connective. Hab. Perak (Scortechini).

I have only seen a very poor specimen, but in its nearly glabrous habit, shape of leaves, and stamens number and form, it seems quite distinct from M. leucocalyx, Müll. Arg., to which Pax refers it.

(5) M. Wrayi King, in Hook. fil. F.B.I. v. 433 .

Tree 60 to $80 \mathrm{ft}$. tall, stem Io to $I_{5} \mathrm{in}$. through, quite glabrous. Leaves opposite elliptic or oblong-lanceolate, long cuspidatecaudate, base acute biglandular; nerves 6 pairs slender elevate beneath, nervules conspicuous transverse; 6 to 7 in. long, 2 to 2.25 in. wide, cusp I. 5 in. long; petioles slender, 5 in. long, thickened at the top. Male flowers unknown. Female racemes axillary, $\mathrm{x} \cdot 5$ in. long, hoary pubescent. Capsule trilobed appressed tomentose with short, stiff spines I in. across, bluish green. Hab. Mountain forests at I000 to $3000 \mathrm{ft}$. altitude, Perak, Larut (Kunstler).

(6) M. lancifolius Hook. fil. F.B.I. v. 434.

Tree about $20 \mathrm{ft}$. tall, stem slender, glabrous except buds and racemes. Leaves thinly coriaceous, lanceolate acuminate, base rounded or narrowed; nerves 5 pairs, elevate beneath; 4 to 8 in. long, $I \cdot 5$ to 2.5 in. wide; petioles $I^{\prime} 5$ to 2 in. long, slender dilate at both ends. Racemes very slender axillary, $I$ in. long. Male flowers in small clusters below the females. Sepals ovate. Stamens 50 to 60 . Female flowers, styles very short. Capsule 3 -lobed, top depressed, $\cdot 5$ in. wide, glandular with a few slender black spines. Hab. Hill forests, Penang Hill (Maingay); Moniot's Road (Curtis). Native names: Ludai jantan; Medang Jarak.

(7) M. brevipetiolatus Gage, Rec. Bot. Surv. Ind. l.c. 242.

Shrub I5 ft. tall. Leaves opposite, slightly unequal oblanceolate shortly cuspidate-acuminate, base narrowed rounded shortly sub-cordate, edge entire or shortly undulate with two minute ovate glands at the base near the midrib, thinly coriaceous, glabrous; nerves 8 to I4 pairs; $2 \cdot I$ to 7 in. long, 75 to $2 \cdot 3$ in. wide; petioles -I in. long. Male panicles slender racemiform many-flowered, I7 in. long, glandular; flowers in distant heads of 9 to I2 flowers. Bracts broadly ovate sub-acute. Pedicels.$I$ in. long or less. Calyx ovoid glabrous, 3-lobed, lobes ovate. Stamens 20 to 22. Female panicles not seen. Fruit racemes 2.75 to 4 in. Iong. Capsules shortly pedicelled, glandular, with a few short wart-like processes $\cdot 25$ in, long. Seeds sub-globose. Hab. Perak (Kunstler). Perlis, Bukit Lagi near Kanga (Ridley).

Near $M$. lancifolius, but the leaf penni-nerved. 
(8) M. cuneatus Ridl. Journ. Roy. As. Soc. S. Br. 59, p. I8r.

Branches red-brown flattened and dilated upwards scabrid. Leaves opposite unequal obovate or sub-rhomboid acuminate, coarsely toothed, base cuneate, glabrous thin-textured; nerves 2, slender from base, above 4 pairs from the midrib pubescent; transverse nervules numerous conspicuous parallel, large leaf 7 in. long, 4 in. wide, smaller 4 in. long, 2 in. wide. Racemes axillary very slender. Males about 5 in. long, pubescent. Flowers 08 in. wide, 3 or 4 together. Bracts ovate acuminate small. Sepals 3, ovatehairy. Stamens numerous. Female spikes 3 in. long, pubescent. Ovary grey-hairy; stigmas plumose red recurved on a shot style. Capsule trilobed, $\cdot 25$ in. wide, green hairy with stellate hair tufts, and short black processes. Seeds sub-globose, blackish brown. $H a b$. Limestone hills, Perlis, Bukit Lagi near Kanga (Ridley).

(9) M. smilaciformis Gage, Rec. Bot. Surv. Ind. l.c. 242.

Shrub. Leaves opposite, membranous or thinly coriaccous ovate caudate acuminate, base cuneate, edge entire or undulate, minutely glandular dentate, 2 minute glands at base; nerves slender, 3 to 5 pairs fulvous-hairy in axils; 3.6 to 9 in. long, $x \cdot 25$ to 4.4 in. wide; petioles minutely puberulous, $I I$ to $I \cdot 6$ in. long. Male racemes slender, $2 \cdot 35$ in. long, puberulous with red glands; flowers 3 to 4 in a bract pedicelled. Bracts triangular puberulous red-glandular. Sepals 3, ovate serrate pubescent red glandular. Stamens 33. Female racemes as in male, but bracts bigger and I-flowered. Sepals 6, linear-oblong or lanceolate acuminate, stellate puberulous. Ovary trigonous depressed puberulous and red-glandular. Stigmas 3, linear-oblong plumose papillose. Capsule $\cdot 2$ in. long, glabrous, more or less granular, red-glandular with a few warts. Seeds sub-globose. Hab. Perak, "Lalema" (Selama ?) (Kunstler).

Near $M$, cunealus, but distinct in the ovate leaf and red glands.

(Io) M. macrostachyus Miill. Arg. in DC. Prod. xv. (2), 963; Hook. fl. F.B.I. v. 429.

Large shrub or treelet io to $\mathrm{I}_{5} \mathrm{ft}$. tall, spreading. Leaves ovate denticulate acuminate or occasionally nearly trilobed, base round peltate, just within the edge, glabrous above, red (when young) to whitish tomentose beneath; nerves 3 from base with strong lateral nerves, 7 from outer side of outer nerves, 5 pairs from midrib; 6 to II in. long and as wide; petioles 3 to 9 in. long. Panicles lax I2 to I8 in. long, tomentose. Male flowers small sessile in small clusters, tomentose. Stamens very numerous. Female racemes solitary unbranched. Bracts ovate acute, rather large. Flowers sub-cylindric, yellow, ${ }^{-}{ }_{5}$ in. long, tomentose. Styles short plumose. Capsule globose densely brown-tomentose and spiny, 5 in. through. Hab. Common in thickets and borders of woods, Singapore, Bukit Timah Road. Johor, Batu Pahat. 
Malacca, Bukit Sadanen and Alor Gajah (Derry). Pahang, Temerloh; Kwala Tembeling; Telom. Selangor, Klang Gates; Sungei Buloh. Perak, Ulu Temengoh; Thaiping Hills; Tanjong Malim; Goping (Kunstler). Penang Hill (Fox). Lankawi, Kwah (Curtis). Tringganu, Bundi (Rostados). Kelantan, river banks, Kelantan River. Native names: Poko Yapoh (Tringganu); Balik Kuning. Distrib. Siam, Java, Sumatra, Borneo.

The whole plant except the upper side of the leaves is thinly but densely stellate hairy; in young leaves the stellate hairs are red, as they are on the nerves of adult leaves. The other stellate hairs are whitish. The black spines on the capsule are often concealed by the thick mass of stellate tomentum.

(II) M. barbatus Miill. Arg. in Linnaa, xxxiv. I84; in DC. Prod. xv. (2), 957; Hook. fil. F.B.I. v. 428.

A large spreading bush about 8 to $20 \mathrm{ft}$. tall. Branches, petioles, racemes, whole of young leaves and under side of adults covered with flocculent, woolly, stellate tomentum. Leaves soft alternate, peltate, trilobed, base round, lobes acute, 8 or 9 in. long, 7 in. wide; nerves radiating from the top of the petiole $I$ in. from the leaf edge, about II elevate beneath with transverse nervules conspicuous; petioles thick woolly, about 4 in. long. Racemes 6 to Io in. long, very woolly. Male flowers at base on short side branches, 5 in. long. Calyx $\cdot 2$ in. wide, lobes oblong acute, glabrous inside. Stamens shorter, very many. Female flowers entirely tomentose. Calyx 4-lobed; stigmas 3, short, broad plumose. Capsule globose, not trilobed, densely yellow-brown-tomentose, .5 in. through. Seeds oblong, black. Hab. Woods, Perak, Batu Gajah; Thaiping (Kunstler, Scortechini); Kwala Kenering. Province Wellesley, Permatang Bertam; Kuban Ulu (Curtis). Penang (Wallich). Kedah, Alor Sta. Distrib. Tenasserim, Java.

(I2) M. cochinchinensis Lour. Fl. Cochinchine, 635; Hook.

fil. F.B.I. v. 430 .

Small tree about $30 \mathrm{ft}$. tall with slender branches reddish scurfy.

Leaves thin ovate slightly peltate, or rhomboid or trifid acuminate; nerves about 5 pairs, lowest pair from the base; above glabrous dull green, beneath nearly white with a fine close tomentum, 3 to 4.5 in. long, 2 to 3 in. wide; petioles I to 4 in. long, tomentose. Panicles tomentose, 7 to 8 in. long, with many long slender branches. Male flowers $\cdot I$ in. wide, white. Sepals ovate tomentose outside. Stamens numerous shorter. Female calyx 3 - or 4-lobed. Capsule tricoccous, tomentose with a number of horn-like processes. Seed black. Hab. Secondary jungle and woods, very common. Singapore, Tanglin. Johor. Malacca (Cuming, Maingay, etc.). Pahang, Leban Chondong, Rumpin River (Evans). Selangor, Rantau Panjang and Rawang (Kloss). Perak, Gunong Bintang (Kunstler). Penang Hill (Curtis, Wallich). Distrib. Burma, Malay isles, Cambodia, China. Native name: Balik Angin.

FI.M.P., 3 . 
(I3) M. puberulus Hook. fil. F.B.I. v. 435.

Young shoots fulvous tomentose, branches puberulous. Leaves membranous elliptic caudate-acuminate, sinuate-toothed, base narrowed deeply cordate; glabrous except the tomentose midrib and nerves beneath; nerves 7 to 9 pairs; 5 in. long, 2.I in. wide; petioles 2 to 2.5 in. long, pubescent. Male racemes slender pubescent, 3 in. long; flowers in clusters of Io to 20. Sepals 3, lanceolate sparsely stellate-hairy and glandular. Stamens 60 to 70 . Hab. Perak (Scortechini).

The only specimen seen is poor.

(I4) M. floribundus Müll. Arg. in Linncea, xxxiv. I87; in DC. Prod. xv. (2), 962; Hook. fil. F.B.I. v. 432; Pax, Pfanzenreich, l.c. I73, Fig. $26 \mathrm{~A}$.

Small tree $40 \mathrm{ft}$. tall or less. Leaves orbicular peltate glaucous beneath cuspidate acuminate; nerves 5 , radiating from end of the petiole; 4.5 to $6 \mathrm{in}$. long and as wide; petioles 3 to $4 \mathrm{in}$. long. Male racemes 3 to $6 \mathrm{in}$. long; flowers crowded, 'I 2 in. wide. Calyx spathaceous. Stamens 40 to 50 puberulous. Female racemes 4 to 6 in. long; flowers distant. Ovary covered with whitetomentose spines. Style-arms very long plumose united at base. Capsule trilobed, $\cdot 75$ in. through, pubescent with long slender flexuous subulate processes. Hab. Edges of forests and woods. Johor, Kota Tinggi. Malacca (Griffith); Bukit Panchur (Derry); Batu Tiga (Holmberg). Pahang, Pekan; Sungei Chenei (Fox). Perak, Temengoh; Goping (Kunstler); Changkat Serdang (Wray). Kedah, Sembing, Kedah Peak (Haniff). Setul, Bukit Rajah Wang. Distrib. Tenasserim, Siam, Cochinchina, Malay islands to Philippines. Native name: Sekubing Ayer.

(I5) M. acuminatus Müll. Arg. in Linnaa, xxxiv. I87; in DC. Prod. xv. (2), 966; Hook, fil. F.B.I. v. 43I.

Tree about $50 \mathrm{ft}$. tall; branchlets scurfy. Leaves thin elliptic entire or shortly toothed, cuspidate peltate glabrous above; nerves and midrib scurfy pubescent beneath, nerves about 7 pairs slender; 6 to $8 \mathrm{in}$. long, 2.5 to 4 in. wide; petioles $\mathrm{I} \cdot 5$ to $2 \mathrm{in}$. long, scurfypubescent or tomentose. Male racemes slender tomentose in terminal axils several on a shoot, 4 to 7 in. long; flower buds conic, glabrous, shortly pedicelled in distant clusters. Sepals 4 , ovate. Stamens very many; filaments slender longer than petals. Female racemes about 6 in. long. Calyx obliquely urceolate. Style stout, $\cdot 2$ in. long; stigmas 2 , short recurved. Capsule trilobed pubescent covered with short spines. Hab. Perak, Goping (Kunstler); Kwala Dipang. Distrib. Tenasserim, Sumatra.

(I6) M. subpeltatus Mïll. Arg. in Linncea, xxxiv. 189 ; in DC. Prod. xv. (2), 968; Hook. fil. l.c. 433.

Small tree nearly glabrous, 30 to $40 \mathrm{ft}$. tall, stem Io to 15 in. through. Leaves thinly coriaceous oblong long-cuspidate, base 
round, very shortly or not peltate, nerves 7 pairs elevate at base; 4 to 6 in. long, 2 to 2.5 in. wide; petioles I. 75 to 3 in. long, slender. Male flowers in sessile fascicles on the branches, very small, globose. Sepals densely pubescent. Stamens very numerous. Female flowers sub-sessile solitary on the branches. Calyx 5- to 6-lobed, hairy. Ovary covered with hairy spines. Capsule obscurely trilobed, I in. through, top flattened, spines subulate acute, numerous slender, 25 in. long. Hab. Woods, Malacca (Griffith); Chabau (Cantley). Pahang, Tahan River and Pahang River. Selangor, Sungei Buloh; Batu Caves. Perak, Goping (Kunstler). Penang (Wallich); Hill (Curtis). Distrib. Java, Sumatra. Native names: Jarak Gajah; Jarak hutan.

(I7) M. Griffithianus Hook. fil. F.B.I. v. 433. Byttneria uncinata Masters, in Hook. fil. F.B.I. i. 377.

Shrub 6 to $8 \mathrm{ft}$. tall, glabrous except inflorescence. Leaves opposite and alternate thinly coriaceous elliptic or oblong cuspidate acuminate entire, base very shortly narrowed, blunt; nerves Io to I2 pairs parallel elevate beneath; 5 to 7 in. long, 2 to 4 in. wide; petioles 2.25 in. long, slender thickened at both ends. Inflorescence leaf-opposed. Males of panicled spikes viscid hairy, I.5 to 4 in. long. Flowers 25 in. wide, hairy. Sepals 3 , receptacle conic. Stamens numerous. Female flowers in simple spikes 4 in. long. Sepals narrow-lanceolate hairy, 6 to 9 . Ovary glandular hairy. Styles 3, rather long subulate hairy. Capsule globose, .75 in. through, densely covered with bristles and with slender stiff glandular spines covered with bristles. Hab. Woods, Pahang, Tahan River; Kwala Lipis (Machado). Malacca (Griffith); Ayer Panas and Sungei Bharu. Selangor, Kwala Lumpur (Curtis). Dindings, Telok Sera. Perak, Goping (Kunstler); Tapah (Wray). Lankawi (Curtis). Native names: Pulut Pulut Bukit; Marpoh; Setampin.

(I8) M. leucodermis Hook. fll. F.B.I. v. 44I.

Tree? Branches stout with white bark. Leaves alternate entire, coriaceous glabrous elliptic or obovate, shortly acuminate, base blunt; nerves 4 or 5 pairs ascending, elevate beneath; 4 to 8 in. long, $2 \cdot 25$ to 5 in. wide; petioles $I$ to 3 in. long. Racemes axillary and from the bare branches stellate-pubescent. Male racemes 4 to 6 in. long, slender. Flowers nearly 25 in. wide, clustered on slender pedicels. Sepals 4 , glabrous. Stamens 40 to 50; anther-cells oblong almost quite connate, connectives usually quite narrow. Capsule on stout pedicels, I to I.25 in. long, I in. through; cocci woody, smooth, no spines, glabrous. Seeds .25 in. through, brown sub-globose. Hab. Malacca (Maingay).

(I9) M. philippinensis Miill. Arg. in Limnea, xxxiv. I96; in DC. Prod. xv. (2), 98x; Hook. fil. F.B.I. v. 442.

Tree 30 to $40 \mathrm{ft}$. tall, stem 6 to $8 \mathrm{in}$. through. Branchlets, young parts and inflorescence rusty pubescent. Leaves alternate thinly coriaceous ovate or obovate-oblong or ovate-lanceolate 
acuminate, base round entire or sinuate toothed, above glabrous, beneath puberulous, sub-glaucous covered with minute scarlet glands; nerves 2 conspicuous basal ones, and three pairs from the midrib with many transverse nervules; 3 to 5 in. long; 2 to 3 in. wide; petioles $I$ to 2.5 in. long. Male spikes panicled, terminal and in upper axils, rusty brown, $3 \mathrm{in}$. wide; flowers clustered. Sepals 3 or 4 oblong-acute, stellate-pubescent outside. Stamens I8 to 32 . Female spikes as male. Sepals 3 to 5 , ovate blunt or acute. Ovary covered with scarlet glands. Styles 3 plumed. Capsule pedicelled globose sub-trigonous, densely covered with scarlet glands. Seeds semi-globose. Hab. Dense jungle. Perak, base of Gunong Bubu (Kunstler). Kedah, Gunong Geriang (Ridley). Distrib. India, China, Java, New Guinea, Australia.

(20) M. repandus Müll. Arg. in Linncea, xxxiv. I97; in DC. Prod. xv. (2), 981; Hook. fil. F.B.I. v. 442.

Climber 20 to $80 \mathrm{ft}$. long, stem 2 to 3 in. through, fulvous scurfy and stellate pubescent. Leaves alternate chartaceous rhombic-ovate acuminate, base narrowed shortly undulate denticulate; nerves 3 , the median one (midrib) with 3 pairs of nerves above; above glabrous, beneath stellate-tomentose, $2 \cdot 5$ to 3 in. long, 2 to $2 \cdot 5$ in. wide; petioles scurfy, 75 in. long. Male panicles densely yellow-tomentose, 4 in. long, lower branches 2 in. long, densely floriferous; pedicels . I in. long. Sepals ovate brownish yellow-tomentose outside. Stamens 50 to 60 , connectives small, light grey. Female racemes chiefly axillary, 4 in. long. Sepals as in male. Ovary 2-celled; no style; stigmas plumed. Capsule $\cdot 5$ in. wide when 2 -celled, often globose I-celled, velvety orange-brown. Seed globose black. Hab. Open jungle, Selangor, Batu Caves. Perak, Gunong Bubu and Chanderiang (Kunstler). Penang. Perlis, Bukit Lagi. Kanga (Ridley). Distrib. India, China, Malay isles to Australia. Native name: Akar Chiarek putih.

(2I) M. Porterianus Müll. Arg. in Linncea, xxxiv. I85; in DC. Prod. xv. (2), 960.

Small tree I5 to $25 \mathrm{ft}$. tall, pubescent. Leaves thin oblonglanceolate cuspidate acuminate sinuate crenate or entire, very slightly peltate; nerves 6 or 7 pairs, very slender; all glabrous except midrib on back pubescent; 4.5 to 6 in. long, 2 in. wide; petioles slender densely pubescent, I in. long. Male racemes very slender, 2 to 3 in. long. Flowers minute shortly pedicelled clustered. Calyx nearly glabrous. Stamens 30. Female racemes much stouter, 4 to 6 in. long. Flowers singly remote. Calyx small, shorter than ovary. Ovary hairy. Style twice as long as the papillose stigmas. Capsule trilobed deeply glabrous with a few short processes, 3 in. through. Hab. Woods and thickets, common. Johor, Sungei Tebrau; Batu Pahat. Malacca, Batu Tiga (Derry). Negri Sembilan, Tampin (Burkill); Bukit Danan (Cantley). Selangor; Batu Caves; Semangkok Pass; Ginting 
Bidai; Bukit Kutu. Perak, Lenggong; Temengoh. Penang (Porter); Hill; Ayer hitam (Curtis). Distrib. Koh Samui; Sumatra. Native names: Markeh; Pulut-Pulut Hutan.

(22) M. oblongifolius Mïll. Arg. in Linnea, xxxiv. I92; in DC. Prod. xv. (2), 973; var. Helferi Mïll. Arg. in Linnea, xxxiv. I9o; in DC. Prod. xv. (2), 968; Hook. fil. F.B.I. v. 43I.

Branches slender sparsely stellate-hairy. Leaves glabrous or nearly so, thin, linear-oblong or elliptic-oblong, caudate-acuminate, sinuate toothed, base round minutely peltate; nerves slender, 7 or 8 pairs; 4 to 4.25 in. long, 2 in. wide; petioles slender, $I \cdot 5$ in. long. Male racemes slender. Flowers minute; pedicels slender. Sepals lanceolate glabrous. Stamens about 20. Female racemes 3 in. long. Flowers distant singly. Calyx spathaceous oblique. Ovary pubescent; style stout, longer than the papillose recurved stigmas. Hab. Perak, Lenggong. Perlis at Tebing Tinggi, female only (Ridley). Setul (Ridley). Distrib. Tenasserim. Other varieties, Siam and Malay islands.

(23) M. Kingii Hook. fil. F. B.I. v. 439.

Tree 40 to $50 \mathrm{ft}$. tall, stem Io to I5 in. through; branchlets, petioles, leaves beneath and inflorescence softly white tomentose and hairy. Leaves alternate elliptic-oblong, caudate acuminate, entire, base slightly narrowed; nerves I2 to 16 pairs elevate, transverse nervules conspicuous; 9 in. long, 3 in. wide; petioles I.5 in. long, swollen at both ends. Stipules oblong-lanceolate. Male panicles of racemes 6 to $8 \mathrm{in}$. long. Peduncles I in. long. Flowers $\cdot 25$ in. wide. Sepals 3, tomentose. Stamens very numerous, anther-cells separated by a broad connective. Female flowers and fruit unknown. Hab. Dense rocky jungle, Perak, Gunong Bubu (Kunstler).

(24) M. penangensis Mïll. Arg. in Linnaa, xxxiv. I86; in DC. Prod. xv. (2), 961; Hook. fil. F.B.I. v. 440.

Tree, glabrous. Leaves opposite coriaceous oblong-lanceolate, shortly blunt acuminate, entire, shining, base blunt or acute; nerves 6 to Io pairs; 4 to 6 in. long, I. 5 to 2.5 in. wide; petioles .25 to $I \cdot 25$ in. long. Male racemes I to 2 in. long, stout, buds puberulous. Stamens about 50, connectives broad glandular. Female racemes stout, rather longer with stiff bristle-like hairs on the rachis. Styles free slender, hairy, long. Ovary densely spiny. Capsule trilobed, $\cdot 3$ in. wide, top flattened covered with short sharp spines and white, bristly hairs. Hab. Forests, Singapore, Bajau; Toas. Perak (Scortechini). Penang (Porter); Muka Head (Curtis); Richmond Pool; Moniot's Road (Ridley).

var. grandifolia Ridl. Leaves stiffly coriaceous, 9 in. long, 3.5 in. wide. Hab. Singapore, Sungei Morai (Ridley). Native name: Pulut-Pulut Poko.

(25) M. anisophyllus Hook. fil. F.B.I. v. 436.

Shrub nearly glabrous. Leaves thin membranous, glabrous 
except for some scattered pale hairs appressed to the midrib, sessile or nearly so in very unequal pairs, large leaf elliptic-lanceolate or oblanceolate acuminate, edge undulate, narrowed to the base; nerves about I4 pairs slender, transverse nervules parallel conspicuous beneath; 6 to 9 in. long, 2 to 3 in. wide; small leaves ovate, base round, I to $I \cdot 25$ in. long, I in. wide. Male racemes very slender, 5 to $I$ in. long. Flowers oll slender pedicels $\cdot 5$ in. wide. Bracts minute ovate. Sepals lanceolate acuminate glabrous. Stamens 15 to 20 , connective broad carunculate. Female flowers few on very short racemes. Sepals pubescent. Ovary covered with hairy spines. No style. Stigma very long, feathery. Capsule trilobed, $\cdot 25$ in. wide, puberulous with very short black processes scattered all over it. Hab. Forests, rare. Malacca (Maingay). Pahang, Kwala Tembeling (Ridley).

52. COCCOCERAS, Miq.

Trees. Leaves alternate entire or toothed. Flowers in axillary and terminal racemes, apetalous. Males clustered sub-sessile. Females pedicelled. Male flower; calyx globose splitting into 3 to 6 sepals. Stamens $I_{5}$ to 20 , free on a convex receptacle. No pistillode nor disc. Female flowers; sepals 5, lanceolate imbricate. Ovary 3-celled; ovule I in a cell. Styles spreading hispid. Capsule with the angles produced horizontally or horned, at length 3-valved. Seeds sub-globose. Species 8, Malayan, I Tenasserim.

(r) C. muticum Mïll. Arg. in Flora, I864, p. 470; in DC. Prod. xv. (2), 950; Hook. fll. F.B.I. v. 424.

Glabrous tree. Leaves thinly coriaceous drying grey elliptic or cuneate-oblong shortly blunt acuminate, base narrowed blunt; nerves 5 pairs, one pair from the base; 6 to 7 in. long, 3 in. wide; petioles $2 \cdot 75$ in. long. Flowers unknown. Fruiting raceme $I^{\cdot} 5$ in. long, pedicels $\cdot 25$ in. long. Fruit (unripe) I in. long, lobes compressed acutely keeled broader than long, top round or truncate with a very short style. Sepals 6 .

var. pedicellatum. Fruiting racemes I2 in. long; pedicels I in. long. Hab. Malacca, Alor Gajah (Griffith).

Only known from Griffith's incomplete specimens.

\section{PTYCHOPYXIS Miq.}

Trees, small to medium-size, tomentose or glabrous. Leaves coriaceous entire. Flowers on axillary racemes or panicles. Males; sepals $4^{-}$or 5-valvate. No disc. Stamens very numerous in a globose head on a receptacle, filaments filiform; anthers oblong, flat, cells 4, two upper oblong, two lower much smaller, connective prolonged into an acute point. Pistillode 0 . Female flowers; sepals 6, lanceolate. Ovary 3-celled, cells I-ovuled. Style villous 
tomentose. Style-arms 3, short recurved. Fruit often large ovoid or pyriform, tomentose woody. Species 5, Malay Peninsula and Sumatra.

Leaves oblanceolate; nerves depressed above, reticulations prominent beneath; fruit large wrinkled

(I) P. costata

Leaves oblanceolate-oblong, smooth above; reticuculate beneath; fruit with long processes .

Leaves smooth obovate large, not reticulate; fruit

wrinkled
Leaves smooth narrow lanceolate; fruit small smooth .

(2) P. caput-medusæ

(3) P. Kingii

(4) P. angustifolia

(I) P. costata Miq. Fl. Ind. Bat. Suppl. 402; Hook. Ic. Pl. t. I703; Hook. fil. F.B.I. v. 455 .

Small tree about $40 \mathrm{ft}$. tall, stem I 2 to I 8 in. through, branchlets tomentose. Leaves crowded at ends of branches oblanceolate acuminate, glabrous above except the tomentose midrib, closely hairy on the midrib and more sparsely on the nerves, I7 pairs, elevate beneath, transverse nervules conspicuous beneath; 9 in. long, 2 in. wide; petioles thick, $\cdot 25$ in. long, tomentose. Male flowers densely tomentose terminal panicles, 3 in. long, about 8 together. Flowers numerous shortly pedicelled, buds globose brown tomentose. Bracts linear-oblong, longer than pedicels. Sepals white inside elliptic or oblong. Stamens numerous shorter. Female flowers on separate trees in dense clusters on the stem, .5 in. through, tomentose. Bracts as in males. Sepals 25 in. long. Fruit ovoid beaked with the enlarged style, pale green densely tomentose (tomentum bright brown when dry) transversely wrinkled, $\mathrm{I} \cdot 5 \mathrm{in}$. long and wide. Hab. Woods and forests up to $2500 \mathrm{ft}$. altitude. Singapore, Garden Jungle; Chan Chu Kang; Bukit Mandai. Malacca (Griffith); Bukit Bruang (Holmberg); Sungei Hudang. Perak, Maxwell's Hill, Thaiping Hills; Larut (Kunstler). Distrib. Sumatra. Native names: Kaliah Toah; Medarah.

(2) P. caput-medusæ Ridl. Mallotus ? caput-medusæ Hook. fil. F.B.I. v. 443 .

Tree So to Ioo ft. tall, stem 3 to 4 in. through. Leaves coriaceous oblanceolate to oblong, tip round, base narrowed blunt, above glabrous, beneath shortly hairy; nerves elevate, about I2 pairs, transverse nervules numerous elevate beneath; 6 to $9 \mathrm{in}$. long, 3 to $3.5 \mathrm{in}$. wide; petioles stout tomentose, 5 to $\mathrm{I}$ in. long. Male flowers unknown. Female flowers in dense woolly racemes 1.5 in. long on the branches; pedicels short and thick. Sepals 5 to 7 , ovate lanceolate woolly. Ovary ovoid woolly on an annular disc. Style arms stout recurved 3. Capsule globose, 2-celled, I.5 in. through, thickly covered with tomentose processes, thick at the base and narrowing upwards, -25 in. long. Seeds oblong, smooth, back rounded, 75 in, long. Hab. Forests. 
Malacca (Griffith, Maingay); Bukit Sadanen (Derry); Panchur. Perak near Gunong Pondok (Kunstler). Native name: Medang Jurnus.

(3) P. Kingii Ridl.

Tree 40 to $50 \mathrm{ft}$. tall, stem Io to I5 in. through. Leaves coriaceous obovate dark green, glabrous above, base blunt, tip round beneath slightly pubescent on the midrib; nerves 9 pairs, elevate beneath; Io in. long, 6 in. wide; petioles puberulous, I.5 to 2 in. long, dilate at top. Fruiting racemes on the branchlets 2 in. long. Fruit pear-shaped, pale yellow to orange-yellow puberulous, pericarp woody, 25 in. thick, whole fruit 3 in. long, 2 in. through. Hab. Mountain forests at 500 to $3000 \mathrm{ft}$. altitude. Perak, Larut (Kunstler).

(4) P. angustifolia Gage, MSS.

Tree 60 to $80 \mathrm{ft}$. tall, stem 2 to $3 \mathrm{ft}$. through, glabrous except inflorescence. Leaves coriaceous lanceolate shortly acute-acuminate narrowed to the base; nerves Io pairs, elevate beneath; 8 to 9 in. long, 2.5 to 3 in. wide; petioles I in. long, slender, geniculate at the tip. Male racemes slender several together axillary pubescent, 3 to 4 in. long. Flowers small in distant fascicles. Pedicels - I in. long. Sepals 3, ovate silky. Stamens 70 on a large hemispherical receptacle, glabrous. Fruit pear-shaped, I.25 in. long, .75 to $I$ in. through, light green, longitudinally wrinkled, thinly velvety on a stout raceme $I \cdot 5$ in. long.

\section{CLEIDION, Bl.}

Shrubs or trees. Leaves alternate. Male flowers in racemes. Calyx globose spreading into 3 or 4 segments. Stamens over 20 in a globose mass on a conical receptacle; filaments free; anthers dorsifixed 4-celled, or the 2 cells transversely didymous on the edge of a broad connective. No pistillode. Female flowers I or 2 on a long axillary peduncle. Sepals 3 to 5 , imbricate. Ovary 2- to 3-celled, cells I-ovuled. Styles 2- to 3-fid, arms long filiform. Capsule large of $I$ to 3 bivalved cocci. Seeds globose. Species $I 6$, tropics generally.

(I) C. javanicum Bl. Bijdr. 613; Hook. fil. F.B.I. v. 444; Pax, Pfanzenreich, l.c. 290, Fig. 47.

Low shrub to medium-sized tree, glabrous. Leaves elliptic cuspidate-acuminate, base cuneate, edge dentate or crenulate or entire; nerves 5 to 7 pairs; 4.5 to $7 \cdot 5$ in. long, $2 \cdot 1$ to 3 in. wide; petioles 5 to $1 \cdot 5$ in. long, slender. Male racemes slender, 6 in. long, pubescent. Flowers pedicelled in small clusters. Anthers 4-celled in a compact head. Female flowers I or 2 on axillary peduncle. Fruit bilobed, I to $\mathrm{I}_{5} 5$ in. through. Styles long; peduncles 2 in. long. Hab. Rocky forests, Selangor, Batu Caves. Penang (Wallich). Setul, Bukit Rajah Wang (Ridley). Distrib. Indo-Malaya. 


\section{MACARANGA, Thouars}

Trees of no great size or shrubs. Leaves alternate usually large and often peltate entire or lobed. Flowers in axillary racemes or branched; panicles apetalous. Male flowers many in clusters, minute. Calyx globose or obovoid; sepals 3 or 4 valvate. Stamens few, I or more; filaments flexuous; anthers 3- or 4-celled, cells more or less bivalved. No pistillode. Female flowers one or few in a large or small often toothed bract. Calyx 2- to 4-lobed or tonthed. Ovary I- to 6-celled, cells I-ovuled. Styles entire. Capsules small of I to 5 bivalved cocci, naked or spiny, usually glandular or viscid waxy. Seeds globose. Species I6o, Old World. Native name for the genus: Mahang.

i. Gigantex. Leaves peltate deeply lobed, palmate-nerved. Stipules lanceolate erect, caducous. Bracts toothed. Stamens I to 3, rarely 4; anthers 4 -celled. Ovary 2-celled. Capsule smooth.

Leaves very large; shoots not glaucous; stamens $\mathrm{I}$ to 3

Leaves moderate; shoots glaucous; stamens 2

(I) M. megalophylla

ii. Pruinosæ. Leaves peltate, palmate-nerved, coriaceous. Stipules broad, reniform reflexed persistent. Bracts toothed. Stamens I to 3 , rarely 4 ; anthers 4-celled. Ovary 2 - to 5-celled. Capsule smooth.

Leaves trilobed coriaceous.

Leaves not white beneath, trilobed nearly to base; to base; stamens 2

Leaves not white beneath, shortly trilobed; stamen I .

Leaves glaucescent beneath, trilobed half way; stamens 4

Leaves white beneath, trilobed nearly to base; stamen I

I.eaves 3 - to 5 -lobed shortly, not coriaceous.

Leaves 5-lobed; fruit rounded not horned

Leaves trilobed denticulate peltate; fruit horned

Leaves trilobed sinuate and incised, not peltate.

Leaves entire coriaceous; stamens 2 or 3 .

Leaves denticulate.

Leaves very stiff quite entire

Leaves entire thin.

Fruit shortly horned

Fruit quite smooth

Leaves entire peltate, not coriaceous.

Stamens 4 to 6 ; floral bracts large toothed

Stamens Io to 12 ; panicles spreading; bracts minute

Leaves entire not peltate, ovate, base broad.

(3) M. Hosei

(4) M. triloba

(5) M Griffithiana

(6) M. hypoleuca

(7) M. Kingii

(8) $\mathbf{M}$. quadricornis

(9) M. incisa

(Io) M. Curtisii

(II) M. recurvata

(I 2) M. Hullettii

(13) M. puncticulata

(I4) M. tanaria

(15) M. denticulata

(I6) M. trichocarpa

( 7) M. robiginosa

(I8) M. populifolia

(19) M. Lowii

- (20) M. setosa

Leaves entirely glabrous

Petiole, edge and midrib strigose 
(I) M. megalophylla Müll. Arg. in DC. Prod. xv. 995; Hook. fil. F.B.I. v. 449. M. rugosa Milll. and M. gigantea Miill. l.c.

Tree $40 \mathrm{ft}$. tall, branches pubescent. Leaves very large coriaceous broadly peltate orbicular-ovate shortly trilobed; nerves 7 , radiating from attachment of petiole, strongly elevate, with about 6 nerves from each of the large side nerves and 6 pairs from the midrib, transverse nervules very prominent, edge undulate toothed, glabrous above when adult, pubescent beneath; I2 to I 8 in. long and wide or more, petioles I 2 in. long, pubescent. Male panicles I2in. long, much branched peduncled, Bracts obcuneate pectinate, strongly ribbed pubescent, ' $I$ in. long. Sepals 3. Stamens I to 3. Female panicles 6 in. long, stout. Sepals 4. Ovary 2-celled. Styles very short. Capsule globose, bilobed glandular. Seeds compressed globose. Hab. Low open swampy ground, Pahang, Kwala Tahan. Malacca (Maingay); Brisu (Derry), common all over Malacca. Negri Sembilan, Gunong Berumbun (Cantley). Selangor, Sungei Buloh. Perak, Goping (Kunstler). Distrib. Borneo and Sumatra. Native names: Chia Kubet; Sapedas; Kubin. Use: The wood, which is very soft, is used in making windmills to scare birds.

(2) M. Maingayi Hook. fil. F.B.I. v. 449.

Tree 30 to $40 \mathrm{ft}$. tall, branches glaucous. Leaves coriaceous, broadly peltate, 3-lobed to about the middle, lobes ovate acuminate brown-tomentose beneath; nerves 3 very prominent, the others less so; 6 in. long, $6 \cdot 5$ in. wide; petioles glabrous, 4 in. long. Male panicles numerous lax slender spreading, 6 in. long, puberulous. Bracts of branchlets ovate acute; floral bracts obcuneate toothed puberulous, $\cdot 05$ in. long. Sepals 2 , ovate puberulous glandular. Stamens 2; anthers 4-celled. Hab. Malacca (Maingay). Perak, Larut (Kunstler).

(3) M. Hosei King, Hook. fil. F.B.I. v. 449.

Tree 30 to $40 \mathrm{ft}$. tall, 6 to 8 in. through; branches glaucous. Leaves coriaceous, peltate and shortly cordate trilobed, lobes obovate cut to below the middle, sparsely toothed, puberulous and hairy on the nerves beneath; nerves 6 pairs on each lobe; 4.5 in. long, 6.5 in. wide; petioles glabrous, 7 in. long. Male panicles $7 \mathrm{in}$. long, lax few branched on a peduncle $6 \mathrm{in}$. long. Bracts puberulous, pectinate toothed. Sepals pubescent. Female panicles shorter and stouter with shorter branches. Calyx 3- to 4-lobed. Ovary covered with yellow glands. Hab. Woods, Malacca (Griffith). Perak, Ulu Bubong (Kunstler); Thaiping (Wray).

(4) M. triloba Miull. Arg. in DC. Prod. xv. (2), 989; Hook. fil. F.B.I. v. 452 ; Ridl. Ann. Bot. xxiv. 473 .

Tree about $40 \mathrm{ft}$. tall, glabrous, branches fistular tenanted by ants. Leaves coriaceous trilobed broadly palmate not glaucous beneath, lobes short, lateral ones about $I^{\prime} 5$ in. long, median 3 in. long and wide; nerves and nervules prominent beneath, hairy, 
Whole leaf 9 to $\mathrm{r} 2 \mathrm{in}$. long, 7 in. wide; petioles $8 \mathrm{in.} \mathrm{long.} \mathrm{Male}$ panicles slender lax, 6 in. long, pubescent. Bracts small ovate acute entire. Sepals obcuneate. Stamen I. Female panicles shorter and stouter, $x_{5} 5$ in. long; flowers 6 to ro sessile. Calyx 4-lobed, tomentose at base with yellow waxy glands at the top. Styles 5, short erect. Capsule trilobed, top depressed, 25 in. wide, crowned by the style-base and 4 glandular patches. Hab. Edges of woods, and secondary growth, common. Singapore very common, Tanglin; Pulau Ubin (Hullett). Johor, Pinerong (Cantley). Malacca, Nyalas (Derry); Selandor and Merlimau (Cantley),

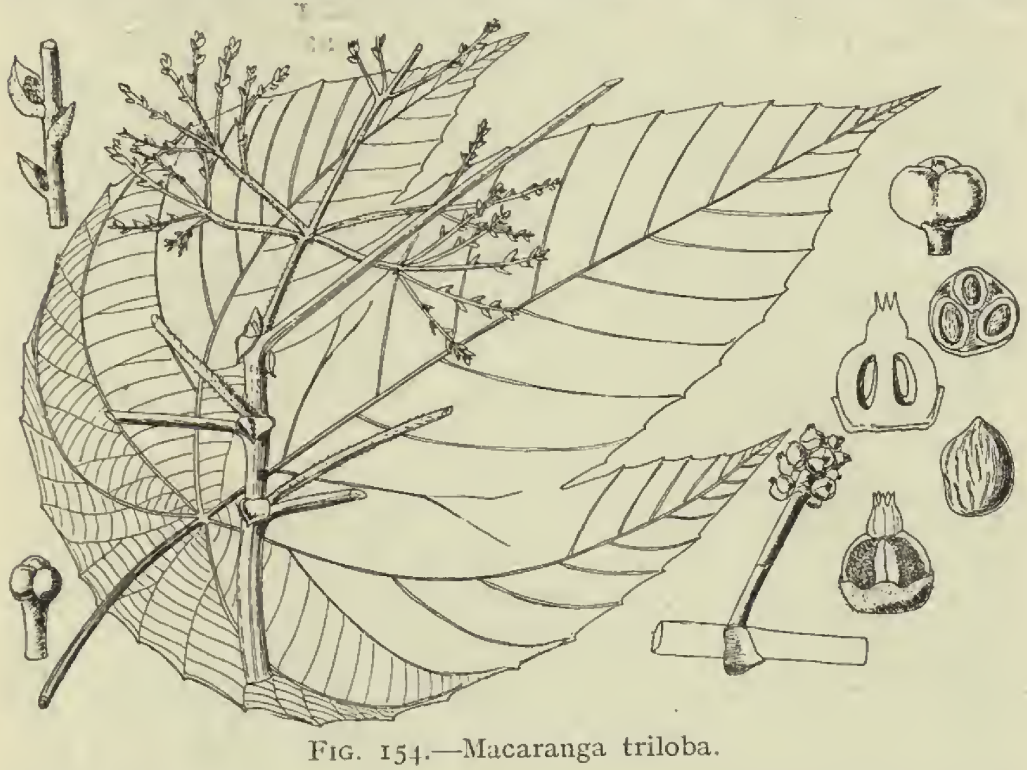

Negri Sembilan, Bukit Bertam (Cantley). Selangor, Kwala Lumpur. Perak, Gunong Batu Putil (Wray). Penang Hill (Curtis). Tringganu, Bundi (Rostados). Distrib. Sumatra, Java, Borneo. Native name: Landas Bukit.

(5) M. Griffithiana Miill. Arg. in DC. Prod. xv. (2), 993; Hook. fil. F.B.I. v. $45^{2}$.

Tree about $40 \mathrm{ft}$. tall, quite glabrous except inflorescence, branches glaucous. Leaves broadly peltate, trilobed coriaceous, glaucous beneath ovate in outline, lobes short cut down for 2 in. Whole leaf $7 \cdot 5$ in. long and wide; petioles 8 in. long. Male panicles 6 to 9 in. long, of few long branches, rusty. Bracts small ovate acute entire. Sepals 4, obovate. Stamens 4. Female panicles stouter, 4 in. long, branches short rusty scurfy; flowers sessile. Calyx cupular, trilobed. Ovary 3 - to 5 -celled, Styles thick at 
base, subulate above. Capsule trilobed, $\cdot 3$ in. wide, top flattened, with base of style in centre and 4 glandular patches on the top of the carpels. Hab. Low swampy ground, Singapore, Tanglin; Changi. Malacca (Griffith). Pahang, Pekan. Perak (Scortechini); Goping (Kunstler).

(6) M. hypoleuca Mïll. Arg. in DC. Prod. xv. (2), 992; Hook. fil. F.B.I. v. 448 .

Tree $60 \mathrm{ft}$. tall with white bark, stem I 2 in. through. Leaves peltate, trilobed, lobes ovate-oblong acuminate, white beneath; nerves 9 pairs; lobes 6 in. long, 3 in. wide, cut down nearly to the petiole; petioles 6 in. long. Male panicles rather slender lax spreading, I2 in. long, glabrous. Flowers small in heads with several ovate toothed bracts. Sepals 3. Stamen I; anther 4-celled. Female panicles stout, 4 in. long, shortly branched redtomentose. Bracts larger than in males, obovate toothed, strongly ribbed. Calyx cupular toothed. Ovary glabrous. Styles subulate. Capsule $\cdot 3$ in. wide, globose trilobed with 6 glandular ridges on the top. Seeds dotted. Hab. Secondary growth, common. Singapore, Tanglin, etc. Malacca, Selandor (Cantley, Griffith). Negri Sembilan, Tampin. Selangor, Kwala Lumpur; common all along the railway from Johor. Perak, Tapah (Wray). Penang (Wallich). Distrib. Sumatra, Borneo. Native name: Mahang putih.

(7) M. Kingii Hook. fil. F.B.I. v. 541.

Small tree, branches fistular, quite glabrous. Leaves submembranous, broadly peltate, 5-lobed, lobes ovate-lanceolate acuminate, widely sinuate toothed, midlobe much the longest; 4 in. wide; 20 in. long, 24 in. across the lobes; nerves prominent, I2 to I5 pairs on midlobe; petioles I2 in. long, stout, swollen at base. Stipules lanceolate acuminate boat-shaped, 75 in. long. Capsules numerous on a stout peduncle and rachis, 2 in. long, axillary. Pedicels $\cdot I$ in. Iong, each capsule $\cdot 5$ in. long, smooth obscurely 4-lobed glandular with 2 glandular patches on each carpel. Styles 4.25 in. long, connate at base. Seed sub-globose. $H a b$. Johor, Jaffaria (King).

(8) M. quadricornis Ridl. Kew Bulletin, I923, p. 367.

Small tree. Leaves large trilobed peltate, lobes lanceolate acuminate, glandular denticulate, median 6 to 7 in. long, 3.75 to 4 in. wide, I2-nerved, lateral lobes 4 in. long, $2 \cdot 75$ in. wide. Whole leaf $\mathrm{I} 3$ in. Iong; nerves and midrib beneath hairy, transverse nervules parallel elevate; petioles 6 to 9 in. long, thickened át both ends. Flowers not seen. Fruit in heads on a panicle of 3 short stout branches 3 in. long, branches 75 in. long. Capsules glabrous sessile, turbinate, top flattened with 4 glandular horns at the corner. Sepals broad rounded. Style-base short. Seeds globose, transversely elliptic, aril red. Hab. Hill forests, Selangor, Semangkok Pass (Ridley); Telok Reserve, Klang (Burkill).

Near $M$. Hullettii, but leaves trilobed, hairy, and fruits panicled. 
(9) M. incisa Gage, Rec. Bot. Surv. Ind. l.c. 245.

Leaves alternate ovate or 3-lobed, side-lobes inæquilateral membranous, tips acuminate, base cordate, edge sinuate and coarsely dentate incised, teeth gland-bearing, above glabrous except midrib and nerves puberulous, beneath glandular punctate ; nerves 4 to 5 pairs puberulous; 2.25 to 3.25 in. long, 5 to 3.75 in. wide; petioles slender, 2 to $4 . I$ in. long. Male panicles large, laxly branched, many-flowered, I2 in. long. Bracts capitate at the branch-ends ovate acute, longer than the flowers, pectinate dentate glandular. Flowers $\mathrm{I} 2$ in a bract fascicled, pedicelled. Sepals 3 , ovate concave pubescent. Stamens 2. Female flowers and fruit unknown. Hab. Selangor, Kwala Lumpur (Ridley).

(Io) M. Curtisii Hook. fil. F.B.I. v. 448.

Medium-sized tree; branchlets rusty-tomentose. Leaves broadly peltate orbicular-ovate, acuminate, sinuate-toothed; nerves 6 from apex of petiole and 7 from the midrib, above glabrous, beneath red and white-hairy, especially on the nerves, 7 in. long, 4.5 in. wide; petioles 6 in. long, hairy, apex $\mathrm{I} \cdot 5$ in. from edge of leaf. Male panicles lax with few distant spreading branches hairy, 7 in. long, lowest branches 2 in. long. Bracts boat-shaped, entire acute, .25 in. long or less. Male flowers very small. Sepals ovate densely glandular. Stamens 2 or 3 . Female flowers and fruit unknown. Hab. Hills at $2000 \mathrm{ft}$. altitude. Very local. Penang, West Hill (Curtis).

(II) M. recurvata Gage, Rec. Bot. Suro. Ind. l.c. 246.

Tree, branches woody not fistulous glabrous. Leaves stiffly coriaceous ovate peltate acuminate, base truncate broad, edge undulate very sparingly glandular, denticulate, finely gland-dotted and cinnamon-brown beneath when dry; nerves from apex of petiole 6 , from midrib Io pairs; I 2 in. long, 8.5 in. wide; petioles 6 in. long, rather stout. Bud-bracts stiffly coriaceous ovate, 5 in. long. Male flowers in lax glabrous viscid panicles below the leaves, 4 in. long. Flowers minute about 20 in a head in the axil of a coriaceous ovate shortly blunt toothed bract with the edge recurved. Bracts in a cone at the tip of a branch. Flowers shortly pedicelled, glabrous. Sepals ovate 3. Stamens 2, filaments very short. Female panicles shortly branched, solitary axillary or below the leaves, 2.6 to 4.75 in. long. Flowers solitary in bracts. Calyx cupular, eventually irregularly 2 - to 3 -fid. Ovary sub-globose miuutely densely glandular, 2 - to 4 -celled. Stigmas 2 to 4 , subulate recurved. Hab. Woods. Singapore, Bukit Mandai; Bukit Timah (Ridley).

(I2) M. Hullettii King in Hook. fil. F.B.I. v. $45^{2}$.

Small tree about $30 \mathrm{ft}$. tall, glabrous. Leaves entire, oblong or ovate-lanceolate peltate occasionally denticulate acuminate caudate, 7 to Io in. long, 5 to $6 \mathrm{in}$. wide; petioles 3 to $8 \mathrm{in.} \mathrm{long.} \mathrm{Male}$ panicles 3 in. long with few branches, the lowest $1 \cdot 5$ in. long on a 
peduncle 4.5 in. long. Bracts ovate caudate, $\cdot$ I in. long, gibbous at base, edge with a few teeth. Flowers sessile minute in sessile clusters of about 20. Sepals 3 obcuneate papillose at the broad top. Stamen r. Female flowers few, capitate on a short stout axillary peduncle. Calyx 4-lobed cupular. Styles 5 short acute, connate on a sub-globose base. Capsule fleshy bluish green flattened orbicular, $\cdot 4$ in. wide with 4 glandular horns at the angles, and base of style at top. Hab. Edges of forests in the hill districts, Malacca, between Jasin and Chabau. Negri Sembilan, Bukit Tangga Pass. Selangor, Batu Tiga; Semangkok Pass at $4000 \mathrm{ft}$. altitude; Klang Gates. Perak, Larut (Kunstler). Native name: Mahang Serindit.

(13) M. puncticulata Gage Rec. Bot. Surv. Ind. l.c. 246.

Bush I2 ft. tall to a tree $3 \mathrm{ft}$. in girth, young parts softly hairy. Branches fistular, with internodes dilated, containing ants, glaucescent glabrous. Leaves entire ovate peltate, acuminate, sparsely denticulate, coriaceous glabrous above, finely closely gland-dotted beneath; nerves from apex of petiole 7 , midrib with 7 to Io pairs of nerves, pubescent beneath; 4 to I 2 in. long, 3.5 to 7.5 in. wide; petioles slender, 6 in. long, hairy. Male inflorescence panicled, 3 to 6 in. long, ferruginous scurfy. Bracts entire ovate cymbiform, -05 in. long. Stamens very short, about I2. Female flowers fewer with larger red-scurfy bracts. Sepals 3 ovate acute. Fruiting racemes 2.5 to $3 \mathrm{in}$. long. Peduncles rather stout, $.25 \mathrm{in}$. long, upper part and pedicles and sepals red-tomentose. Capsules 3 or 4 in a head at the tip on short thick pedicels, sub-globose glabrous, viscid pustular, not horned, 5 in. wide. Style with 3 short arms. Hab. Johor, Tempayan River (Ridley). Pahang, Pinetree Hill, Fraser Hill (Burkill and Holltum), Selangor, Telok River, Klang (Burkill). Distrib. Borneo, Sarawak.

(I4) M. tanaria Müll. Arg. in DC. Prod. xv. (2), 997.

Small tree; branchlets glaucous, young parts softly tomentose pubescent. Leaves membranous, ovate, peltate, base round, edge denticulate or entire; nerves radiating from junction of petiole, 2 in. from edge about Io, nerves from midrib 9 pairs, transverse nervules numerous parallel; above sparsely hairy, beneath glaucescent thickly softly hairy, 9 in. long, 7 in. wide; petioles 6 in. long, pubescent. Male panicles terminal, ro in. long, freely branched pubescent. Bracts $\cdot 2$ in. long, ovate laciniate pubescent. Flowers small in clusters in the bracts. Sepals 3 or 4 glabrous. Stamens 5 or 6 . Female flowers in simple panicled spikes. Ovary hairy; styles longer. Capsule 5 in. through, bilobed with 5 or 6 long spines from the back of each lobe, all densely yellow glandular. Seeds globose rough. Hab. Open forests and river banks. Malacca (Maingay). Pahang, river banks. Selangor, Gombak (Burn-Murdoch) ; Batu Caves; Semangkok Pass. Perak, Plus River, Kampong Kota (Wray). Penang, Penara Bukit (Curtis). Kelantan, river bank. Distrib. Andamans, Malay islands. Nativenames: Kundo; Inchong. 
(15) M. denticulata Mïll. Arg. in DC. Prod. xv. (2) 1000 ; Hook. fil. F.B.I. v. 446 . M. perakensis Hook. fil. F.B.I. v. 447.

Tree 30 to $40 \mathrm{ft}$. tall; young parts rusty-tomentose, branches and petioles hoary sub-glaucous. Leaves deltoid, ovate acuminate, base round peltate or cordate; nerves about Io pairs with close-set transverse nervules glaucous beneath, finely dotted, midrib and nerves scurfy; 5 to 7 in. long, 4 to $5 \mathrm{in}$. wide; petioles $3.5 \mathrm{in}$. long. Male panicles axillary spreading, 4 in. long, 3 in, wide, branches slender scurfy. Flowers minute in small clusters. Sepals 2 or 3 orbicular. Stamens 6 to 30 . Female panicles smaller. Calyx $3^{-}$to 4-lobed. Stigmas tongue-shaped, very short. Capsules .25 in. through, bilobed, black with yellow glands. Seeds globose, black. Hab. Open woods, Pahang. Sungei Chengei, Pahang River; Sungei Tahan. Selangor, Ulu Kerling; Rawang. Perak, Goping (Kunstler); Hermitage Hill; Gapis Pass (Curtis). Distrib. India, Sumatra, Java.

(I6) M. trichocarpa Müll. Arg. in DC. Prod Xv. (2), IOO3; Hook. fil. F.B.I. v. 450.

A slender shrub about $6 \mathrm{ft}$. tall with weak branches, tomentose. Leaves membranous, ovate acuminate, denticulate, base blunt, not peltate, sparsely hairy above, dotted glandular and hairy on the nerves and reticulations beneath; nerves 8 pairs slender; 4 to $4.5 \mathrm{in}$. long, 3 in. wide; petioles slender tomentose, 2.5 in. long. Panicles axillary, $I \cdot 5$ in. long, pubescent, branches few and short. Bracts broad ovate shortly pectinate, $I$ in. long, pubescent outside. Female flowers 2 or 3 on the top of a short peduncle. Calyx elongate urceolate, 4- to 5-lobed. Capsule bilobed, 5 in. across, thickly covered with white pungent irritating bristles. Hab. Lowland woods, Singapore, common, Garden Jungle; Selitar; Changi, etc. Johor, Mount Austin. Perak (Scortechini); Uiu Temengoh (Ridley). Distrib. Cochinchina and Malay islands.

(I7) M. robiginosa Ridl. Kere Bulletin, I923, p. 367. M. javanica Hook. fil. F.B.I. v. 45I. M. montana Pax, Pfanzenreich, iv. l.c. 32 (not of Merrill).

Small tree usually about $20 \mathrm{ft}$. tall, shoots rusty-tomentose. Leaves thinly coriaceous ovate-lanceolate to ovate acuminate, base broad and very shortly cuneate entire, beneath red-brown, densely puncticulate; nerves 8 pairs; 4 to 5 in. long, I-5 to 3 in. wide; petioles slender red, 2 to 4 in. long. Male panicles pendent from the lower part of the branches below the leaves all red-scurfy, slender with short branches, $\cdot 3$ in. long. Bracts $\cdot I$ in. long, deeply laciniate. Sepals 2 or 3 . Stamens 2 or 3. Female panicles much as males. Bracts less deeply cut. Capsule bilobed, $\cdot$ I2 in. wide. $\mathrm{Hab}$. In secondary jungle, coming up in abundance wherever the forest is felled; a short-lived tree, Singapore to Penang. Native names: Mahang Bayan; Mahang Lok; Selaru.

Baillon, by some error, called this plant Rottlera montana, Heyne, in Sched. 
and published the name on in his Etudes Gen. Euphorb. p. 430 . It is not the plant so labelled by Heyne in Wallich's Catalogue. Pax, following Baillon, gave the name montana to this conspicuously lowland Malay Peninsula plant under the description of $M$. montana (Heyne), Pax and Hoffmann, l.c., but this name is anticipated by Merrill, and cannot stand in any case, so I have had to give it a new name.

(I8) M. populifolia Müll. Arg. in DC. Prod. xv. (2), I0o8; Hook. fil. F.B.I. v. 450 .

A fairly large tree about 40 to $60 \mathrm{ft}$. tall with grey bark, nearly quite glabrous. Leaves ovate or oblong-ovate, base round, tip acuminate entire, coriaceous shining bright green, pale or glaucescent beneath; nerves 7 pairs; 3 to 4 in. long, $x \cdot 5$ to 3 in. wide; petioles I to 4 in. long. Male panicles axillary, 5 to $\cdot 25$ in. long. Bracts very small, ovate toothed glandular. Sepals rounded 3. Stamens I or 2. Female racemes short, lengthening to 2.5 in. long in fruit. Capsule smooth, glandular bilobed, 2.5 in. across. Hab. Lowland woods and secondary jungle. Singapore, Chan Chu Kang; Gardens ; Changi; Bukit Timah. Malacca (Griffith); Ayer Panas (Derry); Rellau. Selangor, Kwala Lumpur. Penang Hill (Wallich). Distrib. Sumatra, Borneo. Native name: Pulau Pipi.

(I9) M. Lowii King in Hook. fil. F.B.I. v. 453.

Small tree I5 to $20 \mathrm{ft}$. tall, stem 3 to $4 \mathrm{in}$. through. Leaves thinly coriaceous, elliptic-oblong or elliptic-lanceolate acuminate; nerves 8 pairs; 4 to 7 in. long, I to 2 in. wide; petioles 2.5 in. long. Male racemes 3.5 in. long, tomentose. Flowers minute in distant clusters. Bracts triangular acuminate. Sepals orbicular. Stamens I5 to 20 ; anthers 4-celled. Female peduncles 2 in. long, hairy. Bracts broad orbicular toothed strongly nerved. Flowers I to 9 at the end of the peduncle. Sepals 6 lanceolate. Ovary spiny; styles long filiform. Capsules 5 to $\cdot 6$ in. wide, puberulous covered with short sharp spines. Hab. Open country, edges of forests, Singapore, Jurong; Tanglin; Chan Chu Kang. Malacca (Griffith); Hulu Chembong (Derry); Batu Tiga (Holmberg). Pahang, Gunong Tahan (Robinson). Perak, Larut (Kunstler). Penang Hill (Curtis and Wallich); Telok Bahang (Curtis). Native names: Gasseh Lalat; Ramin betina.

A monstrosity in which the flowers (male) are reduced to bracts is common.

(20) M. setosa Gage, Rec. Bot. Surv. Ind. l.c. 244.

Tree. Branchlets sparsely strigose. Leaves alternate ovate or oblong-ovate acuminate, base round cordate, edge shortly undulate glandular-dentate strigose, coriaceous glabrous above except midrib, beneath glaucescent strigose on the midrib; nerves Io to I2 pairs with nervules prominent; $4 . \mathrm{I}$ to $7 \mathrm{in}$. long, I.75 to $3 \cdot 75$ in. wide; petioles slender strigose, $\mathrm{I} \cdot 5$ to $3 \cdot 25$ in. long. Stipules subulate aculeate, I to 2 in. long, strigose. Male spikes solitary axillary slender, I.25 to $4 \cdot 75$ in. long, puberulous and glandular. Flowers in heads of Io to I2. Bracts widely lanceolate more or less pubescent and strigose. Calyx sub-turbinate. Sepals 3 ovate concave, 
densely glandular outside with 2 or 3 long bristles. Stamens Io to I2. Female flowers and fruit unknown. Hab. Johor, Sungei Ulu Sembrong (Lake and Kelsall).

Near $M$. Lowii, but the petioles, midrib and edges are strigose.

56. ENDOSPERMUM, Benth.

Trees. Leaves alternate coriaceous round-ovate. Flowers small in long simple spikes or racemes, apetalous. Males clustered subsessile. Calyx globose, shortly 4-toothed. Stamens 6 to Io, on a cylindric convex receptacle, filaments short; anthers 4-celled. Females solitary in the bracts. Calyx 5-toothed. Ovary 2- to 3-celled, cells I-ovuled; styles connate, forming a flat entire or 3-lobed disc. Fruit globose or 2- or 3-lobed indehiscent. Seeds globose. Species 4 or 5 , Indo-Malayan, China.

Leaves thinly coriaceous pubescent beneath.

Leaves or bicular, base rounded grey beneath; nervules closely parallel numerous

Leaves ovate narrowed at base, scurfy beneath

Leaves stiffly coriaceous shining ovate cordate .

(I) E. malaccense

(2) E. ovalifolium

(3) E. perakense

(I) E. malaccense Müll. Arg. in Flora xlvii. 469; in DC. Prod. xv. (2), II32; Hook. fil. F.B.I. v. 458.

A big stout tree $80 \mathrm{ft}$. tall, stem $2 \mathrm{ft}$. through, bark smooth, grey; branchlets stout, young parts mealy pubescent. Leaves orbicular-ovate, base broad, slightly cordate and peltate, with a pair of glands at the insertion of the petiole, above glabrous when adult, beneath puberulous; nerves about 4 pairs, elevate beneath, nervules and reticulations prominent; 4.5 to 5 in. long, 3.5 to 4.5 in. wide; petioles 2 in. long. Male racemes 3.5 to 6 in. long, slender, pubescent, often shortly branched at the base. Flowers yellow very fragrant sessile, I to 3 together. Bracts shorter ovate pubescent. Calyx turbinate, 3-lobed. Stamens 9 to 12. Female flowers larger. Calyx tubular pubescent. Ovary longer oblong, $I$ in. long. Fruit globose green, $\cdot 2$ in. through, hoary. Hab. Common in low country forests. Malacca (Griffith, Maingay); Sungei Hudang (all collectors); Ayer Panas (Derry). Negri Sembilan, Bukit Talan (Cantley). Selangor, Kwala Lumpur. Dindings, Pangkor. Perak, Batang Padang and Larut (Kunstler); B'landa Mabok and Thaiping (Wray). Penang, Penara Bukit. Native names: Bebaru Bukit; Sendok-Sendok; Sesundo. Use: The soft white wood is used for making clogs.

The leaves are commonly stated to have no glands at the insertion of the petiole on the underside; they are, however, not uncommonly present, but by no means always so. In the tree from Kwala Lumpur, Damansara Hill, the nerves beneath are distinctly hairy.

(2) E. ovalifolium Pax, Pfanzenreich, l.c. 34.

Big tree. Leaves slightly thinner than in $E$. malaccense, ovate narrowed to the base, sub-acute, base minutely cordate, glabrous

F1.M.P., 3. 
above, except base of midrib puberulous, beneath scurfy on the nerves 5 pairs, 5 in. long, 3 in. wide; petioles 3.5 in. long. Male spikes 4 in. long. Bracts $\cdot 05$ in. long, persistent ovate acute larger than in E. malaccense. Flowers solitary and in pairs. Hab. Singapore (Cantley); Bukit Timah; Kranji (Ridley). Malacca (Maingay).

This tree closely resembles $E$. malaccense, but it has the leaves narrowed at the base, and the spikes seem to be stouter. I should be inclined to make it a local variety. One of Maingay's Malacca sheets seems directly intermediate between the two species.

\section{(3) E. perakense King in Hook. fil. F.B.I.v. 458.}

Tree, 60 to $80 \mathrm{ft}$. tall, stem 15 to 20 in. through, glabrous. Leaves ovate cordate, tip shortly cuspidate ; nerves 7 pairs, elevate beneath, nervules and reticulations conspicuous, glabrous above, minutely puberulous beneath; 6 in. long, $2 \cdot 2$ in. wide; petioles glabrous, 2 in. long. Flowers unknown. Fruiting racemes fairly stout, 3 in. long, globose or slightly bilobed, greenish yellow, viscid, glabrous, $\cdot 2$ in. long and wide; pedicels $\cdot I$ in. long, stout. $H a b$. Dense jungle, Perak, Larut (Kunstler).

\section{Dubious Plant.}

E. Chinense Benth. Fl. Hongkong, 304; Hook. fil. F.B.I. l.c. The only specimen I have seen of this is Wallich's No. 7848 , from Singapore, which consists merely of leaves. These leaves do resemble those of the Chinese plant, but may be a young state of $E$. malaccense. The large glands at the insertion of the petiole mentioned as a distinctive character by Hooker are frequently present in E. malaccense as well as in E. chinense.

\section{CNESMONE, Bl.}

Tomentose or harry climbing shrubs with stinging hairs. Leaves alternate oblong, base broad cordate or peltate denticulate. Stipules broad lanceolate blunt persistent. Flowers in leaf-opposed racemes; males above, females at base. No disc or petals. Male flowers; calyx globose splitting into 3 broad lobes. Stamens 3, filaments free; anthers dorsifixed, connective produced into a reflexed lamina or short point, cells separate. Female flowers; sepals 3, enlarging in fruit. Ovary 3-celled strigose, cells I-ovuled; styles or stigmatic lobes 3 fleshy united at the base in a fleshy mass fimbriate. Capsule of 3 cocci. Seeds globose mottled. Species 2, India, Malay Peninsula, Java, Sumatra.

Branches stout tomentose; leaves cordate

Branches slender sparingly hairy; leaves peltate

(I) C. javanica

(2) C. subpeltata

(I) C. javanica Bl. Bijdr. 630; Hook. fil. F.B.I. v. 466.

Stem about $\cdot{ }_{5}$ in. through, several feet long, tomentose. Leaves abruptly short-acuminate, 6 in. long, 4 in. wide, sparsely hairy 
above, pale tomentose hairy beneath; petioles I to 3 in. long, tomentose. Stipules puberulous, I 5 in. long. Racemes about 2 in. long. Male flowers $\cdot 2$ in. wide, pedicelled. Females larger, subsessile. Sepals $\cdot 3$ to $\cdot 5$ in. long in fruit. Capsule $\cdot 25$ in. long. Seed globose mottled. Hab. Orchards, villages and open country, common. Pahang, Pekan; Kwala Tembeling. Malacca (Griffith, Cuming); Bukit Bruang (Cantley); Malacca town. Negri Sembilan, Tampin (Burkill). Dindings, Lumut. Perak, Jenah (Wray); Ulu Temengoh; Sungei Rayah (Kunstler). Penang, Moniot's Road (Curtis). Kedah, Yan. Kemaman (Vaughan-Stevens). Native names: Akar Jelatang; Jelatang Gajah; Jelatang Rusa.

(2) C. subpeltata Ridl. Kew Bulletin, I923, p. 358.

Slender twiggy climbing shrub shortly white-hairy all over. Leaves membranous elliptic or ovate blunt, base shortly peltate edge crenulate-sinuate, above sparsely hairy, beneath more hairy on the 4 or 5 pairs of nerves; 2 to 3 in. long, I.5 to 2 in. wide; petioles $I \cdot 5$ in. long, hairy. Stipules broadly ovate nearly glabrous. Racemes very slender, 2.5 in. long, hairy. Bracts ovate acuminate, .05 in. long, persistent, distant. Male flowers.$I$ in. wide, shortly pedicelled. Sepals 3 ovate hairy. Stamens 3, filaments very short; anther-cells separated by a wide connective keeled on both sides and prolonged to a short point. Female flowers not seen. Fruit, calyx-lobes lanceolate acute, 25 in. long. Hab. Thickets, Selangor, Batu Caves (Ridley).

\section{TRAGIA, Linn.}

Twining herbs hispid with stinging hairs. Leaves alternate, simple or trilobed serrate, base cordate, 3- to 5-plinerved. Flowers in axillary and leaf opposed racemes apetalous. Males above minute, females at base of raceme. Male flowers; calyx globose or obovoid, 3- to 5-fid. Stamens I to 3, rarely many, filaments free or connate; anthers ovate or oblong. Pistillode minute or 0 . Female flowers; sepals 6 imbricate, entire (or pinnatifid), often enlarged and spreading in fruit. Ovary 3-celled, cells I-ovuled; styles united below in a column, then free spreading simple. Capsule of 3 bivalved cocci crustaceous. Seeds globose. Species 50, Asia, Africa.

(I) T. lævis Ridl. Kew Bulletin, I923, p. 368.

Stems slender twining pubescent or sparsely armed with stinging hairs. Leaves herbaceous hastate-deltoid cordate acuminate mucronulate entire or sparingly serrate or shortly lobed at base, sparsely white hairy above or quite glabrous, beneath with numerous white stinging hairs on the nerves 7 from the base, 3 pairs from the midrib; $2 \cdot 25$ in. long, $I \cdot 5$ in. wide; petioles armed with white stinging hairs $\mathrm{I} \cdot 5$ in. long. Inflorescence racemose opposite the leaves 5 in. long, peduncle white-hairy. Male flowers terminal, - I in. wide; pedicels . I in. long. Bracts linear. Sepals 3 ovate 
free to base velvety pubescent. Disc large circular papillose. Stamens 3, filaments short thick, as long as disc; anther cells 2 separate on a broad thickened connective. Female flower at base. Sepals larger green oblong narrowed at the base, blunt, white-hairy. No disc. Ovary pubescent; style stout short with 3 fleshy arms with thick papillæ on the upper face. Capsule deeply 3-lobed, redbrown pubescent, $\cdot 2$ in. through. Hab. Lankawi, Dayong Bunting (Robinson). Flower greenish, stings but not badly.

59. SPHÆROSTYLIS, Baill.

Woody climbers, stout, branches slender. Leaves elliptic cuspidate acuminate entire, glabrous or membranous. Flowers very small apetalous in axillary unisexual racemes. Male flowers minute. Calyx ovoid, 3-lobed half-way, tube obconic lined with a thickened disc, lobes ovate blunt. Stamens 3 , filaments short thick; anthers triangular-ovate, base intruded. Female flowers; calyx of 5 linear-lanceolate sepals somewhat enlarged in fruit. No disc. Ovary 3-lobed, 3-celled, hairy, cells I-ovuled; style column very large, globose contracted at the base, 3 -lobed to the middle, lobes round, not spreading. Capsule 3 -lobed pubescent of 3 bivalved woody cocci. Seeds globose mottled. Species I, Malay Peninsula.

(I) S. malaccensis Pax, Pfanzenreich, iv. I47, ix. Io6. Megistostigma malaccense Hook. fil. Ic. Pl.t. I592; F.B.I. v. 467 Cnesmone glabrata Kurz. Flora I875 p. 3I (e descr.).

Stem thick. Branches slender pubescent stinging. Leaves 4 to 6 in. long, 2 to 2.5 in. wide, membranous, base sub-acute or round, not cordate; nerves I pair basal, 3 or 4 from midrib; petioles $\cdot 5$ to I in. long, slender pubescent. Racemes male I to 3 in. long, very slender. Bracts minute. Male calyx hairy. Anthers trigonous. Female flowers larger on shorter racemes. Styles forming a $3^{-}$ lobed cup bright yellow larger than the ovary. Capsule $\cdot 5$ to $\cdot 75$ in. wide. Hab. Woods climbing on trees, Singapore (Lobb); Nassim Road; Garden Jungle. Malacca (Maingay); Chabau; Panchur (Ridley). Negri Sembilan, Burunang (Cantley). Native names: Akar Jelatang Bulan; Akar Chemkian.

60. PTEROCOCCUS, Hassk.

Twiners, slender slightly woody. Leaves alternate membranous, often cordate toothed or entire. Flowers in axillary or leaf-opposed slender racemes apetalous, males minute fascicled above; females below male flowers. Sepals 4 - or 5-valvate. Stamens 8 to 30 on a prominent receptacle; filaments short free; anthers erect. Pistillode o or filiform. Female flowers; sepals imbricate. Ovary 3or 4-celled, cells I-ovuled; styles connate in a fleshy globose mass. Capsule depressed, flattened on both sides large of 3 - or 4-bivalved cocci. Seeds globose or lenticular.

Species 3, the 2 others African. 
(I) P. glaberrimus Hassk. Flora, xxv. 2; Beibl. 4I. Plukenetia corniculata Smith in Nov. Act. Upsal. vi. 4 , Hook. fil. F.B.I. v. 464.

Long slender climber glabrous. Leaves oblong deeply cordate, tip caudate-acuminate, edge denticulate, 3.5 in. long, 2 in. wide; petioles I in. long, slender. Spikes very slender, I to $\mathrm{x} \cdot 5$ in. long. Bracts lanceolate containing 3 flowers very minute. Fruit of 4 flattened cocci triangular prolonged into linear wings, $\cdot 5$ in. long, green. Seeds $\cdot 5$ in. long, lenticular sharply keeled all round mottled. Hab. Open waste ground, not common. Singapore, Chan Chu Kang; Economic Gardens found in clearing abandoned cultivation. Malacca, Chabau (Griffith). Distrib. India, Java, Borneo, Amboina. Native name: Pina-Pina. Use: as a vegetable.

\section{RICINUS, Linn.}

Shrubby plant, short-lived. Leaves palmate 7 - or more-lobed serrate alternate. Flowers large in terminal racemes apetalous, upper ones male, lower female. No disc. Male calyx splitting into 3 to 5 valvate lobes. Stamens very many; filaments connate or in branching clusters. Female calyx spathaceous. Ovary 3-celled; styles bifid feathery. Capsule of 3 bivalved cocci. Seed oblong brown mottled silvery. Species I, probably African, now whole world.

(I) R. communis Linn. Sp. Pl. I007; Hook. fil. F.B.I. v. 457.

Usually 6 to $8 \mathrm{ft}$. tall. Leaves 6 to I $2 \mathrm{in}$. long and as wide, membranous, lobes oblong to linear, gland-serrate; petioles 4 to I2 in. long. Racemes 6 in. long. Male flowers 5 in. wide. Capsule 5 to $\mathrm{I}$ in. long. Hab. Villages, cultivated or an escape, probably of African origin, now all over warm countries. Native name: Jarak. Use: for castor-oil.

\section{HOMONOIA, Lour.}

Stiff willow-like shrubs. Leaves alternate narrow linear. Flowers in axillary spikes pendent apetalous small. No disc. Males; calyx globose splitting into 3 segments. Stamens numerous in a dense globose head of branched filaments; anther-cells divaricate. No pistillode. Female flowers; sepals 5 to 8 narrow unequal imbricate. Ovary 3 -celled, cells I-ovuled. Styles spreading entire papillose. Capsule small of 3 smooth 2 -valved cocci. Seeds ovoid. Species 3 or 4 , Indo-Malayan.

(I) H. riparia Lour. Fl. Cochinchine, 637; Hook. fil. F.B.I. v. 455 .

A willow-like shrub about $8 \mathrm{ft}$. tall, branches stiff erect. Leaves linear-lanceolate or oblong entire, acute; nerves about $\mathrm{I} 2$ ascending pubescent beneath; 6 or 7 in. long, $\cdot 25$ to $\cdot 5$ in. wide; petioles $\cdot$ in. long or less. Spikes slender, 5 in. long, pubescent. Bracts small ovate acute. Sepals in male oblong purple, in females ovatelanceolate. Capsule $\cdot 12$ in, wide, pubescent brown sub-sessile. 
$H a b$. Borders of rivers, rocky or gravelly, Pahang, Kwala Tembeling; Tahan River and Pahang River, nearly to Kwala Lipis. Perak, Temengoh (Ridley). Tomoh, Legeh (Machado). Kelantan River, common in the upper reaches; Lankawi, Kesap (Haniff). Distrib. India, Siam, Cochinchina, Sumatra, Java, Philippines.

\section{POLYDRAGMA Hook. fil.}

Tree. Leaves alternate rather thin elliptic-oblong or obovate cuspidate caudate-acuminate. Flowers very small in axillary racemes, apetalous. Disc. o. Male flowers globose. Sepals 3, broad, concave valvate. Stamens very many; filaments combined below in 6 bundles, each bundle branching out at the top into a globose mass of stipitate anthers, connective arching over the top of both cells. Female flowers; sepals 5 unequal lanceolate erect. Ovary globose hairy; ovules I in a cell. Styles 3 elongate subulate, papillose on the inner face. Species 2, Malay Peninsula and Borneo.

(I) P. mallotiformis Hook. fil. F.B.I. v. 457 ; Ic. Pl. I70I.

Branchlets slender pubescent. Leaves grey when dry, glabrous; nerves 8 pairs slender, 6 in. long, 3 in. wide; petioles slender, I in. long. Male racemes pubescent, I to 3 in. long. Females longer; flowers distant, 'I in. long, pedicelled. Hab. Perak (Scortechini).

\section{CH王TOCARPUS, Thwaites.}

Shrubs or trees. Leaves alternate entire coriaceous. Flowers small in axillary clusters apetalous. Disc entire or 4- to Io-lobed. Male flowers; sepals 4 or 5 imbricate. Stamens 5 to 20 ; filaments combined in a slender column; anthers oblong. Pistillode crowning the staminal column trifid villous. Female flowers; calyx of male. Ovary 3-celled, cells I-ovuled. Styles distinct bifid. Capsule subglobose of 3 echinate (or tubercled) bivalved cocci. Seeds ovoid or sub-globose, black shining. Species 8, IndoMalaya, America.

(I) C. castanocarpusThe'aites Enum. 275; Hook. fil. F.B.I.v.46o.

A tree 20 to $40 \mathrm{ft}$. tall. Leaves stiffly coriaceous deep shining green, glabrous ovate to elliptic-lanceolate or oblong acuminate; nerves 7 pairs; 4.5 in. long, 2 in. wide; petioles $\cdot I$ in. long. Male flowers in heads -25 in. across; pedicels short thick. Bracts of clusters pubescent. Sepals oblong blunt. Capsule globose 5 in. through densely covered with rather long pale brown bristles. $H a b$. Open country in the north, Province Wellesley, Tasek Gelugur. Penang Hill (Philipps, Wallich and all collectors); Muka head (Curtis). Kedah, Yan. Setul, Heath. Lankawi (Curtis). Kelantan, Kota Bharu (Ridley). Distrib. India, Ceylon, Andamans.

\section{GELONIUM, Roxb.}

Shrubs or small trees. Branches with stipular lines at the nodes. Leaves alternate (rarely opposite), pellucid punctate entire 
or serrate. Stipules connate sheathing. Flowers small white in axillary clusters sessile or peduncled, often leaf-opposed apetalous. Male flowers; sepals 5 orbicular imbricate. Stamens Io to 60 on a convex receptacle, filaments filiform; anthers oblong dorsifixed. No pistillode. Female flowers; sepals 5 or 6 , narrower than in males. Disc cupular. Ovary 2 - to 4 -elled. Styles minute reniform, crescentic or bifid. Fruit globose, $3^{-}$to $4^{\text {-angled }}$ or lobed, more or less fleshy dehiscing at length. Seeds arillate. Species about 20, Asiatic and African.

Leaves thick shining blunt oblong-obovate; stamens 20 to 40 .

Leaves thin fleshy coriaceous acuminate oblonglanceolate; stamens 40 to 60

Leaves thin lanceolate acuminate; stamens I 2 to 20

Leaves thin elliptic acuminate, 7 in. long; stamens 30 .

(I) G. glomerulatum

(2) G. multiflorum

(3) G. bifarium

(4) G. tenuifolium

(I) G. glomerulatum Hassk. Hort. Bogor. 237; Hook. fil. F.B.I. 460 .

Bushy tree. Leaves fleshy coriaceous elliptic-oblong or ellipticobovate, tip quite round, base cuncate; nerves 5 pairs slender usually faint, reticulations very fine and close; 2.5 to $3 \mathrm{in}$. long, $I \cdot I$ to $I \cdot 75$ in. wide; petioles $I$ in. long. Male flowers numerous in fascicles, greenish yellow on slender short pedicels. Stamens 20 to 40. Capsule globose, 4 in. long, obscurely 3 -lobed, flattened at both ends. Seed pale, 25 in. long, back convex tessellate. $H a b$, Common in open spots. Singapore, Changi; Bukit Timah. Malacca, Pringgit (Griffith); Bukit China (Goodenough). Perak. Penang, Batu Feringhi, and Penara Bukit. Distrib. Malay Archipelago. Native name: Limau-Limau.

Hooker says the fruit shows no signs of dehiscence; however fully ripe, fruit dehisces freely.

(2) G. multiflorum Juss. Euphorb. Tent. iii. t. Io, fig. 3IA.

Shrub 2 to $6 \mathrm{ft}$. tall or small tree. Leaves thinly fleshy coriaceous oblong or oblong-lanceolate, blunt or acuminate, base narrowed entire; nerves 7 pairs slender, faint; 4 to 6 in. long, I. 25 to 2 in. wide; petioles 2 to 4 in. long. Male flowers in fascicles of about I2, white, pedicels ' I in. long. Stamens 40 to 60 . Fruit globose, green rough, 5 in. through; pericarp thick. Seeds $\cdot 3$ in. through, testa pitted. Hab. Woods, Malacca (Maingay); Bukit Bruang and Bukit Panchur (Cantley). Pahang, Kwala Tekam and Kota Tongkat (Evans), Negri Sembilan, Tampin (Burkill). Penang, Pulau Betong (Curtis); Government Hill; Penara Bukit. Distrib. India, Siam. Native names: Ruas-Ruas; Lampun hitam; Buah Punei; Mingantok.

(3) G. bifarium Roxb. Fl. Ind. iii. 830; Hook. fil. F.B.I. v. 459. A low bushy tree. Leaves thin elliptic-oblong to ellipticlanceolate acuminate or acute, base acuminate or shortly narrowed; 
nerves slender 6 pairs sunk above; 4.5 to 5.5 in. long, I.75 to $2 \cdot 25$ in. wide; petioles 2 in. long. Male flowers in sessile fascicles greenish yellow or white, smaller than in G. multiflorum, pedicelled. Stamens I2 to 20. Female flowers rather large. Ovary conic. Fruit bilobed rarely 3 -lobed, $\cdot 3$ in. through. Hab. Open woods, Singapore, Pulau Ubin; Changi. Penang (Wallich, Curtis).

(4) G. tenuifolium Ridl. Journ. Roy. As. Soc. Soc. S. Br. 59, p. I8I.

Tree. Leaves thin membranous, elliptic acuminate acute base cuneate; nerves 6 pairs; 7 in. long, 3.5 in. wide; petioles 25 in. long. Flowers in short axillary tufts of 2 or 3 . Males $\cdot 25$ in. wide on short thick pedicels. Sepals 3 thick, ovate 2 spathulate with thin ciliate margins. Stamens 30, filaments slender; anthers narrowly oblong acute on a hairy disc. Capsule $\cdot 25$ in. through globose obscurely grooved, 3-celled white. Hab. Woods, Lankawi, Burau (Ridley).

This has much broader and thinner leaves than the others.

66. BALIOSPERMUM, Bl.

Shrub. Leaves alternate sinuate-toothed or lobed, base biglandular. Flowers small apetalous panicled or racemed. Male flowers globose. Sepals 4 to 6 orbicular imbricate. Disc of 4 to 6 glands. Stamens Io to 30 ; filaments free or a few connate; anthers terminal, cells adnate to a broad connective or nearly free (B. malayanum). No pistillode. Female flowers, sepals 5 or 6 lanceolate entire or toothed. Disc entire. Ovary 3-celled, cells I-ovuled. Styles long bifid not fimbriate. Capsule of 3 bivalved crustaceous cocci. Seeds ovoid. Species 6, chiefly Indian.

Leaves thin membranous sinuate toothed

Leaves coriaceous crenate or entire
(I) B. axillare

(2) B. malayanum

(I) B. axillare Bl. Bijdr. 604; Hook fil. F.B.I. v. 46r.

Shrub, branches soft. Leaves membranous sinuate-toothed, upper ones small lanceolate, 3 in. long, I.5 in. wide; lower ones broad oblong-ovate rounded entire or palmately 3 - to 5-lobed, base narrowed, 6 to 7 in. long, 3 in. wide; petioles slender, $2 \cdot 5$ in. long or less. Racemes very slender erect 4 or 5 in. long, axillary; male flowers above, a few females at base. Male flowers on long slender pedicels. Sepals 4 or 5 orbicular. Disc-glands lobulate. Stamens I5 to 20; anthers sub-reniform. Female flowers sub-sessile. Sepals ovate toothed. Disc short cupular. Ovary 2- or 3-lobed; styles stout bifid. Capsule 5 in long, crustaceous. Seeds $\cdot 3$ in. long, oblong smooth mottled. Hab. Open ground, villages and thin forest, Perak (Scortechini); Kampong Brokla (Wray). Penang Hill (Curtis). Perlis, Ginting Kabok, Kanga (Ridley). Distrib. India, Siam, Java. 
(2) B. malayanum Hook. fil. F.B.I. v. 463 .

Woody plant. Leaves coriaceous elliptic-oblong, rounded at both ends, entire or crenate; nerves 6 to 8 pairs; 3 to 5 in. long, 2 to 2.5 in. wide; petioles $I$ to $I \cdot I 5$ in. long. Panicles pubescent axillary $I .5$ in. long. Male flowers pubescent. Sepals 5 , rounded toothed. Disc-glands round villous. Stamens Io on a convex hairy receptacle; filaments short; anthers hairy, free except at the top. Pistillode villous. Female flowers and fruit unknown. Hab. Malacca (Maingay). Distrib. Borneo.

67. PIMELEODENDRON, Hassk.

Glabrous trees or shrubs. Leaves alternate, at the branch ends, coriaceous. Flowers small in simple or branched racemes, axillary or lateral below the leaves, apetalous. Male flowers saucer-shaped of 2 very short and broad coriaceous appressed imbricating lobes. No disc. Stamens I2 to 15 in one series; filaments short, fleshy; anthers terminal, broad truncate, cells widely diverging. Female raceme short few-flowered. Calyx 2- to 4-lobed. Ovary sub-cylindric, 2-celled, I cell empty. Stigma thick pulvinate sessile. Fruit I-seeded. Species 2 or 3, Malayan.

(I) P. Griffithianum Benth. Gen. Pl. iii. 33I; Hook. fil. F.B.I. v. 468.

Tree. Leaves elliptic to elliptic-ovate cuspidate or acuminate, sinuate serrate, base narrowed; nerves 5 pairs slender; 3.5 to 4 in. long, 2 to $2 \cdot 5$ in. wide; petioles slender thickened at tip, I.5 in. long. Racemes fascicled below the leaves, I.5 in. long. Bracts small ovate acute; pedicels $\cdot 2$ in. long. Perianth yellow, 25 in. wide. Fruit unknown. Hab. Malacca (Griffith, Maingay). Selangor, Petaling; Sempang, Semangkok Pass (Ridley).

One of Maingay's specimens has 9 in. long stout racemes with several distant branches. My Sempang plant has 9 stamens in 2 rows.

68. HOMALANTHUS, A. Juss.

Trees or shrubs. Leaves alternate entire broad thin. Flowers small apetalous, in terminal racemes. Males many in a bract, numerous at the top of the raceme. Females $I$ in a bract, few at base of the raceme. Male flowers; calyx of 2 appressed sepals; no disc. Stamens 6 to 50 ; filaments very short; anthers. exsert, cells divaricate, 2-valved at the top. Female flowers; calyx terete 2- to 3-lobed. Ovary 2- to 3-celled. Styles linear diverging entire. Capsule bilobed fleshy indehiscent. Seed ovoid with a fleshy aril. Species 7 or 8, Malay Peninsula and islands, Polynesia, Australia.

(I) H. populifolius Grah. Nere Edinb. Journ. Sci. I827; Bot. Mag. t. 2780 ; Hook fil. F.B.I. v. 469 .

A small tree about $\mathrm{I}_{5}$ to $20 \mathrm{ft}$. tall. Leaves rhombic or triangular-ovate acuminate membranous dull green paler or glaucous beneath, quite glabrous; nerves Io pairs slender; 2 to 6 in. long, 
I.5 to 6 in. wide; petioles $2 \cdot 5$ in. long, slender red. Stipules lanceolate, $2 \cdot 25$ to $2 \cdot 5$ in. long. Racemes I to 4 in. long. Male flowers distant. Sepals biglandular at base. Stamens 6 to Io. Capsule $\cdot 25$ in. long on slender pedicels 75 in. long. Hab. Woods and thickets, especially near limestone cliffs, common, Pahang, along the Pahang River; Telom (Ridley). Negri Sembilan, Bukit Sulu and Seremban (Cantley). Selangor, Batu Caves. Perak, Kwala Kangsa; Lenggong; Kamuning; Waterloo (Curtis). Kelantan River at Kwala Krai. Penang (Wallich); Waterfall (Burkill). Distrib. Malay islands and Australasia. Native names : Moyia; Ludai paya.

69. EXCCECARIA, Linn.

Glabrous trees or shrubs with acrid milky latex. Leaves alternate or opposite entire (or sub-serrate). Flowers minute in axillary (or terminal) spike-like racemes or in spikes, apetalous. No disc or pistillode. Male flowers I to 3 in. a bract, bibracteolate. Sepals 3. Stamens free; anthers with 2 globose cells. Female flowers at base of racemes. Calyx trifid. Ovary 3-celled, cells I-ovuled. Styles shortly connate, spreading recurved entire. Capsule of 3 crustaceous cocci, valves twisting elastically. Seeds globose. Species 30, Old World tropics.

Leaves fleshy coriaceous elliptic-ovate; spikes stout, $\mathbf{I} \cdot 5$ in. long.

Leaves membranous elliptic-lanceolate; spikes slender, 5 in. long

(I) E. agallocha

(2) E. quadrangularis

(I) E. Agallocha Linn. Sp. Pl. I45I; Hook, fil. F.B.I. v. 472; Pax, Pflanzenreich, iv. I47 (v) I66, Fig. 30.

Small bushy tree about $20 \mathrm{ft}$. tall. Leaves fleshy coriaceous shining dark green elliptic-ovate shortly blunt acuminate, base narrowed; nerves faint many, sub-horizontal; 3 to 4 in. long, I.75 to 2.25 in. wide; petioles 5 in. long. Racemes sessile thick, 75 to $\mathrm{I}$ in. long yellow, very fragrant. Bracts ovate very close set, fleshy I-flowered. Male flowers minute sessile. Female flowers in fewer and shorter spikes, $\cdot 5$ in. long. Capsule $\cdot 25$ in. wide, 3-lobed. Hab. Tidal swamps, common, Singapore, Gelang; Kranji ; Toas. Malacca, Pungur (Griffith). Pahang, Rumpin River (Evans). Selangor, Kwala Selangor; Telok Kertang (Burn-Murdoch). Penang, Telok Bahang (Curtis). Lankawi, Kwah. Distrib. India, Malay islands to Tonga. Native names: Bubuta; Babuta.

A very poisonous plant, see Gimlette, "Malay Poisons and Charm Cures," ed. ii. $\mathrm{r}_{4} \mathrm{I}$.

(2) E. quadrangularis $M \| l l$. Arg. in DC. Prod.xv. (2), I219; Hook. fil. F.B.I. v. 474 .

Shrub, glabrous; branchlets 4-angled. Leaves opposite elliptic-lanceolate acuminate, base rounded, edge bluntly serrulate, membranous; nerves Io pairs slender curved; 4 to 5 in. long, $I \cdot 25$ 
to $I \cdot 5$ in. wide; petioles $I$ in. long. Racemes axillary, $\cdot 5$ in. long, sessile occasionally with a side-branch. Bracts I-flowered serrulate, bracteoles lanceolate erose. Male sepals oblong, spine-toothed. Stamens 2. Female sepals ovate, edge toothed with spines inside at base. Hab. Open forests and woods. Singapore, Pulau Brani. Perak, Lenggong; Kwala Temengoh (Ridley). Province Wellesley, Bukit Juru. Penang (Wallich) Penara Bukit; Pulau Betong (Curtis). Distrib. Siam. Native name: Kugah.

\section{INSUFFICIENTLY KNOWN.}

E. sp. Hook. fil. F.B.I. v. 475 .

Shrub 8 to $\mathrm{I} 2 \mathrm{ft}$. tall, glabrous, branches terete. Leaves membranous ovate-lanceolate acuminate, edge slightly waved, base acute or round; nerves very many slightly arched; 4 to 6 in. long; petioles $\cdot 25$ to $\cdot 5$ in. long, slender. Capsules sessile clustered in leaf-axils, 3 in. wide, 2- or 3-lobed; cocci globose smooth. Hab. Perak, Larut at 2000 to $3500 \mathrm{ft}$. altitude (Kunstler 2344).

I have not seen this species and can add no more to Hooker's description.

\section{Cultivated Species.}

E. BICOLOR Hassk. Retzia i. 558.

A shrub usually about $5 \mathrm{ft}$. tall with lanceolate leaves deep red beneath and short spikes is common in cultivation. The original home is doubtful. The latex is poisonous.

\section{SAPIUM, P. Br.}

Trees (or shrubs). Leaves alternate entire or serrate. Flowers in terminal simple or panicled spikes or racemes, apetalous small. Male flowers in upper part of spike several in a bract. Females in lower part or separate spikes, one to a bract. No disc, or pistillode. Males; calyx shortly 2- or 3-lobed or toothed or split to base in to 2 or 3 valvate sepals. Stamens 2 or 3 free; anthercells ovoid contiguous. Female flowers; calyx trifid. Ovary 2- or 3-celled, cells I-ovuled. Styles free or connate at base entire Capsule pulpy or crustaceous or woody. Seeds globose. Species Ioo, all tropics.

Fruit small 5 in. through or less.

Leaves ovate not glaucous beneath; fruit pulpy

Leaves elliptic, base narrowed glaucous beneath; fruit tricoccous

Fruit woody, 75 in. through; leaves lanceolate crenulate

(I) S. baccatum

(2) S. discolor

(3) S. indicum

(I) S. baccatum Roxb. Fl. Ind. iii. 694; Hook. F.B.I. v. 470.

Big tree laticiferous. Leaves thickly membranous oblong to ovate or ovate-lanceolate acuminate entire, base round or narrowed; nerves 9 or Io pairs paler beneath; 3.5 to 7 in. long, I.75 to 3 in. wide; petioles $I$ to 2.5 in. long. Racemes in spreading panicles 
about $5 \mathrm{in.}$ long on long peduncles terminal. Male panicles clusters distant; flowers small shortly pedicelled. Stamens 2. Female panicles shorter. Flowers very shortly pedicelled with a punctate gland below the small ovate bract. Calyx cup-shaped 3-lobed. Ovary elliptic. Style very short. Fruit fleshy green, $\cdot 5$ in. through, bilobed obcordate. Hab. Forests, Johor, Batu Pahat. Malacca, Alor Gajah (Griffith); Brisu and Panchur (Derry). Negri Sembilan, Tampin (Burkill). Selangor, Petaling; Kwala Lumpur. Perak, Goping (Kunstler). Province Wellesley, Ara Kudah.

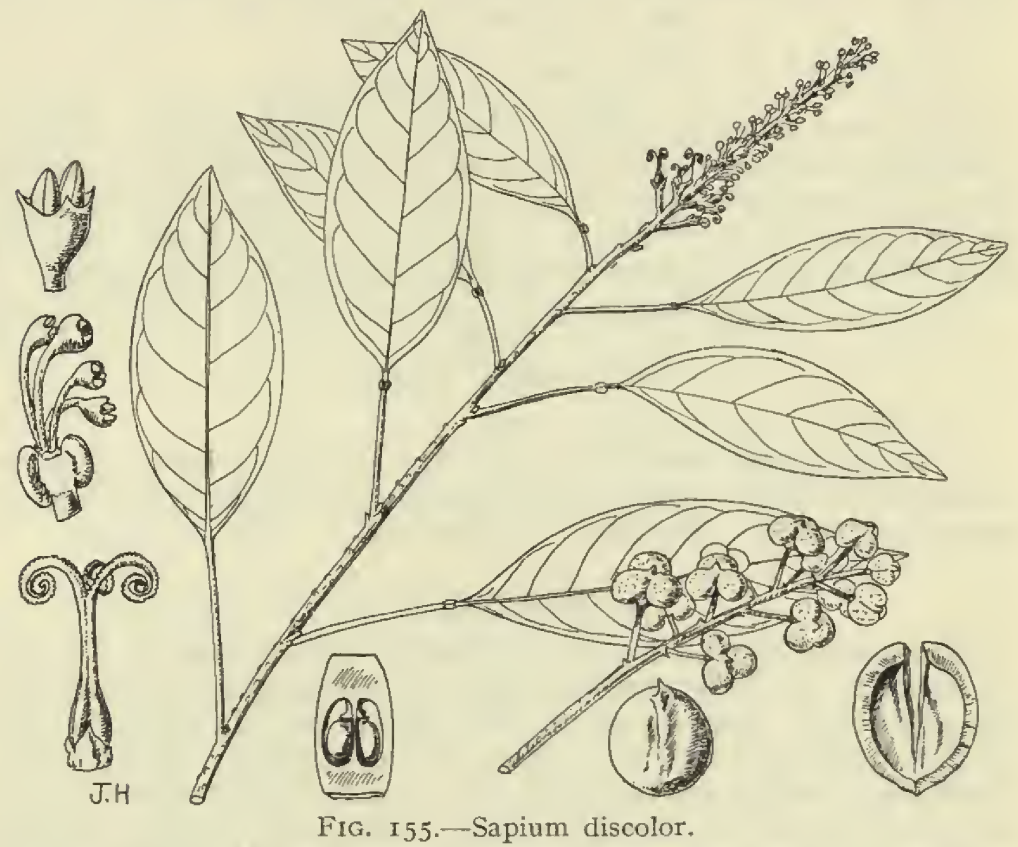

Penang Hill (Curtis); Balik Pulau; Penara Bukit (Curtis). Distrib. India, Sumatra. Native names: Ludai Pelandok; Kayu Rulus.

(2) S. discolor Mïll. Arg. in Linnaa, xxxii. I2I; Hook. fil. F.B.I. v. 469 .

Tall rather slender tree, with few branches at the tip about $60 \mathrm{ft}$. tall, 8 to $\mathrm{I} 2 \mathrm{in}$. through. Leaves thin, glaucous beneath, elliptic acute or acuminate, base slightly narrowed; nerves about I2 pairs nearly horizontal parallel; $\cdot 3$ to 3.5 in. long, $I \cdot 5$ in wide; petioles slender, $\cdot 5$ to $I$ in. long. Racemes 2 in. long, dense. Male flowers very numerous small on pedicels 05 in. long, globose in bud. Female flowers much larger, 5 or 6 at the base of the raceme; pedicels thick; style long; stigmas recurved. Fruit sub-globose black, eventually dehiscing leaving the seeds on the columnella; 
5 in. through. Hab. Lowland woods and secondary jungle. Singapore, Gardens; Jurong; Reservoir woods. Malacca (Griffith); Batang Malacca (Goodenough). Selangor, Kwala Lumpur. Perak, Chanderiang, and Ulu Kal (Kunstler). Distrib. Borneo, China. Native name: Ludai.

(3) S. indicum Willd. Sp. Pl. iv. 572; Hook. fll. F.B.I. v. 47I.

Tree. Leaves sub-coriaceous elliptic-lanceolate bluntly acuminate, base narrowed, blunt, edge serrate; nerves numerous faint; $2 \cdot 5$ to 3.25 in. long, $\cdot 5$ in. wide; petioles $\cdot 2$ in. long, slender. Racemes dense terminal on side-branches I to 4 in. long. Male flowers subsessile in clusters. Calyx lobes acute ciliate. Females longer with long style and stigmas. Fruit a large woody round capsule slightly flattened at both ends, 75 to I in. through. Seed ellipsoid, $\cdot 5$ in. long. Hab. Sea coasts, Singapore, Pasir Panjang. Pahang, Pekan. Penang, Pulau Betong (Curtis). Kedah, Alor Sta. Distrib. India, Malay islands to New Guinea. Native names: Gurah; Guring.

\section{SEBASTIANA, Spreng.}

Herbs (or shrubs). Leaves alternate. Flowers in terminal and axillary racemes apetalous. Males minute, $I$ to 3 in a bract. Calyx membranous, 4 -lobed. Disc o. Stamens 2 to 4 ; filaments short free or nearly so; anther cells contiguous. Pistillode o. Females calyx 3-lobed. Ovary 3 -celled. Styles free or connate at base entire. Capsule globose of 3 cocci, 2 endocarp crustaceous. Seeds oblong strophiolate. Species 40, all American but one.

(I) S. chamælea Miill. Arg. in DC. Prod. xv. (2), II75; Hook. fil. F.B.I. v. 475 .

Annual, glabrous, $\mathrm{I}$ to $2 \mathrm{ft}$. tall, twiggy. Leaves linear blunt finely serrulate, I to 3 in. long, $I_{5}$ to 22 in. wide; petioles .05 in. long or less. Male spikes leaf-opposed $\cdot 2$ in. long. Bracts minute with a large gland on each side, $1-$ to 2 -flowered. Sepals ovate. Females usually solitary at base of males or lateral. Sepals larger than in male, acute lacerate and ciliate, 2 glands within. Capsule sub-globose, oblong $\cdot 2$ in. long with 2 rows of spinules on each coccus. Seed oblong, mottled. Hab. Grassy and sandy spots. Singapore, Telok Kurau; Changi. Pahang, Kwala Pahang River. Malacca, Tanjong Kling (Griffith); Pulau Besar. Dindings, Lumut. Province Wellesley, Prai. Perak, Plus River (Wray); Kwala Kenering. Penang, Waterfall Gardens; Highlands (Haniff). Setul Heath (Ridley). Distrib. Africa, India, China, Malay islands, Australia.

\section{ORDER CXXIX. URTICACEÆE.}

Herbs, shrubs or trees. Leaves rarely opposite, often oblique. Stipules present. Inflorescence cymose or clustered. Flowers minute unisexual, rarely bisexual, often on a concave or flat fleshy 
involucre or in Ficus on the inner walls of a closed receptacle. Perianth lobed or of 3 to 5 sepals. Stamens as many and opposite sepals. Ovary superior, I-celled, I-ovuled; style often excentric simple or bifid or stigma sessile plumose. Fruit simple, a drupe (or samara) or small achene, or compound in a mass of perianths and pericarps. Species I500, whole world.

§ I. Celtidef. Trees or shrubs, sap watery; anthers erect in bud; style bifid; fruit a drupe.

Male sepals valvate. Shrubs or trees; stipules free; drupe small pulpy; flowers bisexual

Male sepals imbricate. Trees; stipules connate; drupe dry; flowers unisexual

Male sepals imbricate. Trees; stipules free; flowers unisexual

I. TREMA

2. GiRONNIERA

3. Celtis

§2. MOREÆ. Trees or shrubs not laticiferous; stamens inflexed in bud.

Male flowers spicate. Females solitary or few on a peduncle. Not milky; bracts minute . . . .

Males sub-capitate; bracts many, large; female sepals foliaceous

Males sub-capitate; bracts

Male and a few female on a dense spike, bare below on central line .

Males in short cymes; females solitary :

Males in spikes; females in heads of white velvety bracts.

$\S$ 3. Artocarpe 2 . Trees, shrubs and climbers, laticiferous. Stamens erect. Flowers congested.

Flowers on the inner wall of a closed receptacle, unisexual .

Big tree. Male flowers numerous on a disc-like receptacle; female solitary .

Trees. Flowers in globose or (male) cylindric head. Male stamen I .

Shrub or small tree. Flowers in globose heads; stamens 4

Shrubs hardly or not laticiferous; male and female heads cymose, or female solitary

Climber. Male and female heads solitary; stamen I

Erect shrub. Male and female heads solitary; stamens 2 ; fruit turbinate, orange

Io. Ficus

II. ANTIARIS

12. ARTOCARPUS

I3. Cudrania

I4. Conocephalus

I5. Prainea

i6. Hullettia

§4. URTICEA. Herbs or shrubs rarely trees, not laticiferous; stamens inflexed in bud.

Herb with stinging hairs; leaves alternate; achene dry . . . .

Trees with stinging hairs; leaves alternate; achene pulpy $\cdot$;

Herbs without stinging hairs; stigma penicillate.

Leaves opposite;
Leaves alternate.

Flowers all cymose; male long peduncled .

Flowers on a fleshy receptacle; male and female sub-sessile

Male flowers cymose; female on fleshy

I7. Fleurya

18. LAPORTEA

I9. Pilea

20. Pellionia

21. Elatostema

22. PROCRIS 
Shrubs, trees or herbs; flowers spicate or clustered ; male flowers 2- to 5-sepaled; female, tubular enclosing achene.

Shrubs. Heads distant on spikes; fruiting

Herbs; flower heads sessile axillary; fruiting perianth dry $\dot{ }$ ' ${ }^{\circ}$ '

Trees or shrubs; perianth fleshy, white or coloured in fruit.

Ovary free; stigma linear ${ }^{2}$ 25. Pipturus

Ovary adnate; stigma sub-peltate. Tree

Ovary adnate; stigna penicillate. Rough shrub
23. BकHMERIA
24. Pouzolzia
26. VILlebrunea
27. Debregeasta

\section{TREMA, Lour.}

Shrubs or trees. Leaves alternate serrate, 3- to 7-nerved from base. Flowers in small axillary cymes, unisexual, bisexual. Males, sepals 4 to 5 valvate. Stamens 4 to 5 . Females, sepals flat sub-imbricate as male. Ovary sessile; style terminal, arms linear. Drupe small, orange or red; endocarp hard. Species about 30 , tropics.

Leaves thin, glabrous

Leaves rather thick, hairy beneath.

Leaves narrow, base slightly narrowed

Leaves broad and long, base cordate

(I) T. virgata Bl. Mus. Bot. Lugd. But. ii. 6o. T. timorensis Hook. ful. F.B.I. v. 483 (not of Blume).

Low shrub with slender pubescent branches. Leaves membranous, glabrous, ovate long, acuminate, base round, edge serrate, $2 \cdot 75$ to 3 in. long, 75 in. wide; petioles slender, 25 in. long. Cymes glabrous, 25 in. long. Drupe 12 in. long, orange. Hab. Waste ground, not very common, Singapore (Murton). Malacca (Griffith, Cuming). Selangor, Sungei Buluh. Perak, Tapah (Wray). Tringganu, Bundi (Rostados). Penang, Bagian Jennal (Curtis, Wallich). Distrib. China, Bangka, Java, Borneo, Tenasserim.

(2) T. angustifolia Bl. Mus. Bot. Lugd. Bat. ii. 58; Hook. fil. F.B.I. v. 484 .

Shrub; branches slender, rough short, hairy. Leaves thick, membranous, ovate acuminate, base broad minutely narrow, closely serrulate pustular scabrid above; nerves hairy beneath, 2.5 in. long, 6 to $\cdot 75$ in. across; petioles $\cdot 2$ in. long, hairy. Cymes compact,.$_{5}$ in. long, pubescent. Drupe orange. Hab. Common, waste ground, edges of woods, Singapore, Chan Chu Kang; Changi ; Paterson Road. Malacca, Mt. Ophir; Bukit Bruang (Derry). Selangor, Kwala Lumpur (Curtis). Negri Sembilan (Cantley). Penang Hill (Curtis, King). Distrib. Borneo. Native names: Menkira Lalat; Menkiri putih.

(3) T. amboinensis Bl. Mus. Bot. Lugd. Bat. ii. 6I; Hook. fil. F.B.I. v. 484 .

Shrub to a small tree about I5 ft. tall; branches pubescent. 
Leaves thick, membranous, ovate acuminate, base round usually cordate, serrulate, strigose scabrid above, silvery hairy beneath (especially young leaves), 5 to 6 in. long, 2 in. wide; petioles $\cdot$ I 2 in. long, hairy. Cymes many-flowered, I in. long, hairy. Flowers silvery hairy. Drupe orange, very small. Hab. Very common in waste ground and woods, clearings, etc. Whole peninsula from Singapore to Penang, Tringganu, Kelantan, etc. Distrib. India, Malay islands. Native names : Mundarong or Menarong; Menkira besar. Use: Wood for firework-charcoal. Occasionally rises to about $40 \mathrm{ft}$. tall.

2. GIRONNIERA, Gaud.

Trees. Leaves alternate. Flowers unisexual on different trees in axillary cymes. Males in clusters; females solitary racemose. Males small; sepals 5, blunt. Stamens 5. Pistillode woolly. Females sepals narrower acute. Ovary sessile; style arms long, filiform. Drupe ovoid or sub-orbicular, flattened, orange, endocarp hard. Species about I2, Indo-Malaya, China.

Leaves coriaceous, sparsely silky hairy beneath, elliptic

Leaves coriaceous, stiff, nearly glabrous elliptic .

Leaves thin coriaceous lanceolate, 2 to 3 in. long 6 :

Leaves chartaceous elliptic, densely long-hairy, 6 to

8 in. long.

(I) G. nervosa

(2) G. subæqualis

(3) G. parvifolia

(I) G. nervosa Planch. Ann.Sc. Nat. Ser. 3, x. 338; Hook. fil. F.B.I. v. 485 .

Tree 40 to $80 \mathrm{ft}$. tall, unisexual; branchlets and bud-scales yellow, hairy. Leaves coriaceous, glabrous above, silky hairy beneath, elliptic or oblong acuminate narrowed, blunt unequal at base; nerves $\mathrm{I} 2$ to I5 pairs, elevate beneath and yellow hairy; 5 to 6 in. long, 2 in. wide; petioles $\cdot I$ in. long. Male flowers in tufts, spicate forming catkins, panicled; catkins I in. long or less ; flowers yellow; rachis hairy. Female flowers secund in slender hairy spikes rather distant. Drupe hard, ovoid, flattened beaked, orange-colour, hairy, 25 in. long. Hab. Common in low country, Singapore; Tanglin; Changi. Johor, Kwala Sembrong (Kelsall). Malacca, Sungei Hudang; Bukit Sabukor (Derry); Chenana putih (Cantley). Negri Sembilan, Tampin; Gunong Berumbun (Cantley). Selangor, Bukit Kudah; Kwala Lumpur (Hose). Perak, Trong (Wray); Ulu Bubong; Larut (Kunstler). Penang Hill (Wallich, Curtis). Distrib. Sumatra, Borneo. Native names : Medang Ampas Tebu; Medang Kesap jantan; Medang Kesap hitam; Medang S'Kasat; Poko Tarah.

(2) G. subæqualis Planch. Ann. Sc. Nat.Ser. 3, x. 339; Hook. fil. F.B.I. v. 485 .

Big tree about $80 \mathrm{ft}$. tall. Leaves stiff, coriaceous, elliptic rounded or acuminate, base cuneate or round, shining light green above, sparsely hairy beneath, midrib and to pairs of nerves elevate 
appressed hairy beneath; 3.5 to 5 (or even 7 ) in. long, $\mathrm{I} \cdot 5$ to 3 in. (or 4 in.) wide. Male spikes in hairy panicles 3 in. long; flowers - 18 in. across. Females as long, slender. Drupe yellow, 3 in. long, flat, ellipsoid, beaked minutely puberulous. Hab. Common in woods, Singapore, Jurong; Garden Jungle; Changi. Malacca, Selandor (Cantley). Selangor, Kwala Lumpur (Foxworthy). Perak, Thaiping Hills, $2500 \mathrm{ft}$. altitude; Gunong Batu Putih (Wray). Penang, Penara Bukit (Curtis). Distrib. Java, Sumatra, Borneo. Native names: Medang Bulanak; Medang Bulapo.

The varieties ceylonica and bimanica, Hook. fil. in F.B.I. are distinct species.

(3) G. parvifolia Planch. Ann. Sc. Nat. 3, x. 338; Hook. fil. F.B.I. v. 486.

Slender tree about $60 \mathrm{ft}$. tall with white bark; branches slender. Leaves slightly puberulous beneath, thin coriaceous lanceolate acuminate, base short, narrowed; nerves elevate, 2 to 3 in. long, .75 to $I$ in. wide; petioles under $I$ in. long. Male cymes very slender branched, about I in. long; flowers in clusters of 2 or 3 . Females few-flowered. Drupes I to 3 on a slender peduncle I to 2 in. long, dark yellow, ovoid, flat, glabrous or slightly puberulous, .25 in. long. Hab. Common in forests, Singapore, Bukit Timah; Kranji. Johor, Gunong Pulai; Tanjong Kupang. Pahang, Tahan River; Kwala Lipis (Foxworthy). Malacca, Selandor and Ayer Panas (Cantley); Bukit Besar, Ophir; Negri Sembilan, Tampin. Selangor, Kampong Kerling (Goodenough); Weld's Hill. Dindings, Lumut. Perak, Thaiping Hills; Ulu Bubong (Kunstler). Penang Hill (Maingay) to Iooo ft. altitude (Curtis). Distrib. Carimon isles. Nativenames : Kurutak hudang; Medang Kuruseh; Meskam.

(4) G. hirta Ridl. Journ. Roy. As. Soc. S. Br. 82, p. I94.

Tree; branchlets, underside of leaves especially midrib and nerves and inflorescence densely covered with long yellow hair, buds very hairy. Leaves sub-chartaceous, broad elliptic, abruptly acute acuminate, base round, edge obscurely serrulate; midrib and nerves ro pairs, elevate beneath; 4 to 6 in. long, 2 to 3 in. wide; petioles ${ }^{\prime} 5$ in. long, hairy. Flowers not seen. Fruit I to 3 on a peduncle $\mathrm{r} \cdot 25$ in. long, hairy. Drupe ovoid, flat, 25 in. long, densely hairy; styles filiform hairy, 75 in. long. Hab. Local in south only, Johor, Simpai (Kelsall); Tebing Tinggi (Ridley).

\section{CELTIS, Linn.}

Trees or shrubs. Leaves alternate ovate, triple-nerved. Flowers small cymose. Males usually at base of shoots; females in upper axils. Sepals 4 to 5 , imbricate. Stamens 4 to 5 , surrounding a woolly torus. Ovary sessile; style central, arms plumose. Drupe small ovoid or globose. Species 50, whole world, chiefly palæarctic.

F1.M.P., 3 . 
(I) C. Collinsæ Craib in Kew Bulletin I9I8, p. 370.

Shrub or small tree. Leaves oblong, base broad, tip shortly cuspidate, blunt, coriaceous (when adult) conspicuously 3-nerved, entire, 3.5 in. long, $I \cdot 5$ in. wide; petioles 3 in. long. "Cymes axillary, short; flowers nearly sessile. Males sepals obovate ciliate. Stamens opposite sepals. Pistillode small, columnar, glabrous." Fruit ovoid shortly beaked, ribbed, 3 in. long. Perlis, Tebing Tinggi (Ridley). Distrib. Siam.

My specimens are only in fruit. Description of flowers from Siamese specimens.

\section{TAXOTROPHIS, Bl.}

Spiny shrubs or trees. Leaves alternate, serrate or spiny. Male flowers in short catkins or fascicles. Sepals valvate. Stamens 4 , inflexed in bud. Pistillode dilate. Females I to 4 on a long peduncle; sepals 4, persistent, shorter than fruit. Ovary ovoid at length oblique; style at length lateral. Fruit oblique subglobose, fleshy on one side. Species 7 , Indo-Malayan.

(I) T. ilicifolia Vidal, Rev. Pl. Vasc. Philip. 349. Balanostreblus ilicifolius Hook. fil. F.B.I. v. 544 (in part, not of Kurz).

A pubescent, white-barked shrub. Leaves coriaceous, oblonglanceolate or elliptic, entire or spiny, 2 to 4.5 in. long, I.5 to $2 \mathrm{in}$. wide; nerves numerous inarching; petioles very short. Male catkins 75 to 2 in. long, cylindric, pale pink, sessile axillary. Female flowers I or 2, very shortly pedicelled. Bracts ovate round. Fruit globose. Hab. Dry woods and rocky spots, Pahang, Temerloh. Pahang River. Perak, Tambun; Lenggong. Penang, Waterfall. Kelantan, Kwala Lebir (Gimlette). Perlis, Kanga. Distrib. S. Siam, Burma, Cambodia, Philippines. Native names: Lalimau; Limau Lelang Antan. Use: The holly-like leaves are gilded and used for Christmas decorations by Europeans.

\section{PHYLLOCHLAMYS, Bureau.}

Glabrous spiny shrubs or small trees. Leaves alternate. Flowers unisexual. Males in short spikes or clusters involucrate. Sepals 3 to 4 ovate imbricate. Stamens 3 to 4 , inflexed in bud. Pistillode dilate at tip. Females solitary peduncled; sepals 3 to 4 accrescent, leafy in fruit. Ovary very oblique; style at length lateral. Fruit shorter than sepals globose or ovoid oblique, fleshy.

Leaves entire or very obscurely toothed, lanceolate; sepals in fruit acuminate.

Leaves toothed rhomboid; sepals in fruit narrowed .

(I) P. Wallichii

(2) P. spinosa

(I) P. Wallichii Hook. fil. F.B.I. v. 489.

Thorny shrub 8 to ro ft. tall. Leaves sub-coriaceous, ellipticlanceolate, acuminate usually blunt and entire, base narrowed blunt, I.5 to 4 in. long, 25 to $I \cdot 25$ in. wide; petioles $\cdot 05$ in. long. Male 
clusters globose sessile puberulous, pale red. Fruit 5 in. through. Sepals ovate acuminate, blunt, 75 in. long. Hab. Dry spots, Malacca, Chabau and Mt. Ophir. Perak, Gunong Bubu Range (Kunstler). Penang Hill, woods below the Waterfall (Wallich, Curtis). Kedah, Alor Sta. Perlis, Kanga. Pulau Adang islands, Rawai and Nipis. Native name: Gaham Badak.

(2) P. spinosa Bureau, in DC. Prod. xvii. 218; Hook. fil. F.B.I. v. 488 .

Spiny bush or tree. Leaves oblong or ovate acuminate or rhomboid, more or less distinctly toothed at the top, base blunt, .5 by $\cdot 2$ in., to 3 by $\mathrm{I} \cdot 5$ in. wide, thinner than in Wallichii; petioles very short. Male flowers larger. Sepals of fruit longer and narrower. Hab. Pahang River, Pulau Chengei. Lankawi, Kwah (Curtis).

I believe these to be identical with the Indian and Ceylon plant, the foliage is identical.

\section{STREBLUS, Lour.}

Unarmed shrubs or trees, laticiferous. Leaves scabrid alternate. Male flowers in peduncled heads or spikes. Sepals 4 imbricate. Stamens 4 inflexed in bud. Pistillode dilate at top. Female solitary or 2 to 4 together; bracteate. Ovary straight; style arms very long. Fruit membranous sub-globose not oblique covered by persistent sepals. Seed globose. Species 2, IndoMalayan.

(I) S. asper Lour. Flor. Cochinchine, ii. 615; Hook. fil. F.B.I. v. 489 .

Shrub or small tree; branchlets pubescent. Leaves ellipticlanceolate, tip narrowed, blunt, base narrowed blunt, edge crenate or toothed, rather stiff scabrid, coriaceous, 2 to 4 in. long, I to I.5 in. wide; petioles very short, $\cdot I$ in. long or less. Male heads globose solitary or 2. Flowers minute. Females, peduncle slender, 4 in. long; flower yellow, about $\cdot \mathrm{I}$ in. long; style arms $\cdot 3$ in. long. Fruit $\cdot 2$ in. long, pea-shaped. Hab. Dry spots in the north, Penang, Perak Road (Curtis). Kedah, Alor Sta; Gunong Geriang. Perlis, Kanga. Lankawi, Kwala Kwah. Distrib. India, Cochin China, Siam, Malaya, China.

\section{SLOETIA, Teysm. and Binn.}

Trees. Leaves sub-coriaceous alternate, entire. Flowers axillary, spikes solitary or paired, mostly males with a few females, 2 or 3 near base. Bracts peltate. Male flower, sepals 3 connate. Stamens 3, inflexed in bud. Female sepals 4. Ovary straight; style arms very long, slender. Fruit globose, pea-shaped; sepals dilate fleshy, white ejecting the fruit on pressure. Species I or more. Malayan. 
(I) S. sideroxylon Teysm. and Binn. Tijdschr. Nat. Ver. I863; Hook. fil. F.B.I. v. 493. S. penangiana Oliv. Hook. Ic. Pl. t. I53I. S. Wallichii King, Hook. l.c.

$\mathrm{A}$ big tree upwards of Ioo ft. tall, but more usually met with about $40 \mathrm{ft}$. tall, twigs milky. Leaves thinly coriaceous, dark green, variable, oblong, abruptly cuspidate, base shortly narrowed, nerves slender, Io to I 6 pairs, slightly elevate, $.8 \mathrm{in}$. long, 3 in. wide or less; narrow lanceolate, 4 in. long, I in. wide, in old trees; petioles $\cdot \mathrm{I} 2 \mathrm{in}$. long. Spike $4 \mathrm{in}$. long or less, $\cdot 2$ in. through, light green, sessile with a bare ridge down one side. Fruit ${ }^{\prime} \mathrm{in}$. through, the enlarged sepals juicy, white and sweet. Hab. Scattered over the whole peninsula, but rarely is a full-sized tree to be found now on account of the value of the timber; valued for carryingsticks, gambir tools, etc., the Chinese cut the stem as soon as big enough, causing the tree to bush. It flowers in this state, producing the large leaves (S. penangiana); in older trees allowed to grow the leaves are smaller (S. Wallichii). Occurs from Singapore to Penang and in Pahang on the east coast. Distrib. Rhio. Native name: Tampinis. The natives distinguish some forms as Tampinis hitam and putih. Use: Perhaps the most valuable timber in the Malay Peninsula.

I have rarely seen a really tall tree, and not for many years. The wood is quite indestructible by rot or termites.

\section{PSEUDOSTREBLUS, Bureau.}

Unarmed glabrous shrubs or trees. Leaves alternate, entire. Male flowers in short cymes; sepals 5, orbicular imbricate. Stamens 5 , inflexed in bud. Pistillode linear. Female flowers solitary in different axils or in the male cyme. Sepals 4, orbicular concave. Ovary sub-globose; style-arms filiform. Fruit enclosed in the enlarged perianth. Species 3 or 4 , Indo-Malaya.

(I) P. caudata Ridl. Journ. F.M.S. Mus. vi. 54.

Glabrous shrub, branches slender. Leaves elliptic caudate alternate thin coriaceous, blunt; nerves 4 pairs, reticulations conspicuous; 3 in. long, 75 in. wide; petioles .1 in. long. Male flowers 4 to 5 together, nearly sessile on axillary peduncles $\cdot 2$ in. long. Sepals 4 to 5 , ovate acute. Stamens 4 to 5 inflexed in bud. Pistillode truncate. Hab. Perak, Gunong Kerbau at $4500 \mathrm{ft}$. altitude (Robinson).

Genus doubtful, as female flowers have not been seen.

\section{MALAISIA, Blanco.}

Scandent shrubs unarmed. Leaves alternate entire or toothed, very variable. Male spikes dense, simple or rarely branched, cylindric. Female globose, capitate. Male flowers; perianth 3-lobed, lobes valvate. Stamens 3, filaments inflexed in bud, spreading when open. Pistillode very small. Female flowers 
immersed in a small head of fleshy white tomentose bracts only one or two in a head fertile. Perianth urceolate. Ovary included; style long bifid; stigmas filiform. Fruit head hardly enlarged. Achene included in the slightly fleshy perianth. Species 2, Siam, Malaya and Australasia.

(I) M. tortuosa Blanco, Flor. Philip. i. 789 .

Leaves chartaceous, oblong cuspidate, 5 in. long, I.75 in. broad, many-nerved or coriaceous elliptic with fewer and stronger nerves, 2 in. long, I in. wide. Male spikes cylindric, I in. long or less, axillary; peduncle about as long. Female heads $I$ in. through, grey tomentose with $I$ to 3 fertile flowers; stigmas 4 in. long, on tomentose peduncles 3 in. long. Fruit ovoid, smooth, $\cdot 2$ in. long. Hab. Tringganu (Yapp). Distrib. Malaya.

\section{FICUS, Linn.}

Laticiferous trees or shrubs often epiphytic and strangling big trees or scandent. Leaves alternate (rarely opposite) entire lobed or toothed. Stipulate. Flowers minute unisexual on the inner walls of a fleshy receptacle (fig), the mouth of which is partly closed by imbricate bracts. Male flowers usually near mouth; perianth 2- to 6-fid. Stamens I to 2, rarely more. Female flowers; perianth as in male or 0 . Ovary straight or oblique; ovule I; style excentric. Achenes crustaceous. Species about 6oo, mostly tropical.

The figs may contain male flowers and gall flowers (which only contain the larvæ of a Hymenopteron fertiliser) only, the female flowers in distinct figs, or the flowers may be mixed. Native name for genus: Ara.

§i. Palemomorne. Small trees or shrubs. Male flowers in figs with gall flowers. Stamen $\mathrm{r}$, with a pistillode. Female flowers in different figs, gamophyllous except in $F$. gibbosa.

Leaves inæquilateral abruptly cuspidate, coarsely serrate. Figs clustered on branches small, white. Epiphyte . . .

Leaves hardly or not unequal coriaceous. Figs orange, solitary axillary . . .

Leaves membranous abruptly cuspidate. Male erect shrubby, female climbing. Epiphyte. Figs orange axillary

Leaves coriaceous pubescent, long-caudate; nerves 3 pairs, strong elevate. Figs orange, globose hairy

Leaves ovate-elliptic abruptly caudate glabrous; nerves prominent. Figs pubescent .

Leaves membranous serrate, hairy beneath. Figs sessile hairy, white .

Leaves sub-coriaceous, glabrous entire lanceolate elliptic

(I) F. pisifera

(2) F. gibbosa

(3) F. subulata

(4) F. parietalis

(5) F. urophylla

(6) F. celebica

(7) F. Burkillii

§ii. Urostigma. Trees or shrubs epiphytic when young. Leaves usually stiff, coriaceous. Figs sessile, axillary usually below the living leaves with 3 large bracts at base. Male, female and gall flowers in one fig. Figs often large. 
Leaves stifly coriaceous, large; figs large; petioles short and thick.

Leaves ovate sometimes cordate, young parts pubescent. Figs red puberulous.

Leaves oblong or lanceolate red-tomentose beneath when young.

Bracts short round. Figs oblong

Bracts short round. Figs globose .

Bracts large acuminate persistent, longer than the round figs.

Leaves oblong or obovate, large, always glabrous.

Leaves obovate very stiff. Figs 2 in. long, oblong, orange

Leaves oblong, pale minutely reticulate beneath. Figs 75 in. long, globose, red

Leaves oblanceolate; bracts large, round. Figs globose

Leaves thinner elliptic acuminate. Figs oblong globose covered by bracts in bud b

Leaves thin coriaceous; nerves few, conspicuous,

Figs shortly peduncled, oblong, I in. long

Figs short peduncled sub-globose, 5 in. long .

Figs ' I in. long, globose; peduncle 5 in. long; leaves finely reticulate

Figs globose on slender $\mathbf{I}$ in. long peduncles, green $; \cdot$

Figs oblong or sub-globose, sessile, orange
Figs sessile globose, with an orange raised ring at mouth

Leaves with numerous inconspicuous parallel nerves.

Leaves very large, $8 \mathrm{in}$, long. Figs small, $\cdot 5 \mathrm{in.}$ long

Leaves 4 to 7 in. long. Figs globose

Leaves small, elliptic rigid, 2 to $5 \mathrm{in}$. long.

Figs sessile globose, small, mouth bracts 3 , large; stipules silky -

Figs sessile globose, small, mouth with elevate ring; stipules glabrous .

Figs globose, sessile, mouth with 3 large
bracts; stipules glabrous.

Leaves obcuneate .
Leaves sub-coriaceous, elliptic; nerves fine, 5 or 6 pairs . .

Leaves sub-coriaceous, very fine and parallel.

Leaves thin coriaceous or membranous. Figs small sessile.

Leaves elliptic 2 to 3 in. long, base blunt; petioles short

Leaves obovate or oblanceolate, larger, base cuneate; petioles short. . .

Leaves ovate caudate acuminate, base acutc; petioles long slender

Leaves ovate caudate-acuminate, base cordate

Leaves oblong, tip blunt, base cordate . .

(8) F. bengalensis

(9) F. pilosa

(I0) F. consociata

(I I) F. bracteata

(I 2) F. xylophylla

(13) F. Lowii

(I4) F. procera

(I 5) F. rigida

(I6) F. annulata

(I 7) F. globosa

(I 8 ) F. dubia

(19) F. pruniformis

(20) F. indica

(2I) F. microstoma

(22) F. elastica

(23) F. obtusifolia

(24) F. acamptophylla

(25) F. microsyce

(26) F. retusa

(27) F. truncata

(28) F. Binnendijkii

(29) F. Benjamina

(3I) F. glabella

(32) F. Rumphii

(33) F. religiosa

(34) F. infectoria 
Leaves oblong-lanceolate, thin coriaceous.
Figs yellow, peduncled
(35) F. vasculosa

§iii. Syxacia. Climbing shrubs with large red pear-shaped figs. Male and gall flowers in one set of figs; females and neuters in another. Stamen $\mathbf{I}$. Leaves coriaceous, tessellate beneath.

Leaves scabrous

Leaves not scabrous, under 2 in. long

Leaves not scabrous, obovate, $3 \mathrm{in}$. long
Leaves oblong large, 6 in. long; young parts hairy
(36) F. aurantiaca
(37) F. punctata
(38) F. callicarpa
(39) F. apiocarpa

§iv. Sycrdium. Shrubs or climbers or trees, not epiphytic. Figs axillary, scabrid small or fascicled from stem. Male and gall flowers in I set of figs; females in another. Stamens I (rarely 2).

Slender creepers often eventually small trees; leaves sometimes lobed.

Figs 5 in. through, pear-shaped

Figs less than 5 in through globular ${ }^{\circ}$

Shrubs or trees. Leaves not lobed.

Leaves very inæquilateral, serrate hairy.

Leaves equilateral, large, ovate cordate, white beneath, serrate

Leaves equilateral oblong-oblanceolate, shortly cuspidate, base blunt

Leaves abruptly cuspidate.

Nerves 5 pairs, cusp long. Figs orange.

Nerves 8 pairs; leaves narrow oblong. Figs crimson .

Nerves Io pairs; leaves thin oblanceolate, large. Figs few, brown . .

(40) F. heterophylla

(4I) F. quercifolia

(42) F, obscura

(43) F. copiosa

(44) F. brevicuspis

(45) F. rostrata

(46) F. cuspidata

\section{(47) F. trachycarpa}

$\S \mathrm{v}$. Coverlia. Trees or shrubs never epiphytic. Figs of moderate size on long pendent branches or tubercles on stem or axillary. Males and gall flowers in one set of receptacles; sepals 3 to 4 . Stamen I. Females in separate figs; perianth gamophyllous or wanting.

Fruiting branches from base of stem, crecping along the ground, slender.

Bush. Leaves very inæquilateral at base, pubescent beneath . . .

Fruiting branches from stem above ground.

Glabrous tree; fruiting branches simple, 6 to I 2 in. long

(48) F. cunia

Hairy shrub; figs on branches, green

Trees.

Figs in clusters on stem.

Leaves and figs glabrous

Leaves hairy beneath, Figs hairy :

Leaves hairy beneath. Figs glabrous

Figs on short lateral branches, large, obpyramidal .

Figs axillary.

Leaves oblong, sub-acute ; figs sessile .

Leaves lanceolate, long cuspidate; figs small peduncled

(50) F. hispida

(5I) F. polysyce

(52) F. fasciculata

(53) F. Scortechinii

(54) F. obpyramidata

(55) F. lepicarpa

(56) F. fistulosa

$\S$ vi. Eusrce. Scandent or erect shrubs or small trees rarely epiphytic, soft hairy or glabrous, not scabrid. Figs axillary. Male and gall flowers in. one set of figs; females in another. Stamens in males 2. 
Climbers.

Leaves round ovate, glabrous.

Leaves small, rather coriaceous; figs very small, sessile .

Leaves large, membranous; figs. ${ }_{5}$ in. through, long peduncled

Leaves ovate-oblong; nerves and young parts and figs red-tomentose . .

Leaves oblong glabrous.

Figs peduncled; leaves mottled, white beneath

Figs very shortly peduncled or sessile; leaves plain beneath.

Mouth of fig ringed; leaves never very large

Mouth of fig not ringed; leaves often large

Leaves oblong hairy beneath.

Leaves small, white-hairy beneath . .

Leaves large, cordate, rigid, hairs red .

Trees, shrubs or bushes, erect.

Bush terrestrial or epiphytic; leaves polymorphous, ocre beneath, usually spathulate

Shrub glabrous; leaves ovate membranous :

Shrubs hairy; leaves ovate, often lobed.

Leaves white beneath. Figs smooth orange and red

Leaves green.

Petioles long slender; leaves cordate; figs oblong, hairy

Petioles short.

Leaves oblong large, entire, yellow hairy beneath; figs hairy sub-sessile.

Leaves ovate cordate, large. Figs hairy peduncled

Leaves ovate acuminate cordate sometimes trilobed, woolly beneath. Figs hairy

Leaves narrow-lanceolate, small, nerves hairy. Figs small minutely hairy slender oblanceolate or elliptic denticulate like figs covered with yellow

Leaves narrow-lanceolate, all glabrous. Figs sub-globose warty .

Leaves elliptic acute hairy on nerves.
Figs hairy Small shrublets, glabrous; leaves narrow; fruit pear-shaped sh with small globose sub-sessile figs .

Erect bush with small globose sub-sessile figs .
Tree. Figs containing all three kinds of flowers

(57) F. excavata

(58) F. lævis

(59) F. obtusa

(6o) F. alutacea

(6I) F. recurva

(62) F. ramentacea

(63) F. araneosa

(64) F. villosa

(65) F. diversifolia

(66) F. glandulifera

(67) F. alba

(68) F. cordata

(69) F. fulva

(70) F. patens

(7I) F. mollissima

(72) F. oreophila

(73) F. chrysocarpa

(74) F. variolosa

(75) F. pedunculosa

(76) F. pyriformis

(77) F. chartacea

(78) F. lepidosa

$\S$ vii. Neomorphe. Trees or shrubs not epiphytic. Figs often very large. Male and gall flowers in one fig; females in another sct. Stamens 2.

Tree. Leaves ovate serrate not cordate. Figs very large over $\mathrm{I}$ in. through from base of stem. 


\section{$\S$ i. PALæOMORPHE}

(I) F. pisifera Wall. Cat. 4504; Hook. fil. F.B.I. v. 496; King, Ann. Bot. Gard. Calc, i. t. I.

Strong climbing epiphyte, later a tree 20 to $50 \mathrm{ft}$. tall. Leaves sub-coriaceous, inequilateral oblanceolate or elliptic cuspidate, toothed at top or not, base narrow very unequal, 7 in. long, 2.5 in. wide; petioles very short. Figs clustered and solitary on the branches, I5 in. long, white, globose; pedicels slender, 5 in. long. Male flowers and gall flowers in the same receptacle. Stamen I. Females in other figs, perianth gamophyllous. Hab. Common in Malay Peninsula, Singapore, Tanglin; Kranji; Bukit Timah (Hullett). Pahang, Kwala Semantan (leaves rather hairy). Malacca, Selandor and Chabau (Cantley). Selangor near Klang Gates. Perak, Goping (Kunstler); Thaiping (Wray). Penang, road to Sungei Penang (Curtis). Distrib. Malay isles. Native names: Akar Beringin; Ara Lidah Rimau; Ara Supideh; Supideh Paya.

(2) F. gibbosa Bl. Bijdr. 466; Hook. fil. F.B.I. v. 496; King, Ann. Bot. Gard. Calc. 4, t. $2 \mathrm{~A}$.

Epiphytic at length a tree; branches scabrid. Leaves coriaceous, glabrous, very slightly or not inequilateral, lanceolate, bluntly acuminate or cuspidate, base cuneate, 3-nerved from base, lateral nerves irregular, $3.5 \mathrm{in}$. long, $\mathrm{I} \cdot 5 \mathrm{in}$. wide or less; petioles $\cdot 2$ in. long or less. Leaves dry brown beneath with pale nerves. Figs orange yellow, $5 \mathrm{in}$. through (dry $\cdot 25$ in.), globose usually solitary below the leaves or in axils; peduncles slender, $I$ in. long. Umbilicus of fig prominent, pale. Male sepals 4 to 6 , linear, hairy. Stamen I. Female sepals 4, linear. Achene papillose oblique ovoid. Hab. Not common. Selangor, Batu Road, Kwala Lumpur (Hashim). Perak, Ulu Bubong (Kunstler, Wray, Scortechini). Distrib. Indo-Malaya, Hongkong.

This is very variable elsewhere, our form is F. cuspidifera Miq.

(3) F. subulata Bl. Bijdr. 46I; Hook. fil. F.B.I. l.c. 497; King, l.c. 8 , pl. 6 .

Climber 80 to roo ft. long, stem 4 to $6 \mathrm{in}$. through, or erect; young parts pubescent. Leaves membranous elliptic-lanceolate to obovate, cuspidate, base acute, glabrous; nerves io to I6 pairs slender, very slightly raised; 6 to 9 in. long, 3 in. wide; petioles - I5 in. long. Figs axillary below the leaves, 2 or 3 together, $\cdot 25$ in. through, yellow; females globose; males ovoid; peduncles $\cdot$ I in. long or less with numerous ovate bracts. Male flowers tubular 4-toothed. Stamen I. Female flowers tubular, teeth 4, long, hairy. The male plant is erect and shrubby; the female a climbing epiphyte. Hab. Not rare. Johor, Kwala Kahang (Kelsall); Castlewood. Muar, Bukit Keyara (Fox). Pahang, Kwala Tembeling. Negri Sembilan, Tampin Hill; Bukit Kandang. Selangor, 
Kwala Lumpur (Curtis); Semangkok Pass. Perak, Temengoh; Tupai (Wray); Goping (Kunstler); and Chanderiang. Penang, Penara Bukit (Curtis). Kelantan, Kota Bharu. Distrib. Chittagong, Malay isles to Philippines, China.

(4) F. parietalis Bl. Bijdr. 462; Hook. fil. l.c. 498; King, l.c. IO, pl. 8.

Epiphytic shrub; branchlets, figs, petioles and underside of leaves rusty pubescent. Leaves coriaceous, elliptic-oblong, long caudate, base narrowed, blunt; nerves and reticulations strongly raised beneath; nerves I pair from base and 2 pairs from midrib, 7 to $\mathrm{I} 2 \mathrm{in}$. long, 3 to 3.5 in. wide; petioles thick, $\cdot 25$ to $\cdot 5$ in. long. Figs bright orange, globose, hairy, $\cdot 4$ in through; peduncles $\cdot 2$ in. long, solitary or in pairs axillary. Male flowers few with gall flowers; sepals 5, connate. Stamen I. Female perianth 3-lobed, lobes linear. Hab. Malacca, Selandor; Brisu (Cantley): Perak, Kampang Kota; Matang Jambu and Thaiping (Wray). Penang (Wallich); Penara Bukit (Curtis). Adang group, Pulau Rawei. Native name: Akar Lendang Putih.

(5) F. urophylla Wall. Cat. 4483 ; King, l.c. ii. II, pl. 9.

Shrub epiphytic. Leaves coriaceous, thinly ovate, abruptly caudate entire or sinuate at top, base narrowed; nerves 2 to 3 pairs, bold; $2 \cdot 5$ to 4 in. long, $\cdot 75$ to 2 in. wide; petioles $\cdot 25$ in. long. Figs 2 to 3 in. through, globose, orange; peduncles slender as long, axillary, glabrous. Male flowers; sepals 4. Stamen I, joined to a pistillode. Female flowers, perianth trifid. Hab. Common in low country, Singapore Gardens; Cluny; Bukit Timah. Johor, Pinerong; Batu Pahat. Malacca, Merlimau (Cantley). Dindings, Pulau Sembilan. Perak, Tapah (Wray); Ipoh (Curtis); Thaiping Hills. Penang Hill (Curtis). Kelantan, Kota Bharu. Distrib. Assam, Burma. Native name: Akar Buntat Ular.

(6) F. celebica Bl. Bijdr. 46I; Hook. fil. l.c. 498; King, l.c. I2, pl. Io. var. Kunstleri.

Sub-scandent shrub; branchlets hairy. Leaves membranous elliptic-lanceolate acuminate (or caudate) serrate, base shortly narrowed blunt inequilateral, scabrid above, beneath hairy, especially on the elevated 6 pairs nerves and reticulations, 4 in. wide; petioles very short. Figs globose, I to 4 , sessile, hairy, white, ' 5 in. through when dry. Hab. Perak, Larut (Kunstler). Distrib. Celebes, Philippines.

(7) F. Burkillii Ridl.

A bush, quite glabrous. Leaves sub-coriaceous lanceolateelliptic narrowed at tip blunt, more narrowed to base, or rounded at tip; nerves 6 pairs, undulate, reticulations oblong or angled, thickly dotted within; 4 to 4.5 in. long, 2 to 2.1 in. wide; petioles $\cdot 3$ in. long. Figs in axillary pairs glabrous except the bracts, globose-pyriform, $\cdot 25$ in. long, peduncles $\cdot I$ in. long, thick. Basal bracts 3 ovate, edges ciliate. Scales at mouth ovate pubescent. 
Male flowers pedicelled. Sepals 4, ovate acute, dark red edged white. Anther I, oblong red; filament short. Rudimentary pistil elliptic nearly as long. Gall flowers few, about ro. Achenes large oblong unequally reniform smooth; style below the tip lateral. Hab. Pahang, Pinetree Hill upon Fraser Hill (Sempang) (Burkill and Holttum).

\section{§ii. Urostigma}

(8) F. bengalensis Linn. Hort. Cliff. 47I, t. 4; Hook. fil. l.c. 499; King. Ann. Bot. Gard. Calc. I8, pl. I3, 8IC.

A big tree rooting from branches; young parts soft pubescent. Leaves coriaceous ovate or orbicular, base round, sub-cordate, pubescent beneath; nerves 5 pairs, prominent; 5 to 8 in. long, 3 to 5 in. wide; petioles $I$ in. long. Figs sessile in pairs axillary, globose, pinkish red, puberulous, as big as a cherry. Hab. Cultivated here and there in Singapore and other towns. The Banyan.

(9) F. pilosa Reinet. Bl. Bijdr. 446; Hook. fil. l.c. 500; King, l.c. $2 \mathrm{I}, p l$. $\mathrm{x} 6$.

Large tree; branches thick, red-tomentose. Leaves stiff, coriaceous, shining above, tomentose beneath, oblong shortly cuspidate acuminate, base narrowed or rounded; nerves about 8 pairs elevate beneath; 5 to 6 in. long, $2 \cdot 75$ to 3 in. wide; petioles thick tomentose, I in. long. Figs solitary, sessile oblong, I in. long, glabrous, red. Bracts at base round, large. Hab. Penang Hill (Curtis). Distrib. Java to Australia.

The leaves are more coriaceous and fruit much larger than the other specimens seen.

(ro) F. consociata Bl. Bijdr. 447; Hook. fil. l.c. 505; King, l.c. $33, \mathrm{pl} .36,37$.

Epiphyte forming a large bush; young parts covered with a red-brown flocculent tomentum. Leaves coriaceous eventually glabrous elliptic or oblanceolate, base round or cordate occasionally narrowed, tip blunt; nerves basal pair and 6 pairs above strongly elevate, midrib stout; II in. long, 4 in. wide; petioles stout, 2 in. long. Figs in pairs, sessile, nearly I in. through, orange, tip flattened with broad rounded umbo scales. Basal bracts large, rounded. Hab. Singapore, Seletar; Changi; Bukit Timah. Johor, Tanjong Kupang. Pahang, Temerloh, Malacca (Griffith). Selangor, Kwala Lumpur. Perak, Tapah (Wray); Larut (Kunstler). Disirib. Sumatra, Java. Native name: Akar Piangu Antan.

(II) F. bracteata Wall. Cat. 4498; Hook. fil. l.c. 50I; King, l.c. 23 , pl. Ig.

Very large shrub or short tree; young branches, leaves beneath, stipules, petioles and figs covered with flocculent red wool. Leaves rigid, coriaceous obovate-oblong with a short point, base cordate; nerves 7 or 8 pairs inarching, very prominent; 9 to II in. long, 4 to 4.5 in. wide; petioles thick, I in. long. Figs sessile at the end 
of the branches in the axils of large triangular acuminate bud-scales, the lowest over I in. long and tomentose on back. Figs globose or turbinate, orange, densely tomentose. Hab. Singapore (Wallich); Batu Putih; Chua Chu Kang. Johor, Malacca (Bland). Selangor, Kwala Lumpur (Curtis). Perak, Larut (Kunstler).

(I2) F. xylophylla, Wall. Cat. 4558; Hook. fil. l.c. 503; King, l.c. $29, \mathrm{pl} .28$.

A big epiphyte or low tree. Leaves very thick, coriaceous, broadly elliptic to obovate, narrowed to base, tip blunt or round; nerves 5 pairs obovate, the lowest pair from the leaf base; midrib very thick, reticulations lax; 6 to 9 in. long, 3 to 3.5 in. wide; petioles thick, 2 in. long. Figs sessile oblong umbonate, $\mathrm{I} \cdot 5$ in. long, yellow-orange or red with white spots; bracts triangular pubescent. Hab. Singapore (Wallich), Bukit Timah; Chan Chu Kang. Johor, Tempayan River. Malacca, Kwala Linggi and Bukit Bruang (Derry) ; Ayer Panas (Hervey). Selangor, Kwala Lumpur. Perak, Gunong Keledang; Goping (Kunstler). Penang, Moniot's Road; Gardens, etc. (Curtis, Wallich). Distrib. Sumatra, Borneo.

(I3) F. Lowii King, l.c. 32, pl. 33; Hook. fil. F.B.I. l.c. 504.

Stout climbing epiphyte, eventually glabrous. Leaves very coriaceous oblong-elliptic abruptly cuspidate, base round, margins thickened revolute, 3-nerved at base; midrib very stout with 6 pairs of nerves; 5 to 8 in. long, 2.5 to 4 in. wide; petioles 75 to I in. long. Figs sessile crowded, 5 to 75 in. long, dark red or yellow, globose. Bracts 3, coriaceous. Hab. Rare; Perak, Larut (Kunstler); Kenering (Wray). Use: Latex for birdlime.

(I4) F. procera Reinwdl. in Bl. Bijdr. 445; King, l.c. 35, pl. 40 and $4 \mathrm{I}$.

A big tree, probably an epiphyte at first, glabrous. Leaves stiffly coriaceous oblanceolate or elliptic, shortly blunt-acuminate, base narrowed; midrib much elevate beneath; nerves fine, not much elevate, reticulations very fine; 5 in. long, 2 to 3 in. wide; petioles $I \cdot 5$ in. long. Stipules broad ovate acuminate glabrous. Figs in pairs, globose sessile, .5 in. long. Bracts very broad ovate, coriaceous nearly as long as the fig. Hab. Singapore, Fort Canning; Changi. Pahang River, Kwala Berah. Perak, Waterloo (Glasgow); Larut (Kunstler). Distrib. Java and Sumatra.

(I5) F. rigida Miq. Ann. Mus. Lugd. Bat. iii. 280; Hook. fil. F.B.I. l.c. 505.

Epiphyte, glabrous. Leaves coriaceous lanceolate acuminate or elliptic cuspidate, base narrowed acute; nerves 4 to 5 pairs, elevate beneath; 3 to 6 in. long, I.5 to 3 in. wide; petioles stout, $\cdot 75$ in. long. Stipules silky. Figs sessile on branch ends in pairs, sub-globose to oblong, 5 in. through, orange yellow with white spots, basal bracts large orbicular at first covering the fig imbricate; umbo rather large, scales round with a fleshy ring below. Hab. Singapore, Bukit Timah. Perak (Kunstler, Scortechini). Penang (Phillips). 
(I6) F. annulata Bl. Bijdr. 448; Hook. fil. F.B.I. l.c. 502; King, l.c. 25, pl. 28 .

Epiphyte glabrous or tree $50 \mathrm{ft}$. tall. Leaves thinly coriaceous, oblong or oblanceolate, short acuminate, base round or short narrowed; nerves Io to I5 pairs prominent beneath; 7 in. long, $2 \cdot 75$ in. wide; petioles 75 in. long. Figs ovoid umbonate, I in. long, greenish yellow with brown and white spots; peduncles stout, $\cdot 5$ in. long with a thickened ring near tip and 3 ovate acute bracts. Male flowers numerous, pedicelled; female flowers few, tube 4-lobed. Hab. Singapore, Bukit Timah. Johor, Batu Pahat. Malacca, Jasin (Goodenough); Jus (Cantley). Negri Sembilan, Johol. Selangor, Kampong Kerling (Goodenough); Kwala Kubu; Kwala Lumpur. Perak, Kwala Wok (Wray); Larut (Kunstler). Province Wellesley, Ara Kuda. Distrib. Burma, Malaya. Native names: Ara Bungkus; Kubangan.

(I7) F. globosa Bl. Bijdr. 449; Hook. fil. F.B.I. l.c. 503; King, l.c. 27 , pl. 25 .

A bushy climber; young branches scurfy eventually quite glabrous. Leaves thinly coriaceous, dark green elliptic or oblong abruptly cuspidate, base rounded or narrowed; nerves 6 to 9 pairs elevate inarching; 3.5 to 6.5 in. long, 2.5 to 3 in. wide; petioles .5 to $I .5$ in. long. Figs in axillary pairs globose, green, umbonate, when adult nearly turbinate. Bracts small 3; peduncles stout, .2 in. long. Male flowers pedicelled. Sepals 4. Anther I, sessile. Female flowers tubular 5-toothed. Hab. Common, Singapore, Reservoir Woods; Changi, Bukit Timah. Johor, Kwala Tebing Tinggi; Pulau Tiuman. Malacca, Merlimau (Cantley). Pahang, Pekan. Negri Sembilan, Bemban (Cantley). Selangor, Kwala Lumpur. Perak, Kinta (Kunstler). Penang (Wallich). Distrib. Malay isles. Native names: Ara Kulalayo; Ara Paya.

(I8) F. dubia Wall. Cat. 456I; Hook. fil. F.B.I.l.c. 509; King, l.c. 46 , pl. 56 .

A big tree, glabrous. Leaves thickly coriaceous elliptic acute, base shortly narrowed; nerves fine, 6 pairs, secondaries nearly as conspicuous, reticulations minute conspicuous; 4 in. long, $2 \cdot 25$ in. wide; petioles 5 in. long. Figs ovoid-globose, bright pink, I in. through, on pedicels ' 25 in. long. Bracts 3 , short round at base. Hab. Singapore, Bukit Mandai; Serangoon Road; Tengeh, Malacca, Ayer Panas; Selandor (Cantley). Penang (Wallich); Penara Bukit (Curtis). Distrib. Sumatra. Native names: Ara Gajah; Ara Kubang; Poko Kuap.

A very fine and handsome tree, the young leaves sometimes oblanceolate.

(I9) F. pruniformis Bl. Bijdr. 45x; Hook. fil. F.B.I. l.c. 502; King, l.c. 24, pl. $2 \mathrm{I}$.

Epiphyte on trees, glabrous except the stipules. Leaves coriaceous lanceolate or ovate-lanceolate acuminate, base sub-acute; 
nerves 8 pairs, slightly elevate; 5 in. long, 2 in. wide; petioles $\cdot 5$ in. long. Figs green with white spots, ovoid, $\cdot 5$ in. long, I in. through; peduncles I in. long. Bracts 3, ovate acute. Male flowers numerous pedicelled. Sepals 2. Stamen I. Female flowers sessile. Hab. Not common, Dindings, Bruas (Burn-Murdoch). Perak, Ipoh (Curtis); Batu Togoh (Wray); Goping (Kunstler). Distrib. Java, Sumatra.

(20) F. indica Linn. Sp. Pl. I060 (part), Hook. fil. F.B.I. l.c. 506; King, Amn. Bot. Gard. Calc. i. 39, pl. 45. F. pellucidopunctata Griff. Notula, iv. 394; Ic. Pl. t. 544.

Big tree. Leaves coriaceous, oblong or elliptic cuspidate, base narrowed, 3-nerved at base, lateral nerves slender, hardly elevate, 4 to 6 pairs; 4 to $7 \cdot 5 \mathrm{in}$. long, 2 to 3 in. wide; petioles 5 to $I$ in. long. Figs in pairs sessile, globose, 4 in. through, orange yellow. Bracts fairly large ovate acute. Hab. Not rare, Singapore, Garden Road; Selitar. Johor, Tebing Tinggi. Pahang, river at Renchong; Gunong Berumbun. Malacca (Griffith); Selandor and near town. Selangor, Weld's Hill; Ulu Sapetang (Burn-Murdoch). Perak, Asam Kumbang and Tapah (Wray). Penang, Waterfall (Curtis). Kelantan, Gunong, Kota Bharu.

var. Gelderi has oblong figs. Malacca, etc. Distrib. Burma, Malaya. Native names: Ara Tampoh Pinang; Ara Tandok.

(2I) F. microstoma Wall. Cat. 4566; Hook. fil. F.B.I.l.c. 506; King, l.c. 38 , pl. 44 .

Tree about 40 to $60 \mathrm{ft}$. tall, stem $\mathrm{I}_{5} 5$ to $2 \mathrm{ft}$. through. Leaves coriaceous, elliptic-ovate shortly cuspidate or round at tip, base shortly narrowed; nerves 4 to 7 pairs little elevate beneath; 4 to 6.5 in. long, 2.5 in. wide; petioles 5 in. long. Figs $\cdot 3$ in. long, sessile in axillary pairs, globose green with a conspicuous yellow umbo, of the scales surrounding the rather large mouth forming a ring. Bracts 3, broad ovate. Hab. Singapore (Wallich); Gelang; Bukit Tanah; Pasir Panjang. Johor, Tempayan River; Sedenak. Malacca, Jus (Goodenough). Negri Sembilan, Tampin Hill. Perak, Larut (Kunstler). Native names: Ara Kechil ; Ara Nasi.

(22) F. elastica Roxb. Hort. Beng. 65; Hook. fil. F.B.I. l.c. 508 ; King, l.c. 45 , pl. 54 .

Big shrub or tree. Leaves large, coriaceous oblong to elliptic, bluntly caudate, base round or narrowed; nerves very fine, parallel and close; midrib prominent, 8 in. long, 5.5 in. wide; petioles 2 in. long. Stipules (bud bracts) 7 in. long, red. Figs sessile in pairs ovate-oblong, greenish yellow, 5 in. long. Hab. Perak on limestone rocks above the railway at Ipoh (Curtis). Distrib. Assam and Sumatra. Native name: Getah Rambong.

Formerly cultivated for the rubber, and thus scattered about in various places in the peninsula. The big plant high up on the rocks at Ipoh is believed to be really wild, but I have never seen another apparently wild in our region. 
(23) F. obtusifolia Roxb. Fl. Ind. iii. 546; Hook. fil. F.B.I. l.c. 507 ; King, Ann. Bot. Gard. Calc. 42, pl. 49I.

A big tree 80 to I20 ft. tall, stem 3 to $4 \mathrm{ft}$. through. Epiphytic when young. Leaves thickly coriaceous, elliptic-oblong or obovate, round, blunt, base acute, 3 -nerved at base, side-nerves very slender parallel, rather inconspicuous, midrib stout, prominent; 4 to $7 \mathrm{in}$. long, $2 \cdot 5$ in. or more wide; petioles $\cdot 5$ in. long. Figs in axillary pairs sessile, globose, pink tipped yellow or all yellow; umbo of 3 broad rounded bracts. Basal bracts 3 , coriaceous round, cordate. Hab. Rare. Perak, Goping (Kunstler). Lankawi (Curtis).

(24) F. acamptophylla Miq. Ann. Mus. Lugd. Bat. iii. 264; Hook. fil. F.B.I. l.c. 507; King, l.c. 40, pl. 46.

Climbing epiphyte (or tree) branchlets and bud-bracts silky pubescent. Leaves coriaceous, thick, glabrous obovate-oblong or elliptic cuspidate acuminate, base narrowed; nerves little raised, conspicuously inarching, 3 to 6 pairs; 3.5 to $4.75 \mathrm{in}$. long, I.5 to 2.5 in. wide; petioles rather stout, $I$ in. long. Figs orange yellow or dark green with yellow or red top, 5 in. through; umbo-scales 3, ovate, round, large. Bracts ovate, round puberulous. Hab. Rather rare. Johor, Sedenah. Dindings; Pangkor. Perak, Goping; Ulu Bubong (Kunstler). Distrib. Bangka.

\section{(25) F. microsyce Ridl.}

Epiphytic or terrestrial shrub, a few feet tall. Leaves stiffly coriaceous oblong shortly blunt cuspidate; nerves about 7 pairs with I pair from the base; 3 in. long, $I$ in. wide; petioles $\cdot 2$ in. long. Figs when adult $\cdot{ }_{5}$ in. through, globose, sessile in pairs with 3 ovate blunt bracts at base, annulus of mouth elevate yellow; scales inflected. Fruit few. Ovary ovoid ellipsoid; style lateral straight. Hab. Singapore, Garden Jungle; Jurong River (Ridley).

Certainly allied to $F$. microstoma, but a bush with smaller coriaceous leaves and much smaller figs.

(26) F. retusa Linn. Mantissa I29; Hook. fil. F.B.I. l.c. 5II; King, l.c. 50, pl. 6I.

A big tree with acrial roots, quite glabrous. Leaves coriaceous, broad ovate or rhomboid, bluntly cuspidate, base 3-nerved narrowed; side-nerves 5 to 6 pairs with numerous secondary ones all fine and not conspicuous, midrib prominent; 2 to 4 in. long, $\mathrm{I} \cdot 5$ in. wide; petioles $\cdot 25$ in. long. Figs in pairs sessile, $\cdot 3$ in. through, yellow or red, basal bracts broad ovate obtuse. Hab. Dry spots near the sea, often planted near shrines by the Chinese. Singapore, Bukit Timah; Changi. Malacca, Bukit Bruang. Negri Sembilan, Gunong Angsi. Perak, Selinsing Bay (Wray). Penang (Wallich). Perlis, Kanga. Distrib. Indo-Malaya, China. Native name: Ara Jejawi.

(27) F. truncata King, Ann. Bot. Gard. Calc. l.c. 4I, t. 48; Hook. fil. F.B.I. l.c. 507; King, l.c. 4I, pl. 43.

Tree 40 to $60 \mathrm{ft}$. tall, Io to I5 in. through. Leaves coriaceous, 
glabrous above, pubescent beneath, oblanceolate, tip broad and round, base narrowed; nerves 3 from base, side nerves 3 pairs with nervules sunk above, strongly raised beneath; 2 to 3.5 in. long, $\mathrm{I} \cdot 25$ to $\mathrm{I} \cdot 75$ in. wide; petioles $\cdot 5$ in. long. Figs densely crowded in terminal spikes; stipules (bud bracts) large ovate acuminate. Figs globose, sessile, 25 in. through, green tinted yellow; umbo of two large rounded scales; bracts rounded, small. . Hab. Rare, Pahang, Pekan. Johor, Tebing Tinggi. Selangor, Kwala Lumpur. Dindings, Bruas, Perak, Goping (Kunstler).

(28) F. Binnendijkii Miq. Ann. Mus. Lugd. Bat. iii. 288; King, l.c. 4I, pl. 47.

Tree glabrous. Leaves coriaceous, lanceolate-acuminate, base acute or rounded, conspicuously 3-nerved, lateral nerves inconspicuous inarching, reticulations nearly as prominent; (drying light greenish brown), 3 to 5 in. long, I.5 to 2 in. wide; petioles $\cdot 5$ in. long. Stipules ovate-lanceolate acuminate. Figs sessile in pairs depressed globose, $\cdot 2$ in. through. Bracts ovate blunt. Hab. Singapore, Chan Chu Kang; Pulau Buru. Pahang, Kwala Lipis (Foxworthy). Negri Sembilan, Bukit Tampin (Goodenough). Dindings, Pangkor (Curtis). Kedah, Gunong Geriang. Distrib. Java, Borneo.

(29) F. Benjamina Linn. Mantissa, I29; Hook. fil. F.B.I. l.c. ; King, l.c. $43, \mathrm{pl} .52$.

A big tree $80 \mathrm{ft}$. or more tall, much branched. Leaves thin, coriaceous ovate-elliptic cuspidate-acuminate, base round; nerves very fine, numerous and close, $\cdot 2$ to 3 in. long, I. 25 to 2 in. across; petioles $\cdot I_{5}$ to $\cdot 2$ in. long. Figs in axillary pairs, 3 in. through, red when ripe, globose. $H a b$. Commonly planted; Singapore, Penang, etc. Perak, Goping (Kunstler). Native of India and Malay isles. Native name: Waringan or Beringan.

I never saw a really wild plant.

(30) F. pisocarpa Bl. Bijdr. 454; Hook. fil. F.B.I. l.c. 510; King, l.c. 48 , pl. 59 .

Small tree $25 \mathrm{ft}$. tall. Leaves on branch-ends membranous, elliptic very short, cuspidate, base round; nerves numerous, horizontal, slender parallel; 2 to 3 in. long, I.5 in. wide; petioles slender, 5 in. long. Figs numerous below the leaves on bare branches, sessile in pairs, turbinate, globose, 25 in. through; bracts 3 , broad, blunt. Hab. Rare. Perak, Larut (Kunstler). Distrib. Java.

(3I) F. glabella Bl. Bijdr. 452; Hook. fil. F.B.I. l.c. 5II; King, l.c. 49 , pl. 60.

Big tree 50 to $60 \mathrm{ft}$. tall, $\mathrm{I} \cdot 5$ to $2 \mathrm{ft}$. through. Leaves thinly coriaceous, oblong or obovate-oblong, very short cuspidate, base narrowed; nerves very fine, not elevate, 6 to 7 pairs, reticulations as distinct; 2 to 3.5 in. long, I.5 to I.75 in. wide; petioles slender, 
.5 in. long. Figs about $\cdot 3$ in. through, globose flattened at top, white spotted purple (eventually black) sessile in pairs usually on leafless branches; umbo of about 3 broad scales, basal bracts small. $H a b$. Singapore, Bedok; Bukit Timah; Chan Chu Kang. Pahang, Pekan; Kwala Tembeling. Malacca, Bukit Sabukor and Ayer Panas (Derry). Perak, Larut (Kunstler). Penang (Philipps); Tanjong Bunga (Curtis).

(32) F. Rumphii Bl. Bijdr. 437; Hook. fil. F.B.I. l.c. 512; King, l.c. $34, \mathrm{pl} .67 \mathrm{~B}$.

A big tree; shoots (glabrous or) hairy. Leaves ovate cuspidate, base shortly narrowed, glabrous, thinly coriaceous, 4 in. long, 3 in. wide; petioles slender, 2 in. long. Figs sessile in axillary pairs, globose, .5 in. through, white with black spots, at length all black, basal bracts round, small. Hab. Not common, on rocks near the sea. Pulau Adang on Pulau Tengah. Dislrib. India and Malay islands.

Resembles $F$. veligiosa, but the leaves are narrowed at the base.

(33) F. religiosa Linn. Hort. Cliff. 47r; Hook. fil. F.B.I. l.c. $5 \mathrm{I} 3 ;$ King, l.c. $55, \mathrm{pl} .67 \mathrm{~A}$.

A big tree with coriaceous ovate caudate leaves, base round, 5- to 7 -nerved, 4.5 to 7 in. long, 3 to $4.5 \mathrm{in}$. wide; petioles 3 to 4 in. long, slender. Figs in axillary pairs sessile depressed spheroidal, dark purple, 5 in. through. Basal bracts broad, round.

A native of India, now gradually spreading round Singapore and other towns, frequently planted as a roadside tree. The Bo-tree, sacred to Buddha.

(34) F. infectoria Roxb. Fl. Ind. iii. 550; Hook. fil. l.c. 515; King, Ann. Bot. Gard. Calc. l.c. 6o, pl. 75 to 79 .

Glabrous tree. Leaves membranous, ovate acuminate, base round (rare narrowed); nerves slender, about 7 pairs; 4.5 to 5 in. long, $2 \cdot 25$ to 2.5 in. wide; petioles slender, $2 \cdot 25$ to 2.5 in. long. Figs globose, sessile in pairs below the leaves, white flushed and dotted red or orange. Basal bracts 3 , ovate, round minute. Hab. Singapore, Bukit Timah. Malacca (Griffith); Pulau Besar. Pahang, Pekan. Dindings, Pulau Sembilan, var, Lambertiana with big orange figs. Penang, Balik Pulau. Lankawi. Perlis, Kanga. Distrib. Indo-Malaya.

(35) F. vasculosa Wall. Cat. 4482; Hook. fil. F.B.I. l.c. 5I7; King, l.c. $65, \mathrm{pl} .86$.

Small tree. Leaves thin coriaceous, bright green when dry oblong or elliptic-lanceolate, blunt acuminate, base narrowed; nerves fine, 6 to I2 pairs, slender, slightly elevate below, conspicuous both sides; 4 to 4.5 in. long, I.5 to I.75 in. wide; petioles slender, 4 in. long. Figs in lower axils pear-shaped, bright yellow, base narrowed, .25 in. long; peduncles slender, $\cdot 5$ in. long. $\mathrm{Hab}$. Common. Singapore, Changi; Grange Road; Bukit Timah, etc.

FI.M.P., 3. 
Malacca, Ayer Keroh; Brisu; Sungei Hudang (Derry). Negri Sembilan, Bukit Senaling (Hudson). Selangor, Weld's Hill, Kwala Lumpur. Perak (Kunstler). Province Wellesley, Tasek Gelugur (Fox). Penang Hill (Curtis). Distrib. Tavoy, Bangka, Java, China. Native names: Ara Nasi; Supudi Tampang Burong.

\section{§iii. Syntecia}

(36) F. aurantiaca Griff. Nolula iv. 394; Ic. Pl. As. t. 504; Hook. fll. F.B.I. l.c. 517; King, l.c. ii. 67, pl. 87 .

Scandent scabrid shrub. Leaves thickly coriaceous, ellipticovate, base and tip narrowed hispid, scabrid beneath; nerves fine 8 to 9 pairs; 2.75 to 4 in. long, 1.5 to 2 in. wide; petioles $\cdot 5$ in. long, rather thick. Figs ovoid-cylindric, solitary russet red, $2 \cdot 25$ in. long, I.5 in. wide. Umbo-scales large. Peduncles 5 in. long. Bracts 3. Hab. Malacca (Griffith). Dislrib. Chappedong (Wallich), Java.

(37) F. punctata Thunb. Fic. 9; Hook. fil. F.B.I. l.c. 517; King, l.c. 68, pl. 88,89 .

Woody creeper. Leaves coriaceous, oblong to oblanceolate or rhomboid, very inæquilateral blunt or sub-acute, glabrous, tessellate beneath; nerves 2 to 4 pairs; 2 in. long, I.5 in. wide (the leaves on barren form very much smaller and narrow); petioles ' 12 in. long. Figs pear-shaped, oblong, 2 in. long, I.5 in. through, red with white marbling. $H a b$. Common on tree trunks and old stumps in open country. Singapore, Tanglin; Selitar. Perak, Tapah; Relau Tujor (Wray); Goping and Larut to 2500 feet altitude (Kunstler). Distrib. Malay isles.

The young form, with small narrow close-set leaves, is cultivated to cover walls, like ivy.

(38) F. callicarpa Miq. Ann. Mus. Lugd. Bat. iii. 268; King, l.c. $69, \mathrm{pl} .90$.

A strong woody creeper. Leaves thinly coriaceous, obovate tessellate, white beneath; nerves 3 to 4 pairs; 2.5 to $4 \mathrm{in}$. long, I.5 to 2 in. wide; midrib prominent; petioles 5 in. long. Figs pear-shaped, obovoid, 2 in. long, red with whitish spotting; peduncles $\cdot 2$ in. long. Hab. Common in woods, Singapore, Sungei Lalang. Johor, Kangka Atang (King). Pahang, Pekan. Malacca, Chenana putih (Cantley). Perak, Simpang (Wray); Larut and Goping (Kunstler). Penang, Pulau Betong and Sungei Penang (Curtis). Distrib. Tenasserim and Malay isles. Native names: Akar JalaJala; Akar Tunku Biawak hitam.

(39) F. apiocarpa Miq. Ann. Mus. Lugd. Bat. iii. 269, 289. Hook fil. F.B.I.l.c. 5 I8; King. l.c. 70 , pl. 92.

Stout climber; shoots pubescent. Leaves coriaceous, ovate or ovate-oblong, short acuminate, base narrowed or round; nerves 2 to 3 pairs, prominent beneath; 6 to 7 in. long, 3.5 in. wide; petioles 
5 in. long. Figs pyriform, 2 in. long, $I \cdot 5$ in. through, orangescarlet; peduncles 25 in. long. Hab. Common in forests, Singapore, Kranji ; Toas; Garden Jungle. Johor, Scudai River; Kwala Sembrong (Kelsall), Malacca (Griffith). Perak, Kota (Wray); Larut; Goping (Kunstler). Province Wellesley, Nibong Tebal. Distrib. Malay islands. Native names: Akar Tangis Burong; A. Halua.

\section{$\S$ iv. Sycidium}

(40) F. heterophylla Linn. fil. Suppl. 442; Hook. fil. l.c. F.B.I. 518; King, Ann. Bot. Gard. Calc. (2) 76, pl. 94.

A low creeping and rooting shrub, later becoming a large bush and finally a bushy tree, $20 \mathrm{ft}$. tall; young parts hairy. Leaves stiffly chartaceous, scabrid, very variable, according to the age of the plant. When it is low and creeping, they are $3 \mathrm{in}$. long and I in. wide, deeply cut into irregular acute toothed lobes, or linear acute, toothed with one or two lobes; 3 in. long, 25 in. wide; in bush form, leaves entire lanceolate acuminate at both ends, 3 in. long, $5 \mathrm{in}$. wide; in tree form elliptic serrate base rounded blunt, tip cuspidate, 4.5 in. long, I.75 in. wide; nerves variable, one to each lobe in the first form, 6 pairs slender in the tree form; petioles -I to $5 \mathrm{in.}$ long; figs globose or more or less pear-shaped, green with white spots; umbo distinct, open. Hab. Sandy river banks and damp spots near rivers, Pahang River, Pulau Datang; Pulau Manis. Selangor, Klang river on the Petaling Road, Kwala Lumpur. Perak, Kampong Kota (Wray); Goping (Kunstler). Distrib. Indo-Malaya.

(4I) F. quercifolia Roxb. Fl. Ind. iii. 534; Hook. fil. F.B.I. l.c. 519; King. l.c. $77, \mathrm{pl} .95$.

Creeping shrub. Leaves thick membranous, entire or lobed ovate or elliptic-obovate, coarsely serrate acuminate scabrid all over; nerves 5 to 7 pairs, raised on both sides; 2 to 5 in. long; petioles $\cdot 5$ to $I$ in. long, hairy. Figs $\cdot 25$ to $\cdot 5$ in. long, crimson, in axillary pairs ovoid or pear-shaped; peduncles $\cdot 25$ to $\cdot 5$ in. long. Hab. Rocks by streams, Pahang River, Pulau Tijau. Perak, Ulu Temengoh. Kelantan, Kwala Lebir (Gimlette). Distrib. Burma, S. Siam. Native name: Kesinan.

var. inconstans, F. inconstans, Miq. in Hook. Lond. Journ. Bot. vii. 232 .

Small slender shrub, 2 to $3 \mathrm{ft}$. tall. Leaves lobed, $7 \mathrm{in}$. long, 3 in. wide; petioles 5 in. long (lower ones). Figs red, $\cdot 25$ in. long. Hab. Kelantan, Chaning, edges of woods. Distrib. Java.

The species is extremely variable in all points, and perhaps may have to be broken up eventually.

(42) F. obscura Bl. Bijdr. 474; Hook. fll. F.B.I. l.c. 52I; King, l.c. 8r, pl. I02 and I03.

Shrub or tree. Leaves membranous scabrid above, hairy 
beneath, oblong to oblanceolate or sub-trapezoid unequal-sided caudate dentate-serrate; nerves 4 to 5 pairs, elevate beneath; 5 to ro in. long, 3 in. wide; petioles 5 in. long. Figs ovoid or globose sub-sessile on the old wood, scabrid or hairy, pink, $\cdot 3$ to .75 in. through; peduncles $\cdot$ I to $\cdot 5$ in. long. Stamens in male flower sometimes 2. Hab. Common, Singapore, Bukit Timah; Chan Chu Kang; Pulau Ubin. Johor, Pulau Aor. Selangor, Ulu Gombak (Burn-Murdoch). Perak, Temengoh. Distrib. Indo-Malaya.

(43) F. copiosa Steud. Nomencl. ed. 2, i. 635; Miq. Ann. Mus. Lugd. Bat. iii. 27I, 29I; King. l.c. 85, pl. I9o.

Shrub or small tree, nearly or quite glabrous. Leaves membranous, oblong, oblanceolate to ovate or coarsely serrate, pale beneath, acute, base blunt, sometimes rounded cordate; nerves 6 or 7 pairs, rather conspicuously tri-nerved at base; I2 in. long, 5 to 8 in. wide; petioles $1 \cdot 5$ to 3 in. long, rather thick; stipules lanceolate acuminate, 5 in. long. Figs globose, 25 in. through, shortly peduncled in clusters on the old branches, minutely warty, no basal bracts; scales of mouth rather large and conspicuous. Hab. Rare, Perak, no locality given (Wray). Distrib. Java, Celebes, Sumatra.

(44) F. brevicuspis Miq. Fl. Ind. Bat. i. (2), 315; King, l.c. 84, pl. ro6.

A shrub; young branches sparsely hispid. Leaves thick, membranous obovate-elliptic, short cuspidate, slightly undulate, base narrowed, blunt often cordate; nerves 8 pairs strongly elevate; quite glabrous, 7 in. long, 3 in. wide; petioles rather thick, 5 in. long. Stipules lanceolate acuminate, 5 in. long. Figs solitary from leaf-axils globose, hairy when young, 5 in. long; peduncles .5 in. long, hairy. Umbo-scales prominent. No basal bracts. Hab. Rare, Johor, Gunong Pantai (Ridley). Distrib. Andamans, Java.

(45) F. rostrata Lam. Encycl. ii. 498; Hook. fil. F.B.I. l.c. 520 ; King, l.c. 85 , pl. IIo.

Glabrous epiphyte climbing on tree. Leaves oblong-elliptic or obovate, caudate, entire or sinuate toothed, base narrowed; nerves about 6 pairs, elevate beneath and conspicuous, as are the reticulations; 3 to 5 in. long, $x \cdot 5$ to 3 in. wide; petioles ${ }^{\prime} 5$ to $\cdot 2$ in. long. Figs globose, pear-shaped, $\cdot 2$ in. long, orange, sessile or peduncles very short in axillary pairs. Hab. Common in woods, Singapore, Gardens. Johor, Sungei Tebrau; Genuang; Gunong Pulai; Tengarah (Feilding). Pahang, Telom. Malacca, Chabau (Griffith); Bukit Bruang (Derry); Mt. Ophir. Selangor, Kwala Lumpur (Curtis). Perak, Thaiping Hills. Penang (Wallich, Curtis). Distrib. Malay isles. Much resembles $F$. urophylla, Wall.

(46) F. cuspidata Reinwdt. Bl. Bijdr. 474; Hook. fil. F.B.I. l.c. 520 ; King, l.c. 88, pl. II2. var. sinuata King, l.c.

Shrub or tree, erect. Leaves sub-coriaceous elliptic-lanceolate 
or linear-oblong, abrupt caudate acuminate glabrous shining undulate; nerves 6 to 8 pairs horizontal; 6 in. long, $I \cdot 5$ in. wide; petioles $\cdot 15$ in. long. Figs globose, $\cdot 12$ in. through, crimson with a yellowish tinge, very shortly peduncled or sub-sessile axillary. Hab. Rare, Perak, Thaiping Hills, at 2500 to $3000 \mathrm{ft}$, altitude. Distrib. of type, Sumatra and Java.

(47) F. trachycarpa Miq. in Hook. Lond. Journ. Bot. vii. 430. F. clavata Wall. Cat. form trachycarpa; King, Bot. Gard. Calc. ii. 87 , pl. B.

Epiphytic shrub, glabrous. Leaves membranous lanceolate or oblanceolate, long or short cuspidate entire or undulate; nerves slender, I2 pairs; 5 to $8 \mathrm{in}$. long, 3 in. wide; petioles 25 in. long. Stipules narrow-linear lanceolate. Figs globose, ' 15 in. through, brown, axillary solitary; peduncles slender, $\cdot 2$ in. long with several bracts at base, and 3 about half-way up the peduncle. Bracts of mouth small ovate, brown. Hab. Malacca (Griffith), Selangor, Batu Caves (Ridley). Distrib. Malay isles.

I do not see how this small fruited plant can be the same species as the big-fruited Indian plant, $F$, clavata.

\section{$\S$ v. Covellia}

(48) F. cunia Ham. in Roxb. Fl. Ind. iii. 56r; Hook. fll. F.B.I. l.c. 523; King, l.c. IOI, pl. I27.

Bush or small tree. Leaves elliptic or oblong-lanceolate, base very inequilateral, one lobe round, acuminate acute, glabrous above, hairy beneath ; nerves elevate beneath, I2 pairs; 4 to 8 in. or more long, $I \cdot 75$ to 3 in. wide; petioles thick, pubescent, $\cdot 25$ in. long. Figs on long leafless pendulous branches $2 \mathrm{ft}$. or more long, pubescent, with short pubescent lateral branchlets 25 in. long, the figs sub-globose, hairy, pink, 5 in. through. Hab. Common in hill forests. The fruiting branches run along the ground and are seldom to be met with. Pahang, Pulau Tawar; Tahan River. Johor, Bukit Jitan; Serom. Selangor, Kwala Kubu; Ginting Bidai, etc. Perak, Temengoh; Thaiping Hills. Kelantan, Chaning. Distrib. India and Burma.

(49) F. Miquelii Hook. fil. F.B.I. l.c. 524; King, Ann. Bot. Gard. Calc. (2), Io6, pl. I24.

Tree about $40 \mathrm{ft}$. tall. Leaves membranous oblanceolate or elliptic cuspidate acuminate, base narrowed; nerves slender conspicuous, 9 pairs, transverse nervules fine, conspicuous; 7 in. long, $2 \cdot 25$ in. wide; petioles $\cdot I$ in. long. Figs ovoid-turbinate on simple or few branched racemes, stout, 6 in. long from lower part of trunk, brownish green, $\cdot 6$ in. through; peduncles $\cdot 5$ to $\cdot 75$ in. long. $H a b$. Common in wet lowland woods, Singapore, Stagmount; Bukit Timah. Pahang, Khol, Pahang River. Negri Sembilan, Tampin Hill (Goodenough). Selangor, Batu Caves; Weld's Hill, 
Kwala Lumpur. Distrib. Malay islands, Tenasserim. Native name: Ara Katak. King. l.c.

(50) F. hispida Linn. fil. Supp. 442, Hook. fil. F.B.I. l.c. 522;

Shrub or small tree 20 to $30 \mathrm{ft}$. tall; branches hollow, hairy. Leaves ovate-oblong or sub-obovate acute obscurely toothed, base round, scabrid above; nerves 5 to 6 pairs and transverse nervules elevate beneath; 8 in. long, 4 in. wide; petioles $\mathrm{I} \cdot 25$ in. long. Figs in fascicles on the old wood, turbinate green, 75 in. through; peduncles o to $I$ in. long, sometimes in long sprays from the lower part of the trunks, as in $F$. ribes. Hab. Pahang, Pekan and Pulau Tawar. Selangor, Batu Caves; Bukit Hitam (Kelsall). Perak,

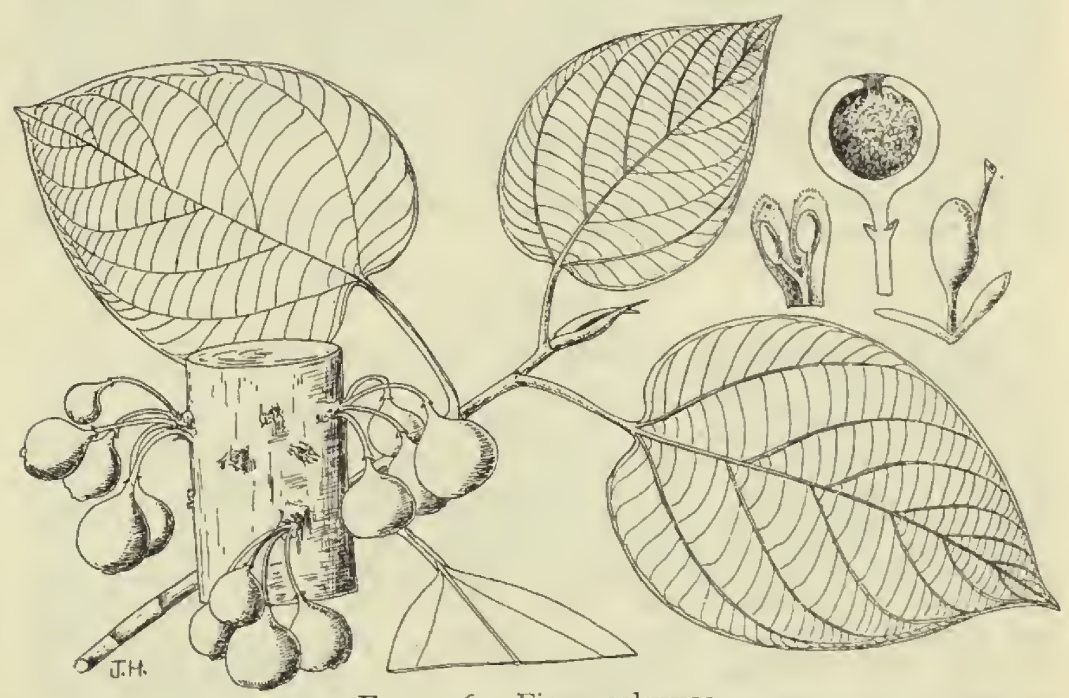

FIG. 156.-Ficus polysyce.

Temengoh; Thaiping Waterfall. Kelantan, Kamposa; Chaning woods. Penang, very common. Kedah, Yan. Distrib. India and Siam, Malay isles, China, Australia.

(5I) F. polysyce Ridl. Journ. Roy. As. Soc. S. Br. 82, p. I95.

Tree about $50 \mathrm{ft}$. tall, stem over I ft. through. Leaves elliptic or lanceolate membranous and short acuminate or cuspidate; nerves about 9 pairs elevate beneath; 6 in. longr $\mathrm{I} \cdot 75$ to $2 \cdot 25$ in. wide; petioles $\mathrm{I} \cdot 25$ in. long. Figs in clusters or tubercles on the stem and branches, obovoid, top flat, green (rarely turning dull red), often completely covering the trunk and boughs, 75 in. through; umbo large; peduncles slender, 5 in. long. $H a b$. Common in secondary growth and forests, lowland, Singapore, Garden Jungle, etc., Johor, Batu Pahat; Gunong Pulai. Pahang, Pekan. Negri 
Sembilan, Tampin; Bukit Klana and Bukit Sulu (Cantley). Selangor, Bukit Kutu; Kwala Lumpur. Dindings, Lumut. Perak, Ulu Bubong (Kunstler); Thaiping Waterfall (Wray). Penang, Waterfall (Curtis). Lankawi (Curtis). Distrib. S. Siam. Native names: Ara Batu; Kedumpong; Kelumpong.

(52) F. fasciculata Hook. fil. F.B.I. v. 524.

Tree I5 ft. tall; shoots hairy. Leaves membranous, oblanceolate elliptic, subcrenate, cuspidate, base narrowed; nerves 9 to Io pairs slender, elevate, strigose, hairy beneath; 8 in. long, 2.75 in. wide; petioles 25 in. long, rather stout. Figs fascicled in clusters on stem, red brown, hairy sub-globose, ridged; peduncles slender, .5 in. long. Hab. Rare, Perak, Kampar River (Kunstler).

(53) F. Scortechinii King, Ann. Bot. Gard. Calc. I., II2, pl. I47.

Small tree I5 ft. tall; shoots appressed hairy. Leaves inequilateral elliptic to obovate-elliptic abruptly cuspidate, base acute, edge undulate; nerves 4 to 5 pairs; underside with minute white tubercles and hairy on nerves; 7 to 9 in. long, 3 in. wide; petioles .4 in. long, brown hairy. Stipules paired, lanceolate, hairy. Figs 5 to 8 on tubercles on the stem peduncled sub-globose, russet brown, vertically ridged, glabrous; bracts 3 , small; peduncles $\cdot 35$ in. long, pubescent. Female flowers only seen. Hab. Perak, banks of Kampo (? Kampar) River (Kunstler).

(54) F. obpyramidata Hook. fil. F.B.I. v. 525; King, Ann. Bot. Gard. Calc. l.c. II6, pl. I53.

Tree 25 to $30 \mathrm{ft}$. tall; branchlets hairy at first, hollow. Leaves elliptic-obovate acute, base round or cordate; nerves 6 pairs, slender, hairy beneath; 6 to 7.5 in. Iong, 3 to 3.5 in. wide; petioles I in. long, hairy. Figs obpyramidal, I in. through from leafless branches on the trunk; peduncle stoutish, 25 in. long. Hab. Selangor, Dusun Tua (Ridley). Perak, Larut (Kunstler).

(55) F. lepicarpa Bl. Bijdr. 459; Hook. fil. F.B.I. v. 525; King, l.c. IIS, pl. 156 .

Small tree; branchlets pubescent at first as are stipules. Leaves thick, membranous oblanceolate sub-acute or blunt, base broad or narrowed; nerves 7 or 8 pairs strongly elevate beneath; 5.5 in. long, 2 to 2.5 in. wide; petioles rather thick, 5 in. long. Figs sessile in axils ellipsoid, warted and sparsely hairy, green tipped grey-brown, $5 \mathrm{in}$. through. Umbo large, scales hairy. Basal bracts large ovate acute. Hab. By water-courses, Negri Sembilan, Bukit Tangga Pass. Selangor, Ulu Gombak. Perak, Thaiping Hills (Kunstler, Wray). Penang (Wallich, Phillips, Curtis). Distrib. Malay isles.

(56) F. fistulosa Reinwdt. in Bl. Bijdr. 470; Hook. fil. F.B.I. v. 525 ; King. l.c. II4, pl. I50, I5I.

Stout bushy tree about $25 \mathrm{ft}$. tall, stem 4 to 6 in. through; branchlets hollow. Leaves membranous, oblong-lanceolate acuminate or cuspidate, base narrowed; nerves 5 pairs, slender, 3.5 to 6 in. 
long, 1.5 to 2 in. wide; petioles $\cdot 5$ in. long. Figs green, 5 to $\mathrm{I}$ in. through, axillary in pairs on pedicels 25 in. long. Hab. Pahang, Kwala Tembeling (figs spotted pink); Fraser Hill (Burkill). Perak, Thaiping Hills; Gunong Batu Putih (Wray); Goping (Kunstler). Penang, Batu Feringhi (Curtis). Kedah, Pulau Song Song. Distrib. Indo-Malaya.

\section{$\S$ vi. EUSYCE}

(57) F. excavata Hook. fil. F.B.I. v. 526; King, Ant. Bot. Gard. Calc. I27, pl. II5B.

Climbing epiphyte with pubescent shoots. Leaves orbicularovate, base round, top blunt, glabrous above, sparse pubescent beneath; nerves 2 pairs, I.25 to $I \cdot 5$ in. long; petioles $\cdot 2$ in. long, pubescent. Figs in clusters of 6 axillary, sessile, depressed globose, - I5 in. through (not ripe), orange-red, basal bracts 3 , triangularovate. Hab. Perak, Goping (Kunstler). Distrib. Borneo.

(58) F. lævis Bl. Bijdr. 437; Hook. fil. F.B.I. v. 526; King, l.c. I28, pl. I6I.

Epiphyte usually glabrous or small tree. Leaves ovate, base broad, acute tip, membranous; nerves 5 pairs; 7 in. long, 4 in. wide or less; petioles 3 in. long, pubescent. Figs I in. through, globose or pear-shaped, greenish yellow, pubescent, glabrous, hairy within; peduncles 75 in. long. Hab. Singapore, Bukit Timah top (Hullett); Chua Chu Kang. Selangor, Batu Caves, Perak, Ulu Leding (Wray); Larut (Kunstler). Penang, Gottlieb Road (Curtis), figs pear-shaped.

var. tomentosa King, l.c. I28. Leaves tomentose. Figs tomentose or pubescent; peduncles I in. long. Distrib. IndoMalaya.

(59) F. obtusa Hassk. Cat. Hort. Bogor, I844, 75; Hook. fil. F.B.I. v. $527 ;$ King. l.c. I30. pl. I63.

Large shrub, climbing on trees, 60 to $80 \mathrm{ft}$. long, stem 3 to 4 in. through; young parts tomentose. Leaves coriaceous, ovate blunt, base round, sparse hairy especially on nerves above, tomentose, greenish yellow beneath; nerves 4 pairs, elevate as are the transverse nervules; 3 to 4 in. long, 2 to 3 in. wide; petioles $\cdot 25$ in. long, thick tomentose. Figs sub-sessile in axillary pairs sub-globose, tomentose or puberulous, crimson, $\cdot 6$ in. through. Bracts 3 , ovate, pubescent; peduncles tomentose, $\mathrm{I}$ in. long or less. Hab. Malacca (Maingay). Selangor, near Klang Gates. Perak, Ulu Bubong and Larut (Kunstler). Penang, West Hill (Curtis). Distrib. Malaya.

(6o) F. alutacea Bl. Bijdr. 457; Hook, fil. F.B.I. v. 527; King, l.c. I3I, pl. I64.

Large epiphytic shrub 30 to $40 \mathrm{ft}$. long; stem I to 4 in. through ; young parts sub-glabrous. Leaves coriaceous elliptic to ellipticovate, blunt or acute, base shortly narrowed, blunt, beneath pustular tessellate and green and white; nerves 5 to 6 pairs promi- 
nent beneath; 3 in. long, 2 in. wide; petioles 75 to $\mathrm{I} \cdot 2$ in. long, scurfy. Figs in axillary pairs or solitary or cauline and fascicled, globose, smooth, red mottled light yellow, 5 in, through. Bracts connate, 3 ; peduncles slender, nearly I in. long. Hab. Rare, Pahang, Gunong Tahan. Perak, Kinta (Kunstler). Distrib. Java, Sumatra.

(6I) F. recurva Bl. Bijdr. 457; Hook. fil. l.c. 527; King. l.c. I32, pl. I65.

Epiphytic and rock climber; shoots villous. Leaves thinly coriaceous, elliptic-oblong or ovate to lanceolate acute, base round or short, narrowed, glabrous or pubescent beneath; nerves 2 or 3 pairs elevate, slender; 3 to 4 in. long, 2 to 3 in. wide; petioles $\cdot 2$ in. long. Figs sessile or short peduncled, solitary or paired in axils. depressed globose generally glabrous, orange yellow, $\cdot 2$ in. through. $H a b$. Very common on trees and rocks, Singapore, Bukit Timah; Chan Chu Kang. Johor, Kota Tinggi. Negri Sembilan, Rantau (Cantley). Dindings, Telok Sera; Gunong Tungul. Perak, Waterfall, Thaiping (Wray); Goping; Bernam River and Chanderiang (Kunstler). Penang, Road to Balik Pulau and West Hill (Curtis). Distrib. Malay isles. Native name: Akar Dahara.

(62) F. ramentacea Roxb. Fl. Ind. iii. 547; Hook. fil. F.B.I. v. 528 ; King. l.c. I35, pl. I69.

Stout climber, glabrous except the stipules. Leaves coriaceous elliptic, acute or ovate, base round, often cordate; nerves 7 pairs, sunk above, strongly elevate beneath; 2.5 to $8 \mathrm{in}$. long, up to $3.5 \mathrm{in}$. wide; petioles stout, $\cdot 6$ to $\cdot 7$ in. wide. Figs sub-sessile, solitary or paired, red, $\cdot 2$ to $\cdot 3$ in. through, globose narrowed at base to a stalk, glabrous. Hab. Very common, Singapore, Bukit Timah; Chan Chu Kang; Tanglin. Malacca, Batu Tiga (Goodenough); Alor Gajah; Ayer Keroh. Selangor, Klang Gates; Batu Caves. Perak. Tupai (Wray); Ulu Temengoh; Thaiping Waterfall (Wray). Penang, Penara Bukit. Distrib. Burma, Malaya. Native name: S'padih.

Latex yellow and bitter.

(63) F. araneosa Hook. fil. F.B.I. v. 529; King, Ann. Bot. Gard. Calc. 136, pl. I70.

Long slender epiphytic climber; branchlets white, woolly beneath, ovate-lanceolate acuminate, base round; nerves 3 pairs; 2.5 to 3 in. long, I.25 to I.5 in. wide; petioles woolly, $I$ in. long. Figs white woolly, pyriform, $\cdot 2$ in. through; peduncles $\cdot 22$ in. long. Hab. Rare, Perak, Goping (Kunstler).

(64) F. villosa Bl. Bijdr. 44r; Hook. fil. F.B.I. v. 529; King, l.c. $\mathrm{I} 37, \mathrm{pl}$. I72.

Strong climber; young parts, underside of leaves and figs redbrown tomentose. Leaves coriaceous, ovate acute, cordate; nerves and nervules sunk above, 7 pairs elevate beneath; 5 to ro in. long, 3 to 4 in. wide; petioles 5 in. long. Figs clustered on 
axillary tubercles, hairy orange yellow, 3 in. through; peduncles - I to $\cdot 3$ in. long, villous. Hab. A common pest on trees, Singapore Gardens; Bukit Mandai; Changi. Malacca, Jasin to Chabau; Batang Malacca (Derry). Selangor, Kwala Lumpur; Batu Caves. Perak, Tapah and Relau Tujor (Wray); Goping (Kunstler). Penang, Road to Balik Pulau; West Hill (Curtis). Disirib. Malay isles. Native name: Ara Buluh.

The creeping shoots of young plants with thinner leaves and very villous branches are the Ficus barbata Wall.

(65) F. diversifolia Bl. Bijdr. 456; Hook. fll. F.B.I. v. 259; King. l.c. I39, pl. I74 and I75.

A terrestrial bush or epiphyte. Leaves coriaceous, sessile obovate, oblanceolate or spathulate blunt, sub-acute or retuse at tip, narrowed to base usually yellow beneath; midrib forked or simple and penni-nerved; I to $4.6 \mathrm{in}$. long and wider or more rarely narrower. Figs small, $\cdot I$ in. through, yellow, to $\cdot 5$ in. through, pink; peduncles 3 in. or more long, slender.

One of the most variable plants I know-the leaves often being quite different from each other on the same bush, yet it does not seem possible to separate the forms specifically.

var. A. ovoidea, F. ovoidea. Jack. Mal. Misc. ii. (7), 7I, F. sideroxylifolia, Griff. Notulce, iv. 389 . A terrestrial bush 3 to $4 \mathrm{ft}$. tall. Leaves spathulate longer than broad, yellow beneath, midrib forking halfway, 2 in. long, 75 in. wide. Figs. ' 15 in. through, yellow; peduncles slender, $\cdot 2$ to $\cdot 5$ in. long. Hab. Abundant on sea shores in sandy spots, Singapore, Changi. Johor, Batu Pahat. Malacca, Tanjong Kling (Griffith). Native name: Ara Juluteh.

var. B. deltoidea, F. deltoidea. Jack. l.c. Epiphytic and terrestrial in low country. Leaves obovate obcuneate, $I \cdot 5$ to 2 in. long, I to $I \cdot 75$ in. wide; midrib forking. Figs globose, - I5 in. through on slender peduncles. Hab. Seashores and sandy lowland country, Singapore, Selitar; Changi (Hullett). Johor, Batu Pahat, Pahang, Tahan River. Malacca, Ayer Keroh and Mt. Ophir. Selangor, Klang Gates. Perak, Relau Tujor (Wray). Dindings, Pulau Sembilan; Lumut.

var. C. lutescens. Epiphyte on high mountains. Leaves narrowlanceolate penni-nerved, acuminate; midrib not branching. Figs larger sub-pyriform. Hab. Growing with spathulate form. Malacca, Mt. Ophir (leaves linear). Pahang, Kiuang Terbang (Barnes); Gunong Tahan. Selangor, Bukit Hitam; Semangkok (leaves lanceolate). Perak, Thaiping Hills at $4200 \mathrm{ft}$. altitude (Kunstler), leaves oblanceolate blunt; Gunong Kerbau at $4000 \mathrm{ft}$. altitude (Robinson). Distrib. Java.

var. D. Kunstleri, King, l.c. Creeping or erect epiphyte. Leaves obcuneate-obovate often retuse, broad at tip, 3 in. long, $2 \cdot 5$ in. wide; midrib forked. Figs over $\cdot 5$ in. long, ovoid, pink or red. 
$H a b$. On trees in mountains, Malacca, Mt. Ophir. Pahang, Gunong Tahan. Selangor, Kwala Lumpur. Perak, Goping (Kunstler); Gunong Inas (Yapp); Gunong Kerbau (Haniff). Native name: Api Telinga Kra.

(66) F. glandulifera Wall. Cat. 448I; Hook. fil. T.B.I. v. 533; King, l.c. 4I3, pl. I80.

Shrub or small tree about ro $\mathrm{ft}$. tall; shoots and petioles pubescent. Leaves membranous ovate or ovate-oblong entire, glabrous except puberulous nerves, 4 to 5 pairs beneath, 3 to 6 in. wide; petioles .75 in. long. Figs glabrous, .25 in. through; tip flat; peduncles 25 in. long. Hab. Common in woods, Singapore, Garden Jungle; Changi. Johor, Kota Tinggi. Malacca (Griffith), Perak, Tupai and Trong (Wray;) Goping (Kunstler). Penang. West Hill (Curtis). Distrib. Malay isles.

(67) F. alba Reineddt. in Bl. Bijdr. 467; Hook. fil. F.B.I.v. 530; King, l.c. I47, pl. I86.

A shrub up to about $8 \mathrm{ft}$. tall. Leaves chartaceous, whitetomentose beneath; adult leaves small, elliptic acuminate, serrate, base blunt or round, 5 in. long, $2 \cdot 25$ in. wide; of younger plants trilobed (on shoots 7 -lobed), ro in. long and wide, cordate; nerves about 5 pairs in adult; petioles 25 in. long in adult to $6 \mathrm{in}$. long, young. Figs globose-ovoid, orange, when quite ripe red, 25 in. through, sessile in pairs. Hab. Common in secondary growth and edges of woods, Singapore, very common. Johor, Gunong Pulai; Tebing Tinggi. Malacca, Bukit Singgeh; Ayer Panas and Selandor (Cantley). Negri Sembilan, Gunong Berumbun (Cantley). Selangor, Kwala Lumpur. Perak, Bujong Malacca; Tapah (Wray). Penang Hills (Wallich, Curtis). Disirib. Malay isles. Native names: Chumantong; Kulupong burong or K. ayer.

(68) F. cordata Ridl. Journ. Roy. As. Soc. S. Br. 57, p. 93.

Shrub; branches and young parts covered with red bristly hair. Leaves thin, membranous, ovate-cordate cuspidate dentate softly hairy all over (young leaves blunt not cordate); nerves 5 pairs; 7 in. long, 4.5 in. wide; petioles slender, 2 to 3.5 in. long, hairy. Figs sessile, $\cdot 5$ in. long, solitary ellipsoid, densely long red hairy especially at the mouth. Female flowers gamopetalous. Achene sub-reniform, keeled and warty. Hab. Rare, Perak, Temengoh (Ridley).

(69) F. fulva Reinzedt. in Bl. Bijdr. 578; Hook. fll. F.B.I. v. 53I; King, l.c. I48, pl. I87.

Small tree; shoots hairy. Leaves membranous, ovate or elliptic, sometimes sinuate serrulate acute, sub-cordate or blunt at base, scabrid above shortly hairy on nerves beneath, basal ncrves conspicuous, elevate beneath, 4 pairs, side nerves from the midrib; 6 to 9 in. long, $3 \cdot 25$ to 5 in. across; petioles hairy, 2 in. long. Figs orange, oblong-globose covered with bristly yellow hair, 25 in. through; peduncles $\cdot 5$ in. long. Hab. Rare, Pahang, Upper Tras 
valley at $3500 \mathrm{ft}$. altitude (Burkill). Selangor, Ulu Gombak Road; Klang Gates. Perak, Larut (Kunstler, Scortechini).

(70) F. patens Ridl. Journ. Roy. As. Scc. S. Br. 86, p. 306.

Large spreading shrub $20 \mathrm{ft}$. tall; branches hairy, with large pith. Leaves large, ovate, cordate, basal lobes round, pale beneath; nerves 3 from base, 2 outer with 7 transverse nervules to edge; midrib with 6 pairs above scabrid hairy; nerves and reticulations densely hairy, beneath shortly bristly, II in. long, 9 in. wide; petioles hairy, 3 in. long. Figs globose, green eventually red, roughly densely hairy, shortly peduncled. Bracts 3 , small ovate connate. Female flowers stalked with 4 spathulate sepals dark purple when dry. Achene oblique, round, stalked, as long as sepals. Male flowers not seen. Hab. Common in passes through the mountains of Selangor. Negri Sembilan, Bukit Tangga. Selangor, Ginting Sempah; Semangkok Pass; near Kanching. (Ridley).

\section{(7I) F. mollissima Ridl.}

Shrubby; branches thick, woolly hairy. Leaves ovate acuminate, cordate, edge crenulate undulate, sub-serrate above, hairy, beneath paler densely woolly hairy especially on the nerves; nerves 5 , radiating from the base; midrib with about 4 pairs alternate transverse nervules conspicuous; 6.5 in. long, 5 in. wide, one leaf seen strongly 3-lobed and 6 in. across; petioles yellow hairy, 3 in. long. Figs sub-globose, I in. through, yellow hairy with numerous lanceolate glabrous scales at the mouth, erect and incurved. Male flowers, stalk hairy, lobes oblong linear, glabrous. Stamens 3. Anthers sessile oblong minutely apiculate. Female flowers with elongate long-haired stalks; perianth-lobes 4, linear blunt, dark brown, glabrous as long as the stalks. Fruit smooth ellipsoid; style excentric, shorter, dark red. Hab. Negri Sembilan, Triang (Foxworthy). Native name: Ara Laut.

(72) F. oreophila Ridl. Journ. Roy. As. Soc. S. Br. 82, p. Ig6.

Shrub or tree; young parts, petiole, midrib and nerves beneath, peduncle and figs short, white, hairy. Leaves lanceolate-acuminate or acute, base blunt, round, edge undulate, glabrous above; nerves 2, basal conspicuous above, 4 pairs; 3.5 to 6 in. long, I.75 in. wide; petioles 4 in. long. Stipules lanceolate acuminate. Figs subglobose, $\cdot 25$ in. long, hairy, solitary, axillary on curved peduncles, $\cdot 25$ in. long with three small ovate bracts about half-way. Mouth bracts rounded, conspicuous, numerous, glabrous. Male flowers in mouth. Stamens 2. Hab. Pahang, Kluang Terbang (Barnes); Teku woods, Tahan mountain (Ridley).

(73) F. chrysocarpa Reinwdt. in Bl. Bijdr. 475; Hook. fil. F. B.I. v. 53I; King, l.c. I5I, pl. I9I.

Shrub about $4 \mathrm{ft}$. tall, yellow hairy. Leaves oblong or lanceolate, serrulate acuminate, base blunt above hairy or scabrid, beneath yellow hairy; adult leaves 3 in. long, I. 5 in. wide; young, lanceo- 
late, $5 \mathrm{in}$. long, $2 \cdot 25 \mathrm{in}$. wide; nerves 5 pairs raised a little; petioles 25 in. long, hairy. Figs oblong to globose, 5 in. through, golden hairy and yellow till quite ripe, when they turn red, sessile in axillary pairs. Hab. Common in low country, secondary jungle, edges of woods, Singapore, Reservoir; Bukit Timah; Gardens. Malacca (Griffith). Selangor, Ulu Gombak Road. Perak, Goping. Distrib. Borneo, Java, Sumatra.

(74) F. variolosa Lindl. in Hook. Lond. Journ. Bot. I842, i. 492; Hook. fil. F.B.I. v. 532; King, l.c. I53. pl. I93.

Shrub glabrous. Leaves thin coriaceous, oblong or oblanceolate, sub-acute, entire, finely reticulate beneath, base cuneate; nerves 8 to ro pairs; $2 \cdot 5$ to $4 \cdot 5$ in. long, I.5 in. wide; petioles $\cdot 3$ to .5 in. long. Figs 5 in. through, globose, base narrowed; umbo large, warted, glabrous with large bracts at mouth. Basal bracts triangular ovate; peduncles 3 to $\cdot 5$ in. long. Hab. Rare, Perak (Kunstler). Pahang, Gunong Berumbun, Telom (Ridley). Distrib. Hongkong.

Resembles $F$. pyriformis, but the figs are globose.

(75) F. pedunculosa Miq. Lond. Journ. Bot. vii. 442, t. 7 , Fig. A.; King, Ann. Bot. Gard. Calc. i. I45. F. ataktophylla Miq. Ann. Mus. Bot. Lugd. Bat. iii. 227, 294.

Shrub or tree. Leaves stiffly coriaceous, elliptic acute, base narrowed, sparsely hairy above, thickly on midrib, hairy beneath on nerves and reticulations; nerves one pair running from base along edge to tip, four pairs from the midrib inarching into the intramarginal one, reticulations fine conspicuous beneath; 3.5 to 5 in. long, $I \cdot 75$ to $2 \cdot 25$ in. wide; petioles I in, long, slender hairy. Figs ovoid hairy, $\cdot 3$ in. long, peduncles $\cdot 25$ in. long. Bracts 3 ovate acute. Pedicels $I$ in. long. All hairy. Scales of mouth ovate short. Male flowers sub-sessile. Sepals 3, broad distinct. Anthers 2 narrow ovate, filaments short united below. Gall flowers sessile. Sepals 2 or 3 broad rounded. Achene broad ovoid. Style subterminal. Hab. Pahang, Fraser Hill at 4000 to $4370 \mathrm{ft}$. altitude (Burkill and Holttum). Distrib. Celebes, Buru and Philippines.

(76) F. pyriformis Hook and Am. Bot. Beech. Voy. 216; Hook. fil. F.B.I. v. 533; King, l.c. I57, pl. 200 and 201.

Shrub small, from I to I $5 \mathrm{ft}$. tall; young parts pubescent. Leaves oblong to linear-lanceolate acuminate, entire, glabrous or pubescent beneath; nerves 5 to Io pairs; $1 \cdot 75$ to 4 in. long, $\cdot 5$ in. wide; petioles $\cdot 2$ in. long. Figs solitary, axillary, pear-shaped, purple, $\cdot 5$ to $\cdot 75$ in. through; peduncles 5 in. long. Hab. Pahang, Gunong Tahan (Robinson). Perak, Gunong Bal; Gunong Kerbau (Haniff); Sira Rimau (Yapp).

var. angustifolia. Dwarf plant with very narrow leaves on rocks in streams, Pahang, Tahan River. Perak, Temengoh; Bujong 
Malacca; Tapah road to Jor. Tomoh (Machado). Kelantan, Pehi River, Chaning. Distrib. India, China.

(77) F. chartacea Wall. Cat. 4580; Hook. fil. F.B.I. v. 533; King, l.c. I59, pl. 203.

Slender branched shrub 5 to $6 \mathrm{ft}$. tall. Leaves membranous, lanceolate or ovate, long cuspidate, base shortly narrowed; nerves 3 to 4 pairs, slender, reticulations small; 3 to 5 in. long, I.5 to 2 in. wide; petioles slender, $\cdot 5$ to $\cdot 75$ in. long. Figs globose, usually sessile axillary narrowed to a stalk at base, sometimes short peduncled, yellow, 'I5 in. through. Han. Common in woods and forests up to $4000 \mathrm{ft}$. altitude. Singapore, Garden Jungle, Changi; Bukit Timah. Johor, Gunong Pantai. Malacca, road to Ayer Panas (Griffith); Bukit Sabukor; Bukit Bruang (Derry). Negri Sembilan, Perhentian Tinggi; Bukit Klana (Cantley). Selangor, Kwala Lumpur; Klang Gates. Perak, Temengoh; Gunong Batu Putih (Wray); Gunong Kerbau at $4200 \mathrm{ft}$. altitude (Robinson); Goping and Chanderiang (Kunstler). Kedah Peak (Haniff); Yan. Pulau Adang, Pulau Butang. Lankawi. Distrib. Burma. Native names: Rami hutan; Kelumpung Agas, Use: Bark for tying.

(78) F. lepidosa Wall. Cat. 454I; Hook. fil. F.B.I. v. 522; King, l.c. I92, pl. 207.

Tree 40 to $60 \mathrm{ft}$. tall, I2 to I 8 in. through. Leaves membranous, ovate-oblong to elliptic-obovate, pale beneath, acute at top, shortly narrowed at base, midrib and nerves 7 pairs elevate, appressed, hairy beneath, $6.5 \mathrm{in}$. long, 3 in. wide; petioles slender, $2.5 \mathrm{in}$. long. Figs sessile, crowded at top just below leaves, male ellipsoid; females globose greenish yellow with red tip, orange-red. Male sepals 4. Hab. Rare, Singapore, Tanglin. Perak, Goping (Kunstler). Distrib. Burma.

\section{$\S$ vii. NeOMORPHE}

(79) F. pomifera Wall. Cat. 4547; Hook. fil. F.B.I. v. 535; King, l.c. I7I, pl. $2 \mathrm{I} 5$.

Stout low tree, wide spreading; bark white. Leaves ellipticsub-ovate coarsely toothed, base broad, round, glabrous or nearly so; nerves 4 to 5 pairs elevate beneath; ro in. long, 6 in. wide; petioles 4 in. long. Figs turbinate, over I in. through, top flattened, pink spotted white; peduncles 5 in. long on tubercles on the stem and large branches. Hab. Damp low spots in forest, Johor, Tengarah (Feilding). Pahang, Kwala Tembeling; Telom. Selangor, Labu; Dusun Tua. Perak, Temengoh; Larut (Kunstler). Distrib. IndoMalaya.

\section{ANTIARIS, Leschen.}

Vast trees, laticiferous. Leaves alternate entire (or serrate). Male flowers on the surface of a fleshy peduncled receptacle surrounded by imbricate bracts; sepals 4 (or 3 ) spathulate imbricate. Stamens 3 to 8 , short erect. Female flower $I$ in a pyriform involucre 
of many bracts. Perianth o. Ovary adnate to involucre; style 2-armed. Drupe fleshy. Species 3 or 4 , Africa, Indo-Malaya.

(I) A. toxicaria Lesch. Ann. Mus. Rar. xvi. 478, t. 22; Hook. fil. F.B.I. v. 537; Comp. Bot. Mag. i. Ir, t. I7; Benn. Pl. Jav. Rar. 52, t. 13; Bl. Rumphia, i. 56, t. 22 and 23 .

Big tree over Ioo ft. tall and several feet through; branchlets hairy. Leaves coriaceous oblong or elliptic, blunt or apiculate, entire or serrulate, scabrid, glabrous or hairy beneath; nerves slender, elevate; 4 to 8 in. long, I to 2.5 in. wide; petioles . I in. long. Male receptacles 3 to 4 together, $\cdot 25$ in. through. Fruit crimson, pear-shaped, velvety, sweet. Hab. Forests, Malacca, Naning; Tabong (Griffith); Bukit Sadanen (Goodenough). Selangor, Batu Caves. Perak, Plus River; Batang Padang and Ulu Selama (Wray), Penang, near the cemetery (Haniff). Kemaman (VaughanStevens). Disirib. Indo-Malaya. Native name: Ipoh (Javanese, Upas). Use: Latex as dart poison by the wild tribes.

An account of the physiological action of the poison was published in the Agricultural Bulletin of the Malay Peninsula, Ser. i. p. 201.

\section{ARTOCARPUS, Linn.}

Trees often very large. Leaves coriaceous, entire (lobed when young) or (A. superba) pinnate. Flowers in unisexual heads or spikes, axillary with peltate bracts. Male spikes often cylindric, or globose. Perianth 2- to 4-lobed, lobes blunt. Stamen I. Pistillode o. Female heads globose. Perianth tubular, connate with receptacle. Ovary straight; style central or lateral; stigma entire, rarely lobed. Fruit usually large oblong or globose receptacle clothed with much-enlarged fleshy perianths and carpels (anthocarps), the tips hard, spinous or pyramidal or truncate. Achenes deep sunk in the mass. Seed exalbuminous. Species about 40 , Indo-Malaya, Polynesia.

Cultivated only, is the bread fruit, Arlocarpus incisa, Linn. fil., a native of Polynesia with pinnatifid leaves and globose smooth green fruits. The commonest form here is the Sukun, a sweettasting form; the typical form with no sweet taste is seldom cultivated as its fruits are dry and hardly eatable. The Jack, $A$. integrifolia Linn. fil., " Nangka," native of S. India, is very commonly cultivated. The leaves are entire and the fruit of very large size, cylindric and yellow.

Nearly all the species have the stool leaves and seedling leaves strongly and variously lobed.

Adult leaves entire simple.

Fruit spiny, tips of anthocarps free.

Fruit lobed; spines conic; leaf nerves few

Fruit not lobed, globose, spines terete; fruit bracteate; nerves many

Fruit globose yellow, spines sub-terete; bract o; nerves many, hairy beneath

(I) A. Forbesii

(2) A. bracteata

(3) A. rigida 
Fruit oblong; leaves very large; anthocarp spines hairy

Fruit tubercled; anthocarp tips flat.

Leaves glabrous.

Leaves ovate; fruit small, tubercles acute

Leaves oblong-lanceolate; fruit small; tubercles blunt .

Leaves ovate-lanceolate; fruit large, globular

Leaves hairy.

Leaves coarsely hairy beneath; fruit large cylindric, white on stem

Leaves minutely pubescent; fruit I in. long, oblong

Leaves soft pubescent beneath, very large; fruit large, rough

Fruit quite smooth; anthocarps quite united, pulpy.

Fruit cylindric, small .

Fruit globose; leaves round at base, pubescent beneath

Fruit globose; leaves narrow to base, glabrous

Adult leaves pinnate.

(4) A. Kunstleri

(5) A. peduncularis

(6) A. Lowii

(7) A. lanceæfolia

(8) A. polyphema

(9) A. Maingayi

(Io) A. Scortechinii

(I I) A. Denisoniana

(I2) A. Lakoocha

(I3) A. Gomeziana

(I4) A. superba

(I) A. Forbesii Hook. fil. F.B.I. v. 539; King. Ann. Bot. Gard. Calc. (2), 7, pl. IA.

Tree 40 to $60 \mathrm{ft}$. tall, glabrous. Leaves oblong or sub-obovateelliptic, shortly bluntly cuspidate, base narrowed; nerves 5 to 6 pairs, slender, slightly elevate, inarching; 5 in. long, 2.25 in. wide; petioles I in. long. Female receptacles peduncled sub-globose irregularly 3 -lobed; when ripe 4 to $8 \mathrm{in}$. through, covered with thick conic spines 8 in. long. Hab. Rare and little known, Perak, Ulu Bubong (Kunstler). Distrib. Sumatra.

(2) A. bracteata Hook. fil. F.B.I. v. 540; King Ann. Bot. Gard. Calc. 7, pl. IB.

Tree medium size. Leaves stiffly coriaceous, obovate, tip round, base blunt, narrowed, glabrous above, hairy beneath; nerves and reticulations strongly elevate and hairy beneath, less so above; 7 to Io in. long, $3 \cdot 75$ to 4.5 in. wide; petioles .75 in. long, shortly stiffhairy. Female receptacles globose on peduncles I in. long, pubescent with three large ovate bracts 25 in. long at the base of the receptacle, which is curved with spines short and straight and is I.5 in. through (not ripe). Hab. Malacca, between Ching and Rumbiya, one tree (Griffith, Maingay). Negri Sembilan, Senawang (Foxworthy). Native name: Rumbiya Ipoh (Griffith).

Foxworthy's collector also calls this Ipoh and says "Poison tree for Sumpitan arrows."

(3) A. rigida Bl. Bijdr. 482; Hook. F.B.I. v. I40; King, Ann. Bot. Gard. Calc. (2), 8, pl. 3. A. echinata, Roxb. Fl. Ind. iii. 3, 27.

A stout tree 80 to Ioo ft. tall. Leaves stiffly coriaceous, obovate, rounded, base shortly decurrent, glabrous, dark green above, pubescent beneath; nerves about I4 pairs strong elevate, as are the 
reticulations, 7 to 8 in. long, 3 in. wide; petioles .5 in. long; pubescent. Male heads globose yellow, 5 in. through; peduncle as long, hairy. Female globose, no bracts at base. Fruit globose, 6 in. through or more, orange yellow, sub-sessile, entirely covered with straight blunt spines $\cdot 3$ in. long. Seed oblong, $\cdot 25$ in. long, covered with a thick yellow pulp, sweet and honey-flavoured. $H a b$. Common in forests, Singapore, Garden Jungle; Bukit Timah; Serangoon Road. Malacca, Bukit Kemuning (Derry); Alor Gajah (Griffith). Selangor, Sungei Buluh; Kwala Lumpur (Foxworthy), Perak, Batang Padang; Larut (Kunstler); Bikum Reserve (BurnMurdoch). Distrib. Java. Native name: Tampuneh; the Monkey Jack. Use: A delicious fruit, the pulp of the seeds very cool, sweet and refreshing.

(4) A. Kunstleri Hook. fil. F.B.I. v. 540; King, Ann. Bot. Gard. Calc. ii. 9. pl. 4 .

Tree 80 to Ioo $\mathrm{ft}$. tall, 2 to $3 \mathrm{ft}$. through. Leaves coriaceous, very large, often conspicuously lobed or obovate, oblong entire blunt, hairy on both sides; nerves and nervules conspicuous; 9 to I5 in. long, 5 to 8 in. across; petioles 2 in. long. Stipules large, lanceolate silky outside. Male heads cylindric, cream-colour pubescent, 4 to 5 in. long on peduncles 2 to 3 in. long. Fruit oblong, 4 to 7 in. long, with reflexed tomentose hairy spines. Hab. Very common in forests, Singapore, Garden Jungle; Bukit Panjang, etc. Johor, Batu Pahat. Pahang, Kwala Tembeling. Malacca, Panchur. Negri Sembilan, Bukit Putus (Cantley). Selangor, Kwala Lumpur; Batu Tiga. Perak, Larut (Kunstler). Native name: Terap. Use: The latex for bird-lime (Getah Terap); timber highly valued.

(5) A. peduncularis Kurz. in Trim. Journ. Bot. iv. 33I; Hook. fil. F.B.I. v. 54I; King, Ann. Bot. Gard. Calc. ii. Io, pl. 6.

Tree 40 to $60 \mathrm{ft}$. tall. Leaves glabrous, coriaceous, oblong cuspidate, narrowed to base; nerves 6 or 7 pairs elevate beneath; 5 to Io in. long, 4 to 5 in. across; petioles I. 5 to 2 in. long. Stipules as long, glabrous. Flower-heads cylindric, blunt; peduncles 2.5 to 3.5 in. long. Female spike $I \cdot 5$ in. long. Fruit 2 in. long, $I$ in. through, covered with short conic processes. Hab. Not very common, Singapore, Bukit Mandai. Malacca (Maingay); Brisu (Derry). Selangor, Weld's Hill. Kwala Lumpur (Foxworthy). Perak, base of Ulu Bubong (Kunstler). Distrib. S. Siam, Nicobars. Native name: Miku.

(6) A. Lowii Hook. fil. F.B.I. v. 542; King, Ann. Bot. Gard. Calc. ii. 10, pl. $7 \mathrm{~A}$.

Tree 50 to $70 \mathrm{ft}$. tall. Leaves thinly coriaceous, oblong-lanceolate acute, glabrous or puberulous, base narrow; nerves Io or II pairs raised beneath; 9 to II in. long, 4.25 in. wide; petioles I in. long. Stipules 3 in. long, narrow, acuminate, glabrous. Male heads .5 to .75 in. long, slender. Unripe fruit 2 to 3 in. long, oblong, I in. P1.M.P., g.

A A 
through, covered with short blunt tubercles. Hab. Perak, Larut (Kunstler).

Possibly only a form of $A$. peduncularis.

(7) A. lanceæfolia Roxb. Fl. Ind. iii. 527; King, Amn. Bot. Gard. Calc. ii. I3, pl. II.

A big tree up to roo $\mathrm{ft}$. tall. Leaves stiffly coriaceous, ovatelanceolate or elliptic-oblong, glabrous; nerves prominent, 8 to Io pairs; 9 to I4 in. long, 4 to 6 in. or more across; petioles 5 to I in. long. Stipules ovate-lanceolate appressed hairy, $\cdot 5$ to $\cdot 75$ in. long. Male heads obovoid-cylindric, $\cdot 75$ to $\mathrm{I}$ in. long, $\cdot 5$ in. through. Fruit oblong, 6 in. long, 3 in. through, brown, anthocarps truncate, pubescent. Hab. Common; forests, Singapore Gardens. Johor, Pinerong (Cantley). Malacca, Kesang Tua (Goodenough). Perak, Larut (Kunstler). Penang (Roxburgh); Batu Feringhi (Curtis). Native name: Keledang. Use: A very highly valued timber.

(8) A. polyphema Pers. Synops. ii. 53I; Hook. fil. F.B.I.v. 542 .

Tree about 30 to $40 \mathrm{ft}$. tall, about I $\mathrm{ft}$. through. Leaves thin, coriaceous elliptic-lanceolate, base narrowed; nerves slender, 5 to 9 pairs, glabrous except midrib and petiole which with shoots and stipules are stiffly bristly hairy; 6 in. long, $2 \cdot 75$ in. wide. Male spikes slender, cylindric, creamy white, I in. long, I 5 in. through on hairy peduncles $I$ in. long in upper axils. Females on trunktubercles or on branches. Fruit cylindric, smooth, white, I2 in. long, 3 to 4 in. through. Hab. Commonly cultivated in all campongs, and wild in the following localities in high forest. The wild tree is more slender and strongly knotted, and fruit usually smaller, than the cultivated form. Hab. Pahang, Tahan River. Negri Sembilan, Tampin. Selangor, Sempang mines, Semangkok; Kwala Lumpur (Foxworthy). Perak, Tapah (Wray). Distrib. Java. Native names: Chempedak; Bongkong (wild form). Use: A very favourite food with natives. It has an unpleasant odour, hence Europeans do not eat it.

(9) A. Maingayi Hook fil. F.B.I.v. 542; King, Ann. Bot. Gard. Calc. ii. II, pl. 8 A.

Small tree 20 to $40 \mathrm{ft}$. tall. Leaves stiff coriaceous, ellipticobovate, blunt, base narrowed, pubescent beneath; nerves 8 to 9 pairs, slightly elevate, 3.5 in. long, 2 in. wide; petioles 5 in. long. Stipules lanceolate, silky, $\cdot 5$ in. long. Male heads cylindric, I. 5 to 2 in. long. Fruit I in. long, $\cdot 5$ in. through, oblong round; peduncles 3 in. long, densely pubescent; anthocarps flat-topped pubescent. Hab. Singapore, Bukit Timah; Toas; Gardens. Malacca, Bukit Kayu Arang; Sungei Hudang (Cantley). Pahang Lubok Pandan, Temerloh (Foxworthy). Selangor, Damansara Road (Burn-Murdoch). Perak, Larut (Kunstler). Native names: Chempedak Ayer; Puda. 
(Io) A. Scortechinii Hook fil. F.B.I. v. 542; King, Ann. Bot. Gard Calc. ii. r2, pl. 9.

Big tree 60 to $80 \mathrm{ft}$. tall. Leaves ovate, oblong blunt narrowed at base, velvety pubescent beneath, glabrous above, I2 to I5 in. long, 7 in. across; nerves strongly elevate; petioles thick, 2 in. long. Stipules golden silky, lanceolate-acuminate, 3 in. long. Male head cylindric, 3 in. long on a slender peduncle, all pubescent. Fruiting head large, oblong blunt, 3 in. long or more; anthocarps truncate scaberulous. Hab. Singapore, Tanglin; Kranji. Malacca (Griffith). Perak, Batang Padang (Kunstler).

This tree closely resembles the Terap (A. Kunstleri).

(II) A. Denisoniana Hook. fil. F.B.I. v. I44; King, Ann. Bot. Gard. Calc. ii. I4, pl. 8B.

Tree $60 \mathrm{ft}$. tall, glabrous. Leaves elliptic-oblong or ovate cuspidate, base narrowed, sub-glaucous and obscurely puberulous beneath; nerves elevate, about 12 pairs ; 6 in. long, 2.75 in. wide; petioles I in. long. Stipules small glabrous ovate-lanceolate. Male flower-heads $\cdot 75$ to $I \cdot 5$ in. long, slender. Fruit obovoid smooth. Hab. Rare. Selangor, Ulu Gombak (Burn-Murdoch). Perak, Ulu Bubong (Kunstler). Native name: Nangka Pipit.

(I2) A. Lakoocha Roxb. Fl. Ind. iii. 524; Hook. fil. F.B.I. v. 543; King, Ann. Bot. Gard. Calc. ii. I4, pl. I3.

Stout bushy tree about $40 \mathrm{ft}$. tall; branchlets villous. Leaves rather thin oblong-elliptic or sub-ovate, base round, tip shortly acuminate, soft pubescent beneath; nerves 8 to I2 pairs elevate as are reticulations; 4 to I2 in. long, 4 in. wide; petioles I in. long, pubescent. Male heads globose yellow, $\cdot 25$ in. through; peduncles short. Fruit soft pulpy, 2 to 3 in. through, green or "orange red." Hab. Common in woods and open country, Singapore, Changi; Bukit Timah; Pulau Ubin. Malacca, Ayer Panas (Griffith). Negri Sembilan, Triang (Foxworthy). Selangor, Kwala Lumpur (Foxworthy). Perak, Trong (Wray); Chanderiang and Goping (Kunstler). Province Wellesley, Krian; Tasek Gelugur. Penang, Pulau Betong. Distrib. India. Native name: Tampang Ambong.

(13) A. Gomeziana Wall. Cat. 4660; Hook. fil. F.B.I. v. 544; King, Ann. Bot. Gard. Calc. ii. I5, pl. I4A and I4B.

Stout bushy tree about 40 to $60 \mathrm{ft}$. tall. Leaves dark shining green, coriaceous glabrous, oblong short apiculate or acuminate, narrowed at base; nerves elevate beneath 8 to I2 pairs, reticulations conspicuous; 3 to $6 \mathrm{in}$. long, $\mathrm{x} \cdot 5$ to $3 \mathrm{in}$. across; petioles $\cdot \mathrm{I}_{5}$ to I in. long. Male heads small obovoid. Females globose on pubescent peduncles. Fruit sub-globose, 2 in. through, soft, smooth shining green, inside rose pink. Hab. Common, Singapore, Bukit Timah; Bukit Mandai; Gardens. Malacca, Batu Tiga (Holmberg); Brisu (Derry); Selandor (Cantley). Selangor; Bukit Kutu; Kwala Lumpur (Curtis). Perak, Waterfall, Thaiping 
(Wray). Dindings, Bruas. Province Wellesley (Fox). Penang, Penara Bukit (Curtis). Distrib. Tenasserim, Andamans. Native names: Tampang; Tampang besih; Tampang Nasi. Use: Fruit rather acid, eaten, but usually as a preserve.

The common form is var. Griffithii King, with small leaves, but I doubt if this is anything more than a full-grown tree.

(I4) A. superba Becc. Nelle Foresti di Borneo, Appendix, p. 625. A. anisophylla Miq. Fl. Ned. Ind. Suppl. i. 422.

A big tree usually about $80 \mathrm{ft}$. tall. Leaves coriaceous, pinnate, deep green, over $2 \mathrm{ft}$. long and I ft. across; pinnæ eight alternate, oblong very unequal at base, short acuminate; nerves I4 pairs; 7 in. long, 3 in. wide; petiolules 25 in. long. Male heads blunt, cylindric, $2 \cdot 25$ in. long, 5 in. through; peduncles $2 \cdot 75$ in. long. Fruit globose, 3.9 in. through, covered with linear-oblong processes tomentose, $\cdot 3$ in. long; peduncles 4 to 5 in. long. Hab. Singapore, Garden Jungle. Malacca (Maingay). Distrib. Bangka, Borneo. Native name: Tukul.

Miquel's wretched description of a leaf only, his $A$. ? anisophylla may be that of a leaf of this plant. It is, however, uncertain and had better be ignored.

\section{CUDRANIA, Trecul.}

Climbing shrubs (or small trees), spiny. Leaves alternate, entire. Flowers in unisexual globose heads. Male flowers; sepals 3 to 5 oblong blunt, adnate to 2 to 4 bracts imbricate. Stamens 4 , erect adnate to sepals. Female flowers; sepals broader, 4; style simple or bipartite. Achenes enclosed in the large fleshy bracts, forming a large fleshy head. Species 3 or 4, Africa, Indo-Malaya.

(I) C. javanensis Trecul, Amn.Sc. Nat. Ser. iii. I23; Hook. fil. F.B.I. v. 538 .

Scrambling spiny shrub; spines often curved. Leaves membranous, fleshy, dark green, oblong-obovate or lanceolate acute or cuspidate, base short narrowed; nerves fine, 7 pairs; glabrous, 2 to 3 in. long, $x$ to $x \cdot 75$ in. wide; petioles 5 in. long. Male heads .25 in. across, yellow; sepals hairy. Female heads enlarging to .75 in. through in fruit orange coloured. Hab. Not common, in forest, Malacca (Griffith). Perak, Larut near a creek; and Ulu Bubong, Bamboo forest (Kunstler). Perlis, Besih Hangat, near Kanga (Ridley). Distrib. E. Africa, Indo-Malaya, Australia.

\section{CONOCEPHALUS, Bl.}

Epiphytic shrubs usually climbing. Leaves alternate, entire, fleshy membranous. Stipules connate. Flowers unisexual in axillary cymose heads, flesh-colour or pink. Male heads more numerous than female and smaller. Perianth tubular or turbinate, 4-lobed. Stamens 2 or 4 . Female heads fewer and much larger. Perianth oblong or clubbed, 4-lobed; style undivided; stigma linear. Achene small. Species I2 to I5, India, China, Malaya. 
These plants preserve poorly and are difficult to distinguish from dried specimens.

Leaves $2 \mathrm{ft}$. long; heads $2 \mathrm{in}$. through or nearly, bright pink

Leaves ovate, under I $\mathrm{ft}$. long; heads $\mathrm{I}$ in. through

or less, flesh-colour

(r) C. amœnus

(2) C. suaveolens

Leaves elliptic-lanceolate; male flower-heads very numerous, dirty white

(3) C. Scortechinii

Leaves oblanceolate, 6 in. long; heads few, small, violet pink

(4) C. subtrinervius

(I) C. amœnus Hook. fil. F.B.I. v. 545, in part. Urtica superba Wall. Cat. 4625.

A very robust, shortly climbing epiphyte. Leaves oblong, $2 \mathrm{ft}$. long, 6 in. across; nerves prominent beneath, purple; petioles $4 \mathrm{in}$, or more long. Male flowers in a branched cyme, 2 in. or more long; heads numerous. Female cyme of 4 to 8 heads; peduncle robust branched pubescent; heads over I in. through, violet pink. Flowers pedicelled. $H a b$. Forests, Singapore (Wallich). Malacca, Ayer Panas (Goodenough). Pahang, Pekan. Selangor, Batu Caves; Langat. Perak, Thaiping Hills; Goping (Kunstler); Plus River (Wray); Gunong Inas (Yapp). Penang, Pulau Betong (Curtis). Lankawi. Distrib. Borneo. Native name: Ara Jangkang.

This is not Urtica amona Wall. but his U. superba. King's description of $C$. amcenus is evidently taken from the big plant with violet-pink flowers.

(2) C. suaveolens Bl. Bijdr. 483; Benn. Pl. Jav. Rar. 47, t. I2 (but flowers coloured pink); Hook. fil. F.B.I. v. 545 in part. C. amœenus King, in part (Wallich Cat. 4626 Urtica amœna). C. ellipticus Trecul, Ann. Sc. Nat. iii. 8, 9I ?

Short, stout climbing epiphyte. Leaves fleshy oblong-ovate, base round, tip blunt; nerves about 8 pairs; 7 in. long, 4.5 in. wide; petioles rough, I in. long. Male heads in small branched cymes, dense and sub-sessile; cymes 5 in. through; heads 22 in. through, flesh-colour, fragrant. Female heads 3 to 5 together, much larger, I in. across; peduncles $I$ in. long. Bracts round. Hab. Common in forests, Singapore, Bukit Timah; Bukit Mandai; Selitar. Johor, Tanjong Kupang. Malacca, Malaka Pindah (Derry, Griffith). Pahang River. Selangor, Petaling; Kwala Lumpur (Curtis); Klang Gates. Penang, West Hill (Curtis, Maingay, Wallich). Distrib. Carimons, Lingga, Bangka, S. Siam. Native name: Tentawan.

C. ellipticus Trecul may be intended for this species. It was collected in Penang by Gaudichaud.

(3) C. Scortechinii Hook, fil. F.B.I. v. 545 .

Climbing epiphyte rather slender. Leaves elliptic-lanceolate acuminate or obovate, cuspidate; nerves 6 to 8 pairs; 4 to 6 in. long, 2 to 3 in. wide; petioles slender, $\cdot 25$ to $\cdot 5$ in. long. Male 
heads very numerous in a panicle 3 or 4 in. across; heads . 15 in. across, dirty white. Female heads much fewer, larger, 3 in. through, about $\mathrm{Io}$ in the panicle. Hab. Singapore (Maingay). Johor, Gunong Pulai (Kloss); Castlewood; Kota Tinggi; Hulu Sembrong (Kelsall). Selangor, Kwala Lumpur (Curtis). Perak, Tapah (Wray); Batang Padang; Goping (Kunstler). Perlis, Kanga. Distrib. Borneo, Native name: Ara Nasi.

(4) C. subtrinervius Miq. Fl. Ind. Bat. Suppl. 4I7; Hook. fil. F.B.I. v. 546 .

Slender erect epiphyte about $\mathrm{I} \mathrm{ft}$. tall. Leaves thin oblanceolate acuminate, narrowed to base; nerves 6 to 8 pairs with a basal pair; 4 to 6 in. long, I.75 to 2 in. wide; petioles slender, 2.5 in. long or less. Male heads I5 in, through; peduncles short slender. Female heads 5 in. through 3 to 4 together on peduncles about - 5 in. long, of a beautiful violet pink. Hab. In wet forests, Johor, Pulau Aor (Feilding). Pahang, Kwala Tembeling. Selangor, Petaling; Semangkok; Bukit Hitam. Negri Sembilan, Bukit Sulu (Cantley). Perak, Thaiping; Tapah (Wray); Hulu Temengoh. Dindings, Gunong Tungul. Penang, Balik Pulau; Richmond Pool (Hullett). Distrib. Borneo. Native names: Akar Sasara; Landang Babi.

\section{PRAINEA, King.}

Woody climbers. Leaves alternate entire. Flowers in globose heads mixed with peltate bracts, axillary, peduncled. Male flowers much larger. Perianth tubular clavate. Ovary free; style deeply bifid. Fruit globose of many abortive flowers and a few oblong achenes enclosed in enlarged fleshy perianth. Species 3 or 4, Malay Peninsula, Borneo.

(I) P. scandens King in Hook. fil. F.B.I. v. 547.

Big climber 50 to Ioo $\mathrm{ft}$. long, stem I 2 to I 5 in. through. Leaves thin coriaceous elliptic or obovate-oblong, glabrous, base acute, apex cuspidate, 3 to 8 in. long, I.5 to $2 \cdot 25$ in. wide; nerves elevate, Io to I2 pairs; petioles 5 in. long. Male heads 5 to I in. across; peduncles $I$ to $I \cdot 5$ in. long. Female heads $I \cdot 5$ to 2 in. across; flowers 5 in. long. Fruit when ripe glossy bright yellow. Hab. Dense jungle, Perak, Larut (Kunstler).

16. HULLETTIA, King.

Shrubs; branches tomentose. Leaves alternate entire. Flowers small Io to I2 sunk in cavities of axillary, peduncled open funnelshaped, 3- to 4-lobed receptacles. Male flowers, perianth oblong tubular, 2-lobed bases connate. Female, perianth tubular clubbed; style short. Fruit pulpy globose or irregularly lobed, I- to 6-seeded. Species 2, Tenasserim and peninsula.

(I) H. dumosa King in Hook. fil. F.B.I. v. 547.

Shrub about $6 \mathrm{ft}$. tall. Leaves coriaceous oblanceolate, base narrowed acuminate; nerves strongly elevate and inarching 
beneath, and reticulations elevate, I 2 pairs; 6 to 9 in. long, $2.5 \mathrm{in}$. wide; petioles 5 to $I .5$ in. long. Male flower-heads $\cdot 25$ to .5 in. long on peduncles 5 in. long, green fragrant flat-topped, tomentose. Female head larger. Fruit oblong or globose, base conic, bright orange pubescent, pulpy, sweet, 2 in. across. Seed $\cdot 5$ in. through. Hab. In forests, not rare, Negri Sembilan, Bukit Sulu (Cantley). Selangor, Kwala Lumpur (Curtis) ; Sempang, Semangkok. Pahang, Telom. Perak, Bujong Malacca; Hermitage Hill; Gunong Batu putih (Wray); Ulu Bubong (Kunstler); Gunong Kerbau at $4000 \mathrm{ft}$. altitude (Robinson). Native name: Sunto Bukit.

\section{FLEURYA, Gaud.}

Herbs with stinging hairs. Leaves alternate thin, toothed trinerved from base. Flowers small, green clustered in solitary axillary spikes or cymes. Males, sepals 4 to 5 , ovate-lanceolate. Stamens 4 to 5 inflexed in bud. Pistillode globose or clubbed. Female perianth cupular, 4-lobed, or sepals 4. Ovary oblique; style oblique ovoid or linear, at length hooked. Achene oblique compressed. Species 8, tropics.

(I) F. interrupta Gaud. Freyc. Voy. Bot. 497, t. 83; Hook. fil. F.B.I. v. 548 .

A branching herb, 6 to 18 in. tall. Leaves ovate base broad acuminate strongly toothed, sparsely hairy on stem and nerves on the back; $I \cdot 5$ to 5 in. long, $I$ to 4 in. wide; petioles slender, $I \cdot 5$ to 3 in. long. Spikes I to 5 in. long, slender. Flowers in distant heads about $2 \cdot 5 \mathrm{in}$. through crowded at the end. Achenes ' I in. long, membranous. Hab. Weed in waste ground, slightly or not stinging, Singapore, Tanglin; Gardens; Serangoon; Rochore. Malacca (Hullett, Griffith). Negri Sembilan, Sulu (Cantley). Kelantan, Kamposa. Tringganu (Yapp). Penang (Wallich, Curtis). Distrib. Tropics and sub-tropics, Africa, India, China, Malaya, Polynesia. Native name: Jelatang Ayam.

18. LAPORTEA, Gaud.

Trees or shrubs, stinging viciously. Leaves membranous usually glabrous, long-petioled; petiole and inflorescence armed with stinging hairs. Inflorescence lax; cymes peduncled unisexual, or racemose. Male flowers 4 to 5. Stamens 4 to 5 inflexed in bud. Pistillode clubbed. Female lobes 4, sub-equal or one smaller. Ovary oblique; style linear papillose on one side. Achene ovoid flat, oblique membranous or fleshy, beaked by style. Species about 25. Tropical Asia, Australia, Polynesia, Africa and N. America.

Leaves lanceolate acuminate; achenes smooth, beak moderately long

Leaves oblong-obovate, pale beneath, achenes pustular, edge keeled; style very short

(I) L. stimulans

(2) L. pustulosa 
(I) L. stimulans Miq. Zoll. Syst. Verz. Ind. Arch. I03; Weddell, Monog. Urt. I34.

Tree about $20 \mathrm{ft}$. tall. Leaves chartaceous lanceolate acuminate, base narrowed; nerves Io pairs; 8 to II in. long, 3 in. wide; petioles 3 in. long. Panicles axillary, about 5 in. long sprinkled with stinging hairs lax; flowers usually scattered; in males, flowers crowded. Achene broadly ovate, flattened when dry, slightly punctate; stigma incurved persistent. Hab. Selangor, Batu Caves. Negri Sembilan, Bukit Payong and Bukit Kandong (Cantley). Perak, Kinta and Ulu Kerling (Kunstler); Ipoh (Curtis). Kelantan, Kwala Lebir (Gimlette). Penang, Wang Seraya; Waterfall (Curtis). Kedah, Gunong Geriang. Distrib. Siam, Java, Borneo. Native names: Jelatang Api; Jelatang Bulan.

King suggests this is $L$. microstigma Wedd., and some of the specimens do resemble Weddell's figure and description, others are identical with Miquel's stimulans. I think the species is only one, however.

(2) L. pustulosa Ridl. Journ. Roy. As. Soc. S. Br. 82, p. I94.

Tree 30 to $35 \mathrm{ft}$. high. Leaves oblong-obovate acuminate, base rounded glabrous, pale beneath; nerves about 12 pairs fine; midrib with a few hairs beneath, many at base; 4.5 to 5.5 in. long, 3 in. wide; petioles I.25 in. long, strongly armed with stinging hairs. Cymes 4 to $5 \mathrm{in}$. long (the peduncle 2 in.) with stinging hairs. Sepals in fruit ovate acute, $\cdot 05$ in. long. Fruit ovoid with a distinct ridge all round; disc papillose flat, I5 $_{5} \mathrm{in}$. long; style short, hooked, .05 in. long. Hab. Perak (Scortechini). Native name: "The dreaded Pulutus of the Malays" (Scortechini).

This is very distinct in its short style and pustular fruits.

19. PILEA, Lindl.

Herbs rarely slightly woody. Leaves opposite equal or unequal, 3-nerved. Stipules connate. Flowers minute in axillary branched cymes peduncled. Males; sepals 2 to 4 free or connate often gibbous on back. Stamens 2 to 4 . Pistillode conic. Females, sepals 3 (rarely 4) very small and unequal dorsal longest. Ovary straight; stigma sessile. Achene ovoid compressed. Species about 60 , tropics generally.

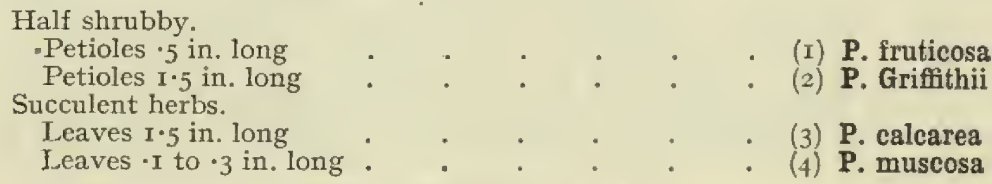

(I) P. fruticosa Hook. fil. F.B.I. v. 558 .

Glabrous shrubby plant 2 to $3 \mathrm{ft}$. tall, branched. Leaves in equal pairs fleshy, elliptic-lanceolate acuminate, edge serrate 3 -nerved, 3 to 4 in. long; I.5 to 2 in. wide; petioles 5 in. long. 
Male cymes few-branched; peduncles 2 in. long; branches I.25 in. long or less. Flowers in small remote clusters 12 in.- through, white. Females small sessile. Achenes very minute. Hab. Limestone rocks, Perak, Goping (Kunstler).

(2) P. Griffithii Bl. Mus. Lugd. Bat. ii. 55; Weddell, Monog. 231 .

Herbaceous or shrubby. Leaves long-petiolate opposite, one rather smaller elliptic or elliptic-oblong blunt acuminate, base round blunt or sub-cordate; 3-nerved acute serrate glabrous, 2.4 to 3.5 in. long, I.2 to I. 8 in. wide; petioles 6 to $I \cdot 4$ in. long. Panicles axillary peduncled in pairs shorter than the leaves. $H a b$. Malacca (Griffith).

Only known from.Blume's description. I have not seen it.

(3) P. calcarea Ridl. Journ. Roy. As. Soc. S. Br. 82, p. I96.

Fleshy herb ascending branched, glabrous, about I2 in. tall, internodes .5 in. long. Leaves fleshy, thin elliptic-ovate blunt acuminate, base narrowed often unequal, slightly crenate serrate, 3-nerved, 1.5 in. long, 75 in. across; petioles 75 to $I$ in. long, slender. Male cymes 4 in. long or less; peduncle very slender. Flowers crowded in very small heads sessile. Perianth-lobes oblong, green. Achene oblong-ovoid flattened very shortly beaked .05 in. long. Hab. On limestone rocks, Selangor, Batu Caves (Ridley).

(4) P. muscosa Lindl. Collectanea, pl. iv.

Small fleshy creeping ascending plant, 2 to 8 in. tall. Leaves spathulate fleshy, elliptic or ovate, $\cdot$ I to 3 in. long, blunt; petioles short. Flowers in minute axillary cymes very short. Male flowers few, very small. Achenes minute. Hab. A garden weed occurring in shady spots in Singapore, Malacca, Kwala Lumpur, Penang Waterfall, etc. Native of South America. "The Artillery plant."

\section{PELLIONIA, Gaud.}

Herbs. Leaves alternate chartaceous or fleshy. Male flowers in open branched or contracted peduncled cymes. Females usually denser. Perianth longer than the compressed tubercled achene. Species about I5, Indo-Malaya, Polynesia.

Half shrubby herbs, leaves petiolate.

Stem rooting at base only; male cymes peduncled branched.

Stem creeping its whole length; male cymes peduncled branched

Stem ascending; male cyme capitulate sessile.

Slender creeper; leaves sessile oblong blunt

(I) P. Helferiana

(2) P. javanica

(3) P. Curtisii

(4) P. Duvauana

(I) P. Helferiana Wedd. in DC. Prod. xvi. i. I7o; Hook. fil. F.B.I. v. 56r.

Stem erect rooting only at base, nearly I ft. tall. Leaves elliptic or ovate acuminate cuspidate, base slightly narrowed, 
inæquilateral, glabrous on both sides, 4 to 5 in. long, $2 \cdot 25$ to 2.5 in. wide; petioles $I$ to 3.5 in. long; male cymes slender, about $I$ in. long; branches spreading, $\cdot 75$ in. long. Female heads dense, $\cdot 25$ in. across, not spreading, sub-capitate. Hab. Johor, Gunong Pantai. Pahang, Kwala Tembeling; Kota Glanggi. Selangor, Batu Caves; Ginting Bidai. Perak. Kelantan, Kwala Aring (Yapp). Distrib. Tenasserim, Andamans.

(2) P. javanica Wedd. Monogr. 288; Hook. fil. F.B.I. v. $56 \mathrm{I}$; Ridl. Journ. Roy. As. Soc. S. Br. 59, p. I87.

Rhizome creeping. Leaves rather stiff, chartaceous, dark green, glabrous above, pale beneath with appressed hairs on midrib, ovate acuminate or cuspidate blunt, base narrowed, 3-nerved with conspicuous lateral nervules 4 to 7 in. long, 2 to 3 in. wide; petioles 5 to 6 in. long. Male inflorescence long peduncled; peduncle 3 in. long or shorter and nearly sessile. Flowers green tipped pink, densely crowded in heads on branched capitate cymes. Females densely crowded in capitate cymes, branched about I in. long, peduncled as in male. Achenes pustular pink. Hab. Perak, Temengoh; Maxwell's Hill. Penang Hill and Balik Pulau (Curtis); Penara Bukit. Setul, Bukit Rajah Wang (Ridley).

var. acaulis Ridl. l.c. P. acaulis Hook. fil. l.c. 562. Dwarf plant with short petioles; nerves and petiole more hairy. Inflorescence compact, Perak, Temengoh. Penang Hill, Pulaı Betong (Curtis).

Erroneously described as from Java by Weddell.

(3) P. Curtisii Ridl. Journ. Roy. As. Soc. S. Br. 82, p. Ig6.

Half shrubby branched herb a foot tall. Leaves oblique elliptic-acuminate, base narrowed inæquilateral, sub-sessile edge at apex undulate obscurely serrate, $3.5 \mathrm{in}$. long, $\mathrm{I}_{5} 5$ in. wide. Male flowers pedicelled; pedicels $\cdot 2$ in. long in a large cluster $\cdot 75$ in. long at base of plant. Sepals 5, oblong, $I$ in. long, blunt. Stamens 5; filaments very short. Female flowers in an axillary sessile head in an upper axil $\cdot 25$ in. through. Sepals lanceolate, keeled, keel prolonged into a subulate point 4 to 5 . Stigma penicillate. Achene ovoid, flat pustular. Hab. Rare, Perak, Bujong Malacca (Curtis, Aug. I8g8).

(4) P. Duvauana N.E.Br. Ill. Hort. xxix. I89, t. 472. P. pulchra N.E.Br. Gard. Chron. I882, xviii. 7I2.

Prostrate creeping herb. Leaves fleshy sessile obliquely oblong, tip round, base round inæquilateral, crenate; nerves pubescent; I. 25 to 3 in. long, $\cdot 75$ to $I \cdot 5$ in. wide. Stipules large ovate acuminate persistent. Male cymes long-peduncled, branched pubescent; peduncle 3 in. long, cyme 2 in. across.

var. viridis Ridley. Leaves pale green. Hab. On banks in forest, common, Pahang River; Tahan River. Negri Sembilan, Bukit Sulu (Cantley). Selangor, Batu Caves. Perak, Ulu Bubong, 
and Larut Hills (Kunstler); Temengoh; Kenering (Wray). Kedah. Setul, Batu Bungah. Kelantan, Kota Bharu. Distrib. Tenasserim. var. pulcherrima. Leaves purple, variegated with grey green above, on limestone rocks, Lankawi. Distrib. S. Siam, Cambodia. Native name: Akar Sisik Naga Bukit.

Often cultivated as a pot plant in the Straits. The original $P$. Duvanana Brown was the ornamental variety pulcherrima.

\section{ELATOSTEMA, Forst.}

Herbs on rocks in streams, or undershrubs. Leaves alternate distichous, sessile or nearly so, oblique and unequal sided, 3-nerved at base, toothed. Flowers minute in sessile or peduncled heads, involucral bracts round or oblong or confluent in a fleshy disc; bracteoles crowded oblong in male, spathulate in female heads. Males; sepals 4 to 5 , two or more spurred or tubercled on back. Stamens 4 to 5 inflexed. Female sepals 3 to 5 very minute; stigma penicillate. Achenes minute, ellipsoid, ribbed. Species 50, tropics of Asia and Africa.

Leaves pubescent beneath.

Base narrowed slightly unequal; bracts distinct .

Base auricled very unequal; bracts connate; big plant

(I) E. sessile

(2) E. platyphyllum

Leaves lanceolate narrow, very unequal, not auricled; nerves yellow hairy.

Bracts distinct broad

(3) E. molle

Leaves glabrous, thin.

Teeth very coarse and few, tip long cuspidate, base acute

Edge shortly crenate, base unequally bilobed :

(4) E. acuminatum

(5) E. inæquilobum

(I) E. sessile Forst. Char. Gen, I06; Hook. fil. F.B.I. v. 563.

Glabrous or pubescent, 6 to I2 in. tall; stems simple. Leaves sessile or short petioled, oblique oblanceolate caudate coarse serrate 4 to 8 in. long, I.5 in. wide. Receptacles 2 solitary (rarely 2 to 3 ) sessile or short peduncled, 25 in. across. Involucral bracts in male free broad ovate. Achenes minute. Hab. Rocks in streams, abundant, Pahang, Kota Glanggi. Selangor, Kwala Lumpur (Curtis); Ginting Simpai; Batu Caves. Perak, Lenggong; Thaiping Hills; Goping (Kunstler). Penang, Gardens near the bath. Distrib. Asia, Africa, Polynesia.

(2) E. platyphyllum Wedd. Monog. 30r; Hook. fil. F.B.I. v. 566.

A big robust plant over I2 in. tall. Leaves sessile or shortpetioled, rather thick obliquely oblong-oblanceolate cuspidate or caudate acuminate serrulate, base inæquilateral auricled, bright green, 4 to 6 in. (Io in.) long, $2 \cdot 75$ in. wide. Male heads often in pairs, 3 in. or more across, lobed peduncled or sessile, involucral bracts confluent fleshy. Hab. Selangor, Batu Caves. Penang, road to Balik Pulau (Curtis). Kelantan, Kwala Aring (Yapp). Distrib. India. 
(3) E. molle Wedd. Monog. 298; Hook. fil. F.B.I. v. 564.

Stem angled branched. Leaves lanceolate long acuminate, base very unequal cuneate serrate, reticulate beneath; nerves (and stem) yellow hairy beneath, 3 to 3.5 in. long, $\cdot 75$ to I in. across; petioles very short or none. Male heads sessile, $\cdot 5$ in. across, white. Involucral bracts broad scarious puberulous. $H a b$. On rocks in streams, Pahang, Tahan River (leaves very narrow, 4 in. across). Perak, Thaiping Hills; Gunong Inas at Sira Rimau (Yapp). Penang Hill (Phillips, Wallich). Distrib. Assam, Khasya.

(4) E. acuminatum Brngn. Du Perr. Voy. Bot. 2II; Hook. fil. F.B.I. v. 566 .

Slender branched glabrous herb, 7 to $\mathrm{I} 2 \mathrm{in}$. tall. Leaves thin sub-sessile oblique oblanceolate caudate coarsely toothed, except the lowest third, base acute, 4 in. long, $\cdot 75$ in. wide; heads sessile, - I in. across, involucral bracts minute. Hab. Mountain streams, Pahang, Telom. Malacca (Maingay). Selangor, Ginting Peras; Semangkok Pass; Bukit Hitam (Kelsall). Perak, Bujong Malacca; Thaiping Hills (Curtis). Distrib. Khasya, Tenasserim, Ceylon, Java.

(5) E. inæquilobum Ridl. Journ. Roy. As. Soc. S. Br. 86, p. 307.

Herb glabrous with a long creeping stem succulent ascending I ft. tall. Leaves alternate inæequilaterally Ianceolate, long acuminate, base very unequally bilobed, one lobe rounded, edge crenate, serrate, trinerved, 4.5 in. long, $\mathrm{I}^{\cdot} 5 \mathrm{in}$. wide or less; petioles - I in. long or less. Male plant unknown. Female heads $\cdot$ I2 in. through on slender filiform axillary peduncles $\cdot 2$ in. long. Flowers numerous shortly pedicelled. Sepals 3, linear caudate with a broader base. Achene ellipsoid strongly tubercled. Hab. Damp forests and on rocky stream edges, Selangor, Ginting Sempah (Ridley). Distrib. Tonkin.

\section{PROCRIS, Juss.}

Succulent glabrous (rarely pubescent) shrubby plants. Leaves alternate, toothed or entire, fleshy. Male flowers in axillary branched cymes. Perianth 5- rarely 4-lobed, stamens 5 to 4 . Females in sessile heads, sessile on a receptacle; perianth cupshaped, very small. Stigma sessile penicillate. Achene ovoid striate. Species about 6, Asia, Africa, Polynesia.

Leaves narrow entire or minutely obscurely-toothed; I in. wide, nerves invisible

Leaves over $\mathrm{x}$ in. broad; nerves conspicuous

(I) P. lævigata

(I) P. lævigata $B l$. Bijdr. 508. P frutescens $H 00 k$ fil. $F$ BI. v. 575 (not of Blume).

Fleshy shrub over I2 in. tall. Leaves oblanceolate cuspidate nearly entire, base narrowed very unequal, 3 in. long, I in. wide; nerves nearly or quite invisible; petioles $I$ in. long. Male cymes lax. Females solitary sessile, $\cdot 2$ in. across. Hab. On rocks at rooo to 
2000 ft. altitude. Penang Hill (Porter, Curtis). Distrib. Java, Borneo, Philippines.

(2) P. latifolia $\mathrm{Bl}$. Bijdr. 508.

Succulent shrub about $2 \mathrm{ft}$. tall; stem stout. Leaves fleshy oblong cuspidate, base acuminate slightly unequal, edge entire; nerves conspicuous, elevate when dry, 5 to Io pairs; 7 in. long, 3 in. wide; petioles 75 in. long. Male flowers white in a lax slender cyme $\mathrm{I} \cdot 5$ in long; (peduncle about half the length). Female heads sessile, 4 in. across. Hab. On rocks in woods, Pahang, Telom; Kota Glanggi. Selangor, Ulu Selangor (Goodenough); Batu Caves; Ginting Bidai; Dusun Tua. Perak, Lenggong; Bujong Malacca; Thaiping Hills. Distrib. Nicobars, Christmas Isle, Java, Timor, Aru, Samoa.

\section{BCEHMERIA, Jacq.}

Shrubs or small trees. Leaves opposite or alternate, 3-nerved, toothed. Flowers in unisexual axillary spikes or racemes of clusters.

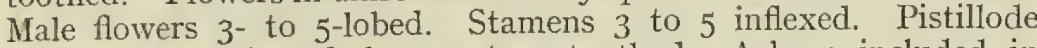
globose. Female tubular, 2- to 4-toothed. Achene included in perianth. Species about 50, Eastern Asia.

The Ramie, B. nivea, Hook and Arn., has long been cultivated in the Malay Peninsula, at least since 1845 (Griffith), its ovate, thin, rough-toothed leaves white beneath, var. candicans, or green beneath, var. tenacissima, and panicles of small clusters of flowers make it easily recognisable.

Flowers clustered on leafy branches . . . . (I) B. sidæfolia

Flowers in clusters in short spikes . . (2) B. lanceolata

(I) B. sidæfolia Wedd. Amm. Sc. Nat. Ser. 4, i. 203; Hook. fil. F.B.I v. 576 .

Slender diffuse undershrub. Leaves opposite and alternate elliptic or ovate-lanceolate caudate acuminate serrate, hairy on both sides, 3 to 5 in. long, $\mathrm{I} \cdot 75$ in. across or more; petioles $\mathrm{I}$ in. long. Flower clusters sessile on leafy branches, very numerous. Hab. Pahang, Telom. Distrib. India, Java.

(2) B. lanceolata Ridl. Journ. Roy. As. Soc. S. Br. 57, p. 94.

Shrub; stems covered with white appressed hairs. Leaves opposite, lanceolate acute, base truncate, edge serrate, glabrous pustular above; nerves hairy beneath, 3 from base elevate, nervules transverse; 6 in. long, I.75 in. wide or less; petioles I in. long. Spikes simple I or 2 axillary, white hairy. Flowers in clusters 'I 2 in. across, distant. Bracts lanceolate acuminate, those of clusters ovate cuspidate. Males minute, 5-lobed. Females sessile, hairy urceolate. $H a b$. Rare, Perak, Temengoh on sandy islets in the River Kertai.

\section{POUZOLZIA, Gaud.}

Herbs or small shrubs. Leaves opposite or alternate. Flowerheads small axillary, sessile. Stamens 4 or 5 ; style slender decid- 
uous otherwise resembling Bchmeria. Species about 50, Asia, Africa.

Shrub; leaves serrate

Herbs; leaves entire.

Leaves narrow lanceolate alternate

Leaves small ovate, hairy opposite; dwarf plant .

Leaves alternate distant ovate, long-petioled

Leaves 4 in. long, $\cdot 75$ in. wide, lanceolate, sessile or nearly opposite .

(I) P. viminea

(2) P. indica

var. angustifolia

var, microphylla

var. alienata

(I) P. viminea Wedd. DC. Prod. xvi. i. 228 ; Hook. fil. F.B.I. V. $58 \mathrm{r}$.

Shrubby plant 4 to $6 \mathrm{ft}$, tall; branchlets and petioles pubescent. Leaves ovate-lanceolate or lanceolate, caudate acuminate, serrate 3-nerved, smooth or scaberulous above, glabrous or strigose pubescent beneath, 3.5 to 4 in. long, I to I.25 in. wide; petioles $\cdot 4$ in. long. Flowers in small axillary clusters $\cdot 2$ in. across, white pubescent. Hab. Mountain forests, Pahang, Frazer Hill (Burkill). Selangor, Ginting Peras. Pahang, Telom (Ridley). Perak, Ulu Bubong and Goping (Kunstler); Temengoh. Kelantan, Kwala Aring (Yapp). Disirib. Indo-Malaya.

var. punctata; robust, woody. Leaves coriaceous, bullate shining above, quite glabrous. Hab. Kelantan, Chaning (Ridley).

This variety is the Untica punctata Ham., Wall. Cat. $46 \mathrm{I} 6 \mathrm{~B}$. from Goalpara. The species appears to be extremely variable in foliage. The common form here has comparatively thin leaves not coriaceous nor shining bullate and is hardly woody.

(2) P. indica Gaud. Freyc. Voy. Bot. 503; Hook. fil. 'F.B.I. v. $58 I$.

Herb about $\mathrm{I}_{2}$ to $\mathrm{I}_{5} \mathrm{in}$. tall, branched. Leaves usually alternate lanceolate (to ovate) acuminate entire, base shortly narrowed, glabrous (or pubescent), 2 in. long, $\cdot 2$ to $\cdot 25$ in. wide (upper ones smallest); petioles $\cdot \mathrm{I}$ in. long. Flowers in small axillary clusters about $\cdot 5$ in. across. Stamens 4. Achenes ribbed, sometimes winged. Hab. Common in damp waste ground.

var. angusiffolia. Erect with narrow leaves. Hab. Whole peninsula from Singapore to Setul and Lankawi. Distrib. Southern Siam. Native names: Balam; Kedudu Paya; Kicha.

var. microphylla. Procumbent, diffuse, about 6 in. tall, dense white hairy. Leaves opposite, small ovate, '5 in. long, ${ }^{1} 5 \mathrm{in.}$ wide. Heads very small, hairy. Fruit ribbed and winged. A very distinct looking little plant, which grows with the common form but is less common. Hab. Singapore, Chan Chu Kang; Bukit Timah. Malacca (Griffith), Malacca Hill; Sungei Baru. Penang, Bagian Jermal (Curtis). Distrib. Java. Native name: Ubai-Ubai. Use: As a vegetable.

var. alienata Roxb. Slender herb creeping at base, a foot or more tall, hairy above. Leaves alternate, distant, ovate, base 
cuneate hairy both sides, $\mathrm{I} \cdot 5$ to $\mathrm{I} \cdot 75 \mathrm{in}$. long, I in. across; petioles .25 in. long. Flower-heads small, few-flowered. Hab. Rare, Kelantan, Kwala Aring (Yapp). Lankawi (Curtis). Distrib. India; common.

There are several more varieties of this species in India and Malaya.

(3) P. Bennettiana Wight Ic.t. 1978; Hook. fll. F.B.I. v. 585.

Tall plant pubescent. Leaves lanceolate acuminate opposite sessile or short petioled, $4.5 \mathrm{in}$. long, 75 in. across. Heads $\cdot 5$ in. across, many-flowered axillary. Stamens 5. Hab. Very rare, Pahang, Telom. Distrib. Indo-Malaya, apparently very common and variable.

\section{PIPTURUS, Weddell.}

Shrubs (or trees erect or) climbing. Leaves alternate 3- to 5-nerved. Stipules bifid. Flowers unisexual in spicate or panicled clusters. Male perianth 4 - to 5 -cleft, valvate. Stamens 4 or 5 . Pistillode woolly. Female flowers on a fleshy receptacle. Perianth ovoid. Ovary adherent to perianth; stigma linear long. Achene free in the fleshy perianth. Species 8, Mascarenes, Malayan, Australasian.

(I) P. mollissimus Wedd. Monog. 449; Hook. fll. F.B.I. v. 589.

Climber about $50 \mathrm{ft}$. long, I in. through. Leaves elliptic to ovate or obovate acute or round at tip, base cuneate entire; nerves 3 , with one pair at top of midrib, nervules transverse, all elevate, puberulous above, tomentose beneath; 3 to 5 in. long, $\mathrm{I} \cdot 5$ to 2.5 in. wide; petioles I in. long. Flower clusters ${ }^{-} 5$ in. across, distant on spikes 3 in. long, 3 to 3 together axillary. Flowers yellow. Fruit white. Hab. Forests, Singapore, Toas. Johor, Tanjong Kupang. Selangor, Klang; Batu Caves. Perak, Sungei Larut, Chanderiang (Kunstler). Penang, Ayer Hitam (Curtis, Porter). Distrib. Java.

\section{VILLEBRUNEA, Gaud.}

Trees. Leaves penninerved sometimes serrate. Flowers in small peduncled heads. Female perianth adnate to ovary. Achenes adnate to the perianth which is fleshy, only at base. Species about 8, Indo-Malaya, Japan.

(I) V. sylvatica $B l$. Mus. Bot. 2, p. I67.

Tree about $50 \mathrm{ft}$. tall; branches spreading, pubescent at tips. Leaves elliptic-oblong cuspidate, base round, edge crenulate above, chartaceous (rarely entire); nerves 8 to I5 pairs, glabrous; 6 in. long, 3 in. wide; petioles slender, $2 \cdot 5$ in. long; peduncles very slender, $\cdot 5$ in. long or less, branched. Heads globose, about $\cdot$ I in. across. Fruit very small white. Hab. Mountain forests at $2500 \mathrm{ft}$. altitude or lower, Negri Sembilan, Tampin (Goodenough); Bukit Tangga. Selangor, Batu caves; Ulu Gombak; Ginting Bidai. Disirib. Java. 


\section{DEBREGEASIA, Gaud.}

Shrubs (or trees). Leaves alternate serrate usually white beneath, 3-nerved. Flowers in capitate (sessile or) panicled clusters. Male sepale 3 - to 5-valvate. Stamens 3 to 5 inflexed. Females on a fleshy receptacle. Perianth ovoid or obovoid, succulent when ripe. Stigma penicillate. Achene cohering with the fleshy perianth. Species 5, Asia and Africa.

(I) D. squamata Hook. fil. F.B.I. v. 59I.

Shrub about $15{ }^{\circ} \mathrm{ft}$. long, covered with rough soft prickles and tomentose. Leaves membranous, ovate cuspidate, close serrate, base round, grey tomentose, sparsely rough hairy above, 4 to 6 in. long, 3 to 4 in. wide; petioles $I \cdot 5$ in. long. Heads globose, $\cdot I$ in. across in branched cymes about .5 in. long, tomentose. Flowers orange. Fruit red. Hab. Selangor, Batu Caves; Ulu Gombak Road. Perak, Thaiping Hills; Tambun; Kwala Dipang and Gapis Pass (Curtis); Gunong Bubu (Kunstler).

\section{ORDER CXXX. JUGLANDACEÆ.}

Large trees. Leaves alternate, pinnate. Flowers unisexual in simple or panicled spikes. Perianth o or of 3 to 6 lobes adnate to bract. Female perianth 4-lobed, superior. Stamens 2 or more on the lobes; filaments very short or 0 . Ovary inferior, I-celled; ovule I, erect. Fruit a drupe or nut, sometimes winged with the enlarged bract. Genera 5, chiefly North Temperate, few tropical. (Gamble, Journ. As. Soc. Beng. lxxv. (4), 399.)

\section{ENGELHARDTIA, Lesch.}

Trees. Leaves pinnate; leaflets often serrate, often with glandular scales. Flowers unisexual in panicled spikes or racemes, with bracts which in the females become expanded into wings in fruit. Perianth irregular or 4-lobed, in male 4-lobed and surmounting ovary in female. Stamens 4 to I2, sub-sessile on sepals. Ovary I-celled, I-ovuled; style short; stigmas 2. Fruit a small globose nut adnate to the 3- to 6-lobed bract; lobes usually 3 , elongate tube hairy or scaly. Species about 6, India, China, Malaya.

Fruit hairy.

Leaflets membranous elliptic-oblong

Leaflets coriaceous crenate, $\mathrm{I}$ in. long, elliptic

Fruit glandular scaly.

Leaflets coriaceous lanceolate, 3.5 in. long

(I) E. spicata

(2) E. nudiflora

(3) E. Wallichiana

(I) E. spicata $B l$. Bijdr. 528; Fl. Jav. Juglandacea, 8, tt. I; 5A; Gamble, l.c. 400.

A big tree $80 \mathrm{ft}$. or more tall. Leaves 9 in. long; leaflets 3 to 7 pairs, membranous or chartaceous, elliptic-oblong acuminate or 
acute, base round or narrowed unequally entire; midrib at least pubescent beneath; nerves Io to I2 pairs; 4 to $6 \mathrm{in}$. long, 2 to 2.5 in. wide; petioles $I_{5}$ in. long. Spikes slender, pubescent, 9 in. long. Perianth irregular in male, $4^{-}$to 5 -lobed in female. Fruit hairy; bract 3-lobed; midlobe longest, 2 in. long, -25 in. wide, linear-oblong to sub-spathulate glabrous papery. Hab. Rare, Perak, Temengoh River bank. Distrib. India to Philippines.

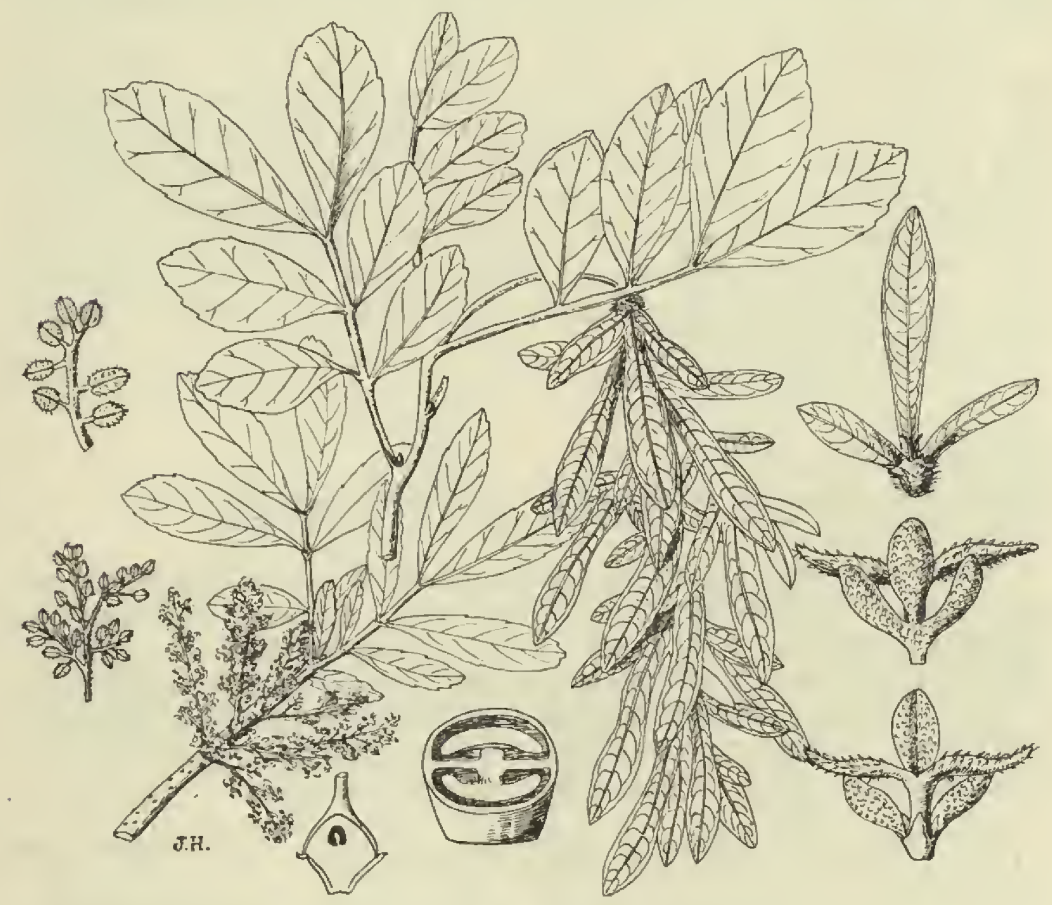

FIG, I58.-Engelhardtia nudiflora.

(2) E. nudiflora Hook. fil. Ic. Pl. 1747; F.B.I. v. 597 ; Gamble, l.c. $40 I$.

Tree; medium or large; young parts red-pubescent and glandular. Leaves about 3 in. long; leaflets 2 to 6 pairs, coriaceous sub-sessile elliptic or obovate blunt, base unequally cuneate, sometimes slightly crenate, $I$ in. long, 6 in. wide. Spikes slender, axillary, 2 in. long, velvety; bracts pectinate lobed. Fruit spikes 6 in. long, nut hairy; midlobe linear-spathulate, 2 in. long, 25 in. wide, strongly veined and reticulate, side half as long. $H a b$. Singapore, Garden Jungle. Pahang, Rumpin River (Evans). Dindings, Bruas. Penang Hill at about $2000 \mathrm{ft}$. altitude (Maingay, etc.).

Fl, M.P., 3. 
var. crenata, Hook. fil. E. serrata Hook. fil. F.B.I. v. 596 (not of Blume).

Leaflets strongly crenate, base very unequal, $2.25 \mathrm{in}$. long, $\mathrm{I} \cdot 5$ in. wide. Fruit-spike 9 in. long. Fruiting bracts with side lobes winged, midlobe expanded. Hab. Penang, Muka Head (Curtis). Possibly a distinct species but the flowers are unknown.

(3) E. Wallichiana Lindl. Wall. Cat. 4942; Gamble, l.c. 402. E. Roxburghiana Lindl. in Wall. Pl. As. Rar. ii. 87, t. I99 (except fruit).

Big tree, 80 to Ioo $\mathrm{ft}$. tall. Leaves $5 \mathrm{in}$. long; petiole and rachis slender, leaflets 2 to 4 pairs coriaceous lanceolate subfalcate, 3.5 in. long, I in. wide, acuminate, base unequally cuneate; petiolules $\cdot$ I 5 in. long. Spikes very slender, 3 in. long, panicled glandular. Perianth lobes 4, obovate. Stamens 3. Fruit globular, 2 in. through, glandular scaly, lobes pubescent; midlobe $\mathrm{I} \cdot 5$ in. long, $\cdot 2$ in. wide, spathulate-linear. Forests at 2000 to $3500 \mathrm{ft}$. altitude. $H a b$. Perak, hills at 3200 to $3500 \mathrm{ft}$. altitude (Kunstler). Penang Hill (Wallich, Curtis, etc.).

\section{ORDER CXXXI. MYRICACEA.}

Glandular (and aromatic) trees and shrubs. Leaves alternate, penni-nerved simple or lobed or serrate. Flowers unisexual or bisexual in catkins very small. Male spikes fascicled or panicled; females simple axillary. Male flowers 3 to 6 stamens on a torus adnate to bract; filaments short. Female ovary sessile I-celled; style bifid. Ovule I anatropous. Drupe ovoid or globose. One genus Myrica. Hab. Whole world except Australia.

Leaves narrowed at base; inflorescence pubescent .

Leaves truncate auricled at base; inflorescence glabrous

(I) M. Farquhariana

(I) M. Farquhariana Wall. Tent. Fl. Nepal, 61. M. æsculenta, Gamble, Journ. As. Soc. Beng. lxxv. (4), p. 404 (not of Buch. Ham.). (Fig. I57, p. 37I.)

A bush to a tree about 20 or $30 \mathrm{ft}$. tall. Leaves dark shining green, coriaceous, oblanceolate, entire when adult, blunt or rounded, base cuneate, 2 to $3.5 \mathrm{in}$. long, $\cdot 75$ to $I$ in. wide; petioles - I to .25 in. long. Spikes, males 2 in. long, velvety pubescent panicled, with small catkins Io- to I2-flowered, a small cordate ovate bract and 3 to 6 stamens. Females, simple slender spikes; flowers I to 3 together. Drupe $\cdot 2$ in. long, red. $H a b$. Sandy woods, usually near the sea. Very common, Singapore, Krangi; Tanglin; Toas; Bajau; Bukit Timah. Malacca, Bukit Bruang (Cantley). Pahang, Pekan; Kuantan (Foxworthy). Negri Sembilan, Bukit Kajang 
(Cantley). Distrib. Bangka. Native names: Kayteng; Kusama; Gilinche; Telor Chichak.

In seedlings the leaves are lanceolate, strongly serrate, as much as 9 in. long, 2 in. across.

(2) M. auriculata Ridl. M. æsculenta var. auriculata Gamble, l.c. 405 .

Glabrous bush Io to $\mathrm{I} 2 \mathrm{ft}$. tall. Leaves oblanceolate, obtusely short acuminate, base truncate auricled; midrib strongly elevate, nerves 8 pairs elevate beneath, inarching, as are nervules and reticu-

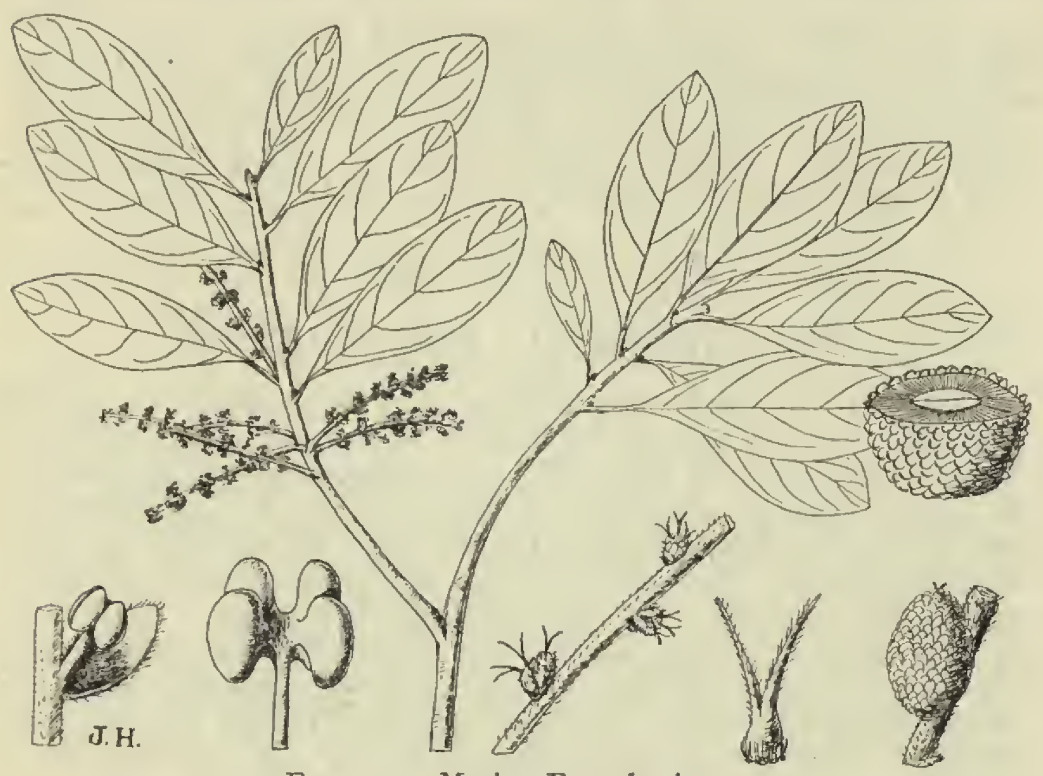

FIG. 157.-Myrica Farquhariana.

lations; $3 \mathrm{in}$. long, I. I5 in. wide; petioles $\cdot \mathrm{I} 2 \mathrm{in}$. long or less. Inflorescence quite glabrous, male panicles $\mathrm{I} \cdot 25$ in. long, reddish-brown, dense, the catkins clustered on a simple spike; bracts of catkins acuminate reflexed, ${ }^{\circ} \mathrm{O}$ in. long. Females unknown. Hab. High mountains, Pahang, Gunong Tahan (Robinson).

\section{ORDER CXXXII. CASUARINEE.}

Trees (or shrubs), branchlets cylindric, grooved jointed, green, internodes ending in a sheath of connate subulate scales. No leaves. Flowers unisexual. Males in whorls in terminal spikes of shorttoothed cups, each flower with 2 bracteoles. Perianth of I or 2 
concave segments, pushed off by the anther. Stamen I. Female in ovoid or globose heads; perianth o. Ovary minute, I-celled; ovules 2, style bifid with 2 long red arms. Fruit an oblong or globose cone formed of the enlarged hardened bracts and bracteoles, forming 2-valved cavities enclosing the flat winged achenes. One genus Casuarina of about 25 species, mostly Australian, a few Malayan (4) and Polynesian.

(I) C. equisetifolia Forst. Char. Gen. I03, t. 53; Gamble, Journ. As. Soc. Beng. lxxv. (4), p. 406.

Tree with rough bark about 80 to Ioo $\mathrm{ft}$. tall and sometimes 2 to $3 \mathrm{ft}$. through; branches filiform, slender, about 9 to I2 in. long; internodes 3 in. long, sheaths with 6 to 8 scales. Male spikes cylindric, $\cdot 8$ in. long. Cones globular-oblong, $\cdot 4$ in. long and thick. Hab. Sea coasts in land and elsewhere planted, Pahang, Pekan; Sungei Meang. Kelantan by river mouth. Pulau Adang. Distrib. From Bengal to Polynesia. Native name: Ru, or Eru.

\section{ORDER CXXXIII. CUPULIFERÆ.}

Trees, rarely dwarfed to shrubs. Leaves alternate, sometimes toothed. Flowers minute unisexual (sometimes hermaphrodite). Males in spikes (rarely capitate). Females spiked, usually solitary. Bracts sometimes involucrate. Perianth usually 6-lobed, membranous free or connate. Female smaller with an involucre of many imbricate scales. Stamens 6 to I2; filaments slender. Ovary 3to 6-celled in female cells 2-ovuled; styles as many. Fruit a nut (acorn) or up to 4 nuts, seated on or more or less included in large involucrate bracts forming a cupule. Pericarp coriaceous or woody. Seed usually solitary. Species numerous, chiefly in temperate climates. Gamble, Journ. As. Soc. Beng. 1xxv. (4), 406 (Fagacea).

Nut I. Cupule cup-shaped, not enclosing the nut.

Stamens 6; stigmas broad covering inner part of style; leaves usually serrate

Stamens I2; stigmas of a single pair terminal; leaves entire, a few with cup entirely covering acorn

Nuts I to 4 . Cup entirely enclosing the nuts splitting, irregularly spiny or tubercled.

I. Quercus

2. Pasania

3. Castanopsis

\section{QUERCUS, Linn.}

Trees. Leaves toothed or lobed, rarely entire. Male spikes pendulous. Perianth cup-shaped, 6-lobed. Stamens 6 (or fewer). Stigmas in female broad, covering the inner surface of the styles or capitate. Cup (in our species) lamellate. About 200 species, chiefly North Temperate region. Native names: Berangan babi (Pigchestnut) and Empening. 
Leaf silvery beneath. Cup obconic at base; hemispheric above; lamellæ 8 to ro, thin.

(1) Q. argentata

Leaves not silvery, more prominently serrate.

Leaves 6 to 7 in. long; cup cylindric, hemispheric ; lamellæ thin

Leaves 2 to $2 \cdot 25$ in. long; cup cylindric, base conic with thickened lamella

\section{(2) Q. oidocarpa \\ (3) Q. turbinata var. crassilamellata}

(I) Q. argentata Korth. in Verh. Nat. Gesch. Bot. 2I5, t. 47. Figs. I to I7; Gamble, l.c. 408; King, Ann. Bot. Gard. Calc., ii. 30, pl. $24 \mathrm{~A}$.

A big tree $80 \mathrm{ft}$. tall. Leaves coriaceous, silvery beneath, elliptic-oblong to oblanceolate, abruptly shortly caudate-acuminate, entire or obscurely repand-serrate, 4 to 5 teeth in upper part; nerves ro to I5 pairs, fairly conspicuous; 5 in. long, 2.25 in. wide; petioles $I$ to $I \cdot 5$ in. long. Male spikes in axillary panicles $I \cdot 2$ in. long. Spikes villous. Females .8 to 2 in. long. Fruit sessile; cup obconic covering half the acorn $\cdot 8$ in. deep, I. 5 in. wide, with 8 to Io thin, grey puberulous minutely-toothed lamellæ. Acorn ovoid, chestnut brown, I in. long, .8 in. through; umbo truncateconic. Hab. Forests, apparently not common, Singapore, Garden Jungle. Malacca, Batu Tiga (Holmberg). Distrib. Bangka, Sumatra, Borneo. Native name: Pening Pening.

(2) Q. oidocarpa Korth. l.c. 2 r6, t. 47, Fig. I8; Gamble, l.c. 409; King, Ann. Bot. Gard. Calc. ii. 28, t. 2IA.

Big tree 80 to Ioo $\mathrm{ft}$. tall, 2 to $3 \mathrm{ft}$. through. Leaves coriaceous elliptic-oblong or oblanceolate acute, base acute, serrate at top; nerves 8 to 12 pairs prominent on both sides but chiefly on back, reticulations prominent beneath; 6 to $7 \mathrm{in}$. long, 2 to $2.5 \mathrm{in}$. wide; petioles .75 in. long. Male spikes unknown. Female solitary shorter than leaves. Fruit sessile, cup cylindric hemispheric, I in. long and wide; lamella 6 to 8 , broad minutely tomentose edges of lower ones crenate. Acorn ovoid-globose, top slightly flattened and conical zoned umbo, all pubescent, 8 to $\mathrm{I} \cdot 2$ in. long. $H a b$. Perak, hills, Larut (Kunstler). Penang, Batu Feringhi (Curtis). Distrib. Sumatra, Borneo. Native name: Berangan antan.

(3) Q. turbinata Bl. Bijdr. 523; Fl. Jav. Cupul. 3I, t. I8; Gamble l.c. 410; King, Ann. Bot. Gard. Calc. l.c. 33, t. 26. 2.

var. crassilamellata Gamble, l.c. A big tree. Leaves coriaceous elliptic-oblong, short blunt acuminate, base attenuate, edges serrate above; nerves 8 to 9 pairs elevate beneath and slightly above; 2 to $2.5 \mathrm{in}$. long, 5 in. wide; petioles slender, $\cdot 25$ to $\cdot 3 \mathrm{in}$, long. Male spikes dense, short villous clustered catkins 25 in. long, in upper axils. Females short. Fruit sessile. Cup obconic at base with 2 belts then cylindric, 6 in. long with 4 belts, top flat with 2 or 3 belts 5 in. across with a small hole from which only the umbo of the ovoid depressed puberulous acorn appears. Hab. Rare at 3000 to $3400 \mathrm{ft}$. altitude. Perak, Ulu Batang Padang (Wray). Penang, West Hill at $2500 \mathrm{ft}$. altitude (Curtis). 


\section{PASANIA, Oerst.}

Oaks with entire leaves and erect male spikes. Stamens I2. Stigma a terminal pore on the slightly curved styles. Acorn ovoid or globose, sometimes quite enclosed in the cup, only the umbo visible. Cup with imbricate separate scales or combined in rings of ten reduced to mere lines. Seed I. About Ioo species, Malaya and Polynesia. Native names as for Quercus.

§i. EU-PASANia.

Cups with imbricate scales, tips free, acorns much exsert.

Scales of cup soft spreading.

Cup thin enclosing most of the silky acorn; leaves membranous .

Cup thick enclosing $\frac{2}{3}$ of velvety acorn; leaves coriaceous

Cup saucer-shaped enclosing base of glabrous acorn; leaves coriaceous .

Scales of cup appressed.

Cup hemispheric; acorns cylindric-conic .

Scales not in rings; acorns glabrous in dense spikes. Cups saucer-shaped.

Acorn ovoid conic; leaves 6 to $8 \mathrm{in.} \mathrm{long} \mathrm{.}$

Acorn globose-conic; leaves ro to $13 \mathrm{in.} \mathrm{long}$

Acorn ovoid-cylindric; leaves 7 to 8 in. long, linear-oblong .

Scales of cup distinct apiculate in obscure rings; acorns ovoid conic.

Acorn silky, tips of scales not spreading.

Leaves elliptic sub-coriaceous; nerves 9 to ro pairs not raised .

Leaves oblong - lanceolate 'coriaceous; nerves 8 to I 4 pairs, prominent

Acorn glabrous; scales spreading.

Leaves thin coriaceous glabrous as are

Acorn praberulous, cup-scales appressed,

(I) P. lappacea

(2) P. Kingiana

(3) P. Scortechinii

(4) P. Kunstleri

(5) P. spicata

(6) P. grandifrons

(7) P. Falconeri

(8) P. lamponga

(9) P. Wallichiana

(Io) P. sundaica

(I I) P. hystrix

(1 2) P. Curtisii

$\S$ ii. Cyclobalanus.

Scales of cup united in entire or minutely toothed rings.

Acorn longer than broad ovoid-conic.

Acorn sharp conic; leaves coriaceous tomentose beneath .

Acorn not longer than broad hemispheric, cup very thin, rings rather indistinct.

Acorn ovoid glabrous; leaves silvery beneath

Acorn broad, hemispheric; leaves stellate pubescent beneath

Cup thick; leaves coriaceous.

Cup rings not prominent.

Leaves elliptic glabrous; acorn conic.

Leaves oblong-lanceolate pubescent beneath; acorn depressed hemispheric .

Cup-rings prominent and thick.

Leaves elliptic; acorn depressed globose

Leaves lanceolate, small; acorn conic.

(13) P. conocarpa

(I 4) P. Ewyckii

(15) P. cyrtorhyncha

(I6) P. Bennettii

(I 7) P. Cantleyana

(I 8) P. Wenzigiana

(I9) P. rassa 
Acorn depressed hemispheric, broader than Iong.

Cups single thin, flat; acorn silky; Ieaves white beneath : .

Cups single thick, edges incurved; leaves thin coriaceous.

Rings few about 5 ; leaves caudate

(20) P. Eichleri

Rings many broad below.

Leaves blunt acuminate

Leaves very coriaceous oblanceolate

Leaves oblong acuminate; acorn tomentose very flat and large

Leaves lanceolate caudate acuminate; acorn glabrous, very large .

Cups combined in threes; Ieaves lanceolate very coriaceous

(2I) P. Clementiana

(22) P. omalokos

(23) P. lucida

(24) P. cyclophora

(25) P. costata

(26) P. lampadaria

§iii. Chlamydobalanus.

Cups covering the whole acorn except umbo, only adnate at base; cupscales appressed; acorn silky.

Cups thin; leaf nerves I2 to I 4 pairs.

Cup thick tubercled; nerves 6 to 8 pairs

Cups spiny; acorns pubescent or silky.

Cups covered with hooked spines

Spines in tufts or broken rings ; leaves entire

Spines in oblique rings; leaves serrate a bove

Cups smooth; rings faint or o; acorns silky.

Fruit pedicelled; leaves chartaceous; fruit spikes large.

Fruit sessile spikes short; leaves coriaceous

(27) P. Blumeana

(28) P. confragosa

(29) P. Wrayii

(30) P. discocarpa

(3I) P. acuminatissima

(32) P. encleisacarpa

(33) P. Robinsonii

§iv. LITHOCARPUS,

Cups covering acorn except umbo and adhering to it.

Fruit pear-shaped, rings obscure . ( (34) P. Maingayi

Fruit ovoid or obovoid, rings 5 to 7 : (35) P. Beccariana

\section{$\S$ i. EU-PASANIA} l.c. $4 \mathrm{I} 6$.

(I) P. Lappacea Oerst. Kjoeb. Vidensk. Meddel. 84; Gamble,

Tree 60 to $80 \mathrm{ft}$. tall; young parts fuscous tomentose. Leaves membranous, oblong-lanceolate or oblanceolate, caudate-acuminate, base acute pubescent beneath especially on midrib and $\mathrm{I} 2$ to I 6 pairs elevate nerves; 4 to 9 in. long. I 3 to $2 \cdot 6$ in. wide. Spikes simple, solitary, yellow-villous, lowest 5 in. long male, upper female or both male and female. Male flowers clustered or solitary; perianth 5-lobed; stamens 9 to I2. Female flowers single or 2 or 3 together. Fruits clustered or solitary in spikes 6 in. long; cup sessile velvety, ovoid, $\cdot 8$ to $\mathrm{I}$ in. across, $\cdot 4 \mathrm{in}$. wide, covered with soft curved spines. Acorn ovoid-conic, 8 in. long, silky. Hab. Rare, Perak, Larut at 300 to $500 \mathrm{ft}$. altitude (Kunstler, Scortechini). Distrib. India and Burma.

(2) P. Kingiana Gamble, in Kew Bulletin, I9I4 p. I77; Journ. As. Soc. Beng. l.c. $4 \mathrm{I} 7$.

Tree. Leaves very coriaceous, glabrous, ovate, shortly blunt acuminate, base round and decurrent on petiole, nerves 6 to 8 
pairs elevate beneath, areolation conspicuous; 3 to 5 in. long, I 75 to 3 in. across; petioles stout, I I in. long. Spikes up to 7 in. long, stout puberulous on the branch ends. Flowers solitary, mixed lowest female, uppermost male, rather distant on cushions of pubescent scales. Cup I.5 in. across the recurved lips, cup-shaped covered with ovate cuspidate scales becoming smaller towards the top. Acorn ovoid-globose, base flat, velvety, 8 to I in. through, .6 to $\cdot 8$ in. tall; umbo thick. Hab. Mountains at 4500 to $7000 \mathrm{ft}$. altitude, Perak, Gunong Bubu; Gunong Inas and Gunong Berumbun (Wray). l.c. $4 \mathrm{I} 8$.

(3) P. Scortechinii Schky, in Engl. Jahrb. xlvii. 676; Gamble,

Big tree 80 to Ioo $\mathrm{ft}$. tall, $2 \mathrm{ft}$. through. Leaves coriaceous, oblong or elliptic blunt or sub-acute, base cuneate; nerves 8 to ro pairs slender, elevate beneath; 3.5 to 6 in. long, I. 8 to $2 \cdot 25$ in. wide; petioles $\cdot 4$ in. long. Fruit-spikes erect large. Cup saucershaped, I in. across, 4 in. deep, covered with dense soft conical pubescent scales. Acorn cylindro-globular shining chestnut brown, base truncate, top depressed, with a small umbo. Hab. Rare. Perak, Larut at 3200 to $3500 \mathrm{ft}$. altitude (Kunstler).

(4) P. Kunstleri Gamble, l.c. 49. Quercus Kunstleri King, in Hook. fil. F.B.I. v. 606; Ann. Bot. Gard. Calc. ii. 40, $t$. 3 I.

Tree 30 to $50 \mathrm{ft}$. tall; young parts tomentose. Leaves thin, coriaceous, elliptic or oblanceolate-oblong acute, base round or cordate, young puberulous, adult glabrous except midrib and nerves, puberulous; nerves strongly elevate, 8 to I2 pairs sunk above; 4 to 5 in. long, $I \cdot 5$ to $2 \cdot 25$ in. wide; petioles short or 0 , pubescent. Spikes axillary and terminal solitary fascicled, slender, 6 to 7 in. long, tomentose pubescent. Flowers scattered, male and female together. Fruit in long spikes; cup sub-sessile hemispheric, shallow, $\cdot 25$ in. long, 5 in. wide; scales broad ovate appressed tomentose; acorn narrow cylindric-conic, $\mathrm{I} \cdot 5 \mathrm{in}$. long, $\cdot 4$ in. through; umbo conspicuous contracted below the perianth. Hab. Forests in the lowlands; Selangor, Kwala Lumpur; Kanching (Foxworthy). Perak, Chanderiang; Larut (Kunstler); Batang Padang (Wray). Native name: Kelempening.

(5) P. spicata Oerst. Kjoeb. Vidensk. Meddel. 83; Gamble, l.c. 4I9. Quercus spicata, Smith, in Rees Encycl. xxix. I2; King, Ann. Bot. Gard. Calc. ii. 47, t. 4 I and 42.

Big tree, usually about $80 \mathrm{ft}$. tall. Leaves coriaceous, glabrous elliptic-oblong or lanceolate or obovate acuminate, point usually turned sideways, base narrowed; nerves to to 20 pairs elevate beneath, slender; 6 to 8 in. long, 3 in. wide; petioles $I$ in. long. Spikes erect, terminal in fascicles usually unisexual, 7 to 8 in. long tomentose, the flowers in crowded sessile clusters. Fruits 20 or more, sessile crowded on a woody rachis 8 or 9 in. long, single or in clusters of 3 to 5: cup saucer-shaped, edge acute; scales broad 
apiculate, $\cdot 2$ in. deep, $\cdot 6$ in. across. Acorn ovoid conic to depressed globose, little taller than the cup. Hab. Forests; common and variable.

var. gracilipes DC. Prod. xvi. (2), 86 .

Leaves lanceolate or oblanceolate narrowed to petiole; cup prominently scaly. Acorn round depressed at top. Hab. Singapore, Bukit Timah. Malacca, Sungei Hudang (Derry). Pahang, Bentong (Foxworthy). Negri Sembilan, Tampin (Burkill). Perak, Goping; Larut (Kunstler). Province Wellesley, Bukit Mertajam (Curtis).

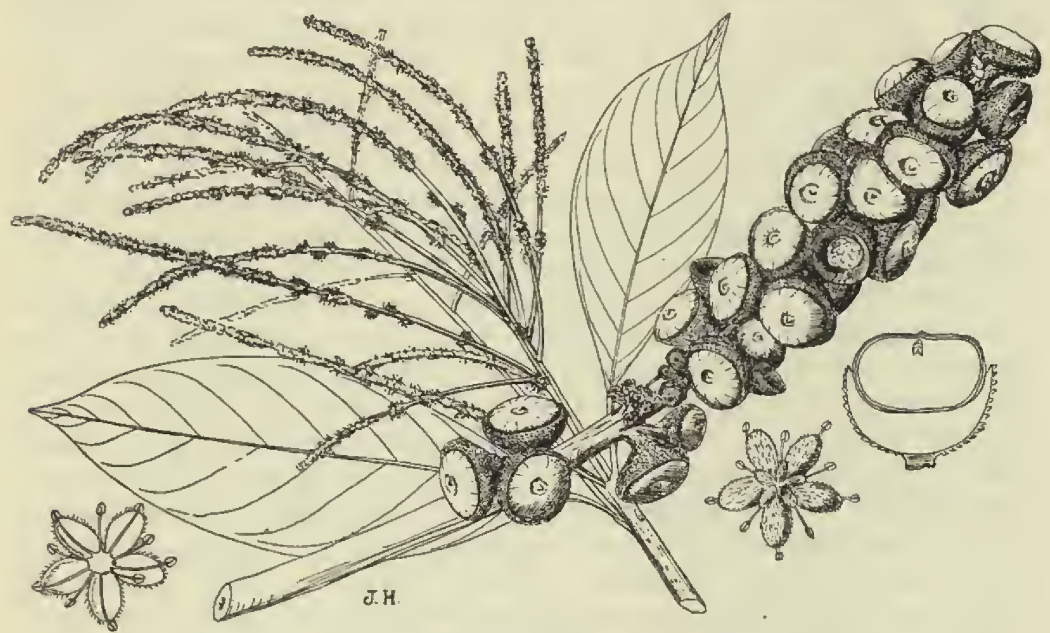

FIG. I59.-Pasania spicata var. gracilipes.

var. microcalyx. Leaves 3 by I.75 in. Fruit smaller; acorn tip conic, Perak, at $3000 \mathrm{ft}$. altitude on a large rock (Kunstler). Distrib. India, Burma, Java, Sumatra. Native names: Mempening Bungkas; Berangan Padi.

(6) P. grandifrons Gamble l.c. 42I. Quercus grandifrons King in Hook. fil F.B.I. v. 610; Ann. Bot. Gard. Calc, ii. 49 t. 83 B.

Big tree so to roo ft. tall, 2 to $3 \mathrm{ft}$. through. Leaves very large coriaceous, silvery beneath, elliptic-oblong abrupt caudate-acuminate; midrib thick, sunk above very prominent beneath, nerves I2 to 20 pairs parallel; Io to 13 in. long, 3 to 6 in. across; petioles very thick, $\cdot 5$ in. long. Spikes in hairy, terminal panicles 6 in. long, slender. Flowers in distant elongate clusters. Fruit distant in stout woody spikes on stout short pedicels scaly; cup with ovate acuminate scales pubescent appressed except tip very shallow, $\cdot 8 \mathrm{in}$. across. Acorns globose-conic, base flat, smooth, $\cdot 6$ in. tall, $\cdot 8$ in. across; umbo small. Hab. Mountain forests, Perak, Larut at 
Iooo ft. altitude (Kunstler); Gunong Kerbau at $5000 \mathrm{ft}$. altitude (Robinson); Relau Tujor (Wray). Penang, Penara Bukit (Curtis).

(7) P. Falconeri Schky, Engl. Jahrb. xlvii. 676; Gamble, l.c. 422. Quercus Falconeri Kurz in Journ. As. Soc. Beng. ii. 97; King, Ann. Bot. Gard. Calc. ii. 42, t. 34. Q. minor Ridl. Journ. Roy. As. Soc. S. Br. 57, p. 95 .

A small tree 20 to $30 \mathrm{ft}$. tall. Leaves thickly coriaccous linearoblong to oblong-lanceolate acuminate, often cuspidate, base acute or round; nerves sunk above, raised beneath, I2 to 20 pairs; 7 to 8 in. long, $2 \cdot 5$ in. wide; petioles thick, $\cdot 25$ in. long. Spikes slender erect from the axils of the terminal shoots, villous up to $7.8 \mathrm{in}$. long. Males solitary or in clusters; females distant solitary. Fruit spikes up to I4 in. long; rachis stout, villous at first. Cups saucershaped velvety shallow, scales close appressed, edge reflexed when ripe, 3 in. tall, 75 in. wide. Acorn ovoid cylindric, $x$ in. long, $\cdot 67$ to .87 in. wide; umbo blunt. Hab. Perak, Temengoh. Kedah, Alor Sta. Lankawi, Burau Bay; Telaya Tujoh (Curtis). Distrib. Tenasserim.

(8) P. lamponga Gamble, l.c. 423. Quercus Lamponga Miq. Fl. Ind. Bat. Suppl. 348; King, Ann. Bot. Gard. Calc., ii. 53, t. 49.

Tree $80 \mathrm{ft}$. tall. Leaves sub-coriaceous elliptic or ellipticlanceolate short abrupt caudate acuminate, base acute, silvery beneath; nerves 9 to Io pairs slender, elevate beneath; 4 in. long, I.75 to 2 in. wide; petioles $\cdot 2$ in. long. Spikes slender in terminal panicles about 4 in. long; rachis grey pulverulent flowers. Males above, females below, solitary or in groups of 3 or 4 rather distant. Fruit-spikes 6 in. long, woody; cups hemispheric, saucer-shaped; scales broad connate with acute appressed tips in faint regular rings 7 in. across, 23 in. deep. Acorn ovoid-conic, tawny velvety, $\cdot 6$ to $7 \cdot 2$ in. across, $\cdot 8$ in. tall; umbo acute. Hab. Common in lowland woods, Singapore, Bukit Timah; Pulau Ubin; Garden Jungle. Johor, Castlewood. Malacca, Merlimau. Selangor, Klang Gates, Perak, Tapah and Asam Kumbang (Wray); Gunong Batu Putih; Thaiping. Province Wellesley; Nibong Tebal (Curtis). var. eroyckioides Gamble, l.c. 425. Leaves smaller, 4 in. long, I. 6 in. wide, more silvery beneath; nerves more numerous. Spikes more slender. Fruit-cups more lamellate and scale points less prominent. Hab. Singapore, Garden Jungle; Chan Chu Kang; Selitar (King). Malacca, Brisu (Derry). Selangor, Kwala Lumpur. Perak, Asam Kumbang (Wray). Distrib. Sumatra, Bangka, Borneo to Papua.

King called this variety lamponga passing into Erwyckii. The foliage is very like that of Ewyckii. Can it be a hybrid?

(9) P. Wallichiana Gamble, l.c. 425. Quercus Wallichiana Wall. Cat. 2778; King Ann. Bot. Gard. Calc., ii. 51, t. 46.

Tree 30 to $60 \mathrm{ft}$. tall, I5 to $20 \mathrm{in}$. through; branchlets tomentose. Leaves coriaceous oblong-lanceolate, abruptly caudate-acuminate, base acuminate, grey and puberulose or glabrous beneath; nerves 
8 to I4 pairs elevate beneath; 6 to 6.5 in. long. 2.5 in. wide; petioles $\cdot 4$ in. long, rather thick. Spikes solitary and 2- to 3-panicled axillary and terminal, 7 in. long, male, or with females below. Male flowers clustered in oblong groups. Female flowers in rather distant clusters of 4 or 5. Fruits crowded in stout spikes about 7 in. long or less; pedicels very short thick; cups saucer-shaped, $\cdot 6$ in. across, -I to $I \cdot 35$ in. deep, hoary puberulous; scales broad in obscure rings, tips minute acute, free. Acorns hemispheric, conic at top tawny velvety, $\cdot 6$ in. through, 4 in. tall. $H a b$. Common in forests, Singapore, Selitar; Jurong; Pulau Ubin. Malacca, Sungei Hudang. Selangor, Semangkok Pass. Negri Sembilan, Bukit Kajang (Cantley). Perak, Ulu Bubong and Larut Hills (Kunstler). Penang (Wallich and all collectors).

(I0) P. sundaica Oerst. l.c. 83; Gamble, l.c. 426. Quercus sundaica Bl. Fl. Jav. Cupul, ii.t. 2 to 3 ; King, Ann. Bot. Gard. Calc., ii. 5 I, $t$ t. 47,48 .

Tree about 60 to $80 \mathrm{ft}$. tall; young parts fulvous tomentose. Leaves thinly coriaceous tomentose beneath when young; adult silvery, elliptic or elliptic-subobovate shortly blunt-acuminate, base narrowed or round; nerves Io to 15 pairs pubescent; 5 to 6 in. long, $2 \cdot 25$ in. wide; petioles stout, I I in long. Spikes in large spreading terminal panicles 4 to 8 in. long, fulvous tomentose, rather slender, 5 in. long, numerous. Flowers solitary or in loose clusters, males most numerous. Fruits in stout spikes rather crowded; pedicels short, thick. Cup flat saucer-shaped, $4 \mathrm{in}$. across, very shallow; scales broad ovate, connate in rings with rather long spreading points. Acorn ovoid-conic, glabrous, $\cdot 8$ in. long, I in. through, dark chestnut; umbo sharp rather long. Hab. Forests; common, Johor, Kwala Sembrong (Kelsall). Malacca, Hulu Chembong (Derry). Perak, Thaiping (Wray, Kunstler). Penang Hill (Curtis; King). Distrib. Java, Sumatra, Borneo.

(II) P. hystrix Gamble, l.c. 428. Quercus hystrix King, Ann. Bot. Gard. Calc., ii. 54, t. 50.

Fairly large tree about $80 \mathrm{ft}$. tall; branchlets densely fulvous tomentose. Leaves coriaceous elliptic acute or short cuspidate, base acute, tomentose on midrib and nerves above and altogether beneath ; nerves I2 to I6 pairs, transverse nervules conspicuous on both sides and raised beneath; 5 to 8 in. long, 2 to 3 in. wide; petioles $\cdot 2$ in. long, tomentose. Male spikes in fulvous tomentose panicles 4 to 5 in. long; females axillary solitary. Fruit-spikes 4 in. long; pedicels thick. Cup saucer-shaped flat, $\cdot 8$ in. wide, $\cdot I$ in. deep; scales ovate, points sharp, rather long, tomentose. Acorns conichemispheric, glabrous dark brown, about 4 in. tall; umbo long prominent. Hab. Common in lowlands, Singapore, Gardens. Toas. Malacca, Bukit Bruang (Curtis); Sungei Hudang; Hulu Chembong (Derry); Selandor. Negri Sembilan, Bukit Tangga. Perak, Ulu Bubong, etc. (Kunstler). 
var. longispica Gamble, l.c. has 7 in. long spikes of young fruits in twos and threes; scales appressed not spiny. It may be a distinct species. Hab. Perak (Scortechini). Distrib. Sumatra. Native name: Gugiring.

(I2) P. Curtisii Gamble, l.c. 429. Quercus Curtisii King, in Hook. fil. F.B.I. v. 6I2; Ann. Bot. Gard. Calc., ii. 56, t. 52.

Tree $40 \mathrm{ft}$. tall, ro to $20 \mathrm{in}$. through. Leaves thinly coriaceous elliptic-oblong to lanceolate, long caudate-acuminate, base narrowed, glabrous shining above, silvery beneath; midrib elevate both sides; nerves 9 to to pairs elevate beneath; nervules and reticulations invisible; 8 to 9 in. long, $2 \cdot 5$ to 3 in. wide; petioles thick, $\cdot 2$ in. long. Spikes rather slender, 6 to 8 in. long, panicled terminal or single; rachis puberulous, angled. Flowers solitary or few together. Fruits crowded touching, six in 6 in. spikes, sessile. Cups flat, thin, $\cdot 7$ in. across; scales connate free, points very minute. Acorn ovoid puberulous, $\cdot 8$ in. high and wide. Hab. Local, Selangor, Rawang. Perak, Slim; Larut (Kunstler). Penang, Waterfall (all collectors).

\section{$\S$ ii. Cyclobalanus}

(I3) P. conocarpa Schky, Engl. Bot. Jahrb. xlix. 357; Gamble, l.c. 430 .

Big tree $80 \mathrm{ft}$. tall; branchlets and young leaves red stellatetomentose. Leaves coriaceous elliptic-oblong or lanceolate abrupt caudate-acuminate, base acute, glabrous except tomentose midrib above, stellate-tomentose silvery beneath; nerves ro to I4 pairs elevate beneath, nervules conspicuous; 4 in. long, $\mathrm{I} \cdot 5$ in. wide; petioles $\cdot \mathrm{I}$ in. long. Male spikes solitary axillary; female terminal panicles or solitary axillary, tomentose, 5 in. long or less. Male flowers I to 3 together; female flowers solitary. Fruit touching each other in woody spikes to 3.9 in. long. Cups saucer-shaped, .7 in. across, 2 to $\cdot 24$ in. deep, with 5 - or 6-toothed lamellæ. Acorn glabrous or silky conic, $\cdot 6$ to $\cdot 8$ in. tall; umbo very prominent and long. Hab. Lowland woods. Not rare, Singapore, Garden Jungle; Changi; Selitar. Selangor, Klang (Burkill). Perak, Goping; Ulu Bubong (Kunstler). Distrib. Java, Sumatra, Borneo.

(I4) P. Ewyckii Gamble, l.c. 43I. Quercus Ewyckii Korth. Verh. Nat. Gesch. Bot. 212, t. 46; King, Ann. Bot. Gard. Calc., ii. 68, t. $62 \mathrm{~A}$.

Tree 30 to $40 \mathrm{ft}$. tall, 8 to Io in. through; branchlets scaly puberulous. Leaves thinly coriaceous lanceolate or oblong-lanceolate, long caudate-acuminate, base acute decurrent on petiole, silvery beneath; nerves II to I4 pairs parallel, fine with transverse nervules; 4.5 in. long, $2 \cdot 25$ in. wide; petioles $\cdot 15$ to 2 in. long. Male spikes 4 in. long in few branched terminal panicles; rachis angled, scaly puberulous; female spike at base of panicle. Flowers solitary or clustered. Fruit spikes 9 in. long or less; rachis stout; pedicel thick, ringed. Cup very thin saucer-shaped, grey tomentose, rings 7 to Io entire, 7 in. across, nearly flat. Acorn hemispheric, 
.8 in. through, $\cdot 6$ in. tall; umbo conic. Hab. Apparently not very common, Singapore, Bukit Timah. Perak, Batang Padang (Kunstler).

var. latifolia King, l.c. $62 \mathrm{~B}$ has bigger leaves, 5 by 2.5 in., elliptic. Cups thicker, rings slightly toothed and acorn puberulous. Hab. Singapore, Bukit Timah. Perak, Thaiping (Kunstler). Distrib. Sumatra.

(I5) P. cyrtorhyncha Gamble, l.c. 432. Quercus cyrtorhyncha Miq. Fl. Ind. Bat. Suppl. 350; King, Ann. Bot. Gard. Calc., ii. 66, t. 6 ов.

Tree 60 to $80 \mathrm{ft}$. tall, $\mathrm{I} \cdot 5$ to $2 \mathrm{ft}$. through; young parts puberulous. Leaves chartaceous elliptic or elliptic-oblong, shortly abruptacuminate, base round or cuneate, glabrous, underside grey; nerves Io to 15 pairs fine, nervules and reticulations visible; 6 to 6.5 in. long, 2.8 to 3 in. wide; petioles ${ }^{2} 5$ in. long. Spikes 3 in. long in large terminal panicles 9 in. long or more, grey puberulous. Flowers solitary or in clusters of 4. Fruits sessile on short, stout spikes. Cups very thin saucer-shaped with indistinct undulate rings 6 or 7 I in. across, $\cdot 23$ in. deep. Acorn broad, hemispheric, smooth, dark chestnut brown, 7 in. tall; umbo short conic. Hab. Forests, Johor, Pulau Tinggi (Burkili). Negri Sembilan, Bukit Angsi (Foxworthy). Selangor, Ginting Bidai. Perak, Ulu Bera and Larut (Kunstler). Distrib. Sumatra, Borneo.

(I6) P. Bennettii Gamble, l.c. 433. Quercus Bennettii Miq. Fl. Ind. Bat. i. (I), 857; King, Amn. Bot. Gard. Calc., ii. 64, $t$. $58 \mathrm{~A}$.

Tree glabrous except inflorescence. Leaves rather stiffly coriaceous, broad elliptic blunt-cuspidate narrowed at base, whitish beneath; nerves I 2 to I 8 pairs, fine hardly elevate, faint, nervules as conspicuous; 3.5 to 3.75 in. long, 2 to 2.25 in. wide; petioles . I2 in. long, winged half-way. Male spikes in terminal grey puberulous panicles 4 in. long; female few, solitary or panicled. Flowers solitary. Fruits nearly touching in short 3 in. long spikes with many undeveloped. Cups saucer-shaped, 4 in. tall, $\cdot 75$ in. across; rings distinct. Acorn ovoid-conic, $\cdot 8$ in. across, $\cdot 6$ in. tall, dark chestnut brown, base deeply intruded; umbo short. Hab. Lowland near the sea and on mountains, Singapore, Selitar; Tengeh. Johor, Hadji Senawi; Tanjong Kupang. Pahang, Kluang Terbang (Barnes). Perak, Gunong Inas (Wray) at $5000 \mathrm{ft}$. altitude. Distrib. Bangka, Sumatra, Java.

(I7) P. Cantleyana Gamble, l.c. 344. Quercus Cantleyana King, in Hook. fil. F.B.I., v. 613; Ann. Bot. Gard. Calc., ii. 64, t. 59.

Big tree 60 to $80 \mathrm{ft}$. tall, $1 \cdot 5$ to $2 \mathrm{ft}$. through; branches glabrous. Leaves stiffly coriaceous, grey beneath, oblong-lanceolate to oblanceolate, cuspidate-acuminate, base narrowed and decurrent; nerves distinct, elevate beneath I2 to I5 pairs; 6 to 7 in. long, $2 \cdot 75$ to 3 in. wide; petioles $\cdot 25$ in. long. Spikes solitary, axillary or panicled, up to 7 in. long, either male or female. Flowers solitary and clustered. Fruit-spikes 5 to 9 in. long; fruits rather crowded; peduncle 
stout. Cup saucer-shaped minutely grey puberulous, rings 5 to 7 , obscurely toothed, .75 in. wide, $\cdot 2$ in. deep. Acorn depressed hemispheric, $\cdot 6$ in. tall ; umbo conic, all silvery silky. Hab. Forests lowlands, common, Singapore, Changi; Garden Jungle; Kranji ; Bukit Timah. Malacca, Sungei Hudang (Derry). Pahang, Pekan. Perak, Chanderiang and Goping (Kunstler).

(I8) P. Wenzigiana Gamble, l.c. 435. Quercus Wenzigiana King in Hook. fil. F.B.I., v. 6r3; Ann. Bot. Gard. Calc. ii. 65, t. 588.

Tree 60 to $80 \mathrm{ft}$. tall, ro to $15 \mathrm{in}$. through, glabrous. Leaves coriaceous elliptic, abruptly caudate acuminate, base acute; midrib stout raised both sides; nerves fine, not raised, I2 to I4 pairs, nervules few inconspicuous; 4 to 5 in. long, $I \cdot 5$ to $2 \cdot 25$ in. wide; petioles black, $\cdot 25$ in. long. Spikes solitary axillary and terminal panicled; panicles 5 in spikes 4 to 6 in. long, puberulous. Flowers male solitary or 2 to 3 together, Fruit-spikes stout, 6 in. long; pedicels thick; cup saucer-shaped thick, $\cdot 75$ in. wide. $I$ in. deep, rings 5 to 7 thick silky, lowest one thickest. Acorn depressed hemispheric, glabrous, chestnut colour with a conic umbo ; 6 in. tall, $\cdot 7$ in. through. Hab. Perak, Goping (Kunstler). Penang Hill at top (Maingay, Curtis) and Pantai Acheh (Curtis). Distrib. Borneo.

(I9) P. rassa Gamble, l.c. 436. Quercus Rassa Miq. Fl. Ind. Bat. Suppl. 350. King, Ann. Bot. Gard. Calc., ii. 66, t. 60A.

Tree 40 to $60 \mathrm{ft}$. tall in exposed spots, a bush. Leaves coriaceous, narrow lanceolate to elliptic-lanceolate, caudate-acuminate, base narrowed decurrent; nerves very faint, I2 to I5 pairs; 2 to 3.25 in. long, $\cdot 5$ to $I \cdot 5$ in. wide; petioles $\cdot 25$ in. long. Spikes about 2 in. long or less, axillary and a few in a panicle pubescent. Male flowers in threes; females solitary. Fruit-spikes about 2 in. long. Cup turbinate sessile above flat or shallow, rings rather broad thickened, $\cdot 2$ in. tall, $\cdot 3$ in. across. Acorn ovoid-conic, $\cdot 6$ in. tall and wide, base intruded; umbo conic, light chestnut. Hab. Mountains. Malacca, Bukit Besar, Ophir. Pahang, Gunong Tahan at $6000 \mathrm{ft}$. altitude (Robinson). Selangor, Gunong Mengkuang Lebah (Robinson). Perak, Gunong Hijau at $5000 \mathrm{ft}$. altitude (Kunstler). Penang Hill at $2000 \mathrm{ft}$. altitude (Curtis). Distrib. Sumatra, Java, Borneo.

var. lanuginosa Ridl. Journ. Roy. As. Soc. S. Br. 6r, p. 36. Leaves thinner, more lanceolate, underside and upper midrib densely fulvous pubescent. Selangor, Semangkok Hill at $4375 \mathrm{ft}$. altitude (Ridley).

var. suffruticosa Ridl. Bush glabrous. Leaves stiffly coriaceous, ovate or oblong ovate acute; nerves 6 pairs faint ; reticulations hardly visible; 3 in. long, $I .5$ in. wide; petioles $\cdot 25$ in. long. Spikes 3 in. long in panicles terminal. Male clusters separate; cup sessile, shallow, rings Io with distinct teeth 5 in. across, ' 12 in. deep. Acorn a short broad cone $\cdot 5$ in. long, minutely silky. Hab. Selangor, top of Gunong Semangkok (Ridley).

I take this to be a form of $Q$. vassa. Mr. Gamble thinks it distinct. 
(20) P. Eichleri Gamble, l.c. 438. Quercus Eichleri Wenzig. in King, Ann. Bot. Gard. Calc., ii. 72, t. 68; Jahrb. Bot. Gard. Berl., iv. 236.

Large tree 50 to $100 \mathrm{ft}$. tall, $\mathrm{I} \cdot 5$ to $2 \mathrm{ft}$. through. Leaves coriaceous elliptic-oblong or oblong-lanceolate, caudate-acuminate, very minutely white pubescent all over, base cuneate; 6 to 12 in. long, 3 in. wide; petioles $\cdot 2$ in. long, stout. Panicle of spikes 6 to 7 in. long; pedicels very short or 0 . Cups saucer-shaped at first covering the whole or half of the acorn finally nearly flat, scurfy, I in. across, with broad flat rings 5 to 7 . Acorn flattened hemispheric minutely silky, I in. across, $\cdot 5$ in. tall; umbo small. Hab. Selangor, Rawang (Ridley). Perak, Thaiping (Kunstler); Asam Kumbong and Relau Tujor (Wray). Distrib. Sumatra. Native names: Mempening Jantan; Mempening putih.

(2I) P. Clementiana Gamble, l.c. 439 . Quercus Clementiana King in Hook. fil. F.B.I. v. 6I4; Ann. Bot. Gard. Calc. ii. 69, t. 63A.

Tree glabrous. Leaves thinly coriaceous, oblong-lanceolate or oblanceolate, caudate-acuminate; base narrowed acute; midrib stout, raised on both sides; nerves II to I3 pairs slender, hardly elevate, nervules and minute areolation visible; 6 to 7 in. long, 2 to 3 in. wide; petioles 4 in. long. Spikes 3 to 4 in. long, panicled, terminal or solitary axillary; females all solitary axillary. Male flowers in fours. Fruit spikes short; cups sessile, saucer-shaped, edges thick incurved, rings 5 , broad, $I \cdot 2$ in. across. Acorn turbinate glabrous, $\cdot 8$ to $I$ in. across, $\cdot 4$ in. tall; umbo conic. Hab. Not common, Malacca, Sungei Hudang. Penang Hill (Maingay, Curtis).

(22) P. omalokos Schky, Engl. Jahrb. xlvii. 676; Gamble, l.c. 439. Quercus omalokos Korth. Verh. Nat. Gesch. Bot. 2I4. King, Am. Bot. Gard. Calc. ii. 70, t. 23в.

Big tree 80 to Ioo ft. tall, 2 to $3 \mathrm{ft}$. through; branchlets puberulous. Leaves thinly coriaceous, elliptic-oblong or oblanceolate abrupt, shortly acuminate, base cuneate decurrent on petiole, nerves very fine and inconspicuous; $3 \cdot 25$ in. long, I.25 in. wide; petioles . I2 in. long. Spikes up to 6.5 in. long, grey puberulous solitary axillary or few in a terminal panicle. Flowers in elongate clusters of three or four. Fruit in stout spikes 7 in. long. Cup saucershaped very thick, sessile, rings 8 to Io, lowest broadest, upper narrow tomentose, $\mathrm{I} \cdot 25$ in. across. Acorn hemispheric, glabrous, chestnut, I in. tall. Hab. Forests, Malacca, Sungei Hudang (Derry). Perak, Goping and Thaiping (Kunstler). Distrib. Sumatra. Native name: Mempening putih.

(23) P. Iucida Gamble, l.c. 440. Quercus lucida Roxb. Fl. Ind. iii. 635; King, Ann. Bot. Gard. Calc. ii. 69, t. 64.

$\mathrm{Big}$ tree $50 \mathrm{ft}$. or more tall, glabrous. Leaves stiffly coriaceous oblanceolate, blunt rounded at tip, base long cuneate, dark shining green, 2 to 6 in. long, I to $2 \cdot 25$ in. wide; midrib stout elevate both sides, nerves faint not elevate, Io to 20 pairs; petioles winged to 
base, ${ }^{\prime} 5$ in. long. Spikes 6 in. long, solitary, axillary or in a terminal panicle, grey puberulous. Flowers solitary or 3 together, rather distant. Fruit-spikes stout, 3 to 4 in. long, puberulous with deep pits, scars of abortive flowers. Cup sessile, saucer-shaped, flat with a much-intruded base, edge rather thick, rings 8 to I3 thick, I.25 in. across, ' $I$ in. deep. Acorn dark chestnut brown, .8 in. tall, $I$ in. through, hemispheric, smooth shining; pericarp very thick. Hab. Forests, common, Singapore, Selitar; Tampinis; Bukit Timah. Johor, Castlewood. Perak, Chanderiang and Larut (Kunstler); Selama (Wray). Penang Hill (Maingay, Curtis, King).

(24) P. cyclophora Gamble, l.c. 442. Quercus cyclophora King, Ann. Bot. Gard. Calc. ii. 7I, $t .67$.

Big tree 70 to $100 \mathrm{ft}$. tall, $I \cdot 5$ to $2 \mathrm{ft}$. through. Leaves coriaceous, oblong or oblong-lanceolate cuspidate-acuminate, dark green above, silvery grey beneath; nerves I6 to 20 pairs elevate beneath, transverse nervules conspicuous; 6 to 9 in. long, 3.5 in. wide or less; petioles thick, 25 in. long. Spikes in large panicle terminal or axillary, 6 in. long, puberulous or glabrous. Flowers solitary or 2 to 4 in a cluster; females solitary. Fruits very large in a stout spike sessile. Cup thick, saucer-shaped nearly flat, I.75 in. across, $\cdot 25$ in. thick, with 5 to 7 broad flat rings rather indistinct. Acorn flattened, discoid, $\cdot 75$ in. tall, I.5 in. across, puberulous; umbo short conic. $H a b$. Forests, our largest acorn. Singapore, North Selitar; Garden Jungle. Selangor, Semangkok Pass. Perak, Gunong Batu Putih (Wray); Larut Hills (Kunstler). Penang Hill (Wallich, Curtis, etc.).

(25) P. costata Gamble, l.c. 443. Quercus costata Bl. Bijdr. 522; King, Ann. Bot. Gard. Calc., ii. 8I, t.76A.

Tree 30 to $80 \mathrm{ft}$. tall, I2 to I8 in. through. Leaves coriaceous, oblong abruptly caudate, base cuneate shining dark green beneath glaucescent; midrib stout prominent both sides, nerves very faint Io to I4 pairs; 6 to 7 in. long, 2 to $2.5 \mathrm{in}$. wide; petioles 4 in. long. Spikes terminal and axillary, solitary or panicled, puberulous, 6 in. long; bracteoles in bud very conspicuous, linear subulate, 07 to -I in. long. Male flowers in threes, females solitary. Fruit spikes about 6 in. long, very stout. Cup basin-shaped, narrowed to the thick pedicel, $\cdot 5$ in. long, the cup I in. tall and $I \cdot 75$ in. wide, woody, edge thin curved over acorn; rings 2 very broad and 3 narrow along the edge. Acorn shining brown, flattened, discoid, slightly convex at top, I.5 in. across, little higher than cup; umbo small. $H a b$. Hill forests up to I00o ft. altitude, Perak, Goping and Larut (Kunstler). Distrib. Java, Sumatra.

(26) P. Iampadaria Gamble, Kew Bulletin I9r4, p. I77; Journ. As. Soc. Beng. l.c. 444.

Small tree. Leaves very coriaceous, lanceolate acuminate, blunt acuminate, base narrowed and decurrent on petiole, shining above, minutely grey puberulous beneath; midrib stout both sides, nerves I2 to I4 pairs, slightly elevate both sides, transverse 
nervules conspicuous, numerous; 5 to 7 in. long, 3 to 4 in wide. Fruits immature in stout spikes 3 in. long; cups three together or more, some solitary, covering three-quarters of the acorn, rings five; acorn white silky; umbo conic. Hab. Very little known. Perak, Gunong Batu Putih and Ulu Batang Padang (Wray). Use: Saplings used for torches when fishing by Sakais.

\section{$\S$ iii. Chlamsdobalanus}

(27) P. Blumeana Gamble, l.c. 445. Quercus Blumeana Korth. Verh. Nat. Gesch. Bot. 208, t. 44; King, Ann. Bot. Gard. Calc. ii. $75, t .69 \mathrm{~B}$.

Tree 40 to $50 \mathrm{ft}$. tall, 2.5 to $3 \mathrm{ft}$. through. Leaves coriaceous elliptic-oblong to oblong-lanceolate, acuminate or cuspidate, base acute minutely grey tomentose beneath; 7 to 8.5 in. long, I.75 to 3 in. wide; nerves sunk above, raised beneath, I2 to I4 pairs, transverse nervules conspicuous; petioles 4 in. long, stout. Spikes male, or both male and female, slender axillary and in terminal panicles, grey-tomentose. Flowers very small, males in threes or fours; females solitary. Fruit single in dense spikes about 4 in. long. Cup short peduncled, thin covering nearly the whole acorn, with faint rings and splitting in vertical fissures. Acorn depressed turbinate, 75 in. long and about as wide, densely silky-tomentose ; umbo conic. $H a b$. Rare in woods at 3500 to $4000 \mathrm{ft}$. altitude. Perak, Larut Hills (Kunstler). Distrib. Java, Sumatra, Borneo.

(28) P. confragosa Gamble, l.c. 446. Quercus confragosa King in Hook. fil. F.B.I. v. 6I6; Amm. Bot. Gard. Calc. ji. 77, t. 7I.

Big tree 40 to $50 \mathrm{ft}$. tall, Io to $I_{5} \mathrm{in.} \mathrm{through.} \mathrm{Leaves} \mathrm{grey,}$ vęry coriaceous, elliptic or elliptic-lanceolate, bluntly cuspidate acuminate, base acute, dark green above, greyish beneath; midrib stout elevate both sides, nerves 6 to 8 pairs obscure above, elevate beneath, transverse nervules faint; 5 to 6 in. long, $2 \cdot 25$ to 3 in. wide; petioles 4 in. long. Flowers unknown. Fruit sessile, single or in rather slender spikes up to $7.8 \mathrm{in.} \mathrm{long.} \mathrm{Cup} \mathrm{globose}$ entirely covering the acorn except the umbo, rugose with irregular blunt tubercles, bluish-grey when alive, dark brown when dry, I.5 in. long, I.25 in. wide. Acorn globose, minutely velvety, umbo prominent; when young the cup only covers one-half or two-thirds of the fruit and is roughly reticulate. Hab. Rare, Perak, Goping (Kunstler).

(29) P. Wrayii Gamble, l.c. 446. Quercus Wrayii, King, Ann. Bot. Gard. Calc. ii. 77, t. I04.

Tree; branchlets fulvous-tomentose. Leaves sub-coriaceous oblong-lanceolate, long caudate-acuminate, base blunt and often unequal, hairy on midrib and nerves especially beneath; nerves I2 to I6 pairs elevate beneath; 4 to $6 \cdot I 5 \mathrm{in}$. long, I. 5 to 2 in. wide; petioles $I$ in. long, tomentose. Flowers not known. Fruit spike 3 to 3.5 in. long, tomentose. Cup sessile solitary, depressed, sub- 
globose entirely covering the acorn and covered with stout incurved rather soft spines, hooked at tip, softly tomentose. Acorn depressed silky. Hab. Little known, only unripe fruits seen. Pahang, Telom (Ridley). Perak, Kota (Wray).

(30) P. discocarpa Gamble, l.c. 447. Quercus discocarpa Hance, Journ. Bot. 1874, p. 242; King, Ann. Bot. Gard. Calc. ii. 76, t. 70.

Tree Ioo to I3o ft. tall, $4 \mathrm{ft}$. through. Leaves coriaceous lanceolate or oblong-lanceolate, long acuminate, dark green above, cinnamon brown beneath; nerves 8 to ro pairs slender, sunk above, elevate beneath; 4.5 to 6 in. long, I.5 to I.75 in. wide; petioles - I5 in. long. Spikes 3.5 in. long in large panicles, tomentose. Male flowers clustered, 2 to 4 ; female solitary. Fruit solitary, pedicel short or 0 , hemispheric or turbinate, conic tawny pubescent, $.6 \mathrm{in}$. long, $\cdot 8 \mathrm{in}$. wide, the cupule entirely covering the acorn except the umbo and covered with tufts or lines of simple or branched sharp spines as much as $\cdot 3$ in. long. Acorn pubescent, base very concave; umbo conic. Hab. Mountain forests. Perak, Gunong Bubu (Scortechini); Larut to Iooo ft. altitude (Kunstler). Distrib. Bangka, Borneo.

(3I) P. acuminatissima Oerst. Kjoeb, Vidensk, Meddel, 84; Gamble, l.c. 448; King, Ann. Bot. Gard. Calc. ii. $78, t .73$.

Tree $60 \mathrm{ft}$. or more tall; branchlets black. Leaves coriaceous lanceolate or ovate-lanceolate, long-acuminate, acute, reddish brown beneath entire (or coarsely serrate at the top); midrib slender, nerves fine, 8 to II pairs slightly elevate beneath, faint above transverse nervules and areolations visible above and beneath; 3 in. long, I.5 in. wide; petioles slender, 2 in. long. Spikes axillary erect, 3 in. long. Males filiform; females stouter; flowers all solitary and distant. Fruit spikes about 3 in. long; fruit obliquely ovoid; cupule pubescent tomentose covered with thick soft spines entirely covering the acorn; acorn ovoid apiculate flattened on one side; umbo round. Hab. Rare, Perak, Gunong Bubu (Scortechini). Distrib. Java, in mountains.

A sketch in Bonplandia, vi. 82, shows a tree with a large mass of descending roots big enough to form a hut, and many suckers growing from them. I have only seen young fruits of this species.

(32) P. encleisacarpa Gamble, l.c. 449. Quercus encleisacarpa Korth. Verh. Nat. Gesch. Bot. 208, t. 45; King, Ann. Bot. Gard. Calc. ii. 8o, t. 75 .

Tree 40 to $60 \mathrm{ft}$. tall or more. Leaves chartaceous, elliptic abruptly caudate-acuminate, base acute, dark green above, beneath silver grey, 3 to 5 in. long, I to I.5 in. wide; nerves conspicuous beneath, 7 to 9 pairs. Spikes slender, grey-pubescent, up to 7 in. long. Males panicled; females solitary axillary. Male flowers in elongate clusters; females solitary or 3 to 4 together. Fruit depressed globose on short thick peduncles on stout spikes 7 in. long; cup covering the acorn except at the top, dark brown, thin with 6 or 7 conspicuous slender rings, $\cdot 8$ in. tall, $\cdot 8$ in. through. 
Acorn $\cdot 6$ in. through, hemispheric, white silky. Hab. Common in lowland forests, Singapore, Garden Jungle; Selitar; Changi, Johor, Pengerang (Cantley). Malacca, Bukit Sadanen; Sungei Hudang (Derry). Selangor, Rawang. Perak, Chanderiang and Larut (Kunstler); Matang Jambu (Wray). Province Wellesley, Ara Kudah. Penang (Curtis, King).

var. aperta King, has a thicker conspicuously ribbed cup with a more conic free projecting acorn. Hab. Pahang, Fraser Hill (Burkill and Holttum). Penang Hill (Kunstler and Curtis). Native names: Berangan babi hutan; Mempening putih.

(33) P. Robinsonii Gamble, l.c. 450. Quercus Robinsonii Ridl. Journ. F.M.S. Mus. v. 46.

Tree. Leaves coriaceous, lanceolate-acuminate acute, base narrowed cuneate silvery on the back; nerves II to 12 pairs elevate, brown, nervules conspicuous; 3 to 5.5 in. long, I.5 to 2 in. wide; petioles +4 in. long. Racemes erect puberulous, 5.5 in. long; spikes dense, 3 in. long. Male flowers very numerous crowded. Females on separate spikes. Fruit sessile; cup thin covering the acorn nearly to top, splitting into 5 irregular lobes puberulous, brown. Acorn ovoid acute, white silky. Hab. Mountains, Selangor, Gunong Mengkuang Lebah (Robinson).

\section{$\S$ iv. Lithocarpus}

(34) P. Maingayi Schky, Engl. Bot. Jahrb. xlvii. 627; Gamble, l.c. $45 \mathrm{I}$.

Very large tree; branchlets fulvous tomentose. Leaves coriaceous elliptic-oblong or obovate-oblong short acuminate, base acute nearly glabrous above, minutely pale pubescent beneath; midrib stout prominent both sides; nerves 15 to 20 pairs parallel, elevate beneath, transverse nervules fine; .8 in. long, 3 in. wide; petioles $\mathrm{I} \cdot 5$ in. long. Male spikes very slender, yellow-tomentose, 7 in. long; flowers in distant elongate clusters; female spikes single. Flowers solitary. Fruit racemes about 6 in. long; cups pear-shaped woody, brown-velvety, narrowed to a thick pedicel with 3 to 6 obscure rings 2 in. long, $I \cdot 5$ in. through ; peduncles 5 in. long when fully ripe. Acorn confluent with the walls of the cup and quite covered by it, its pericarp $\cdot 25$ in. thick, woody. Hab. Selangor, Semangkok Pass (Ridley). Penang Hill (Maingay and Curtis).

(35) P. Beccariana Prantl. Engl. Pflanzenfam. iii. (I) 55; Gamble, l.c. 452. Quercus Beccariana Benth. Ic. Pl.t. I3I5; King, Ann. Bot. Gard. Calc. ii. 83, $t .78$.

Tree 60 to $70 \mathrm{ft}$. tall. Leaves sub-coriaceous lanceolate or narrow elliptic bluntly acuminate hoary pubescent beneath; nerves 8 to Io pairs, slender elevate beneath; 3.5 in. long, I.25 in. wide; petioles $\cdot 2$ in. Iong. Spikes solitary from upper leaf axils, about 3 in. long; male flowers in clusters. Fruit obovoid, 3 in. long, 2 in. through in short spikes, rachis puberulous. Cups woody; thick-walled, covering the whole acorn except the styles and adnate 
to it, dark brown with 5 to 7 prominent rings and beaked; acorn ovoid, pericarp very thick and hard. Hab. Singapore (Murton). Pahang, Fraser Hill (Burkill and Holttum), Distrib. Borneo.

Murton says "very abundant," but I never saw it.

\section{CASTANOPSIS, Spach.}

Trees, rarely shrubs. Leaves entire or toothed. Flowers unisexual in spikes usually male or female only. Perianth cupshaped, lobes 6. Stamens I2 (or less); filaments slender; anthers small ovate or globose. Pistillode a villous cushion. Ovary 3-celled; ovules 2 in a cell; styles 3 ; stigma a terminal pore. Fruit of I to 4 ovoid or plano-convex nuts covered by the fruiting involucre, which is irregularly dehiscent and covered with spines or tubercles. Species 357, tropical and sub-tropical Asia, I N. America. Native name: Berangan.

Nuts 3 in a cupule.

Cupules spiny.

Spines needle-like in dense tufts covering cupules. Leaves red puberulous beneath; spines hairy

Leaves red pubescent beneath; spines long,

Spines not covering cupule entirely; tufts stalked.

Leaves villous beneath

Spines flattened antler-like.

Leaves very large

Leaves small

Cupule with no spines but tubercles in lines.

Tubercles sharp; leaves puberulous beneath

Tubercles blunt; leaves glabrous

(I) C. malaccensis

(2) C. Scortechinii

Nuts solitary.

Spines subulate; tufts in rings not stalked .

Spines in stalked tufts.

Fruit oblong, 3 in. long; leaves velvety beneath

Fruit globose or oblong small; leaves small, glabrous.

Spines flat triangular; leaves small lanceolate

Cupules tubercled, flattened on inner side, obovoid

Cupule pyriform with vertical ridges only, no tubercles

(3) C. fulva

(4) C. catappæfolia

(5) C. Andersoni

(6) C. Hullettii

(7) C. sumatrana

(8) C. costata

(9) C. megacarpa

(ro) C. Ridleyi

(I I) C. Wallichii

(I 2) C. nephelioides

(13) C. Curtisii

(I) C. malaccensis Gamble, Kew Bulletin, I9I4, p. I78; Journ. As. Soc. Beng. l.c. 455 .

Tree. Leaves thinly coriaceous ovate or lanceolate acuminate, base round above, glabrous beneath tawny puberulous; nerves 8 to Io pairs, nervules and reticulations conspicuous beneath; 3 in. long, $\mathrm{I} \cdot 5$ to 2 in. wide; petioles $5 \mathrm{in}$. long. Fruit few in spike globose; cupule covered with very fine pubescent needle-like spines. Hab. Singapore, Toas. Malacca (Maingay); Brisu (Derry); Batu Tiga (Holmberg); Selandor (Cantley). Negri Sembilan, Senawang (Foxworthy). 
(2) C. Scortechinii Gamble, Kero Bulletin, I9I4, p. I78; Journ. As. Soc. Beng. l.c. 455 .

Tree. Leaves sub-coriaceous elliptic or oblanceolate-cuspidate acuminate, base acute, glabrous except the midrib above, thickly red-pubescent beneath; nerves I2 to I5 pairs, prominent; 4 to $4.5 \mathrm{in}$. long, $\mathrm{I} \cdot 75$ to 2 in. wide; petioles 22 in. long, thickly redpubescent. Female spikes 6 in. long, grey-pubescent. Fruit globose, $\mathrm{I} \cdot 5$ in. through, covered thickly with tufts of branching spines, densely hairy Hab. Perak (Scortechini).

(3) C. fulva Gamble, Kew Bulletin I9r4, p. I79; Joum. As. Soc. Beng. l.c. 456 .

Tree 60 to $80 \mathrm{ft}$. tall, I 8 to 20 in. through; branchlets tomentose. Leaves coriaceous, elliptic shortly abrupt-acuminate, base acute or round, bright green speckled brown and grey when fresh and roughly red villous beneath when dry; nerves I2 to I 6 pairs elevate beneath; 3 to 6.5 in. long, $I \cdot 5$ to 2.75 in. wide; petioles tomentose, .75 in. long. Female spikes solitary, axillary tomentose, 7 in. long; flowers I to 4 together. Fruit globose, $\cdot 8$ to $I$ in. through, covered with fascicles of flattened grooved tawny villous spines, on short stalks, the tips glabrous. Nuts usually 3 ; pericarp silky. Hab. Selangor, Sungei Buluh (Burn-Murdoch). Perak, Batang Padang (Kunstler). Native name: Kertah Tanga.

(4) C. catappæfolia King, in Hook. fil. F.B.I. v. 62I; Gamble, Journ. As. Soc. Beng. l.c. 457; King, Ann. Bot. Gard. Calc. ii. I00, $t .92$.

Tree 60 to $80 \mathrm{ft}$. tall, I5 to $20 \mathrm{in}$. through. Leaves coriaceous, very large oblanceolate, acute narrowed to base, glabrous shining above, puberulous beneath; nerves 25 to 30 pairs sunk above, very prominent beneath; I5 to I8 in. long, 6 to 7.5 in. wide. Female spikes II in. long; rachis puberulous; flowers in threes. Fruit globose, I in. through, fulvous puberulous, sessile. Cupule covered with close packed subulate flattened pubescent dagger-like spines in tufts. Hab. Open jungle on low hills. Perak, Goping (Kunstler).

(5) C. Andersoni Gamble, Kew Bulletin, I914, p. I79; Journ. As. Soc. Beng. l.c. $45^{8}$.

Big tree. Leaves thinly coriaceous obovate or oblanceolate acute, base acutely narrowed, glabrous; nerves Io to I5 pairs slightly raised both sides, nervules and areolations visible; 3 to 4 in. long, I.5 to I.75 in. wide; petioles 5 in. Iong. Male spikes slender, 3 in. long, puberulous, panicled. Flowers solitary or 5clustered. Fruits sessile, globose in stout 8 in. long spikes, I in. high, I. 4 in. long, 8 in. thick; cupules thick; spines scanty subulate, curved, flattened, simple or slightly branched, $\cdot 2$ to 4 in. long. $H a b$. Singapore, Garden Jungle; Changi. Malacca, Sungei Hudang (Goodenough).

(6) C. Hullettii King, in Hook. fil. F.B.I. v. 623; Ann. Bot. Gard. Calc. ii. I04, t. 98; Gamble, Journ. As. Soc. Beng. l.c. 459. 
A big tree $80 \mathrm{ft}$. tall or more, 2 to $3 \mathrm{ft}$. through. Leaves coriaceous, elliptic to oblong-lanceolate acuminate shortly, base acute or round, glabrous above, minutely puberulous beneath; nerves I5 to 18 pairs prominent; 6 to 9 in. long, 3 to 5 in. wide; petioles .5 in. long. Spikes about 6 in. long in axillary or terminal, many branched panicles. Male flowers in clusters of 5 or less; females in threes. Fruit sessile in dense woody spikes 4 or 5 in. long. Cupules obovoid minutely tomentose with 3 or 4 vertical grooves and 4 to 6 curved transverse ridges with short sharp pyramidal tubercles, dehiscing to near the base into 3 or 4 valves, $I \cdot 2$ in. high, $x \cdot 6$ in. long, I.4 in. thick. Nuts 2 to 4 , chestnut brown, hairy above. $H a b$. Common, Singapore, Tanglin; Bukit Timah. Malacca, Bukit Bruang; Merlimau (Dèrry). Perak, Batang Padang. Penang Hill (Curtis, King, etc.). Native name: Berangan Papan.

(7) C. sumatrana A. DC. in Seem. Journ. Bot. I863, p. I82; Gamble, l.c. 460 .

Tree 60 to $80 \mathrm{ft}$. tall, 2 to $3 \mathrm{ft}$. through. Leaves thin, coriaceous, oblong-lanceolate or oblanceolate, short acuminate, acute at base; nerves $\mathrm{I} 2$ to 20 pairs slender raised on both sides, transverse nervules many; 6 to 8 in. long, 2 to 4.5 in. wide; petioles .5 in. long or less. Spikes slender, panicled, 4 in. long, males numerous. Male flowers few together or solitary. Fruit in long woody spikes about 7 in. long, sub-sessile; cupule rather thickwalled with I to 3 nuts, ovoid or with more than I nut transversely oblong, slightly bilobed, grey puberulous with 3 or 6 transverse ridges of short tubercles, $\cdot 75$ to $I$ in. tall, $\cdot 75$ in. (I-seeded) to $I$ in. wide (2-seeded). Nuts ovoid silky except the base. Hab. Common, especially in the north, Malacca, Pringit and Ayer Panas (Griffith); Perak, Batang Padang river; near Gunong Bubu (Kunstler); Gapis (Wray); Selama; Ulu Bubong and Goping (Kunstler); Penang Hill (Wallich, Curtis). Distrib. Burma, Sumatra, Lingga, Borneo. Berairge Crelul

(8) C. costata A. DC. Prodr. xvi. ii. IIo; Gamble, l.c. 456.

Big tree 40 to $50 \mathrm{ft}$. tall, I.5 to $2 \mathrm{ft}$. through. Leaves subcoriaceous, elliptic, shortly abrupt-acuminate, acute or round at base, bright green above, red brown pubescent or villous beneath; nerves I2 to I6 pairs raised beneath; 4 in. long, I. 5 to 2 in. wide; petioles $\cdot 25$ in. long. Spikes slender, 4 to 6 in. long; rachis velvety. Male flowers solitary or clustered, distant; females in threes. Fruit globose in a dense spike 4 in. long. Spines crowded in fascicles in rings, connate at the base but not stalked and hairy like the rest of the cupule. Nut usually I densely fulvous-silky. Hab. Perak, Larut, Thaiping (Kunstler, Wray) up to Gunong Hijau at 4500 to $4600 \mathrm{ft}$. altitude. Distrib. Java, Sumatra, Borneo.

(9) C. megacarpa Gamble, Kew Bulletin I9I4, p. I8o, Journ. As. Soc. Beng. l.c. 462. C. javanica Hook. fil. F.B.I. v. 620; King, Ann. Bot. Gard. Calc. ii. 97, t. 88, (not of A. DC.). 
A big tree $80 \mathrm{ft}$. tall. Leaves coriaceous oblong shortly cuspidate-acuminate; base acute or round, bright green above, redpubescent beneath; nerves conspicuous, elevate I2 to I6 pairs; 4.9 to $6 \mathrm{in}$. long, 2 to $4.5 \mathrm{in}$. wide; petioles 4 in. to $\mathrm{I}$ in. long. Spikes slender, 4 in. long. Flowers in distant clusters; rachis pubescent. Fruit globose, when ripe oblong, 3 in. long; cupule thick and hard covered with scattered tubercles forming thick stalks from the top of which radiate simple or branched spines about .4 in. long. Nut I, oblong very large, rounded both ends. Hab. Common in forests in lowlands. Singapore, Garden Jungle; Bukit Timah. Malacca, Sungei Hudang; Ayer Panas (Derry). Perak, Larut; Kinta (Kunstler). Province Wellesley, Ara Kudah. Native names: Sebilek; Kata Bilek; Berangan Gajah.

Fruit said to produce flatulence and diarrhœea.

(Io) C. Ridleyi Gamble, Kew Bulletin I9I4, p. I8o; Journ. As. Soc. Beng. l.c. 463.

Tree 60 to $80 \mathrm{ft}$. tall, 2 to $3 \mathrm{ft}$. through. Leaves lanceolate coriaceous, short acuminate sub-acute; base unequally round, glabrous, minutely puberulous grey beneath when young, 4 in. long, I.5 in. wide; nerves very slender, Io to I4 pairs. Fruit globose, oblong $I \cdot 5$ in. through in short spikes; cupule crustaceous, puberulous covered with tufts of spines usually stalked, $\cdot 3$ in. long; strigose. Nut ovoid-oblong, I in. long. Hab. Malacca, Sungei Hudang (Ridley), Perak, Larut (Kunstler).

Like $C$. megacarpa, but leaves and fruit much smaller.

(II) C. Wallichii King, in Hook. fll. F.B.I. v. 624; Ann. Bot. Gard. Calc. ii. Io6, pl. Iora; Gamble, l.c. 464.

Big rather slender tree about $80 \mathrm{ft}$. tall or more. Leaves chartaceous lanceolate or ovate-lanceolate, acuminate blunt, base narrowed shortly, red-pubescent beneath; nerves slender, 6 to ro pairs; 2 to 3 in. long, I. 3 in. wide; petioles $\cdot 2$ in. long. Spike slender, about 3 in long. Flowers clustered. Fruits sessile, ovoidhemispheric, I in. tall, $\mathrm{x} \cdot 25$ in. wide, cupule covered with stout black triangular spines about $\cdot 25$ in. long with broad bases. Nut $\mathrm{r}$, red-pubescent. Hab. Common in woods, Singapore, Garden Jungle; Bukit Timah; Changi, etc. Malacca, Jus; Sungei Hudang (Goodenough); Ayer Panas (Curtis). Perak, Birch's Hill (Fox). Penang Hill (Wallich, Curtis). Native name: Berangan Duri. Use: The chestnuts though small and tough rinded are good, and used for putting on cakes in place of almonds.

(12) C. nephelioides King, in Hook. fil. F.B.I. v. 624; Ann. Bot. Gard. Calc. ii. t. I02; Gamble, l.c. 464.

Tree 30 to $60 \mathrm{ft}$. tall, I.5 to $2 \mathrm{ft}$. through. Leaves chartaceous elliptic to nearly ovate bluntly acuminate, base acute, bright green above, silvery beneath; nerves 9 to I2 pairs, slender elevate; 3.5 to 4 in. long, I.5 in. wide; petioles $\cdot 2$ in. long. Spikes slender, 
3 to 4 in. long. Male flowers in clusters distant below, crowded above; females single. Fruit obovoid flattened on inner side, often curved, pear-shaped. Cupule very thick enclosing nut entirely, outside covered with short pyramidal angled grey pubescent tubercles acute in young fruit but reduced to flat ridges in ripe ones, about I in. long. Hab. Common in forests, Singapore, Bukit Timah; Pulau Damar. Malacca, Brisu (Derry). Perak, Ulu Bubong; Goping; Batang Padang and Larut (Kunstler). Native name: Resak.

(13) C. Curtisii King, Ann. Bot. Gard. Calc. ii. I07, t. I03; Gamble, l.c. 465 .

Tree $60 \mathrm{ft}$. tall. Leaves chartaceous oblong-lanceolate cuspidate acuminate, base blunt or acute unequal, entire or serrate near tip, glabrous except midrib, puberulous beneath; nerves slender, Io to I2 pairs; nervules transverse, very many, $.8 \mathrm{in}$. long, I.5 in. wide; petioles 05 to .12 in. long, slender. Flowers unknown. Fruits curved, pear-shaped; pedicels $\cdot 2$ in. long, thick on an axillary spike $3 \mathrm{in}$. long. Cupule $I$ in. long, $\cdot 75$ in. through, puberulous with low vertical ridges; nut adherent to cupule. Hab. Very rare. Penang, Penara Bukit, at Iooo ft. altitude (Curtis).

\section{Doubtful SPEcies.}

C. ARgentea $A . D C$.? Gamble suggests it may be $C$. hysirix A. DC. A small tree in young fruit only. Leaves stiffly coriaceous, oblong shortly blunt acuminate, base cuneate pale beneath, nerves 9 pairs elevate beneath: 4 in. long, $I \cdot 25$ in. wide; petioles $\cdot I$ in. long. Young fruit crowded in long spikes 6 in. or more long. Spines numerous close-set narrowed upwards from a rather broad base silky pubescent. Hab. Pahang, Telom (Ridley).

C. hystrix A. DC. has the spines clustered on a short stalk in ripe fruit; in this plant the spines appear free to the base. The specimen is too young to be certain.

\section{ORDER CXXXIV. SALICINEÆ.}

Trees and shrubs. Leaves alternate. Flowers in catkins, unisexual, each bract with one flower. Perianth 0 . Dise of I or more scales (or glands or cup-shaped). Stamens 2 to ro; filaments free (or connate); anthers ovate or orbicular. Ovary I-celled; ovules few or many; style (short or o); stigmas lobed. Fruit an ovoid or lanceolate, 2- to 4-valved capsule. Seeds few or many, silky-plumed. Genera 2, mostly North Temperate regions.

SALIX, Linn.

Leaves usually narrow. Disc of $I$ to 2 scales; ovules numerous. Species over I00, rare in tropics. 
(I) S. tetrasperma Roxb. Cor. Pl. i. 68, t. 97; Gamble, Journ. As. Soc. Beng. l.c. 467 .

A small tree about $30 \mathrm{ft}$. tall. Leaves linear-lanceolate or ovate-lanceolate, long acuminate, base narrow or round entire or serrulate, glabrous above, silky beneath, 2.5 in. long, I in. wide; petioles .75 in. long. Stipules subulate. Male catkins lateral villous long sessile; bracts ovate, silky; disc of 2 glands. Stamens 5 to Io; anthers orbicular. Females in shorter catkins pedicelled; bracts obovate-oblong. Ovary fusiform, glabrous. Seeds 4 to 6 . $H a b$. In ditches in open country, borders of rice fields, etc., in deep forest according to Maingay. Pahang, Pekan; Malacca, Machan (Maingay); Jus (Derry); Batang Malaka (Holmberg). Negri Sembilan, Bukit Tangga. Selangor, Bukit Kutu; Weld's Hill (Burn-Murdoch); Rawang. Perak, Ulu Temengoh; Lenggong; Plus River (Wray). Penang, Balik Pulau; Ayer Hitam (Curtis). Distrib. India, China, Malay islands. Native names: Dalu Dalu; Jendalu; Dahu.

The female plant of this has never been found here, and it is propagated by cuttings, being used as a boundary hedge. Though very widely distributed and common, I suspect it is introduced, and as the form here closely resembles the Javanese S. Horsfieldiana Miq., a local form, it was probably introduced by Javanese. A fruiting specimen labelled "Salix calophylla Wall., Malacca (Griffith)" in Herb. Kew. is utterly unlike the Malay Peninsula plant, having thick, polished glabrous ovate cuspidate leaves. It closely resembles a specimen collected in Mishmee, Bengal, by Griffith and is doubtless wrongly localised. 



\title{
INDEX OF ORDERS, GENERA, SPECIES, AND SYNONYMS
}

\author{
VOLUME III
}

The Orders are printed in small capitals and the Synonyms in italics

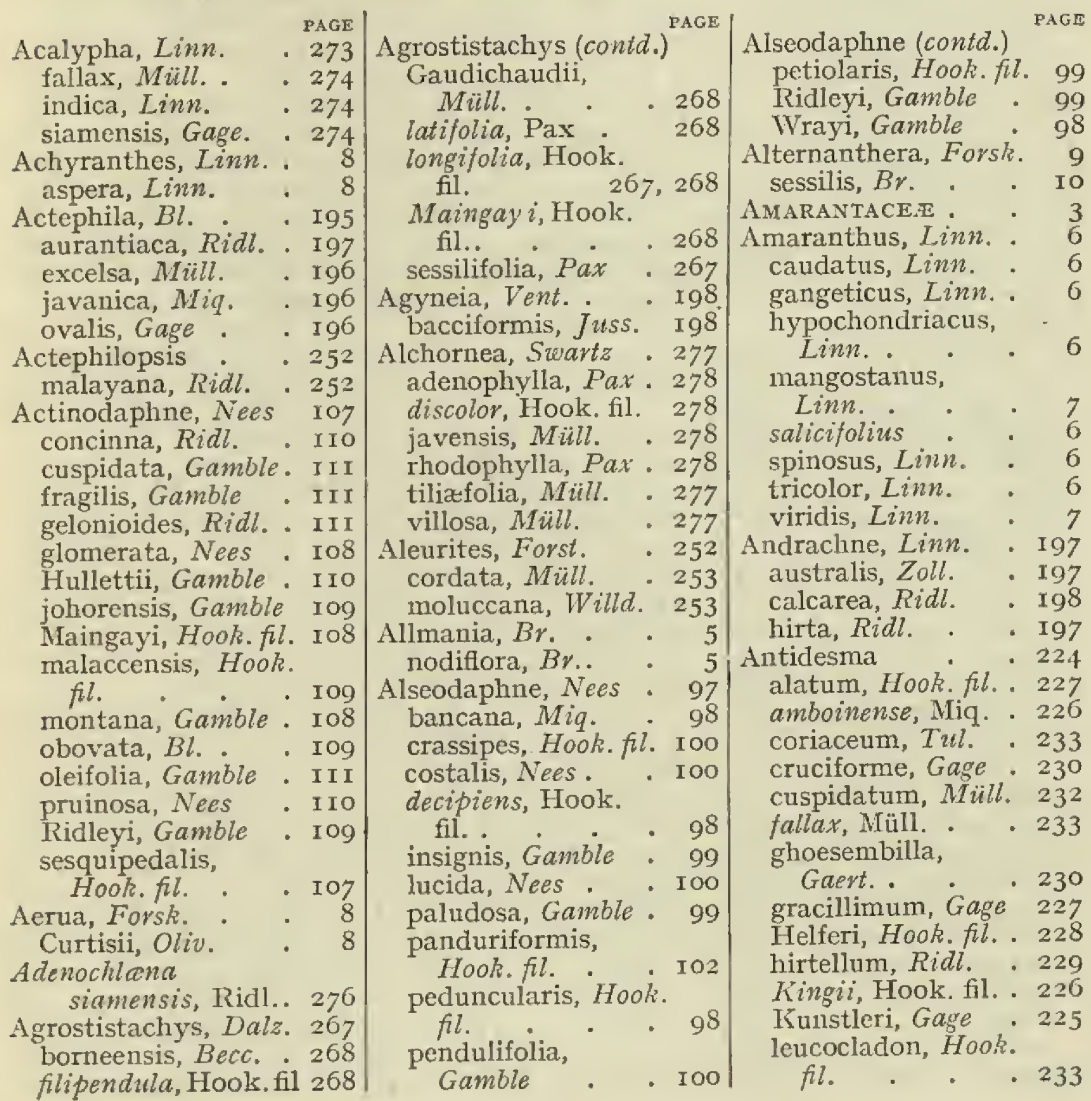


PAGE

longipes, Hook. fil. 229

montanum, $B l$. . 23I

Moritzii, Múll. . 23I

pachystachys,

Hook. fil. . 226

pendulum, Hook. fil.

perakense, Pax $\cdot 227$

perserula, Hook. fil. 229

persimile, Kurz. . 229

phanerophlebium,

Merrell

230

rotatum, Müll. . 232 salicitolium, Hook.

fil.

228

salicinum, Ridl. $\quad 228$

stenophyllum, Gage 226

stipulare, $\mathrm{Bl}$. . 226

tomentosum, $B l$. . 226

velutinosum, $B l$. . 231

Antigonon leptopus, Endl.

Apama, Lam. Io corymbosa, Soler. I 5 tomentosa, Soler . I5

Aporosa, $\mathrm{Bl}$. $\quad . \quad 235$ arborea, Müll. $\quad 239$ aurea, Hook. fil. . 240 Benthamiana,

Hook. fil. . . 236

bracteosa, Pax . 237

confusa, Gage . 238

falcifera, Hook. fil. 236

ficifolia, Hook. fil. 237

frutescens, $B l$. 24. I

fruticosa, Müll. . $24 \mathrm{I}$

globifera, Hook.

fil. . 237

Griffithii, Hook.

fil. . 233

lunata, Kuvz. $\quad 237$

Maingayi, Hook. fil. 24I microcalyx, Hassk. 238 microsphoera,

Hook. fil. . 24I

Miqueliana, Müll. 24I nervosa, Hook. fil. 238 nigricans, Hook. fil. 239

Prainiana, King . 240 pseudoficifolia, Pax 237 stellifera, Hook. fil. 239 symplocoides, Gage 240

Aquilaria, Lam. - I47 hirta, Ridl. . . I48 malaccensis, Lam. I47 rostrata, Ridl. . I48
Arceuthobium, Rich PAGE dacrydii, Ridl. $\quad .163$

ARISTOLOCHIACEF - I4

Aristolochia, Linn. . I 7

Curtisii, Gamble . I8

minutiflora, Ridl. . I 8

Roxburghiana, Klotsch . I8 Tagala, Cham. . I8 ungulifolia, Mast. . 18

Artocarpus, Linn. . 35I anisophylla, Miq. . 356 bracteata, Hook. fil. : $\cdot 352$ Denisoniana, Hook. fil. echinata, Roxb. . $35^{2}$ Forbesii, Hook. fil. 352 Gomeziana, Wall. 355 Kunstleri, Hook. fil.

. 353

Lakoocha, Roxb. . 355 lanceæfolia, Roxb.. 354 Lowii, Hook. fil. . 353 Maingayi, Hook. fil. peduncularis, Kurz. 353 polyphema, Pers. . 354 rigida, $\mathrm{Bl}$. . $\quad 352$ Scortechinii, Hook. fil. . . 355 superba, Becc. $\quad 356$

Baccaurea, Lour. . 242 bracteata, Milll. . 246 brevipes, Hook. fil. 250 Griffithii, Hook. fil. 248 Hookeri, Gage . 247 Kingii, Gage . . 245 Kunstleri, Gage . 248 lanceolata, Müll. . 248 latifolia, King . 249 leucodermls, Hook. fil. . 244 macrophylla, Müll. 246 Maingayi, Hook. fil. 247 malayana, Jack . 247 minor, Hook. fil. . 245 Motleyana, Müll. . 250 parviflora, Mïll . 243 platyphylla, Pax . 250 platyphylloides, Pax . . 249 polyneura, Hook. fil. pubescens, $P a x$. 250 pyriformis, Gage . 249
Baccaurea (contd.)

reticulata, Hook. fil. . . 246 Scortechinii, Hook. fil. . . 244 singaporica, $\mathrm{Pax} \cdot 243$ symplocoides,

Hook. fil. . 240

Wallichii, Hook. fil. 245

Wrayi, King . . 244

BALANOPHORACE 2 . I73

Balanophora . . I 73 gigantea, Wall. . I 74 globosa, Jungh. . I74 insularis, Ridl. . I75 multibrachiata, Farec. . . I74 truncata, Ridl. . I74

Balanostreblus ilicifolius, Hook. fil.

Baliospermum, $B l$. 312 axillare, $B l$. . . 3I2 malayanum . 3I3

Beilschmiedia, Nees. 82 brevipes, Ridl. $\quad$. 86 Curtisii, Gamble . 84 Foxiana, Gamble . 86 glomerata, var. Merrill . 85 insignis, Gamble . 82 Kunstleri, Gamble 85 longipes, Hook. fil. 85 lumutensis, Gamble . 84 Maingayi, Hook. fil. 84 malaccensis, Hook. fil.. . . 83 membranacea, Gamble pahangensis, Gamble penangiana,

Gamble • 85

perakensis, Gamble 85

Scortechinii, Gamble . 84 tonkinensis, Ridl. . 85

\section{Bennettia} affinis, Br. . 255

Finlaysonii, Br. .257 pedicellata, $\mathrm{Br}$. 257 phlebocarpa, Br. . 255 Wallichii, $\mathrm{Br}$. .256 Blumeadendron, Kurz. . . 28I concolor, Gage . 28I 


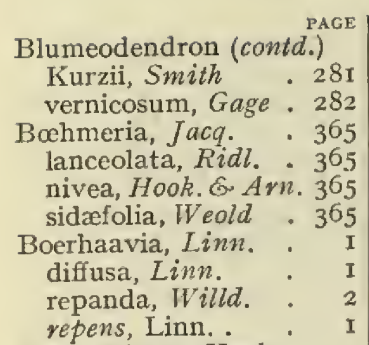

Botryophora, Hook. fil. . . 282 Kingii, Hook. fil. . 282 Bradleia coronata, Wall. . . $2 \mathrm{I}_{2}$

Bragantia, Lour. . I4 corymbosa, Griff. . I5 tomentosa, $\mathrm{Bl}$. - I5

Breynia, Forst. . . 217 angustifolia, Hook. fil. coronata, Hook. fil. 218 discigera, Müll. . 2 I 7 Keithii, Ridl. . 219 rhamnoides, $M$ üll. 2 I8 reclinata, Hook. fil. 219

Bridelia, Willd. cinnamomea, $\mathrm{Hook}$. fil. . I 85 183 Curlisii, Hook. fil. I 84 Griffithii, Hook. fil. I 85 minutiflora, Hook. fil. ovata, Decne . . $\mathrm{I} 84$ pedicellata, Ridl. . I 84 penangiana, Hook. fil. ${ }^{\circ}$. 185 retusa, Spring 184 rufa, Hook. fil. - 195 stipularis, $B l$. , I 83 tomentosa, $B l$. . I 84

Brugmansia, $B l$. . I9 Lowii, Becc. . . 20

Buxus, Linn. . . I 82 rupicola, Ridl. . I82

Byttneria . . 291 uncinata, Mast. . 291

Cansjera, Juss. . . 172 zizyphifolia, Griff. $\quad$ I $^{2}$

Cassytha, Linn. . I37 filiformis, Linn. . I37

Castanopsis, Spach . 388 Andersoni, Gamble 389 argentea, A.DC. $\quad 392$
Castanopsis (contd.)
catapprefolia, King

(contd.) 380 costata, A.DC. $\quad 390$ Curtisii, King . 392 fulva, Gamble $\quad$ - 389 Hullettii, King . 389 hystrix, A.DC. - 392 javanica, Hook. fil. 390 malaccensis,

Gamble

megacarpa,

Gamble 388 nephelioides, $K \ddot{n} n$ Ridleyi, Gamble . $39 \mathrm{I}$ Scortechinii,

Gamble

sumatrana $A D C \cdot 389$ Wallichii, King . 391

CAsuarinez $\cdot$ - 37 I

Casuarina, Forst. $\quad .372$ equisetifolia, Forst. $37^{2}$

Celosia, Linn. . . 5 argentea, Linn. . 5 cristata, Linn.

Celtis, Linn. $\quad$. 321 Collinsæ, Craib. $\quad$. 322

Cephalomappa, Baill. 279 penangensis, Ridl. 279

Chetocarpus, Thw. . 3 Io castanocarpus,

Thw. . . 3Io

Champereia, Griff. . I $7^{2}$ Griffithii, Hook. fil. I 72

Chloranthace IE $\quad 52$

Chloranthus, Sw. $\quad 52$ brachystachys, $B l$. $\quad 53$ inconspicuus, Siv. 53 officinalis, $B l$. $\quad 52$ Choriophyllum . malayanum, Benth. 224 montanum, Ridl. . 224

Cicca, Linn. . . 216 disticha, Linn. . 216

Cinnamomum, $B l . \quad$. 90 aureofulvum, Gamble cinereum, Gamble. 95 Deschampsii, Gamble graciliflorum, Gamble

iners, $B l$.

inunctum, Meissn. javanicum, $B l$.

Kunstleri, Ridl. microphyllum, Ridl.
Cinnamomum (contd.) mollissimum, Hook. 95 fil.

paraneuron, Miq. . 92 parthenoxylon,

Meissn. . . 96 parvifolium, Ridl. 92 puberulum, Ridl. . 96 rhynchophyllum, Miq.

Ridleyi, Gamble . 93

Scortechinii,

Gamble

velutinum, $R i d l . \quad$. 95

vimineum, Nees . 92

zeylanicum, $\mathrm{Bl}$. . 97

Cladogynos, Zipp. $\quad$. 276 orientalis, Span. $\quad 276$ Claoxylon, Juss. . 27 I indicum, Hassk. . $27 \mathrm{I}$ Kingii, Hook. fll. . 272 longifolium, Mïll. 272 mercurialis, Thw. . $27^{2}$ Wallichianum, Müll.

Cleidion, $B i$. $\quad . \quad 296$ javanicum, $B l$. . 296 Cleistanthus, Hook. fil. . I 86 albidiscus, Ridl. . I9I bracteosus, Jabl. . I 87 Curtisii, Jabl. . I 88 dasyphyllus, Will. I9o decurrens, Hook.

fil. . I9I

dubius, Ridl. . . 205 ellipticus, Hook. fil. I94 flavescens, Jabl. . I88 glandulosus, Jabl. I 89 glaucus, $J a b l$. , I 88 gracilis, Hook. fil. . 190 heterophyllus, Hook. fil. .

hirsutopetalus, Gage . . . I 89 hirsutulus, Hook. fil. . I92 Kingii, Jabl. . . I93 lavis, Hook. fil. . I9o lanuginosus, Jabl. 192 macrophyllus, Hook. fil. 192 Maingayi, Hook. fil. 193 malaccensis, Hook. fil. I 89 membranaceus, Hook. fil. - 188 


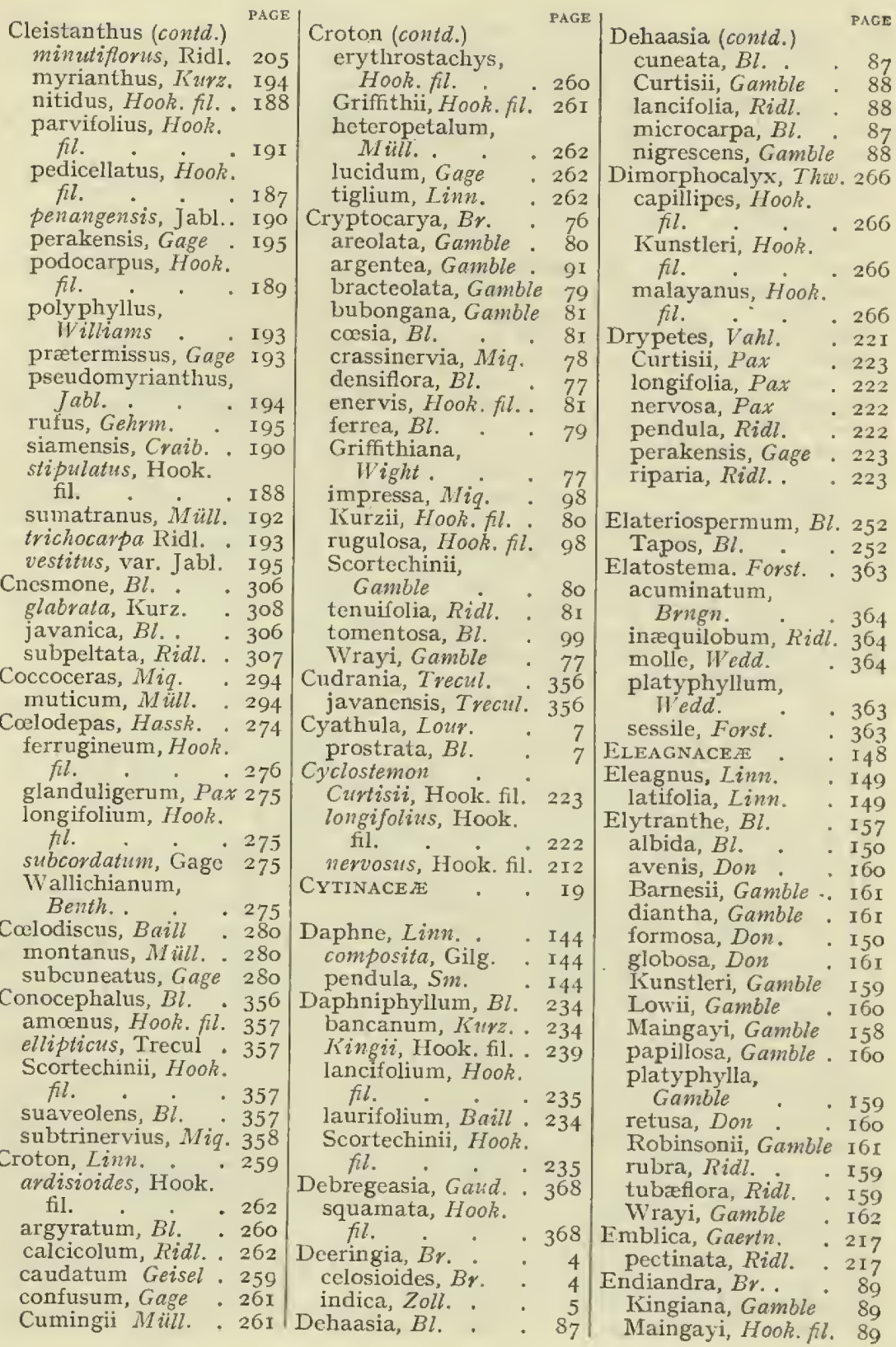




$\begin{array}{lr}\text { Endiandra (contd.) } & \\ \text { PAGE } \\ \text { praclara, Gamble } & 89 \\ \text { rubescens, Miq. } & 89 \\ \text { Wrayi, Gamble } & 89 \\ \text { Endospermum, } & \\ \text { Benth. } & \end{array}$

chinense, Benth. 306 malaccense, Müll. 305 ovalifolium, Pax . 305 perakense, King . 306

Engelhardtia . 368 nudiflora, Hook. fil. 369 Roxburghiana,

Lindl. . $37^{\circ}$ serrata, Hook, fil. . 370 spicata, $B l$. . . 368 Wallichiana, Lindl. 370

Enkleia, Griff. . . I 47 malaccensis, Griff. I 47

Epiprinus, Griff. $\quad$. 279 malayanus, Griff. . 279

Erismanthus, Wall. . 270 obliqua, Wall. . $27 \mathrm{I}$

EUPHORBIACEE . I 76

Euphorbia, Linn. . I 80 antiquorum, Limn, I80 atoto, Forst. . . I $8 \mathrm{I}$ cyathophora, Murr. I8I heterophylla, Linn. I 8I hirta, Linn. . . I8I neriifolia, Linn. . I 82 pilulifera, Linn. . I8I pulcherrima, Willd. 182 synadenium, Ridl. 180 thymifolia, Burm. $\quad$ I 82 Tirucalli, Linn. . I 82

Excæcaria, Linn. : 3I agallocha, Linn. . 3I 4 bicolor, Hassk. . 3I5 quadrangularis, Miull. .

Ficus, Linn. . . 325 acamptophylla,

Miq. • . 335

alba, Reinudt. $\quad$. 347

alutacea, $B l$. . 344

annulata, $B l$. . 333

apiocarpa, Miq. . 338

araneosa, Hook. fl. 345 ataktophylla, Miq. 349 aurantiaca, Griff. . $33^{8}$ barbata, Wall. . 346 bengalensis, Linn. $33^{I}$ Benjamina, Linn. 336 Binnendijkii, Miq. 336 bracteata, Wall. . 33I
Ficus (contd.)

brevicuspis, Miq. . 340

Burkillii, Ridl. . 330

callicarpa, $M i q . \quad$. 338

celebica, $\mathrm{Bl}$. . $\quad 330$

chartacea, Wall. . 350

chrysocarpa,

Reinvat. . . 348

clavata, Wall.. . 34I

consociata, $\mathrm{Bl}$. . 33 I

copiosa, Steud. $\quad 34^{\circ}$

cordata, Ridl. . 347

cunia, Ham. . $34 \mathrm{I}$

cuspidata, Reinredt. 340

deltoidea, Jack . 346

diversifolia, $\mathrm{Bl}$. $\quad 346$

dubia, Wall. . . 333

elastica, Roxb. . 334

excavata, Hook. fil. 344

fasciculata, Hook. fil.

343

fistulosa, Reinwdt. 343

fulva, Reinzedt. . 34I

gibbosa, $\mathrm{Bl}$. . $\quad 329$

glabella, $\mathrm{Bl}$. . $\quad .336$

glandulifera, Wall. 347

globosa, $\mathrm{Bl}$. . $\quad .333$

heterophylla, Linn. 339

hispida, Linn. . 342

inconstans, Miq. . 339

indica, $\operatorname{Linn}$. . 334

infectoria, Roxb. - 337

lævis, $B l$. . $\quad 344$

lepicarpa, $B l$. $\quad 343$

lepidosa, Wall. $\quad$. $35^{\circ}$

Lowii, King . . 332

microstoma, Wall. 334

microsyce, Ridl. . 335

Miquelii, Hook. fil. 34 I

mollissima, Ridl. . 348

obpyramidata, Hook. fil. . 343

obscura, Bl. . $\quad$. 339

obtusa, Hassk. $\quad$ - 344

obtusifolia, Roxb. . 335

oreophila, Ridl. . 348

ovoidea, Jack . . 346

parietalis, $\mathrm{Bl}$. $\quad .330$

patens, Ridl. . . 348

pedunculosa, Miq. 349

pellucido-punctata, Griff.

334

pilosa, Reinwdt. . 331

pisifera, Wall. 329

pisocarpa, $B l$. $\quad 336$

polysyce, Ridl. $\quad 342$

pomifera, Wall. $\quad 350$
Ficus (contd.)

procera, Reinwdt. . 332

pruniformis, $\mathrm{Bl}$. $\quad$. 333

punctata, Thwb. . 338

pyriformis, Hook. . 349

quercifolia, Roxb. 339

ramentacea, Roxb. 345

recurva, $\mathrm{Bl}$. . $\quad \cdot 345$

religiosa, Linn. . 336

retusa, Linn. . 335

rigida, Miq. . . 332

rostrata, Lam. $\quad$ 340

Rumphii, Bl. $\quad 336$

Scortechinii, King 343 sideroxylifolia,

Griff. . . 346

subulata, $B l$. . $\quad 329$

trachycarpa, Miq. 34I

truncata, King . 335

urophylla, Wall. . 330

variolosa, $L i n d l$. $\quad 349$

vasculosa, $W$ all. . 336

villosa, $B l$. * $\quad 345$

xylophylla, Wall. . 332

Fleurya, Gaud. . $\quad$. 359

interrupta, Gaud. . 359

Flueggia, Wild. . 216

microcarpa, $\mathrm{Bl}$. . $2 \mathrm{I} 6$

virosa, Baill. . . 216

Galearia, Zoll. . . 254

affinis, Hook. fil. . 255

Finlaysonii, Hook.

fil. . $\cdot 257$

fulva, Mïll. . $\quad 257$

fusca, Ridl. . $\quad$. 257

Jackiana, Hook. fil. 257

Lindleyana, Müll. 255

Maingayi, Hook. fil. 332

minor, Gage . . 256

pedicellata, Hook.

fil. . . 257

phlebocarpa, Hook.

fil. . . 255

Ridleyi, Gage $\quad .256$

subulata, Mïll. . 258

Wallichii, Hook f fl. 256

Gelonium, Roxb. . 3IO

bifarium, Roxb. . 3II

glomerulatum,

Hassk. . . 3II

multiflorum, Juss. 3 II

tenuifolium, Ridl. 3 I2

Ginalloa, Korth . I63

siamica, var. . . 162

Gironniera, Gaud. $\quad 320$

hirta, Ridl. . . $32 \mathrm{I}$ 
$\begin{array}{lr}\text { Gironniera (contd.) } & \text { PAGE } \\ \text { nervosa, Planch. } & 320 \\ \text { parvifolia, Planch. } & 32 \mathrm{I} \\ \text { subrqualis, Planch. } & 320 \\ \text { Glochidion, Forst. } & \text {. } 206 \\ \text { arborescens, Bl. } & \text { - } 2 \mathrm{II} \\ \text { brunneum, Hook. } & \end{array}$

fil. . . 207 coronatum, Hook.

fil. $2 \mathrm{I} 2$

Curtisii, Hook. fil. 2 I3 desmocarpum,

Hook. fil. . . 214

flavum, Ridl. . . 205

glaberrimum, Ridl. 208 glomerulatum,

Boerl.

. 209

goniocarpum,

Hook. fil.

. $2 I I$

insulare, Hook. fil. 213

Kunstlerianum,

Gage

. 210

lævigatum, Hook.

fil. * $2 \mathrm{I} 5$

leiostylum, Kurz. . 213

littorale, $\mathrm{Bl}$. . . 207

Llanosii, Müll. . 221

macrostigma,

Hook. fil.

- 214

Maingayi, Gage . 2 ro microbotrys, Hook.

fil.

209

microphyllum, Ridl. 202 nanogynum, Hook.

$\begin{array}{cc}\text { fil. } & 2 \mathrm{r} 4 \\ \text { obscurum, } B l . & 208\end{array}$

pedunculatum,

Ridl. . . . 207

perakense, Hook.

fil.

sclerophyllum,

Hook, fil.

. 213

$2 I I$

sericeum, Hook. fil. 2 I 5

singaporensis, Gage 209 stylosum, Ridl. . 2I5 superbum, Baill. . 208 tetrapteron, Gage . 2 II trilobum, Ridl. . 2 Io villicaule, Hook. fil. 2 I I Wallichianum,

Miill.

213

Glochidiopsis sericea,

Bl. . $2 I_{5}$

Gomphrena, Linn. IO globosa, Linn. . Io Gymnacranthera, Warb.
Gymnacranthera (contd.)
Farquhariana, Warb.

Forbesii, Warb.

Murtoni, Warb.

Gyrocarpus, Jacq

Jacquinii, Gaertn. $\quad$ I39

Hedycarpus

malayanus, Jack 247

Helicia, Lour. : . I40

attenuata, $B l$. . I 4 I

Curtisii, Gamble . I42

excelsa, $B l$. . . I 43

javanica, Benn. . I42

Kingiana, Prain. . I42

petiolaris, Benn. . I4I

robusta, Wall. . I42

rufescens, Prain . 142

Scortechinii,

Gamble . I43

suffruticosa, Ridl. . I4I

velutina, Prain . I43

Henslowia, $B l$. . . I66

buxifolia, $D C$. . I 70

Lobbiana, $D C$. . . I69

minor, Ridl. . . I67

monticola, Gamble. I69

philippinensis, $D C$. 168

plurinervis, Boerl. I69

Reinwardtiana, $B l$. I69

Ridleyi, Gamble . 167

umbellata, $B l$. . I67

varians, $B l$. . . I70

Wrayi, Gamble . 168

Hernandia, Linn. . 138 peltata, Meissn. . I38

Homalanthus, Juss. 313 populifolius, Grah. 3 I 3

Homonoia, Lour. . 309 riparia, Lour.. . 309

Horsfieldia, Willd. . 54 amygdalina, Warb. 57 brachiata, Warb. . 59 canaroides, Warb. 55 crassifolia, Warb. . 59 flocculosa, Warb. . 55 fulva, Warb. . 56 globularia, Wavb. . 54 grandis, Warb. . 58 Irya, Warb. . $\quad .58$ Lehmanniana, Warb. 59 majuscula, Warb. . 57 racemosa, Warb. . 60 Ridleyana, Warb. subglobosa, Warb. sucosa, Warb.
Horsfieldia (contd.)

superba, Warb. . 55

sylvestris, Warb. . 60 tomentosa, Warb. $\quad 56$

Wallichii, Warb. . 57

Hullettia, King . 358

dumosa, King . 358

Hymenocardia, Wall. 25 I

punctata, Wall. . $25 \mathrm{I}$

Wallichii, Tul. . 252

Illigera, $B l$. . . I 39

appendiculata, $B l$. 139

lucida, Teysm. . I40

Jatropha, Linn. . 253

curcas, Linn. . 254

gossypifolia, Linn. 254

JUGLANDACEAE $\quad 368$

Kibara, Endl. . . 74

chartacea, $B l$. . 74

coriacea, Tul. . 75

serrulata, Perk. * 75

Knema, Lour. . . 66

Cantleyi, Warb. . 68

conferta, Warb. . 70

Curtisii, Warb. . 68

furfuracea, Warb. 70

geminata, Warb. . 72

Hookeriana, Warb. 67

intermedia, Warb. 68

Kunstleri, Warb. . 69

laurina, Warb. . 72

malayana, Warb. . 69

missionis, Warb. . 7 I

oblongifolia, Warb. 70

retusa, Warb. . 72

Wrayi, Warb. $\quad 70$

Korthalsella, Van

Tieg. . . $\mathrm{I}_{3}$

japonica, Engl. . 163

Kunstlerodendron, Ridl.

283

cuspidata, Ridl. . 283

sublanceolata, Ridl. 283

Laportea, Gaud. $\quad .359$ pustulosa, Ridl. . 360 stimulans, Miq. $\quad$. 360 LAURINEIE $\cdot 75$ Lepidadenia Wightiana, Nees. 128

Lepeostegeres, $B l$. $\quad$ I6z Beccarii, Gamble . I62 Kingii, Gamble . 162 Lepionurus, $B l$. I72 
Lepionurus (contd.) oblongifolius, Mast. I73 sylvestris, $B l$. . $\mathrm{r}_{2}$

Lindera, Thunb: . I 33 bibracteata, Boerl. I 36 cæsia, Boerl. . . 136 caudifolia, Ridl. . I 35 cinnamomea, Ridl. I 36 concinna, Ridl. . I 37 malaccensis, Hook. fil. : oxyphylla, Hook.<smiles>[AlH]</smiles>
pipericarpa, Boerl. I35 polyantha, Boerl. . 135 rufa, Gamble . . 136 selangorensis, Ridl. I34 stricta, Ridl. . . I35 Wrayi, Gamble . I34

Linostoma, IV all. . I 46 pauciflorum, Griff. $x_{46}$

Litsea, Lour. ․ . I12 acrantha, Ridl. . I 23 amara, $B l$. . . II 7 angulata, $B l . \quad$. 120 artocarpifolia,

Gamble . II6

Blumei, Hook. fil. I 29 brachystachya,

Boevl. . . . II9 castanea, Hook. fil. I2I cinerascens, Ridl. . II8 claviflora, Gamble. 125 cordata, Hook. fil. II 8 cylindrocarpa,

Gamble

Curtisii, Gamble: 127

fenestrata, Gamble 123

ferruginea, $\mathrm{Bl}$. . 129

firma, Hook. fil. . II6

Foxiana, Gamble . 123

glabrifolia, Ridl. . II9

gracilipes, Hook.

fil. . . I30

gracilis, Gamble . II7

grandis, Hook. fil. II 5

Griffithii, Gamble . I29

Helferi, Hook. fil. . 125

hirsutissima,

Gamble . II8

johorensis, Gamble II4

Kunstleri, Gamble I25

lancifolia, Hook.

fil. . I30

machilifolia,

Gamble

- 126

FI.M.P., 3.

\begin{tabular}{|c|c|c|c|}
\hline & PAG & & PA \\
\hline ntd.) & & Loranthus (contd.) & \\
\hline ca, Gamble & II 5 & Jack & I 52 \\
\hline Hook. & & is, King & I 52 \\
\hline 8 & I 28 & $\begin{array}{l}\text { ok. fil.. } \\
\text { ing }\end{array}$ & \\
\hline & 127 & King & 156 \\
\hline 1on & & tapf. & I 54 \\
\hline & 124 & & $\mathrm{I}$ \\
\hline folia, & & & \\
\hline & 12 & $n g$ & 15 \\
\hline Gamble & 12 & Wall. & \\
\hline$R l$ & 128 & $\mathrm{~K}$ & 16 \\
\hline 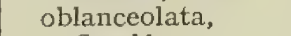 & & $K$ & I5 \\
\hline & 12 & . fil. & 15 \\
\hline & 13 & longifloru & 15 \\
\hline chracea, Boerl. & 12 & $\begin{array}{l}\text { Lowii, King } \\
\text { Maingayi, Hoo }\end{array}$ & \\
\hline
\end{tabular}

fil. . . 158

fil. . . 127

patellaris, Gamble I23

penangiana, Hook.

fil. . I2I

perakensis, Gamble 122 petiolata, Hook.

fil. . . II

polyantha, Juss. . II8

pustulata, Gamble 122

quercina, Gamble . I2I

Ridleyi, Gamble . I20

robusta, $B l$. . $\quad$. I29

sarawacensis,

Gamble . I30

Scortechinii,

Gamble . . I24

sebifera, Bl. : . 128

sessiliflora, Hook.

fil.

singaporensis,

Gamble . 122

spathacea, Gamble 120

Teysmanni,

$$
\text { Gamble : 126 }
$$

tomentosa, $B l$. . II 5

trunciflora, Gamble II 4 ujongensis, Gamble r3I villosa, $\mathrm{Bl}$. . . 132

Wrayi, Gamble . I22

Lobbia dependens,

Planch. . I6

Longetia, Baill.. : 224

malayana, Pax. . 224

montana, Pax. . 224

LORANTHACE㞔 . . I49

Loranthus . . ${ }_{50}$ ampullaceus, Roxb. 16r Beccarii, King . 162 bicolor, Roxb. . $\mathrm{r}_{55}$ casuarinæ, Ridl. : I54 malaccensis, $\dot{H} o o k$. fil. . . 154 obtectus, Wall. . 153 Parishii, Hook. fil. I5I pentandrus, Linn. I 55 pentapetalus, Roxb. ${ }^{52}$ perakensis, Engl. . I5I platyphyllus, King I 59 productus, King . I 52 pulcher, $D C$. . $15 \mathrm{I}$ Scortechinii, King. I 56 scurrula, var. Hook.

fil. . . I53 speciosus, King . $\mathrm{I}_{57}$ Loxanthera, $B l$. . $\mathbf{r}_{57}$ speciosa, $B l$. . . I57

Macaranga, Thouars. 297 Curtisii, Hook. fll. $30 \mathrm{r}$ denticulata, Miill. 303 gigantca, Müll. . 298 Griffithiana, Mïlll. 299 Hosei, King . . 298 Hullettii, King . 30I hypoleuca, Mïll. . 300 incisa, Gage - 30r javanica, Hook. fil. 303 Kingii, Hook. fil. . 300 Lowii, King . . 304 Maingayi, Hook. fil. . . 298 megalophylla, Müll. . . 298 montana, Pax. $\quad 303$ perakensis, Hook.

fil. . . 303 populifolia, Müll. . 304 puncticulata, Gage 302 quadricornis, Ridl. 300

D D 


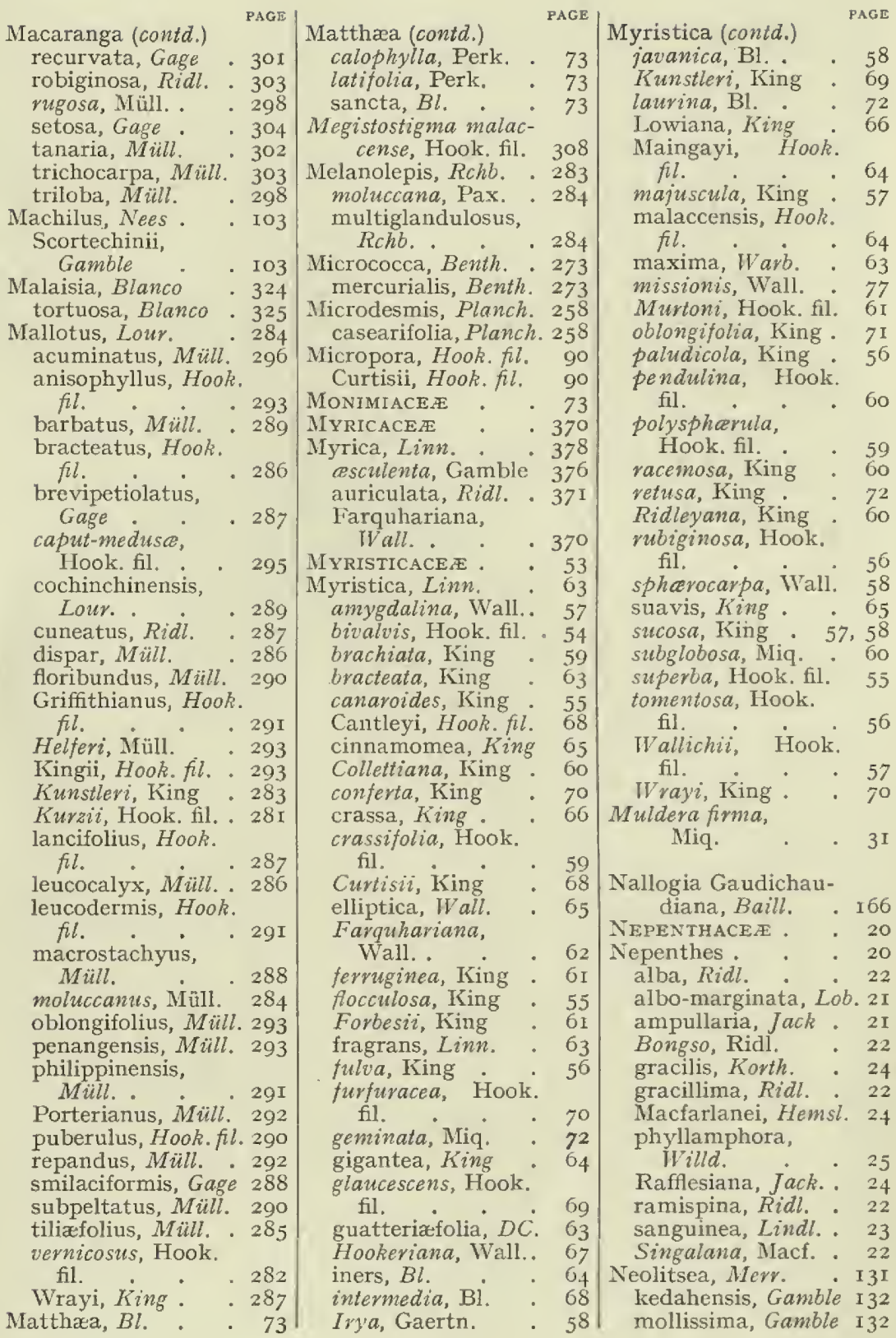




\begin{tabular}{|c|c|c|c|c|c|}
\hline & & & & & \\
\hline ea (contd.) & & Pasania (contd.) & & Phyllanthus (contd.) & \\
\hline ble & 132 & lampadaria, Gamble & 384 & eleg & \\
\hline errill & I 32 & lamponga, Gamble & 378 & erythrocarpus, & \\
\hline Tothophoebe, $B l$. & 100 & lappacea, Oerst. & 375 & Ridl. & \\
\hline ifolia, Ridl.. & ro3 & lucida, Gamble & 383 & filicifolius, Gage & \\
\hline idl. . & 102 & Maingayi, Schky & 387 & frondosus, $W$ all. & \\
\hline amble. & IOI & omalokos, Schky & 383 & s, Ridl. & \\
\hline $\begin{array}{l}\text { Kingiana, Gamble . } \\
\text { panduriformis, }\end{array}$ & IOI & $\begin{array}{l}\text { rassa, Gamble } \\
\text { Robinsonii, Gamble }\end{array}$ & $\begin{array}{l}382 \\
387\end{array}$ & $\begin{array}{l}\text { glomevulatus, Müll. } \\
\text { gomphocarpus, }\end{array}$ & \\
\hline$e$ & 102 & Scortechinii, Schky. & .376 & Hook. fil. & \\
\hline Gamble & 102 & Oerst. & $37^{6}$ & gracilipes, Mull. & \\
\hline & IOI & , Oerst. & 379 & nianus, & \\
\hline $\begin{array}{l}\text { iver } \\
\text { Olis. }\end{array}$ & $\begin{array}{l}165 \\
165\end{array}$ & ana, & & ii. $R i d i$ & \\
\hline $\begin{array}{l}\text { malayanus, Olir. } \\
\text { subaureus, Oliv. }\end{array}$ & $\begin{array}{l}165 \\
165\end{array}$ & $\begin{array}{l}\text { Gamble. } \\
\text { Wenzigiana, }\end{array}$ & 78 & $\begin{array}{l}\text { Hullettii, Ridl. } \\
\text { Kunstlevi, Hook. fil. }\end{array}$ & \\
\hline NYCTAGINEA & I & $\begin{array}{l}\text { Gamble } \\
\text { Wrayi, Gamble }\end{array}$ & $\begin{array}{l}382 \\
385\end{array}$ & $\begin{array}{l}\text { Llanosii, Müll. } \\
\text { maderaspatensis, }\end{array}$ & \\
\hline OPILIACEF & I 71 & Pellionia, Gaud. & 361 & Linn.: & \\
\hline $\begin{array}{l}\text { Ostodes, } B l . \\
\text { appendiculata, }\end{array}$ & & $\begin{array}{l}\text { acaulis, Hook. fil. } \\
\text { Curtisii, Ridl. . }\end{array}$ & $\begin{array}{l}362 \\
362\end{array}$ & $\begin{array}{l}\text { niruri, Linn. } \\
\text { pectinatus, Hook. }\end{array}$ & \\
\hline Hook. fll. & 70 & Duvauana, N.E. & & fil. ${ }^{\circ}$ & \\
\hline $\begin{array}{l}\text { phylla, } \\
\text { th. }\end{array}$ & 209 & na, $\dot{\text { Wedd... }}$ & $\begin{array}{l}362 \\
361\end{array}$ & $\begin{array}{l}\text { ngensis, Müll. } \\
\text { ensis, Ridl. . }\end{array}$ & \\
\hline Hook. & 269 & Wedd. & 362 & Wall. & \\
\hline tundata, & & Peperomca, Ruiz, . & 26 & reticulatus, Poir. & \\
\hline & 170 & $\begin{array}{l}\text { dlensis, Miq. } \\
\text { Miq. . }\end{array}$ & & $\begin{array}{l}\text { iflora, Ridl. } \\
\text { x, Retz. }\end{array}$ & \\
\hline Oerst. . & 374 & C.DC & 27 & a, Linn. & \\
\hline issima, & & $\begin{array}{l}\text { malaccensis, Ridl. } \\
\text { Maxwellana C DC. }\end{array}$ & & $\begin{array}{r}\text { Phyllo } \\
B\end{array}$ & \\
\hline na, Prantl. & 387 & ida, Korth. & $\begin{array}{l}27 \\
27\end{array}$ & , Bureau & \\
\hline Gamble & $38 \mathrm{I}$ & ides, & & ii, Hook. fil. & \\
\hline Gamble & 385 & & 26 & Pilea, & \\
\hline - & & Pha & $\begin{array}{r}26 \\
170\end{array}$ & Ridl. & \\
\hline Clementiana, & & $\begin{array}{l}\text { laria, Benth. . } \\
\text { yana, Ridl. }\end{array}$ & 170 & $\begin{array}{l}\text { fruticosa, Hook. thl. } \\
\text { Griffithii, } B l \text {. }\end{array}$ & \\
\hline $\begin{array}{l}\text { Gamble } \\
\text { confragosa, }\end{array}$ & & $\begin{array}{l}\text { Phoebe, Nees. } \\
\text { cuneata, Bl. }\end{array}$ & $\begin{array}{l}103 \\
106\end{array}$ & $\begin{array}{l}\text { muscosa, Lindl. } \\
\text { Pimeleodendron, }\end{array}$ & \\
\hline Gam & 385 & Nees. & 104 & & \\
\hline & & Nees & 105 & $\begin{array}{l}\text { Griff } \\
H\end{array}$ & \\
\hline Gamble & 38 & macrophylla, $B l$. & 105 & Piperace & \\
\hline rat & & ook, fil. & & $\begin{array}{l}\text { Piper, Linn. } \\
\text { acre } B l\end{array}$ & \\
\hline yrtorhyncha, & & $\begin{array}{l}\text { a, Hook. Ml. } \\
\text { adendron, }\end{array}$ & Is & $\begin{array}{l}\text { acre, Bl. } \\
\text { argyrites, Ridl. }\end{array}$ & \\
\hline & & & 20 & Betle, Linn. & \\
\hline amble & & $\begin{array}{l}\text { m, Gage } \\
\text { Gage. }\end{array}$ & 205 & $\begin{array}{l}\text { bipedale, } C . D C \text {. } \\
\text { boehmeriæfolium, }\end{array}$ & \\
\hline arpa, & & $\begin{array}{l}\text { I, Gage. } \\
\text { ius, Linn. : } \\
\text { ulatus, }\end{array}$ & $\begin{array}{l}205 \\
198\end{array}$ & $\begin{array}{l}\text { boehmer1æfolum } \\
\text { Wall. ' } \\
\text { Burkillii, Ridi. }\end{array}$ & \\
\hline Gamble & 380 & & 203 & caninum, $B l$. & \\
\hline i, Schky & 378 & chamæpeuce, Ridl. & 200 & chaba, Roxb. & \\
\hline $\begin{array}{l}\text { grandifrons, } \\
\text { Gamble }\end{array}$ & & & 204 & Vall. . & \\
\hline 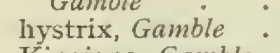 & & $\begin{array}{l}\text { s, Wall. } \\
\text { oides, }\end{array}$ & & um, C.I & \\
\hline & & ichus, $M \ddot{u l l}$. & & curtipetiolum, & \\
\hline$a n$ & & ichus, $M u ̈ l l$. & & C. $D C$. & \\
\hline
\end{tabular}




\begin{tabular}{|c|c|c|c|c|c|}
\hline & & & & & \\
\hline iper (contd.) & & Piper (contd.) & & POLYGonacele & 10 \\
\hline Curtisii, C. $D C$ & 37 & paucistigmum, & & Polygonum, Linn. & 10 \\
\hline cyrtostachys $f$ & $3 /$ & & 35 & $\mathrm{~m}$, Linn. & II \\
\hline Ind 1 & & um, Wall & 34 & Linn. & 12 \\
\hline & 38 & Linn. . & 27 & Meissn. & 12 \\
\hline$C . D C$ & 43 & C. $D C$ & 42 & hydropiper, Linn. & $\mathrm{I} 2$ \\
\hline imbum, & & ,C.DC. & 30 & Huds. & I I \\
\hline$\therefore$ : & 49 & $D C$ & $3 \mathrm{I}$ & $\begin{array}{l}\text { lare, Wall } \\
\mathrm{m}, \mathrm{Ham} .\end{array}$ & \\
\hline DC. $D C$ & 39 & & & strigosum, $\mathrm{Br}$. & $\begin{array}{l}12 \\
13\end{array}$ \\
\hline C. D & 49 & $C . D C$. & $\begin{array}{l}43 \\
33\end{array}$ & tomentosum, Will & ild. I I \\
\hline um, C. $D \dot{C}$ & 49 & eum, & & Pou & - 365 \\
\hline latum, & & $\therefore D$ & $4^{r}$ & & \\
\hline $\mathrm{m}, \dot{C} \cdot D \dot{C}$ & $3 I$ & $\begin{array}{l}C . D C \text {. } \\
C . D C \text {. }\end{array}$ & $\begin{array}{l}39 \\
32\end{array}$ & indica, Gaud. & $\begin{array}{l}\cdot 300 \\
: 366\end{array}$ \\
\hline num, & & Wall. . & 34 & viminea, Wedd. & . 366 \\
\hline & 43 & $D C$ & 33 & rphe subpel- & \\
\hline dum, & 46 & & 48 & Praine & . 358 \\
\hline hyllum, & &,$C . D C$. & 42 & $\begin{aligned} \text { sc } & \\
\text { Pro } & \end{aligned}$ & $\begin{array}{l}-358 \\
364\end{array}$ \\
\hline$i d l$. & 35 & $b$. & 40 & frutescens, Hook. & \\
\hline C. DC. . & 45 & schi & & - & 364 \\
\hline C. $D C$. & 50 & & 3 & lævigata, $B l$. . & - 364 \\
\hline dl. & 43 & $D C$. & 5 & $B l$. & 365 \\
\hline$a x b$. & 38 & ense, & & PROTEACE & . 140 \\
\hline C. DC & 25 & $C$ & 34 & Pse & \\
\hline $\begin{array}{l}\text { 1, C. DC. } \\
\text { Hook. }\end{array}$ & 37 & banum, & & $\begin{array}{l}\text { Bureau } \\
\text { caudatus, Ridl. }\end{array}$ & \\
\hline & 5 & Miq. & 42 & Psilotrichum, $B l$. & \\
\hline Wall. & & ns, $C . D C$. & 37 & num, $B l$. & \\
\hline tum, & & $\begin{array}{l}C . D C \text {. } \\
\text { erve, }\end{array}$ & & $\begin{array}{l}\text { Hassk. } \\
\text { us, Hassk }\end{array}$ & \\
\hline teum, & & $\begin{array}{l}C . D C \text {. } \\
\text { subrubrispicum, }\end{array}$ & & $\mathrm{Ou}$ & \\
\hline$C \cdot \dot{D}$ & 3 & & & Kort & \\
\hline$i n n$. & $5 \mathrm{I}$ & subs & & $\mathrm{Ber}$ & 387 \\
\hline cum, & & & & & \\
\hline . & 31 & Linn. & & King & $\begin{array}{l}385 \\
81\end{array}$ \\
\hline & 5 & & & , King & \\
\hline n, & & & & King & \\
\hline & 35 & xanthocarpum, & & . & \\
\hline & 39 & int & & ing & \\
\hline & 43 & s, Wedc & 36 & yncha, Miq. & \\
\hline tum, & & iso & & $a$, Home & 86 \\
\hline & 36 & ta, Linn. & & Wenzig & \\
\hline$B l$. & & $\begin{array}{l}\text { excelsa, } B l . \\
\text { Plukenetia. }\end{array}$ & & arpa, & \\
\hline & & CD & & & \\
\hline$r$ & & Poinsettia & & & \\
\hline . & & Polys & & $n$ & \\
\hline 0 & $4 \mathrm{I}$ & fil. & & tleri, King & 76 \\
\hline Hook. fil. . & & Hook. fil. . & & lucida, Roxb.. & \\
\hline
\end{tabular}




\begin{tabular}{|c|c|c|c|c|c|}
\hline & & & & & \\
\hline d.) & & Scleropyrum (contd.) & & Trigonopleura, Hook. & \\
\hline & $37^{8}$ & Maingayi, Hook. & & fil. $\dot{1}$ malaya & 263 \\
\hline $\begin{array}{l}\text { Korth. } \\
\text { Korth. }\end{array}$ & $\begin{array}{l}373 \\
383\end{array}$ & $\begin{array}{l}\text { fil. } \\
\text { Ridleyi, Gamble }\end{array}$ & $\begin{array}{l}\mathbf{I} 7 \mathbf{I} \\
\mathbf{I} 7 \mathbf{I}\end{array}$ & 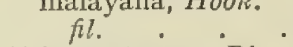 & \\
\hline iq. & 382 & Scortechinia, Hook. & & Trigonostemon, $B l$. & \\
\hline Ridl. & 387 & & $25 \mathrm{I}$ & indicus, Müll. & \\
\hline . & 376 & Kingii, Hook. fil. & $25 \mathrm{I}$ & lavigatus, $M$ üll. & \\
\hline 1. . & 379 & Sebastiana, Spreng. & - 317 & lius, Baill. . & 264 \\
\hline$B l$. & - 373 & Mill. & $\begin{array}{l}317 \\
308\end{array}$ & $\begin{array}{l}\text { inus, Mull. } \\
\text { ius, Ridl. }\end{array}$ & 264 \\
\hline $\begin{array}{l}\text { Wallichiana, Wall. } \\
\text { Wenzigiana, King }\end{array}$ & $\begin{array}{l}378 \\
382\end{array}$ & $\begin{array}{l}\text { Sphærostylis, } \\
\text { malaccensis, }\end{array}$ & & tomentellus, Pax. & \\
\hline IVra & 385 & $\begin{array}{c}\text { Pax. } \\
\text { Sloetia, Teysm. }\end{array}$ & $\begin{array}{l}308 \\
323\end{array}$ & $\begin{array}{l}\text { villosus, Hook. fil. } \\
\text { Tritaxis macrophylla, }\end{array}$ & 265 \\
\hline $\begin{array}{l}\text { afflesia, Br. } \\
\text { Hasseltii, Sur. }\end{array}$ & - I9 & penangiana, Oliv. & 324 & $\begin{array}{l}\text { Müll. } \\
\text { Tupeia Reinward- }\end{array}$ & 26 \\
\hline $\begin{array}{l}\text { HasseIti, Sur. } \\
\text { EIDIA }\end{array}$ & & : & 324 & tiana, $\mathrm{Bl}$ & \\
\hline $\begin{array}{l}\text { glaucescens, Miq. } \\
\text { Rhopalocnemis, }\end{array}$ & 201 & $\begin{array}{l}\text { Wallichii, King } \\
\text { Stemmatodaphne, }\end{array}$ & & umbellata, Bl. & 67 \\
\hline $\begin{array}{l}\text { Jungh. } \\
\text { ruficeps, Ridl. }\end{array}$ & $\begin{array}{l}175 \\
176\end{array}$ & $\begin{array}{l}\text { Gamble } \\
\text { perakensis, }\end{array}$ & & URTI & \\
\hline icint & 309 & Gamble & - 106 & $\begin{array}{c}\text { Unirca amona, wan. } \\
\text { punctata, Ham. }\end{array}$ & 57 \\
\hline co & 309 & $\begin{array}{l}\text { Streblus, Lour. . } \\
\text { asper, Lour. . }\end{array}$ & $\begin{array}{l}323 \\
323\end{array}$ & (Wull & 357 \\
\hline ALI & - 392 & & & & \\
\hline Salix, Linn. & - 392 & is, $B l$. & & $\begin{array}{l}\text { Villebrunea, Gand. } \\
\text { sylvatica, } B l \text {. }\end{array}$ & \\
\hline 1a, thest. & $\begin{array}{l}393 \\
166\end{array}$ & ilicifolia, Vid. & 322 & Viscu & 10 \\
\hline$B r$. & 315 & Tetrad & & articulatum, & \\
\hline 1, Roxb. & - 315 & Nees & 132 & $\cdot$ & \\
\hline Mïl & - 316 & Thott & & $\mathrm{m}$, Don. & 4 \\
\hline in & $3 \mathrm{I}$ & Klot & & ramble & \\
\hline$n$ sessili- & & Rottb. & & Willd. • & 4 \\
\hline $\begin{array}{l}\text { Kurz. } \\
l l .\end{array}$ & $\begin{array}{l}267 \\
219\end{array}$ & Maing. & $\begin{array}{l}17 \\
\cdot \quad 16\end{array}$ & Gamble & \\
\hline Bl & 220 & THYMELEACE & . $\quad 143$ & $\mathrm{Je}$ & 2 \\
\hline & & Trag & & tr & \\
\hline Wight & $\begin{array}{l}220 \\
220\end{array}$ & $\begin{array}{l}1 æ \\
\text { Tren }\end{array}$ & $\begin{array}{l}307 \\
\text {. } 319\end{array}$ & Endl. & \\
\hline age & 221 & sis, $B l$. & - 313 & $M e$ & \\
\hline H & & $\begin{array}{l}\text { folia, } B l \text {. } \\
\text { sis, Hook. }\end{array}$ & $3^{I}$ & Gamble & $\begin{array}{l}\text { I } 45 \\
146\end{array}$ \\
\hline $\begin{aligned} & \\
\text { par } & \end{aligned}$ & & & & ora, Meisn.. & \\
\hline$M$ & 220 & virgata, $B l$. & $3 \mathbf{I}$ & & \\
\hline & 20 & $\begin{array}{l}\text { Trewia macrophyll } \\
\mathrm{Bl} \text {. }\end{array}$ & & a, $B$ & \\
\hline & & & & & \\
\hline
\end{tabular}




\title{
ERRATA AND CORRIGENDA
}

\author{
VOL. I.
}

P. 209, line 42. For wings, 4 read wings, 5 .

P. 876, line 30. For S. Scortechinii Ridl, read S. Scortechinii Viguier, Ann. Sc. Nat. ix. 9, p. 345.

P. 876 , line 43. For S. pergamacea Ridl. read S. pergamacea Viguier, l.c. 350

P. 877 , line 8. For S. tomentosa Ridl. read s. tomentosa Viguier, 1.c. 346 .

P. 877 , line 24. For $\mathbf{S}$. singalangensis Riäl. read $\mathbf{S}$. singalangensis Viguier, 1.c. 33 I.

P. 877, line 36. For $\mathbf{S}$. latifoliata Ridl. read $\mathbf{S}$. latifoliata Viguier, 353.

P. 877, line 46. For S. Hullettii Ridl. read S. Hullettii Viguier, l.c. 353.

P. 878, line 2r. For $\mathbf{S}$. scandens Ridl. read S. scandens Viguier, 1.c. 348 .

P. 878, line 32. For S. subracemosa Ridl. read S. subracemosa Viguier, 353.

P. 878, line 44. For $\mathbf{S}$. subulata Ridl. read S. subulata Viguier, 1.c. $35 \mathrm{I}$.

P. 879, line I7. For S. nervosa Ridl. read S. nervosa Viguier, I.c. 35r.

P. 879, line 27. For $\mathbf{S}$. affinis Ridl. read $\mathbf{S}$. affinis Viguier, 1.c. 354 .

P. 879, line 39. For S. Ridleyi Ridl. read S. Ridleyi Viguier, 1.c. 353.

P. 882, line 9. For S. Wrayi Ridl. read S. Wrayi Viguier, 1.c. 333.

\section{VOL. II,}

In the orders Myrsineæ, Sapotaceæ, Ebenaceæ, Styraceæ, Apocynaceæ, Asclepiadaceæ, Loganiaceæ, where King, l.c. occurs read King and Gamble, l.c.

Page 547, Bignoniace $æ$, line 39, and pp. 548, 549, 550, 551, 552, for Prain read Gamble. 



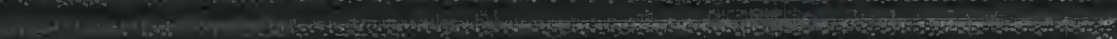

